\title{
Nevada
}

Environmental

Restoration

Project

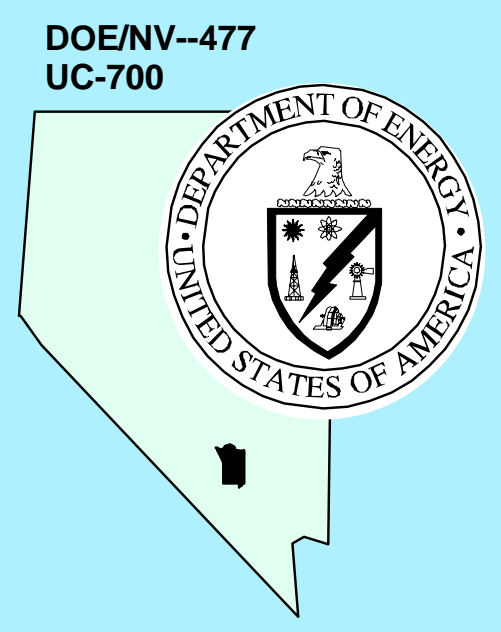

Regional Groundwater Flow

and Tritium Transport Modeling

and Risk Assessment of the

Underground Test Area,

Nevada Test Site, Nevada

October 1997

Approved for public release; further dissemination unlimited.

Environmental Restoration

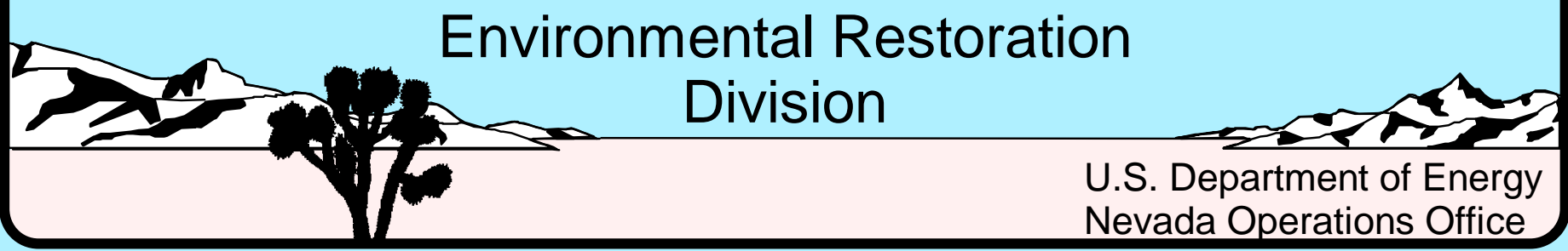


This report has been reproduced directly from the best available copy.

Available to DOE and DOE contractors from the Office of Scientific and Technical Information, P.O. Box 62, Oak Ridge, TN 37831; prices available from (423) 576-8401.

Available to the public from the National Technical Information Service, U.S. Department of Commerce, 5285 Port Royal Rd., Springfield, VA 22161, telephone (703) 487-4650. 


\section{REGIONAL GROUNDWATER FLOW AND TRITIUM TRANSPORT MODELING AND RISK ASSESSMENT OF THE UNDERGROUND TEST AREA, NEVADA TEST SITE, NEVADA}

DOE Nevada Operations Office

Las Vegas, Nevada

October 1997 


\section{REGIONAL GROUNDWATER FLOW AND TRITIUM \\ TRANSPORT MODELING AND RISK ASSESSMENT \\ OF THE UNDERGROUND TEST AREA, \\ NEVADA TEST SITE, NEVADA}

Approved by: Robert M. Bangerter Q7.

Date: $10 / 30 / 97$

Robert M. Bangerter, Project Manager

Underground Test Area Subproject

Approved by:
Sor Stephen A. Mellingtón, Project Manager
Nevada Environmental Restoration Project

Date: $10 / 30 / 97$ 


\section{Acknowledgments}

This document presents the results of the data analysis activities conducted during the regional investigation of the Underground Test Area Subproject. These activities have been led by IT Corporation; Tetra Tech, Inc.; GeoTrans, Inc.; and Daniel B. Stephens Corporation; however, the investigation could not have been completed without the cooperative efforts of many other participants involved in work at the Nevada Test Site. Their organizations are listed here in alphabetical order:

- Bechtel Nevada

- Desert Research Institute

- Lawrence Livermore National Laboratory

- Los Alamos National Laboratory

- Professional Analysis, Inc.

- Raytheon Services Nevada

- U.S. Geological Survey, Geologic Division

- U.S. Geological Survey, Water Resources Division

- U.S. Geological Survey, Yucca Mountain Project

The data analysis activities have been reviewed by a panel of subject matter experts who provided technical input that has been incorporated into the document packages. Their invaluable contributions are reflected in this report. The reviewers and their respective organizations are alphabetically listed as follows:

- Anthony Armstrong

- Dave Burden

- Joe Downey

- Lynn Gelhar

- Gerry Grisak

- Brad Hill

- Carla Johnson

- Charles Menzie

- David Prudic
Oak Ridge National Laboratory

U.S. Environmental Protection Agency/ National Risk Management Research Laboratory

Downey \& Gutentag LLC

Massachusetts Institute of Technology

Intera, Inc.

Computer Data Sytems, Inc. - Kerr Lab

Brogan-Johnson Consultants

Menzie-Cura

U.S. Geological Survey 


\section{Abstract}

The groundwater flow system of the Nevada Test Site and surrounding region was evaluated to estimate the highest potential current and near-term risk to the public and the environment from groundwater contamination downgradient of the underground nuclear testing areas. The highest, or greatest, potential risk is estimated by assuming that several unusually rapid transport pathways as well as public and environmental exposures all occur simultaneously. These conservative assumptions may cause risks to be significantly overestimated. However, such a deliberate, conservative approach ensures that public health and environmental risks are not underestimated and allows prioritization of future work to minimize potential risks.

Historical underground nuclear testing activities, particularly detonations near or below the water table, have contaminated groundwater near testing locations with radioactive and nonradioactive constituents. Tritium was selected as the contaminant of primary concern for this phase of the project because it is abundant, highly mobile, and represents the most significant contributor to the potential radiation dose to humans for the short term. It was also assumed that the predicted risk to human health and the environment from tritium exposure would reasonably represent the risk from other, less mobile radionuclides within the same time frame. Other contaminants will be investigated at a later date.

Existing and newly collected hydrogeologic data were compiled for a large area of southern Nevada and California, encompassing the Nevada Test Site regional groundwater flow system. These data were used to develop numerical groundwater flow and tritium transport models for use in the prediction of tritium concentrations at hypothetical human and ecological receptor locations for a 200-year time frame.

A numerical, steady-state regional groundwater flow model was developed to serve as the basis for the prediction of the movement of tritium from the underground testing areas on a regional scale. The groundwater flow model was used in conjunction with a particle-tracking code to define the pathlines followed by groundwater particles originating from 415 points associated with 253 nuclear test locations. Three of the most rapid pathlines were selected for transport simulations. These pathlines are associated with three nuclear test locations, each representing one of the three largest testing areas. These testing locations are: BOURBON on Yucca Flat, HOUSTON on Central Pahute Mesa, and TYBO on Western Pahute Mesa. 
One-dimensional stochastic tritium transport simulations were performed for the three pathlines using the Monte Carlo method with Latin hypercube sampling. For the BOURBON and TYBO pathlines, sources of tritium from other tests located along the same pathline were included in the simulations. Sensitivity analyses were also performed on the transport model to evaluate the uncertainties associated with the geologic model, the rates of groundwater flow, the tritium source, and the transport parameters.

Tritium concentration predictions were found to be mostly sensitive to the regional geology in controlling the horizontal and vertical position of transport pathways. The simulated concentrations are also sensitive to matrix diffusion, an important mechanism governing the migration of tritium in fractured carbonate and volcanic rocks. Source term concentration uncertainty is most important near the test locations and decreases in importance as the travel distance increases. The uncertainty on groundwater flow rates is as important as that on matrix diffusion at downgradient locations.

The risk assessment was performed to provide conservative and bounding estimates of the potential risks to human health and the environment from tritium in groundwater. Risk models were designed by coupling scenario-specific tritium intake with tritium dose models and cancer and genetic risk estimates using the Monte Carlo method. Estimated radiation doses received by individuals from chronic exposure to tritium, and the corresponding human health risks at hypothetical point-of-use locations along each of the pathlines were calculated for six potential land-use scenarios. Conservative land-use scenarios were postulated to ensure that the calculated exposures would bound any realistic dose received by individuals.

Based on the human-health risk estimates, tritium exposures associated with the HOUSTON and BOURBON pathlines do not present a human health hazard off the Nevada Test Site in the present, the near term, or in the future. However, the estimates show that the TYBO pathline has the greatest potential for off-site release with a projected groundwater discharge at Oasis Valley. Using the most conservative scenario for tritium exposure demonstrates that dose could exceed the 100-mrem/yr limit at locations along the TYBO pathline. However, the risk predictions for the TYBO pathline are not supported by results from the current environmental monitoring network. Water samples from the Oasis Valley springs and wells, west and south of Pahute 
Mesa, do not show tritium is present in levels above background. These monitoring results confirm the premise that the conservative modeling approach was likely to overestimate tritium transport. Results also indicate that ecological risks due to tritium exposure are not anticipated to occur outside of federal lands. 


\section{Table of Contents}

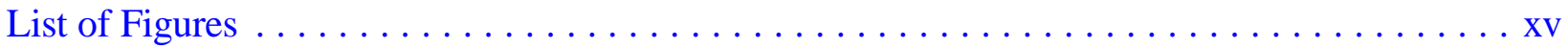

List of Plates $\ldots \ldots \ldots \ldots \ldots \ldots \ldots \ldots \ldots \ldots \ldots \ldots \ldots \ldots \ldots \ldots \ldots \ldots \ldots \ldots \ldots \ldots i i$

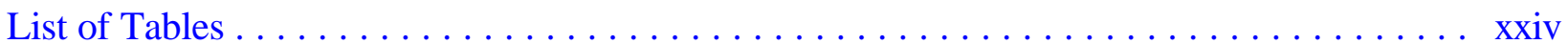

List of Acronyms and Abbreviations $\ldots \ldots \ldots \ldots \ldots \ldots \ldots \ldots \ldots \ldots \ldots \ldots \ldots \ldots \ldots$

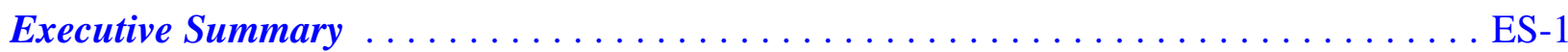

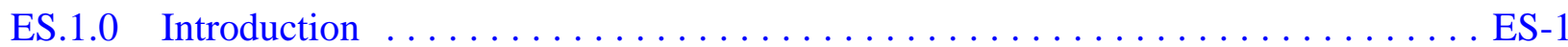

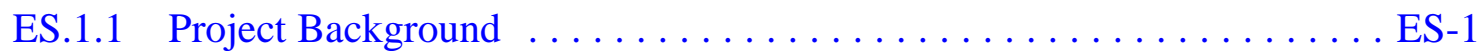

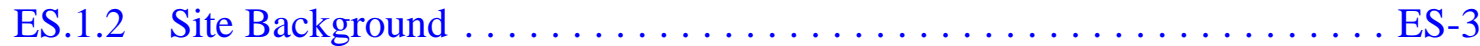

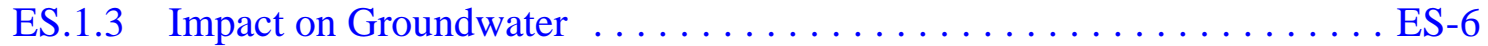

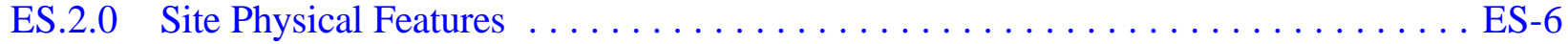

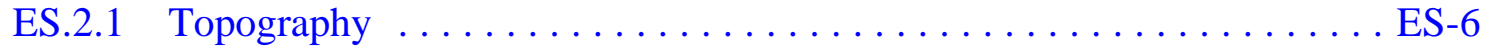

ES.2.2 Climate .............................

ES.2.3 Surface Hydrology $\ldots \ldots \ldots \ldots \ldots \ldots \ldots \ldots \ldots \ldots \ldots \ldots \ldots \ldots$

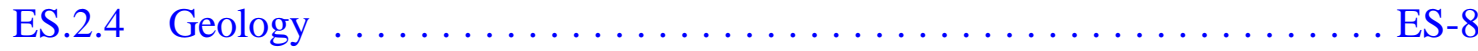

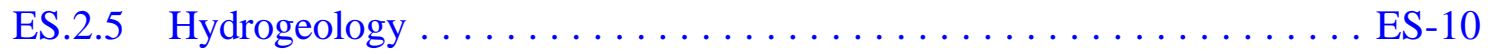

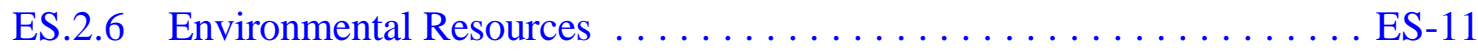

ES.2.7 Land Use . . . . . . . . . . . . . . . . . . . . ES-13

ES.2.8 Demography . . . . . . . . . . . . . . . . . . ES-13

ES.2.9 Archaeological and Historical Resources . . . . . . . . . . . . . ES-13

ES.3.0 Technical Approach $\ldots \ldots \ldots \ldots \ldots \ldots \ldots \ldots \ldots \ldots \ldots \ldots \ldots \ldots \ldots$. . . . . . . . . . . . . . . . .

ES.4.0 Conceptual Regional Groundwater Flow Model . . . . . . . . . . . . . . . . . ES-16

ES.4.1 Groundwater Flow System Extent . . . . . . . . . . . . . . . . ES-16 


\section{Table of Contents (Continued)}

ES.4.2 Hydrogeologic Framework . . . . . . . . . . . . . . . . . ES-16

ES.4.3 Groundwater Occurrence and Movement ................. ES-19

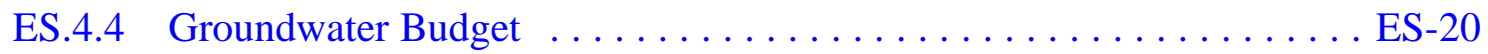

ES.5.0 Numerical Regional Groundwater Flow Model $\ldots \ldots \ldots \ldots \ldots \ldots \ldots \ldots$ ES-21

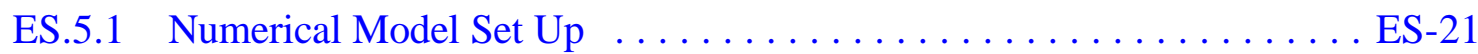

ES.5.2 Model Calibration . . . . . . . . . . . . . . . . . . . . . . . . ES-22

ES.5.3 Groundwater Flowpath Identification $\ldots \ldots \ldots \ldots \ldots \ldots \ldots \ldots$ ES-23

ES.5.4 Sensitivity Analyses . . . . . . . . . . . . . . . . . . . . . . . ES-23

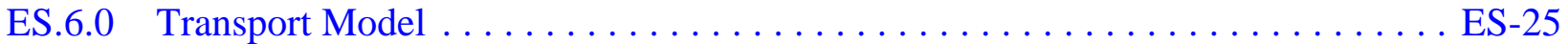

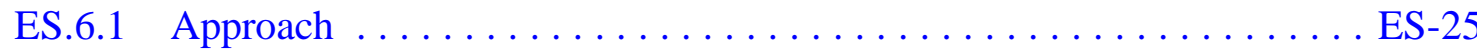

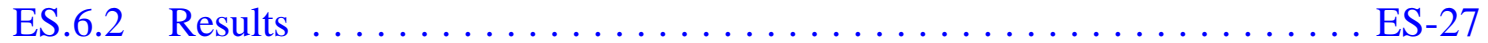

ES.7.0 Risk Assessment . . . . . . . . . . . . . . . . . . . . . . . . ES-29

ES.7.1 Approach ................................. ES-30

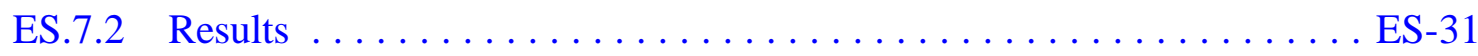

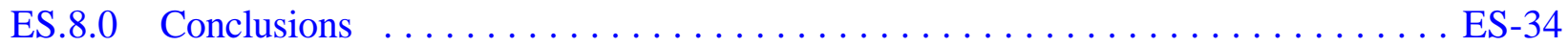

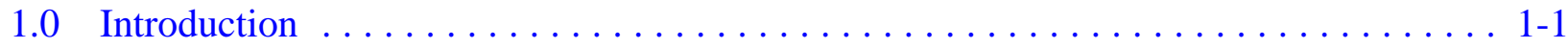

1.1 Project Background $\ldots \ldots \ldots \ldots \ldots \ldots \ldots \ldots \ldots \ldots \ldots \ldots \ldots \ldots \ldots \ldots \ldots \ldots \ldots \ldots \ldots \ldots \ldots, 1-1$

1.2 Site Background $\ldots \ldots \ldots \ldots \ldots \ldots \ldots \ldots \ldots \ldots \ldots \ldots \ldots \ldots \ldots \ldots \ldots \ldots \ldots, 2$

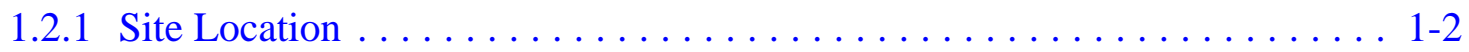

1.2.2 History of Operations $\ldots \ldots \ldots \ldots \ldots \ldots \ldots \ldots \ldots \ldots \ldots \ldots \ldots \ldots \ldots \ldots \ldots \ldots, 2$

1.2.3 Underground Nuclear Testing $\ldots \ldots \ldots \ldots \ldots \ldots \ldots \ldots \ldots \ldots \ldots \ldots \ldots \ldots$

1.2.4 Impact on Groundwater . . . . . . . . . . . . . . . . . . . . 1-6

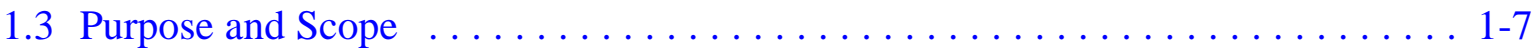

1.4 Regional Evaluation Completion Process ........................ 1-7

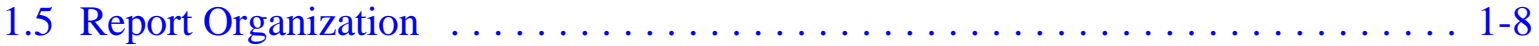

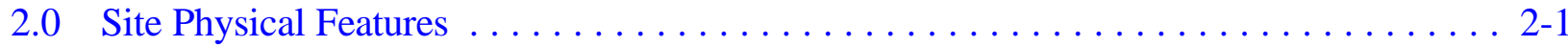

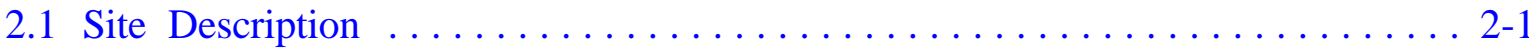




\section{Table of Contents (Continued)}

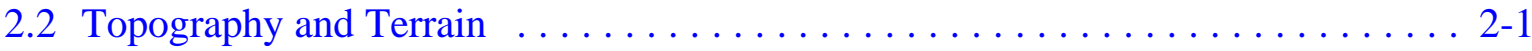

2.3 Climate and Meteorology ............................... 2-4

2.4 Surface Hydrology . . . . . . . . . . . . . . . . . . . . . . . . . . . 2 2-5

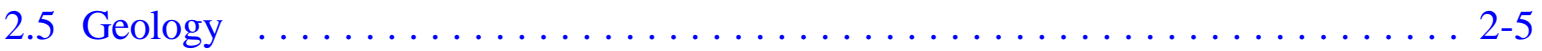

2.5.1 Precambrian and Paleozoic $\ldots \ldots \ldots \ldots \ldots \ldots \ldots \ldots \ldots \ldots \ldots \ldots \ldots$

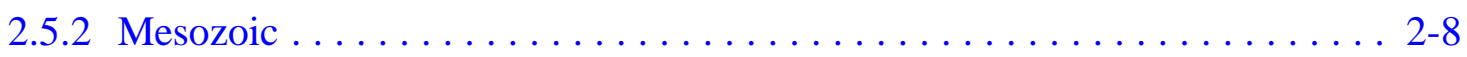

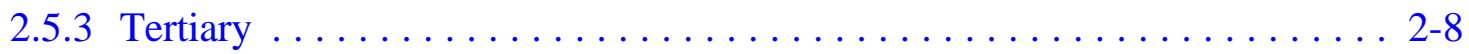

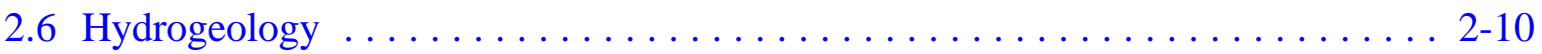

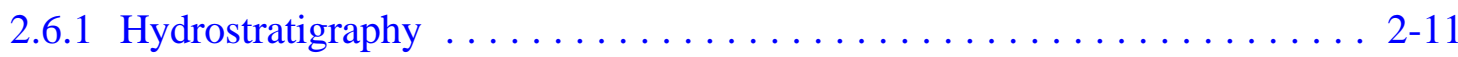

2.6.2 Groundwater Occurrence and Movement . . . . . . . . . . . . . . . 2-11

2.6.3 Groundwater Radiological Monitoring . . . . . . . . . . . . . . . . 2-14

2.7 Environmental Resources . . . . . . . . . . . . . . . . . . . . . . . . . . . . 2 2-16

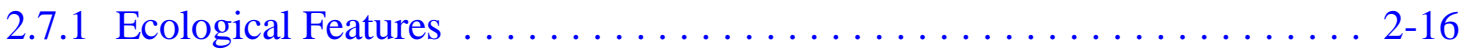

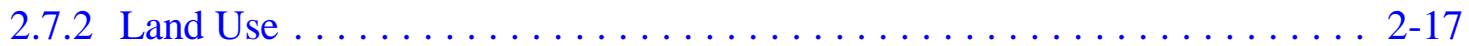

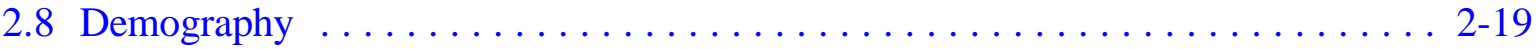

2.9 Archaeological and Historical Resources $\ldots \ldots \ldots \ldots \ldots \ldots \ldots \ldots \ldots \ldots . .2-21$

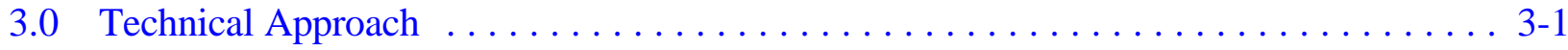

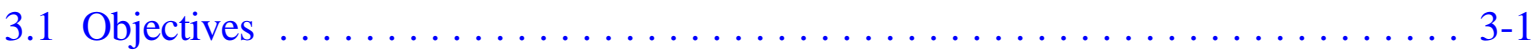

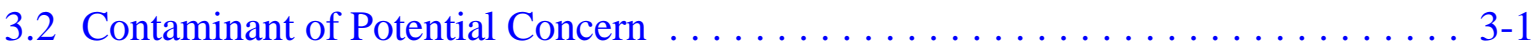

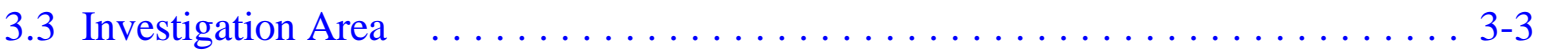

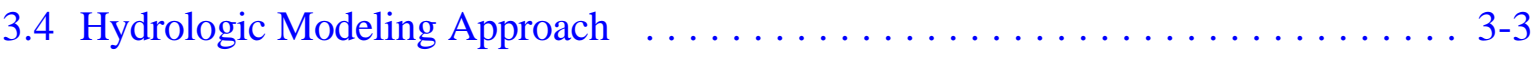

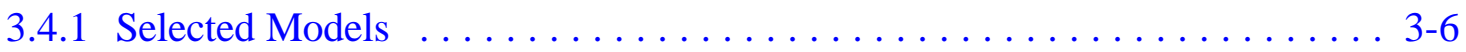

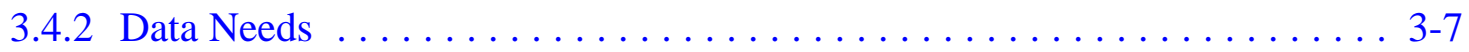

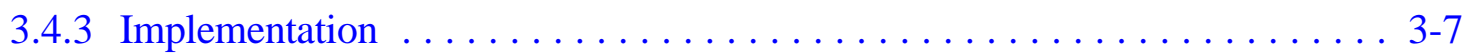

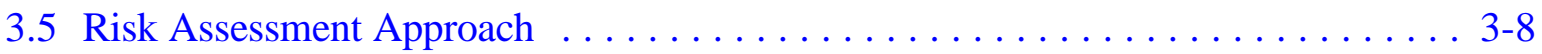

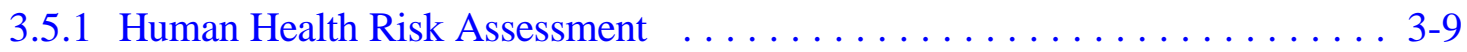

3.5.2 Ecological Risk Assessment $\ldots \ldots \ldots \ldots \ldots \ldots \ldots \ldots \ldots$. . . . . . . . . . . . . .

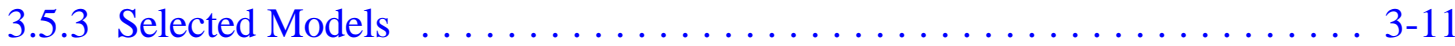

3.5.4 Data Needs .................................... 3-12

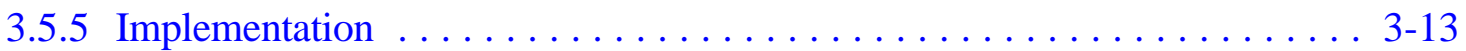

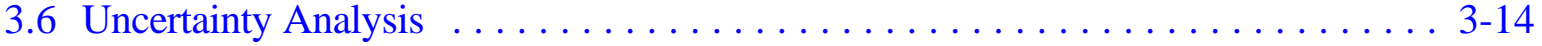




\section{Table of Contents (Continued)}

4.0 Geologic Data Analysis . . . . . . . . . . . . . . . . . . . . 4-1

4.1 Geologic Model Domain . . . . . . . . . . . . . . . . . . . . 4-1

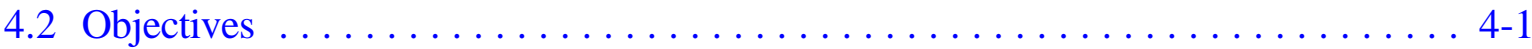

4.3 Approach Overview . . . . . . . . . . . . . . . . . . . . . .

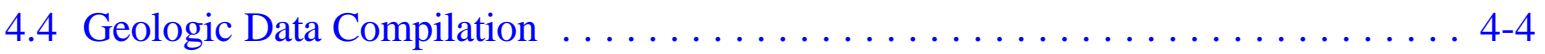

4.5 Conceptual Geologic Model Development . . . . . . . . . . . . . . . . 4-5

4.5.1 Stratigraphic Cross Section Construction . . . . . . . . . . . . . . . 4-5

4.5.2 Hydrostratigraphic Unit Definition . . . . . . . . . . . . . . . 4-5

4.5.3 Hydrostratigraphic Cross Section Development . . . . . . . . . . . . . 4-10

4.6 Digital Geologic Model Development . . . . . . . . . . . . . . . . . . . 4-10

4.6.1 Data Integration into $\mathrm{ERMA}^{\circledR} \ldots \ldots \ldots \ldots \ldots \ldots \ldots \ldots \ldots$. . . . . . . . . .

4.6.2 Construction of Surface Contour Maps . . . . . . . . . . . . . . . 4-11

4.6.3 Gridding of Contoured Surfaces $\ldots \ldots \ldots \ldots \ldots \ldots \ldots \ldots$. . . . . . . . .

4.6.4 Map Products . . . . . . . . . . . . . . . . . . . . . . . . 4-13

4.7 Geologic Uncertainty and Model Revisions $\ldots \ldots \ldots \ldots \ldots \ldots \ldots \ldots$. . . . . . . . . .

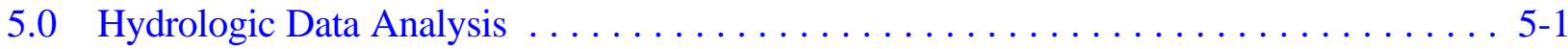

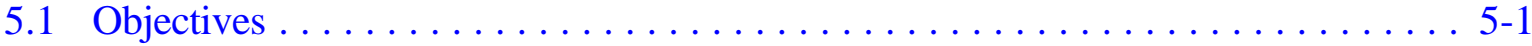

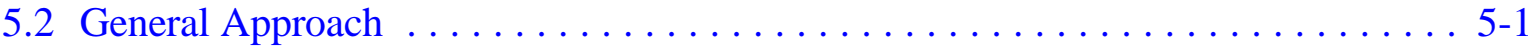

5.3 Data Types . . . . . . . . . . . . . . . . . . . . . . . .

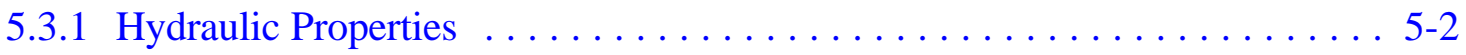

5.3 .2 Water-Levels . . . . . . . . . . . . . . . . . . . 5-2

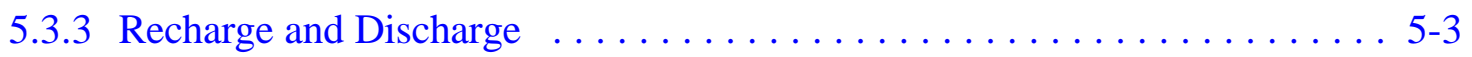

5.4 Data Sources . . . . . . . . . . . . . . . . . . . . . . 5-4

5.5 Hydraulic Properties . . . . . . . . . . . . . . . . . . . . . 5-4

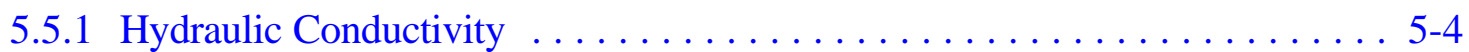

5.5.1.1 Data Compilation and Evaluation .............. 5-4

5.5.1.2 Tested Interval . . . . . . . . . . . . . . . . . . . . 5-7

5.5.1.3 Hydrostratigraphic Unit Assignment . . . . . . . . . . . . . 5-8

5.5.1.4 Statistical Analysis . . . . . . . . . . . . . . . 5-8

5.5.1.5 Distribution of Hydraulic Conductivity with Depth . . . . . . . . 5-9

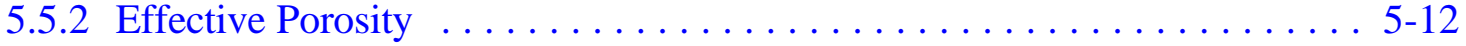

5.5.2.1 Porosity Data From Tracer Migration Studies . . . . . . . . . . 5 5-12 


\section{Table of Contents (Continued)}

5.5.2.2 Fracture Porosity ......................... 5-14

5.5.2.3 Summary of Porosity Data $\ldots \ldots \ldots \ldots \ldots \ldots \ldots \ldots \ldots . \ldots \ldots \ldots$

5.6 Water Levels ................................... 5-15

5.6.1 Data Compilation and Evaluation .................... 5-16

5.6.2 Identification of Predevelopment Hydraulic Heads . . . . . . . . . . . . . 5-17

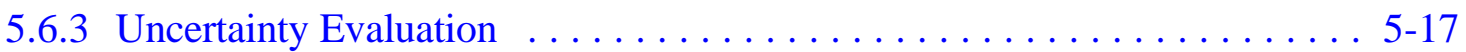

5.6 .4 Site Hydrostratigraphic Unit Definition $\ldots \ldots \ldots \ldots \ldots \ldots \ldots \ldots .5-20$

5.6.5 Dataset and Map Generation ......................... 5-21

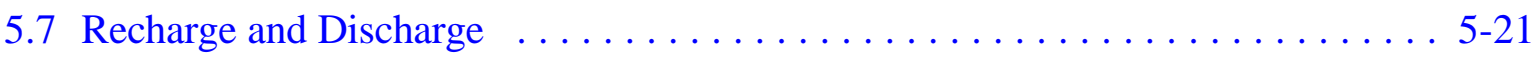

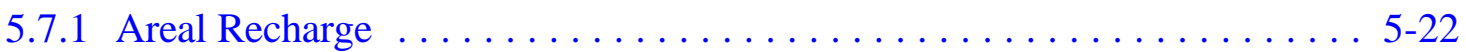

5.7.1.1 Maxey-Eakin Method $\ldots \ldots \ldots \ldots \ldots \ldots \ldots \ldots \ldots . \ldots \ldots$ 5-22

5.7.1.2 Modified ME Method ........................ 5-24

5.7.1.2.1 Precipitation ..................... 5-24

5.7.1.2.2 Preliminary Recharge Distribution .......... 5-25

5.7.1.2.3 Recharge Allocation .................... 5-26

5.7 .2 Discharge ............................... 5-30

5.7.2.1 Spring Discharge $\ldots \ldots \ldots \ldots \ldots \ldots \ldots \ldots \ldots \ldots \ldots . \ldots \ldots$

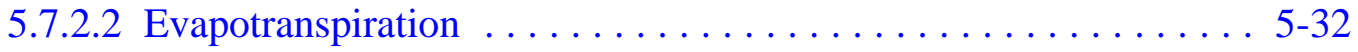

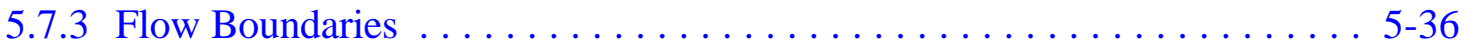

6.0 Conceptual Groundwater Flow Model $\ldots \ldots \ldots \ldots \ldots \ldots \ldots \ldots \ldots \ldots .6 .6 .1$

6.1 Groundwater Flow System Boundary $\ldots \ldots \ldots \ldots \ldots \ldots \ldots \ldots \ldots \ldots \ldots \ldots . \ldots \ldots \ldots \ldots$

6.2 Regional Groundwater Flow System $\ldots \ldots \ldots \ldots \ldots \ldots \ldots \ldots \ldots \ldots \ldots \ldots \ldots \ldots \ldots \ldots .2$

6.2 .1 Hydrogeologic Framework $\ldots \ldots \ldots \ldots \ldots \ldots \ldots \ldots \ldots \ldots \ldots \ldots \ldots \ldots .2$

6.2.1.1 General Features .......................... 6-2

6.2.1.1.1 East of the NTS ................... 6-5

6.2.1.1.2 North of the NTS . . . . . . . . . . . . . . 6-5

6.2.1.1.3 West of the NTS $\ldots \ldots \ldots \ldots \ldots \ldots \ldots .6 .6$

6.2.1.1.4 Amargosa Desert and Death Valley Areas ......... 6-10

6.2 .2 Regional Groundwater Flow $\ldots \ldots \ldots \ldots \ldots \ldots \ldots \ldots \ldots \ldots .6 .6 .12$

6.2.2.1 Groundwater Occurrence and Movement ............. 6-14

6.2.2.2 Recharge Estimates ........................ 6-15

6.2.2.3 Discharge Estimates ........................ 6-15 


\section{Table of Contents (Continued)}

6.2.2.4 Boundary Fluxes $\ldots \ldots \ldots \ldots \ldots \ldots \ldots \ldots \ldots \ldots .6 .16$

6.2.2.5 Groundwater Budget $\ldots \ldots \ldots \ldots \ldots \ldots \ldots \ldots \ldots .6 .6 \ldots \ldots$

6.3 Groundwater Flow System at the NTS and Vicinity $\ldots \ldots \ldots \ldots \ldots \ldots .6-17$

6.3 .1 Hydrogeologic Framework . . . . . . . . . . . . . . . . . 6-18

6.3 .1 .1 Yucca Flat and Vicinity $\ldots \ldots \ldots \ldots \ldots \ldots \ldots \ldots \ldots . \ldots \ldots . \ldots \ldots$

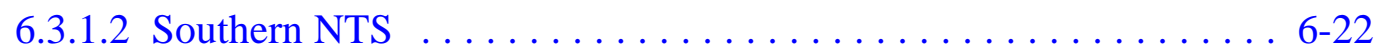

6.3.1.3 Pahute Mesa/Timber Mountain Caldera Complex ........... 6-24

6.3.2 Groundwater Occurrence and Movement $\ldots \ldots \ldots \ldots \ldots \ldots .6 .25$

6.3 .2 .1 Yucca Flat .......................... 6-27

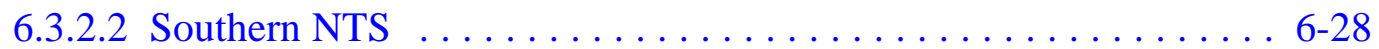

6.3.2.3 Pahute Mesa/Timber Mountain Caldera Complex . . . . . . . . . . . . 6-29

6.4 Conceptual Model Uncertainties . . . . . . . . . . . . . . . . . . . . . . 6-30

6.4.1 Geologic Model Uncertainties . . . . . . . . . . . . . . . . . . . . . 6 6-30

6.4.2 Hydrologic Uncertainties . . . . . . . . . . . . . . . . . . . . . . . 6-31

7.0 Numerical Groundwater Flow Model $\ldots \ldots \ldots \ldots \ldots \ldots \ldots \ldots \ldots \ldots .7-1$

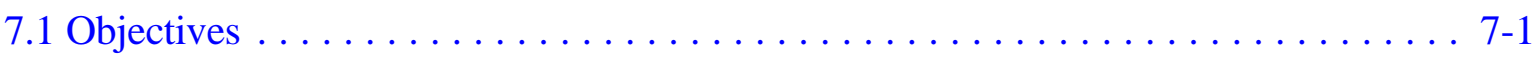

7.2 Modeling Approach $\ldots \ldots \ldots \ldots \ldots \ldots \ldots \ldots \ldots \ldots \ldots \ldots \ldots \ldots \ldots \ldots \ldots \ldots, 3$

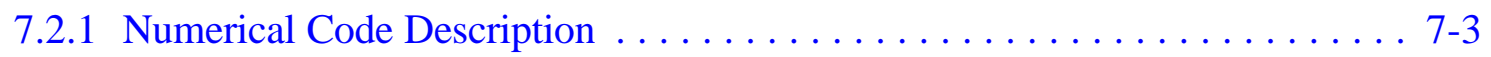

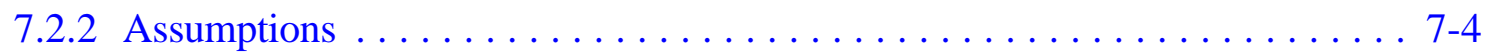

7.2.3 Modeling Data Requirements $\ldots \ldots \ldots \ldots \ldots \ldots \ldots \ldots \ldots \ldots . \ldots \ldots .4$

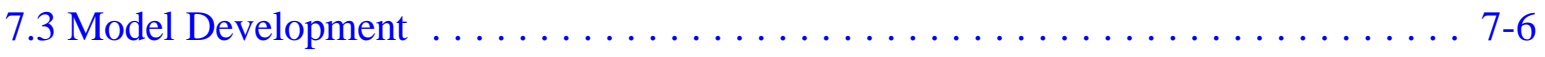

7.3.1 Model Boundaries . . . . . . . . . . . . . . . . . . . . . 7-6

7.3.2 Model Discretization . . . . . . . . . . . . . . . . . . . . 7-7

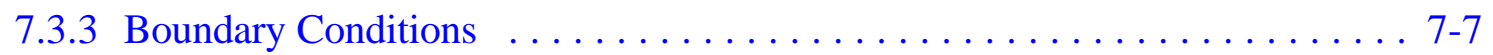

7.3.3.1 Recharge Package $\ldots . \ldots \ldots \ldots \ldots \ldots \ldots \ldots \ldots \ldots . . \ldots \ldots .13$

7.3.3.2 General-Head Boundary Package $\ldots \ldots \ldots \ldots \ldots \ldots \ldots \ldots . \ldots \ldots$

7.3.3.3 Well Package .......................... 7-15

7.3.3.4 Drain Package $\ldots . \ldots \ldots \ldots \ldots \ldots \ldots \ldots \ldots \ldots . \ldots . \ldots \ldots$

7.3.4 Hydraulic Conductivity and Vertical Conductance Calculations ......... 7-18

7.3.4.1 Hydraulic Conductivity Parameters . . . . . . . . . . . . . 7-19

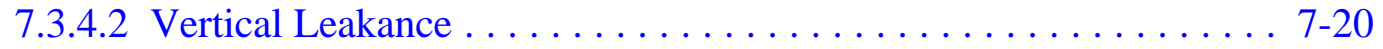




\section{Table of Contents (Continued)}

7.4 Calibration Process .................................... 7-20

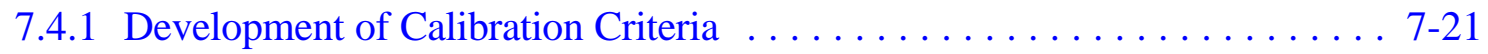

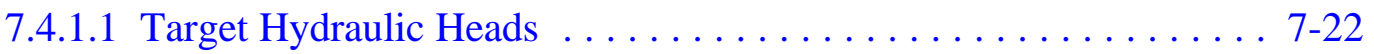

7.4.1.2 Hydraulic Head Residuals ...................... 7-23

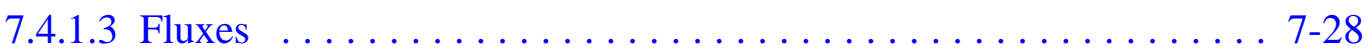

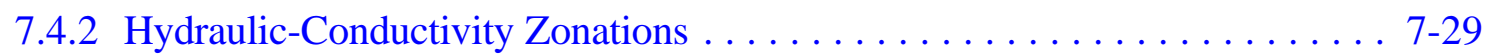

7.5 Flow Model Results and Sensitivity Analyses . . . . . . . . . . . . . . . 7-40

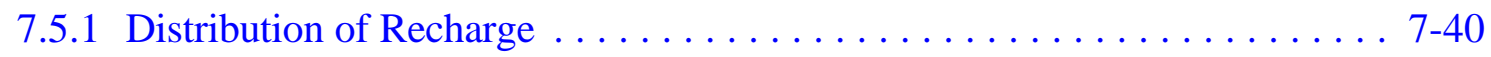

7.5.2 Hydraulic Parameters . . . . . . . . . . . . . . . . . . . . . . . . . . . 7-41

7.5.3 Hydraulic-Head and Residual Distributions . . . . . . . . . . . . . 7-53

7.5.3.1 Hydraulic-Head Distributions ..................... 7-53

7.5.3.2 Head Residual Distributions by Zone $\ldots \ldots \ldots \ldots \ldots \ldots$ 7-61

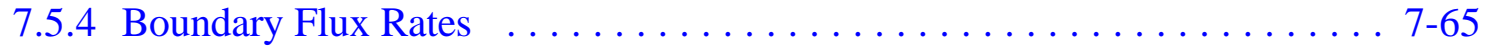

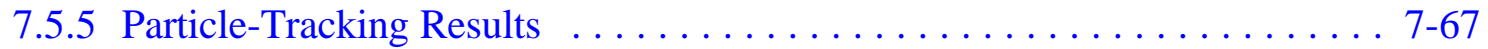

7.5.6 Sensitivity Analyses . . . . . . . . . . . . . . . . . . . . . . . . . . . 7-74

7.5.6.1 Special-Case Sensitivity Analyses $\ldots \ldots \ldots \ldots \ldots \ldots \ldots .7 .74$

7.5.6.1.1 Geologic Model Interpretations ............. 7-75

7.5.6.1.2 Evaluation of Recharge Estimates . . . . . . . . . 7 7-80

7.5.6.1.3 Hydraulic Conductivity ..................... 7-84

7.5.6.1.4 Summary of Special-Case Sensitivity Analyses ....... 7-85

7.5.6.2 Sensitivity Analyses of Hydraulic Parameters . . . . . . . . . . . 7-86

7.5.6.3 Particle-Tracking Results for Hydraulic

Parameter Sensitivities . . . . . . . . . . . . . . . . . . 7 7-88

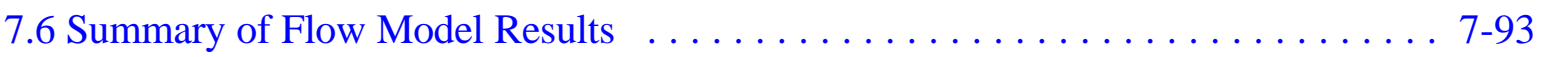

7.6.1 Model Design ................................. 7-94

7.6.2 Model Calibration ............................... 7-95

7.6.3 Particle Tracking . . . . . . . . . . . . . . . . . . . . . . . .

7.6.4 Sensitivity Analysis . . . . . . . . . . . . . . . . . . . . . . 7-96

8.0 Transport Parameters and Source Term $\ldots \ldots \ldots \ldots \ldots \ldots \ldots \ldots \ldots . . \ldots \ldots \ldots$

8.1 Objectives $\ldots \ldots \ldots \ldots \ldots \ldots \ldots \ldots \ldots \ldots \ldots \ldots \ldots \ldots \ldots \ldots \ldots .1$

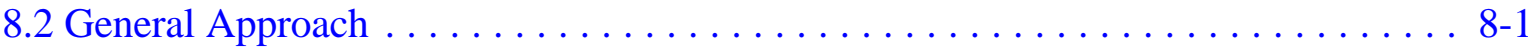

8.3 Data Types $\ldots \ldots \ldots \ldots \ldots \ldots \ldots \ldots \ldots \ldots \ldots \ldots \ldots \ldots, 2$ 


\section{Table of Contents (Continued)}

8.4 Data Sources $\ldots \ldots \ldots \ldots \ldots \ldots \ldots \ldots \ldots \ldots \ldots \ldots \ldots . \ldots, 3$

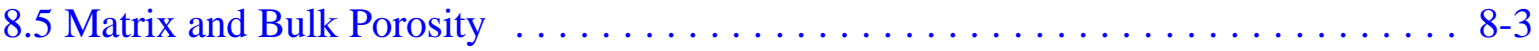

8.5.1 Data Compilation and Evaluation $\ldots \ldots \ldots \ldots \ldots \ldots \ldots \ldots \ldots . \ldots \ldots$

8.5.2 Data Analysis . . . . . . . . . . . . . . . . . . . . . 8 8-4

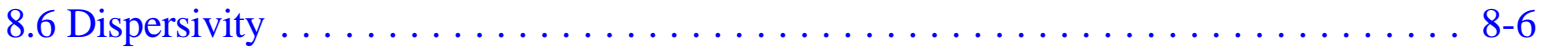

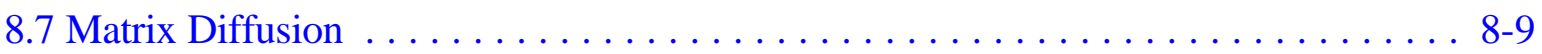

8.8 Tritium Source Term . . . . . . . . . . . . . . . . . . . . . . . . . . 8-10

8.8.1 Data Compilation and Evaluation $\ldots \ldots \ldots \ldots \ldots \ldots \ldots \ldots \ldots . \ldots \ldots \ldots$

8.8.2 Data Analysis . . . . . . . . . . . . . . . . . . . . . . . . . . . . 8 8-11

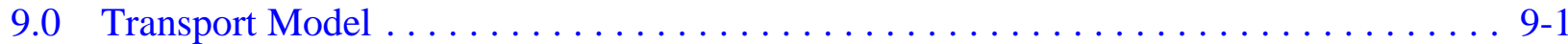

9.1 Objectives $\ldots \ldots \ldots \ldots \ldots \ldots \ldots \ldots \ldots \ldots \ldots \ldots \ldots \ldots \ldots \ldots . \ldots . \ldots . \ldots \ldots$

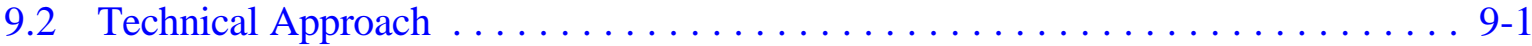

9.2.1 General Approach ................................ 9-2

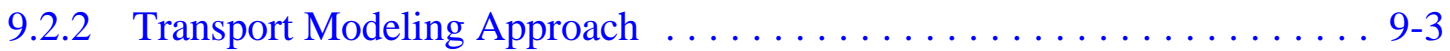

9.2.3 Data Requirements ............................. 9-5

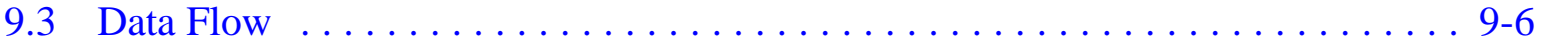

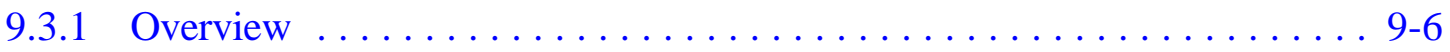

9.3.2 Selection of Particle Starting Locations ................. 9-7

9.3 .3 MODPATH Simulations $\ldots \ldots \ldots \ldots \ldots \ldots \ldots \ldots \ldots \ldots \ldots . .6 .7$

9.3.4 Identification of Hydrostratigraphic Units along a Pathline .......... 9-7

9.3.5 Calculation of Advective Velocity along a Flow Path ........... 9-10

9.3.6 Selection of Starting Locations for Regional Modeling . . . . . . . . . 9-12

9.3.7 Evaluation of Upgradient and Downgradient Nuclear Tests Along the Same Pathline . . . . . . . . . . . . . . . . . . . . . . . . . . . . . . 9-12

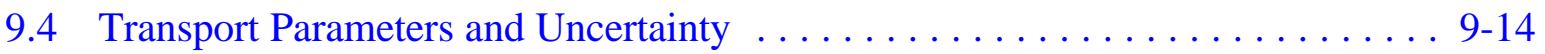

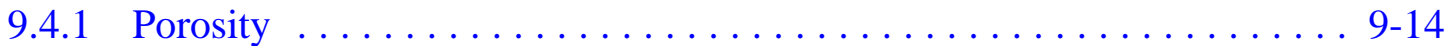

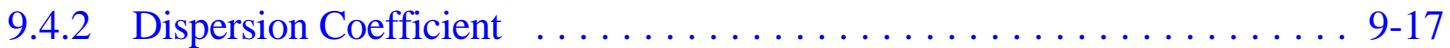

9.4 .3 Advective Velocity . . . . . . . . . . . . . . . . . . . . 9-18

9.4.4 Diffusion Coefficient ............................. 9-19

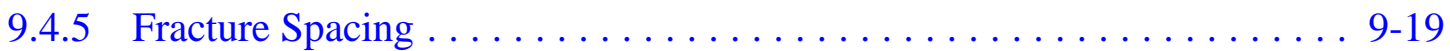

9.4.6 Initial Tritium Concentrations $\ldots \ldots \ldots \ldots \ldots \ldots \ldots \ldots \ldots \ldots . . \ldots 9.20$ 


\section{Table of Contents (Continued)}

9.4.7 Correlation of Parameters . . . . . . . . . . . . . . . . . . . . . 9-21

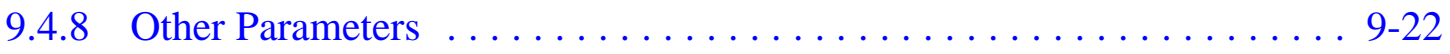

9.5 Transport Calculations $\ldots \ldots \ldots \ldots \ldots \ldots \ldots \ldots \ldots \ldots \ldots \ldots \ldots \ldots \ldots \ldots \ldots \ldots \ldots .22$

9.5.1 Pathlines ................................ 9-22

9.5.2 Tritium Transport Simulations - General . . . . . . . . . . . . . 9-26

9.5.3 Tritium Transport Simulations - BOURBON (Yucca Flat) . . . . . . . 9-27

9.5.4 Tritium Transport Simulations - HOUSTON (Central Pahute Mesa) . . . 9-38

9.5.5 Tritium Transport Simulations - TYBO (Western Pahute Mesa) ...... 9-41

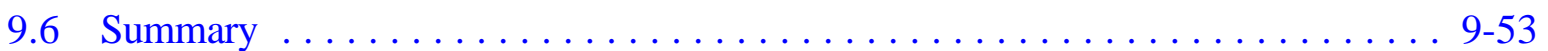

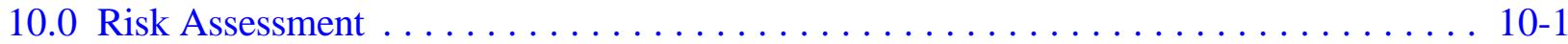

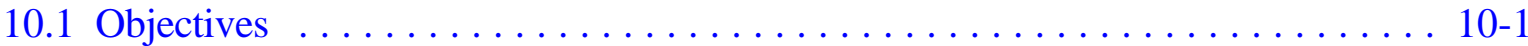

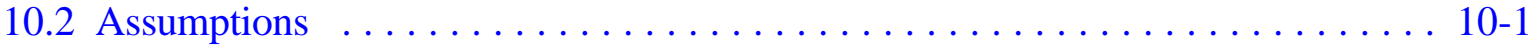

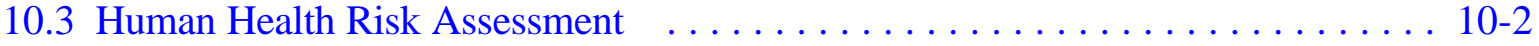

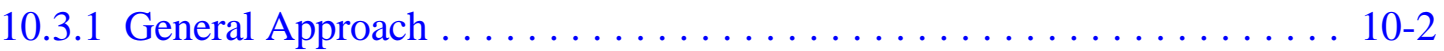

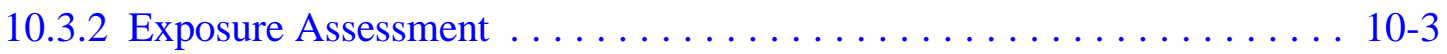

10.3.2.1 Land Use Scenarios $\ldots \ldots \ldots \ldots \ldots \ldots \ldots \ldots \ldots . \ldots \ldots$ 10-3

10.3.2.2 Exposure Scenarios ...................... 10-4

10.3.2.2.1 Calculation of Tritium Concentrations . . . . . . . 10-4

10.3.2.2.2 Calculation of Intakes $\ldots \ldots \ldots \ldots \ldots \ldots$ 10-7

10.3.3 Dose Assessment . . . . . . . . . . . . . . . . . . . . . . . . 10-9

10.3.3.1 Dose Assessment Approach . . . . . . . . . . . . . . . . . . 10 10 9

10.3.3.2 Dose Assessment Results . . . . . . . . . . . . . . . . . . . 10-11

10.3.3.2.1 BOURBON Pathline . . . . . . . . . . . . . . . . 10-11

10.3.3.2.2 HOUSTON Pathline . . . . . . . . . . . . . . . . . 10-12

10.3.3.2.3 TYBO Pathline . ................... 10-13

10.3.4 Risk Characterization .......................... 10-14

10.3.4.1 Risk Characterization Approach ................. 10-15

10.3.4.2 Risk Characterization Results . ............... 10-15

10.3.4.2.1 BOURBON Pathline .................. 10-15

10.3.4.2.2 HOUSTON Pathline $\ldots \ldots \ldots \ldots \ldots \ldots . . \ldots 10-20$

10.3.4.2.3 TYBO Pathline . .................. 10-21

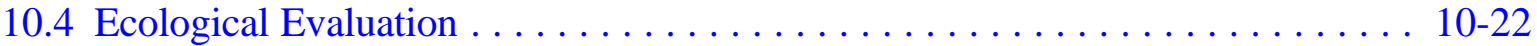




\section{Table of Contents (Continued)}

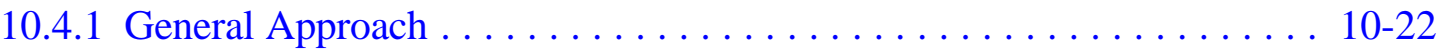

10.4.2 Problem Formulation $\ldots \ldots \ldots \ldots \ldots \ldots \ldots \ldots \ldots \ldots \ldots \ldots \ldots$

10.4.2.1 Study Site Identification . . . . . . . . . . . . . . . 10-24

10.4.2.2 Exposure Pathways ...................... 10-27

10.4.2.3 Endpoints ........................... 10-28

10.4.3 Exposure Assessment . . . . . . . . . . . . . . . . . . . . . . . . 10-29

10.4.4 Effect Assessment ............................. 10-29

10.4.5 Ecological Risk Evaluation ..................... 10-31

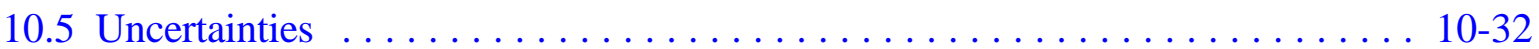

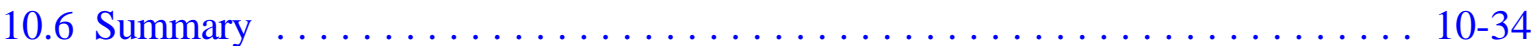

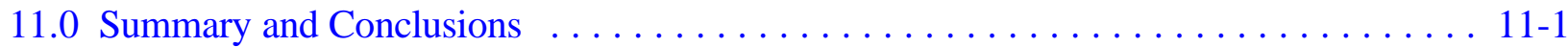

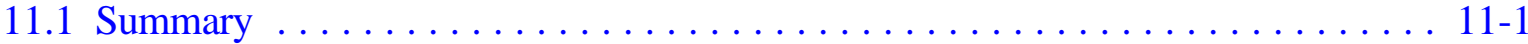

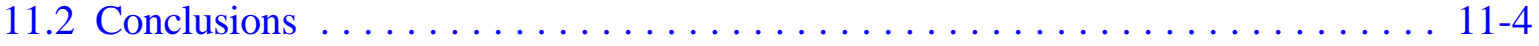

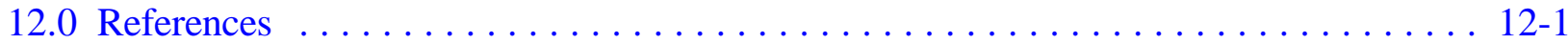

Appendix A - Quality Control .................................... A-1

Appendix B - Comparison of Simulated and Observed Hydraulic Heads . . . . . . . . . . . . B-1

Appendix C - Numerical Groundwater Flow Model Sensitivity Analysis Results . . . . . . . C-1 


\section{List of Figures}

Number

Title

Page

ES-1 Area of Investigation Location Map $\ldots \ldots \ldots \ldots \ldots \ldots \ldots \ldots \ldots . \ldots \ldots$ ES-2

ES-2 Location of Underground Test Areas and Testing Locations . . . . . . . . . . E ES-5

ES-3 Topographic Features of the Nevada Test Site and Vicinity $\ldots \ldots \ldots \ldots \ldots$ ES-7

ES-4 Schematic North-South Cross Section across the NTS Region $\ldots . . \ldots \ldots \ldots$ ES-9

ES-5 Groundwater Flow within the Nevada Test Site and Vicinity $\ldots \ldots \ldots \ldots$ ES-12

ES-6 Nevada Test Site Regional Groundwater Flow System . . . . . . . . . . . . . ES-17

ES-7 Groundwater Pathlines from Selected Testing Locations . ............. ES-28

1-1 Location of the Nevada Test Site $\ldots \ldots \ldots \ldots \ldots \ldots \ldots \ldots \ldots \ldots \ldots \ldots \ldots$

1-2 Location of Underground Test Areas and Testing Locations ............. 1-5

1-3 Report Organization ............................... 1-9

2-1 Nevada Test Site Area Designations, Principal Facilities, and Testing Areas . . . . 2-2

2-2 Topographic Features of the Nevada Test Site and Vicinity $\ldots \ldots \ldots \ldots \ldots$ 2-3

2-3 Localized Surface Drainage Basins Around the Nevada Test Site $\ldots . . \ldots \ldots$. 2-6

2-4 Locations of Springs at the Nevada Test Site .................. 2-7

2-5 Groundwater Flow within the Nevada Test Site and Vicinity .......... 2-13 


\section{List of Figures (Continued)}

Number

Title

Page

2-6 Long-Term Hydrologic Monitoring Program Off-Site Locations $\ldots . . . \ldots .2-15$

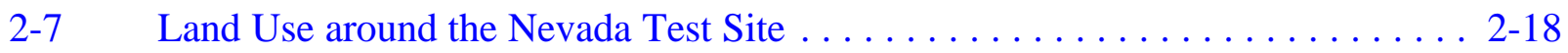

2-8 Population Distribution in Counties Surrounding the Nevada Test Site . . . . . 2-20

3-1 Hydrologic Modeling and Risk Assessment Process . . . . . . . . . . . . . . 3-2

3-2 Area of Investigation Location Map $\ldots \ldots \ldots \ldots \ldots \ldots \ldots \ldots \ldots \ldots \ldots \ldots \ldots \ldots \ldots$

4-1 Area of the Geologic Model Surrounding the NTS . . . . . . . . . . . . 4-2

4-2 Areas of Volcanic Hydrostratigraphic Differentiation ................. 4-8

4-3 Aerial View of the LCCU Grid Surface: Viewed from the Southeast ...... . 4-14

5-1 Relation Between Hydraulic Conductivity and Depth for Tests in the Alluvial Aquifer, Volcanic Rocks, and the Lower Carbonate Aquifer ................. 5-11

5-2 Hydrograph Example Showing Stable and Unstable Trends $\ldots \ldots \ldots \ldots \ldots$ 5-18

5-3 Recharge Redistribution Areas in the Vicinity of the Nevada Test Site . . . . . 5-27

5-4 Location of Springs and Evapotranspiration Areas in the Nevada Test Site Region $\ldots \ldots \ldots \ldots \ldots \ldots \ldots \ldots \ldots \ldots \ldots \ldots \ldots . \ldots \ldots . \ldots \ldots$

6-1 Surficial Hydrogeologic Map of the NTS Region and NTS Regional Groundwater Flow System Boundary $\ldots \ldots \ldots \ldots \ldots \ldots \ldots \ldots \ldots \ldots \ldots \ldots \ldots$

6-2 Four East-West Cross Section Panels Showing the NTS and Area to the East: Aerial View from the Southeast $\ldots \ldots \ldots \ldots \ldots \ldots \ldots \ldots \ldots \ldots .6,6$ 


\section{List of Figures (Continued)}

Number

Title

Page

6-3 East-West Cross Section Panels of the Area North of the NTS:

Aerial View from the Southeast $\ldots \ldots \ldots \ldots \ldots \ldots \ldots \ldots \ldots \ldots .6 .7$

6-4 East-West Cross Sections Across the NTS and the Area West of the NTS:

Aerial View from the Southwest ....................... 6-9

6-5 Southwest-Northeast Cross Section from Death Valley to the Halfpint Range:

Aerial View from the Southeast $\ldots \ldots \ldots \ldots \ldots \ldots \ldots \ldots \ldots . \ldots \ldots . \ldots \ldots$

6-6 Southwest-Northeast Cross Section from Death Valley to the Mercury Ridge:

Aerial View from the Southeast $\ldots \ldots \ldots \ldots \ldots \ldots \ldots \ldots \ldots . \ldots .6 .13$

6-7 East-West Cross Section of North-Central Yucca Flat: Aerial View

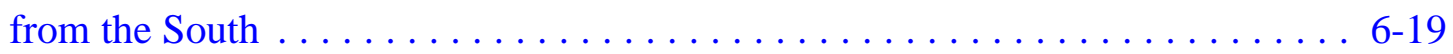

6-8 East-West Cross Section North of Yucca Flat: Aerial View from the South . . . 6 6-21

6-9 North-South Cross Section Along the Western Boundary of the NTS:

Aerial View from the Southeast $\ldots \ldots \ldots \ldots \ldots \ldots \ldots \ldots \ldots . \ldots . \ldots .23$

6-10 Southwest-Northeast Cross Section from the Amargosa Desert Across

Pahute Mesa: Aerial View from the Southeast . . . . . . . . . . . . 6-26

$7-1 \quad$ Location of Model Area Boundary and Grid $\ldots \ldots \ldots \ldots \ldots \ldots \ldots \ldots \ldots$

$7-2 \quad$ Relationship of HSUs to Model Layers . . . . . . . . . . . . . . . . 7-9

7-3 Location of Active, Inactive and Boundary Condition Cells $\ldots \ldots \ldots \ldots \ldots$ 7-12

7-4 Distribution of Residual Zones for the NTS Model $\ldots \ldots \ldots \ldots \ldots \ldots \ldots$ 7-25 


\section{List of Figures (Continued)}

Number

Title

Page

7-5 Distribution of Conductivity for the LCA Hydrostratigraphic Unit $\ldots \ldots \ldots \ldots$ 7-30

7-6 Distribution of Conductivity Zones for the AA Hydrostratigraphic Unit . . . . 7-31

7-7 Distribution of Conductivity Zones for the TMA, TC, TCB, TBA, BCU,

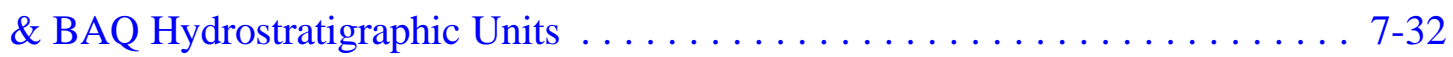

7-8 Distribution of Conductivity Zones for the VA Hydrostratigraphic Unit .... . 7-33

7-9 Distribution of Conductivity Zones for the LCCU Hydrostratigraphic Unit . . . . 7-34

7-10 Distribution of Conductivity Zones for the VCU Hydrostratigraphic Unit . . . . 7 7-35

7-11 Distribution of Conductivity Zones for the VU Hydrostratigraphic Unit . . . . . 7-36

7-12 Distribution of Conductivity Zones for the TSDV Hydrostratigraphic Unit . . . . 7-37

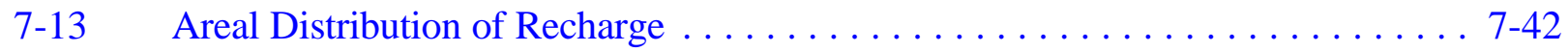

7-14 Relationship of Hydraulic Conductivity to Depth for Alluvial Aquifers . . . . . 7 7-45

7-15 Relationship of Hydraulic Conductivity to Depth for Volcanic Aquifers and Confining

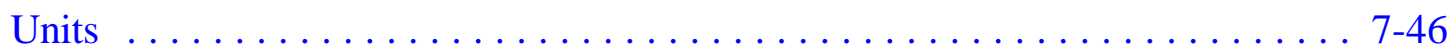

7-16 Relationship of Hydraulic Conductivity to Depth for the LCA $\ldots \ldots \ldots \ldots$.

$7-17$ Distribution of the HSUs for Model Layer $8 \ldots \ldots \ldots \ldots \ldots \ldots \ldots \ldots \ldots$ 7-50

7-18 Distribution of Transmissivity for Model Layer $8 \ldots \ldots \ldots \ldots \ldots \ldots \ldots$ 7-51

7-19 Log Leakance Values for Active Model Cells in Model Layer 8 . . . . . . . . 7-52 


\section{List of Figures (Continued)}

Number

Title

Page

7-20 Elevation of the Simulated Water Table for the Calibrated Model . . . . . . . . . 7-54

$7-21 \quad$ Simulated Heads for Model Layer $5 \ldots \ldots \ldots \ldots \ldots \ldots \ldots \ldots \ldots \ldots \ldots \ldots \ldots \ldots \ldots \ldots$

$7-22 \quad$ Simulated Heads for Model Layer $7 \ldots \ldots \ldots \ldots \ldots \ldots \ldots \ldots \ldots \ldots \ldots \ldots \ldots \ldots$

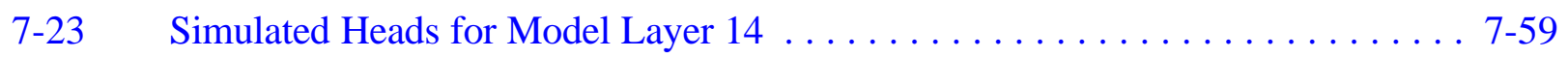

7-24 Simulated Heads from the Calibrated Model versus Observed Heads . . . . . . . 7-62

7-25 Particle Pathlines from Fourteen Testing Locations . . . . . . . . . . . . 7-69

7-26 Locations of Particles After 25 Years (Western Pahute Mesa Shots) and 100 Years (All Others) for the Base Case and the Hydraulic Parameter Sensitivity Runs . . 7-90

9-1 Illustration of a Nuclear Shot Below the Water Table $\ldots \ldots \ldots \ldots \ldots \ldots$. . .

9-2 Illustration of a Pathline Segment Through a Flow Model Cell . . . . . . . . . . 9-9

9-3 Groundwater Pathlines from Nuclear Test Locations Below the Water Table for a $200-$ Year Period . . . . . . . . . . . . . . . . . . . . . . . .

9-4 Groundwater Pathlines, from Source to Receptor, Chosen for Transport

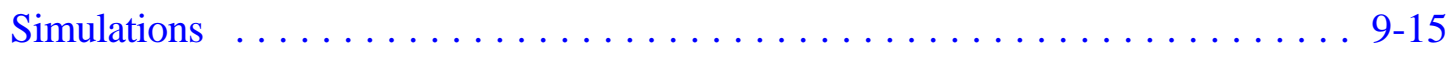

9-5 Geologic Model Cross-Section Along the BOURBON Pathline $\ldots . . \ldots \ldots$. $9-23$

9-6 Geologic Model Cross-Section Along the HOUSTON Pathline . . . . . . . . . 9-24

9-7 Geologic Model Cross-Section Along the TYBO Pathline $\ldots \ldots \ldots \ldots \ldots$. . . . . 


\section{List of Figures (Continued)}

Number

Title

Page

9-8 Concentration Contours Along the Pathline for KANKAKEE, BOURBON, and MICKEY/TORRIDO (Tritium in Matrix and Fractures) . . . . . . . . . 9 9-29

9-9 Histogram of Tritium Concentration for All Realizations for the 30-Year Period Around the Maximum Concentration at the 95 percent Level ............ 9-31

9-10 Cumulative Density of Maximum Tritium Concentration at a Distance of $1 \mathrm{~km}$ Along the Pathline Originating at BOURBON for Variation of Individual Parameters . . . . . . . . . . . . . . . . . . . . . . .

9-11 Cumulative Density of Maximum Tritium Concentration at a Distance of $10 \mathrm{~km}$ Along the Pathline Originating at BOURBON for Variation of Individual Parameters .......................... 9-34

9-12 Cumulative Density of Maximum Tritium Concentration at a Distance of $20 \mathrm{~km}$ Along the Pathline Originating at BOURBON for Variation of Individual Parameters ................................ 9-35

9-13 Results of Varying BOURBON Conceptual Model at the 95 Percent Level . . . 9-37

9-14 Concentration Contours Along the HOUSTON Pathline (Tritium in Matrix and Fractures)

9-15 Histogram of Tritium Concentration for All Realizations for the 30-Year Period Around the Maximum Concentration at the 95 percent Level

9-16 Cumulative Density of Maximum Tritium Concentration at a Distance of $1 \mathrm{~km}$ Along the Pathline Originating at HOUSTON for a Variation of Individual Parameters 


\section{List of Figures (Continued)}

Number

Title

Page

9-17 Cumulative Density of Maximum Tritium Concentration at a Distance of $5 \mathrm{~km}$ Along the Pathline Originating at HOUSTON for a Variation of Individual Parameters . . . . . . . . . . . . . . . . . . . .

9-18 Cumulative Density of Maximum Tritium Concentration at a Distance of $20 \mathrm{~km}$ Along the Pathline Originating at HOUSTON for a Variation of

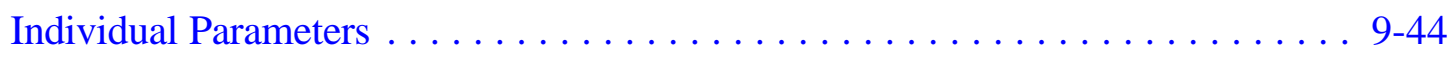

9-19 Concentration Contours Along the HOUSTON Pathline - Initial Tritium in

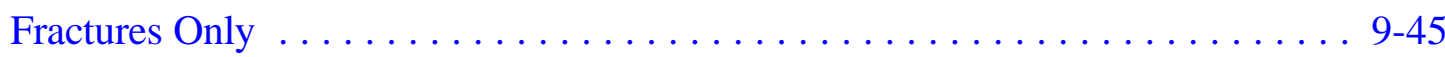

9-20 Concentration Contours Along the Pathline for PEPATO, KASH, and TYBO

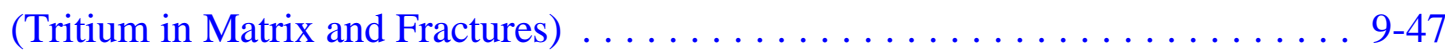

9-21 Histogram of Tritium Concentration for All 200 Realizations for the 30-Year Period Around the Maximum Concentration at the 95 Percent Level ....... . 9-48

9-22 Cumulative Density of Maximum Tritium Concentration at a Distance of $1 \mathrm{~km}$ Along the Pathline Originating at TYBO for Variation of Individual Parameters . . . . . . . . . . . . . . . . . . . . . . . 9 9-49

9-23 Cumulative Density of Maximum Tritium Concentration at a Distance of $10 \mathrm{~km}$ Along the Pathline Originating at TYBO for Variation of Individual Parameters ........................... 9-50

9-24 Cumulative Density of Maximum Tritium Concentration at a Distance of $30 \mathrm{~km}$ Along the Pathline Originating at TYBO for Variation of Individual Parameters 


\section{List of Figures (Continued)}

Number

9-25 Comparison of Concentration Contours Along the TYBO Pathline Base Case and Tritium Source in Fractures at the 95 Percent Level . . . . . . . . . . . . 9-52

10-1 Simplified Ecological Exposure Pathway Model . . . . . . . . . . . . . . . 10-25 


\section{List of Plates}

Plate 1 - Precipitation Map for the Nevada Test Site Region

Plate 2 - Distribution of Groundwater Recharge in the Nevada Test Site Region, Using Maxey-Eakin Coefficients

Plate 3 - Predevelopment Regional Water-Level Map

Plate 4 - Study Area Basemap

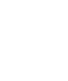




\section{List of Tables}

Number

Title

Page

ES-1 Range of Hydraulic Parameters for Major Aquifers . . . . . . . . . . . ES-18

ES-2 Peak Tritium Concentrations At Selected Locations

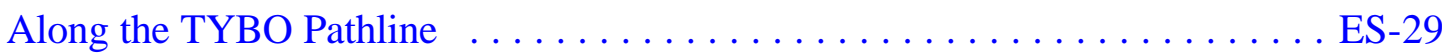

ES-3 Maximum Simulated Distances of Regulatory Limits and Guidelines

Along the BOURBON Pathline $\ldots \ldots \ldots \ldots \ldots \ldots \ldots \ldots \ldots \ldots \ldots \ldots \ldots \ldots$

ES-4 Maximum Simulated Distances of Regulatory Limits and Guidelines

Along the HOUSTON Pathline $\ldots \ldots \ldots \ldots \ldots \ldots \ldots \ldots \ldots \ldots \ldots \ldots . \ldots \ldots$

ES-5 Maximum Downgradient Locations of Regulatory Limits and Guidelines

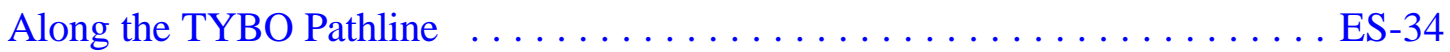

2-1 Pre-Tertiary Stratigraphic Correlation/Death Valley Drainage Basin ......... 2-9

2-2 Tertiary Stratigraphy of the NTS Region $\ldots \ldots \ldots \ldots \ldots \ldots \ldots \ldots \ldots \ldots \ldots$

4-1 Volcanic Hydrostratigraphy of the Southern NTS/Yucca Mountain Area . . . . . 4 4-7

4-2 Hydrostratigraphy of the Pahute Mesa/Timber Mountain Caldera Complex . . . . 4-7

4-3 Hydrostratigraphic Units/Geologic Model Layers . . . . . . . . . . . . . . . . . 4-9

5-1 Hydraulic Conductivity Summary Statistics Based on Well Averages

(Variable is $\log [\mathrm{K}]$ with $\mathrm{K}$ in meters per day) $\ldots \ldots \ldots \ldots \ldots \ldots \ldots \ldots \ldots \ldots$

5-2 Hydraulic Conductivity Decay Coefficients with Depth .............. 5-13

5-3 Effective Porosity Obtained From Tracer Migration Experiments ........ 5 5-13 


\section{List of Tables (Continued)}

5-4 Fracture Porosity Obtained from the Study of Volcanic Core . . . . . . . . . . 5-14

5-5 Precipitation Zones and Corresponding Coefficients for the ME Method .... 5-22

5-6 Areas of Potential Recharge Redistribution in the Nevada Test Site Region . . . 5-28

6-1 Range of Hydraulic Parameters for Major Aquifers . . . . . . . . . . . . 6-4

6-2 ET Discharge Data for the NTS Regional Groundwater Flow System . . . . . . 6 6-16

6-3 Estimated Rates of Groundwater Inflow/Outflow for

Boundaries of the NTS Regional Groundwater Flow System .......... 6-17

6-4 Estimated Steady-State Groundwater Budget

for the NTS Regional Groundwater Flow System . . . . . . . . . . . 6-17

7-1 Elevations of Model Layers (Top to Bottom of Model) $\ldots \ldots \ldots \ldots \ldots$. . . .

7-2 Calculation of Model Recharge Rate Based on Model Area

Discharge Estimate ............................ 7-14

7-3 Recharge Redistribution in Seven Hydrographic Areas in the Vicinity

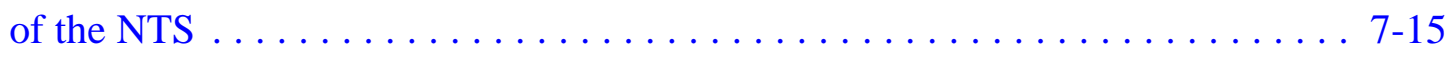

7-4 Estimated and Target Ranges

in Discharge Fluxes for Eight Discharge Areas .................. 7-19

7-5 Calibration Criteria for Weighted Hydraulic-Head Residuals by Zone . . . . . . 7-26

7-6 Comparison of Maxey-Eakin Coefficients and Coefficients Used

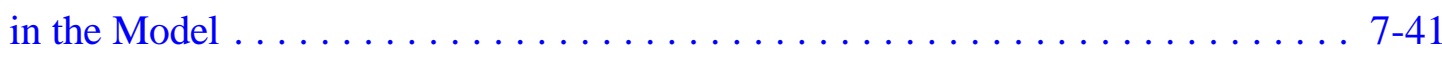




\section{List of Tables (Continued)}

7-7 Final Hydraulic Parameters for the NTS Flow Model

7-8 Summary Statistics for Hydraulic-Head Residuals by Zone . . . . . . . . . . . 7-64

7-9 Hydraulic Head Values used in the GHB and Well Package $\ldots \ldots \ldots \ldots$. $7-65$

7-10 Comparison of Target and Simulated Boundary Fluxes ............. 7-66

7-11 Estimated 25-Year (Western Pahute Mesa) and 100-Year (all Others)

Particle Travel Distances Derived from Calibrated Model .............. 7-70

7-12 Change in Hydraulic-Head Residuals and Boundary Fluxes

Due to Different Geologic Model Interpretations $\ldots \ldots \ldots \ldots \ldots \ldots \ldots$. 7-76

7-13 Change in Hydraulic Head Residuals and Boundary Fluxes

Due to Recharge Distributions and Subsurface Inflow $\ldots \ldots \ldots \ldots \ldots \ldots$ 7-77

7-14 Change in Hydraulic Head Residuals and Boundary

Fluxes Due to Large Changes in Hydraulic Conductivities $\ldots \ldots \ldots \ldots \ldots$. 7-78

7-15 Conductivity Parameters that Caused More than a 10\% Change in the

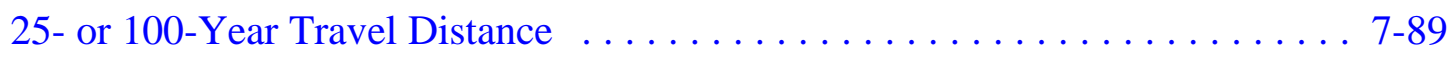

$8-1 \quad$ Statistical Summary of Porosity $\ldots \ldots \ldots \ldots \ldots \ldots \ldots \ldots \ldots \ldots \ldots \ldots \ldots \ldots \ldots \ldots \ldots$

8-2 Summary of Porosity Data for Major Hydrostratigraphic Units as Compared to Work by Others $\ldots \ldots \ldots \ldots \ldots \ldots \ldots \ldots \ldots \ldots \ldots \ldots$

8-3 Longitudinal Dispersivity Information Summary $\ldots \ldots \ldots \ldots \ldots \ldots \ldots$ 8-7

8-4 Matrix Diffusion Coefficients for Tritium in the Welded Tuff Aquifer . . . . . . 8-10 


\section{List of Tables (Continued)}

9-1 Effective Porosity Values for Each Hydrostratigraphic Unit used to Calculate Travel Times Along Pathlines . . . . . . . . . . . . 9-11

9-2 Porosity Data and Uncertainty for Each HSU $\ldots \ldots \ldots \ldots \ldots \ldots \ldots \ldots$ 9-16

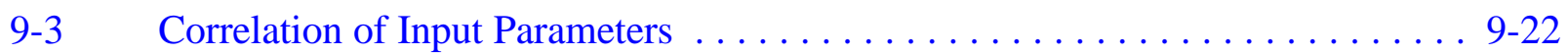

9-4 Approximate Distances Beyond Which Tritium Concentration Does Not Exceed 20,000 pCi/L . . . . . . . . . . . . . . . . . 9-54

10-1 Land-Use Scenarios and Receptors Considered in the Human Health Risk Assessment . . . . . . . . . . . . . . . . . . . . 10-4

10-2 Estimated Dose for Potential Agricultural Scenario at the Nevada Test Site . . 10-12

10-3 Estimated Dose for Potential Residential Scenario at the Nevada Test Site . . . 10-13

10-4 Estimated Risk for Potential Agricultural Adult Scenario at the

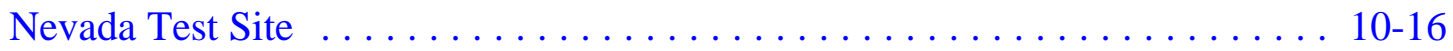

10-5 Estimated Risk for Potential Agricultural Child Scenario at the Nevada Test Site . . . . . . . . . . . . . . . . . . . . . . . . . . . 10-17

10-6 Estimated Risk for Potential Residential Adult Scenario at the

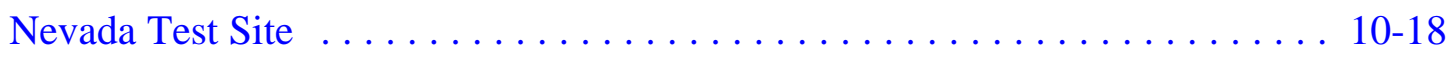

10-7 Estimated Risk for Potential Residential Child Scenario at the

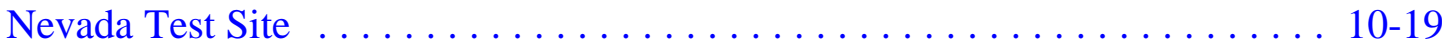




\section{List of Acronyms and Abbreviations}

\begin{tabular}{|c|c|}
\hline AFB & Air Force Base \\
\hline amsl & Average mean sea level \\
\hline $\mathrm{BN}$ & Bechtel Nevada \\
\hline BRT & Belted Range Thrust \\
\hline$\lambda$ & Lambda or conductivity decay coefficient \\
\hline $\mathrm{cm}^{2} / \mathrm{s}$ & Square centimeters per second \\
\hline${ }^{\circ} \mathrm{C}$ & Degree (s) Centigrade \\
\hline${ }^{\circ} \mathrm{F}$ & Degree(s) Fahrenheit \\
\hline$\%$ & Percent \\
\hline${ }^{235} \mathrm{U}$ & Uranium \\
\hline${ }^{239} \mathrm{Pu}$ & Plutonium \\
\hline $1-\mathrm{D}$ & One-dimensional \\
\hline $3-\mathrm{D}$ & Three-dimensional \\
\hline AA & Alluvial Aquifer \\
\hline $\mathrm{ac}-\mathrm{ft} / \mathrm{y}$ & Acre-feet per year \\
\hline $\mathrm{AF}$ & Alkali Flat \\
\hline $\mathrm{AM}$ & Ash Meadows \\
\hline Ariv or AR & Amargosa River \\
\hline ASTM & American Society for Testing and Materials \\
\hline $\mathrm{B}$ & Bottom \\
\hline BAQ & Basal Aquifer \\
\hline BARR & Barrier \\
\hline $\mathrm{BCF}$ & Block-centered flow \\
\hline $\mathrm{BCU}$ & Basal Confining Unit \\
\hline BLM & Bureau of Land Management \\
\hline $\mathrm{CAB}$ & Citizens Advisory Board \\
\hline C.I. & Confidence Interval \\
\hline $\mathrm{cm}$ & Centimeter(s) \\
\hline $\mathrm{cm} / \mathrm{d}$ & Centimeter(s) per day \\
\hline $\mathrm{cm} / \mathrm{yr}$ & Centimeter(s) per year \\
\hline $\mathrm{CP}$ & Control Point \\
\hline DCF & Dose conversion factor \\
\hline
\end{tabular}




\section{List of Acronyms and Abbreviations (Continued)}

\begin{tabular}{|c|c|}
\hline DEM & Digital Elevation Model \\
\hline DNA & Deoxyribonucleic acid \\
\hline DoD & U.S. Department of Defense \\
\hline DOE & U.S. Department Energy \\
\hline $\mathrm{DOE} / \mathrm{NV}$ & U.S. Department of Energy, Nevada Operations Office \\
\hline DTW & Depth to water \\
\hline DV or DVal & Death Valley \\
\hline DVS & Death Valley Section \\
\hline EM & Eagle Mountain \\
\hline EMSL-LV & Environmental Monitoring Systems Laboratory, Las Vegas, Nevada \\
\hline EOI & Effective open interval \\
\hline EPA & U.S. Environmental Protection Agency \\
\hline ER & Environmental Restoration \\
\hline ERDA & U.S. Environmental Research and Development Administration \\
\hline ERDBMS & Environmental Restoration Data Base Management System \\
\hline $\mathrm{ERMA}^{\circledR}$ & Environmental Resource Management Applications \\
\hline ERP & Environmental Restoration Program \\
\hline ET & Evapotranspiration \\
\hline EYF & Eastern Yucca Flat \\
\hline FARM & Amargosa Farm \\
\hline $\mathrm{FF}$ & Frenchman Flat \\
\hline FFACO & Federal Facility Agreement \& Consent Order \\
\hline $\mathrm{FL}$ & Franklin Lake \\
\hline $\mathrm{ft}$ & Foot (feet) \\
\hline $\mathrm{ft} / \mathrm{d}$ & Foot (feet) per day \\
\hline $\mathrm{ft}^{2} / \mathrm{s}$ & Square feet per second \\
\hline $\mathrm{ft}^{2} / \mathrm{yr}$ & Square feet per year \\
\hline $\mathrm{ft}^{3} / \mathrm{s}$ & Cubic foot per second \\
\hline $\mathrm{ft} / \mathrm{yr}$ & Foot (feet) per year \\
\hline $\mathrm{ft}^{2}$ & Square foot (feet) \\
\hline FWS & U.S. Fish and Wildlife Service \\
\hline g & $\operatorname{Gram}(\mathrm{s})$ \\
\hline
\end{tabular}




\section{List of Acronyms and Abbreviations (Continued)}

\begin{tabular}{|c|c|}
\hline GHB & General Head Boundary \\
\hline GIS & Geographic Information System \\
\hline $\mathrm{gal} / \mathrm{min}$ & Gallon(s) per minute \\
\hline gpd & Gallons per day \\
\hline GWSI & Groundwater Site Inventory \\
\hline Gy & Gray \\
\hline $\mathrm{H}$ & Hydrogen \\
\hline HA & Hydrographic areas \\
\hline HSU & Hydrostratigraphic unit(s) \\
\hline I & Intrusives \\
\hline IAEA & International Atomic Energy Agency \\
\hline ICRP & International Commission on Radiation Protection \\
\hline in. & $\operatorname{Inch}(\mathrm{es})$ \\
\hline in./d & Inch(es) per day \\
\hline INEL & Idaho National Engineering Laboratory \\
\hline IS & Indian Springs \\
\hline IT & IT Corporation \\
\hline $\mathrm{J}$ & Joule \\
\hline $\mathrm{K}$ & Hydraulic conductivity calculation \\
\hline $\mathrm{keV}$ & Kiloelectron volts \\
\hline $\mathrm{kg}$ & Kilogram(s) \\
\hline $\mathrm{kg} / \mathrm{d}$ & Kilogram(s) per day \\
\hline $\mathrm{K}_{\mathrm{h}}$ & Horizontal hydraulic conductivity calculation \\
\hline $\mathrm{km}$ & Kilometer(s) \\
\hline $\mathrm{km} / \mathrm{hr}$ & Kilometer(s) per hour \\
\hline $\mathrm{km}^{2}$ & Square kilometer(s) \\
\hline $\mathrm{K}_{\mathrm{vg}}$ & Vertical hydraulic conductivity calculation \\
\hline $\mathrm{L} / \mathrm{d}$ & Liter(s) per day \\
\hline $\mathrm{L} / \mathrm{s}$ & Liter(s) per second \\
\hline LANL & Los Alamos National Laboratory \\
\hline $\mathrm{lbs} / \mathrm{d}$ & Pounds per day \\
\hline LCA & Lower Carbonate Aquifer \\
\hline
\end{tabular}




\section{List of Acronyms and Abbreviations (Continued)}

LCA1

LCA2

LCA3

LCCU

LCCU1

LCCU2

$\mathrm{LCF}$

LD

LLNL

LSE

LTHMP

LVVSC

$\mathrm{m}$

$\mathrm{m} / \mathrm{d}$

$\mathrm{m} / \mathrm{y}$

$\mathrm{m}^{2}$

$\mathrm{m}^{2} / \mathrm{yr}$

$\mathrm{m}^{3}$

$\mathrm{m}^{3} / \mathrm{d}$

$\mathrm{m}^{3} / \mathrm{s}$

MCL

MCLG

ME

$\mathrm{MeV}$

mi

$\mathrm{mi}^{2}$

mph

$\mathrm{mrem} / \mathrm{yr}$

NAFR

NCRP

NDOW

NPS
Lower Carbonate Aquifer-Upper Plate

Lower Carbonate Aquifer-Lower Plate

Lower Carbonate Aquifer-Yucca Flat Upper Plate

Lower Clastic Confining Unit

Lower Clastic Confining Unit - upper plate

Lower Clastic Confining Unit - lower plate

Latent cancer fatality

Lethal dose

Lawrence Livermore National Laboratory

Land surface elevation

Long-Term Hydrological Monitoring Program

Las Vegas Valley Shear Zone

Meter(s)

Meter(s) per day

Meter(s) per year

Square meter(s)

Square meter(s) per year

Cubic meter(s)

Cubic meter(s) per day

Cubic meter(s) per second

Maximum contaminant level

Maximum contaminant level goal(s)

Maxey-Eakin

Megaelectron volt(s)

Mile(s)

Square mile(s)

Miles per hour

Millirem(s) per year

Nellis Air Force Range

National Council on Radiation Protection

Nevada Department of Wildlife

National Park Services 


\section{List of Acronyms and Abbreviations (Continued)}

\begin{tabular}{|c|c|}
\hline NRTH & Northern Area \\
\hline NTS & Nevada Test Site \\
\hline NWIS & National Water Information System \\
\hline OV, OASI & Oasis Valley \\
\hline $\mathrm{oz}$ & Ounce(s) \\
\hline PAHR & West of Pahranagat Valley \\
\hline PCG2 & Preconditioned conjugate - gradient solver \\
\hline $\mathrm{pCi} / \mathrm{L}$ & PicoCurie(s) per liter \\
\hline $\mathrm{pCi} / \mathrm{min}$ & PicoCurie(s) per minute \\
\hline $\mathrm{pCi} / \mathrm{m}^{3}$ & PicoCurie(s) per cubic meter \\
\hline PI & Principle Investigator \\
\hline PM & Pahute Mesa \\
\hline $\mathrm{PP}$ & Pahrump Valley \\
\hline PT & Pahranagat Valley \\
\hline PV & Penoyer Valley \\
\hline QA & Quality Assurance \\
\hline $\mathrm{RD}$ & Radiation detriment \\
\hline $\mathrm{rad} / \mathrm{d}$ & $\operatorname{Rad}(\mathrm{s})$ per day \\
\hline RESRAD & Residual radiation \\
\hline RMS & Root mean square \\
\hline RWMS & Radioactive Waste Management Site \\
\hline SF & Sarcobatus Flat \\
\hline SHON & Shoshone \\
\hline SHRG & Sheep Range \\
\hline SPMT & Spring Mountain \\
\hline SPT & Schuab Peak Thrust \\
\hline SRT & Specter Range Thrust \\
\hline SWNVF & Southwestern Nevada Volcanic Field \\
\hline $\mathrm{T}$ & Transmissivity \\
\hline TBA & Welded Tuff (also Belted Range Aquifer) \\
\hline TBAQ & Welded tuffs above BCU \\
\hline $\mathrm{TC}$ & Tuff cone(s) \\
\hline TCB & Bullfrog Containing Unit (also Non-Welded Tuff) \\
\hline
\end{tabular}




\section{List of Acronyms and Abbreviations (Continued)}

$\begin{array}{ll}\text { TCBCU } & \text { Tuff cone basal confining unit (nonwelded tuffs) } \\ \text { TCI } & \text { Total cancer incident } \\ \text { TCU } & \text { Tuff Confining Unit } \\ \text { TD } & \text { Total depth } \\ \text { TMA } & \text { Timber Mountain Aquifer } \\ \text { TMBR } & \text { Timber Mountain } \\ \text { TMAQ } & \text { Uppermost Welded Tuff(s) (also Timber Mountain Aquifer) } \\ \text { TPTA } & \text { Topopah Spring Tuff Aquifer } \\ \text { TPTC } & \text { Paintbrush Tuff Cone } \\ \text { TS } & \text { Tertiary sediments } \\ \text { TSDVS } & \text { Tertiary Sediments, Death Valley Section } \\ \text { TTR } & \text { Tonopah Test Range } \\ \text { U.S. } & \text { United States } \\ \text { UCCU } & \text { Upper Clastic Confining Unit } \\ \text { UGTA } & \text { Underground Test Area } \\ \text { USGS } & \text { U.S. Geological Survey } \\ \text { UTM } & \text { Universal Transverse Mercator } \\ \text { VA } & \text { Volcanic Aquifer(s) } \\ \text { VCCU } & \text { Volcaniclastic Confining Unit } \\ \text { Vcont } & \text { Vertical leakance value } \\ \text { VCU } & \text { Volcanic Confining Unit(s) } \\ \text { VTA } & \text { Vitric Tuff Aquifer } \\ \text { VU } & \text { Volcanic Undifferentiated } \\ \text { WLA } & \text { Wahmonie Lava Aquifer } \\ \text { WP } & \text { Working point } \\ \text { WPT } & \text { Wheeler Pass Thrust } \\ \text { WT } & \text { Water table } \\ \text { WTA } & \text { Welded Tuff Aquifer } \\ \text { WUSE } & \text { Water Use Database } \\ \text { WYF } & \text { Western Yucca Flat } \\ \text { yr } & \text { Year } \\ \mu & \text { Micrometer } \\ \end{array}$




\section{Executive Summary}

\section{ES.1.0 Introduction}

This Executive Summary is a synopsis of the report entitled, Regional Groundwater Flow and Tritium Transport Modeling and Risk Assessment of the Underground Test Area, Nevada Test Site, Nevada, prepared for the U.S. Department of Energy. The report contains the results of a regional evaluation of the groundwater flow system encompassing the Nevada Test Site and the highest, potential, current and near-term risk to the public and the environment from possible groundwater contamination downgradient of the underground testing areas. The highest potential risk is estimated by assuming that several unusually rapid transport pathways and exposure factors are encountered simultaneously. These conservative assumptions ensure that risk to the public and the environment are not underestimated; however, using this approach may cause risks to be significantly overestimated.

\section{ES.1.1 Project Background}

Various types of underground nuclear tests were conducted at the Nevada Test Site (Figure ES-1) in southern Nevada between 1951 and 1992 by the DOE and the U.S. Department of Defense. These tests resulted in groundwater contamination in the immediate vicinity of the underground test areas. To ensure protection of the public and the environment, the DOE Nevada Operations Office established a long-term program in 1972 to detect the presence of any radioactivity that may be related to nuclear testing activities.

Since 1972, groundwater has been monitored at various on-site and off-site locations. In 1994, groundwater monitoring was conducted at 30 off-site locations around the Nevada Test Site. Groundwater sampling results show that no contamination from the underground test areas has been found at off-site locations. However, contamination has been found in groundwater samples from wells located near the nuclear test locations on the Nevada Test Site (DOE, 1995), and studies have raised the possibility of radionuclide movement (i.e., Borg et al., 1976; Laczniak et al., 1996). The Pilot Study Risk Assessment for Selected Problems at the Nevada Test Site (NTS) (Daniels, 1993) also predicted that tritium could migrate to Oasis Valley (Figure ES-1) several decades after underground testing stopped. Based on these studies, the DOE has initiated an investigation of the underground test areas to ensure protection of the public and the environment. 
The purpose of the Underground Test Area Subproject investigation has been to define the hydrologic boundaries encompassing groundwater resources that may be unsafe for domestic or municipal use. The first part of the investigation was a regional evaluation which is the subject of this report. The main objectives of the regional evaluation were to develop groundwater flow and transport models representative of regional conditions, to use them to estimate any potential immediate risks to human health and the environment, to identify significant data gaps, and to provide focus and priorities for ongoing local investigations. The second part of the investigation consists of several local studies, focused on estimating contaminant movement and on developing boundaries that encompass the extent of contaminant migration from the underground testing areas.

The regional evaluation consisted of data analysis, model development, model predictions, and peer reviews. The peer review process was an integral step of the regional evaluation to ensure the validity of the data analysis approach and the results. The peer reviewers included subject matter experts in the fields of geology, hydrogeology, and risk assessment, and they provided their feedback on the technical approach and results through meetings and formal comments. Peer review comments were used to improve the technical approach and revise the models.

The results of this regional evaluation are presented in the report and documented in detail in eight packages as follows: Regional Geologic Model Documentation Package (IT, 1996a); Potentiometric Data Documentation Package (IT, 1996b); Groundwater Recharge and Discharge Data Documentation Package (IT, 1996c); Hydrologic Parameter Data Documentation Package (IT, 1996d); Transport Parameter and Source Term Data Documentation Package (IT, 1996e); Groundwater Flow Model Documentation Package (IT, 1996f); Tritium Transport Model Documentation Package (IT, 1996g); and Risk Assessment Documentation Package (IT, 1996h).

\section{ES.1.2 Site Background}

The Nevada Test Site is located in southern Nye County, Nevada, approximately 105 kilometers (65 miles) northwest of Las Vegas, Nevada, and 360 kilometers (224 miles) southeast of Reno, Nevada (Figure ES-1). The Nellis Air Force Range and the Tonopah Test Range surround the Nevada Test Site, providing a 24- to 104-kilometer (15- to 65-mile) separation zone between nuclear test areas and public lands. In combination, the Nellis Air Force Range, the Tonopah Test Range, and the Nevada Test Site comprise one of the largest unpopulated land areas in the United States, covering some 14,200 square kilometers (5,480 square miles). 
Between 1945 and 1962, atmospheric and underground tests were conducted at remote locations in the United States and in the South Pacific. Extensive logistical planning and large shipments of materials and test equipment were required to perform these tests in remote areas. To decrease the amount of time required for a test at a remote location, the Nevada Test Site was selected as the location meeting the criteria for atmospheric tests. It also proved ideally suited for underground tests. Since July 1962, all nuclear tests conducted in the United States have been underground, and most were at the Nevada Test Site (DOE, 1994).

The first underground nuclear test at the Nevada Test Site (RAINIER) was conducted on September 19, 1957 (DOE, 1994). On August 5, 1963, the United States and the Soviet Union signed the Limited Test Ban Treaty restricting all nuclear tests to the subsurface. Starting in 1992, a moratorium on nuclear testing was enacted by the United States, which halted nuclear testing at the Nevada Test Site. As a result, no nuclear tests have been performed at the Nevada Test Site since 1992; however, a state of readiness and capability to resume testing continues to be maintained.

Underground nuclear testing conducted at the Nevada Test Site included a total of 908 tests in shafts and tunnels at depths ranging from 27 to 1,452 meters ( 89 to 4,764 feet) below ground surface. The underground nuclear tests were conducted at 878 locations, some of which contained multiple tests (Figure ES-2). Of those, 717 were conducted in Yucca Flat, ten in Frenchman Flat, 18 in western Pahute Mesa, 64 in central Pahute Mesa, 66 in the Rainier Mesa/Shoshone Mountain area, and three in the Climax Mine area (Figure ES-2) (FFACO, 1996). About one third of these tests were conducted near or below the water table and have introduced contaminants into the NTS groundwater (IT, 1996g).

The total mass of radioactive elements that are present following an underground nuclear detonation is called the radiologic source term. The minor portion of the radiologic source term that is not tightly contained within the melted rock and metal residues, and which can be dissolved or transported with groundwater, is called the hydrologic source term. Only limited information based upon actual field data is available regarding the actual composition of the hydrologic source term. The three predominant types of potential contaminants associated with the source term are in situ material or those contained within the device which have not undergone fission or thermonuclear reaction; direct products of the nuclear reactions, such as fission products; and radionuclides produced by activation of the fuel, materials used within the test, and those injected into the surrounding geologic layers during the nuclear test. 
During the nuclear test, large quantities of materials used to support the test were introduced into the shafts or tunnels (Bryant and Fabrika Martin, 1991). These materials included steel used to support the device, lead and magnetite used as shielding material, and cement and gravel used to backfill the opening. In addition, nuclear devices commonly contained fissionable or fusionable radioactive elements in the critical mass for detonation. These elements included uranium, plutonium, tritium, and lithium. Small amounts of radiochemical detectors were also used. Incomplete consumption of these radioactive materials during detonation from testing would leave them within the subsurface for potential leaching to groundwater.

\section{ES.1.3 Impact on Groundwater}

During detonation of tests conducted at or below the water table, groundwater is evacuated from the shot cavity and then seeps back into the cavity after the detonation. As the water seeps back into the shot cavity and rubble chimney, leaching of radionuclides to the groundwater begins. Radionuclides are also introduced into the groundwater through the prompt injection that occurs during the detonation. Groundwater might also be impacted from tests conducted in the vadose zone through leaching of radionuclides by downward percolating precipitation and surface runoff through the rubble chimney. Tritium, one of the radionuclides, is commonly found in the subsurface as unconsumed material from a fusion detonation. Tritium has been selected as the contaminant of primary potential concern because it easily dissolves into water and can be readily transported in the groundwater flow system.

\section{ES.2.0 Site Physical Features}

The Nevada Test Site (Figure ES-3) occupies an area of approximately 3,500 square kilometers (1,370 square miles) with dimensions varying between 46 and 56 kilometers (28 to 35 miles) in width (east to west) and 64 and 88 kilometers (40 to 55 miles) in length (north to south). The general layout of the Nevada Test Site, including general topographic and physiographic features, is shown in Figure ES-3.

\section{ES.2.1 Topography}

The topography of the Nevada Test Site is typical of the Basin and Range physiographic province of Nevada, Arizona, and Utah and is characterized by north-south-trending mountain ranges, separated by broad, gently sloping valleys. Land surface elevations vary from about 910 meters (2,980 feet) above mean sea level in the south and east of the Nevada Test Site to 2,100 meters (6,890 feet) in the mesa areas to the north and west (Figure ES-3). The slopes of the upland areas are steep and dissected, whereas the slopes on the lower areas are gentle and 
covered with erosional debris from the adjacent highlands. The topography of the Nevada Test Site has been affected by subsidence craters formed by the collapse of underground nuclear shot cavities.

\section{ES.2.2 Climate}

The climate of the Nevada Test Site is characterized by limited precipitation, large diurnal changes in temperature, and winds that are dependent on the season and location. Precipitation is important because it contributes to groundwater recharge. At the Nevada Test Site, precipitation is light and is dependent upon altitude. Average annual precipitation on the mesa tops (Pahute Mesa) is about 23 centimeters ( 9 inches), which includes wintertime snow accumulations. Lower elevation areas such as Frenchman Flat (Figure ES-3) receive approximately 15 centimeters ( 6 inches) of precipitation annually with occasional snow accumulations lasting only a few days. The annual average temperature is $19^{\circ}$ Centigrade ( $66^{\circ}$ Fahrenheit) in the Nevada Test Site area; however, the temperatures vary widely with altitude and seasons. The movements of large-scale pressure systems control the seasonal changes in the wind direction frequencies. Predominating winds are southerly during summer and northerly during winter.

\section{ES.2.3 Surface Hydrology}

There are no perennial surface water bodies on the Nevada Test Site; however, the intermittent flow in the drainage channels caused by flash floods may be the source of small amounts of groundwater recharge. The major drainages that exist within the Nevada Test Site discharge to the Amargosa River and the Amargosa Desert. Other drainages terminate in playas. These drainages discharge off the Nevada Test Site boundary only occasionally, during the infrequent flash floods, particularly from Fortymile Canyon (Figure ES-3).

Discharge from springs at the Nevada Test Site is limited to nine minor perched springs in the eastern and northern areas. This discharge exhibits significant seasonal and annual fluctuations and either infiltrates or evaporates downgradient from the discharge points, located within the Nevada Test Site boundary. These waters are not used as drinking water supply sources.

\section{ES.2.4 Geology}

The geology of the Nevada Test Site and surrounding area consists of three major geologic units: Precambrian and Paleozoic sedimentary rocks, Cenozoic volcanic tuffs and lavas, and late Cenozoic alluvium-filling valleys between the nearby hills of Cenozoic and Paleozoic rocks.

A schematic, north-south geologic cross section of the Nevada Test Site region (Figure ES-4) shows the distribution of the major geologic units and their typical structural relationships. 
The Precambrian and Paleozoic sedimentary rocks are thousands of feet thick and represent major sequences of clastic and carbonate sedimentation. The Precambrian and lower Cambrian section consists of clastic rocks; the middle Cambrian through Devonian section consists predominately of carbonate rocks; the Mississippian section consists mostly of clastic rocks; and the Permian/Pennsylvanian section consists of carbonate rocks. The lowermost clastic rocks have been locally elevated structurally. Where elevated, the overlying carbonate units are thinner or missing due to erosion. Isolated Mesozoic granitic plutons occur within the region. Regional Cenozoic volcanic rocks are predominantly rhyolitic tuffs and lavas extruded from several volcanic caldera centers located in and near the Nevada Test Site. Primary calderas that affect Nevada Test Site geology are the Silent Canyon Caldera and the Timber Mountain Caldera complexes. Volcanic units associated with the calderas vary widely in distribution, thickness, lithology, and degree of welding. Volcanic rocks are thickest near their caldera sources.

The pre-Cenozoic surface, on which the oldest volcanics were deposited, had substantial topographic relief (up to 600 meters [1,970 feet]) that was later filled in by volcanic extrusions. Minor associated Cenozoic sedimentary rocks include conglomerates, tuffaceous sandstones, lacustrine limestones, and claystones. Late Cenozoic alluvial materials that fill the valleys were derived from surrounding highlands of sedimentary and volcanic rocks. These alluvial-fill deposits are up to 900 meters (2,950 feet) thick.

\section{ES.2.5 Hydrogeology}

Major hydrogeologic units defined for the Nevada Test Site region include: clastic confining units, carbonate aquifers, volcanic aquifers and confining units, and the Alluvial Aquifer (Figure ES-4). The entire sequence of hydrogeologic units may be missing or may be repeated in some of the Nevada Test Site areas due to lack of deposition, normal faulting, melting and replacement from plutons or caldera formation, or thrust faulting.

Groundwater occurs in the Alluvial, Volcanic, and Carbonate Aquifers and within the Volcanic and Clastic Confining Units (Figure ES-4). Generally, the aquifer units have transmissivities greater than 2.5 meters per day ( 8.2 feet per day), and the aquitards have transmissivities less than 2.5 meters per day ( 8.2 feet per day). The zones of saturation may be regional, semiperched, or perched. Regional groundwater flow occurs primarily within the lower carbonate and volcanic aquifers. Perched groundwater is found locally throughout the Nevada 
Test Site. Depths to groundwater beneath the Nevada Test Site vary greatly. In the southern part of the test site, depth-to-water ranges from about 10 meters (33 feet) in upper Fortymile Wash to 157 meters (515 feet) beneath Frenchman Lake (Winograd and Thordarson, 1975), compared to more than 610 meters (2,000 feet) at Pahute Mesa in the northern Nevada Test Site.

Groundwater flow within the Nevada Test Site subsurface is dependent on the regional flow system. The regional groundwater flow system is the subject of this evaluation and is described in detail in later sections of this document. A limited amount of groundwater recharge occurs in areas of the Nevada Test Site, such as Pahute Mesa. No groundwater discharge from the regional flow system occurs on the test site. The general groundwater flow directions within the Nevada Test Site groundwater flow system is southerly (Figure ES-5). Groundwater flow in many areas is structurally controlled by faults, fractures, and caldera formations associated with Tertiary volcanics. Regional groundwater flow in Yucca Flat and Frenchman Flat occurs within the major Cenozoic and Paleozoic hydrogeologic units.

\section{ES.2.6 Environmental Resources}

The flora and fauna of the Nevada Test Site and surrounding environs is comprised of the desert shrub associations typical of both the Mojave Desert and Great Basins. Extensive surveys have been conducted at the Nevada Test Site to characterize the biota on site. Federally endangered or threatened species within the area are limited to the peregrine falcon (endangered, Falco Peregrinus); the Western snowy plover (threatened, Charadrius alexandrinus); the mountain plover (candidate, Charadrius montanus); and the desert tortoise (Gopherus agassizii). Several formerly federally protected species also retain protection by the Bureau of Land Management and the State of Nevada.

A greater number of endemic species are found in the off-site spring areas than on the Nevada Test Site. The area of greatest endemism is Ash Meadows, a major discharge of the regional groundwater flow system located in the Amargosa Desert. Federally endangered species and threatened species within the off-site areas include pupfish species, one turtle species, and three birds species. Numerous species that were formerly federally protected are also protected by Nevada and California regulations, the National Park Service, and/or the Bureau of Land Management. 


\section{ES.2.7 Land Use}

The Nevada Test Site is not open to public entry for purposes such as agriculture, mining, homesteading, or recreation. Off-site land uses within a 200-kilometer radius of the Nevada Test Site Control Point (CP-1) include farming, mining, grazing, camping, fishing, and hunting. Natural resources at the Nevada Test Site are managed under a five-party cooperative agreement among: the DOE Nevada Operations Office, the U.S. Air Force, the Nevada Department of Wildlife, the Bureau of Land Management, and the U.S. Fish and Wildlife Service.

\section{ES.2.8 Demography}

There are no permanent residents at the Nevada Test Site. The population density within a 150-kilometer (94-mile) radius of the Nevada Test Site is about 0.5 persons per square kilometer (1.3 persons per square mile), excluding Clark County which contains the City of Las Vegas, NV. The estimated average population density for all of Nevada (including Clark County) was 2.8 persons per square kilometer (7.2 persons per square mile) in 1990. In comparison, the 48 contiguous states (1990 census) had population densities of approximately 29 persons per square kilometer (74 persons per square mile).

The off-site area within 80 kilometers (50 miles) of the Nevada Test Site is predominantly rural. Several small communities are located southwest of the Nevada Test Site, the largest being Pahrump Valley. This growing rural community has an estimated population of 15,000 and is located 80 kilometers (50 miles) south of the Nevada Test Site. The Amargosa farm area, with a population of about 950 , is located approximately 50 kilometers ( 31 miles) southwest of the Nevada Test Site. The largest town closest to the Nevada Test Site is Beatty which has a population of about 1,900 and is located approximately 65 kilometers (40 miles) west of the test site.

\section{ES.2.9 Archaeological and Historical Resources}

Because readily available surface water was the most important, single determinant governing the location of human occupation, historic sites are often associated with prehistoric ones, both being situated near springs. As a consequence of this superposition of historic occupation, disturbance of certain aboriginal sites by modern man occurred long before use of the area as a nuclear testing facility. The larger valleys show little or no evidence of occupation, and these areas comprise almost the entire floors of Yucca, Frenchman, and Jackass Flats. Testing and associated operational activities have generally been most intense in those parts of the Nevada Test Site where archaeological and historic sites are absent. In contrast, there are many 
archaeological sites at the Pahute and Rainier Mesas testing areas. In addition to the archaeological sites, there are also some sites of historical interest at the Nevada Test Site. The principal sites include the remains of primitive stone cabins with nearby corrals at three springs, a natural cave containing prospector's paraphernalia in Area 30, and crude remains of early mining and smelting activities.

\section{ES.3.0 Technical Approach}

As stated earlier, one of the main objectives of the regional evaluation was to develop hydrologic and risk models capable of predicting the migration of tritium from the underground test areas and the associated risks to human health and the environment. To achieve this objective, it is important to understand three key elements: the volume and concentration of the tritium source to groundwater, the migration process of tritium in groundwater, and the locations of potential human and ecological receptors of the tritiated groundwater.

The transport of tritium in groundwater is primarily dependent on the groundwater flow system and the migration pathways it provides to tritium. The process of tritium transport may not be easily defined in complex groundwater flow systems such as that of the Nevada Test Site. Numerical hydrologic models are usually used to help understand such complex flow systems and predict the movement of contaminants within them. Two types of hydrologic models are usually required. The first model calculates only the movement of water and is commonly called a "flow model." The second type of model is a "transport model" which computes concentrations of dissolved radioactive contaminants traveling within the groundwater flow system. Risk models are then used to evaluate the doses and corresponding risks to human health and ecological receptors, based on the contaminant concentrations calculated by the transport model.

The flow model incorporates information on the hydraulic conductivity (ability of geologic media to transmit water), thickness and areal extent of hydrogeologic units, and the locations and rates of recharge and discharge. A three-dimensional groundwater flow code was used to simulate groundwater flow and the hydraulic head (water level) distribution. In addition, a particle-tracking code was used to define the specific pathlines followed by water particles originating from the test sites. The code uses information on layer geometry, boundary conditions, specific discharge rates (rates of moving water), and effective porosities (void space 
through which water moves) to calculate the velocities and positions of particles at different times. The code was used to compute and display pathlines originating from individual underground nuclear testing locations.

The transport model uses the information on groundwater flow directions and rates derived from the flow model in conjunction with parameters describing the processes affecting the movement and distribution of dissolved contaminants to calculate the concentration of tritium in time and space. The selected contaminant-transport code is one-dimensional and stochastic (accounts for uncertainties in the data). This code can simulate physical and chemical processes that affect the migration of tritium in groundwater. Physical processes include advection and dispersion. Advection is the transport caused solely by the movement of the groundwater, whereas dispersion is the spreading caused by varying velocity of water and subsequent mixing within a porous medium. Chemical processes may affect the contaminant in groundwater and retard its movement relative to groundwater. A chemical process that is important for tritium transport is matrix diffusion. Matrix diffusion occurs in fractured geologic media and represents the local diffusion of tritium from the water in the fractures into the surrounding geologic media. In addition, tritium is a radioactive contaminant and is subject to radioactive decay. The transport code was used to predict tritium concentrations at potential human and ecological receptor locations, along three of the fastest groundwater pathlines.

Risk assessment quantifies the relationship between tritium in the environment and the effect it has on human health and ecological receptors. The risk assessment process follows tritium from an exposure location, through intake by receptors, and finally to extrapolation to the resultant risk. The mechanisms that enable tritium to be transported through the environment and taken up by receptors were evaluated and quantified. For the human health risk assessment, scenariospecific tritium intake mechanisms were coupled with tritium dose models and with cancer and genetic risk estimates. Analytical expressions from the peer-reviewed technical literature were then used to develop a spreadsheet-based computer model to calculate dose and risk from tritium-contaminated groundwater. To the extent possible, site-specific data were applied in the analytical expressions and models. Statistical techniques were used to sample from an assigned distribution covering the range of the probable values for each parameter in the model. For the ecological risk assessment, published radiological dose models for fish and wildlife were used. 
Following the selection of the modeling approach, the necessary data relating to geology, hydrology, tritium fate and transport, and risk were compiled and evaluated. The data were then employed to develop and to use groundwater flow, transport, and risk models following the approach described above. A very conservative approach was adopted during the development of the models to ensure that the risk to the public and the environment was not underestimated. Although the flow model was designed to represent the "most likely"conditions, only the fastest groundwater pathways were selected for transport simulations. The transport model and risk assessment were designed to represent conditions that were closest to a "worst-case" scenario. The intent was to evaluate what might happen if the contamination migrated through the fastest paths without dilution, at the highest possible rate and reached a hypothetical homesteader or miner. In this sense, the models serve a useful purpose in bounding the risk so that local-scale studies may be conducted without worry of near-term public health risks.

\section{ES.4.0 Conceptual Regional Groundwater Flow Model}

A good understanding of the conceptual regional groundwater flow system is the basis for the numerical groundwater flow model. To develop such an understanding, existing geologic and hydrologic data relevant to the Nevada Test Site region were collected, evaluated, and incorporated in a comprehensive description of the groundwater flow system. The ranges of uncertainties associated with the geologic and hydrologic data were also evaluated.

\section{ES.4.1 Groundwater Flow System Extent}

The Nevada Test Site regional groundwater flow system (Figure ES-6) covers approximately 26,200 square kilometers (10,200 square miles) of the Death Valley groundwater flow system and includes parts of Clark, Lincoln, and Nye Counties in Nevada, and Inyo County, California. The area is bounded by Death Valley, the Funeral Mountains, Bullfrog Hills, and the Cactus Range on the west; by the Kawich, Reveille, and Quinn Canyon ranges on the north; by the Timpahute, Pahranagat, and Sheep ranges on the east; and by parts of the Spring Mountains, the Resting Spring Range, and the Greenwater Range on the south.

\section{ES.4.2 Hydrogeologic Framework}

The hydrogeologic framework consists of a description of those geologic units that host the regional groundwater flow system. The description includes the geologic and hydraulic properties of the hydrogeologic units hosting the groundwater flow system. 
To describe the geology, a digital geologic model was developed. The geologic model consists of the regional distribution and thickness of the aquifers and confining units and their depths relative to the hydrologic basement. The geologic model also incorporates major structural features of the hydrogeologic units that control groundwater flow within the regional flow system and, therefore, the migration of contaminants.

Hydraulic parameters consist of hydraulic conductivity and effective porosity which control the amount of groundwater moving and its velocity. Hydraulic conductivity is a measure of the ability of the hydrogeologic units to transmit water. Effective porosity is that portion of the void space within a geologic unit through which groundwater moves. The actual (advective) groundwater velocities are calculated by dividing the specific discharges calculated by the groundwater flow model by the effective porosity. Data on hydraulic parameters were gathered and evaluated to help describe the hydrogeologic framework of the groundwater flow system.

The most expansive aquifer within the regional flow system is the Lower Carbonate Aquifer. This is the most important aquifer in the region because of its wide distribution and its high transmissivities. The regional distribution and thickness of the Lower Carbonate Aquifer are spatially variable and controlled by the structural position of the underlying extensive Lower Clastic Confining Unit. The Lower Carbonate Aquifer is the most transmissive aquifer in the region (Table ES-1). The Lower Clastic Confining Unit is generally considered impermeable

Table ES-1

Range of Hydraulic Parameters for Major Aquifers

\begin{tabular}{||c|c|c|c||}
\hline \multirow{2}{*}{ Aquifer } & \multicolumn{2}{|c||}{ Hydraulic Conductivity } & \multirow{2}{*}{$\begin{array}{c}\text { Effective Porosity } \\
\text { Range } \\
(\%)\end{array}$} \\
\cline { 2 - 3 } & $\begin{array}{c}\text { Mean } \\
(\mathrm{m} / \mathrm{d})^{\mathrm{a}}\end{array}$ & $\begin{array}{c}\text { Range } \\
(\mathrm{m} / \mathrm{d})\end{array}$ & $31-35$ \\
\hline \hline Alluvial Aquifer & 8.44 & $0.00005-83$ & $0.00001-0.006$ \\
\hline Volcanic Aquifers & 1.18 & $0.0003-12$ & $0.0006-10$ \\
\hline Carbonate Aquifer & 31.71 & $0.0008-1570$ & 0 \\
\hline
\end{tabular}

$a_{m / d}=$ Meters per day

although it may locally exhibit hydraulic properties consistent with an aquifer due to fracturing. Other regional hydrogeological units include the Alluvial Aquifer and Volcanic Aquifers. The hydraulic conductivity for the Alluvial Aquifer is smaller than that of the Lower Carbonate Aquifer, but it is higher than that of the Volcanic Aquifers. The distributions and thicknesses of 
the Alluvial Aquifer and Volcanic Aquifers are highly variable throughout the region and are assumed to be discontinuous. In most instances, the Alluvial Aquifer is confined to the basin in which it resides by surrounding mountain ranges. In general, these two aquifers are considered depositional elements overlying the regional flow system and only influence regional flow in localized areas. Their ability to transmit water is less than that of the Lower Carbonate Aquifer.

\section{ES.4.3 Groundwater Occurrence and Movement}

Groundwater occurrence and movement may be defined based on existing water-level data, areas of recharge and discharge, and major geologic features (for example, barriers to flow).

Within the Nevada Test Site region, groundwater occurs within alluvial, volcanic, and carbonate geologic units. Saturated alluvial materials are present in central and southern Yucca Flat, Frenchman Flat, and Jackass Flats on the Nevada Test Site and in the basins located throughout the flow system. Saturated Tertiary volcanics are present in the western section of the region. The underlying Lower Carbonate Aquifer is the principal aquifer of the flow system. The Lower Carbonate Aquifer forms a nearly continuous aquifer across the region except where interrupted by calderas, truncated by structural controls, or penetrated by intrusive rocks. Depths to groundwater vary greatly across the Nevada Test Site region. Groundwater occurs at more than 610 meters (2,000 feet) beneath Pahute Mesa in the northern Nevada Test Site and flows to springs at discharge areas in Oasis Valley, Ash Meadows, and Death Valley.

Within the Nevada Test Site regional groundwater flow system, groundwater flows in a general southerly direction, from recharge areas located in the higher altitudes of mountain ranges, to discharge areas downgradient. Recharge occurs in the northern and eastern portions of the flow system (Grant Range, Kawich Range, Belted Range, Pahute Mesa, Sheep Range), and discharge occurs in the south-southwest (Death Valley, Oasis Valley, Ash Meadows) and in Penoyer Valley (Figure ES-6). Regional groundwater flow is through the Lower Carbonate Aquifer and is influenced by local confining units and structural features that control the position of the Lower Clastic Confining Unit. Local volcanic aquifers overlying the regional system are of relative importance due to their influence on vertical flow gradients in selected areas (example: the Nevada Test Site).

The direction of groundwater flow is locally influenced in areas where structural and geologic conditions have controlled the distribution and thickness of the Lower Carbonate Aquifer. In some areas of the regional flow system groundwater encounters structural and geologic 
conditions, such as structural highs of the Lower Clastic Confining Unit, that promote an upward flow component. The upward flow component brings water to discharge at the surface in the form of a wet playa or springs. The discharge is then lost from the flow system through evapotranspiration. Such discharge characteristics are observed at Oasis Valley, Penoyer Valley, and Amargosa Flat. Conversely, there is groundwater flow between basins in the form of subsurface inflow and outflow. Ultimately, however, the groundwater is lost from the groundwater flow system at other surface discharge areas located downgradient (example: Death Valley).

\section{ES.4.4 Groundwater Budget}

An estimate of the groundwater budget is an important part of understanding and modeling the regional groundwater flow system. The groundwater budget consists of an inventory of recharge and discharge. Under natural steady-state conditions, the total amounts of groundwater recharge and discharge to a given flow system are equal. Recharge and discharge occur either through the external boundary of the groundwater flow system or the surface.

Groundwater recharge to and discharge from the regional groundwater flow system may occur through its external boundary (Figure ES-6). There is no groundwater crossing the boundary by underflow along much of its length. The areas where underflow occurs include the boundaries with Pahranagat Valley, Sarcobatus Flat, Pahrump Valley, and the Amargosa Valley near Eagle Mountain. The greatest underflow occurs between Pahranagat Valley and Desert Valley along the southern part of the Pahranagat Range where it is estimated that the flux across the boundary is approximately one-third of the discharge at Ash Meadows. Groundwater discharges from the system as underflow in the vicinity of Eagle Mountain.

Water may also recharge or discharge from the groundwater flow system from the surface in the form of areal recharge from precipitation or evapotranspiration in regional discharge areas. Areas of recharge were mostly assumed to correspond to precipitation areas. The greatest recharge occurs on the Spring Mountains in the south, followed by the Sheep Range to the east. Other mountain ranges in the Nevada Test Site groundwater flow system are areas of moderate recharge. Lower-elevation areas such as Death Valley are not recharge areas. However, in some areas such as Fortymile Canyon, recharge is known to occur. Thus, some of the recharge assumed to occur at higher elevations was redistributed to lower elevations in the vicinity of the 
Nevada Test Site. Eight surface-discharge areas were identified: Penoyer Valley, Indian Springs, Oasis Valley, Alkali Flat (also known as Peter's Playa), Ash Meadows, Franklin Lake/Playa, Amargosa River, and Death Valley.

The estimated total amount of groundwater recharge to the Nevada Test Site regional groundwater flow system ranges between 183 and 360 thousand cubic meters per year (54 and 106 thousand acre-feet per year). The total amount of groundwater discharge ranges between 136 and 306 thousand cubic meters per year (40 and 90 thousand acre-feet per year). The wide ranges of these estimates demonstrate the associated uncertainties.

\section{ES.5.0 Numerical Regional Groundwater Flow Model}

The numerical regional groundwater flow model was designed to provide a basis for predicting the movement of contaminants from the underground test areas on a regional scale. It was also intended to provide a means for evaluating the range of uncertainty in these predictions due to uncertainties associated with the geologic and hydrologic data. In the future, the model will also be used to provide boundary conditions for more detailed models of the underground testing areas that are consistent with the regional groundwater budget. The numerical groundwater flow model was developed to represent the conceptual model discussed in the previous section. The development of this mathematical representation of the flow model consists of four major steps: model set-up, model calibration, identification of flow paths from the nuclear test locations, and sensitivity analysis.

\section{ES.5.1 Numerical Model Set Up}

Model set up is the process of preparing the data in the format required by the computer code. Model set-up includes: the statement of all assumptions, the definition of a spatial grid, the assignment of appropriate boundary conditions, the assignment of hydraulic property distributions over the grid, and the distribution of recharge and discharge areas and rates over the grid.

The major assumptions used in development of the numerical groundwater-flow model include the following:

- At the scale of the regional model, movement of water in fractured rock can be adequately described by flow in porous media. 
- The geologic units represented in the model are homogeneous or can be divided into homogeneous zones.

- The hydraulic conductivity is assumed to decrease in an exponential manner with increasing depth with the same geologic unit.

- The model represents steady-state conditions representative of the flow system prior to groundwater development and underground nuclear testing.

- Because of the steady state assumption, the volumetric recharge is based on estimates of discharge from the groundwater flow system.

To set up the groundwater flow model, the geologic model domain was subdivided into a threedimensional grid consisting of 68 columns by 76 rows and 20 layers. The large number of layers was necessary to accurately simulate the geologic complexity of the thinner, hydrologically significant hydrostratigraphic units, primarily located in Pahute Mesa and Yucca Flat, and to increase numerical accuracy. The grid was constructed to more accurately simulate the hydrology of the areas of concern which include the underground testing areas and downgradient regions. It was also aligned with the average fracture direction in the primary testing areas of concern, Pahute Mesa and Yucca Flat (Figure ES-6).

Boundary conditions were specified to match communication of the Nevada Test Site groundwater flow system with neighboring flow systems as described in the conceptual model. Initial recharge areas were defined over the grid and assigned rates based on the estimates described above. Areas where groundwater exits the flow system through springs and evapotranspiration were also defined on the grid. The initial estimates of hydraulic conductivities were assigned to each of the layers, based on the geologic unit distribution across a given layer, using the data discussed above.

\section{ES.5.2 Model Calibration}

Once the computer flow model was set, the model calibration was initiated. Calibration is a procedure used in modeling to ensure that the computer model is representative of the real groundwater flow system. Model calibration is usually conducted by varying the hydraulic conductivities and recharge rates within their limits of uncertainties in sequential steps. Each step consisted of modifying hydraulic conductivity or recharge in a given area and then comparing the water levels and fluxes to the corresponding observed data (Fluxes include boundary inflow and outflow and evapotranspiration rates.). This step was repeated until the 
model results matched the observed data within a predetermined calibration criteria. These criteria were different throughout the flow model area; they were strictest in areas of concern such as the underground test areas.

The calibrated model provided a good match overall and accurately reproduced several observed, prominent features of the hydrology of the Nevada Test Site and surrounding areas. The high gradient between Emigrant Valley and Yucca Flat along the northern border of Yucca Flat was present as was the high gradient north of the Yucca Mountain area. The higher water levels in the western part of Yucca Flat above the Upper Clastic Confining Unit were present. A moderately low gradient across Timber Mountain, increasing to the north beneath Pahute Mesa, was well-simulated. The very low gradient throughout most of the area underlain by the Lower Carbonate Aquifer was present as was the moderate gradient between the Penoyer and Desert Valleys. The high gradient between the Amargosa Desert and Death Valley was reproduced along with the recharge mounds in the Spring Mountains, the Sheep Range, the Kawich Range, and the Grant Range. The eastward gradient present in the western part of the Pahute Mesa testing area was not well-developed in the model although there was a slight gradient reversal present in this area.

\section{ES.5.3 Groundwater Flowpath Identification}

The flowpaths of groundwater from selected nuclear test locations were identified with the particle-tracking code. Particle-starting locations were chosen (415 of them) so that each testing area (Pahute Mesa, Rainier Mesa, Yucca Flat, Climax Stock, Shoshone Mountain, and Frenchman Flat) was represented. Results indicated that the particles originating in the Pahute Mesa testing area discharge in Oasis Valley. Particles originating in the eastern testing areas (Yucca Flat and Frenchman Flat) discharge in Death Valley or the Amargosa Desert, but not at Ash Meadows. Particles originating in other testing areas did not leave the Nevada Test Site.

\section{ES.5.4 Sensitivity Analyses}

Sensitivity analysis is useful in the calibration process and in evaluating the effect of parameter uncertainty on the model results. A parameter is said to be very sensitive if a given change in its value causes a large change in the model results. Conversely, a parameter is said to be insensitive if a given change in its value causes little change in the model results. Extensive sensitivity analyses were performed to evaluate the impact of parameter uncertainty on waterlevel and boundary flux responses and on particle-tracking results. 
Two types of sensitivity analyses were performed. The first type involved changing basic assumptions of the model such as using different versions of the regional geologic model and different recharge distributions. The second type was a systematic variation of the hydraulicconductivity parameters, which consisted of both increasing and decreasing the values.

The sensitivity analysis of the different geologic models confirmed that a barrier to flow in the area of Calico Hills westward to Bare Mountain was needed to match estimated discharge rates at Oasis Valley and observed gradients in that area. This barrier was based on structural relationships associated with the Belted Range Thrust and alteration of volcanic rocks in the Claim Canyon caldera segment and northern Yucca Mountain. This interpretation was consistent with geologic and hydrologic information in the area. The changes in the geologic model near Penoyer Valley resulted in an improvement in the hydrologic model; however, a lower hydraulic conductivity for the Lower Carbonate Aquifer in the northeastern part of the model than in the southern part was still needed to match water levels and estimated fluxes in that part of the model.

The results from the recharge sensitivity analysis indicate the following:

- The model responds in an approximately linear fashion to identical relative changes in the recharge rates and hydraulic conductivities.

- Travel distances for particles on Pahute Mesa increase several-fold when the recharge rates and hydraulic conductances are increased, while the increases for particles from other testing areas are moderate.

- Use of the Maxey-Eakin recharge model caused a greater percentage increase in discharge in higher gradient areas upgradient of the Lower Clastic Confining Unit barrier (example: Penoyer Valley).

- Redistribution of recharge to downstream areas on and near the Nevada Test Site has little effect on water levels, discharge rates, and particle movement.

Sensitivity analyses were performed to evaluate the effects of uncertainty in the specified flux boundary conditions and in changes to hydraulic conductivity values other than those that were evaluated as part of the systematic analysis. The results were as follows:

- The travel distance in Frenchman Flat is sensitive to the hydraulic conductivity of the Alluvial Aquifer in Frenchman Flat, but the travel distances are likely to be short for reasonable values of hydraulic conductivity values at the surface. 
- Removing the low-conductivity zonation in the vicinity of Black Mountain also removed the potentiometric trough near Area 20 on Pahute Mesa. This indicates that the low conductivity zone can explain the presence of the trough, but there may be other interpretations that would provide similar results.

The sensitivity analysis performed on 116 hydraulic conductivity values showed that the effect on water levels and boundary fluxes was small. The response in an area was dependent on local conditions such as the geometric relationships between hydrogeologic units and the threedimensional extent of the hydrogeologic unit.

\section{ES.6.0 Transport Model}

The purpose of the transport model was to predict the regional-scale migration of tritium in the groundwater flow system away from selected underground test locations. The simulations were limited to tritium because this radionuclide was produced in the greatest abundance during underground nuclear detonations, and it is mobile in the groundwater environment.

Objectives of the transport model were as follows:

- Calculate the tritium concentration in groundwater downgradient from underground test locations. These concentrations are used in the ecological and human health risk assessment calculations to assess the potential risks over a 200 -year time frame.

- Assess the impacts of flow and transport parameter uncertainty on the predicted downgradient tritium concentration. Assess the impact of uncertainty in different input parameters on the predicted tritium concentration.

\section{ES.6.1 Approach}

Groundwater pathways were determined by tracking the movement of groundwater through the three-dimensional groundwater flow system starting at underground test locations that are at or below the water table. The particle tracking computer code follows an imaginary particle as it flows through the groundwater flow system. The code defines the groundwater flow paths by summarizing the travel times and distances from each starting location for each of the pathlines. Three nuclear test locations (TYBO, HOUSTON, and BOURBON) were selected for tritium transport simulations to represent pathlines from Western and Central Pahute Mesa as well as from Yucca Flat.

The tritium transport simulations along each of the selected pathlines were made under a conservative assumption. Tritium was assumed to stay on the pathline from the nuclear test 
location, that is, no lateral dispersion of contaminants away from pathline nor dilution of contaminants by converging pathlines at the discharge location occur during the migration process. This simulates a fast-track fracture pathway or conduit in which contaminant concentrations are constrained from lateral movement, representative of a conservative, or pessimistic, scenario.

The steps in the simulation of tritium transport within the Nevada Test Site regional groundwater flow system were:

- Calculate groundwater pathlines from underground test locations at or below the water table using a three-dimensional groundwater flow model.

- Select three of the fastest pathlines which were closest to the southern edge of a test area for transport simulations to represent each of the main underground test areas.

- Identify parameter uncertainty for flow and transport parameters.

- Determine the form of the source term and the uncertainty in values.

- Simulate the transport of tritium along the pathways in a manner that accounts for the uncertainties in the data.

- Determine the downgradient distance beyond which tritium concentration does not exceed the maximum 20,000 picoCuries per liter standard set by the State of Nevada for drinking water after 200 years.

- Determine how uncertainty in selected input parameters impacts results.

- Provide conservative tritium concentrations at preselected downgradient locations for risk assessment.

The transport model required the following parameters to be defined at each node: initial tritium concentrations, radioactive decay coefficient, specific discharge, dispersivity, effective and matrix porosity, and the effective diffusion coefficient.

The maximum flow path length was 99 kilometers, based on preliminary scoping simulations. Assuming an initial cavity concentration of $1 \times 10^{9}$ picoCuries per liter, the concentration decays to less than 20,000 picoCuries per liter in slightly less than 200 years. 
It was assumed that tritium was evenly spread over the entire rock volume occupied by a sphere of radius equal to approximately two times the estimated cavity radius. This assumption allowed for a prompt injection zone around the actual cavity and resulted in larger (and therefore conservative) initial concentrations.

\section{ES.6.2 Results}

One-dimensional tritium transport simulations were performed along the three selected pathlines named after three nuclear tests: BOURBON conducted at Yucca Flat, HOUSTON on central Pahute Mesa, and TYBO on western Pahute Mesa (Figure ES-7). For each pathline, sources of tritium from other nuclear tests located along or near the same pathline were included in the simulations. The BOURBON pathline originates at the KANKAKEE test location and passes through the BOURBON and MICKEY/TORRIDO test locations. The HOUSTON pathline originates at the HOUSTON test location and does not pass through any other test location. The TYBO pathline starts at the PEPATO test location and passes through the KASH and TYBO test locations.

The transport simulations indicate that at many downgradient receptor locations, the range of maximum tritium activity was quite large, often extending over five orders of magnitude. Simulated tritium activities were high in the vicinity of the nuclear test locations for all three pathlines, but were low outside of the Nevada Test Site boundary for the BOURBON and HOUSTON pathlines. However, for the TYBO pathline, transport simulations based on conservative assumptions indicate that the highest potential tritium concentration could have reached the end of the TYBO pathline 14 years after the release of tritium, assuming that the time of release occurred as early as 1975, immediately following the nuclear detonation. The TYBO pathline results are summarized in Table ES-2.

Several other observations were made based on these transport modeling results:

- The regional geology, as depicted in the geologic model, is the dominant factor controlling the horizontal and vertical position of paths.

- Matrix diffusion is an important mechanism governing the migration of tritium in fractured carbonate and volcanic rocks.

- Source term concentration uncertainty is most important near the nuclear test locations and decreases in importance as the travel distance increases.

- The recharge coefficient which accounts for the total groundwater flux uncertainty is as important as matrix diffusion at downgradient locations. 


\section{Table ES-2 \\ Peak Tritium Concentrations \\ At Selected Locations Along the TYBO Pathline}

\begin{tabular}{|c|c|c|c|c|c|c|c|}
\hline \multirow{2}{*}{$\begin{array}{l}\text { Distance } \\
\text { from } \\
\text { PEPATO } \\
(\mathrm{km})^{\mathrm{a}}\end{array}$} & \multirow[b]{2}{*}{ Location } & \multicolumn{2}{|r|}{$5 \%$ Level } & \multicolumn{2}{|r|}{$50 \%$ Level } & \multicolumn{2}{|r|}{ 95\% Level } \\
\hline & & $\begin{array}{c}\text { Time } \\
(\mathrm{yr})^{b}\end{array}$ & $\begin{array}{c}5 \% \text { Peak } \\
\text { Concentration } \\
(p \mathrm{ci} / \mathrm{L})^{d}\end{array}$ & $\underset{(y r)}{\text { Time }}$ & $\begin{array}{c}\mathbf{5 0 \%} \text { Peak } \\
\text { Concentration }^{\mathrm{e}} \\
(\mathrm{pCi} / \mathrm{L})\end{array}$ & $\underset{(\mathrm{yr})}{\operatorname{Time}}$ & $\begin{array}{c}\text { 95\% Peak } \\
\text { Concentration } \\
\quad(p C i / L)\end{array}$ \\
\hline 0.10 & $\begin{array}{c}\text { PEPATO } \\
\text { (Edge of cavity) }\end{array}$ & 0 & $8.5 \times 10^{6}$ & 0 & $4.4 \times 10^{7}$ & 0 & $2.3 \times 10^{8}$ \\
\hline 9.80 & $\begin{array}{l}\text { TYBO location } \\
\text { and Nevada Test } \\
\text { Site boundary }\end{array}$ & 3 & $3.0 \times 10^{6}$ & 3 & $2.4 \times 10^{7}$ & 1 & $1.2 \times 10^{8}$ \\
\hline 31.80 & $\begin{array}{l}\text { Nellis Air Force } \\
\text { Range boundary }\end{array}$ & 91 & $<1.0$ & 23 & $1.6 \times 10^{4}$ & 9 & $7.3 \times 10^{6}$ \\
\hline 37.10 & $\begin{array}{c}\text { Oasis Valley } \\
\text { discharge area }\end{array}$ & 100 & $<1.0$ & 26 & $8.6 \times 10^{3}$ & 13 & $6.2 \times 10^{6}$ \\
\hline
\end{tabular}

Note: Concentrations are based upon several pessimistic assumptions to assure conservative, bounding values for input into the risk assessment.

$\mathrm{a}_{\mathrm{km}}=$ Kilometers

$\mathrm{yr}=$ Year

The concentration level which $5 \%$ of the modeled values are at or below.

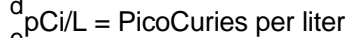

e The concentration level which $50 \%$ of the modeled values are at or below.

The concentration level which $95 \%$ of the modeled values are at or below.

- A $95 \%$ peak concentration means that $95 \%$ of the model runs, or realizations, predicted concentrations at that level or lower. It does not mean that there is 95 percent confidence that concentrations will be that high.

- The results presented at the 50 percent level are conservative and likely to be an overestimate of what will occur in reality. The results presented at the 95 percent level were intended to provide a bounding result which is, in reality, somewhat improbable.

\section{ES.7.0 Risk Assessment}

Human health and ecological risk assessments were performed to provide a conservative and bounding estimate of potential risks to human and ecological receptors of tritium released as a result of the underground detonation of nuclear devices. The risk calculations were based on the conservative estimates of tritium concentrations derived from the transport model, assuming no dilution and no mixing (Section ES.6.0). 


\section{ES.7.1 Approach}

The risk assessment process followed tritium from its point of origin along the three primary pathlines described in Section ES-7.0 (Figure ES-7), and evaluated the various mechanisms that cause tritium to reach individuals, human populations and ecological receptors.

The human health risk assessment quantifies tritium intake, dose, and risk to individuals from exposure to tritiated groundwater. It also illustrates the relationship between the concentration of tritium in groundwater and the effects it is expected to have on human health due to potential land-use scenarios for adults and children.

The conservative tritium concentration distributions simulated by the transport model were applied to the human exposure model which describes the transport of tritium from groundwater to environmental media and then to humans. Sixty exposure locations were selected along the three selected pathlines for each of six potential future land uses at the Nevada Test Site. Types of land uses considered are agricultural, industrial, mining, recreational, residential, and tourism. The exposure scenarios used were assumed to occur as a result of lands being relinquished by the DOE for public use. The selected scenarios were conservative in order to provide a pessimistic bounding calculation of risk.

Once the tritium transport and human exposure mechanisms were determined, the tritium intake mechanisms were defined. Tritium intake mechanisms considered in the human health evaluation were inhalation, skin absorption, and ingestion of tritiated food, water, and soil. Environmental transport media were air, water, soil, and food. The doses and resulting risk to human health were then calculated using standard dose and risk models.

Risk models were designed by coupling scenario-specific tritium intake with tritium dose models and cancer and genetic risk estimates. Calculations were performed on spreadsheets using Monte Carlo analytical techniques. The technique uses a random-number generator to sample for the distribution of parameter values ten thousand times while performing a calculation.

The ecological risk assessment consisted of an evaluation of the seeps, springs, and wells located downgradient from underground test areas. It also described risks to ecological receptors, defined the contaminant benchmark concentration that will preclude unacceptable risk to the receptors, and compared the benchmark concentrations to predicted concentrations in the groundwater. 
The problem formulation phase of the assessment included the identification of the constituent of concern, the conceptual site model, exposure pathways, and ecological endpoints. The ecological exposure characterization briefly identified contaminant flow and transport phenomena, identified specific ecological receptors, and quantified exposure point concentrations for both primary and secondary exposure pathways. The ecological effects characterization examined quantitative links between contaminant concentrations and effects on receptors. Finally, the risk characterization portion of the assessment described potential risks to ecological receptors and populations of interest.

\section{ES.7.2 Results}

Estimated radiation doses received by individuals from chronic exposure to tritium and the risks at the selected exposure locations along each of the pathlines were calculated, based on each land-use scenario. The land-use scenarios were postulated to be very conservative to ensure that the calculated exposures would bound any realistic dose received by individuals. For each pathline, the selected exposure locations includes a point near the source, the point where the pathline crosses the Nevada Test Site boundary, the point where the pathline crosses the Nellis Air Force Range boundary, and the point of groundwater discharge to the surface in the case of the TYBO pathline (Figure ES-7).

The most conservative results of all child and adult scenarios are presented for each pathline. The results are presented in terms of maximum simulated distances to points along the pathlines representing regulatory limits or guides.

The regulatory limits set by the State of Nevada and the Department of Energy are as follows:

- The 20,000 picoCuries per liter tritium concentration represents the maximum concentration limit for Nevada Drinking Water Standards.

- The 100 millirem dose represents the maximum allowable dose limit set by the Department of Energy.

Regulatory guidelines relating to Superfund sites were also used for comparison purposes only. They do not constitute regulatory limits that are applicable to DOE operations in Nevada. These guidelines are as follows:

- The $10^{-4}$ lifetime total cancer incidence represents the risk level above which an immediate interim remedial action must be taken at Superfund sites. 
- The $10^{-6}$ lifetime total cancer incidence represents the risk level below which no corrective action is needed at Superfund sites.

The results associated with the BOURBON and HOUSTON pathlines are presented in Tables ES-3 and ES-4, respectively. The maximum distances of the regulatory limit points are presented at the 5, 50, and 95 percent levels. A given level on a maximum distance signifies that the subject regulatory limit will not be exceeded beyond that distance at the specified level. The estimated doses and risks discussed are for the most limiting land-use scenarios.

For the BOURBON pathline (Table ES-3), the largest maximum distance of all four regulatory limits is $15 \mathrm{~km}(9 \mathrm{mi})$ at the 5 percent level, 20 kilometers (12 miles) at the 50 percent level, and 50 kilometers (31 miles) at the 95 percent level. None of the regulatory limits are exceeded outside of the Nevada Test Site boundary at any of the three levels.

For the HOUSTON pathline (Table ES-4), the largest maximum distance of all four regulatory limits is $2 \mathrm{~km}(1.2 \mathrm{mi})$ at the 5 percent level, 15 kilometers ( 9 miles $)$ at the 50 percent level, and 42 kilometers (26 miles) at the 95 percent level. The $10^{-6}$ total cancer incidence risk is exceeded at all receptor locations for the agricultural and residential land-use scenarios. At the 50 percent level, none of the regulatory limits are exceeded outside of the Nevada Test Site boundary. At the 95 percent level, the maximum tritium concentration limit of 20,000 picoCuries per liter is exceeded outside of federal lands, in the Amargosa Desert. This location is, however, within three miles of the Nellis Air Force Range boundary. At the 95 percent level, the $10^{-6}$ total cancer incidence risk is exceeded along the entire HOUSTON pathline. Based on the human-health risk evaluation along the BOURBON and HOUSTON pathlines, tritium exposures do not present a hazard to human health off the Nevada Test Site in the present, in the near-term, or in the future. However, results associated with the TYBO pathline are quite different.

The results associated with the TYBO pathline are presented in Table ES-5. The maximum distances range between 12.5 and 30 kilometers ( 8 and 19 miles) at the 50 percent level for all limits except the $10^{-6}$ lifetime total cancer incidence risk. This limit is exceeded at all locations on the pathline. At the 95 percent level, all of the regulatory limits are exceeded outside of the Nevada Test Site and the Nellis Air Force Range at the Oasis Valley discharge area. 
Table ES-3

Maximum Simulated Distances of Regulatory Limits and Guidelines Along the BOURBON Pathline

\begin{tabular}{|c|c|c|c|c|c|c|}
\hline \multirow[b]{2}{*}{ Regulatory Limit } & \multicolumn{2}{|c|}{$5 \%$ Level } & \multicolumn{2}{|c|}{$50 \%$ Level } & \multicolumn{2}{|c|}{ 95\% Level } \\
\hline & $\begin{array}{l}\text { Distance } \\
\text { from } \\
\text { Origin }^{\mathrm{a}}\end{array}$ & Location & $\begin{array}{l}\text { Distance } \\
\text { from } \\
\text { Origin }^{\mathrm{c}}\end{array}$ & Location & $\begin{array}{l}\text { Distance } \\
\text { from } \\
\text { Origin }^{d}\end{array}$ & Location \\
\hline $\begin{array}{l}20,000-\mathrm{pCi} / \mathrm{L} \\
\text { tritium } \\
\text { concentration }\end{array}$ & $\begin{array}{l}15 \mathrm{~km} \\
(9 \mathrm{mi})^{b}\end{array}$ & $\begin{array}{l}\text { Nevada } \\
\text { Test Site }\end{array}$ & $\begin{array}{c}20 \mathrm{~km} \\
(12 \mathrm{mi})^{\mathrm{b}}\end{array}$ & $\begin{array}{l}\text { Nevada } \\
\text { Test Site }\end{array}$ & $\begin{array}{l}35 \mathrm{~km} \\
(22 \mathrm{mi})\end{array}$ & $\begin{array}{l}\text { Nevada Test } \\
\text { Site }\end{array}$ \\
\hline 100-millirem dose & $\begin{array}{c}12.5 \mathrm{~km} \\
(8 \mathrm{mi})\end{array}$ & $\begin{array}{l}\text { Nevada } \\
\text { Test Site }\end{array}$ & $\begin{array}{c}12.5 \mathrm{~km} \\
(8 \mathrm{mi})\end{array}$ & $\begin{array}{l}\text { Nevada } \\
\text { Test Site }\end{array}$ & $\begin{array}{c}17.5 \mathrm{~km} \\
(11 \mathrm{mi})\end{array}$ & $\begin{array}{l}\text { Nevada Test } \\
\text { Site }\end{array}$ \\
\hline $\begin{array}{l}10^{-4} \text { Lifetime Total } \\
\text { Cancer Incidence } \\
\text { Risk }\end{array}$ & $\begin{array}{l}15 \mathrm{~km} \\
(9 \mathrm{mi})\end{array}$ & $\begin{array}{l}\text { Nevada } \\
\text { Test Site }\end{array}$ & $\begin{array}{l}15 \mathrm{~km} \\
(9 \mathrm{mi})\end{array}$ & $\begin{array}{l}\text { Nevada } \\
\text { Test Site }\end{array}$ & $\begin{array}{c}30 \mathrm{~km} \\
(19 \mathrm{mi})\end{array}$ & $\begin{array}{l}\text { Nevada Test } \\
\text { Site }\end{array}$ \\
\hline $\begin{array}{l}10^{-6} \text { Lifetime Total } \\
\text { Cancer Incidence } \\
\text { Risk }\end{array}$ & $\begin{array}{l}15 \mathrm{~km} \\
(9 \mathrm{mi})\end{array}$ & $\begin{array}{l}\text { Nevada } \\
\text { Test Site }\end{array}$ & $\begin{array}{c}17.5 \mathrm{~km} \\
(11 \mathrm{mi})\end{array}$ & $\begin{array}{l}\text { Nevada } \\
\text { Test Site }\end{array}$ & $\begin{array}{c}50 \mathrm{~km} \\
(31 \mathrm{mi})\end{array}$ & $\begin{array}{l}\text { Nevada Test } \\
\text { Site }\end{array}$ \\
\hline
\end{tabular}

Note: The locations of the regulatory limits are based upon several pessimistic assumptions to assure conservative and bounding values.

${ }_{b}^{a}$ The distance from the origin which $5 \%$ of the simulated regulatory limits are at or below.

$\mathrm{b}_{\mathrm{mi}}=$ Miles

The distance from the origin which $50 \%$ of the simulated regulatory limits are at or below.

The distance from the origin which $95 \%$ of the simulated regulatory limits are at or below.

Table ES-4

Maximum Simulated Distances of Regulatory Limits and Guidelines Along the HOUSTON Pathline

\begin{tabular}{|c|c|c|c|c|c|c|}
\hline \multirow[b]{2}{*}{ Regulatory Limit } & \multicolumn{2}{|c|}{$5 \%$ Level } & \multicolumn{2}{|c|}{$50 \%$ Level } & \multicolumn{2}{|c|}{ 95\% Level } \\
\hline & $\begin{array}{c}\text { Distance } \\
\text { From } \\
\text { Origin }^{\mathrm{a}} \\
\end{array}$ & Location & $\begin{array}{c}\text { Distance } \\
\text { From } \\
\text { Origin }^{\mathrm{c}} \\
\end{array}$ & Location & $\begin{array}{c}\text { Distance } \\
\text { From } \\
\text { Origin }^{\mathrm{d}} \\
\end{array}$ & Location \\
\hline $\begin{array}{l}20,000-p C i / L \text { tritium } \\
\text { concentration }\end{array}$ & $\begin{array}{c}2 \mathrm{~km} \\
(1.2 \mathrm{mi})^{\mathrm{b}}\end{array}$ & $\begin{array}{l}\text { Nevada } \\
\text { Test Site }\end{array}$ & $\begin{array}{c}14 \mathrm{~km} \\
(8.7 \mathrm{mi})^{\mathrm{b}}\end{array}$ & $\begin{array}{l}\text { Nevada } \\
\text { Test Site }\end{array}$ & $\begin{array}{l}42 \mathrm{~km} \\
(26 \mathrm{mi})\end{array}$ & $\begin{array}{l}\text { Amargosa } \\
\text { Desert }\end{array}$ \\
\hline 100-millirem dose & $\begin{array}{l}0.2 \mathrm{~km} \\
(0.12 \mathrm{mi})\end{array}$ & $\begin{array}{l}\text { Nevada } \\
\text { Test Site }\end{array}$ & $\begin{array}{c}2 \mathrm{~km} \\
(1.2 \mathrm{mi})\end{array}$ & $\begin{array}{l}\text { Nevada } \\
\text { Test Site }\end{array}$ & $\begin{array}{l}15 \mathrm{~km} \\
(9 \mathrm{mi})\end{array}$ & $\begin{array}{l}\text { Nevada Test } \\
\text { Site }\end{array}$ \\
\hline $\begin{array}{l}10^{-4} \text { Lifetime Total } \\
\text { Cancer Incidence Risk }\end{array}$ & $\begin{array}{l}<0.1 \mathrm{~km} \\
(<0.06 \mathrm{mi})\end{array}$ & $\begin{array}{l}\text { Nevada } \\
\text { Test Site }\end{array}$ & $\begin{array}{l}9 \mathrm{~km} \\
(6 \mathrm{mi})\end{array}$ & $\begin{array}{l}\text { Nevada } \\
\text { Test Site }\end{array}$ & $\begin{array}{l}35 \mathrm{~km} \\
(22 \mathrm{mi})\end{array}$ & $\begin{array}{l}\text { Nellis Air } \\
\text { Force Range }\end{array}$ \\
\hline $\begin{array}{l}10^{-6} \text { Lifetime Total } \\
\text { Cancer Incidence Risk }\end{array}$ & $\begin{array}{l}<0.1 \mathrm{~km} \\
(<0.06 \mathrm{mi})\end{array}$ & $\begin{array}{l}\text { Nevada } \\
\text { Test Site }\end{array}$ & $\begin{array}{l}15 \mathrm{~km} \\
(9 \mathrm{mi})\end{array}$ & $\begin{array}{l}\text { Nevada } \\
\text { Test Site }\end{array}$ & $\begin{array}{l}40 \mathrm{~km} \\
(25 \mathrm{mi})\end{array}$ & $\begin{array}{l}\text { Amargosa } \\
\text { Desert }\end{array}$ \\
\hline
\end{tabular}

Note: The locations of the regulatory limits are based upon several pessimistic assumptions to assure conservative and bounding values.

${ }_{b}^{a}$ The distance from the origin which $5 \%$ of the simulated regulatory limits are at or below.

${ }_{\mathrm{mi}}=$ Miles

C The distance from the origin which $50 \%$ of the simulated regulatory limits are at or below.

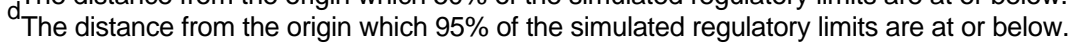




\section{Table ES-5 \\ Maximum Downgradient Locations of Regulatory Limits and Guidelines Along the TYBO Pathline}

\begin{tabular}{|c|c|c|c|c|c|c|}
\hline \multirow[b]{2}{*}{ Regulatory Limit } & \multicolumn{2}{|c|}{ 5\% Level } & \multicolumn{2}{|c|}{$\overline{50 \% \text { Level }}$} & \multicolumn{2}{|c|}{ 95\% Level } \\
\hline & $\begin{array}{l}\text { Distance } \\
\text { from } \\
\text { Origin }^{\mathrm{a}} \\
\end{array}$ & Location & $\begin{array}{l}\text { Distance } \\
\text { from } \\
\text { Origin }\end{array}$ & Location & $\begin{array}{l}\text { Distance } \\
\text { from } \\
\text { Origin }^{d} \\
\end{array}$ & Location \\
\hline $\begin{array}{l}20,000-\mathrm{pCi} / \mathrm{L} \\
\text { tritium } \\
\text { concentration }\end{array}$ & $\begin{array}{l}14 \mathrm{~km} \\
(9 \mathrm{mi})^{b}\end{array}$ & $\begin{array}{c}\text { Nellis Air } \\
\text { Force Range }\end{array}$ & $\begin{array}{c}30 \mathrm{~km} \\
(19 \mathrm{mi})^{\mathrm{b}}\end{array}$ & $\begin{array}{c}\text { Nellis Air } \\
\text { Force Range }\end{array}$ & $\begin{array}{l}37 \mathrm{~km} \\
(23 \mathrm{mi})\end{array}$ & $\begin{array}{l}\text { Oasis Valley } \\
\text { Discharge } \\
\text { Area }\end{array}$ \\
\hline 100-millirem dose & $\begin{array}{l}<1 \mathrm{~km} \\
(<0.6 \mathrm{mi})\end{array}$ & $\begin{array}{l}\text { Nevada Test } \\
\text { Site }\end{array}$ & $\begin{array}{c}12.5 \mathrm{~km} \\
(8 \mathrm{mi})\end{array}$ & $\begin{array}{c}\text { Nellis Air } \\
\text { Force Range }\end{array}$ & $\begin{array}{l}37 \mathrm{~km} \\
(23 \mathrm{mi})\end{array}$ & $\begin{array}{l}\text { Oasis Valley } \\
\text { Discharge } \\
\text { Area }\end{array}$ \\
\hline $\begin{array}{l}10^{-4} \text { Lifetime Total } \\
\text { Cancer Incidence } \\
\text { Risk }\end{array}$ & $\begin{array}{c}12.2 \mathrm{~km} \\
(7.6 \mathrm{mi})\end{array}$ & $\begin{array}{c}\text { Nellis Air } \\
\text { Force Range }\end{array}$ & $\begin{array}{c}19.6 \mathrm{~km} \\
(2 \mathrm{mi})\end{array}$ & $\begin{array}{c}\text { Nellis Air } \\
\text { Force Range }\end{array}$ & $\begin{array}{l}37 \mathrm{~km} \\
(23 \mathrm{mi})\end{array}$ & $\begin{array}{l}\text { Oasis Valley } \\
\text { Discharge } \\
\text { Area }\end{array}$ \\
\hline $\begin{array}{l}10^{-6} \text { Lifetime Total } \\
\text { Cancer Incidence } \\
\text { Risk }\end{array}$ & $\begin{array}{l}12.2 \mathrm{~km} \\
(7.6 \mathrm{mi})\end{array}$ & $\begin{array}{c}\text { Nellis Air } \\
\text { Force Range }\end{array}$ & $\begin{array}{l}37 \mathrm{~km} \\
(23 \mathrm{mi})\end{array}$ & $\begin{array}{c}\text { Oasis Valley } \\
\text { Discharge } \\
\text { Area } \\
\end{array}$ & $\begin{array}{l}37 \mathrm{~km} \\
(23 \mathrm{mi})\end{array}$ & $\begin{array}{l}\text { Oasis Valley } \\
\text { Discharge } \\
\text { Area } \\
\end{array}$ \\
\hline
\end{tabular}

Note: The locations of the regulatory limits are based upon several pessimistic assumptions to assure conservative and bounding values.

The distance from the origin which $5 \%$ of the simulated regulatory limits are at or below.

$\mathrm{b}_{\mathrm{mi}}=$ Miles

CThe distance from the origin which $50 \%$ of the simulated regulatory limits are at or below.

The distance from the origin which $95 \%$ of the simulated regulatory limits are at or below.

Two complementary radiological dose models were used to evaluate risk to fish and wildlife. A tritium concentration of $9.32 \times 10^{7}$ picoCuries per liter was selected as the threshold level for protection of pupfish eggs in the spring ecosystems. Also, a dose of $1 \mathrm{rad} /$ day to pupfish and a dose of $3.6 \mathrm{rad} /$ day for the heron were calculated as exposure thresholds, both corresponding to a tritium concentration of $3.37 \times 10^{9}$ picoCuries per liter in spring discharge or irrigation ditch water. Estimated tritium concentrations, calculated through fate and transport modeling at the 95 percent level, were not projected to exceed $6.2 \times 10^{6}$ picoCuries per liter at the spring discharge points.

\section{ES.8.0 Conclusions}

The major conclusions derived from the groundwater flow modeling, transport modeling, and risk assessment are summarized in the following text. 
A numerical model was developed and calibrated for the Nevada Test Site regional groundwater flow system. Particle-tracking simulations based on the calibrated flow model and sensitivity analyses were then conducted which led to the following conclusions:

- Groundwater flow paths from the Yucca Flat and Frenchman Flat underground test areas discharge either in Death Valley or the Amargosa Desert, but not at Ash Meadows.

- Groundwater flow paths from the Pahute Mesa testing area discharge in Oasis Valley.

- Groundwater flow paths from other testing areas do not leave the Nevada Test Site.

- Simulated water levels and fluxes are very sensitive to the interpretation of major geologic features.

- Generally, particle travel distances doubled or tripled at specified times in response to a 50 percent increase in recharge and conductivities. The effect was not as significant when recharge and conductivities were decreased.

- The redistribution of recharge to low-lying areas did not have a significant impact on the simulated water levels.

- The sensitivity analysis performed on 116 hydraulic conductivity values showed that the effect on groundwater flow was small.

A stochastic numerical transport model was developed to simulate tritium transport in groundwater along three of the fastest groundwater paths from the underground test areas: the BOURBON, HOUSTON and TYBO pathlines. The simulated tritium concentrations along these fastest pathlines are higher because lateral dispersion and dilution from adjacent clean water were not considered. The major conclusions are as follows:

- Based on transport simulations along the BOURBON and HOUSTON pathlines, the maximum concentration limit of 20,000 picoCuries per liter for tritium in groundwater will not likely be exceeded outside of the Nevada Test Site.

- Based on transport simulations along the TYBO pathline and the incorporation of several conservative assumptions, the maximum concentration limit of $20,000 \mathrm{pCi} / \mathrm{L}$ for tritium in groundwater could be exceeded outside of the Nevada Test Site, at Oasis Valley. 
Near-term, bounding risks to human health and biota were calculated based on tritium migration predictions from nuclear tests associated with the BOURBON pathline, the HOUSTON pathline, and the TYBO pathline. The conclusions are as follows:

- In the near term, tritium migration from the HOUSTON and BOURBON nuclear test locations does not contribute to human health hazards off the Nevada Test Site.

- As a result of the high ecotoxicological thresholds associated with tritium exposure, future ecological risks are not anticipated to occur.

- As a result of the conservatively high estimates of tritium concentrations along the TYBO pathlines, the calculated human health risks at receptor points along this pathline are higher than $10^{-4}$.

In spite of this conclusion, the estimated risks from the TYBO pathline are not supported by results from the existing environmental monitoring network. Long-term monitoring of water samples from the Oasis Valley springs and groundwater wells west and south of the Pahute Mesa do not show tritium levels above the background levels. As the transport model was intended to predict contaminant levels if multiple pessimistic conditions existed, monitoring results support the conclusion that tritium is migrating at a more normal, nonexceptional rate. In other words, the monitoring results confirm the premise that the conservative modeling approach used was likely to overestimate tritium transport. 


\subsection{Introduction}

The purpose of this report is to present the results of a regional evaluation of the highest, potential, current and near-term risk to the public and the environment from possible groundwater contamination downgradient of the underground testing areas of the Nevada Test Site (NTS). The highest potential risk is determined by assuming that several unusually rapid transport pathways and exposures factors are encountered at once. These assumptions ensure that risks to the public and the environment are not underestimated; however, risks are likely to be significantly overestimated using this approach.

\subsection{Project Background}

Various types of underground nuclear tests were conducted at the Nevada Test Site in southern Nevada between 1951 and 1992 by the U.S. Department of Energy (DOE) and the U.S. Department of Defense (DoD). These tests resulted in groundwater contamination in the immediate vicinity of these underground test areas. To ensure protection of the public and the environment, the DOE Nevada Operations Office established a long-term monitoring program in 1972 to detect the presence of any radioactivity that may be related to nuclear testing activities.

Sampling results have shown that no contamination from the underground test areas has been found at off-site locations. However, contamination has been found in groundwater samples from wells located near the nuclear test locations on the Nevada Test Site (DOE, 1995), and studies have raised the possibility of radionuclide movement (i.e., Borg et al., 1976; Laczniak et al., 1996c). The Pilot Study Risk Assessment for Selected Problems at the Nevada Test Site (NTS) (Daniels, 1993) also predicted that tritium could migrate to off-site areas several decades after underground testing stopped. Based on these studies, the DOE Nevada Operations Office initiated an investigation of the underground test areas to ensure protection of the public and the environment.

The purpose of the Underground Test Area (UGTA) Subproject has been to define the regional and site-specific hydrologic boundaries encompassing groundwater resources that may be unsafe for domestic or municipal use. The first part of the project is a regional evaluation which is the subject of this report. The main objectives of the regional evaluation were to develop groundwater flow and transport models representative of regional conditions, to use them in determining potential immediate risks to human health and the environment, and to provide focus and priorities for ongoing local investigations. The second part of the investigation consists of 
focus and priorities for ongoing local investigations. The second part of the investigation consists of several local studies, focused on estimating contaminant movement and developing boundaries that encompass the extent of contaminant migration from the underground testing areas.

\subsection{Site Background}

Background information about the NTS is provided in this section, including its location, a history of the operations conducted there, and a description of the underground test areas.

\subsubsection{Site Location}

The NTS is located in southern Nye County, Nevada, approximately 105 kilometers $(\mathrm{km})$ (65 miles [mi]) northwest of Las Vegas, Nevada, and $360 \mathrm{~km}$ (224 mi) southeast of Reno, Nevada (Figure 1-1). The Nellis Air Force Range (NAFR) and the Tonopah Test Range (TTR) surround the NTS, providing a 24- to $104 \mathrm{~km}$ (15- to 65-mi) separation between nuclear test areas and public lands. In combination, the NAFR, the TTR, and the NTS comprise one of the largest unpopulated land areas in the United States, covering some 14,200 square kilometers $\left(\mathrm{km}^{2}\right)(5,480$ square miles[mi²]) (DOE, 1992a).

\subsubsection{History of Operations}

Although the NTS has been the site of various types of operations (DOE, 1992a), the focus of the UGTA Subproject is the subsurface area and the associated sources of contamination to groundwater. Thus, this history of operations at the NTS is presented with emphasis on underground nuclear testing.

Between 1945 and 1962, atmospheric and underground tests were conducted at several remote locations in the United States and in the South Pacific. Extensive logistical planning and large shipments of materials and test equipment were required to perform these remote tests. To decrease the amount of time required for an atmospheric nuclear test at a remote location, the NTS was selected as the location which met the logistics criteria. It has also proved ideally suited for underground tests (ERDA, 1977). Since July 1962, all nuclear tests conducted by the United States have been underground, and most have been at the NTS (DOE, 1994).

The first underground nuclear test at the NTS (RAINIER) was conducted in a tunnel under the Rainier Mesa on September 19, 1957 (DOE, 1994). Since 1962, nearly all tests have been conducted in either the unsaturated or saturated zones of the subsurface through vertical shafts 
drilled into either the valley floor of Yucca Flat, the top of Pahute Mesa, or in horizontal tunnels mined into the face of Rainier Mesa (DOE, 1994). Beginning in 1992, a moratorium on nuclear testing was enacted by the U.S. Government, which halted nuclear testing at the NTS. As a result, no nuclear tests have been performed at the NTS since 1992; however, in the interest of national defense, a state of readiness and the capability to resume testing continues to be maintained.

\subsubsection{Underground Nuclear Testing}

Underground nuclear testing conducted at the Nevada Test Site included a total of 908 tests conducted in shafts and tunnels at depths ranging from 27 to 2,452 meters (83 to 4,764 feet) below ground surface. These underground tests were conducted at 878 locations, some of which contained multiple tests (Figure 1-2). Of the 878 underground testing locations, 717 are in Yucca Flat, 10 in Frenchman Flat, 18 in Western Pahute Mesa, 64 in Central Pahute Mesa, 66 in the Rainier Mesa/Shoshone Mountain area, and three in the Climax Mountain area (FFACO, 1996). About one-third of the underground nuclear tests were conducted near or below the water table (IT, 1996g).

In general, steps involved in conducting an underground nuclear test include test hole drilling and preparation, nuclear device and rack emplacement, backfilling, device detonation, and re-entry hole drilling (Bryant and Fabrika-Martin, 1991). During the device detonation, radioactive material is released in the puddle glass, crushed zone, and chimney rubble. During detonation of tests conducted at or below the water table, groundwater is evacuated from the shot cavity and then slowly seeps back into the cavity after the detonation (Borg et al., 1976).

The total mass of radioactive elements that are present following an underground nuclear detonation is called the radiologic source term. The minor portion of the radiologic source term that is not tightly contained within the melted rock and metal residues, and which can be dissolved or transported with groundwater, is called the hydrologic source term. Only limited information based upon actual field data is available regarding the actual composition of the hydrologic source term. The three predominant types of potential contaminants associated with the source term are: in situ material or those contained within the device which have not undergone fission or thermonuclear reaction; direct products of the nuclear reactions, such as fission products; and radionuclides produced by activation of the fuel, materials used within the test, and materials injected into the surrounding geologic layers during the nuclear test. 
During the nuclear test, large quantities of materials used to support the test were introduced into the shafts and tunnels (Bryand and Febrika Martin, 1991). These materials included steel used to support the device, lead and magnetite used as shielding material, and cement and gravel used to backfill the opening. In addition, nuclear devices commonly contained fissionable or fusionable radioactive elements in the critical mass for detonation. These elements included uranium $\left({ }^{235} \mathrm{U}\right)$, plutonium $\left({ }^{239} \mathrm{Pu}\right)$, tritium, and lithium. Small amounts of radiochemical detectors were also used. Incomplete consumption of these radioactive materials during detonation from testing would leave them within the subsurface for potential leaching to groundwater.

\subsubsection{Impact on Groundwater}

During detonation of tests conducted at or below the water table, groundwater is displaced from the shot cavity and then seeps back into the cavity after the detonation. As the water seeps back into the shot cavity and rubble chimney, leaching of radionuclides to the groundwater begins. Radionuclides are also introduced into the groundwater through the prompt injection that occurs during the detonation. Groundwater might also be impacted from tests conducted in the unsaturated zone through leaching of radionuclides by downward percolating precipitation and surface runoff through the rubble chimney. The types of contaminants present in the subsurface as result of a nuclear test are briefly discussed in the following text.

Nuclear devices commonly contain fissionable or fusionable radioactive elements in the critical mass for detonation. These elements include uranium, plutonium, tritium, and lithium. Also, small amounts of radiochemical detectors (isotopes of uranium, plutonium, americium, or curium) and radioactive tracers (yttrium, zirconium, thulium, and lutetium) have been used in the weapons.

Tritium is commonly found in the subsurface either as unconsumed material from a fusion detonation, as a direct fission product, or from neutron activation. Tritium is important because it easily dissolves into water and can be readily transported in the groundwater flow system. Borg et al. (1976) estimated the cumulative amount of tritium deposited below or near the water table to be about 3 kilograms $(\mathrm{kg})$ at Yucca Flat and $10 \mathrm{~kg}$ at Pahute Mesa. The quantity of tritium at Frenchman Flat is believed to be relatively smaller. This estimate is based upon a total of 78 tests that had been detonated at or below the water table at that time (Borg et al., 1976). 


\subsection{Purpose and Scope}

The purpose of the regional evaluation described in this report was to assess the effects of the underground testing on groundwater, including assessing the risk from tritium contamination.

The scope of the regional evaluation includes the development of hydrologic models and risk models for the test site region. The scope also includes the use of the hydrologic and risk models to make predictions, to understand the physical system and processes, and to prioritize further UGTA activities. The hydrologic models were used to predict tritium transport in groundwater and to identify the most important variables that affect the movement of tritium. Transport predictions were used to identify the groundwater pathways and points of exposure to human and ecological receptors. The risk models were used to evaluate risk to human health and to the ecological receptors.

\subsection{Regional Evaluation Completion Process}

The process used to complete the regional evaluation consisted of several steps: regional evaluation, documentation of approach and results, peer reviews, and incorporation of peerreview comments. Peer review was an integral step of the process to ensure the validity of the data analysis approach and subsequent results.

The regional evaluation consisted of data analysis, model development, and model predictions. Various data relating to geology, hydrology, tritium fate and transport, and risk were compiled and evaluated. The data were then used to develop groundwater flow, transport, and risk models. The models were then used to assess both the current and potential impacts to groundwater. The details of the technical approach that were used for data analysis are provided in Section 3.0 of this report.

The preliminary results of the regional evaluation were peer-reviewed by subject matter experts in the fields of geology, hydrogeology, and risk assessment. The peer reviewers provided their feedback on the technical approach and the subsequent results through meetings and formal comments. Based on the peer review comments, the data analysis and the models were revised and submitted for another peer review. Based on the resulting comments, the data analysis and models were revised to produced the results.

Following completion of the data analysis, the data, the approach used, and the results were summarized in this report and documented in detail in eight packages as follows: Regional Geologic Model Documentation Package (IT, 1996a); Potentiometric Data Documentation 
Package (IT, 1996b); Groundwater Recharge and Discharge Data Documentation Package

(IT, 1996c); Hydrologic Parameter Data Documentation Package (IT, 1996d); Transport

Parameter and Source Term Data Documentation Package (IT, 1996e); Groundwater Flow

Model Documentation Package (IT, 1996f); Tritium Transport Model Documentation Package

(IT, 1996g); and Risk Assessment Documentation Package (IT, 1996h).

\subsection{Report Organization}

This section outlines the contents of the entire report and summarizes the interrelationships between the sections. Figure 1-3 depicts the sequence and relationship of the report sections which are described as follows:

- Section 1.0 is the introduction to the report, presenting the NTS background, the purpose, and the scope of the regional evaluation and the process used.

- Section 2.0 contains a description of the NTS and vicinity, including the physical features.

- Section 3.0 describes the regional evaluation purpose and scope, objectives, and technical approach. As a part of the technical approach, the hydrologic modeling needs and processes are defined. Data storage and management and quality assurance issues are introduced here; however, full details are provided in Appendix A.

- Section 4.0 includes the data compilation and evaluation activities associated with the development of the geologic model. The data used, the methodology, and the uncertainties are discussed.

- Section 5.0 details the assessment activities that include data compilation and evaluation of hydrogeologic data associated with the groundwater flow model. Section 5.0 also documents the specific methods and tasks of data evaluation leading to the modeling.

- Section 6.0 describes the conceptual groundwater flow model. Results from the geologic and hydrogeologic data analysis (Sections 4.0 and 5.0) are integrated in the conceptualization.

Sections 4.0, 5.0, and 6.0 represent the information requirements for the development of the numerical groundwater flow model.

- Section 7.0 presents a description of the numerical groundwater flow model including the approach and assumptions, the results, and the associated uncertainties and limitations. Information described in Sections 4.0, 5.0, and 6.0 was used to develop the numerical model. 
- Section 8.0 addresses assessment activities including the compilation and evaluation of data associated with the tritium transport model. Section 8.0 also documents the specific methods and tasks of data evaluation needed for the numerical transport model.

- Section 9.0 describes the numerical tritium transport model including the conceptual model, approach and assumptions, results, and associated uncertainties and limitations. The solute transport model uses velocities calculated along selected flow pathlines and the data described in Section 8.0 to calculate solute concentrations along the pathlines.

- Section 10.0 explains the risk assessment process for human health and the environment. Risk is calculated at potential receptor locations along the selected pathlines, using tritium concentrations calculated by the transport model (Section 9.0). The approach, assumptions, results, and associated uncertainties and limitations are discussed.

- Section 11.0 summarizes the report and includes the main conclusions.

- Section 12.0 is a list of the references cited in the report.

This document summarizes and discusses the results of the regional evaluation. The reader is referred to the supporting data analysis documentation packages (IT, 1996a; 1996b; 1996c; 1996d; 1996e; 1996f; 1996g; and 1996h) for detailed technical discussions and a comprehensive presentation of data and figures. 


\subsection{Site Physical Features}

A description of the physical features of the Nevada Test Site and vicinity is presented in this section with an emphasis on areas located hydraulically downgradient from the underground testing areas. The physical features which relate to the scope of the regional evaluation in the region include the extent of the area, topography and terrain, climate and meteorology, surface water, geology, hydrogeology, environmental resources, demography, and archaeological and historical resources. The geology and hydrogeology of the area are the subject of this regional evaluation and are discussed in greater detail in subsequent sections. Two documents provided the information contained in this section: Environmental Assessment for the Groundwater Characterization Project, Nevada Test Site, Nye County, Nevada (DOE, 1992c) and the Nevada Field Office Annual Site Environmental Report for 1994 (DOE, 1995).

\subsection{Site Description}

The Nevada Test Site (Figure 1-1) occupies an area of approximately 3,500 $\mathrm{km}^{2}\left(1,350 \mathrm{mi}^{2}\right)$ with dimensions varying between 46 and $56 \mathrm{~km}$ (28 and $35 \mathrm{mi}$ ) in width (east to west) and 64 and $88 \mathrm{~km}$ (39 and $55 \mathrm{mi}$ ) in length (north to south) (DOE, 1995). Figure 2-1 shows the general layout of the NTS, including general physiographic areas, locations of major facilities, and the NTS-designated area numbers referenced in this report. The shaded areas in Figure 2-1 indicate the principal underground nuclear testing areas.

\subsection{Topography and Terrain}

The topography of Nevada Test Site is typical of the Basin and Range physiographic province of Nevada, Arizona, and Utah and is characterized by north-south-trending mountain ranges, separated by broad, flat-floored, and gently-sloping valleys as shown in Figure 2-2. Land surface elevations vary from about 910 meters $(\mathrm{m})$ (2,985 feet [ft]) above mean sea level in the south and east of the NTS to $2,100 \mathrm{~m}(6,888 \mathrm{ft})$ in the mesa areas to the north and west. The slopes of the upland areas are steep and dissected, whereas the slopes on the lower areas are gentle and alluviated with rock debris from the adjacent highlands (DOE, 1995).

The local topography of the NTS has been affected by nuclear testing, and the principal effect has been the creation of numerous dish-shaped surface subsidence craters, particularly in Yucca Flat. Most underground nuclear tests conducted in vertical shafts resulted in surface subsidence 
craters when the overburden above a nuclear shot cavity collapsed and formed a rubble chimney to the surface. A few craters have also been formed as a result of tests conducted on or near the surface during atmospheric testing or by shallow depth-of-burial cratering experiments (DOE, 1995).

\subsection{Climate and Meteorology}

The climate of the Nevada Test Site is characterized by limited precipitation, large diurnal changes in temperature, and winds that are dependent on seasonality and location.

Although precipitation is limited, it is an important aspect of the NTS climate because it contributes to groundwater recharge. Precipitation at NTS is typical of Southern Nevada where precipitation is very light and dependent upon altitude. At the NTS, mesas receive an average annual precipitation of 23 centimeters $(\mathrm{cm})$ (9 inches [in.]), which includes wintertime snow accumulations (DOE, 1995). The lower elevations receive approximately $15 \mathrm{~cm}$ (6 in.) of precipitation annually with occasional snow accumulations lasting only a few days (Quiring, 1968). The average annual precipitation distribution of the NTS region is presented in detail in Section 5.0 of this report.

The annual average temperature is 19 degrees centigrade $\left({ }^{\circ} \mathrm{C}\right)\left(66\right.$ degrees Fahrenheit $\left.\left[{ }^{\circ} \mathrm{F}\right]\right)$ in the NTS area (NOAA, 1991); however, the temperatures vary with altitude and seasons. At an elevation of 2,000 m (6,560 ft) above mean sea level in Area 20 on Pahute Mesa, the average daily maximum $/$ minimum temperatures are $4.4^{\circ} /-2.2^{\circ} \mathrm{C}\left(39.9^{\circ} / 28.0^{\circ} \mathrm{F}\right)$ in January and $26.7^{\circ} / 16.7^{\circ} \mathrm{C}\left(80.1^{\circ} / 58.7^{\circ} \mathrm{F}\right)$ in July. At an elevation of $1,200 \mathrm{~m}(3,936 \mathrm{ft})$ above mean sea level in Area 6 at Yucca Flat, the average daily maximum/minimum temperatures are $10.6^{\circ} /-6.1^{\circ} \mathrm{C}$ $\left(51.1^{\circ} / 21.0^{\circ} \mathrm{F}\right)$ in January and $35.6^{\circ} / 13.9^{\circ} \mathrm{C}\left(96.1^{\circ} / 57.0^{\circ} \mathrm{F}\right)$ in July (DOE, 1995).

The movements of large-scale pressure systems control the seasonal changes in the wind direction frequencies. Predominating winds are southerly during summer and northerly during winter. The general downward slope in the terrain from north to south results in an intermediate scenario that is reflected in the characteristic diurnal wind reversal from southerly winds during the day to northerly winds at night. This north to south reversal is strongest in the summer and, on occasion, becomes intense enough to override the wind regime associated with large-scale pressure systems (DOE, 1995). At higher elevations in Area 20, the average annual wind speed is 17 kilometers per hour (km/hr) (11 miles per hour [mph]), and in Area 6 at Yucca Flat, the average annual wind speed is $11 \mathrm{~km} / \mathrm{hr}$ (7 mph) (DOE, 1995). 


\subsection{Surface Hydrology}

There are no perennial surface water bodies on the Nevada Test Site; however, the intermittent flow in the drainage channels caused by flash floods may be the source of small amounts of groundwater recharge. There are six major drainages within the NTS that discharge to the Amargosa River and to the Amargosa Desert, west and south, respectively, of the test site (Figure 2-3); the other six major drainages terminate in valley-bottom playas (DOE, 1992c). Drainages rarely discharge off the NTS boundary; however, infrequent flash floods occasionally discharge from the NTS, particularly from Fortymile Canyon.

On the NTS, discharge from springs emanating from local perched groundwater systems is limited to nine minor springs in the eastern and northern portions (Figure 2-4) and ranges from approximately 0.014 to 2.2 liters per second (L/s) $(0.22$ to 35 gallons per minute [gal $/ \mathrm{min}])$. Discharge from springs exhibits significant seasonal and annual fluctuations and either infiltrates or evaporates downgradient from the outflow points. These waters are not used as drinking water supply sources (DOE, 1992c).

\subsection{Geology}

The geology of the Nevada Test Site and the surrounding area is the product of a complex history, marked by major structural events (ERDA, 1977). The historical events that shaped the stratigraphy and structure of the region during the Precambrian, Paleozoic, Mesozoic, and Tertiary geologic times are described in this section. For a view of the surficial geology of the area, the reader is referred to the State of Nevada Geologic Map (Stewart and Carlson, 1977).

\subsubsection{Precambrian and Paleozoic}

The lowermost and oldest rocks in the NTS region are Precambrian in age. This region of the western United States was a stable, continental margin from Late Precambrian time until Late Devonian time (middle Paleozoic). During the period of Late Precambrian to Early Cambrian, a thick section of sandstone and minor shales was deposited over the whole model area. A thick section of predominately carbonate sediments from Late Cambrian to Late Devonian time was deposited on top of those clastic rocks. During the Mississippian Era, uplift north and west of the investigation area resulted in erosion and deposition of thick sandstones interfingering with marine shelf shales in a foreland basin. During the Pennsylvanian Age, the basin was filled, and 
shallow marine carbonates were deposited on the Mississippian clastics. More than 10,600 m $(34,700 \mathrm{ft})$ of Paleozoic and late Precambrian sediments were deposited over the model area. This stratigraphic section is detailed, and regional stratigraphic correlations are shown in Table 2-1.

\subsubsection{Mesozoic}

During the Mesozoic Era, regional crustal shortening of the Sevier orogeny (mountain forming process) produced large-scale, complex contractional features such as thrust fault systems, folds, and wrench faults. The entire model area was affected by the contraction with regional detachments and generally north-south-trending predominant thrust systems (Armstrong, 1968). Locally the stratigraphic sections were repeated vertically because of thrusting. The Sevier orogenic zone may have been extended prior to late Mesozoic time and the intrusion of granitic plutons.

\subsubsection{Tertiary}

Following the Sevier orogeny, the highlands were severely eroded and late Precambrian clastic rocks were exposed at the surface locally. Following erosion throughout most of the early Tertiary Period, the area in and around the Nevada Test Site began to be pulled apart along normal and strike-slip faults associated with the formative stages of the modern Basin-and-Range structural province (Guth, 1981; Wernicke et al., 1988; Cole et al., 1989). Eruptions of the Southwestern Nevada Volcanic Field (SWNVF) occurred in the Middle Tertiary Period (Sawyer et al., 1990; Warren et al., 1989). Successive eruptions produced no less than seven large, partially overlapping calderas which were filled with lava flows and blanketed surrounding Paleozoic and Precambrian rocks with vast deposits of tuff. Volcanic rocks now cover parts of the NTS region.

Stratigraphic nomenclature of the SWNVF (Ferguson et al., 1994) is shown in Table 2-2. The volcanic units in Table 2-2 are listed in relative depositional order with the oldest at the bottom of the table. Volcanic units vary widely in distribution, thickness, lithology, and degree of welding with respect to distance from their source caldera. At most localities, only a partial section is present. North of the NTS, volcanic units other than those listed in Table 2-2 are present. For simplicity, they were lumped together in the geologic model and are not detailed here. 
Table 2-1

Pre-Tertiary Stratigraphic Correlation/Death Valley Drainage Basin

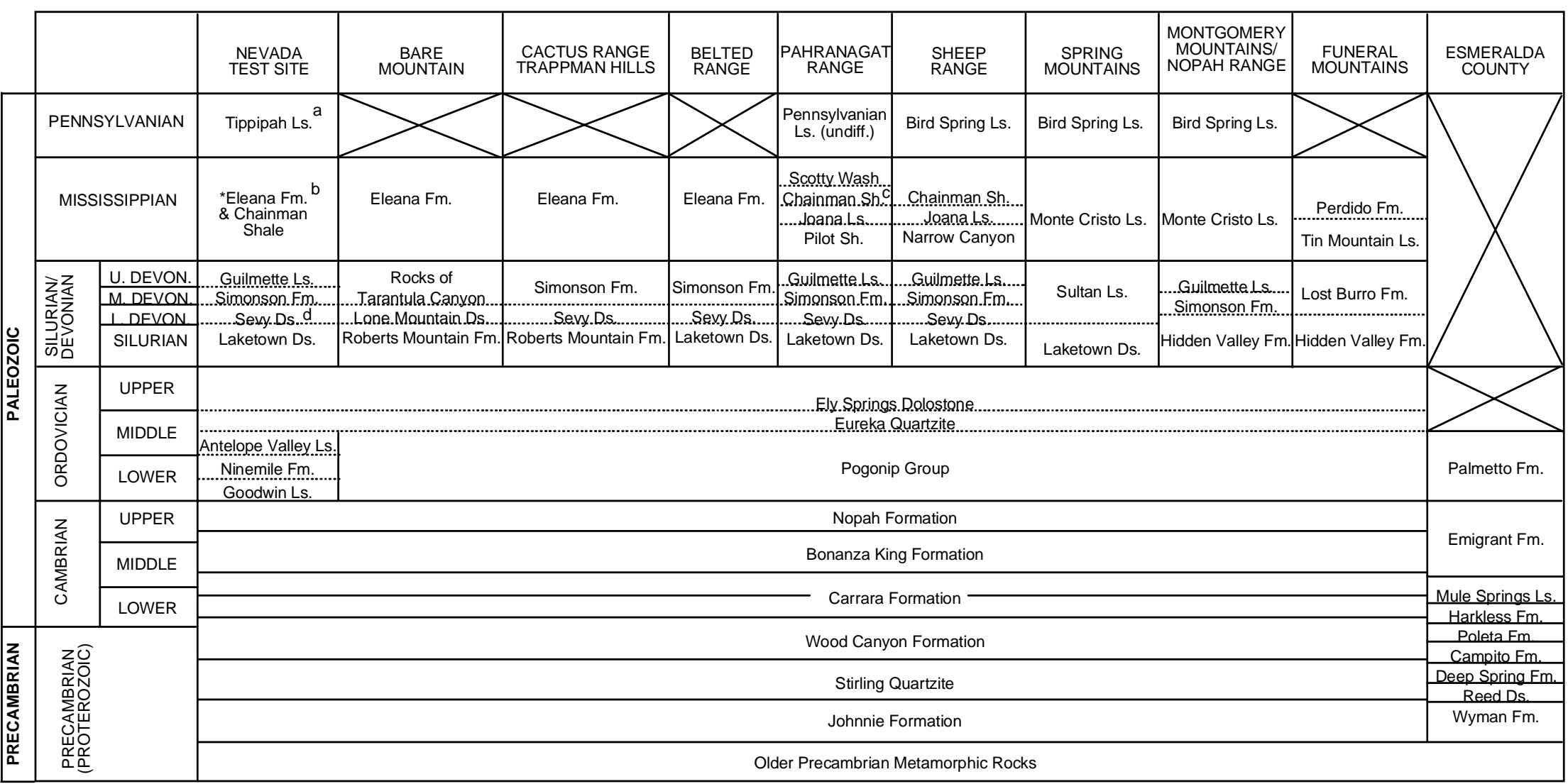

*In the southeastern portion of the NTS, the Mississippian section is represented by the Mercury Limestone which is correlative to the Monte Cristo Limestone.
The Upper Carbonate Aquifer consists of all Pennylvanian strata, plus Mississippian sections that do not include Eleana Formation.

The Upper Clastic Confining Unit consists of the Eleana Formation.

The Lower Carbonate Aquifer consists of all Devonian, Silurian, and Ordovician strata, plus the Nopah Formation, the Bonanza King Formation, and the upper half of the Carrara Formation. The Lower Clastic Confining Unit consists of the lower half of the Carrara Formation, the Wood Canyon Formation, and all Precambrian units. The predominantly clastic facies of Esmeralda

County is also

b Limestone

c Formation

d Shale 
Table 2-2

Tertiary Stratigraphy of the NTS Region

\begin{tabular}{||c|c||}
\hline Stratigraphic Unit & $\begin{array}{c}\text { Stratigraphy } \\
\text { Symbol }\end{array}$ \\
\hline \hline Volcanics of Fortymile Canyon & Tf \\
\hline Timber Mountain Group & Tm \\
\hline Ammonia Tanks Tuff & Tma \\
\hline Rainier Mesa Tuff & Tmr \\
\hline Tuff of Holmes Road & Tmrh \\
\hline Rhyolite of Sorugham Peak & Tps \\
\hline Paintbrush Group & Tp \\
\hline Tiva Canyon Tuff & Tpc \\
\hline Topopah Spring Tuff & Tpt \\
\hline Volcanics of Area 20 & Ta \\
\hline Calico Hills Formation & Tac \\
\hline Volcanics of Area 20 & Ta \\
\hline Wahmonie Formation & Tw \\
\hline Tuff of Mara Wash & Tww \\
\hline Crater Flat Group & Tcp \\
\hline Crater Flat Group & \\
\hline Prow Pass Tuff & Tc \\
\hline \hline
\end{tabular}

\begin{tabular}{||c|c||}
\hline Stratigraphic Unit & $\begin{array}{c}\text { Stratigraphy } \\
\text { Symbol }\end{array}$ \\
\hline \hline Bullfrog Tuff & Tcb \\
\hline Tram Tuff & Tct \\
\hline Belted Range Group & Tb \\
\hline Dead Horse Flat Formation & Tbd \\
\hline Grouse Canyon Tuff & Tbg \\
\hline Team Ridge Group & Tr \\
\hline Tunnel Formation & Tn \\
\hline Volcanics of Quartz Mountain & tq \\
\hline Volcanics of Big Dome & Tu \\
\hline Tub Spring Tuff & Tub \\
\hline Older Volcanics & To \\
\hline Tunnel Bed 2 & Ton2 \\
\hline Yucca Flat Tuff & Toy \\
\hline Tunnel Bed 1 & Ton1 \\
\hline Redrock Valley Tuff & Tor \\
\hline Fraction Tuff & \\
\hline Paleocolluvium & Tof \\
\hline \hline
\end{tabular}

Source: Ferguson et al., 1994

Tertiary crustal extension and consequent normal faulting was greatest after eruption of the SWNVF. The extension caused severe tilting, large vertical displacements, and lateral translation of upper crustal fault blocks. Modern alluvial basins have been filled with as much as 1,200 m $(3,900 \mathrm{ft})$ of coarse gravels, sands, and localized deposits of playa silt and clay.

\subsection{Hydrogeology}

The Nevada Test Site groundwater flow system is part of the regional groundwater flow system which is discussed in later sections. A description of the NTS regional groundwater flow system is provided in Section 6.0. The NTS hydrostratigraphy and groundwater occurrence and movement are presented followed by a description of the groundwater radiological monitoring network. 


\subsubsection{Hydrostratigraphy}

Geologic formations of hydrologic significance in the NTS subsurface and vicinity have been grouped in seven major hydrogeologic units by Winograd and Thordarson (1975). These hydrogeologic units are classified as either aquifers or aquitards. An aquifer is defined as a saturated, permeable geologic unit that can transmit significant quantities of water under natural hydraulic gradients, whereas an aquitard is defined as a saturated geologic unit that is incapable of transmitting significant amounts of water under the same conditions (Freeze and Cherry, 1979). As stated by Freeze and Cherry (1979), these definitions are fairly generic with respect to transmissivity, so that the two terms may be used in a relative sense. Generally, the aquifer units have transmissivities greater than 2.5 meters per day ( 8.2 feet per day $[\mathrm{ft} / \mathrm{d}])$, and the aquitards have transmissivities less than $2.5 \mathrm{~m} / \mathrm{d}(8.2 \mathrm{ft} / \mathrm{d})$.

Winograd and Thordarson (1975) defined seven major hydrogeologic units (HSUs) within the NTS region. These units include, from oldest to youngest: the Lower Confining Unit, the Lower Carbonate Aquifer (LCA), the Eleana Confining Unit, the Upper Carbonate Aquifer, the Volcanic Aquifers (VAs) and Volcanic Confining Units (VCU), and the Alluvial Aquifer (AA). The entire sequence of hydrostratigraphic units may not be present or may be repeated in some of the study areas due to lack of deposition, normal faulting, melting and replacement from plutons or caldera formation, or thrust faulting. The LCA is the most extensive and transmissive aquifer in the region. The VAs which control groundwater flow in the mesa areas are moderately transmissive. The AA forms a discontinuous aquifer on the NTS.

The lower confining unit is generally present beneath the NTS except in caldera complexes. This unit is designated as the basement rock. The LCA is also present beneath the NTS and the vicinity, although it does not control regional groundwater flow beneath the saturated volcanics within the caldera complexes. The Upper Confining Unit is present in the north-central section of the NTS and restricts flow between overlying and underlying units; the degree of structural continuity within the formation in areas of imbricate (overlapping) faulting has not been determined. Saturated Tertiary volcanics are generally present in the western sections of the NTS, and the presence of saturated alluvial materials is generally restricted to central and southern Yucca Flat, Frenchman Flat, Jackass Flats, and the Amargosa Desert.

\subsubsection{Groundwater Occurrence and Movement}

Within the Nevada Test Site subsurface, groundwater occurs in the alluvial, volcanic, and carbonate aquifers and within the Volcaniclastic Confining Units (VCCUs). The zones of saturation may be regional, semiperched, or perched as defined by Winograd and 
Thordarson (1975). Regional groundwater flow occurs primarily within the Lower Carbonate and Volcanic Aquifers. Perched groundwater is found locally throughout the NTS and occurs locally within the tuff aquitards wherever aquitards compose ridges or hills that lie above the regional zone of saturation (Winograd and Thordarson, 1975). In the highlands, springs emerge from perched groundwater lenses. Spring discharge rates are low, and this water is used only by wildlife.

Depths to groundwater beneath the NTS vary greatly. In the southern NTS, depth-to-water ranges from about $10 \mathrm{~m}(33 \mathrm{ft})$ in upper Fortymile Wash to $157 \mathrm{~m}(515 \mathrm{ft})$ beneath Frenchman Lake (Winograd and Thordarson, 1975), compared to more than $610 \mathrm{~m}$ (2,000 ft) at Pahute Mesa in the northern NTS. In the eastern portions of the NTS, the water table generally occurs in the alluvium and volcanic rocks above the LCA.

Groundwater flow within the NTS subsurface is dependent on the regional flow system. The regional groundwater flow system is the subject of this evaluation and is described in detail in Section 6.0 of this report. Regional groundwater recharge and discharge are discussed in Sections 5.0 and 6.0. A limited amount of groundwater recharge occurs in areas of the NTS, such as Pahute Mesa. No groundwater discharge from the regional flow system occurs on the NTS. General groundwater flow directions within the NTS groundwater flow system are depicted in Figure 2-5. Groundwater flow in many areas is structurally controlled by faults, fractures, and caldera formations associated with Tertiary volcanics. Regional groundwater flow in Yucca Flat and Frenchman Flat occurs within the major Cenozoic and Paleozoic hydrostratigraphic units. The general groundwater flow direction is southerly. Winograd and Thordarson (1975) hypothesized that groundwater from Cenozoic units flows between Yucca Flat and Frenchman Flat through the underlying lower carbonate aquifer. In addition, horizontal gradients within the saturated volcanic units exist and may indicate groundwater flow toward the central areas of Yucca and Frenchman Flats prior to vertical infiltration.

Pahute Mesa is located in the northwestern part of the NTS (Figure 2-5). Groundwater in this area occurs in volcanic aquifers and confining units and moves south and southwest through Oasis Valley, Crater Flat, and western Jackass Flats (Blankennagel and Weir, 1973) toward points of discharge in Oasis Valley, Alkali Flat, and Furnace Creek. The amount of recharge to Pahute Mesa and the amount of flow to the discharge points are not accurately known. Vertical gradients within Pahute Mesa suggest that flow may be downward in the eastern portion of the mesa, but upward in the western part (Blankennagel and Weir, 1973). 
The Rainier Mesa test area is located between Yucca Flat and Pahute Mesa. Groundwater in this area occurs in the volcanic aquifers and confining units, Lower Carbonate Aquifer, and tuffaceous and Lower Clastic Confining Units (LCCU). The Volcanic Aquifer and Volcanic Confining Units support a semiperched groundwater lens. Nuclear testing at Rainier Mesa was conducted within the tuff confining unit. Studies conducted by Thordarson (1965) indicate that the perched groundwater is moving downward into the LCA. Regional groundwater flow from Rainier Mesa may be directed either toward Yucca Flat or, because of the intervening upper clastic aquitard, toward the Alkali Flat discharge area to the south. Groundwater flow in the shallower units of the NTS is generally toward major valleys, such as Yucca and Frenchman Flats, and includes a downward hydraulic gradient component to the LCA.

\subsubsection{Groundwater Radiological Monitoring}

The U.S. Environmental Protection Agency (EPA) operates a nationwide Long-Term Hydrological Monitoring Program (LTHMP) instituted by the U.S. Department of Energy, Nevada Operations Office (DOE/NV) in 1972. Under the LTHMP, the EPA's Environmental Monitoring Systems Laboratory in Las Vegas, Nevada (EMSL-LV), conducts radiological monitoring of wells on the Nevada Test Site and of wells, springs, and surface water in areas located outside and downgradient from the NTS (DOE, 1995). As of 1994, the LTHMP monitoring locations off the NTS are presented in Figure 2-6.

All sampling locations on the NTS were selected by the DOE and are mainly sources of drinking water. Samples are analyzed for gamma-emitting radionuclides by gamma spectrometry and for tritium by the enrichment method. In samples collected in 1994, no gamma-emitting radionuclides were detected. The highest tritium activity was detected in a sample from Well UE-5n. This activity was $2.6 \times 10^{4}$ picoCuries per Liter $(\mathrm{pCi} / \mathrm{L})$ which is less than 33 percent $(\%)$ of the Derived Concentration Guide for tritium. Several other wells have shown activities above the minimum detectable concentration (DOE, 1995).

The sampling locations outside of the NTS include 23 water wells, seven springs, and one surface water site. Except for three wells located in Penoyer Valley, all locations are sampled on a monthly basis and are subjected to gamma-spectrometry. Tritium analysis is performed on a 
semiannual basis. No gamma-emitting radionuclides were detected in any of the samples in 1994. Tritium has been detected at only three off-site locations over the last decade: Lake Mead Intake located near Boulder City to the east of the NTS, Adaven Spring located near Adaven to the northeast of the NTS, and Specie Springs located near Beatty to the west of the NTS. For all three locations, the detected tritium activity represents negligible environmental levels that have been decreasing over the last decade (DOE, 1995).

\subsection{Environmental Resources}

An understanding of the environmental resources of the Nevada Test Site region is important in the risk evaluation. Environmental resources of the NTS described in this section include ecological features, land use, demography, and archeological and cultural resources. The discussion refers to locations that are physically on the NTS as "on site" and those areas outside of NTS as "off site."

\subsubsection{Ecological Features}

Ecological features are particularly important to the ecological risk evaluation. A summary description of the biota of the Nevada Test Site region, with emphasis on the species of concern, is provided. A detailed listing and discussion of the species is provided in the Risk Assessment Documentation Package (IT, 1996h).

The flora of the NTS region is composed of the desert shrub associations typical of both the Mojave and Great Basin Deserts or the transition desert between these two. The fauna of the NTS region consists of various species of mammals, birds, and reptiles which inhabit the Nevada Test Site and the off-site spring areas such as Ash Meadows, Oasis Valley, Furnace Creek, and Amargosa Canyon. The area of greatest endemism is Ash Meadows. Microorganisms are known to be present in the aquifers and aquitards beneath NTS. Work is in progress to identify these organisms, and there is a possibility that unknown species may be present (Russell, 1996).

Federally endangered or threatened species within the area are limited to the peregrine falcon (endangered, Falco Peregrinus); Western snowy plover (threatened, Charadrius alexandrinus); mountain plover (candidate, Charadrius montanus); and desert tortoise (Gopherus agassizii). Several formerly federally protected species also retain protection by the Bureau of Land Management (BLM) and the State of Nevada. 
Federally endangered and threatened species within the off-site areas include one species of endangered pupfish, one species of turtles, and three species of birds. Numerous species that were formerly federally protected are also protected by Nevada and California regulations, the National Park Service, and/or the BLM.

\subsubsection{Land Use}

The Nevada Test Site is not open to public entry for purposes such as agriculture, mining, homesteading, or recreation. Figure 2-7 is a map showing the wide variety of off-site land uses such as farming, mining, grazing, camping, fishing, and hunting, within a 200-km (124-mi) radius of the NTS Control Point (CP-1). Natural resources at the NTS are managed under a five-party cooperative agreement among: the DOE Nevada Operations Office, the U.S. Air Force, the Nevada Department of Wildlife (NDOW), the U.S. Bureau of Land Management, and the Fish and Wildlife Service (FWS). Because of the nature of land use at the NTS over the last four decades, it is unlikely that the area will be returned to public use in the foreseeable future (DOE, 1992c).

The Nellis Air Force Range (NAFR) was originally withdrawn from public use in 1940 for training of World War II bomber pilots and crews. Those withdrawals were renewed by Congress in 1986 for a period of 15 years. Buildings, roads, and targets at NAFR occur in limited locations; thus, most of the land is not actually used by the Air Force, but simply provides a safety buffer between Air Force activities and adjacent public land. No co-use of the lands for mining, grazing, or other activities is currently allowed (DOE, 1992c).

Elevations west of NTS range from $85 \mathrm{~m}$ (279 ft) below mean sea level in Death Valley to 4,400 m (14,436 ft) above mean sea level in the Sierra Nevada Range, including parts of one major agricultural valley. The areas south of the NTS are more uniform because the Mojave Desert ecosystem (mid-latitude desert) comprises most of this portion of Nevada, California, and Arizona. The areas east of NTS are primarily mid-latitude steppes with some of the older river valleys, such as the Virgin River Valley and Moapa Valley, supporting irrigation for small-scale, but intensive farming of a variety of crops. Grazing is also common in this area, particularly toward the northeast. The area north of NTS is also a mid-latitude steppe where the major agricultural activity is grazing of cattle and sheep. Minor agriculture, primarily the growing of alfalfa hay, is found in this portion of the state within $200 \mathrm{~km}$ (124 mi) of CP-1 (DOE, 1992c). 
Recreational areas lie in all directions around NTS and are used for such activities as hunting, fishing, and camping.

In general, the camping and fishing sites to the northwest, north, and northeast are used in spring, summer, and fall. Camping and fishing locations to the southeast, south, and southwest are used throughout the entire year. The peak hunting season is from September through January (DOE, 1992c).

\subsection{Demography}

The population distribution in counties surrounding the Nevada Test Site is presented in Figure 2-8. Most of the numbers presented in this discussion and shown in Figure 2-8 are based on the 1990 census; updated numbers are provided where available.

There are no permanent residents at the NTS. Excluding Clark County (population over 1,032,161 in 1995) which has Las Vegas as its major population center, the population density within a $150-\mathrm{km}(93-\mathrm{mi})$ radius of the NTS is about 0.5 persons per square kilometer (DOE, 1996c). In comparison, the 48 contiguous states (1990 census) had population densities of approximately 29 persons per square kilometer. The estimated average population density for Nevada in 1990 (including Clark County) was 2.8 persons per square kilometer (DOE, 1992c).

The off-site area within $80 \mathrm{~km}$ of CP-1 is predominantly rural. Several small communities are located southwest of CP-1, the largest being Pahrump, NV. This growing rural community, with an estimated population of 15,000, is located $80 \mathrm{~km}$ (50 mi) south of CP-1. The Amargosa farm area, which has a population of about 950 , is located about $50 \mathrm{~km}$ (31 mi) southwest of CP-1. The largest town in the near off-site area is Beatty which has a population of about 1,900 and is located approximately $65 \mathrm{~km}$ (40 mi) west of CP-1 (DOE, 1992c).

The Mojave Desert of California, which includes Death Valley National Monument, lies along the southwestern border of Nevada in Inyo and San Bernardino counties (Figure 2-8). The National Park Service has estimated that the population within the Monument boundaries ranges from a minimum of 200 permanent residents during the summer months to as many as 5,000 tourists and campers on any particular day during the major holiday periods in the winter months. As many as 30,000 visitors are in the area during "Death Valley Days" in the month of November. The largest nearby populated area in this desert, nearly 28,000 people, is the Ridgecrest-China Lake area (California), about $190 \mathrm{~km}$ (118 mi) southwest of the NTS. The 
next largest, in the Barstow, California, area located $265 \mathrm{~km}$ (165 mi) south-southwest of the NTS, had a 1991 population of 21,000. The Owens Valley, where numerous small towns are located, lies $50 \mathrm{~km}$ (31 mi) west of Death Valley. The largest town in Owens Valley is Bishop, located $225 \mathrm{~km}$ (140 mi) west-northwest of NTS, with a population of 3,500 (DOE, 1992c).

The extreme northwestern region of Arizona is mostly range land except for that portion in the Lake Mead Recreation Area. In addition, several small communities lie along the Colorado River. The largest towns in the area are Bullhead City, Arizona, $165 \mathrm{~km}$ (102 mi) south-southeast of NTS, with a 1991 population estimate of 22,000, and Kingman, Arizona, located 280 km (174 mi) southeast of the NTS, with a population of about 13,000 (DOE, 1992d).

\subsection{Archaeological and Historical Resources}

Archaeological and historical resources are usually associated with locations where water was naturally available. Human habitation of the Nevada Test Site area ranges from as early as 10,000 B.C. to the present. Various aboriginal cultures occupied the NTS area over this extended period as evidenced by the presence of artifacts at many surface water sites and more substantial deposits of cultural material in several rock shelters. This period of aboriginal occupation was sustained primarily by a hunting and gathering economy based on using temporary campsites and shelters. The area was occupied by the Paiute Indians in 1849 when the first known outside contact was made (DOE, 1992c).

Because readily available surface water used to be the most important, single determinant governing the location of human occupation, historic sites are often associated with prehistoric ones, both being situated near springs. As a consequence of this superposition of historic occupation, disturbance of certain aboriginal sites by modern man occurred long before use of the area as a nuclear testing facility. The larger valleys show little or no evidence of occupation. These areas comprise almost the entire floors of Yucca, Frenchman, and Jackass Flats. Thus, testing and associated operational activities have generally been most intense in those parts of NTS where archaeological and historic sites are absent. In contrast, there are many archaeological sites at the Pahute and Rainier Mesas testing areas (DOE, 1992c).

In addition to the archaeological sites, there are also some sites of historical interest at NTS. The

principal sites include the remains of primitive stone cabins with nearby corrals at three springs, a natural cave containing prospector's paraphernalia in Area 30, and crude remains of early mining and smelting activities (DOE, 1992c). 
Prior to the NTS land withdrawal in 1941 as part of the Las Vegas Army Air Field School, the area encompassed by NTS was used for mining, grazing, and hunting. Most mining at the NTS was an outgrowth of the great gold and silver discoveries at Tonopah, Goldfield, Bullfrog, and Rhyolite, Nevada, during the first decade of the twentieth century. In addition to the numerous, uninventoried prospector and temporary mining camps that resulted from this activity, major mining districts were established at Oak Springs, Mine Mountain, and Wahmonie (Nevada). Ranching never occurred on a grand scale because of the isolation and extreme aridity of the NTS area. However, small ranches that focused on gathering wild horses were established at the major hot springs in the area, including Tippipah, Topopah, Cane, White Rock, Captain Jack, Oak, and Tub Springs. 


\subsection{Technical Approach}

Modeling and risk assessment approaches cover a wide range of data needs as well as the various models used for specific types of parameters and objectives. The purpose of this section is to describe the objectives of the regional evaluation, the contaminant of potential concern, and the extent of the evaluation area. It also presents the specific technical approaches used to perform the hydrologic and risk modeling. A flow diagram summarizing the technical approach is presented in Figure 3-1.

\subsection{Objectives}

One of the main objectives of the regional evaluation was to develop hydrologic and risk models capable of predicting the migration of tritium from the underground test areas and the associated risks to human health and the environment. Specific goals of the regional evaluation included the following items:

- Compilation of existing and newly acquired data for development of conceptual hydrologic and risk assessment models

- Development of a numerical, three-dimensional groundwater flow model to evaluate the regional conditions

- Development of a numerical solute transport model to evaluate the transport of tritium in groundwater from the source areas to potential receptor locations

- Evaluation of the highest credible risk to human health and the environment from contaminated groundwater beneath the Nevada Test Site

\subsection{Contaminant of Potential Concern}

As discussed in Section 1.2.4, the underground detonation of nuclear devices at the Nevada Test Site has resulted in the release of a variety of radionuclides to the groundwater. However, tritium was selected as the contaminant of potential concern for the regional evaluation because of its abundance, its low attenuation in groundwater, and its radioactivity. Essentially, all of the tritium released from the underground nuclear testing has formed water, either by oxidation or exchange (Stead, 1963). In this form, tritium moves and behaves, both chemically and physically, as water in the groundwater flow system. In the near term (within the next 200 years), tritium is expected to be the only contaminant of concern. 


\subsection{Investigation Area}

As described in Section 1.0, the smallest regional groundwater basin that fully encompasses the groundwater flow system underlying the NTS is a portion of the Death Valley groundwater basin, referred to as the NTS regional groundwater-flow system (Figure 3-2). The boundaries defined by Waddell et al. (1984) for this flow system were used as the starting point.

The selected area of investigation is large enough to allow for potential expansion of the northern and western groundwater flow system boundaries (Figure 3-2). This area covers a large part of southern Nevada and part of Inyo County in eastern California and extends from Death Valley, north to Antelope Valley and from the Palmetto Mountains, east to the Sheep Range, over an area of $80,650 \mathrm{~km}^{2}\left(31,140 \mathrm{mi}^{2}\right)$.

\subsection{Hydrologic Modeling Approach}

Predicting the movement of contaminants in complex groundwater flow systems usually requires the use of two different types of numerical models. The first type of model calculates only the movement of water and is commonly called a flow model. The second type of model is a transport model which computes concentrations of dissolved radioactive contaminants traveling in subsurface media.

A flow model incorporates information about the hydraulic conductivity, thickness, and areal extent of hydrogeologic units and the locations and rates of recharge and discharge of groundwater. Flow models provide information on the directions and rates of groundwater flow. The movement of groundwater is affected by the following:

- Types and thicknesses of the geologic units

- Hydraulic conductivities of the geologic units

- Distribution and rates of groundwater recharge

- Location of groundwater discharge areas

The hydrologic behavior of fractured media, such as those present within the investigation area, may be modeled as the following: a porous-media equivalent, a network of discrete fractures, and a dual-porosity media. Under the porous-media-equivalent approach, it is assumed that on the scale being modeled, there is a large enough number of connected fractures to ensure that the media behave as porous media. The discrete-fracture approach more closely simulates the fractured media, but becomes computationally difficult when the number of fractures is large. It models water and contaminant movement in individual fractures within a network of fractures. 
The dual-porosity-media approach is an attempt to offset the problems associated with the other two approaches and assumes that most of the fractured media can be modeled as a porous-media equivalent and that only the large fractures need to be modeled as discrete fractures.

A groundwater flow system is said to be under steady-state conditions when the amount of water that recharges the system is equal to the amount of groundwater that discharges from the system. Under such conditions, the system is in equilibrium, and water levels are stable. Groundwater flow systems under natural conditions are usually assumed to be under steady-state conditions; groundwater flow systems that have been disturbed by man or major natural events are said to be under transient conditions. In a transient groundwater flow system, the water levels and the amount of groundwater in storage change with time. For example, man-imposed stresses (such as pumping) cause a decrease in both storage and water levels. Underground nuclear testing may also cause a transient response of the flow system. The assumption of steady-state conditions is suitable when simulating the behavior of groundwater flow systems with negligible effects from pumping or other transient stresses.

A transport model simulates the processes affecting the movement and concentration of dissolved contaminants as follows:

- Advection (transport caused by movement of the water)

- Dispersion (spreading caused by varying velocity of water and subsequent mixing within a porous medium)

- Chemical reactions (such as sorption, ion exchange, and precipitation or dissolution of solids containing the contaminant)

- Diffusion into low-permeability materials or matrix diffusion

- Radioactive decay

The transport model includes equations to calculate changes in concentration due to these processes with distance and time. The flow model provides the information needed to account for the advective process in the transport model.

The selected approach was to develop a three-dimensional groundwater flow model using the porous-media-equivalent assumption, to generate pathlines using the particle-tracking technique, and to simulate one-dimensional tritium transport along the pathlines. The models selected to 
implement this approach and their data requirements are presented in the following sections. Their relationships are depicted in the flow diagram summarizing the technical approach (Figure 3-2).

\subsubsection{Selected Models}

Three models were used to simulate groundwater flow, particle pathlines, and tritium concentrations. A three-dimensional groundwater flow model, MODFLOW (McDonald and Harbaugh, 1988), was first used to simulate groundwater flow and the hydraulic head distribution. A particle-tracking code, MODPATH (Pollock, 1989), was then used to define the specific pathlines of particles originating from the nuclear test cavities. Finally, MC_TRANS (IT, 1996i), a one-dimensional contaminant-transport model, was used to predict tritium concentrations along the pathlines and at potential ecological receptor locations.

MODFLOW was developed by the U.S. Geological Survey (USGS) for the numerical simulation of three-dimensional saturated groundwater flow in porous media, and it was designed to simulate flow under both steady-state and transient conditions. By invoking an equivalent porous media assumption, the code may also be used to simulate flow in fractured media.

MODPATH was developed by the USGS to compute and display three-dimensional pathlines based on results of steady-state simulations using MODFLOW. The program uses information about layer geometry, boundary conditions, and flux rates to calculate the velocities and positions of particles at different times. MODPATH was used to compute and display pathlines

originating from individual underground nuclear testing locations throughout the weapons testing areas. MODPATH also provided specific discharge distributions along the pathlines which were used in the transport model.

MC_TRANS (IT, 1996i) was developed specifically for this project. This finite-element, onedimensional, radionuclide transport model is capable of simulating advection in a dual-porosity, fractured system with dispersion, sorption, and first-order decay. The code may be used in a deterministic or stochastic mode based on the Monte Carlo or the Latin hypercube sampling techniques. It was used to simulate the concentrations of tritium downgradient from selected nuclear test sites. The code was used in the stochastic mode to evaluate the uncertainties associated with the predicted tritium concentrations. 


\subsubsection{Data Needs}

Data needed to achieve the objectives of the regional data analysis are:

- Geologic and hydrologic data for regional groundwater flow and transport modeling

- Transport parameter and source data for tritium transport modeling

MODFLOW data requirements include geologic framework, hydraulic conductivity, hydraulic head, and groundwater recharge and discharge data. Estimates of the uncertainties that are used to define the input variable bounds and the output variable target ranges for use in the model calibration process and the uncertainty evaluation are also needed. MODPATH data requirements include layer geometry, boundary conditions, specific discharge rates calculated by MODFLOW, and effective porosity data.

MC_TRANS requires transport parameter data, including matrix porosity, effective porosity, dispersion, and tritium matrix diffusion data. Tritium source data needed for the transport model include the initial spatial extent and concentration of the tritium source.

\subsubsection{Implementation}

The implementation of hydrologic modeling consists of developing a geologic model, setting up the flow model using MODFLOW, calibrating the flow model, defining the groundwater flow pathlines, and simulating tritium concentrations using the transport model.

Geologic data were compiled and incorporated into a comprehensive geologic model that consists of hydrostratigraphic unit elevations, including major structural effects such as unit displacements. Hydrologic data were collected and prepared for MODFLOW, MODPATH, and MC_TRANS.

MODFLOW was set up to simulate groundwater flow in the fractured media of the NTS regional groundwater flow system by invoking an equivalent porous media assumption. This assumption implies that at the scale of the model, the hydraulic behavior of fractured geologic units is analogous to that of porous media.

The model for the NTS regional groundwater flow system was developed through the process of steady-state calibration. The calibration of the steady-state flow model was performed using the trial-and-error technique. Transmissivities were first varied within predetermined bounds to match the simulated heads and flux rates with predefined target values derived from observed 
data. Second, the recharge rates and distribution were modified, as needed, to achieve a reasonable calibration.

The groundwater flow model was calibrated to observed conditions using the trial-and-error technique which consists of two major steps. First, the hydraulic conductivities were varied within predetermined bounds to match the simulated hydraulic heads and boundary fluxes with predefined target values derived from observed data. Second, the recharge rates and distribution were modified, as needed, to satisfy a set of predetermined calibration criteria. After calibration was achieved, MODFLOW data were used in MODPATH to identify the pathlines followed by particles placed in selected shot cavities.

Groundwater pathlines were determined by tracking the movement of groundwater through the three-dimensional system from underground test locations that are at or below the water table. MODPATH was used to track an imaginary particle as it flowed through the system defined by the flow model. The locations of the particle were recorded using the PATHLINE option. Effective porosity values appropriate for each HSU along the pathline were assigned, and travel times were calculated. Three shot locations (TYBO, HOUSTON, and BOURBON) were selected to represent pathlines from each of the major testing areas, and the pathlines were discretized for use by the transport model.

Concentrations of tritium were then simulated along the pathlines generated by MODPATH for selected nuclear shots using MC_TRANS. Processes modeled for tritium include advection, dispersion, and matrix diffusion. Matrix diffusion is thought to be an important process within the geologic framework of NTS and vicinity because preliminary carbon-14 velocities are significantly smaller than estimated advective velocities.

\subsection{Risk Assessment Approach}

Risk assessment quantifies the relationship between a contaminant in an environmental media (e.g., tritium in groundwater) and the effect it has on human health and ecological receptors. The general risk assessment process consists of the evaluation of tritium at an exposure location and its intake by receptors and the computation of the resultant risk. The risk assessment describes the mechanisms that enable tritium to be transported through the environment and taken up by receptors. Though there are similarities in the general concepts, significant differences exist 
between the methodologies for performing human health and ecological risk assessments. The specific approaches and selected models for each type of assessment are discussed below.

\subsubsection{Human Health Risk Assessment}

The approach used in the human health risk assessment is based upon coupling three types of models. The first model evaluates the circumstances under which intake of contamination by a human receptor may occur and is called an intake model. The second model calculates the amounts of contamination intake by humans and is called a dose model. The third model calculates the risks associated with the doses to human receptors and is called a cancer and genetic risk model.

The intake model describes the movement and concentration of tritium through the environmental and biotic media and the tritium intake by the human dose receptor. It incorporates information on the fraction of groundwater released to the atmosphere, soil, and surface water as a function of the land use (e.g., agricultural, industrial, mining, residential, recreational, and tourism). The tritium movement and concentration through the environmental and biotic media and the resultant intake by individuals are affected by the following:

- The land-use scenario and type and quantity of groundwater use

- The fraction of the tritium taken up from the environmental media by crops, beef and dairy cattle, and human dose receptors

- The consumption rates of the dose receptors (e.g., ingestion rate of drinking water, inhalation rate of the contaminated air, and the incidental ingestion of contaminated soil and dust)

The dose model calculates the radiological dose due to the tritium intake of the tissues. This model calculates a tritium dose conversion factor which is used to calculate the committed effective dose equivalent from all tritium intakes by the human dose receptor. The tritium dose conversion factor calculation is affected by the following:

- The tritium quality factor, average energy of the tritium beta particle, the effective half-life of tritium in the body, and the mass of soft tissue assumed for the human dose receptor

- The definition of dose as a function of energy deposited per unit mass of tissue 
The risk model calculates the risk due to the dose received by the various types of tissue. Risk may be calculated as the lifetime fatal cancer risk and genetic detriment. In addition, risk may be calculated using the EPA slope factors. The following parameters that affect the calculated risk received from an individual dose:

- The committed effective dose equivalent

- The total tritium intake

- The exposure duration

\subsubsection{Ecological Risk Assessment}

The ecological risk assessment was conducted following the general guidance of the Risk Assessment Guidance for Superfund, Volume II, Environmental Evaluation Manual (EPA, 1989). This approach consists of the problem formulation, the ecological exposure characterization, the ecological effects characterization, and the risk characterization.

The problem formulation includes identifying the constituent of concern, the conceptual site model, exposure pathways, and ecological endpoints. The ecological exposure characterization briefly identifies contaminant movement and specific ecological receptors, and it quantifies exposure point concentrations for both primary and secondary exposure pathways. The ecological effects characterization defines quantitative links between contaminant concentrations and their effects on receptors. Finally, the risk characterization portion of the assessment describes potential risks to ecological receptors and populations of interest.

The ecological risk assessment was performed using an indirect method. Instead of calculating risk from dose values, toxicological benchmarks were used to estimate the tritium concentration in groundwater that would result in a specific dose rate to the selected ecological receptors. The toxicological benchmark is a maximum dose rate recommended by the National Council on Radiation Protection and Measurements' (NCRP) Scientific Committee on the Effects of Ionizing Radiation on Aquatic Organisms (NCRP, 1991 as cited in Kahn, 1992). This benchmark is designed to ensure protection to aquatic and semiaquatic populations. The tritium concentration in groundwater that would result in the toxicological benchmark dose rate is known as the threshold value. The ecological risk assessment estimates the threshold value and compares it to the modeled tritium concentration in groundwater where the selected ecological receptors are located. The main ecological receptors selected include a generic pupfish, the heron, and fish eggs. 
The following parameters affect the calculated internal doses:

- The bioaccumulation factor and effective energy absorbed per unit activity for tritium in the pupfish

- The intake rate of pupfish, bioaccumulation factor of tritium, tritium retention fraction, and body mass of the heron

- The concentration of tritium in the fish egg

- The radius, tritium distribution, and bioaccumulation of tritium in the fish egg

The external dose from tritium to the pupfish, fish eggs, and heron was not considered because the external dose rate from immersion and sediment is zero (Baker and Soldat, 1992).

Probabilistic methods for calculating risk were not used for the ecological risk assessment because very limited data exist about the risk from radiation to aquatic and semiaquatic ecological dose receptors. To account for the uncertainties associated with the various parameters used, conservative end-point values and assumptions were used in the ecological risk models.

\subsubsection{Selected Models}

Human health risk assessment was conducted using the GW.RISK code which implements the three coupled models. GW.RISK is a series of linked spreadsheets written in Crystal Ball, Version 4.0 (Decision Engineering, 1995). Existing dose models were used to implement the ecological risk assessment approach.

The calculation of the tritium intake, dose, and risk for either the child or adult dose receptor requires a set of seven linked spreadsheets for each of the 63 dose points. Five of the seven spreadsheets are used to model the tritium transport, concentration, and intake by the dose receptor; one is used to calculate dose and risk; and one provides the tritium concentration distribution at the specific dose location. The calculational methodology and the parameter values used in the spreadsheets are derived from the open scientific literature or are recommended by scientific bodies such as the National Council on Radiation Protection and Measurements. The first five spreadsheets calculate the following:

- Tritium concentration in air and the inhalation intake of tritium contaminated air

- Ingestion intake of tritium-contaminated drinking water 
- Dermal absorption of tritium from contaminated air and water

- Concentration of tritium in soil and the ingestion intake of tritium contaminated soil and dust

- Tritium concentration in food and the intake from ingestion of the tritium contaminated food

The sixth spreadsheet is used to calculate the dose due to the tritium intake and the resultant risk from the tritium dose. The dose is calculated based upon the recommendation of the International Commission on Radiological Protection (ICRP, 1978) and information found in the open scientific literature. The lifetime cancer, lifetime genetic detriment, and lifetime cancer incidence risk are calculated. The recommendations of the ICRP (1991) were used to calculate the first two types of risk. The lifetime cancer incidence rate was calculated using the EPA slope factor for tritium intake (EPA, 1995). The seventh spreadsheet contains the tritium concentration distribution for a specific dose location simulated by MC_TRANS (IT, 1996i).

Parameter values used by the GW.RISK code to calculate the human exposure to tritium are treated probabilistically, as are the hydrologic parameters. For example, the amount of water an individual drinks each day was treated as a frequency distribution rather than as a single number. Details for the human health risk assessment models are presented in Section 10.0 of this report.

Two complementary radioecological dose models were used in the evaluation of risk to ecological receptors. An aquatic dose model created by Pacific Northwest Laboratory (Baker and Soldat, 1992) was used to estimate the threshold concentration of tritium in water for fish and wildlife. An aquatic dose model developed by Blaylock et al. (1993) was used to estimate the maximum concentration of tritium in surface water below which fish eggs are protected.

\subsubsection{Data Needs}

Data needed to achieve human health and ecological risk assessment objectives of the regional evaluation are as follows:

- Parameters describing the lifestyle of the individuals participating in each land use

- Distribution coefficients describing the fraction of groundwater distributed to each environmental and biotic medium 
- Concentration factors for tritium in the environmental and biotic media

- Intake rates of the dose receptors for each environmental and biotic medium

- Dose and risk conversion factors for converting tritium intake to dose and dose to risk

GW.RISK data requirements include the following:

- Tritium concentration distribution at every receptor location

- Identification of the exposure pathways for individuals participating in each land use

- Climatography at the receptor location

- A description of the human activities associated with each land use

- The fraction of groundwater that is distributed to the soil, air, and surface water

- Transfer coefficients for tritium into soil, air, surface water, food plants, forage, milk, and beef

- Tritium transfer coefficients from environmental and biotic media (e.g., food, air, water, and soil) to the dose receptor for ingestion, inhalation, and skin absorption

- Radiological and biological half-life of tritium and its beta energy spectrum

- Physicochemical attributes of tritium in humans

- Tritium dose conversion factors for adults and children

- Cancer and genetic risk factors for adults and children

The ecological risk assessment data needs require selection of the aquatic and semiaquatic ecological dose receptors. Upon their selection, the bioaccumulation factors for tritium, effective energy absorption factors, ingestion rate of environmental and biotic media, tritium concentration in the environmental and biotic media, tritium retention factors, biological and physical decay constants of tritium, exposure period, and the body mass of the selected aquatic and semiaquatic dose receptors are needed.

\subsubsection{Implementation}

Available data were compiled and interpreted into a human health and ecological risk assessment model. The human health risk assessment was performed using the GW.RISK code. The code 
was used to calculate the tritium intake from ingestion, inhalation, and skin absorption; the resultant dose from the tritium intake; and the estimated lifetime cancer and genetic risk due to the tritium dose. GW.RISK was used to calculate these end points for six conservative land-use scenarios: agricultural, residential, recreational, tourism, mining, and industrial. For the first four land-use scenarios, GW.RISK was used to calculate the intake, dose, and risk for both children and adults. For the last two land-use scenarios, adult end-point values were calculated.

For the ecological risk, available data were gathered to formulate the problem, characterize the ecological exposure, the ecological effects and the risk to the selected ecological receptors. Risk was assessed by estimating the threshold values for each receptor and comparing them to the simulated tritium concentrations in groundwater where the selected ecological receptors are located.

\subsection{Uncertainty Analysis}

The uncertainty analysis provides a quantitative method to gauge the credibility of decisions made from the results of modeling. This section presents the approaches and methods used to account for uncertainty. This analysis is an important activity in the overall modeling process because the results help identify data gaps and prioritize data collection efforts. The purpose of the uncertainty analysis is to provide information about the best estimate of the risk (e.g., the excess cancer risk to this receptor is $3 \times 10^{-8}$ ) as well as information about the range (e.g., there is less than a 5 percent chance that the risk is higher than $4 \times 10^{-6}$ ). Providing this type of information requires estimating the uncertainty in the input parameters to the models, the risk assessment parameters and calculations, and the estimated concentrations and risk.

Development of the flow and transport models involves two types of uncertainty. One uncertainty is about the values of modeling parameters, such as thickness of a unit, hydraulic conductivity, or effective porosity. The other uncertainty is about important features of the geologic units, such as the uncertain western extent of the Eleana Formation (confining unit). The models provide a technique for determining whether uncertainty in various parameters has a significant impact on contaminant transport.

Several approaches are available for addressing uncertainty in parameter values. The best approach involves estimating the frequency distribution of estimates of a particular parameter and representing the degree of confidence placed in the estimate. For example, the frequency 
distribution for the thickness of a unit at a particular location might be a normal distribution with a mean of $100 \mathrm{~m}(328 \mathrm{ft})$ and a standard deviation of $10 \mathrm{~m}(33 \mathrm{ft})$. This distribution indicates

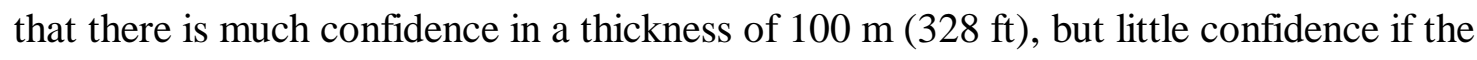

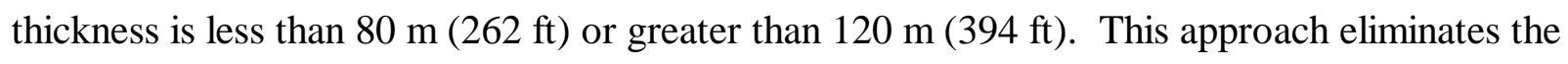
possibility of a negative value which would mathematically require negative concentrations of the contaminant on the mineral surfaces. Theoretically, any frequency distribution can be mathematically treated in the models.

Once the distributions of modeling parameters have been estimated, the next step is to evaluate the effect of parameter uncertainty on predicted concentrations and associated risk. Several approaches are possible: Monte Carlo, Latin hypercube, and nonrandom sampling. While the details of these methods differ, the basic approach is to run the model thousands of times using different values for parameters and to examine the resultant frequency distributions for the decision variables (i.e., the key results). The parameter values are determined for use in the model by statistical sampling from the estimated frequency distributions for the parameters. The results reflect the characteristics of the groundwater system, the properties of the contaminants, the uses of the groundwater, and the uncertainty about each of these.

Although the transport of tritium is simulated in one-dimension, it has a three-dimensional character. However, the lateral dispersion of contaminants across the major transport direction (pathline) is not accounted for by using this approach. This approach simulates a fast-track pathway or conduit in which contaminant concentrations are constrained from lateral movement, which is representative of a conservative (pessimistic) scenario.

The level of uncertainty in calculating the risk to individuals and human populations is a function of the uncertainty in the models and parameter values used to determine tritium source terms; groundwater concentration at exposure locations; and tritium intake, dose, and risk models. Uncertainties in the models were expressed through the use of distributions of parameter values instead of the use of single-point values. Parameter value distributions were chosen from the peer-reviewed technical literature with an emphasis on site-specific data. Monte Carlo techniques were applied to sample values several thousand times from the distributions for each calculation. 
The most significant sources of uncertainty in the human health risk assessment were:

- The distribution of tritium concentration in groundwater

- The lack of knowledge about the effect of nonexchangeable organic-bond tritium on the rate of removal of tritium from the body and sensitive nuclear molecules

- The use of the linear non-threshold risk model in the risk coefficients

- The fact that there is no cancer risk or genetic risk information available about human exposure to tritium.

The uncertainties that are associated with the assessment of ecological risks include the radiological source term, the tritium concentration at exposure locations, the exposure models, and the benchmark values used to evaluate risk. Probabilistic methods for calculating risk were not used for the ecological risk assessment because very limited data exist about the risk from radiation to aquatic and semi-aquatic ecological dose receptors. To account for the uncertainties associated with the various parameters used, conservative end-point values and assumptions were used in the ecological risk models.

The human health and ecological risk methodologies are designed to be conservative. Care was taken in the design of the human health exposure scenarios for each land use to ensure that the probability and quantity of tritium intake will encompass (bound) any realistic situation. The exposure models and benchmark values used in the ecological risk assessment are conservative in nature and may, therefore, actually be over-protective. Details on the human health and ecological risk methodology, models, and parameter values may be found in Section 10.0 of this report. 


\subsection{Geologic Data Analysis}

A three-dimensional conceptualization of the geology and structure of the Nevada Test Site region with emphasis on the NTS groundwater flow system was developed, based on the evaluation of regional geologic data. It is referred to as the geologic model. The geologic model provides the geologic framework for the NTS regional groundwater flow system. This section presents a description of the objectives, geologic model domain, approach, geologic data compilation, conceptual geologic model development, digital geologic model construction, and the model uncertainties. The resulting geologic model was used in the description of the conceptual groundwater flow model in Section 6.0 and is described in detail in the Regional Geologic Model Documentation Package (IT, 1996a).

\subsection{Geologic Model Domain}

The selected geologic model domain is large enough to encompass the NTS regional groundwater flow system or flow domain (Figure 4-1). The geologic model area extends over approximately $28,000 \mathrm{~km}^{2}\left(11,000 \mathrm{mi}^{2}\right)$ and covers a large part of southern Nevada and some of Inyo County, California. The geologic model area (Figure 4-1) is centered around the NTS and ranges from Death Valley to the Pahranagat Valley and from the Sheep Range to Scotty's Junction.

The depth of the geologic model is expected to be less than about $10,000 \mathrm{~m}(32,800 \mathrm{ft})$ below sea level. The vertical extent of the geologic model domain is described in terms of the geologic units of the area described in Section 2.0. The domain includes the following rocks from older to younger: several thousand feet of Precambrian and Paleozoic sedimentary rocks, Cenozoic volcanic tuffs and lavas in some areas, and late Cenozoic alluvium filling valleys between the nearby hills of Cenozoic and Paleozoic rocks.

\subsection{Objectives}

The main objective of the geologic data analysis was to determine the regional distributions and thicknesses of the aquifers and confining units and their depths relative to the hydrologic basement. 
A secondary objective was to have a basis for the estimation of hydrologic and attenuation properties of the rocks through which water flows and radionuclides might migrate.

The specific objectives were as follows:

- Provide an understanding of the genesis of the geology so that reasonable prediction of the distribution of various rock types may be made where geologic data are missing.

- Develop a three-dimensional model of the geology, based on available data (e.g., surface maps, borehole information, and geophysics), and on sound and accepted geologic principles and theories.

- Develop a digital estimate of the elevation of contacts between rocks of different hydrologic and geochemical properties.

\subsection{Approach Overview}

The geologic model was based on an evaluation of existing data by a multiorganizational team of geologists from: Los Alamos National Laboratory (LANL), Lawrence Livermore National Laboratory (LLNL), the USGS, and DOE. The methodology used consisted of data compilation, conceptual geologic model development, and digital geologic model development. Existing geologic data were compiled and evaluated by the team of geologists, and each participating organization was assigned a geographic area corresponding to a portion of the geologic model area described in Section 4.1.

The conceptual geologic model was also developed by the participating organizations. Detailed structural cross sections were drawn to depict structural and stratigraphic features and then were simplified to focus on hydrostratigraphic cross sections. In these hydrostratigraphic sections, detailed stratigraphy was categorized in HSUs with only hydrologically significant structures being depicted. The Geographic Information System-based Environmental Resources Management Applications $\left(\mathrm{ERMA}^{\circledR}\right)$ computer system integrated the geologic data and digitized the simplified cross sections.

The digital geologic model was prepared by geologists from IT Corporation (IT) and GeoTrans, Inc. Maps indicating the geographic extent of each HSU were constructed, digitized, and matched with cross section data. Structure contour maps of each hydrostratigraphic unit were made by combining data from cross sections, surface geology, digital elevation models, and unit extent maps. In the calderas of the SWNVF, elevations of hydrostratigraphic units were 
provided in map and database form. The products of the geologic analysis are 2-km gridded elevations of the surface of each of 20 hydrostratigraphic units.

Applicable procedures and geologic and hydrostratigraphic cross sections contributing to the model are contained in the appendices to the Regional Geologic Model Documentation Package (IT, 1996a) which presents all supporting documentation for the geological interpretations included in the model. Gridded surface elevation data for the hydrostratigraphic units are also included.

\subsection{Geologic Data Compilation}

The purpose of the geologic data compilation was to gather all available, existing geologic data to develop the conceptual geologic model. Geologic data consisted of geologic maps, measured stratigraphic sections, cross sections, geophysical data and interpretations, and existing and Environmental Restoration (ER) borehole data.

Regional geologic data are mostly in the form of geological or geophysical reports or maps. Each participant has been responsible for gathering all pertinent reports and maps of their assigned area and for gaining an understanding of the structural and stratigraphic relationships. These reports generally contain geologic maps, well data, or geophysical data and interpretations. They may also contain measured stratigraphic sections and published cross sections. For the NTS areas, existing and borehole data are available. References to reports, maps, and the borehole data used by each participant are contained in Appendix C of the Regional Geologic Model Documentation Package (IT, 1996a).

Stewart and Carlson's regional "Geologic Map of Nevada, Southern Half" (1977) served as the basis of regional structural and stratigraphic correlation. This map was used to correlate geology between cross sections and to determine the surface distributions and elevations of hydrostratigraphic units. A set of regional geologic cross sections by Grose (1983) served as a guide for subsurface geologic interpretations in some areas. Regional subsurface geologic interpretations (published by the Nevada Bureau of Mines and Geology) were also aided by data from a series of bouguer gravity maps which covered much of the area.

Thousands of boreholes have been drilled on the NTS; however, most are concentrated within the underground testing areas or at Yucca Mountain. Borehole data were included in existing underground testing area maps. Environmental Restoration Program (ERP) boreholes were 
located to address high uncertainty subsurface geology. All pertinent ERP well data were incorporated. In areas outside of the NTS, most borehole data are from water wells in alluvial valleys; thus, they provide little bedrock information. There is a small number of petroleum exploration wells in the geologic model area. Those data are included in the geologic model either as data points on a cross section or as a control between cross sections. The petroleum exploration wells, however, provided little stratigraphic differentiation other than an alluvium/Paleozoic rock contact because paleontological information in the Paleozoic rocks was rarely available.

\subsection{Conceptual Geologic Model Development}

The development of the conceptual geologic model consisted of constructing a set of stratigraphic and hydrostratigraphic cross sections and defining hydrostratigraphic units.

\subsubsection{Stratigraphic Cross Section Construction}

Cross section locations were selected by group consensus with suggestions and approval of the Principal Investigator (PI). Sections were generally oriented perpendicular to regional structural trends to maximize structural relief. Three sections were oriented parallel to groundwater flow directions from north of the NTS to Death Valley. Other sections were added during the task to make accurately representative, complex structural and stratigraphic relationships. Cross section locations are shown in Figure 4-1.

Cross sections were generally constructed at the most convenient scale, based on the scale of the available maps for the area. Most regional sections were constructed at 1:100,000 or 1:125,000; sections across Yucca Flat were constructed at 1:12,000 or 1:24,000.

Borehole data were incorporated into the geologic cross sections differently, depending on the location. For cross sections located on the NTS, only pertinent boreholes were included or projected onto cross sections. ERP boreholes were located to address high uncertainty subsurface geology, and all pertinent ERP well data were incorporated. Data from some of the petroleum exploration wells were also included as data points on cross sections; others were used in the geologic model described in later sections.

\subsubsection{Hydrostratigraphic Unit Definition}

The hydrogeologic model is based on an understanding of the relationships of hydrostratigraphy. Aquifer versus confining unit distinctions are generally related to observations and assumptions 
of the degree to which stratigraphic units, as a whole, tend to be fractured (both primary and tectonic fractures). Using well test data to support these assumptions, Winograd and Thordarson (1975) grouped Paleozoic sedimentary formations into HSUs. These HSUs in the Paleozoic rocks and alluvium include the Lower Clastic Confining Unit, the Lower Carbonate Aquifer, the Upper Clastic Confining Unit (UCCU), the Upper Carbonate Aquifer, and the overlying Alluvium Aquifer.

Volcanic rocks of the SWNVF cover most of the Paleozoic rocks of the NTS in addition to major portions of the regional geologic model area. The volcanic stratigraphy is very complex, and a complete listing of volcanic stratigraphic units of the SWNVF can be found in Ferguson et al. (1994). The most commonly occurring volcanic members and formations of the NTS are listed in Table 4-1.

Unlike the Paleozoic strata, the volcanics had not been defined in terms of their hydrostratigraphy prior to this study. Grouping the Tertiary volcanic rocks into a regional hydrostratigraphic hierarchy proved to be very difficult, and considerable simplification was required for modeling purposes. Because physical characteristics of the volcanic stratigraphy as well as the amount of data available on the rocks vary within geographic areas, the hydrostratigraphic differentiation varied across the region.

Four geographic areas in which the volcanic hydrostratigraphy was separately differentiated were defined: regional volcanics outside of the NTS, the southern NTS, Yucca Flat, and Pahute Mesa/Timber Mountain caldera complex. These areas are shown in Figure 4-2. Regional volcanic stratigraphy outside the NTS has not been subdivided and is referred to as Volcanics Undifferentiated (VU). The volcanic differentiation at the southern NTS and Yucca Flat are detailed in Table 4-1. The differentiation scheme for volcanic rocks within the caldera complex is detailed in Table 4-2.

Volcanic hydrostratigraphy differentiation within the SWNVF was developed as a structural block model for this project; the rationale for the block model is presented in Appendix E-3 of the Regional Geologic Model Documentation Package (IT, 1996a). The basis for the differentiation is that volcanic stratigraphy and its physical features are related to its location with respect to particular structural blocks and volcanic centers. The HSUs were defined on the basis of their stratigraphic position within the volcanic pile, lithologic properties related to depositional environment, post-depositional alteration, and degree of welding. The structural 
Table 4-1

Volcanic Hydrostratigraphy of the Southern NTS/Yucca Mountain Area

\begin{tabular}{||c|c|c|c||}
\hline & $\begin{array}{c}\text { Yucca Mountain/ } \\
\text { Jackass Flats }\end{array}$ & Wahmonie Center & Frenchman Flat \\
\hline \hline Volcanic Aquifer & $\mathrm{Tm}$ & $\mathrm{Tm}$ & $\mathrm{Tm}$ \\
& $\mathrm{Tp}$ & $\begin{array}{c}\mathrm{Tp} \\
\mathrm{Tw}\end{array}$ & $\mathrm{Tp}$ \\
& $\mathrm{Tc}$ & $\mathrm{Tc}$ & $\mathrm{Tw}$ \\
& & $\begin{array}{c}\mathrm{Tn} / \mathrm{To} \\
\mathrm{Tps}\end{array}$ \\
\hline $\begin{array}{c}\text { Volcanic Confining } \\
\text { Unit }\end{array}$ & $\mathrm{Tn} / \mathrm{To}$ & $\mathrm{Tps}$ \\
\hline
\end{tabular}

Table 4-2

Hydrostratigraphy of the Pahute Mesa/Timber Mountain Caldera Complex

\begin{tabular}{||l|l|l||}
\hline \multicolumn{1}{|c|}{ Hydrostratigraphic Unit } & \multicolumn{1}{c|}{ Properties } & \multicolumn{1}{c||}{ Stratigraphic Units } \\
\hline \hline Timber Mountain Aquifer (TMA) & Uppermost welded tuffs & $\mathrm{Tm}, \mathrm{Tf}, \mathrm{Tt}, \mathrm{Tp}$ \\
\hline $\begin{array}{l}\text { Paintbrush Tuff Cone, } \\
\text { Calico Hills Tuff Cone (TC) }\end{array}$ & $\begin{array}{l}\text { Laterally variable } \\
\text { tuffs and lava flows }\end{array}$ & $\mathrm{Tp}, \mathrm{Ta} / \mathrm{Tc}$ \\
\hline Bullfrog Confining Unit (TCB) & Non-welded tuff & $\mathrm{Tcb}$ \\
\hline Belted Range Aquifer (TBA) & Welded tuffs above BCU & $\mathrm{Tb}, \mathrm{Tub}, \mathrm{Tcb}, \mathrm{Tr}$ \\
\hline Basal Confining Unit (BCU) & Non-welded tuffs & $\mathrm{Tn}, \mathrm{Tub}, \mathrm{To}, \mathrm{Tr}, \mathrm{Tq}$ \\
\hline Basal Aquifer (BAQ) & Welded tuffs & $\mathrm{To}, \mathrm{Tl}, \mathrm{Tq}$ \\
\hline
\end{tabular}

block model for the SWNVF covered an area larger than the Pahute Mesa/Timber Mountain caldera areas. Outside the caldera complex, the block model was used as guidance for mapping volcanic HSUs, but structural relationships were taken from the hand-drawn cross sections. Within the caldera complex, volcanic units have very low dips and were mapped as horizontal layers.

A total of 26 regional HSUs were defined and mapped for the conceptual geologic model (Table 4-3). For practical purposes, some adjacent volcanic layers were further grouped into larger HSUs. The grouping included only volcanic layers having a limited extent in the Yucca Flat/Frenchmen Flat area, the southern NTS area, and the tuff cone units in Pahute Mesa. Layers 
Table 4-3

Hydrostratigraphic Units/Geologic Model Layers

\begin{tabular}{|c|c|c|c|}
\hline $\begin{array}{l}\text { Consolidated } \\
\text { Unit }\end{array}$ & $\begin{array}{c}\text { Geologic } \\
\text { Model } \\
\text { Layer }\end{array}$ & $\begin{array}{l}\text { Original } \\
\text { Unit }\end{array}$ & Description \\
\hline$\overline{\mathrm{AA}}$ & 20 & $\overline{\mathrm{AA}}$ & Alluvial Aquifer \\
\hline TMA & 19 & TMAQ-7 & Uppermost Welded Tuffs \\
\hline \multirow[t]{2}{*}{$\mathrm{TC}$} & \multirow[t]{2}{*}{18} & TPTC-6 & $\begin{array}{l}\text { Laterally Variable Tuffs and Lava Flows of Paintbrush } \\
\text { Group Tuff Cone }\end{array}$ \\
\hline & & TPTC-5 & Laterally Variable Tuffs and Lava Flows of Calico Hills \\
\hline TCB & 17 & TCBCU-4 & Non-Welded Tuffs \\
\hline TBA & 16 & TBAQ-3 & Welded Tuffs Above BCU-2 \\
\hline $\mathrm{BCU}$ & 15 & BCU-2 & Non-Welded Tuffs \\
\hline $\mathrm{BAQ}$ & 14 & BAQ-1 & Welded Tuffs \\
\hline \multirow{5}{*}{ VA } & \multirow{5}{*}{13} & WTA & Welded Tuff Aquifer \\
\hline & & VTA & Vitric Tuff Aquifer \\
\hline & & TCU2 & $\begin{array}{l}\text { Zeolitized Tuff Confining Unit (Upper) Volcanic Tuff } \\
\text { Aquifer }\end{array}$ \\
\hline & & TPTA & Topopah Springs Tuff Aquifer \\
\hline & & WLA & Wahmonie Lavas Aquifer \\
\hline \multirow[b]{2}{*}{ VCU } & \multirow{2}{*}{12} & TCU1 & Zeolitized Tuff Confining Unit (Lower) \\
\hline & & VCCU & $\begin{array}{l}\text { Volcaniclastic Confining Unit (Volcanic Tuff Confining } \\
\text { Unit) }\end{array}$ \\
\hline VU & 11 & VU & Volcanics Undifferentiated \\
\hline TSDVS & 10 & $\begin{array}{l}\text { TS } \\
\text { DVS }\end{array}$ & $\begin{array}{l}\text { Tertiary Sediments } \\
\text { Death Valley Section }\end{array}$ \\
\hline LCA3 & 9 & LCA3 & $\begin{array}{l}\text { Lower Carbonate Aquifer (Yucca Flat Upper Plate), } \\
\text { Upper Carbonate Aquifer in NTS Area }\end{array}$ \\
\hline UCCU & 8 & UCCU & Upper Clastic Confining Unit \\
\hline LCA & 7 & LCA & Lower Carbonate Aquifer \\
\hline LCCU & 6 & LCCU & Lower Clastic Confining Unit \\
\hline LCA1 & 5 & LCA1 & Lower Carbonate Aquifer (Upper Plate) \\
\hline LCCU1 & 4 & LCCU1 & Lower Clastic Confining Unit (Upper Plate) \\
\hline LCA2 & 3 & LCA2 & Lower Carbonate Aquifer (Lower Plate) \\
\hline LCCU2 & 2 & LCCU2 & Lower Clastic Confining Unit (Lower Plate) \\
\hline 1 & 1 & 1 & Intrusives \\
\hline
\end{tabular}


were consolidated according to the scheme outlined in Table 4-3, resulting in a total of 20 layers that were used in the hydrogeologic model.

\subsubsection{Hydrostratigraphic Cross Section Development}

For each detailed cross section, a simplified version showing only hydrostratigraphic units and larger structures was constructed. Geologic relationships in detailed cross sections, both observed and inferred, were greatly simplified for model input in order to accommodate mapping limitations inherent in having such a large map area and to be consistent with the level of detail that could be incorporated into such a large groundwater flow model. In constructing the simplified section, emphasis was placed on maintaining a highly generalized structure and stratigraphic framework. The following guidelines were used in the simplification process:

- Geologic formations were grouped into hydrostratigraphic units developed by the Geologic Data Analysis team and approved by the PI.

- Faults were eliminated if they had relatively moderate displacement along which different hydrostratigraphic units were not juxtaposed.

- Overturned HSU layering was represented with vertical contacts to prevent vertically repeated contacts.

- Relatively minor folds or structural distortions in an HSU surface or within an HSU were smoothed.

- In some cases, thin units in the unsaturated zone were deleted.

- Larger fault displacements were treated as smoothed changes in the top of hydrostratigraphic units instead of cross-cutting planes.

\subsection{Digital Geologic Model Development}

The development of the digital geologic model consisted of integrating data into the ERMA ${ }^{\circledR}$, constructing surface contour maps, gridding contoured surfaces, and generating maps.

\subsubsection{Data Integration into ERMA ${ }^{\circledast}$}

The simplified hydrostratigraphic cross sections became geologic data for the digital geologic model. The cross sections were scanned to produce raster images that were imported into ERMA $^{\circledR}$. Raster images were registered in geographic location and in depth. Faults and the tops of each HSU were digitized as separate files. Horizon tops were sampled at 100-m elevation intervals, and cross sections were matched where two sections intersected. All digitized cross 
sections were checked for accuracy, and records of digital files and any updates were made according to applicable procedures.

HSU extent maps were also scanned, digitized, and checked. Extent map and cross section data were posted together for comparison. Inconsistencies usually occurred between these two data sets because of variations in simplification detail, especially when they were compiled from source maps of different scale. Inconsistencies were corrected by the geologist authors, and digital data were modified as necessary to match the reinterpretation.

In the southern part of the map area, the simplified hydrostratigraphic cross sections contain vertically repeated HSUs due to thrust faulting. Because of operational constraints inherent in the ERMA ${ }^{\circledR}$ computer mapping system, repeated layers in these thrust "windows" had to be named and mapped separately. For example, the thrust windows contain LCCU2 (the lower clastic confining unit) and LCCU1 (the overlying repeated layer). Topography was represented in the model by 90-m (295-ft) gridded Digital Elevation Model (DEM) data which were resampled to a 2-km (1.25-mi) grid.

\subsubsection{Construction of Surface Contour Maps}

HSU surface elevation contour maps were made by combining the following data:

- Geologic data from cross sections

- Unit extent map data (to define areas where a unit does not exist)

- Elevations of hydrostratigraphic contacts at the surface

Surface hydrostratigraphy was compiled from the digital version of Stewart and Carlson's "Geologic Map of Nevada, Southern Half" (1977). Geologic units on this map were combined into hydrostratigraphic units as previously defined. This digital HSU map was then merged with the DEM to determine surface elevations of the HSU contacts. All of the surface data were posted together and contoured by computer.

Specific well data were not used as a separate database for HSU surface mapping, but well data were included in cross section construction. Cross sections were specifically situated to tie pertinent wells. Except at the NTS, most wells are in alluvium, and well data were considered in constructing the isopach of alluvium. In some regional locations, specific well data were used as control points by posting them to the appropriate maps. 
Elevation data were contoured using the ERMA ${ }^{\circledR}$ system. A "convergent" algorithm was used with an elongated north-south contouring grid which was selected because of the north-south structural anisotropy of the Basin and Range structures and the close east-west proximity of the data on east-west cross sections. Contour intervals and search radii varied with different surfaces.

Computer contouring was used only as a guide. In areas with higher concentrations of data, the computer-generated contours were generally thought to be acceptable. In areas with sparse data and where the cross sections are relatively far apart, computer-generated contouring was poor or incomplete. In the northern part of the map area, the cross sections were farther apart than the search distance of the contouring routine, and no contours could be generated. Additionally, sparse data tended to cause closed contours, "bulls eyes," around the cross section data. Within these problem areas, each surface map was contoured by hand. Hand-contouring was performed while ensuring that contours followed structural trends and honored faults, surface data, and cross section data. Regional structural contouring was guided by the isopach map of Cenozoic units (Saltus, 1994) for consistency of Basin and Range structural trends.

\subsubsection{Gridding of Contoured Surfaces}

The main products of the regional geologic model are gridded digital-elevation data for each HSU surface. Surface grids at 2-km spacing were generated from the surface contour maps. All grids have the same origin, and each grid covers the entire map area regardless of the unit extent. Grid nodes that fall outside the extent of an HSU have "void" values.

A problem was discovered with the gridding process within ERMA ${ }^{\circledR}$. The ERMA $^{\circledR}$ gridding routine was used to smooth the contour data that were also smoothed as a result of the contouring routine. Therefore, the calculated grid values were a second generation away from the original data. Grid-elevation values, compared with posted cross section data, were locally different up to $300 \mathrm{~m}$ (984 ft). These errors were corrected by adding intermediate contours, regridding, and manually editing grid node values to match data. Elevations across faults were notably smoothed over and had to be manually edited to maintain fault offsets. Grid development is an iterative exercise of plotting, checking against contours and adjacent surfaces, editing, and rechecking until the grid values reasonably match the data and interpolations in between.

Surface grids within the caldera areas were handled differently. Contours were not generated for the HSU surfaces. Instead, because of the very low dips, each layer within each structural block 
was considered to be horizontal. Each structural block was given an elevation for each HSU, which was applied to all grid nodes within the block.

\subsubsection{Map Products}

The products are the digital, two-dimensional, 2-km (1.25-mi) grids showing elevations of the upper surface for each of the 20 HSUs. An isometric view of the LCCU is shown in Figure 4-3. These grids were used as the basis of groundwater flow model discretization. The ERMA ${ }^{\circledR}$ VOXEL Analyst was used to generate various views of the digital geologic model which were used to describe the conceptual groundwater flow model in Section 6.0 of this document.

\subsection{Geologic Uncertainty and Model Revisions}

The geology of the Basin and Range Province is structurally complex. Any conceptualization of subsurface geology, and therefore hydrologic properties, contains great uncertainties. In general, uncertainty in subsurface interpretations increases with distance from surface outcrops and boreholes and with surficial alluvium cover. The greatest density of subsurface borehole data is in the NTS weapons testing areas such as Yucca Flat and Pahute Mesa. Most boreholes in the region surrounding the NTS penetrate only alluvium.

Uncertainties in the geologic interpretations have been reduced by peer input and review. In hydrologically significant areas with highly uncertain geology, alternate interpretations were presented for consideration during the groundwater flow model calibration.

During the course of groundwater flow model calibration, it was noted that in some locations, the geologic model did not adequately simulate measured water levels. Usually a higher elevation for confining units was locally needed to create the observed water levels. In such locations, the uncertainty in the existing geological interpretation was considered, and alternate interpretations were evaluated. Alternate interpretations were incorporated for the Emigrant Valley, Penoyer Valley/Timpahute Range, Rainier Mesa, and Timber Mountain Caldera/Yucca Mountain areas. The rationale for each of these alternate interpretations, with references, is documented in Appendix G of the Regional Geologic Model Documentation Package (IT, 1996a). These areas are also discussed in the following text.

Emigrant Valley, northeast of Yucca Flat, was underlain by the Lower Carbonate Aquifer in the geologic model. This LCA allowed groundwater flow into Yucca Flat from the northeast without a sufficient flow barrier to effect higher water levels in Emigrant Valley. Reexamination 
of the local Emigrant Valley geology showed that Tertiary volcanic layers were locally deposited directly on Sterling Quartzite and Wood Canyon Formations of the Lower Clastic Confining Unit. The current interpretation is that the LCCU is exposed in a large, eroded, pre-Tertiary uplift and is much nearer to the surface over a large area than was originally modeled. The LCCU would immediately underlie the alluvium in the Emigrant Valley.

Penoyer Valley is northeast of Emigrant Valley and has a small outcrop of LCCU present in the central portion of the valley. This outcrop, in conjunction with regional structural trends, indicates that the structural uplift which brought LCCU to the surface in Emigrant Valley also extends northeastward under Penoyer Valley. The original geologic model was revised to incorporate this structural uplift.

Another area which required revision of the geologic interpretation is immediately north of Yucca Mountain. Originally, the model did not affect higher water levels seen in wells north of Yucca Mountain. Following discussions with USGS geologists, the model was changed to more closely incorporate their structural interpretations and the rock properties evidenced in the field. The Belted Range thrust fault system is interpreted to be present, passing north of Yucca Mountain. This interpretation brings LCCU nearer the surface immediately north of Yucca Mountain. Another modification is in the classification of the Timber Mountain Tuff as a confining unit at that location. Field evidence indicates that the volcanic units inside and near the ring fractures of the Timber Mountain Caldera are heavily altered and are confining units instead of aquifers as initially modeled.

Tongue Wash is in the north-central part of the Nevada Test Site. Because of structural complexities associated with the Belted Range thrust fault system and possibly the CP thrust fault system in the area, the subsurface geology is highly uncertain. Devonian carbonate outcrops in Tongue Wash could be either LCA exposed at the surface, or LCA3 carbonates structurally positioned on top of UCCU. Because of the downward potentiometric gradient recorded in nearby Well ER-12-1, the favored geologic interpretation in the model is that the carbonates at the surface in Tongue Wash are hydrologically isolated from the LCA below and are equivalent to LCA3. 


\subsection{Hydrologic Data Analysis}

The purpose of the hydrologic data analysis was to prepare all necessary data (excluding geologic data) necessary to set up the conceptual and numerical groundwater flow models. This section presents the hydrologic data analysis objectives, the general approach and assumptions, the data types and sources, and the specific steps taken in the generation of each required dataset. This section was summarized from four of the documentation packages (IT, 1996b; 1996c; 1996d; and 1996e).

\subsection{Objectives}

The main objective of this analysis was to assemble all hydrologic datasets necessary for the design of a steady-state, three-dimensional groundwater flow model of the NTS regional groundwater flow system. In addition to the geologic framework described in Section 4.0, the groundwater flow model requires information on the hydraulic properties of the hydrostratigraphic units, water levels, and recharge and discharge.

\subsection{General Approach}

Preparation of specific types of data needed for the groundwater flow model consisted of the following tasks:

- Data Type Identification: Based on the technical approach described in Section 3.0, the data needs were identified.

- Data Source Identification: Based on the data needs, the available major sources of data and related information were located.

- Data Compilation and Evaluation: The data were compiled and evaluated for their quality. The methods varied depending on the type of data.

- Data Analysis: The methods of data analysis also depended on their types. They are presented in the subsections of Section 5.3. The major products derived from the analysis include maps, figures, and tables summarizing the data.

\subsection{Data Types}

Types of hydrologic data needed for the flow modeling effort are the hydraulic properties of rocks, hydraulic head data, and recharge/discharge data. These data types are briefly discussed in the following sections. 


\subsubsection{Hydraulic Properties}

Hydraulic properties needed for the groundwater flow modeling are the hydraulic conductivities and effective porosities of the HSUs.

Hydraulic conductivity is a measure of the ability of a geologic medium (rock or soil) to transmit water. Transmissivity is a related term and is the product of the hydraulic conductivity and thickness of the geologic unit. Field tests generally measure the transmissivity of the tested interval. Hydraulic conductivity is then commonly obtained by dividing the transmissivity value by the length of the tested interval.

Effective porosity is that portion of the void space within a rock through which groundwater moves. The actual or advective groundwater velocities are calculated by dividing the specific discharges calculated by the groundwater flow model by the effective porosity. In granular porous media such as the Alluvial Aquifer, the effective porosity is typically almost equal to the total or bulk porosity. In fractured media such as the volcanic aquifers and the LCA, two components of the porosity can be identified: a fracture porosity and a matrix porosity. Water generally flows through the more permeable fracture openings rather than through the matrix. Thus, the effective porosity of rocks where water flows primarily through the fractures is approximately equal to the fractures, but not of the rock matrix.

\subsubsection{Water-Levels}

Water-level data are used to estimate observed hydraulic heads which are compared to those simulated by the groundwater flow model during the calibration process. Hydraulic heads provide a measure of the driving energy that causes groundwater to move through permeable rocks. Hydraulic head is a measure of the potential energy of the water at one point. This energy is due to the fluid pressure and the height of the point from an arbitrary datum, commonly mean sea level. The water level measured in a well is the hydraulic-conductivity weighted average of the open interval in the well. Water-level data are used to estimate directions of flow in groundwater systems. The difference between the observed water levels and the hydraulic heads calculated by the groundwater flow model helps indicate how well the model simulates the groundwater flow system.

For the purposes of the steady-state groundwater flow model, the groundwater flow system is assumed to be in equilibrium before human interference with the system. Human-imposed 
stresses on the groundwater system within the study area include groundwater pumping and underground nuclear testing at or below the water table.

The dataset includes all points where water-level elevations can be obtained, including boreholes, mining shafts, and springs. Each water-level data point is referred to as a site and is defined by its coordinates, predevelopment hydraulic head elevation, and assigned water-contributing HSU(s). In addition, an estimate of the uncertainty associated with the hydraulic head elevation at the site is needed for groundwater flow model calibration and uncertainty analysis purposes.

The water-level elevation data are used as calibration targets during the steady-state groundwater model calibration. The estimate of measurement uncertainty in the form of a variance or standard deviation is used during the calibration process. The bulk of the water-level data was derived from boreholes and mining shafts. Land surface elevations at regional spring locations are used as estimates of the hydraulic heads to supplement the dataset. The resulting data are referred to as the observed hydraulic head dataset or target heads in the numerical groundwater flow model section (Section 7.0). Specific data types compiled to build the hydraulic head dataset include site information, depth-to-water data, well construction data, and well stratigraphy or hydrostratigraphy.

\subsubsection{Recharge and Discharge}

Information about the volume of water moving through the groundwater flow system is needed in developing a model of the system. Water enters the groundwater flow system in recharge areas, moves through the system, and exits the system from discharge areas. Under steady-state conditions, the amount of recharge equals the amount of discharge.

Recharge to a groundwater flow system occurs as areal recharge from precipitation and from subsurface inflow from adjacent groundwater flow systems. Areal recharge from precipitation is input to the groundwater flow model in the form of spatially distributed rates. The areal recharge distribution and rates may not be directly and accurately measured for large areas. However, they may be estimated using other specific types of data and acceptable scientific techniques. Specific variables needed to estimate natural areal recharge are precipitation rates and distribution, land surface elevation distribution, and the location and extent of potential valleyfloor recharge areas such as canyons. 
Natural groundwater discharge occurs primarily from evapotranspiration (ET), spring discharge, and subsurface underflow to adjacent groundwater flow systems located downgradient. Specific types of data needed to estimate discharge are the following: ET area locations and rates; spring locations, elevations, and discharge rates; and subsurface underflow locations and rates.

\subsection{Data Sources}

Data have been collected at the NTS for many years, and nearly all of the data used in the modeling were obtained from existing sources which included databases of governmental agencies and other DOE contractors. A significant amount of data were also obtained from published and unpublished documents and from communications with scientists through meetings and telecommunications. Data collected from ongoing and recently completed Environmental Restoration field activities were also used.

The bulk of the data were obtained from the USGS National Water Information System/ Groundwater Site Inventory (NWIS/GWSI), Water Use Database (WUSE) (USGS, 1989), and geochemistry databases. Other sources included the USGS Yucca Mountain Project, Las Vegas Office of the Nevada District; Desert Research Institute; Lawrence Livermore National Laboratory, Environmental Restoration Program geologic and field activity reports; the National Park Services (NPS); and various publications.

\subsection{Hydraulic Properties}

Available data on the hydraulic properties of the HSUs, including hydraulic conductivity and effective porosity data, are presented in this section.

\subsubsection{Hydraulic Conductivity}

Information about hydraulic conductivity is provided from field tests in which water is injected or withdrawn from wells, and the response of the water levels is measured. This section describes the summary results of these tests, the results of analyses performed to generate probabilistic distributions of hydraulic conductivity for each HSU, and the definition of the relationship between hydraulic conductivity and depth.

\subsubsection{Data Compilation and Evaluation}

Published and unpublished formation hydrogeologic data were compiled. Published transmissivity and hydraulic conductivity values derived from interpretation of aquifer tests, packer tests, specific capacity, and laboratory data were compiled. Unpublished data and 
interpretations were obtained from the USGS, the Desert Research Institute, and data collected by IT Corporation as part of the Environmental Restoration Program.

Both published and unpublished categories of data often included raw or reduced drawdown and recovery data and corresponding interpretations. Having the raw drawdown or recovery data was important for assessing the adequacy of the interpretation and for data quality evaluation.

Nearly all of the formation hydrogeologic property data are collected from single-well tests. These tests are most strongly affected by near-well conditions, particularly during the early part of the test. The shorter the test, the more likely the data represent conditions near the well only. Much of the early time data is of suspect quality and must be used with caution. The integrity of the well itself and the adequacy of the well development are also often in question. These factors cannot be quantitatively incorporated into the analysis, but they increase the uncertainty associated with the measured hydraulic conductivity data.

The tested intervals of wells are defined as the perforated interval, sometimes extended for gravel packs or the length of open hole. This measure of tested interval for a well does not account for converging flow lines in the case of partial penetration and assumes that the integrity of grout seals is intact. Thus, the reported test intervals are approximations.

Winograd and Thordarson (1975) note that the drawdown curves often show anomalous behavior characterized by steep initial drawdown curves and recovery responses that do not match the drawdown. They state that the causes of the rapid initial drawdowns are probably partial penetration, a zone of reduced transmissivity surrounding the wellbore, or abnormally high head losses due to flow through a small number of fractures. The true causes are not well known, but anomalies decrease the confidence in some of the available data.

The reported or calculated values of transmissivity or hydraulic conductivity were qualitatively ranked in terms of the relative confidence that might be expected. Confidence is a function of the type of test, the quality of the data, and the method of analysis; therefore, confidence is a reflection of how well the data fit the model used for interpretation and whether the model used 
was appropriate. Based on the following criteria, confidence was ranked into high, medium, or low:

- High:

- Good level of documentation

- Pumping aquifer test (using either the drawdown or recovery portion)

- Good test conditions with no pump failures or unusual fluctuations in the drawdown

- Good match of the theoretical model to the data over a significant number of data values

- Medium:

- Data that cannot be ranked as either high or low. The medium classification does not have specific criteria of its own, but rather serves to distinguish data that are neither high or low. It is a broad category by design.

- Low:

- Unusual test conditions such as variable pumping rates, pump failures, temperature or density fluctuations during the test that result in unusual water level responses, such as rising water levels when they should be falling

- An incorrect method applied to the data. For example, the Theim method is not applicable to a typical aquifer test under transient conditions.

- Values determined from early-time data that are very likely influenced by casing storage, skin effects, etc.

- Specific capacity or relative-specific capacity data used to calculate transmissivity (T) or hydraulic conductivity $(\mathrm{K})$

- Little or no documentation of the test method

Several sources of uncertainty are associated with a given value of hydraulic conductivity for a particular location and HSU. These sources of uncertainty are as follows:

- Measurement errors in water levels and time

- Disturbances during testing

- Scientist subjectivity in the curve-fitting process

- Differing conceptual models (for example, single versus double porosity)

- Spatial variability 
Errors due to time and water-level measurement inaccuracies are unimportant compared to the other sources of error. Disturbances during testing include hydraulic perturbations caused by nearby wells, earth tides, barometric fluctuations, unexpected pump failures, well construction, or well development. The quantification of these uncertainties is difficult. However, if these effects were noted in the documentation, the test result was given a lower confidence ranking.

To assess the uncertainty caused by scientists' subjectivity of the curve fitting process, published drawdown and recovery pumping test data were reanalyzed to obtain a verification of the hydrologic parameter. The results of this exercise indicated that the derived hydraulic parameters are within 10 to 20 percent; this source of error is, therefore, relatively small.

A limited analysis was performed to examine the effect of different conceptual models using the Theis and double-porosity models and pumping data from five wells. The results suggest that the choice of different interpretive models may result in differences of up to a factor of 3 in the transmissivity obtained. Moench (1984) found that the difference in drawdown slopes resulted in a difference factor of 10 in the calculated hydraulic conductivity. Thus, for aquifers that are actually double-porosity in nature, the reported transmissivity values may be overestimated by a factor that ranges from about 3 to 10 .

Spatial variability is characterized as natural variability and is caused by aquifer heterogeneity. The summary statistics for the HSUs with the largest number of values (AA and LCA) suggest a standard deviation of about one order of magnitude. The spatial variability is at least four times larger than the uncertainty due to different conceptual models, and it is many times larger than the uncertainty caused by curve fitting subjectivity.

\subsubsection{Tested Interval}

The tested interval is important for several reasons. First, it is used to assign a hydrostratigraphic unit to the value. Second, if the data are reported as a transmissivity, then the tested interval thickness is needed to calculate hydraulic conductivity. The hydraulic conductivity is obtained by dividing the transmissivity by the tested interval thickness which is defined by the top and bottom of the tested interval.

The definition of the tested interval varied from well to well, but followed several basic criteria. For an open-hole completion, the top of the tested interval was either the bottom of the casing or the water table. The bottom of an open hole completion was typically chosen as the bottom of 
the hole. In some cases, the top of the tested interval was extended a short distance above the bottom of the casing to account for converging flow lines. For perforated completions, the top and bottom perforations were used. If the water table occurred within the perforated interval, the water table was chosen as the top of the tested interval. In a few cases, more than one perforated interval was present. In those cases, the top of the uppermost perforation and the bottom of the lowermost perforation were used.

\subsubsection{Hydrostratigraphic Unit Assignment}

The HSU is assigned on the basis of the tested, or open, interval and corresponding lithologic and stratigraphic information available in the ER stratigraphic database or the published literature. It is recognized that few wells fully penetrate any one HSU. More commonly, the tested intervals cross more than one HSU or partially penetrate others. The assigned HSU represents the predominant unit tested. Some wells have multiple, but separate, test intervals and provide data for more than one HSU.

\subsubsection{Statistical Analysis}

The statistical analyses of the hydraulic conductivity data are important to the modeling effort. Mean values of hydraulic conductivity per HSU will guide the initial values of hydraulic conductivity in the model, modified as appropriate for regional variation. Similarity or dissimilarity of the mean and standard deviation of hydraulic conductivity per HSU will aid the process of categorizing the HSUs into a smaller number of model layers. The standard deviation of hydraulic conductivity per HSU also serves as a measure of the spatial variability of hydraulic conductivity and will be important for assessing the latitude with which hydraulic conductivity values can be adjusted during calibration.

Statistical analyses were performed on a subset of the hydraulic conductivity data provided in Appendix C of the Hydrologic Parameter Data Documentation Package (IT, 1996d). The following two criteria were used to select this subset of data:

- Laboratory data were excluded from consideration because field-scale data were deemed more representative of larger portions of the aquifer than the smaller scale tests.

- All measurements that rated as high or medium confidence were used. Data given a low confidence ranking were excluded from the statistical analyses. 
Means and variances were first calculated on a "per well" basis by assuming that the hydraulic conductivity data are spatially, log-normally distributed. The geometric mean of the "per well" data is given in Table 5-1. Another aspect complicated the calculation and interpretation of the statistics. Many of the wells have multiple interpretations for the same drawdown or recovery curve. In other cases, multiple intervals were tested in the same well. To account for these complications, a weighted arithmetic mean was calculated for each HSU in each well. The length of the tested interval was the weighting factor; thus, the means were transmissivity weighted. The results of this statistical analysis are presented in the Hydrologic Parameter Data Documentation Package (IT, 1996d).

Based on the results, the two most conductive HSUs are the AA and the carbonate aquifer (LCA, LCA3). For those same two HSUs, the standard deviation ranged from 0.9 to 1.5 , which implies a range of values over four orders of magnitude, based on \pm two standard deviations. This large range suggests that over the study area, large variability in hydraulic conductivity can be expected. Similar ranges of values for different rock types have been reported in Freeze and Cherry (1979), indicating that the data from the NTS region are not unusual.

\subsubsection{Distribution of Hydraulic Conductivity with Depth}

The relationship between hydraulic conductivity and depth can help in estimating the total depth of the groundwater flow system and the hydraulic conductivity of the deeper strata for which data are not available. Data specific to the major types of geologic units were used to develop relationships between hydraulic conductivity and depth for use in estimating the hydraulic conductivities of the lower strata, thus the flow model layers. The relationships were developed for the following three rock types that form the major aquifers: the Alluvial Aquifer, the Volcanic Aquifer, and the Lower Carbonate Aquifer (Figure 5-1). The graphs exhibit similar relationships between hydraulic conductivity and depth for the three rock types. Two features are evident on these graphs. First, there is a trend of decreasing hydraulic conductivity with depth, suggesting that a lower bound for the flow system can be defined on the basis of these figures. Second, for depths of approximately 3,000 m (9,843 ft) and more, the extrapolated hydraulic conductivity values are less than $10^{-7}$ meters per day $\left(3.3 \times 10^{-7}\right.$ feet per day), which are representative of virtually impermeable media. 
Table 5-1

Hydraulic Conductivity Summary Statistics Based on Well Averages

(Variable is $\log [\mathrm{K}]$ with $\mathrm{K}$ in meters per day)

\begin{tabular}{|c|c|c|c|c|c|c|}
\hline Hydrostratigraphic Unit & Mean & $\begin{array}{l}\text { Standard } \\
\text { Deviation }\end{array}$ & Variance & Minimum & Maximum & Count \\
\hline Alluvial Aquifer & 0.368 & 1.25 & 1.56 & -3.96 & 1.56 & 21 \\
\hline Tertiary Sediments & -0.810 & NA & $\mathrm{NA}$ & -0.810 & -0.810 & 1 \\
\hline Basal Aquifer & -2.36 & NA & $\mathrm{NA}$ & -2.36 & -2.36 & 1 \\
\hline Lower Carbonate Aquifer & 0.158 & 1.09 & 1.19 & -1.45 & 2.86 & 22 \\
\hline $\begin{array}{l}\text { Lower Carbonate Aquifer - } \\
\text { Upper Plate }\end{array}$ & -0.555 & 1.81 & 3.28 & -3.09 & 1.17 & 4 \\
\hline $\begin{array}{l}\text { Belted Range Aquifer/ } \\
\text { Basil Aquifer }\end{array}$ & 0.870 & NA & NA & 0.870 & 0.870 & 1 \\
\hline Belted Range Aquifer & -0.409 & 0.86 & 0.742 & -1.39 & 0.615 & 5 \\
\hline Calico Hills Tuff Cone & -0.982 & 0.08 & 0.00718 & -1.04 & -0.922 & 2 \\
\hline $\begin{array}{l}\text { Calico Hills Tuff Cone/ } \\
\text { Belted Range Aquifer }\end{array}$ & -1.83 & 0.59 & 0.349 & -2.36 & -1.19 & 3 \\
\hline Tuff Confining Unit & -2.81 & 1.95 & 3.79 & -5.11 & -0.212 & 5 \\
\hline Timber Mountain Aquifer & -0.555 & NA & $\mathrm{NA}$ & -0.555 & -0.555 & 1 \\
\hline $\begin{array}{l}\text { Paintbrush Tuff Cone/ } \\
\text { Calico Hills Tuff Cone }\end{array}$ & -0.521 & NA & NA & -0.521 & -0.521 & 1 \\
\hline Volcanics Undifferentiated & -2.15 & 0.74 & 0.543 & -3.28 & -1.38 & 5 \\
\hline $\begin{array}{l}\text { Welded Tuff Aquifer/ } \\
\text { Tuff Confining Unit }\end{array}$ & -1.30 & 1.31 & 1.71 & -2.86 & -0.0635 & 6 \\
\hline $\begin{array}{l}\text { Welded Tuff Aquifer/ } \\
\text { Tuff Confining Unit/ } \\
\text { Lower Carbonate Aquifer }\end{array}$ & -1.61 & NA & NA & -1.61 & -1.61 & 1 \\
\hline Welded Tuff Aquifer & -0.599 & 1.15 & 1.33 & -3.18 & 0.641 & 10 \\
\hline
\end{tabular}


Other researchers have also estimated the depth of the flow system underlying the NTS.

Winograd and Thordarson (1975) state that fractures in the LCA are open to at least 1,300 m $(4,265 \mathrm{ft})$ below land surface. In the volcanics units on the mesas, Blankennagel and Weir (1973) found that water leaks downward along fractures at depths greater than $2,500 \mathrm{~m}$ $(8,202 \mathrm{ft})$. Thus, the depth of 3,000 $\mathrm{m}(9,843 \mathrm{ft})$ estimated from the volcanic data is of a similar magnitude to other studies.

A decreasing linear trend is observed in the logarithm of hydraulic conductivity with increased depth; thus, hydraulic conductivity decreases exponentially with depth. The relationship is provided by the following equation:

$$
\mathrm{K}_{\text {depth }}=\mathrm{K}_{\mathrm{h}}\left(10^{-\lambda \mathrm{d}}\right)
$$

where:

$\mathrm{K}_{\text {depth }}=$ horizontal hydraulic conductivity at specified depth (L/T);

$\mathrm{K}_{\mathrm{h}} \quad=$ horizontal hydraulic conductivity at land surface $(\mathrm{L} / \mathrm{T})$;

$\lambda=$ Hydraulic conductivity decay coefficient (1/L); and

$\mathrm{d}=$ depth from land surface $(\mathrm{L})$.

The rate of decrease of hydraulic conductivity with depth is determined by the value of $\lambda$, the conductivity decay coefficient. The $\lambda$ values for the three aquifers are provided in Table 5-2. The relationship in equation (5-1) with coefficients from Table 5-2 is shown in Figure 5-1.

\subsubsection{Effective Porosity}

In fractured geologic materials, the effective porosity is best measured via a tracer migration test. However, because effective porosity values from tracer experiments are scarce for the hydrostratigraphic units at the NTS, data on fracture porosity have also been used to estimate the effective porosities of the HSUs.

\subsubsection{Porosity Data From Tracer Migration Studies}

To describe large-scale movement of solutes in the subsurface, the effective porosity is usually obtained from tracer or solute migration experiments. Three studies of tracer or radionuclide movement on or near the NTS have yielded estimates of the effective porosity and are summarized in Table 5-3. 
Table 5-2

Hydraulic Conductivity Decay Coefficients with Depth

\begin{tabular}{|c|c|c|c|c|c|c|}
\hline \multirow{2}{*}{ Aquifer } & \multicolumn{3}{|c|}{ Decay Coefficient $\left(\right.$ day $\left.^{-1}\right)$} & \multicolumn{3}{|c|}{$\begin{array}{l}\text { Hydraulic Conductivity } \\
\text { at Land Surface meters per day }(\mathrm{m} / \mathrm{d})\end{array}$} \\
\hline & $\begin{array}{l}\text { Lower } 95 \% \\
\quad \text { C.I. }\end{array}$ & Mean & $\begin{array}{l}\text { Upper } 95 \% \\
\text { C.I. }\end{array}$ & $\begin{array}{c}\text { Lower } \\
95 \% \\
\text { C.I. }\end{array}$ & Mean & $\begin{array}{l}\text { Upper } 95 \% \\
\text { C.I. }\end{array}$ \\
\hline Alluvial & 0.00724 & 0.00563 & 0.00402 & 6.04 & 21.18 & 74.25 \\
\hline Carbonate & 0.00160 & 0.00102 & 0.00044 & 2.60 & 6.76 & 17.59 \\
\hline Volcanics & 0.00306 & 0.00256 & 0.00205 & 2.15 & 7.75 & 27.87 \\
\hline
\end{tabular}

C.I. $=$ Confidence Interval

Table 5-3

Effective Porosity Obtained From Tracer Migration Experiments

\begin{tabular}{||l|c|l|l||}
\hline \hline \multicolumn{1}{|c|}{ Location } & $\begin{array}{c}\text { Effective } \\
\text { Porosity } \\
(\%)\end{array}$ & Hydrostratigraphic Unit & \multicolumn{1}{|c||}{ Reference } \\
\hline \hline $\begin{array}{l}\text { U.S. Geological Survey } \\
\text { Amargosa Tracer } \\
\text { Calibration Site }\end{array}$ & 10 & Lower Carbonate Aquifer & Leap and Belmonte (1992) \\
\hline Wells C and C-1 & $0.064-0.5$ & Lower Carbonate Aquifer & $\begin{array}{l}\text { Winograd and West (1962): } \\
\text { analysis using Welty and Gelhar } \\
\text { (1989) }\end{array}$ \\
\hline Cambric Site & $31-35$ & Alluvial Aquifer & Burbey and Wheatcraft (1986) \\
\hline
\end{tabular}

Leap and Belmonte (1992) examined data from the U.S. Geological Survey's Amargosa Tracer Calibration Site (south of the NTS) and determined an effective porosity of 10 percent for a fractured 10-m thick interval of the Bonanza King dolomite of the LCA. Burbey and Wheatcraft (1986) used an effective porosity of 32 to 36 percent for the alluvium at the Cambric Site in Frenchman Flat. A preliminary assessment of the tracer experiment at Wells C and C-1 (Winograd and West, 1962) yielded effective porosity between 0.064 and 0.5 percent for the Lower Carbonate Aquifer. 


\subsubsection{Fracture Porosity}

The small number of tracer studies on the NTS limits the applicability of the data to the entire study area. To supplement the tracer studies, data from the examination of fractures in core were used to calculate fracture porosity values on the NTS. In addition, fracture porosity data from sites outside the NTS were examined to determine if data from the NTS are representative. Two recent studies of carbonate (IT, 1996j) and volcanic (IT, 1996k) core provided insights into fracture porosity values.

Core from Well ER-6-2 (IT, 1996j) was examined and described with respect to fracture density (number of fractures per 1.5-m [5-ft] interval), fracture aperture, and fracture dip angle. In the analysis, only open fractures were included. Sealed fractures were excluded because they are unlikely to transmit much water. The average fracture spacing along the borehole is $1.5 \mathrm{~m}$ $(4.8 \mathrm{ft})$. The mean dip angle is $81^{\circ}$, and the mean aperture is 0.9 millimeter $(0.003 \mathrm{ft})$. Using the fracture spacing along the borehole and the dip angle, the true fracture spacing is shown to be $0.22 \mathrm{~m}(0.7 \mathrm{ft})$. The fracture porosity is $4 \times 10^{-3}$, which is estimated as the aperture divided by the true spacing. This value compares well with the larger value obtained from the tracer test in Wells $\mathrm{C}$ and $\mathrm{C}-1$ in Table 5-3.

A similar study (IT, 1996k) of core from seven wells from Pahute Mesa was conducted to characterize fractures in the volcanic units. A range of fracture porosities (calculated from aperture, density, orientation, and percent open-area data) is presented in Table 5-4.

Table 5-4

Fracture Porosity Obtained from the Study of Volcanic Core

\begin{tabular}{|c|c||}
\hline Hydrostratigraphic Unit & Fracture Porosity Range \\
\hline \hline TMA & $2.2 \times 10^{-5}$ to $2.1 \times 10^{-4}$ \\
\hline TC & $2.6 \times 10^{-6}$ to $4.7 \times 10^{-4}$ \\
\hline TBAQ & $1.2 \times 10^{-5}$ to $4.4 \times 10^{-5}$ \\
\hline BAQ & $6.1 \times 10^{-6}$ to $2.3 \times 10^{-4}$ \\
\hline
\end{tabular}

Several literature sources for fracture porosity were examined to determine if the data from the NTS were consistent with other work from around the world. Lee and Farmer (1993) summarized a large amount of information about fluid flow in fractured rocks. They showed that 
fracture porosity typically ranges from $5 \times 10^{-6}$ to $5 \times 10^{-4}$ for clastic, metavolcanic, and crystalline rocks. This range is similar to the ranges indicated in Table 5-4.

At the Stripa Site in Sweden, the flow porosity is in the range of $1 \times 10^{-5}$ to $2 \times 10^{-4}$ (Neretnieks et al., 1989). In the fractured basalts of eastern Washington state, Gelhar (1982) measured a porosity of $4.3 \times 10^{-4}$ using a two-well tracer test. For carbonate rocks, the measured porosities tend to be larger. In the Culebra Dolomite of eastern New Mexico, a range of values from $2 \times 10^{-4}$ to $2 \times 10^{-2}$ has been proposed (Tomasko et al., 1989).

\subsubsection{Summary of Porosity Data}

The effective porosity value for the Alluvial Aquifer ranges between 31 and 35 percent. This range seems reasonable because the effective porosity is similar to the matrix and bulk values obtained from core and geophysical log data discussed in Section 8.0.

The effective porosity of the LCA ranges between .01 and 1 percent. The lower-bound estimates come from the fracture aperture data and may be as low as 0.01 percent. Upper-bound values from the Amargosa tracer site are about 10 percent. Winograd and Thordardson (1975) also assumed average effective fracture porosities ranging from 0.01 to 1 percent for the LCA beneath Yucca Flat and the Specter Range. This range is similar to the porosity values assumed for the Culebra Dolomite of New Mexico. The LCA value for effective porosity determined by Leap and Belmonte (1992) is larger than would be expected for a fractured aquifer. The Well $\mathrm{C}$ and C-1 values, although approximate, are closer to expectation. The 10 percent value may be accurate for the Amargosa site, but it is unlikely to be representative for the NTS as a whole. The Amargosa tracer site is a very thin $(<10 \mathrm{~m}[32.8 \mathrm{ft}])$ aquifer about $200 \mathrm{~m}(656 \mathrm{ft})$ below land surface; these conditions are not typical of the study area as a whole.

For the fractured volcanic rocks, a range of effective porosity values from $2 \times 10^{-6}$ to $5 \times 10^{-4}$ appears appropriate. This is a very large range, covering more than two orders of magnitude. As a result, the uncertainty associated with predicting radionuclide velocity will be quite large.

\subsection{Water Levels}

In the evaluation of water-level data for the generation of a hydraulic head dataset, the following steps were followed:

- Compile and evaluate the data.

- Perform a statistical analysis to identify stable trends. 
- Evaluate the uncertainties associated with the hydraulic head values.

- Assign a hydrostratigraphic unit.

- Develop hydraulic head distribution maps.

\subsubsection{Data Compilation and Evaluation}

The level of detail in the analysis of water-level data depends on the scale of the modeled area. The following assumptions, deemed appropriate for a regional evaluation, were made:

- Spatial variations in groundwater density do not cause a significant effect on the hydraulic heads. Thus, no corrections were made on the hydraulic heads for density variation due to changes in temperature or chemistry.

- The degree of deviation of the boreholes is negligible enough so that no correction is necessary on the depth-to-water measurements for a regional scale study.

- No leakage occurs between hydrostratigraphic units within the casing in boreholes open to multiple hydrostratigraphic units. Thus, observed hydraulic heads are representative of the hydrostratigraphic units targeted for measurement.

The specific types of data associated with the hydraulic head dataset were obtained mainly from the USGS/GWSI database (USGS, 1989) and loaded in the ER database. The NWIS/GWSI data were complemented with data from the literature reviewed. Additional depth-to-water data were obtained from the Yucca Mountain database and various other publications. Most of the contributing units information was derived from USGS reports.

Three main categories of wells were identified during the compilation of depth-to-water and ancillary data: wells with multiple measurements, wells with single measurements, and wells without measurements.

The first category consists of wells not having any depth-to-water measurement available and labeled "inadequate" for the statistical analysis. Wells eliminated from the statistical analysis were those which had no depth-to-water measurements. Measurements were usually lacking if the well was dry, obstructed, flowing, or destroyed.

The second category consists of sites having a single depth-to-water measurement. These wells were usually private wells located outside of the NTS on nuclear test sites at which the measurement was made prior to exploding the nuclear device. 
The third category consists of wells with multiple measurements. For such sites, hydrographs were examined to identify stable periods that would best represent predevelopment conditions. A horizontal stable trend is defined as that part of the hydrograph that includes only cyclical variations about a mean value (Figure 5-2). Such a stable trend is representative of steady-state conditions. For a given site, data points which are anomalously low or high and those which are not part of the stable portion of the hydrograph were excluded from the statistic analysis.

\subsubsection{Identification of Predevelopment Hydraulic Heads}

The method of defining the predevelopment water levels is dependent on the category of wells used to derive hydraulic heads from depth-to-water values.

For sites with no depth-to-water measurements, an estimate of the water level was based on the circumstance. If the well was dry or obstructed, a maximum head value was estimated to be the elevation of the well's total depth (TD) or the elevation of the depth at which the obstruction was encountered. If the well was naturally flowing, a minimum value for the head was the land surface elevation (LSE) at the well location.

For sites having a single record of hydraulic head, the measured value was selected to be the steady-state hydraulic head for that site. The associated temporal variances are unknown for such sites and are assigned an estimated value.

For sites with multiple head elevation records "consistent" with a stable trend, simple statistics were performed to calculate mean water-level values and hydrograph variances for use in the uncertainty estimate. The predevelopment water level was calculated as a simple average (mean) representative of that location. For sites with multiple records, but no consistent trend, a spatial evaluation was made to select the most likely value for head elevation at that location.

\subsubsection{Uncertainty Evaluation}

The two variables used to calculate the hydraulic head are depth-to-water (DTW) and land surface elevation. Thus, the uncertainty associated with a mean hydraulic head value at a given site stems from three main sources of error: the error associated with estimating the land surface elevation, the error associated with depth-to-water measurements, and the error associated with reducing the temporal water-level measurements to a mean value. 
The USGS database provides an estimate of the land surface elevation accuracy based on the method used, including topographic maps or surveying (both of which provide better accuracies). These estimates are only gross indicators of the potential error based on the method of estimation. For the purposes of this evaluation, they are assumed to represent the errors on LSEs for sites reported in the NWIS database. These errors range between 0 and $70 \mathrm{~m}$ ( 0 and $230 \mathrm{ft}$ ). The LSE errors for other sites are unknown.

The error associated with the depth-to-water measurements is generally less than $0.2 \mathrm{~m}(0.5 \mathrm{ft})$. When averaging measurements, the error associated with taking individual depth-to-water measurements is included within the fluctuations of the hydrograph.

The hydrograph error is dependent on the site under consideration and may be estimated from the hydrograph variance. For flow model calibration purposes, estimates of the variances associated with the hydraulic head values, rather than errors, are used to weigh the hydraulic heads. The variance of the average hydraulic head value was calculated as the sum of the variances of the two independent variables as follows:

$$
\sigma_{\overline{\mathrm{H}}}^{2}=\sigma_{\mathrm{LSE}}^{2}+\sigma_{\mathrm{DTW}}^{2}
$$

Where:

$\sigma_{\overline{\mathrm{H}}}^{2} \quad=$ Variance associated with the average hydraulic head square meters $\left(\mathrm{m}^{2}\right) ;$

$\sigma_{\text {LSE }}^{2}=$ Variance associated with the land surface elevation $\left(\mathrm{m}^{2}\right)$; and

$\sigma_{\text {DTW }}^{2}=$ Hydrograph variance of "consistent" measurements $\left(\mathrm{m}^{2}\right)$.

For sites having a single measurement of DTW, temporal variances are unknown for such sites and were assigned a "999" code value in the database. Thus, the total variance is unknown and also is assigned a "999" code. For springs, the variance of the LSE is used as the total hydraulic head variance. A total hydraulic head variance value of $100 \mathrm{~m}^{2}\left(1,072\right.$ square feet $\left.\left[\mathrm{ft}^{2}\right]\right)$ is recommended for all hydraulic head values assigned a "999" code. This variance is equivalent to an estimated error of +/- $20 \mathrm{~m}(65.6 \mathrm{ft})$ or plus or minus two standard deviations with a 95 percent confidence level. 


\subsubsection{Site Hydrostratigraphic Unit Definition}

For most sites located on the Nevada Test Site, hydrostratigraphic information was derived using a stratigraphic database developed during the course of this evaluation and the hydrostratigraphy described in Section 4.0. For other sites, the hydrostratigraphic information was directly obtained or derived from published and unpublished references.

An effective open interval (EOI) was defined for each site for which well construction data were available. The definition of the EOI varied from well to well as a result of differences in well construction and the water level, but followed several basic criteria. For an open-hole completion, the top of the tested interval was either the bottom of casing or the water table. The bottom of an open-hole completion was typically chosen as the bottom of the hole. For perforated completions, the top and bottom of perforations were used. If the water table occurred within the perforated interval, the water table was chosen as the top of the EOI. In some cases, more than one perforated interval was present; in those cases, the top of the uppermost perforation or water level and the bottom of the lowermost perforation were used.

The assignment of hydrostratigraphic units was dependent on the type of data available to define the HSU. For most of the wells located on the Nevada Test Site, the stratigraphic units to which the well was open were identified, using the EOI defined above; then the corresponding HSU was identified, based on the relative estimated identified transmissivities. The HSU with the highest transmissivity within the EOI was selected as the primary HSU for the well. Sources of data were the ER stratigraphy database and publications.

For some of the wells, particularly those on the NTS and in Amargosa Desert, the HSUs tapped by the wells were identified in USGS publications (Arteaga et al., 1991; La Camera and Westenburg, 1994). For private wells located in the Amargosa Desert and Penoyer Valley, the HSU was identified using lithologic or drillers' logs. Most of these private wells were completed in the Quaternary Alluvial Aquifer.

Numerous wells outside of the NTS were lacking the geology and well construction information necessary to assign an HSU with confidence; however, their TDs were known. These wells with their water-level elevations and TD were posted on isopach maps of the Alluvial Aquifer and surficial geology maps. The well depth was then compared to the thickness of the alluvium at that location. If the well depth was less that the thickness of the AA at that location, the well was assigned the AA HSU. If no geology, well construction, and TD data were available, the HSU 
was assigned, based on information from neighboring wells and water-level comparison to those of neighboring wells.

\subsubsection{Dataset and Map Generation}

The generation of a potentiometric-level map was performed in three steps:

- Step 1: Contours were generated using the ERMA ${ }^{\circledR}$ automatic contouring software package.

- Step 2: Groundwater flow controlling features such as topographic, geologic, or structural controls and recharge and discharge areas were mapped on separate layers on the Environmental Restoration Data Base Management System (ERDBMS) and superposed on the head contour map.

- Step 3: The hydraulic head contours were modified by hand to account for the effect of the controlling features and to interpolate the lines in areas where large data gaps exist.

A spatial data analysis was conducted during the generation of the regional composite potentiometric map. The objective of the spatial analysis was to identify and flag spatial "outliers" in the hydraulic head dataset. The hydraulic head dataset was evaluated to identify those measurements that were not representative of regional conditions; these data were not included on head contour maps. For example, water levels indicating perched conditions were flagged as not being representative. These included many springs at higher elevations in the northern part of the model area and in the Spring Mountains. Also excluded are measurements in NTS wells made during or shortly after drilling when it was questionable whether water levels had stabilized.

Several maps depicting the hydraulic head distributions for various areas were generated. The regional water level map is presented and discussed in Section 6.0. All other maps and the associated hydraulic head dataset have been provided in the Potentiometric Data Documentation Package (IT, 1996b).

\subsection{Recharge and Discharge}

The development of the steady-state, three-dimensional groundwater flow model requires knowledge about the recharge and discharge areas and rates of flow in the groundwater flow system. Under natural steady-state conditions the major recharge component is from precipitation, and discharge is by ET. Minor recharge and discharge to and from the NTS 
regional groundwater flow system also occurs by underflow across the boundaries of the flow system.

\subsubsection{Areal Recharge}

The distribution and rates of areal groundwater recharge from precipitation may not be directly and accurately measured. Two major methods of estimating groundwater recharge from precipitation have been documented in the literature. They consist of the Maxey-Eakin (ME) Method (Maxey and Eakin, 1949) and related methods; and a method modified from that of Maxey-Eakin by D'Agnese (1994). The ME method is a widely used empirical method which estimates recharge directly from precipitation estimates. A modified ME method, which is based on an updated precipitation map, was used in this evaluation.

\subsubsection{Maxey-Eakin Method}

Between 1947 and 1951, Maxey and Eakin developed a method of estimating recharge to groundwater from precipitation The method was described in a report about groundwater in White River Valley (Maxey and Eakin, 1949). Since then, this method has been used in several studies in Nevada to estimate recharge on a basin scale (Eakin et al., 1951; Walker and Eakin, 1963; Malmberg, 1967; and Czarnecki, 1985).

In the ME method, recharge is estimated by assuming that a zone-specific percentage of precipitation infiltrates to recharge the groundwater flow system. Based on precipitation, the percentages assigned are the ME coefficients. These coefficients were determined by trial and error balancing of recharge with estimates of groundwater discharge for 13 valleys in east-central Nevada (Maxey and Eakin, 1949). In these studies, the precipitation zones were defined using a precipitation map developed by Hardman (1936). The estimated ME coefficients are presented in Table 5-5.

Table 5-5

Precipitation Zones and Corresponding Coefficients for the ME Method

\begin{tabular}{|c|c|}
\hline $\begin{array}{c}\text { Precipitation Zone Based on Rate } \\
\text { (in centimeters per year) }\end{array}$ & $\begin{array}{c}\text { ME Coefficient } \\
\text { (\% of precipitation) }\end{array}$ \\
\hline \hline 551 & 25 \\
\hline $38-51$ & 15 \\
\hline $30-38$ & 7 \\
\hline $20-30$ & 3 \\
\hline$<20$ & 0 \\
\hline
\end{tabular}


In the ME method, recharge for a given groundwater basin is calculated using the following equation:

$$
R=\Sigma r_{i} P_{i}
$$

Where:

$\mathrm{R}=$ Total ME recharge for a given basin;

$\mathrm{r}_{\mathrm{i}}=$ ME recharge coefficient; and

$\mathrm{P}_{\mathrm{i}}=$ Volume of precipitation for each delineated precipitation zone.

An evaluation of the ME method for calculating recharge to groundwater in Nevada was performed by the Las Vegas Valley Water District (1992). Estimates of recharge made using the ME Method were compared with recharge estimates obtained using computer models and other methods such as water budget methods. The ME method showed good agreement with the other methods, and it was concluded that the method provides a good approximation for recharge (Las Vegas Valley Water District, 1992). However, the ME method has some limitations.

The ME method does not account for factors that may significantly affect infiltration such as vegetation, rock type, relative topography (flat or steep slopes), and bedrock permeability. In the ME method, precipitation zones of less than $20.3 \mathrm{~cm}$ (8 in.) of annual precipitation (Table 5-5) are not generally considered groundwater recharge areas. However, over the NTS, recharge is known to occur in these areas. For example, in Fortymile Canyon (Wash), Savard (1994) found that recharge to groundwater occurs by infiltration along the stream beds. However, based on the ME method, a zero recharge is assigned to these areas because the annual precipitation is less than $20.3 \mathrm{~cm}(8 \mathrm{in}$.).

Thus, although the recharge estimated using the ME method may be appropriate for regionalscale modeling, it may not be adequate for the NTS and vicinity in view of the future local groundwater flow modeling to be performed for the weapons testing areas. It is important that the regional groundwater flow model provides realistic head distributions in these areas to help define the boundary conditions of these local models. Thus, a more accurate depiction of the recharge distribution on the NTS and vicinity would be advantageous. Such recharge distribution would include recharge to areas such as canyons and washes. This would allow for a more detailed simulation of the hydraulic head distribution in the vicinity of the canyons and washes of the Nevada Test Site. 


\subsubsection{Modified ME Method}

The recharge distribution used in the regional groundwater flow model was constructed using a modification of the ME method (1949). This method consisted of constructing an updated precipitation map, estimating recharge using ME coefficients, and allocating a portion of the total recharge within selected subbasins to low-lying areas.

\subsection{Precipitation}

The precipitation map was constructed using existing precipitation maps, satellite imagery (BN, 1996), precipitation station data (Jacobson, 1996), and a Digital Elevation Model (USGS, 1987). The method by which the precipitation map and grid file were constructed is explained in detail in the following sections.

The Precipitation Map of Nevada (Hardman, 1965) was used as a basis for construction of the precipitation map used in determining the recharge distribution by the modified ME method. The Precipitation Map of Nevada was adapted by Hardman in 1965 from an earlier version constructed in 1936 (Hardman, 1936). The map coverage includes the entire state of Nevada, but does not include the Death Valley portion of the NTS regional groundwater flow system. To complete this portion of the precipitation map, the Death Valley section of the precipitation map developed by James (1993) was used.

The two maps were scanned and digitized to produce a combined map. The precipitation station data were posted on the combined map; only those stations with greater than eight years of record were posted.

Precipitation contours in selected areas were modified to incorporate the new data from the selected precipitation stations. However, in most instances, the precipitation station data validated the existing precipitation contours, and only minimal modifications were necessary. The satellite imagery and digital elevation model data were consulted prior to modifying the contours. Contour lines were only modified where there were sufficient data to substantiate any changes.

The precipitation map was validated using the digital elevation model and satellite imagery. In general, the contour shape coincided with the shape of the topographic features of the mountain ranges. Due to the poor copy and large scale of the Hardman map (1965), the validation process proved to be a very important step in constructing the digital precipitation map because an error 
was introduced in the tracing and scanning of the maps developed by Hardman (1965) and James (1993).

Products consisted of a 1 - by $1-\mathrm{km}$ (0.6- by 0.6-mi) digital precipitation grid and a map presented in Plate 1. In addition, the hydrographic areas (HA) defined by Harrill et al. (1988) (Plate 1) were used to estimate the total precipitation within each hydrographic area for comparison with those published by Scott et al. (1971). The total precipitation was calculated for each hydrographic basin located within the NTS groundwater flow system. This total of $12,481,935$ cubic meters per day $\left(\mathrm{m}^{3} / \mathrm{d}\right)(3,693,973$ acre feet per year [ac-ft/yr] $)$ is comparable to that derived from Scott et al. (1971) estimates for the same area which is $12,363,624\left(\mathrm{~m}^{3} / \mathrm{d}\right)$ $(3,658,959 \mathrm{ac}-\mathrm{ft} / \mathrm{yr})$.

\subsection{Preliminary Recharge Distribution}

A preliminary recharge distribution was generated using the updated precipitation map and the ME coefficients (Table 5-5). The resulting groundwater recharge map is presented in Plate 2.

The recharge rates were first calculated for each 1 - by $1-\mathrm{km}(0.6-$ by $0.6-\mathrm{mi})$ grid cell by multiplying the corresponding precipitation value by the Maxey-Eakin coefficients shown in Table 5-1. For the lower precipitation zone, recharge was calculated using a Maxey-Eakin coefficient of 2 percent. Total recharge values for the groundwater flow system were also calculated using the 1 and 3 percent ME coefficient for the lowest recharge zone to evaluate the range of potential recharge. The corresponding recharge estimates and distribution are presented in Plate 2.

The estimated total recharge for the NTS regional groundwater flow system is $233,447 \mathrm{~m}^{3} / \mathrm{d}$ $(69,097 \mathrm{ac}-\mathrm{ft} / \mathrm{yr})$. The discrepancies observed between the calculated values and the literature values for some of the hydrographic areas may be due to two reasons. The first reason is that literature values were derived for different studies and were derived using different ME coefficients for the lower recharge zone, varying between 1 and 3 percent. The second reason relates to the method used to calculate recharge from the 1- by 1-km precipitation grid, which can introduce additional errors. The recharge range derived using the 1 and 3 percent $\mathrm{ME}$ coefficient for the lower recharge zone is from 177,484 to $289,410 \mathrm{~m}^{3} / \mathrm{d}(52,526$ to $85,650 \mathrm{ac}-\mathrm{ft} / \mathrm{yr})$. 


\subsection{Recharge Allocation}

A method for determining a hydrogeographic area where recharge to groundwater may occur by infiltration through canyons and washes was developed. The method consists of identifying different types of recharge allocation zones corresponding to the canyons and washes and then allocating portions of the total HA recharge to the identified zones.

A given hydrographic area may be subdivided into three types of recharge zones: A, B, and C. The following are descriptions of each zone:

- Type A zone: Upgradient recharge areas that receive greater than $20.3 \mathrm{~cm}(8 \mathrm{in}$.) of annual precipitation per year. This is where the majority of infiltration occurs.

- Type B zone: Canyon-wash recharge areas that receive less than $20.3 \mathrm{~cm}$ (8 in.) of precipitation per year, but include alluvial fans and streams through which recharge may occur

- Type $\mathrm{C}$ zone: Areas of no recharge that receive less than $20.3 \mathrm{~cm}$ (8 in.) of precipitation per year, but contain no alluvial fans or stream reaches to facilitate infiltration

Ten hydrographic areas where type B zones occur have been identified on the NTS and vicinity. The subject HAs are Topopah Wash, Beatty Wash, Thirsty Canyon, Lower Fortymile Canyon, Upper Fortymile Canyon, Frenchman Flat, Yucca Flat, Silent Canyon, Kawich Valley South, and Groom Lake (Figure 5-3).

Each HA has been further subdivided into Types A, B, and C. Type B areas are, in turn, further subdivided into three types of recharge areas: B1, B2, and B3. Type B1 represents bottoms of canyons and valleys; Type B2 represents mountain fronts; and Type B3 represents valley bottoms. See Table 5-6 for more detailed descriptions.

For each hydrographic area where B-type areas are known to exist, a portion of the HA recharge volume is redistributed from Type A areas to Type B areas. It is important to emphasize that the total rate of recharge calculated for each area has not been modified; only the areal distribution is modified. 
Table 5-6

Areas of Potential Recharge Redistribution in the Nevada Test Site Region

\begin{tabular}{|c|c|c|}
\hline $\begin{array}{l}\text { Recharge } \\
\text { Area Type }\end{array}$ & $\begin{array}{c}\text { Recharge Area } \\
\text { Subtype }\end{array}$ & Description \\
\hline $\begin{array}{l}\text { A } \\
\text { Highland } \\
\text { Recharge } \\
\text { Areas }\end{array}$ & None & $\begin{array}{l}\text { Highlands where precipitation and climatic conditions are sufficient } \\
\text { to create recharge by deep infiltration. This type was defined as } \\
\text { areas with precipitation above } 20.3 \text { centimeters per year }(\mathrm{cm} / \mathrm{yr}) \text {. }\end{array}$ \\
\hline \multirow{3}{*}{$\begin{array}{l}\text { B } \\
\text { Canyon- } \\
\text { Wash } \\
\text { Recharge } \\
\text { Areas }\end{array}$} & B1 & $\begin{array}{l}\text { Upland canyon and valley washes and stream reaches where runoff } \\
\text { periodically infiltrates through the stream bed and recharges the } \\
\text { groundwater. Type B1 subareas are more likely to be steeply } \\
\text { dipping with thin sediments above bedrock. It is expected that } \\
\text { infiltration would be relatively small in B1 subareas. Type B1 } \\
\text { subareas receive less than } 20.3 \mathrm{~cm} / \mathrm{yr} \text { of precipitation. }\end{array}$ \\
\hline & B2 & $\begin{array}{l}\text { Mountain front washes and stream reaches where runoff periodically } \\
\text { infiltrates through the stream bed and recharges the groundwater. At } \\
\text { type B2 subareas, the topography flattens, and sediments are } \\
\text { thicker and more abundant than in Type B1 areas. Water can be } \\
\text { stored in the sediment and allowed to infiltrate more readily than in } \\
\text { B1 subareas. Type B2 subareas receive less than } 20.3 \mathrm{~cm} / \mathrm{yr} \text { of } \\
\text { precipitation. }\end{array}$ \\
\hline & B3 & $\begin{array}{l}\text { Valley bottom washes and stream reaches where runoff periodically } \\
\text { infiltrates through the stream bed and recharges the groundwater. } \\
\text { Type B3 subareas are at the distal end of the streams. They are } \\
\text { typically low gradient, fan-like, and have the capacity to infiltrate } \\
\text { large quantities of water. However, B3 subareas rarely receive flow. } \\
\text { Type B3 subareas receive less than } 20.3 \mathrm{~cm} / \mathrm{yr} \text { of precipitation. }\end{array}$ \\
\hline $\begin{array}{l}\text { C } \\
\text { Areas of } \\
\text { No } \\
\text { Recharge }\end{array}$ & None & $\begin{array}{l}\text { Lowlands and inter-stream areas where infiltration is assumed not to } \\
\text { occur. This type was defined as areas with precipitation below } \\
20.3 \mathrm{~cm} / \mathrm{yr} \text {. }\end{array}$ \\
\hline
\end{tabular}


The calculated total $\mathrm{ME}$ recharge rate $\left(\mathrm{V}_{\mathrm{T}}\right.$ - total recharge rate in the basin) is redistributed from Type $A$ areas $\left(V_{A}\right)$ where recharge rates are greater than zero to Type $B$ areas $\left(V_{B}\right)$ so that:

$$
\mathrm{V}_{\mathrm{T}}=\mathrm{V}_{\mathrm{A}}+\mathrm{V}_{\mathrm{B}}
$$

Where:

$\mathrm{V}_{\mathrm{T}}=$ Total recharge rate;

$\mathrm{V}_{\mathrm{A}}=$ Recharge rate in Type $\mathrm{A}$ areas; and

$\mathrm{V}_{\mathrm{B}}=$ Recharge rate in Type $\mathrm{B}$ areas.

The redistribution factor, $\alpha$, is a fraction of the total recharge (between 0 and 1) so that $\mathrm{V}_{\mathrm{A}}=\alpha \mathrm{V}_{\mathrm{T}}$ and $\mathrm{V}_{\mathrm{B}}=(1-\alpha) \mathrm{V}_{\mathrm{T}}$. For example, if $\mathrm{V}_{\mathrm{T}}=100$ and $\alpha=.30$, then $\mathrm{V}_{\mathrm{A}}=30$ and $\mathrm{V}_{\mathrm{B}}=70$.

For each hydrographic area, the recharge rates in Type B areas are further distributed to each recharge subarea $(\mathrm{B} 1, \mathrm{~B} 2$, and $\mathrm{B} 3)$ based on fractions $\beta, \gamma$, and $\delta$ of recharge volume in $\mathrm{B}\left(\mathrm{V}_{\mathrm{B}}\right)$, so that the following relationships hold true:

$$
\beta+\gamma+\delta=1
$$

Where:

$\beta=$ Fraction of $\mathrm{V}_{\mathrm{B}}$ assigned to Type $\mathrm{B} 1$ subareas;

$\gamma=$ Fraction of $\mathrm{V}_{\mathrm{B}}$ assigned to Type $\mathrm{B} 2$ subareas; and

$\delta=$ Fraction of $\mathrm{V}_{\mathrm{B}}$ assigned to Type B3 subareas.

The areas of types B1, B2, and B3 are canyons or washes. Within a given HA, each of them is subdivided into several reaches that are compatible with a selected grid. Recharge rates for each reach are then obtained by dividing the recharge rate assigned to a given subarea type (B1, B2, or B3) by the number of reaches available within a given hydrographic area.

A utility FORTRAN code was developed to implement the modified ME method. The code requires the $\mathrm{ME}$ recharge distribution by $\mathrm{HA}$; the spatial distribution of different types of recharge areas described above; and values for $\alpha, \beta, \gamma$, and $\delta$ based on estimates of recharge rates at B-type and subtype areas. The code calculates a new recharge distribution in the form of a 
grid that can be made compatible with the flow model grid, an important feature that allows adjusting of the recharge grid during the calibration process. The code listing and Quality Assurance (QA) requirements are provided in the Groundwater Flow Model Documentation Package (IT, 1996f).

The recharge allocation coefficients $\alpha, \gamma, \beta$, and $\delta$ are unknown because the amounts of recharge that occur in Type B areas located in the different hydrographic areas are also largely unknown. Arbitrary initial values must be assigned to these coefficients to generate the initial recharge grid. They are to be adjusted during the groundwater flow model calibration process. The process and the results are provided in the Groundwater Flow Model Documentation Package (IT, 1996f).

\subsubsection{Discharge}

Groundwater discharge to the surface occurs through springs and by evapotranspiration. Although spring discharge is important within the Death Valley groundwater basin, only a negligible portion of it is discharged from the basin through surface flow in the Amargosa River in the southern boundary of the NTS regional flow system. A flow rate of less than 0.03 cubic meter per second $\left(\mathrm{m}^{3} / \mathrm{s}\right)\left(1\right.$ cubic foot per second $\left.\left[\mathrm{ft}^{3} / \mathrm{s}\right]\right)$ was observed in the Amargosa River at that location in 1992. The majority of the groundwater discharged by springs is effectively lost from the groundwater basin through evapotranspiration in the vicinity of the springs. However, spring discharge data were used to provide an estimate of ET losses in regional discharge areas.

\subsubsection{Spring Discharge}

Springs occur at numerous locations within the NTS flow system area (Figure 5-4). Springs located on the NTS and the mountains are perched. Springs of importance to this study are regional springs, defined as such because they originate from the regional groundwater system.

Within the NTS regional groundwater flow system, numerous regional springs occur in Ash Meadows, Oasis Valley, and Death Valley. Average individual discharges for springs located in major regional discharge areas such as Ash Meadows and Oasis Valley were calculated and then summed up by area. The total spring discharge at Ash Meadows is $56,277 \mathrm{~m}^{3} / \mathrm{d}$ $(16,650 \mathrm{ac}-\mathrm{ft} / \mathrm{yr})$. This value is consistent with the previously reported value of $57,460 \mathrm{~m}^{3} / \mathrm{d}$ (17,000 ac-ft/yr) (Winograd and Thordarson, 1975). The total spring discharge at Oasis Valley is $9,700 \mathrm{~m}^{3} / \mathrm{d}(2,870 \mathrm{ac}-\mathrm{ft} / \mathrm{yr})$. This discharge value is based only on available data and may actually be larger. 


\subsubsection{Evapotranspiration}

Discharge by evapotranspiration constitutes the majority of the total discharge from the NTS groundwater flow system. Based on previous investigations, significant groundwater losses by ET are known to occur in Death Valley, Oasis Valley, and areas of the Amargosa Desert.

The ET discharge areas were selected based on identification of vegetated areas and spring locations on the corresponding USGS 1:24,000-scale (71/2 minute) topographic maps. The following eight areas were identified as surface discharge areas (Figure 5-4): Ash Meadows, Oasis Valley, Death Valley, Franklin Lake Playa, Alkali Flat (Peters Playa), Penoyer Valley, Amargosa River, and Indian Springs.

For each of these areas, an estimate of the evaporative loss is presented. It is assumed that only evaporative losses are net losses from the groundwater flow system. Spring discharge alone may overestimate groundwater discharge because some of that water may infiltrate back to the shallow groundwater system. For several of the areas, the estimates are approximate with large uncertainty that cannot be eliminated without additional investigation.

\section{Ash Meadows}

Estimation of evapotranspiration rates in the Ash Meadows area and vicinity is an ongoing project conducted by the USGS Nevada District Office. This USGS study includes direct measurements of temperature, solar radiation, heat flux, and depths to groundwater.

The preliminary result of ET rates in Ash Meadows ranges from 0.12 to 0.29 centimeters per day $(\mathrm{cm} / \mathrm{d})(1.5$ to 3.5 feet per year [ft/yr]). Based on these rates and an approximate value of 10 acres for the discharge area, Laczniak (1996a) estimated a range of 50,685 to $118,265 \mathrm{~m}^{3} / \mathrm{d}$ $(15,000$ to $35,000 \mathrm{ac}-\mathrm{ft} / \mathrm{yr})$, including maximum uncertainty. He also commented that a narrower range of 67,500 to $101,400 \mathrm{~m}^{3} / \mathrm{d}(20,000$ to $30,000 \mathrm{ac}-\mathrm{ft} / \mathrm{yr})$ was more probable, based on a narrower range of average ET rates between 0.16 to $0.25 \mathrm{~cm} / \mathrm{d}$ ( 2 to $3 \mathrm{ft} / \mathrm{yr}$ ) (Laczniak, 1996a).

\section{Oasis Valley}

The Oasis Valley groundwater discharge area is located to the west of the Nevada Test Site and appears to be the discharge area of a portion of the groundwater in volcanic rocks on Western Pahute Mesa (Figure 5-4). Malmberg and Eakin (1962) have estimated that evaporative losses from the groundwater system in Oasis Valley are on the order of $\left(7,000 \mathrm{~m}^{3} / \mathrm{d}\right) 2,000 \mathrm{ac}-\mathrm{ft} / \mathrm{yr}$. 
Laczniak (1996a) believes that this estimate is too low and should be in the range of 17,000 to $27,000 \mathrm{~m}^{3} / \mathrm{d}(5,000$ to $8,000 \mathrm{ac}-\mathrm{ft} / \mathrm{yr})$.

The discharge flux for Oasis Valley range estimates from 7,000 to 27,000 $\mathrm{m}^{3} / \mathrm{d}(2,000$ to $7,700 \mathrm{ac}-\mathrm{ft} / \mathrm{yr}$ ). The low end of this range represents older estimates and appears to be too low. The upper end is at present unsubstantiated by any data. Estimated total spring discharges (less the Amargosa Narrows underflow) and the approximate ET rate times the area of vegetation produce a narrower range of 13,000 to $17,000 \mathrm{~m}^{3} / \mathrm{d}(3,700$ to $5,000 \mathrm{ac}-\mathrm{ft} / \mathrm{yr})$ that will be used as a calibration target.

\section{Death Valley}

The Death Valley discharge area of interest is located in the central Death Valley subregion of the Death Valley Groundwater Flow System (PAL Consultants, 1995). A number of estimates of the evapotranspiration losses are available in Hunt et al. (1966) and Miller (1977). These estimates are summarized in a report by PAL Consultants (1995) and range from 44,000 to $406,000 \mathrm{~m}^{3} / \mathrm{d}$ (13,000 to $\left.120,000 \mathrm{ac}-\mathrm{ft} / \mathrm{yr}\right)$; they cover slightly different areas of Death Valley and represent total discharge regardless of source. The largest range of 44,000 to $80,000 \mathrm{~m}^{3} / \mathrm{d}$ $(13,000$ to $23,500 \mathrm{ac}-\mathrm{ft} / \mathrm{yr})$ is from D'Agnese (1994) and is much larger than that presented by other investigators (Hunt et al., 1966; Miller, 1977). However, his estimate is for central Death Valley, and the discharge area included within the NTS regional groundwater flow system as defined in this study does not extend across the entire central Death Valley subregion and does not account for groundwater discharge originating from the Panamint Mountains located south of Death Valley. Thus, the estimated range of this discharge should be smaller than the above estimates.

Hunt et al. (1966) focused their work in the salt pan area of Death Valley and differentiated components of groundwater that came from the east and west sides of the valley. In the Hunt et al. study (page B-38, 1966), the total discharge of groundwater from the east side of the valley for the Cottonball Basin, Furnace Creek Wash, Middle Basin (south of Furnace Creek Wash), and Badwater Basin areas is given as 3,220 gallons per minute $\left(17,500 \mathrm{~m}^{3} / \mathrm{d}\right.$ or $5,200 \mathrm{ac}-\mathrm{ft} / \mathrm{yr})$. The total discharge from both sides of the valley is given as 8,000 gallons per minute $\left(43,600 \mathrm{~m}^{3} / \mathrm{d}\right.$ or $\left.12,900 \mathrm{ac}-\mathrm{ft} / \mathrm{yr}\right)$. The discharge area of interest corresponds quite well with the areas discussed in the Hunt et al. study except that the model does not include the southern half of the Badwater Basin. The majority of the discharge in the Badwater Basin occurs in the vicinity of Badwater, so little error is introduced by taking the values of Hunt et al. (1966). 
The amount of uncertainty in these estimates is not known, but experience in Ash Meadows and Oasis Valley suggests that a factor of two might be appropriate. Therefore, using the discharge from the east side of Death Valley as given by Hunt et al. (1966) and assuming the uncertainty is a factor of two, the calibration target for Death Valley is given by the range 8,750 to $35,000 \mathrm{~m}^{3} / \mathrm{d}$ $(2,590$ to $10,350 \mathrm{ac}-\mathrm{ft} / \mathrm{yr})$.

\section{Franklin Lake Playa}

Evapotranspiration was studied in the Franklin Lake Playa (Alkali Flat) by Czarnecki (1990).

Measurements to estimate evapotranspiration were made between June 1983 and September 1984 using the eddy-correlation technique coupled with the energy-balance method.

The groundwater table in the vicinity of the playa ranges from $1 \mathrm{~m}(3.3 \mathrm{ft})$ above land surface to $3 \mathrm{~m}$ (9.8 ft) below land surface. Czarnecki (1990) used seven different techniques to estimate the evapotranspiration rate from Franklin Lake playa. The estimates range from 0.06 to $1.7 \mathrm{~cm} / \mathrm{d}$ (0.02 to 0.7 inches per day [in./d]). Czarnecki (1990) considered the narrower range of 0.1 to $0.3 \mathrm{~cm} / \mathrm{d}(0.04$ to $0.1 \mathrm{in} . / \mathrm{d})$ from the energy-balance, eddy-correlation method to provide the most reasonable and representative estimates of the ET rates. Taking the area of the playa $\left(14.2 \mathrm{~km}^{2}\left[5.5 \mathrm{mi}^{2}\right]\right)$ into consideration, the total discharge rates range from 14,200 to $42,600 \mathrm{~m}^{3} / \mathrm{d}(3,800$ to $11,500 \mathrm{ac}-\mathrm{ft} / \mathrm{d})$. Czarnecki stated that an ET rate of $0.16 \mathrm{~cm} / \mathrm{d}(0.06 \mathrm{in} . / \mathrm{d})$ $\left(22,700 \mathrm{~m}^{3} / \mathrm{d}[6,100 \mathrm{ac}-\mathrm{ft} / \mathrm{yr}]\right)$ is representative of the average ET rate measured with the energybalance eddy correlation method (Czarnecki, 1990).

\section{Alkali Flat (Peters Playa)}

Alkali Flat or Peters Playa is a discharge area northeast of Ash Meadows referred to as "the unnamed valley northeast of the spring line" by Winograd and Thordarson (1975). In their report, Winograd and Thordarson (1975) described it as an area of some groundwater discharge, but only crudely estimated the ET discharge to be less than $3,400 \mathrm{~m}^{3} / \mathrm{d}(1,000 \mathrm{ac}-\mathrm{ft} / \mathrm{yr})$.

The playa has an area of about $12.6 \mathrm{~km}^{2}(1.2 \mathrm{~m})$ based on Figure 34 in the Winograd and Thordarson study (1975), in which a circular area or radius $2 \mathrm{~km}$ (1.2 mi) was used to approximate the playa extent. Recent drilling of well MSH-C in the northern portion of the playa confirmed a generally upward hydraulic gradient. The water table may be within a few meters of the land surface beneath much of the playa. If ET rates similar to Franklin Lake Playa are used, then the discharge rate could range from 12,600 to $37,800 \mathrm{~m}^{3} / \mathrm{d}(3,400$ to $10,200 \mathrm{ac}-\mathrm{ft} / \mathrm{yr})$. The possible range of discharge rates is quite large with little data to reduce the uncertainty. A large 
range of 3,000 to $35,000 \mathrm{~m}^{3} / \mathrm{d}$ (800 to $9,400 \mathrm{ac}-\mathrm{ft} / \mathrm{yr}$ ) is recommended for use in the groundwater flow model calibration. Additional work would be required to reduce this range further.

\section{Penoyer Valley}

Penoyer Valley, also known as Sand Spring Valley, is located north-northeast of the NTS. Van Denburgh and Rush (1974) investigated discharge in Penoyer Valley and determined the evaporative discharge to be $13,500 \mathrm{~m}^{3} / \mathrm{d}(4,000 \mathrm{ac}-\mathrm{ft} / \mathrm{yr})$. Using Plate 1 of the report prepared by Van Denburgh and Rush (1974), the discharge area is estimated to be $69 \mathrm{~km}^{2}$ (26.6 $\left.\mathrm{mi}^{2}\right)$, which yields an average ET rate of $0.02 \mathrm{~cm} / \mathrm{d}(0.008 \mathrm{in} . / \mathrm{d})$. This rate is substantially lower than the rates for Ash Meadows or Oasis Valley, both of which are at lower elevations. The ET rate for Penoyer Valley may be larger than $0.02 \mathrm{~cm} / \mathrm{d}(0.08 \mathrm{in} . / \mathrm{d})$ if the recent data from Ash Meadows are considered. In the latter case, older estimates appear to be too small by a factor of two. If that pattern holds for Penoyer Valley as well, then the discharge could be as large as $27,000 \mathrm{~m}^{3} / \mathrm{d}$ (7,990 ac-ft/yr). For the purposes of model calibration, a discharge range of 13,500 to $27,000 \mathrm{~m}^{3} / \mathrm{d}(3,990$ to $7,990 \mathrm{ac}-\mathrm{ft} / \mathrm{yr})$ is recommended.

\section{Amargosa River}

Discharge of groundwater occurs along selected reaches of the Amargosa River. One area of discharge is southwest of Ash Meadows where satellite photographs show vegetation. It is not known how much water evaporates from this area. The evapotranspiration area is very small compared to Ash Meadows, and presumably the total ET flux is also much less. It is difficult to determine the relative areas, but from satellite images, the ET area for the Amargosa River appears to be less than 5 percent of the ET area for Ash Meadows. Therefore, an estimate of the ET flux is taken to be 5 percent of the range of values given for Ash Meadows. This yields discharge values in the range of 3,400 to $5,100 \mathrm{~m}^{3} / \mathrm{d}$ (900 to $1,400 \mathrm{ac}-\mathrm{ft} / \mathrm{yr}$ ). These values should be viewed as upper bounds when used as calibration targets.

\section{Indian Springs}

A small amount of groundwater discharge occurs in the Indian Springs area. The ET rate was estimated using a measured discharge rate at the springs (Winograd and Thordarson, 1975). Because ET estimates were not available for this discharge area, the upper estimate was calculated by increasing the spring discharge rate by 80 percent to take ET effects into account. 


\subsubsection{Flow Boundaries}

The boundary of the NTS regional groundwater flow was delineated to correspond to areas where no flow occurs (such as groundwater divides). However, flow across the basin boundary occurs in some areas. Four areas along the Death Valley groundwater basin boundary are known to be flux boundaries. The first and most important area is along the northeastern boundary with inflow occurring from Pahranagat Valley to Desert (Tickaboo) Valley. The second area is along the western boundary of Pahrump Valley, and the third area is located at the southern boundary by Eagle Mountain. The fourth area where flow might occur is on the western boundary with potential inflow or outflow from Sarcobatus Flat into the Death Valley basin. Estimates of subsurface flow across the boundaries of the Death Valley groundwater system are provided in the following paragraphs.

\section{Pahranagat Valley}

The occurrence of subsurface inflow from Pahranagat Valley is supported by studies using isotope and other chemical data (Thomas, 1988). Winograd and Thordarson (1975) also postulated a groundwater underflow from Pahranagat Valley on the basis of potentiometric head data, major geologic features, and the deuterium content of spring waters in both basins. Winograd and Thordarson (1975) estimated that as much as 20,280 $\mathrm{m}^{3} / \mathrm{d}$ (5,400 ac-ft/yr) may enter Desert (Tickaboo) Valley from Pahranagat Valley. The deuterium data have been interpreted to suggest that 35 percent of the discharge at Ash Meadows comes from the Pahranagat Valley. The uncertainty in this value is unknown, but can be estimated from the deuterium data presented in Table 13 of the Winograd and Thordarson study (1975). Using the given mean, standard deviation, and number of samples, a 95 percent confidence interval about the mean value has been determined for each set of samples, assuming normally distributed random variables. With the uncertainty in the mean values, the percentage of springflow at Ash Meadows that is derived from Pahranagat Valley can be shown to vary from 8 to 60 percent. Using the range of discharge values already provided for Ash Meadows (67,500 to 101,400 $\mathrm{m}^{3} / \mathrm{d}$ [18,200 to 27,000 ac-ft/yr]), the range of values for inflow from Pahranagat Valley is given by 8 percent of $67,500 \mathrm{~m}^{3} / \mathrm{d}$ to 60 percent of $101,400 \mathrm{~m}^{3} / \mathrm{d}$ or 5,400 to $60,800 \mathrm{~m}^{3} / \mathrm{d}(1,500$ to $15,400 \mathrm{ac}-\mathrm{ft} / \mathrm{yr})$.

\section{Pahrump Valley}

Several investigators, including Maxey and Jameson (1948), Malmberg (1967), Loeltz (1960), and Hughes (1966) present estimates of groundwater movement from Pahrump Valley to Ash Meadows that range from 10,000 to 43,900 m³/d (3,000 to 13,000 ac-ft/yr). Winograd and 
Thordarson (1975) suggest, on the basis of the presence of the lower clastic aquitard between Pahrump and Ash Meadows (a significant head difference and different geochemistry of the water), that the discharge is much smaller. Using hydraulic parameters, they present a range of values from 5 to $7,600 \mathrm{~m}^{3} / \mathrm{d}$ ( 1 to $1,400 \mathrm{gal} / \mathrm{min}$ ). It would appear that the inflow from Pahrump is small and probably balanced by the outflow near Eagle Mountain.

\section{Sarcobatus Flat}

Sarcobatus Flat is located to the west of Oasis Valley, and it is possible that there may be some flux of groundwater between the two areas. Malmberg and Eakin (1962) examined the groundwater resources of Oasis and Sarcobatus Valleys. In both valleys, the estimated discharge by evapotranspiration and underflow far exceeds the local recharge. Malmberg and Eakin (1962) suggest that the difference between recharge and discharge is made up by underflow from valleys to the north such as Gold Flat and Stonewall Flat. There is no mention of underflow between Oasis and Sarcobatus valleys. Regional potentiometric maps suggest that the boundary between the two basins is a groundwater divide. Malmberg and Eakin (1962) present limited groundwater level data to suggest that the direction of groundwater flow in Sarcobatus Flat is to the west. The direction and amount of underflow between Oasis and Sarcobatus valleys is not known. It will be assumed that the magnitude of underflow will be less than $1,700 \mathrm{~m}^{3} / \mathrm{d}(500 \mathrm{ac}-\mathrm{ft} / \mathrm{yr})$. Therefore the range of values to use in the model will be $-1,700$ to $1,700 \mathrm{~m}^{3} / \mathrm{d}(-500$ to $500 \mathrm{ac}-\mathrm{ft} / \mathrm{yr})$.

\section{Eagle Mountain}

The underflow occurs at Eagle Mountain, located southeast of Death Valley Junction and between the Resting Spring and the Greenwater mountain ranges. The Eagle Mountain boundary accounts for underflow in alluvium underlying the Amargosa River. Walker and Eakin (1963) estimated the subsurface flow to be about $1,700 \mathrm{~m}^{3} / \mathrm{d}(500 \mathrm{ac}-\mathrm{ft} / \mathrm{yr})$. The uncertainty in this estimate is unknown. This discharge is not mentioned in most other documents describing groundwater flow in the Death Valley groundwater flow system with the exception of Harrill (1986) who considered it in the context of a water balance for Pahrump Valley. The conclusion to be drawn is that the flux is small and not considered a significant factor in the flow system. For lack of a better estimate, the uncertainty will be assumed to be a factor of two. Therefore, the range of values to be used for calibration is 850 to $3,400 \mathrm{~m}^{3} / \mathrm{d}$ (250 to $1,000 \mathrm{ac}-\mathrm{ft} / \mathrm{yr}$ ). 


\subsection{Conceptual Groundwater Flow Model}

The conceptual groundwater flow model provides a comprehensive description of the Nevada Test Site regional groundwater flow system based upon the geologic and hydrogeologic data presented in Sections 4.0 and 5.0. This section discusses the groundwater flow system boundary, the regional hydrogeologic framework and groundwater flow, the detailed hydrogeologic framework and groundwater flow of the NTS, and the uncertainties regarding the conceptual model.

\subsection{Groundwater Flow System Boundary}

The boundary for the NTS regional groundwater flow system has been modified from Waddell et al. (1984) as a result of this evaluation. Plate 3 depicts the extent of this boundary. The boundary has been delineated to match groundwater divides that occur along the crests of the Sheep Range, Spring Mountains, Cactus Range, and Quinn Canyon Range. The boundary has been further delineated by following selected groundwater flow lines between the Sheep Range and the Spring Mountains, west from the Spring Mountains to the Resting Spring and Greenwater Ranges to Death Valley. From Death Valley, the boundary follows selected flow lines north to the Grapevine Mountains and continues north to the west of Bullfrog Hills and the Cactus Range. From Cactus Range, the boundary continues east across the Kawich Range to Railroad Valley and continues north to Garden Valley and then south to the Timpahute Range and Pahranagat Range (Plate 3).

Those portions of the boundary based on groundwater flow lines are more uncertain than those based on groundwater divides. Therefore, the locations of the western and northern portions of the boundary are the most uncertain. Some uncertainty also exists regarding the location of the boundary in the vicinity of the southern Sheep Range. The interpretation used in this model incorporates the Sheep Range within the Death Valley flow system, while others (e.g., Dettinger et al., 1995) have suggested that water recharged in the Sheep Range may, instead, flow toward the Las Vegas Valley. Water-level data in this area can be interpreted both ways, depending upon the configuration and properties of the Las Vegas Shear Zone. The Sheep Range was included within the boundary because the top of the Lower Clastic Confining Unit is highest near the crest of the Sheep Range and slopes to the west. This geometry favors flow to the west rather than the south. 


\subsection{Regional Groundwater Flow System}

The following interpretation of the hydrogeologic framework and groundwater flow within the NTS regional groundwater flow system is presented at the regional scale to which the groundwater flow model was constructed. The hydrostratigraphy and structural features that comprise the hydrogeologic framework of the NTS regional groundwater flow system are discussed in terms of the HSUs defined in Section 4.0. The interpretation includes discussions of geologic structures that potentially influence groundwater flow and direction within the flow system. Alternate interpretations are offered where applicable; however, the simpler structural interpretations have been preferred due to the complexity of a model of this magnitude.

\subsubsection{Hydrogeologic Framework}

The regional hydrogeologic framework provides the foundation of the groundwater flow system and is described in the following sections in general terms; then is discussed for selected areas surrounding the NTS.

\subsubsection{General Features}

The Lower Carbonate Aquifer and Lower Clastic Confining Unit predominantly control regional groundwater flow within the study area and, therefore, the transport of contaminants. The LCA and LCCU are the most expansive HSUs within the NTS region. The LCA is the most important aquifer due to its distribution and high hydraulic conductivity. The regional distribution and thickness of the LCA is spatially variable and controlled by the structural position of the underlying LCCU. Figure 4-3 is an isometric projection of the LCCU throughout the model area and shows the structural highs and lows of the LCCU, implying the relative thickness of the LCA. In general, the Lower Carbonate Aquifer is thin or missing on the structural highs and is thickest in the structural lows. Outcropping locations of the Lower Clastic Confining Unit are shown on Figure 6-1 as well as the surficial distributions of the LCA, LCCU, and other HSUs. The map was constructed by stacking the grid of each HSU in stratigraphic sequence.

The hydraulic conductivity of the LCA is relatively high compared to that of the LCCU. The LCCU is generally considered impermeable, although it may locally exhibit hydraulic properties consistent with an aquifer due to fracturing. Table 6-1 summarizes the range of hydraulic parameters for major aquifers of the NTS region. The range of hydraulic conductivity for carbonate aquifers is large, representing interstitial porosity at the lower limit and fracture 
Table 6-1

Range of Hydraulic Parameters for Major Aquifers

\begin{tabular}{|c|c|c|c||}
\hline \multirow{2}{*}{ Aquifer } & \multicolumn{2}{|c||}{ Hydraulic Conductivity } & \multirow{2}{*}{$\begin{array}{c}\text { Effective Porosity } \\
\text { Range } \\
(\%)\end{array}$} \\
\cline { 2 - 3 } & $\begin{array}{c}\text { Mean } \\
(\mathrm{m} / \mathrm{d})^{\mathrm{a}}\end{array}$ & $\begin{array}{c}\text { Range } \\
(\mathrm{m} / \mathrm{d})\end{array}$ & \\
\hline \hline Alluvial Aquifer & 8.44 & $0.00006-83$ & $31-35$ \\
\hline Volcanic Aquifers & 1.18 & $0.0003-12$ & $0.00001-0.006$ \\
\hline Carbonate Aquifers & 31.71 & $0.0008-1,570$ & $0.0006-10$ \\
\hline
\end{tabular}

$a_{m / d}=$ Meters per day

porosity at the upper limit. The mean hydraulic conductivity for carbonate aquifers is also very large, implying that groundwater flows predominantly through fractures. This is supported by the small gradients observed between water-level wells completed in the Lower Carbonate Aquifer.

Other major aquifers include the alluvial and volcanic aquifers. The hydraulic properties estimated for these aquifers are presented in Table 6-1. The hydraulic conductivity for Alluvial Aquifers is smaller than that of carbonate aquifers, but higher than that of volcanic aquifers. The distribution and thicknesses of alluvial and volcanic aquifers are highly variable throughout the region and are not interpreted to be continuous. In most instances, an Alluvial Aquifer is confined to a basin by surrounding mountain ranges. In some basins, Alluvial Aquifers are discontinuous due to structural controls elevating the bottom of the alluvium above the water table. In general, alluvial and volcanic aquifers are considered depositional elements overlying the regional flow system and only influence regional flow in localized areas.

As previously discussed, the distribution and thickness of the regional LCA is spatially variable across the NTS regional groundwater flow system. This variability is controlled in large part by the structural position of the LCCU. The following sections discuss the regional hydrogeologic framework of selected areas surrounding the NTS: east, north, and west of the NTS, as well as the Amargosa Desert and Death Valley areas. 


\subsection{East of the NTS}

The hydrogeologic framework of the area east of the NTS, from the Halfpint Range east to the Sheep Range and Pahranagat Range, is controlled by the structural configuration of the Lower Clastic Confining Unit and overlying Lower Carbonate Aquifer. The LCA in this area is comprised of interconnected erosional remnants of the LCA, preserved within Mesozoic-age synclines. Thrust faulting in the area has tectonically thickened the LCA to an interpreted thickness of 7,500 $\mathrm{m}(25,000 \mathrm{ft})$. Figure 6-2 is a series of east-west cross sections indicating the structural highs of the LCCU and the interpreted thickness of the LCA east of the NTS. The most prominent uplift is interpreted to extend from the Halfpint and Groom Ranges, north to the Grant Range. The structural uplifts of the LCCU typically trend north-south.

Volcanic rocks are hydrologically important locally in the southern part of this area where Tertiary sediments occur on the east flank of the Pintwater Range. These sediments are erosional remnants of an exhumed early Tertiary basin, possibly greater than $400 \mathrm{~m}$ (1,300 ft) in thickness. At the regional scale, these sediments are not hydrologically significant.

\subsection{North of the NTS}

A third of the NTS regional groundwater flow system lies north of the NTS, extending north from the southern portions of the Kawich and Belted Ranges to the southern portions of Railroad Valley and Grant Range. Structurally, the area is characterized by Mesozoic-age contractional structures trending north-south, which have uplifted the LCCU and controlled the distribution and thickness of the LCA. In localized areas, younger Basin and Range structures have modified the regional structure. The structural trends of the LCCU for this area are depicted in Figures 4-3 and 6-3.

Figure 6-3 illustrates how the structural highs of the Lower Clastic Confining Unit influence the distribution and thickness of the Lower Carbonate Aquifer in the northern portion of the model area. In the east, the LCCU is structurally high in a long, north-south trending uplift that extends from the Halfpint Range to the Grant Range. East of this structural high, the LCA is very thick (up to $5,400 \mathrm{~m}[17,700 \mathrm{ft}]$ ). The increased thickness can be attributed to structural duplexing of the LCA by Mesozoic thrust faults. Due to erosion and the depositional manner by which the rock was formed, the LCA progressively thins to the west of the Halfpint and Grant Ranges. 
From approximately the middle of the northern part of the model area, an east-to-west carbonate/shale facies change progressively increases the relative amount of shale in the LCA. The time-transgressive boundary of the LCCU/LCA climbs through the Paleozoic section with shale increasing in the lower part of the LCA. The Lower Carbonate Aquifer shales out on the northwestern side of the model area where it outcrops at the San Antonio Mountains. In this area, the model interpretation includes no LCA in the subsurface. Instead, a thick section of volcanics covers the Lower Clastic Confining Unit. Therefore, southernly flow of groundwater in this area is impeded by the lack of LCA and the thick section of volcanics covering the LCCU. Several igneous intrusives are also present in the area and are treated as vertical-sided blocks penetrating all layers to the surface.

It is interpreted in the geologic model that the complete section of LCA is present in the subsurface northwest of the NTS at Cactus Range. This interpretation is supported by the occurrence of sporadic outcrops of the LCA in the Cactus Range. It is reasonable to assume that the entire LCA section lies beneath this area, given the LCA outcrops and barring any unknown structural features that might disprove this interpretation.

\subsection{West of the NTS}

West of the NTS, from western Pahute Mesa to Slate Ridge, the hydrogeologic framework is characterized by structural uplifts of the LCCU and volcanic cover. The LCCU is exposed along the western boundary of the geologic model area, while volcanic rocks cover the remainder of the area between the western geologic boundary and western portion of Pahute Mesa. However, there is a small outcrop of Devonian carbonate (upper portion of the LCA) exposed at the west end of the Black Mountain caldera, just west of Pahute Mesa. There is a high uncertainty of how much of the LCA exists under the volcanic cover, but barring any unknown structural features, the LCA outcrop suggests that most of the LCA thickness might underlie the volcanics. Therefore, the LCA has been interpreted to underlie the volcanic cover in this area west of the Pahute Mesa Timber Mountain Caldera complex and north of Oasis Valley.

The geologic model interprets the presence of the Lower Carbonate Aquifer under the Cactus Range, as discussed in Section 6.2.1.1.2, allowing for an LCA corridor from the northern part of the model area, around the volcanic cover, to the west side of the NTS. The LCA corridor ends at Bare Mountain where the Belted Range thrust system has erosionally truncated the LCA against the structurally uplifted LCCU. This truncation, displayed in Figure 6-4, has created a barrier to southernly flow coincident with the location of springs at Oasis Valley, implying 
spring discharge from the regional LCA and volcanics of the Pahute Mesa/Timber Mountain caldera complex.

A local feature in the area is the Black Mountain Caldera. The caldera is not associated with a gravity low (Saltus, 1994); therefore, it was not interpreted as a typical caldera with large vertical displacements on bounding faults. As interpreted in the conceptual model, the Black Mountain Caldera does not influence regional groundwater flow in the area.

\subsection{Amargosa Desert and Death Valley Areas}

As in other areas within the NTS groundwater flow system, the structural position of the Lower Clastic Confining Unit also controls the distribution and thickness of the regional LCA in the Amargosa Desert and Death Valley. The hydrogeologic framework of the Amargosa Desert area is characterized by a complex geologic structure resulting from the offset of the Bare Mountain Fault. The Bare Mountain Fault has subdivided the Amargosa Desert area into areas of significantly different structure on the west and east sides of the fault. The Bare Mountain Fault and separately defined thrust fault areas have uplifted the LCCU so that its structural position is higher than that of the LCA. Therefore, groundwater flow in this area is generally impeded and provided with an upward flow component by the structurally high LCCU.

The Bare Mountain Fault, located near the east side of Bare Mountain in Crater Flat, is a major normal fault that strikes north-south from northern Crater Flat to the southern Amargosa Desert. Figure 6-5 is an east-west cross section through the northern portion of the Amargosa Desert and Yucca Mountain, and it illustrates the differences between the area west of the fault and the area east of the fault. West of the Bare Mountain Fault, the LCCU is structurally high with surface exposures in the Grapevine Mountains. The alluvial basin is interpreted to be shallow and floored by the structurally high LCCU with a relatively thin veneer of Tertiary sediments beneath the alluvium. East of the Bare Mountain Fault, the LCCU is dropped down by the fault where a thick section of LCA is preserved. In the Yucca Mountain area, the LCA is covered by the volcanics of the Volcanic Aquifer and Volcanic Confining Unit. The southern limit of the Southwestern Nevada Volcanic Field occurs south of the NTS and coincides with the position of the Bare Mountain fault.

The Amargosa Desert area contains separately defined thrust fault systems in which the LCCU has been lifted to a higher structural position than that of the LCA. The thrust zones trend to the east-northeast (Figure 4-3) and are depicted in the cross sections of Figure 6-2. Uplift of the 
LCCU in the hanging wall of each of the thrusts impedes groundwater flow, so that groundwater flow through the LCA is laterally confined between thrust faults and is approximately parallel to the cross section depicted in Figure 6-6.

Figure 6-6 is a northeast-southwest cross section extending from the Desert Range through Mercury, Nevada, to the Furnace Creek area in Death Valley. Figure 6-6 depicts the gradual westward erosional thinning of the LCA and the thick alluvium overlying the LCA in the Amargosa Desert. South of the Funeral Mountains, the LCA is present, but has been tectonically thinned and eroded during Tertiary extension. The Tertiary Sediments/Death Valley Section, consisting of the Artist Drive, Furnace Creek, and Funeral Formations, directly overlies the LCA and is interpreted to be a local confining unit. South of the Funeral Mountains, the TSDVS, LCCU, and local intrusives comprise a barrier to southwestward groundwater flow into Death Valley. In the Funeral and Grapevine Mountains, the barrier is comprised of structurally high LCCU.

\subsubsection{Regional Groundwater Flow}

In the NTS region, groundwater occurs within alluvial, volcanic, and carbonate rocks and flows from recharge areas located in the higher altitudes of mountain ranges to discharge areas downgradient. Recharge occurs in the northern and eastern portions of the flow system (Grant Range, Kawich Range, Belted Range, Pahute Mesa, Sheep Range), and discharge occurs in the south-southwest (Death Valley, Oasis Valley, Ash Meadows) and Penoyer Valley. The general direction of groundwater flow is from the northern and eastern recharge areas towards the Death Valley and Ash Meadows discharge areas. Regional groundwater flow is through the LCA and is influenced by local confining units (Upper Clastic Confining Unit and Tertiary Sediments, Death Valley Section) and structural features that control the structural position of the LCCU. Local volcanic aquifers overlying the regional system are of relative importance due to their influence on vertical flow gradients in selected areas (e.g., the NTS).

The following sections discuss the regional groundwater flow system in terms of groundwater occurrence and movement, recharge and discharge, boundary fluxes, and budget. Plate 3 is a regional water-level map that was constructed using water-level and spring-elevation data from selected wells and springs in the region. This map was developed to depict the flow characteristics of the regional groundwater flow system, the flow system boundary, areas of recharge and discharge, and structural controls. The map interpretation incorporated recharge distribution data, digital elevation data, geologic model interpretations, and hydrostratigraphy. 


\subsubsection{Groundwater Occurrence and Movement}

Saturated alluvial materials are present in central and southern Yucca Flat, Frenchman Flat, and Jackass Flats on the NTS and in the basins located throughout the flow system. Saturated Tertiary volcanics are present in the western section of the region. The underlying LCA is the principle aquifer of the flow system. The LCA forms a nearly continuous aquifer across the region except where interrupted by calderas, truncated by structural controls, or penetrated by intrusive rocks. Depths to groundwater vary greatly across the NTS Region. Groundwater occurs at more than $610 \mathrm{~m}(2,000 \mathrm{ft})$ beneath Pahute Mesa in northern NTS and flows from springs at discharge areas in Oasis Valley, Ash Meadows, and Death Valley.

The general direction of groundwater flow in the regional flow system is from north to south and east to southwest. Water-level data and elevation contours of Plate 3 depict this general trend. The direction of groundwater flow is locally influenced in areas where structural and geologic conditions have controlled the distribution and thickness of the LCA. In some areas of the regional flow system, groundwater encounters structural and geologic conditions, such as structural highs of the LCCU, that promote an upward flow component. The upward flow component brings water to discharge at the surface in the form of a wet playa or springs. The discharge is then lost from the flow system through evapotranspiration. Such discharge characteristics are observed at Oasis Valley, Penoyer Valley, and Amargosa Flat. Conversely, there is groundwater flow between basins in the form of subsurface inflow and outflow. Ultimately, however, the groundwater is lost from the flow system at other surface discharge areas located downgradient (e.g., Death Valley).

The general flow directions are consistent with the fact that groundwater moves from areas of recharge to areas of discharge. Recharge on the higher elevations of the Spring Mountains, Sheep Range, Kawich Range, and Grant Range have created groundwater mounds and large hydraulic gradients between the ranges and valley floors. Hydraulic gradients are also indicative of geologic conditions in selected areas.

Hydraulic gradients are very low to the east and west of the NTS, suggesting the presence of very transmissive media (thick LCA). In other areas, the prevailing flow direction and hydraulic gradients may locally be influenced by the structural position of geologic units with significantly lower transmissivity than that of the regional LCA. If the low transmissive units are structurally oriented so that they are perpendicular to flow, flow might be significantly altered, causing steep hydraulic gradients (damming effect). If their structural orientation is parallel to the prevailing flow direction, their effect may be insignificant. Structural uplifts of the LCCU and the 
distribution of the UCCU have caused several of the observed steep gradients within the flow system. Low permeability sediments along the Funeral Mountains (the TSDVS) have also caused a steep hydraulic gradient between Amargosa Desert and Death Valley.

The effect of structure on regional flow patterns is significant in the Pahute Mesa/Timber Mountain caldera complex, Yucca Flat, and the southwestern portion of the region where the Furnace Creek Ranch fault is located (Plate 3). In the caldera complex, the extensive fault system is important because the faults constitute secondary porosity through which the groundwater flows. The Furnace Creek fault is interpreted to act as a conduit to groundwater flow from the Amargosa Desert to Death Valley.

\subsubsection{Recharge Estimates}

The groundwater flow system of the NTS region exhibits several areas of recharge. Areas of recharge to the north include Cactus Range, Kawich Range, Reveille Range, Quinn Canyon Range, and Grant Range. Areas of recharge to the east include the Golden Gate Range, Pahranagat Range, and Sheep Range. The Sheep Range and Spring Mountains provide a significant amount of recharge to the flow system. Other areas of recharge include the mesas and areas of higher elevation surrounding the NTS. Recharge might also occur along the canyons such as Fortymile Canyon. The recharge distribution is depicted in Plates 2 and 3, and it is based upon a Maxey-Eakin percentage of precipitation as described in Section 5.0. Based on this distribution, the estimated total recharge for the NTS regional groundwater-flow system is $182,889-359,510 \mathrm{~m}^{3} / \mathrm{d}(54,118-106,382 \mathrm{ac}-\mathrm{ft} / \mathrm{yr})$.

\subsubsection{Discharge Estimates}

Discharge by evapotranspiration constitutes the majority of the total discharge from the NTS regional groundwater flow system. As discussed in Section 5.0, significant groundwater losses by evapotranspiration occur in eight areas within the flow system boundary: Ash Meadows, Oasis Valley, Death Valley, Franklin Lake Playa, Alkali Flat (Peters Playa), Penoyer Valley, Indian Springs, and the Amargosa River. At Ash Meadows, an upward component of groundwater flow is evidenced by numerous springs originating from the Lower Carbonate Aquifer and similar water-level elevations for closely spaced wells that were completed in both the AA and the LCA. Table 6-2 presents evaporative losses estimated for each area. It is assumed that only evaporative losses are net losses from the groundwater flow system.

For several areas, the estimated discharge is approximate with large uncertainty that cannot be eliminated without additional investigation. Discharge may be overestimated for springs due to 
Table 6-2

ET Discharge Data for the NTS Regional Groundwater Flow System

\begin{tabular}{|c|c|c|c|c|c|}
\hline Location & $\begin{array}{c}\text { Estimated } \\
\text { Surface Area } \\
\left(\mathrm{km}^{2}\right)\end{array}$ & $\begin{array}{l}\text { ET Rate } \\
(\mathrm{cm} / \mathrm{d})\end{array}$ & $\begin{array}{l}\text { Approximate ET } \\
\text { Discharge }\left(\mathrm{m}^{3} / \mathrm{d}\right)\end{array}$ & $\begin{array}{l}\text { Depth to } \\
\text { Water }(m)\end{array}$ & References \\
\hline Ash Meadows & $34.0-36.4$ & $0.19-0.30$ & $67,000-101,400$ & $5-10$ & $\begin{array}{l}\text { Laczniak, 1996a and } \\
1996 b\end{array}$ \\
\hline Oasis Valley & 8.9 & 0.2 & $17,000-27,000$ & $2-10$ & $\begin{array}{l}\text { Malmberg and Eakin, } \\
\text { 1962; Laczniak, 1996a }\end{array}$ \\
\hline Death Valley & NA & NA & $17,500-60,200$ & $0-5$ & $\begin{array}{l}\text { Hunt et al., 1966; } \\
\text { PAL Consultants, } 1995\end{array}$ \\
\hline $\begin{array}{l}\text { Franklin Lake } \\
\text { Playa }\end{array}$ & 14.2 & $0.1-0.3$ & $14,200-42,600$ & $(-1)-3$ & Czarnecki, 1990 \\
\hline $\begin{array}{l}\text { Alkali Flat } \\
\text { (Peters Playa) }\end{array}$ & 12.6 & $0.1-0.3$ & $3,000-35,000$ & $2-5$ & $\begin{array}{l}\text { Winograd and } \\
\text { Thordarson, 1975; } \\
\text { Estimated this study }\end{array}$ \\
\hline Penoyer Valley & 69 & $0.02-0.04$ & $13,000-27,000$ & $2-10$ & $\begin{array}{l}\text { Van Denburgh and } \\
\text { Rush, 1974; Estimated } \\
\text { this study }\end{array}$ \\
\hline $\begin{array}{l}\text { Amargosa } \\
\text { River }\end{array}$ & 1.7 & $0.19-0.30$ & $2,040-5,100$ & $2-5$ & Estimated this study \\
\hline Indian Springs & NA & NA & $1,600-2,400$ & - & PAL Consultants, 1995 \\
\hline
\end{tabular}

the uncertainty regarding infiltration of the discharged groundwater back into the shallow depths of the groundwater flow system.

\subsubsection{Boundary Fluxes}

As discussed in Section 5.0, four areas along the NTS regional groundwater flow system boundary are known to be flux boundaries. The first and most important area is along the northeastern boundary with inflow occurring from Pahranagat Valley to Desert (Tickaboo) Valley. The second area is along the western boundary of Pahrump Valley. The third area is located at the southern boundary of the flow system near Eagle Mountain. The fourth area is on the western boundary with potential inflow or outflow from Sarcobatus Flat into the NTS regional groundwater flow system. The subsurface inflow and outflow estimates are summarized in Table 6-3. Negative values indicate flow out of the regional flow system, and positive values indicate flow into the regional flow system. 
Table 6-3

Estimated Rates of Groundwater Inflow/Outflow for Boundaries of the NTS Regional Groundwater Flow System

\begin{tabular}{||l|r|l||}
\hline $\begin{array}{c}\text { Location } \\
\text { Boundary }\end{array}$ & $\begin{array}{c}\text { Inflow/Outflow } \\
\left(\mathrm{m}^{3} / \mathrm{d}\right)\end{array}$ & \multicolumn{1}{|c||}{ Source } \\
\hline \hline Pahranagat Valley & 5,400 to 60,800 & Winograd and Thordarson (1975) \\
\hline Pahrump Valley & 5 to 7,600 & Winograd and Thordarson (1975) \\
\hline Sarcobatus Flat & $-1,700$ to 1,700 & Malmberg and Eakin (1962) \\
\hline Eagle Mountain & -850 to $-3,400$ & Walker and Eakin (1963) \\
\hline
\end{tabular}

\subsubsection{Groundwater Budget}

Based on the analysis of recharge and discharge presented in Section 5.0, an approximate groundwater budget (mass balance) for the NTS regional groundwater flow system has been derived and is presented in Table 6-4. The estimates of ET discharge and boundary fluxes have been calculated as the middle of the ranges provided in Tables 6-2 and 6-3, respectively. The budget unbalance is due to the uncertainties associated with the available recharge and discharge components of the budget.

Table 6-4

Estimated Steady-State Groundwater Budget for the NTS Regional Groundwater Flow System

\begin{tabular}{|c|c|}
\hline $\begin{array}{l}\text { Recharge } \\
\text { Recharge from precipitation } \\
\text { Subsurface inflow } \\
\text { Total Natural Recharge }\end{array}$ & 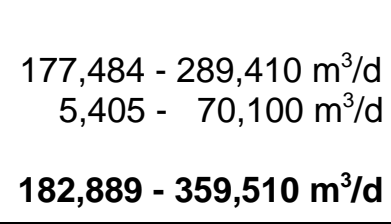 \\
\hline $\begin{array}{l}\text { Discharge } \\
\text { Surface discharge (ET and springs) } \\
\text { Subsurface outflow } \\
\text { Total Natural Discharge }\end{array}$ & 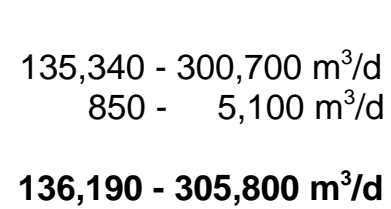 \\
\hline
\end{tabular}

\subsection{Groundwater Flow System at the NTS and Vicinity}

Numerous drillholes and water-level wells penetrate the subsurface of the NTS, allowing for detailed interpretations of the hydrogeologic framework and groundwater flow of the regional 
groundwater flow system at the NTS and vicinity. The following discussion provides a more detailed description of the conceptual model for the NTS and vicinity.

\subsubsection{Hydrogeologic Framework}

Due to the many underground nuclear tests at the NTS, the hydrogeologic framework of the testing areas is an important factor when considering the introduction of contaminants into the regional groundwater flow system. Numerous data from drillholes and wells have allowed for a more detailed interpretation of the flow system in this area and further delineation of the Tertiary volcanics. The volcanics of Yucca Flat and the southern NTS (Frenchman Flat and Yucca Mountain) have been delineated into two separate units: the VA and the VCU. The volcanics comprising the caldera complexes have also been delineated as described in Table 4-3. The following sections present the hydrogeologic framework constructed for the underground testing areas of Yucca Flat, southern NTS, and caldera complexes of Pahute Mesa and Timber Mountain.

\subsubsection{Yucca Flat and Vicinity}

As discussed previously, the LCA is a regional aquifer whose distribution and thickness is controlled by the structural position of the LCCU. A structural high of the LCCU at Halfpint Range isolates northeast Yucca Flat and has exposed the LCA to erosional forces. The LCCU has also been uplifted in western Yucca Flat by major thrust faulting (Belted Range thrust fault). These structural features have in turn controlled the distribution and thickness of the LCA at Yucca Flat.

In northeast Yucca Flat, the LCCU outcrops with the base of the LCA at the Halfpint Range. The LCA dips away from the structural high towards Yucca Flat, but has completely eroded east of the Halfpint Range in Emigrant Valley. Dipping westward into Yucca Flat, the LCA becomes progressively thicker as distance from the structural high increases. The full thickness of the LCA (approximately 4,000 $\mathrm{m}[13,000 \mathrm{ft}]$ ) is interpreted to occur near the center of Yucca Flat (Figure 6-7).

The hydrogeologic framework in western and central Yucca Flat has been structurally modified by major thrust faulting. Below the Tertiary volcanics (VA and VCU), the Belted Range thrust fault system controls the HSU relationships between the Lower Clastic Confining Unit, the Lower Carbonate Aquifer, the Upper Clastic Confining Unit, and the upper plate of the Lower Carbonate Aquifer (LCA3). The nature of this thrust faulting and the distribution of the 
UCCU (Eleana Formation and Chainman Shale) are not thoroughly understood

(Cole et al., 1994), but gross structural relationships can be depicted (Figure 6-7). The Belted Range thrust-fault system dips to the west and strikes southwest from Rainier Mesa, west of the Eleana Range where the UCCU is exposed at the surface. Northwest of the Eleana Range, near Gold Meadows, the upper portion of the LCCU (Wood Canyon Formation) is exposed at the surface and is penetrated nearby by Well ER-19-1 immediately beneath the volcanics. The juxtaposition of the LCCU and the UCCU over a narrow geographic area is interpreted to be the result of reverse displacement along the Belted Range thrust-fault system (Cole et al., 1994). Consequently, the LCA has been truncated by the fault under Rainier Mesa on the east side, and the LCCU is structurally high on the west side. These relationships are shown in Figure 6-7. Simplification of the geologic model interprets the Belted Range thrust-fault system as vertically displaced.

Overlying the UCCU are Pennsylvanian carbonate rocks which outcrop at Syncline Ridge of western Yucca Flat. These carbonate rocks have been designated as the LCA3 to distinguish them from the regional LCA underlying the UCCU (Figure 6-7). The LCA3 carbonates have been interpreted to be remnants of a thrust sheet, named the CP Thrust, which is interpreted to have been emplaced over the UCCU from the east (Caskey and Schweickert, 1992). The CP thrust is rooted in Yucca Flat, but its geometry is unknown because it is buried beneath the Tertiary volcanics and alluvium. The Upper Carbonate Aquifer was mapped with the LCA3 because of its similar position with respect to the LCA3.

The LCA and LCA3 have been confined by Tertiary volcanics. As stated previously, the volcanic strata in Yucca Flat have been organized into two volcanic HSUs, the Volcanic Aquifer and the underlying Volcanic Confining Unit. In general, the altered volcanic rocks (typically zeolitized tuffs) are the confining units, and the unaltered rocks comprise the aquifers (welded to densely welded tuffs). These two units have approximately the same distribution in Yucca Flat and also occur as erosional remnants preserved in the deeper parts of the Tertiary basin. The hydraulic properties of the VA are much less than those of the LCA or LCA3, but higher than those of the VCU and UCCU.

Located in northern Yucca Flat is an intrusive (Climax Stock). Located between the two cross sections shown in Figures 6-7 and 6-8, it intrudes the LCA. As modeled, the intrusive is a narrow, steep-sided feature that is not considered to be a regional barrier to groundwater flow. 
In summary, the LCA thins from east to west and is controlled by the structural position of the LCCU in the northeast and the Belted Range thrust fault system in the west. The LCA3 is a portion of the LCA that has been thrust upon the UCCU by the CP thrust fault system. The Tertiary volcanics overlying the LCA3 and LCA have been organized into a Volcanic Aquifer and Volcanic Confining Unit. In general, welded to densely welded tuffs comprise the VA, while zeolitized tuffs comprise the VCU.

\subsubsection{Southern NTS}

Similar to the area of Yucca Flat and vicinity, lateral movement of groundwater at southern NTS is generally restricted to the regional LCA which is controlled by the structural position of the LCCU and the Belted Range thrust system. In the southeastern NTS, the LCA functions as a continuous groundwater conduit extending from Yucca Flat, south under French Peak, and across the southern NTS to Yucca Mountain. In addition, the VA and VCU are present and cover most of the southern NTS from Frenchman Flat to Bare Mountain (Figure 4-1). In the western portion of the NTS, north of Yucca Mountain, the VCU overlies the LCCU and inhibits groundwater flow south from the Pahute Mesa/Timber Mountain caldera complex.

The Belted Range thrust system has proved to be one of the most important hydrogeologic features in the area of investigation because it has juxtaposed two regionally important confining units (LCCU and UCCU), creating a significant barrier to groundwater flow in the south-central NTS, north of Yucca Mountain. The Belted Range thrust system strikes southwestward from Rainier Mesa in northern Yucca Flat to Bare Mountain where it is interpreted to connect with a thrust fault exhibiting similar structural relationships (Caskey and Schweickert, 1992;

Cole et al., 1994). The trend of the Belted Range thrust system and the corresponding structural uplift of the LCCU are depicted in Figure 4-3. This displacement is also depicted in Figures 6-7 and 6-9. The thrust system truncates the LCA with the LCCU north of a UCCU exposure in the Calico Hills (between Yucca Mountain and Shoshone Mountain in Figure 4-1) where the UCCU overlays the Lower Carbonate Aquifer.

Figure 6-9 is a north-south cross section through Yucca Mountain that depicts these interpreted structural relationships. The LCA dips north at the southern NTS boundary and extends north to where it is truncated and juxtaposed against the LCCU by the Belted Range thrust system. At Yucca Mountain, the LCA is penetrated beneath the VA and VCU by Well UE-25p1 PTH. There is little evidence suggesting that the groundwater flow barrier defined by the structural positions of the LCCU and UCCU has been disrupted by Tertiary extensional faults that would 
allow groundwater to flow south. One exception might be the Bare Mountain fault which has positioned the Crater Flat Basin across the feature.

Also shown in Figure 6-9 are the VA and the VCU. The VCU occurs in deeper areas and is generally overlain by the VA. Between northern Yucca Mountain and the Pahute Mesa/Timber Mountain caldera complex, the volcanic rocks are zeolitized, even at the surface. The VA is not present in this area, and the entire volcanic section is considered to be VCU. The VCU overlies the LCCU and has created a barrier to groundwater flow to the south.

Because the Chainman Shale of the Upper Clastic Confining Unit is locally exposed in much of the eastern and southern NTS, the underlying LCA is interpreted to be present. The LCA3 is also present in the southern NTS where it locally overlies the UCCU. Distribution of the LCA3 in this area is generally coincident with that of the UCCU.

\subsubsection{Pahute Mesa/Timber Mountain Caldera Complex}

As it is interpreted in the geologic model, the caldera complex is comprised of nested calderas and horizontally layered HSUs. The caldera volcanics vary from aquifers comprised of rhyolitic lava flows and densely to partially welded tuffs, to confining units comprised of non-welded and zeolitized tuffs. Figure 6-9 demonstrates the structural relationships of the Timber Mountain Caldera with HSUs in the neighboring calderas and surrounding areas. The cross section depicts thick TC (Paintbrush Group and Calico Hills Formation) north of Timber Mountain in the Area 20 Caldera and south of Timber Mountain in the Claim Canyon Caldera. The TC is comprised of laterally variable tuffs and lava flows. As modeled, the Timber Mountain Caldera is filled with the Timber Mountain Welded-Tuff Aquifer (TMA). The hydraulic properties of the TMA, much like all of the caldera volcanics, are spatially variable. Inside the Timber Mountain Caldera, the TMA is interpreted to have poor aquifer properties due to pervasive zeolitization, and it was modeled as a confining unit. Extending radially from the caldera center, the zeolitization becomes less pervasive until the TMA in the north is non-zeolitized, such as that penetrated by Well PM-3.

To the south of the Timber Mountain Caldera lies the Claim Canyon Caldera where the Basal Aquifer (BAQ) overlies a structural high of the LCCU created by the Belted Range thrust system. This important hydrostratigraphic relationship is displayed in Figure 6-9. At the southern portion of the Claim Canyon caldera, the BAQ is bounded by the UCCU and VCU and is capped by a thick confining section of the Basal Confining Unit. The structural configuration 
interpreted in the model forms a hydrologic barrier with this juxtaposition of Paleozoic and Tertiary confining units. The barrier inhibits southernly flow of groundwater from Pahute Mesa; instead, it directs flow to the southwest towards discharge areas in Oasis Valley.

Figure 6-9 also illustrates the three different nomenclature schemes used to differentiate HSUs for the volcanics across the area. For example, at the northern boundary of the NTS, the TC and TBA are in contact with Volcanics Undifferentiated. Similarly, at the southern edge of the Claim Canyon Caldera, the TC and the BCU are bounded by the Volcanic Confining Unit. These are actually the same stratigraphic units on either side of the boundary, but are shown as different HSUs because different nomenclature schemes were used at the regional scale.

Figure 6-4 is a series of east-west cross section panels of the area west of the NTS (see Figure 6-9 for HSU color labels). This section demonstrates the complex relationships of the nested Grouse Canyon, Area 20, Timber Mountain, and other calderas. The Grouse Canyon caldera is filled with a thick section of welded tuffs of the Belted Range Aquifer (shown in orange). The inner collapse zone of the Grouse Canyon caldera is well-depicted with the large vertical offset and thickest TBA. The Area 20 caldera collapse zone occurs west of the Grouse Canyon caldera and is shown by the thicker tuff cones of the TC (shown in teal) which is comprised of the Calico Hills Formation and the Paintbrush Group.

Figure 6-10 is a cross section of the area west of the NTS from Amargosa Desert through Oasis Valley to eastern Pahute Mesa. As Figure 6-10 illustrates, aquifers of the caldera complex are bounded in the east by the structurally high LCCU, the UCCU, and BCU. To the west, the Area 20 caldera is bounded by structurally high BAQ and BCU. The model interprets the BAQ to be in contact with the LCA on the western margin of the Black Mountain caldera and interprets aquifer communication across the Area 20 caldera wall between the TBA, BAQ, and the LCA. As discussed previously, there is a high uncertainty regarding the BAQ thickness and the presence and thickness of LCA in this area.

\subsubsection{Groundwater Occurrence and Movement}

Groundwater at the NTS occurs within the alluvium, volcanics, clastic confining units, and regional carbonate aquifer. Perched groundwater is found locally throughout the NTS, and occurs within tuff aquitards where they compose "ridges" or "hills" overlying the regional zone of saturation (Winograd and Thordarson, 1975). Springs with low rates of discharge emerge from these aquitards in the higher elevations of the northern NTS. Lateral flow of groundwater 
at Yucca Flat and the southern NTS is generally through the regional LCA. The direction of flow in this area is from the northern and eastern portions of the NTS towards discharge areas in the Amargosa Desert and Death Valley. Groundwater flow within the Pahute Mesa/Timber Mountain caldera is driven by recharge in the northeastern portion of Pahute Mesa. Structural controls created by the Belted Range thrust system impede southernly flow of groundwater from the caldera complex. Instead, groundwater flows from recharge areas in the northeastern section of Pahute Mesa to discharge areas in Oasis Valley. Numerous water-level wells at the NTS and Yucca Mountain have provided hydrologic data, allowing for the following detailed discussion of groundwater occurrence and flow at Yucca Flat, the southern NTS, and the Pahute Mesa/Timber Mountain caldera complex.

\subsubsection{Yucca Flat}

In Yucca Flat, the depth-to-water ranges from approximately $160 \mathrm{~m}(525 \mathrm{ft})$ to $580 \mathrm{~m}(1,900 \mathrm{ft})$ below the ground surface and occurs within the following HSUs: the Alluvial Aquifer, the Volcanic Aquifer, the Volcanic Confining Unit, the upper plate of the Lower Carbonate Aquifer, the Upper Clastic Confining Unit, and the regional Lower Carbonate Aquifer. The AA is discontinuous and exists primarily in the center of Yucca Flat. The VA and VCU occur beneath the AA and are saturated in the north and eastern two-thirds of the flat. The distribution of the LCA3 is generally restricted to the eastern portion of the flat and is confined below by the UCCU. The regional LCA occurs beneath the UCCU and VCU.

Lateral movement of groundwater in Yucca Flat is generally restricted to the LCA because of its distribution, thickness, and high hydraulic conductivity. The hydraulic conductivity of the LCA is spatially variable, but is much higher than other HSUs due to its high fracture porosity.

Groundwater flow within the LCA is influenced by the distribution of the LCCU, directing flow towards the center of Yucca Flat where the LCA is interpreted to be the thickest. This scenario is supported by water-level data collected from wells completed in the LCA. Wells U-10k \#1 and U-101 \#1, located in northeast Yucca Flat, have water-level elevations of $735 \mathrm{~m}(2,412 \mathrm{ft})$. The water-level elevation decreases from the higher elevations of northern Yucca Flat, where the influence of the underlying LCCU is the greatest, to the central portion of Yucca Flat where Well U-3cn \#5 has a water-level elevation of $729 \mathrm{~m}(2,392 \mathrm{ft})$. The water-level elevation continues to decrease to the south where Well WW-C-1 has an elevation of $725 \mathrm{~m}(2,379 \mathrm{ft})$ and the LCA is presumed thickest. 
The influence of the LCCU on water-levels is also suspected east of the LCCU structural high at Emigrant Valley where water-level elevations from wells completed in the VU are much higher than those wells completed in the VA or VCU in Yucca Flat (e.g., Watertown $1 \mathrm{WW}$ at 1,204 m $[3,950 \mathrm{ft}]$; Watertown $2 \mathrm{WW}$ at 1,079 $\mathrm{m}$ [3,540 ft]). In the volcanics, current water-levels have been affected by underground nuclear testing, making it difficult to define steady-state groundwater flow and direction.

Lateral movement of groundwater within the LCA3 is from the west towards Yucca Flat and is controlled by the structural position of the UCCU. Well UE-2ce, completed in the LCA3 and located at the western edge of Yucca Flat, has a water-level elevation of 1,052 m (3,451 ft). To the east of Well UE-2ce, Well UE-2s, also completed in the LCA3, has a water-level elevation of $805 \mathrm{~m}(2,641 \mathrm{ft})$. The water-level elevations in these wells indicate flow to the east toward Yucca Flat.

The water levels for the VA and VCU have been influenced by numerous underground nuclear tests in the area. With only composite water levels typically available, the vertical gradients between the VA and VCU are very difficult to define. At northern Yucca Flat, current water levels from wells completed in the VA have lower elevations than surrounding wells completed in the VCU. These water levels suggest vertical gradients in the upward direction, but are most likely a result of underground nuclear tests in the area.

\subsubsection{Southern NTS}

In the southern NTS, groundwater occurs within the Alluvial Aquifer, the Volcanic Aquifer, the Volcanic Confining Unit, and the regional Lower Carbonate Aquifer at depths ranging from 157 to $360 \mathrm{~m}$ (515 to $1,181 \mathrm{ft})$ below the ground surface. Shallow, perched water is found within the tuff and lava-flow aquitards in the southwestern part of the valley. In Frenchman Flat, the water table is considerably more shallow and stratigraphically higher than in Yucca Flat (Winograd and Thordarson, 1975).

Lateral movement of groundwater in the southern portion of the NTS is generally restricted to the regional LCA. The LCA functions as a groundwater conduit extending from Yucca Flat, south under French Peak, and across the southern NTS towards Yucca Mountain to discharge areas in Ash Meadows, the Amargosa Desert, and Death Valley. This "groundwater conduit" of continuous LCA extends around the groundwater flow barrier of juxtaposed LCCU and UCCU created by the Belted Range thrust system. 
To the north of Yucca Mountain, the Belted Range thrust system has truncated the LCA with the LCCU. The Volcanic Confining Unit overlies the LCCU north of the thrust and has created a barrier to groundwater flow to the south. The groundwater flow barrier in this area is observed with a steep gradient between water-level wells completed in the VCU and those completed in the VA. Water-level data collected from Well USW G-2 and Well UE-25 WT 6, completed in the VCU, have corresponding water-level elevations of 1,031 and 1,034 $\mathrm{m}$ (3,383 and 3,392 ft). Just south of these wells at Yucca Mountain, Well UE-25 WT 16 and Well USW H-1 HTH, completed in the VA, have corresponding water-level elevations of 738 and $731 \mathrm{~m}(2,421$ and $2,398 \mathrm{ft}$ ). In this area, south of the Belted Range thrust system, it is interpreted that the LCA is

present beneath the UCCU where it remains continuous with the LCA underlying Yucca Flat and Frenchman Flat.

\subsubsection{Pahute Mesa/Timber Mountain Caldera Complex}

Groundwater in the Pahute Mesa/Timber Mountain caldera complex occurs in Volcanic Aquifers and Volcanic Confining Units and is interpreted to flow southwest to discharge areas in Oasis Valley, Alkali Flat, and Furnace Creek. Groundwater flow within the caldera complex is driven by recharge in the east and subsurface inflow from the north. Groundwater flow is influenced by the discontinuous nature of the caldera aquifers, and the structure created by overlapping and intersecting caldera complexes and high angle basin and range faults (Laczniak et al., 1996).

Composite water-level data collected from wells in Pahute Mesa indicate lateral movement of groundwater in a southwestern direction towards discharge areas in Oasis Valley. Vertical movement of groundwater is difficult to define due to the lack of data and the complex structure associated with the area. However, selected water-level data suggest that there is a downward flow component in areas of recharge and an upward flow component downgradient near discharge areas in Oasis Valley.

In the eastern portion of the caldera complex at Rainier Mesa, groundwater occurs in the Volcanic Aquifer, zeolitized-tuff confining unit, the LCA3, UCCU, LCA, and LCCU. The volcanic aquifer and confining units support a semiperched groundwater lens. Nuclear testing at Rainier Mesa has been conducted within the tuff confining unit. Data from multiple completion wells indicate that the perched groundwater is moving downward into the Lower Carbonate Aquifer as reported by Thordarson (1965). Regional groundwater flow from Rainier Mesa may be directed either toward Yucca Flat or, because of the intervening UCCU, toward the Alkali Flat discharge area to the south. 


\subsection{Conceptual Model Uncertainties}

The hydrogeology of the NTS regional groundwater flow system is complex. Interpretations of the flow system contain great uncertainties regarding the geologic structure and distribution of hydrostratigraphic units. Equally uncertain are estimates of groundwater recharge and discharge, boundary fluxes, and delineations of the flow system boundary. Uncertainty is greatest where no data exist to validate the conceptual model. Therefore, the greatest uncertainty lies in those areas outside of the NTS where there are few geologic and hydrologic data available to validate the interpretation. However, even on the NTS, where numerous hydrogeologic studies and a high density of geologic and hydrologic data exist, the uncertainties are still high because of the complexity of the hydrogeologic framework. The following sections discuss uncertainty in the geologic model interpretation and hydrologic components of the conceptual model.

\subsubsection{Geologic Model Uncertainties}

The geology of the Basin and Range Province is structurally complex. Any conceptualization of subsurface geology and, therefore, hydrologic properties contains uncertainties. In general, uncertainty in subsurface interpretations increases with distance from surface outcrops and boreholes and with superficial cover. There is naturally high uncertainty in the projection of surface geologic interpretation to depths of 7,000 m (nearly 23,000 ft) into the subsurface where data do not exist.

The areas of greatest uncertainty in the geology interpretation are those with extensive cover of volcanic rocks and alluvium. The volcanic rocks hide the structural relationships of the regional Lower Carbonate Aquifer and Lower Clastic Confining Units as well as the distribution of underlying volcanic hydrostratigraphic units. The uncertainties have hydrological importance in areas near the higher potentiometric gradient that crosses the NTS. The most hydrologically significant areas of geologic uncertainty are:

- The area immediately north of Yucca Flat where the Paleozoic rocks are covered by volcanic rocks of the Belted Range

- The large area of volcanic cover northwest of the NTS in the Gold Flat/Cactus Flat area

- The area between Pahute Mesa and Oasis Valley

- The relationship of the Belted Range thrust system with caldera units near Yucca Mountain 
In each of these areas, there is high uncertainty about the thickness of the volcanic units, the nature of the volcanic units at depth, and the presence of the LCA underneath the volcanic rocks.

\subsubsection{Hydrologic Uncertainties}

Uncertainties regarding the NTS regional groundwater flow system result from a lack of hydrogeologic data. Although there are numerous wells within the flow system boundary, most wells were not constructed for the acquisition of hydrologic data. In addition, only a few wells within the flow system boundary have estimates for hydraulic parameters. A number of factors regarding components of the conceptual model have resulted in uncertainty in estimates of recharge, discharge, and subsurface inflow and outflow at the flow system boundaries.

In many instances, the interpretation of the regional water-level table is based upon the geologic model interpretation (Plate 3) due to the lack of adequate hydrologic data. For example, at the NTS, most wells are completed across multiple HSUs and provide only composite water levels. Wells off the NTS are typically completed in the alluvium and do not provide information or data about the regional LCA. There is a large range of uncertainty in water-level elevations as a result of estimates of land surface elevations for the many wells not surveyed and the inherent error of depth-to-water measurements. This has introduced uncertainty in the depiction of a steady-state flow system for the NTS region. Uncertainty is a result of the inability to validate the interpretations of the potentiometric surface in these areas, and it is presented in detail in the Potentiometric Data Documentation Package (IT, 1996b)

Hydraulic tests conducted in selected wells estimate the hydraulic parameters of the penetrated HSUs. Results of the hydraulic testing only estimate the local properties of the tested HSUs. These results have been extrapolated to incorporate the entire NTS regional groundwater flow system. As evidenced by the hydraulic parameters presented in Table 6-1, hydraulic parameters range in orders of magnitude and represent great hydraulic variability within HSUs. For example, within the regional LCA the range of hydraulic conductivity is estimated to be between 0.0008 and $1570 \mathrm{~m} / \mathrm{d}(0.003$ and 5,150 ft/d), representing interstitial and fracture porosity. Uncertainty regarding the hydraulic parameters estimated for HSUs are presented in greater detail in the Hydrologic Parameter Data Documentation Package (IT, 1996d).

Recharge from precipitation, discharge by evapotranspiration, and subsurface inflow and outflow at the flow system boundary are based upon literature review and selected station data. These components of the conceptual model are uncertain due to the lack of adequate data needed to 
validate the interpretation. The recharge distribution was developed from sparse precipitation station data and highly interpretive precipitation contour maps. The boundaries of discharge areas are relatively well-defined, but spring discharge volumes and evapotranspiration for these areas are not. Subsurface inflow and outflow at flow system boundaries are estimated based upon the local hydraulic gradients and the hydrogeologic framework. The uncertainty regarding these components of the flow system are discussed in greater detail in the Groundwater Recharge and Discharge Data Documentation Package (IT, 1996c). 


\subsection{Numerical Groundwater Flow Model}

This section presents the objectives, approach, assumptions, development and results of the regional three-dimensional groundwater flow model of the Nevada Test Site groundwater flow system. The model integrates the hydrogeologic and hydrologic data presented in Sections 4.0 through 6.0 into a consistent, numerical interpretation of the natural groundwater flow system. It should be noted that all references to the term "model" in this section refer to the numerical flow model unless specifically stated otherwise. For more detailed technical discussions and a comprehensive presentation of supporting data and figures, the reader is referred to the Groundwater Flow Model Documentation Package (IT, 1996f).

\subsection{Objectives}

The regional flow model was designed to provide a framework for regional contaminant transport modeling and to provide a basis for future detailed modeling at the local scale. The groundwater flow model uses the principle of conservation of mass (the governing equation of flow through porous media) and Darcy's Law to simulate a distribution of hydraulic heads that is representative of actual conditions. The hydraulic conductivity and simulated hydraulic heads are used to calculate groundwater flow paths which, in conjunction with porosity data, are used to determine groundwater velocities along those paths. The distribution of velocities along flow paths originating from the weapons testing areas was used to perform preliminary, conservative regional-scale, one-dimensional transport simulations that, in turn, were used to quantify the maximum credible risk to human health and the environment at downgradient receptors.

In addition to providing a framework for regional transport modeling, the three-dimensional (3-D) groundwater flow model will also be used as a basis for future detailed modeling in the individual weapons testing areas. Flux estimates are not well-known in the vicinity of the weapons testing areas; however, fluxes are better known along the boundaries of the regional model. The calibrated regional model provides internal flux values across model cell boundaries that can then be used as boundary fluxes for the near-field models, thus ensuring that the nearfield models are consistent with the regional water budget. This provides a means to evaluate the uncertainty in prediction of local-scale radionuclide transport resulting from the uncertainty in the regional hydrologic parameters. 
The regional flow model was designed and developed to evaluate flow directions and velocities within and downgradient from the primary area of interest, the NTS. The model was not developed to evaluate flow in areas distal from the NTS, such as in the Spring Mountains or the Pahranagat Range. If more detailed hydrologic modeling is to be conducted in these areas, detailed geologic data from the respective areas would first have to be integrated into the model.

The regional groundwater flow model was also not developed for detailed modeling on the nearfield scale. The geologic data have been grouped into 20 hydrostratigraphic units (Table 4-3) that are appropriate for the regional scale modeling; however, more detailed geologic information will be necessary for the near-field modeling. Additionally, the model assumes that its parameter values provide good estimates of the average flow behavior within fractured rock, characterized by the concept of the representative elementary volume (Bear, 1979). This concept, or continuum approach, may not be valid on the local scale where fracture-flow characteristics dominate the flow pattern.

Specific modeling objectives were to:

- Provide an integrated tool with which to understand the groundwater flow system in the vicinity of the NTS.

- Identify flowpaths from weapons testing areas and calculate flow rates within and downgradient from these areas for use in the evaluation of regional groundwater contaminant transport.

- Provide a mechanism for determining the importance of regional-scale hydraulic parameters on estimates of contaminant transport.

- Provide a three-dimensional framework on which to base more detailed models of the weapons testing areas, so that the near-field models are consistent with the regional water budget.

These objectives were met through development of the flow model, calibration of the model based on criteria established for hydraulic heads and fluxes, sensitivity evaluations of hydraulic parameters, and generation of pathlines and corresponding velocity distributions from selected nuclear shots. The approach used to implement each of these steps is described in the following sections of this report. 
It is important to realize that the numerical groundwater flow model is only an approximation of the groundwater flow system, and there is uncertainty in both the three-dimensional distribution of the geologic units and their hydrologic properties. The values of parameters used in the calibrated model result in a reasonable fit between modeled and measured hydraulic heads and between modeled and measured/estimated discharge rates. However, different parameter values may provide similar agreement between simulated and observed data, but result in different estimates of radionuclide transport. The model provides a technique with which to evaluate the uncertainty in these estimates.

\subsection{Modeling Approach}

This section provides a brief description of the numerical code used for the Nevada Test Site regional model, the assumptions used in model development, and the input data required for the model.

\subsubsection{Numerical Code Description}

The three-dimensional numerical code selected for the simulation of the groundwater flow system is the finite-difference code, MODFLOW (McDonald and Harbaugh, 1988). The code uses finite-difference equations to approximate the partial differential equation for 3-D groundwater flow of constant density in a heterogeneous, anisotropic medium. The model uses the Block Centered Flow (BCF2) package (McDonald and Harbaugh, 1991) to calculate conductances and flow between adjacent cells. The BCF2 package has the capability of allowing a model cell to resaturate, or "rewet," if the water table drops below the bottom of a cell during one iteration, but rises above the bottom in a subsequent iteration. This feature was required to accurately model the extreme change in head values between the upgradient and downgradient areas of the model.

The preconditioned conjugate-gradient solver, (PCG2) (Hill, 1990) was used to solve the system of finite-difference equations. The solver has converged when the following two criteria are met: the maximum absolute value in the change in hydraulic head between two successive iterations is less than a specified convergence criterion, and the maximum absolute value of the flux residual between successive iterations is less than a second specified convergence criterion. The hydraulic head change convergence criterion used for the NTS model is $0.005 \mathrm{~m}(0.02 \mathrm{ft})$; the flux residual criterion is $0.25 \mathrm{~m}^{3} / \mathrm{d}(0.07 \mathrm{ac}-\mathrm{ft} / \mathrm{d})$. These closure criteria resulted in mass balance errors of less than 0.03 percent. 


\subsubsection{Assumptions}

The following assumptions were used in development of the groundwater-flow model:

- At the scale of the regional model, movement of water in fractured rock can be adequately described by a porous media model.

- Spatial variations in groundwater density due to changes in temperature or chemistry are negligible.

- The system is laterally isotropic and vertically anisotropic.

- The geologic units represented in the model are homogeneous or can be divided into homogeneous zones.

- The hydraulic conductivity is assumed to decrease in an exponential manner with increasing depth.

- The model represents steady-state conditions representative of natural stresses to the system prior to groundwater development and underground nuclear testing.

- Because of the steady-state assumption, the volumetric recharge is based on estimates of discharge from the basin.

- Recharge can be adequately simulated by using a technique similar to that used by Maxey and Eakin (1949) modified to account for runoff (recharge redistribution).

The assumptions on which a model is based are very important because they dictate when and under what conditions the model can be applied. The assumptions listed above are described in detail in the text where appropriate. Water-level data representative of pre-pumping, pre-nuclear testing conditions were not always available. Therefore, the available data were augmented by data collected during times that may not be representative of pre-anthropogenic (before human influence), steady-state conditions. These data and the effect they may have on the "steadystate" water levels on which the model calibration is based are summarized in Section 5.0. It is believed that the water-level data selected for use in the study are generally representative of preanthropogenic stress conditions.

\subsubsection{Modeling Data Requirements}

The characteristics of any groundwater flow system are determined by the spatial distribution of the rocks present in the subsurface environment, their hydrologic properties, and the locations and rates of fluxes at the system's boundaries. The locations and rates of discharge of water 
from the system are determined by these characteristics, as are the water levels throughout the system. There were, therefore, three basic sets of information used as input to the model: the geologic framework, the hydraulic properties of the rocks, and the locations and rates of fluxes into the system. The physical locations of discharge areas are also required as model input, but the discharge flux is determined by the model. These components are described in the following text.

The comprehensive, regional 3-D geologic model developed specifically for this task has been described in Sections 4.0 and 6.0 of this report. The digital geologic model is comprised of a set of 20 two-dimensional arrays, each consisting of 140 rows and 114 columns. The arrays provide the elevations for the tops of the 20 hydrostratigraphic units on a 2- x 2-km (1.2- x 1.2-mi) grid.

The second set of information required for the flow model is an estimate of the hydraulic conductivity for each HSU. The approach taken was to initially assign a single hydraulic conductivity value to all geologic units of similar origin. For example, there are several different HSUs that are classified as welded-tuff aquifers. These rocks are considered to be of similar origin and were initially assigned the same hydraulic conductivity value. During model calibration, hydraulic conductivity values were modified as necessary to derive the best fit between observed and model-generated data.

Areal variability exists within HSUs, especially if the units are widespread, such as the Lower Carbonate Aquifer. Hydrostratigraphic units are divided into zones of differing hydrologic properties when supported by hydrogeologic data or interpretations or when designation of a separate area for sensitivity analysis was necessary.

Hydraulic-conductivity data collected at the Nevada Test Site indicate that conductivity values decrease with depth. The relationships between depth and hydraulic conductivity for three classes of HSUs (the Alluvial Aquifer, the Volcanic Aquifers, and the Lower Carbonate Aquifer) were presented in Section 5.0. The values of the depth-decay coefficient, $\lambda$, for the volcanic rocks and LCA (Table 5-2) were used in the model without modification. The value for $\lambda$ of the AA was decreased from 0.00563 to $0.0037 \mathrm{~m}^{-1}\left(0.00172\right.$ to $\left.0.00113 \mathrm{ft}^{-1}\right)$, which is the regression value obtained after eliminating hydraulic conductivity values for the Faultless Site in the Hot Creek area, located north of the model boundary. 
The final data required as input to the flow model include information about fluxes into and out of the system. The influxes include recharge from precipitation and underflow from areas located outside of the model boundary. Discharges from the system include losses due to evapotranspiration, spring flow, and underflow across model boundaries. Because the model is simulating steady-state natural-stress conditions, losses due to pumping are not considered.

Because of the complexity of the geologic model and the large amounts of hydrologic data that needed to be handled, the modeling effort was very dependent on many support programs developed for the UGTA Subproject. Several of the support programs, called preprocessors, were used to convert the geologic, hydrologic, and boundary flux data into input datasets used by the flow model, and the flow model was run. Flow model results consisted of an areal distribution of water levels (also called hydraulic heads, or heads) for each of the model layers and calculated fluxes at each of the boundary condition cells. These model-calculated, or simulated, hydraulic heads were then compared to a dataset consisting of observed, or target, hydraulic heads that were representative of steady-state conditions. The model-simulated fluxes were compared to measured and estimated boundary fluxes. Modeling parameters were then adjusted, the model rerun, and simulated hydraulic heads and fluxes again compared to the observed or target heads and fluxes. This process of adjusting modeling parameters to improve the agreement between calculated and observed values is called "calibration." Obtaining good agreement to measured water levels within and downgradient from the testing areas was given a higher priority than other areas located within the model boundary.

\subsection{Model Development}

The numerical groundwater flow model was based on the conceptual model described in Section 6.0. The development of the numerical model consisted of delineating the model boundaries, discretizing the model domain into a 3-D grid, defining boundary conditions, and selecting calibration criteria.

\subsubsection{Model Boundaries}

The model boundaries correspond as much as possible to regional groundwater flow divides identified in Section 6.0. The model covers approximately $25,400 \mathrm{~km}^{2}\left(9,806.9 \mathrm{mi}^{2}\right)$ of the Nevada Test Site groundwater flow system and includes parts of Clark, Lincoln, and Nye Counties in Nevada, and Inyo County, California. The model area is bounded by Death Valley, the Funeral Mountains, Bullfrog Mountain, and the Cactus Range on the west; transects the Kawich, Reveille, and Quinn Canyon ranges on the north; is bounded by the Timpahute, 
Pahranagat, and Sheep ranges on the east; and includes parts of the Spring Mountains, Resting Spring Range, and Greenwater Range on the south. The location of the model boundary is shown in Figure 7-1.

\subsubsection{Model Discretization}

The modeled area must be discretized both laterally and vertically. The areal grid consists of 68 columns by 76 rows (Figure 7-1). The nonuniform grid includes $1.5-\mathrm{x} 1.5-\mathrm{km}$ (0.9- x 0.9-mi) cells in the vicinity of the site, grading to a coarser spacing along the model boundaries where detailed geologic and hydrologic data are sparse and where numerical accuracy is less important. The origin for the grid is in the upper left-hand corner, corresponding to the Universal Transverse Mercator (UTM) (NAD 27, Zone 11) coordinates 507,220 East and 4,231,307 North. The grid is rotated 5 degrees clockwise about this point to align the columns with the average fracture direction in the primary weapons testing areas, Yucca Flat and Pahute Mesa. By orienting the grid in this manner, the effects of anisotropy can be incorporated in subsequent, detailed models of the testing areas.

Vertical discretization consists of dividing the model into layers. Model layers were selected based on elevation where the top of each model layer was assigned a constant elevation value. The hydraulic properties assigned to each cell are composites of the properties of all HSUs present within that cell. Figure 7-2 illustrates this concept. Cell 1 in Model Layer 1 includes portions or all of three HSUs (HSUs 1, 2, and 3), whereas Cell 2 in Model Layer 1 contains only one HSU: HSU 3. The hydraulic properties assigned to Cell 2 will be equivalent to those of HSU 3, whereas the hydraulic properties assigned to Cell 1 will represent a thickness-weighted average of the properties of HSUs 1, 2, and 3.

This approach requires that many thin model layers be used to preserve the geologic complexity, especially of thin, hydrologically significant HSUs. Model layers were, therefore, defined to preserve the detail present in the geologic model, especially in the elevations in which weapons testing occurred. HSUs with low conductivities were included explicitly in the model because of the subsequent use of particle-tracking in evaluating contaminant transport. The elevations of the tops and bottoms of the 20 model layers are presented in Table 7-1.

\subsubsection{Boundary Conditions}

Boundary conditions are used to identify areas where water enters or leaves the modeled system. The following MODFLOW modules, or packages, were included in the NTS model to simulate 
Table 7-1

Elevations of Model Layers

(Top to Bottom of Model)

\begin{tabular}{|c|c|}
\hline Model Layer & $\begin{array}{c}\text { Elevation } \\
\left(\mathrm{m} \text { above ams }{ }^{\mathrm{a}}\right)\end{array}$ \\
\hline 1 & 1,750 to 2,000 \\
\hline 2 & 1,500 to 1,750 \\
\hline 3 & 1,350 to 1,500 \\
\hline 4 & 1,200 to 1,350 \\
\hline 5 & 1,050 to 1,200 \\
\hline 6 & 900 to 1,050 \\
\hline 7 & 700 to 900 \\
\hline 8 & 600 to 700 \\
\hline 9 & 475 to 600 \\
\hline 10 & 350 to 475 \\
\hline 11 & 225 to 350 \\
\hline 12 & 100 to 225 \\
\hline 13 & -50 to 100 \\
\hline 14 & -250 to -50 \\
\hline 15 & -500 to -250 \\
\hline 16 & $-1,000$ to -500 \\
\hline 17 & $-1,500$ to $-1,000$ \\
\hline 18 & $-2,000$ to $-1,500$ \\
\hline 19 & $-3,000$ to $-2,000$ \\
\hline 20 & $-4,000$ to $-3,000$ \\
\hline
\end{tabular}

$\mathrm{a}_{\mathrm{amsl}}=$ Average mean sea level 
those fluxes: the Recharge, General-head boundary (GHB), Well, and Drain Packages. The Recharge and Well Packages apply a specified flux boundary condition while the GHB and Drain Packages apply head-dependent flux boundary conditions. For head-dependent flux boundary conditions, the flux entering or leaving the system is a function of the difference in hydraulic head between the head in the model cell and the head specified as part of the boundary condition.

The GHB, well, and drain boundary condition cells are shown in Figure 7-3. The figure also differentiates between active and inactive cells. Inactive cells fall outside of the hydrologic boundary (Figure 7-1) and have no impact on flow within the model domain. Active cells are cells for which hydraulic heads are calculated by the model.

A special case of the specified-flux boundary condition is the no-flow boundary where water is not permitted to enter or leave the model cells across this boundary. No-flow boundaries are implicitly defined between active and inactive cells everywhere along the model boundary where drain, well, and GHB cells are not explicitly specified (Figure 7-3). These no-flow boundaries represent both groundwater divides and flow lines that are coincident with the model boundary as shown in Plate 3. Groundwater divides occur along the model boundary in the Sheep Range, Spring Mountains, Cactus Range, the Quinn Canyon Range, and the Timpahute Range. The remaining majority of the no-flow cells along the model boundary represent flow lines. Flow lines that are coincident with the boundary are present (clockwise, from the southeastern corner of Figure 7-3) between the Sheep Range and the Spring Mountains, across the Resting Spring and Greenwater Ranges to Death Valley, from Death Valley across the Grapevine Mountains and north along the eastern flanks of those mountains, across Bullfrog Mountain and north to the Cactus Range, from the Cactus Range across the Kawich Range to Railroad Valley, and from the Timpahute Range down the length of the Pahranagat Range. here it was evident that recharge was occurring, the hydrologic model boundary was selected to be coincident with hydrographic basin boundaries.

The location of the flow-system boundary in the vicinity of the southern Sheep Range is uncertain. The interpretation used in this model incorporates the Sheep Range within the Nevada Test Site flow system, while others (e.g., Dettinger et al., 1995) have suggested that water recharged in the Sheep Range may flow toward the Las Vegas Valley. Water-level data can be interpreted both ways, depending on the configuration of the shear zone and its properties on the southern end of the Desert Range. The Sheep Range was included within the model because the 
top of the Lower Clastic Confining Unit is highest near the crest of the Sheep Range, and it slopes down to the west. This geometry favors flow to the west rather than to the south. Additional water-level data would help resolve this area of uncertainty.

\subsubsection{Recharge Package}

Recharge to the groundwater flow system occurs either as infiltration from precipitation or as underflow across upgradient model boundaries. The MODFLOW Recharge Package simulates recharge from precipitation; underflow is simulated using either the GHB or well packages.

Measurements of recharge are difficult to obtain. As a result, recharge has been estimated using an empirical model known as the Maxey-Eakin method (Maxey and Eakin, 1949) which was discussed in Section 5.0. In the development of the regional flow model, the basic Maxey-Eakin concepts were used, but the coefficients were adjusted to result in a total recharge flux that approximated the total estimated discharge from evapotranspiration and the external boundary fluxes. Target discharge ranges for all discharge areas were estimated based on a thorough literature review; a target discharge rate (best estimate) for each area was selected based on the literature review and discussions with subject matter experts from the USGS. Table 7-2 presents the model target flux ranges, the target values selected for each flux area, and the total recharge flux calculated from these estimates for the model area. Positive fluxes within the table indicate discharge from the model, whereas negative fluxes indicate flow into the model.

As discussed in Section 5.0, precipitation within ten hydrographic subbasins on or within the vicinity of the Nevada Test Site was redistributed from upland areas to downstream areas. The redistribution percentages used in the flow model are listed in Table 7-3. It is important to emphasize that redistribution did not modify the total volume of recharge calculated for each subbasin, it only modified the areal distribution of the recharge.

\subsubsection{General-Head Boundary Package}

The model boundary was selected to correspond as much as possible to areas of groundwater divides that are simulated as no-flow boundaries. However, in certain areas, no-flow boundaries were not present. These areas represent sections of the boundary where groundwater is either entering or exiting the model as underflow. These fluxes were simulated by applying constant flux boundary conditions using the Well Package or head-dependent flux boundary conditions using the GHB Package to the appropriate cells. 
Table 7-2

Calculation of Model Recharge Rate
Based on Model Area Discharge Estimate

\begin{tabular}{||l|c|c||}
\hline \multicolumn{1}{||c|}{ Discharge Area } & $\begin{array}{c}\text { Target Discharge } \\
\text { Range } \\
\left(\mathrm{m}^{3} / \mathrm{d}\right)\end{array}$ & $\begin{array}{c}\text { Target } \\
\text { Discharge Rate } \\
\left(\mathrm{m}^{3} / \mathrm{d}\right)\end{array}$ \\
\hline \hline Alkali Flat (Peter's Playa, [AF]) & $5,000-7,300$ & 6,100 \\
\hline Amargosa River (ARiv) & $2,040-5,100$ & 2,500 \\
\hline Ash Meadows (AM) & $67,000-87,300$ & 77,700 \\
\hline Death Valley (DV) & $17,500-60,200$ & 60,100 \\
\hline Franklin Lake/Alkali Flats (FL) & $14,200-42,600$ & 35,500 \\
\hline Oasis Valley (OV) & $17,000-27,000$ & 25,000 \\
\hline Penoyer Valley (PV) & $13,000-27,000$ & 20,300 \\
\hline Indian Springs (IS) & $1,600-2,400$ & 2,400 \\
\hline Eagle Mountain (EM) & $850-3,400$ & 3,400 \\
\hline Sarcobatus Flat (SF) & $(-1,700)-1,700$ & 0 \\
\hline Pahrump Valley (PP) & $(-5,000)-(-7,600)$ & $-5,000$ \\
\hline Pahranagat Valley (PAHR) & $(-5,400)-(-60,800)$ & $-27,000$ \\
\hline \multicolumn{2}{|c|}{ Total Estimated Recharge Rate: } & 201,000 \\
\hline
\end{tabular}

General-head boundary conditions were used to simulate inflow from Pahrump Valley across the Resting Springs Range and outflow near Eagle Mountain (Figure 7-3); initial boundary head values were based on the potentiometric surface map developed of the study area (Plate 3). The GHB boundary condition was selected because the amount of flux across the two boundaries is not well-known, but hydraulic heads outside the model near these boundaries are reasonably well-known. Additionally, the flux is expected to be low, based on the types of geologic units present.

The General Head Boundary Package requires both hydraulic head values external to the boundary cell and boundary conductances. The boundary conductance is calculated by multiplying the boundary cell transmissivity by the cell horizontal dimension perpendicular to the primary flow direction for the cell and dividing by half the cell dimension parallel to flow. This procedure places a constant head value at the outer model boundary. The flux across the 


\section{Table 7-3}

\section{Recharge Redistribution in Seven Hydrographic Areas in the Vicinity of the NTS}

\begin{tabular}{||l|c|c|c|c||}
\hline \multirow{2}{*}{$\begin{array}{c}\text { Hydrographic } \\
\text { Area }\end{array}$} & \multirow{2}{*}{$\begin{array}{c}\text { Redistribution } \\
\text { to Type B Zone } \\
\text { (percent) }\end{array}$} & \multicolumn{2}{c|}{$\begin{array}{c}\text { Percent of Type B Zone Subdivided } \\
\text { Among Three Subareas }\end{array}$} \\
\cline { 3 - 5 } & & B1 & B2 & B3 \\
\hline \hline Topopah Wash (227C) & 20 & 10 & 70 & 20 \\
\hline Beatty Wash (228A) & 20 & 50 & 40 & 10 \\
\hline Thirsty Canyon (228) & 20 & 70 & 20 & 10 \\
\hline Lower Forty Mile (227B) & 20 & 30 & 60 & 10 \\
\hline Upper Forty Mile (227A) & 20 & 60 & 30 & 10 \\
\hline Frenchman Flat (160) & 20 & 10 & 80 & 10 \\
\hline Yucca Flat (159) & 20 & 20 & 40 & 40 \\
\hline Silent Canyon (147A) & 20 & 40 & 40 & 20 \\
\hline Kawich Valley South (157A) & 20 & 40 & 20 & 40 \\
\hline Groom Lake (158C) & 20 & 40 & 20 & 40 \\
\hline \hline
\end{tabular}

${ }_{\mathrm{b}}^{\mathrm{H}}$ Hydrographic areas are shown in Figure 5-3
Subareas are defined in Table 5-6.

boundary is then based on the difference between the boundary head and the head calculated at the cell node by MODFLOW. The estimated boundary fluxes for the two GHB areas were presented in Table 7-2.

\subsubsection{Well Package}

The Well Package, which stimulates constant-flux boundary conditions at individual cells, was used to describe flow into the model west of Pahranagat Valley and to allow evaluation of inflow or outflow at Sarcobatus Flat. The Well Package, rather than the General Head Boundary Package, was used for more explicit control of the flux. The greatest underflow is projected to occur between Pahranagat Valley and Desert Valley along the southern part of the Pahranagat Range. Winograd and Friedman (1972) estimated that the flux across this boundary is approximately one-third of the discharge at Ash Meadows; a similar estimate that approximately 40 percent of the Ash Meadows discharge originates as flux across the southern Pahranagat Range was developed by Thomas (1996). Although these studies provide good initial estimates 
for the boundary flux, it should be emphasized that information on the groundwater system near Pahranagat Valley is limited. The Well Package was used at these cells to facilitate sensitivity analyses of model results to these boundary fluxes.

For the boundary with Sarcobatus Flat, a zero-flux condition was used during calibration. This assumption was also evaluated during sensitivity analyses. Sensitivity evaluations of flux boundary conditions are presented in Section 7.5.6.1.

With the Well Package, the flux into or out of the model is specified for each boundary cell. A preprocessor was written that calculates the flux for each cell in a vertical column of boundary cells based on the following parameters: the assigned flux for the column of cells, the assigned elevation of the water table, and the relative transmissivities of the cells in the column. The assigned water table elevations for the boundary cells were based on the potentiometric surface map developed of the study area (Plate 3). If the simulated water table is lower than the assigned value, then upper cells with an assigned flux may become inactive, and the total boundary flux will change. On the other hand, if the simulated water level is higher, the total flux will remain the same, but no flux will be assigned for those cells above the assigned water table. A postprocessor was written to sum the boundary fluxes for specified groups of cells as a quality assurance check.

For the boundary with Pahranagat Valley, four vertical columns of cells were assigned a flux of $6,750 \mathrm{~m}^{3} / \mathrm{d}(1,998 \mathrm{ac}-\mathrm{ft} / \mathrm{y})$ each, resulting in a total flux into the model of $27,000 \mathrm{~m}^{3} / \mathrm{d}$ (7,991 ac-ft/y). For the boundary with Sarcobatus Flat, seven columns of cells were used, but the flux for each column was set to zero for the calibration process. The estimated boundary fluxes for Pahranagat Valley and Sarcobatus Flat were presented in Table 7-2.

\subsubsection{Drain Package}

Groundwater can exit the system by underflow, simulated using the GHB Package, or as discharge to the surface via springs or evapotranspiration. Eight areas were identified as surfacedischarge boundaries (Figure 7-3, "Drain Cells"). These areas include: Penoyer Valley to the north of the test site; Indian Springs along the Las Vegas Valley Shear Zone; Oasis Valley to the west of the Nevada Test Site in the vicinity of Beatty; Alkali Flat, also known as Peter's Playa, located northeast of the Ash Meadows discharge area; Ash Meadows; Franklin Lake Playa; Amargosa River; and Death Valley. 
Within the study area, water discharging from springs either reinfiltrates the groundwater system a short distance downstream from the discharge point or is evaporated or transpired. Therefore, water lost from the groundwater system through surface discharge is in the form of evapotranspiration, and estimated ET rates were used for model calibration with one exception. Water does exit the modeled system via surface discharge along the Amargosa River west of Eagle Mountain. Streamflow measurements have not been located, but flow was visually estimated in the fall of 1992 to be less than 0.03 cubic meters per second (one cubic foot per second). Because this value was minimal compared to rates from the remaining discharge areas, discharge across the model boundary due to streamflow in the Amargosa River was ignored.

Surface discharge from the model due to evapotranspiration losses could have been simulated using either the ET or Drain Packages. The ET Package requires specification of an "extinction depth" (the elevation below which ET does not occur), land-surface elevation, and an ET rate at land surface. Modeled evapotranspiration linearly increases with the rise in the water table above the extinction depth until land surface is reached, at which time a maximum evapotranspiration rate is reached. The discontinuous function used to represent ET at land surface has been problematic in previous studies (Prudic et al., 1993). Additionally, the function does not have the flexibility of representing increasing discharge as water levels continue to rise above land surface, which would be necessary to simulate the change from an ET to a spring discharge mechanism. Therefore, evapotranspiration was handled using the Drain Package.

The Drain Package requires specification of a drain elevation. Discharge is zero when the simulated hydraulic head is below the elevation of the drain and increases linearly as a function of the conductance as the difference between the calculated hydraulic head and the drain elevation increases. The drain elevation was initially set to an elevation approximately $5 \mathrm{~m}$ $(16.4 \mathrm{ft}$ ) below land surface elevation to approximate the ET extinction depth. The land surface elevation used in the calculation of the drain elevation was the lowest point in each model cell that fell within the discharge area.

The conductance values required for the Drain Package represent composite conductances due to all hydraulic head losses resulting from converging flow in the discharge areas. Because 
conductances are difficult, if not impossible, to measure, they were estimated using the following formula:

$$
\operatorname{Cond}_{\mathrm{i}, \mathrm{j}, \mathrm{k}}=\frac{\mathrm{A}_{\mathrm{i}, \mathrm{j}, \mathrm{k}}}{\mathrm{A}_{\text {D.A. }}} \times \frac{\text { Flux }_{\text {D.A. }}}{\left(\mathrm{h}_{\mathrm{i}, \mathrm{j}, \mathrm{k}}-\mathrm{d}_{\mathrm{i}, \mathrm{j}, \mathrm{k}}\right)}
$$

Where:

Cond $_{\mathrm{i}, \mathrm{j}, \mathrm{k}}=$ conductance of drain cell $\mathrm{i}, \mathrm{j}, \mathrm{k}\left[\mathrm{L}^{2} / \mathrm{T}\right]$;

$\mathrm{A}_{\mathrm{i}, \mathrm{j}, \mathrm{k}} \quad=$ area of drain cell $\mathrm{i}, \mathrm{j}, \mathrm{k}\left[\mathrm{L}^{2}\right]$;

$\mathrm{A}_{\text {D.A. }} \quad=$ total area of specified discharge area (e.g., Oasis Valley, OV) $\left[\mathrm{L}^{2}\right]$;

Flux $_{\text {D.A. }}=$ total estimated discharge flux from specified discharge area $\left[\mathrm{L}^{3} / \mathrm{T}\right] ;$

$\mathrm{h}_{\mathrm{i}, \mathrm{j}, \mathrm{k}} \quad=$ hydraulic head in drain cell $\mathrm{i}, \mathrm{j}, \mathrm{k}[\mathrm{L}]$; and

$\mathrm{d}_{\mathrm{i}, \mathrm{j}, \mathrm{k}}=$ drain elevation in cell $\mathrm{i}, \mathrm{j}, \mathrm{k}[\mathrm{L}]$.

In calculating the conductance using the above formula, the difference between the hydraulic head in the boundary cell and the respective drain elevation was assumed to be $3.01 \mathrm{~m} \mathrm{(10} \mathrm{ft).}$

The estimated ranges in discharge fluxes for each of the eight discharge areas were discussed in Section 5.0 and are presented in Table 7-4. Table 7-4 also provides target flux ranges for each of the discharge areas. In some cases, the target flux range is narrower than the estimated range. The target ranges for those areas were decreased, based on either review of literature values or discussions with experts from the USGS in those specific areas and their most current estimates of ET rates. The ranges were narrowed when possible to help provide more realistic goals during model calibration. The target discharge value for each of the eight areas was presented in Table 7-2.

The first seven entries in Table 7-4 represent estimated evapotranspiration rates. The lower estimate for Indian Springs, the final entry in the table, represents a measured discharge rate at the spring (Winograd and Thordarson, 1975). Because ET estimates were not available for this discharge area, the upper estimate was calculated by increasing the spring discharge rate by 50 percent to incorporate effects of ET.

\subsubsection{Hydraulic Conductivity and Vertical Conductance Calculations}

The lateral and vertical distribution of the hydrostratigraphic units and their hydraulic conductivity values help determine flow patterns and rates; therefore, it is extremely important to 
Table 7-4

Estimated and Target Ranges

in Discharge Fluxes for Eight Discharge Areas

\begin{tabular}{||l|c|c||}
\hline \multicolumn{1}{|c|}{ Discharge Area } & $\begin{array}{c}\text { Estimated } \\
\text { Discharge Range } \\
\left(\mathrm{m}^{3} / \mathrm{d}\right)\end{array}$ & $\begin{array}{c}\text { Target } \\
\text { Discharge Range } \\
\left(\mathrm{m}^{3} / \mathrm{d}\right)\end{array}$ \\
\hline \hline Alkali Flat (or Peter's Playa) & $3,000-35,000$ & $5,000-7,300$ \\
\hline Amargosa River & $2,040-5,100$ & $2,040-5,100$ \\
\hline Ash Meadows & $67,000-101,400$ & $67,000-87,300$ \\
\hline Death Valley & $17,500-60,200$ & $17,500-60,100$ \\
\hline Franklin Lake/Alkali Flats & $14,200-42,600$ & $14,200-42,600$ \\
\hline Oasis Valley & $17,000-27,000$ & $17,000-27,000$ \\
\hline Penoyer Valley & $13,000-27,000$ & $13,000-27,000$ \\
\hline Indian Springs & $1,600-2,400$ & $1,600-2,400$ \\
\hline \hline
\end{tabular}

map or translate these values as accurately as possible from the geologic grid to the flow model grid. To accomplish this, several preprocessing programs were written. These programs, described in the Groundwater Flow Model Documentation Package (IT, 1996f, Appendix A) translate information on the 3-D distribution of HSUs and their hydraulic conductivities into transmissivity and vertical conductance values for each model cell.

\subsubsection{Hydraulic Conductivity Parameters}

The transmissivity is calculated at each cell on the uniform $2-\mathrm{km} \times 2-\mathrm{km}(1.2-\mathrm{mi} \times 1.2-\mathrm{mi})$ geologic grid for each model layer by summing the transmissivities of all hydrostratigraphic units present in the cell. The transmissivity of each HSU within the cell is calculated by integrating the product of the parameter, $K_{h}$ (the horizontal hydraulic conductivity projected to land surface), and the depth-decay function over the depth interval occupied by the HSU (Equation 5-1). This process results in some averaging of hydraulic conductivity values; however, model layer thicknesses were initially selected to represent the properties of hydrologically important HSUs as much as possible to minimize this effect.

A preprocessing program is used to translate and rotate the hydrologic grid relative to the geologic grid and to calculate values for the center of each active flow model cell using bilinear 
interpolation. In this manner, each active cell within the flow model was assigned a $K_{h}$ value in a form consistent with the input data format required by MODFLOW.

\subsubsection{Vertical Leakance}

Vertical flow between model layers is described by the vertical conductance which is the product of the vertical leakance (vcont parameter) of the cell and the cell area. The vcont value is calculated between the center of each cell in the current layer $(\mathrm{i}, \mathrm{j}, \mathrm{k})$ and the layer below it $(\mathrm{i}, \mathrm{j}, \mathrm{k}+1$, where the model layer increases with increasing depth). The vertical interval between the two nodes is composed of $n$ HSUs, with vertical hydraulic conductivities $K_{v 1}, K_{v 2} \ldots K_{v n}$ and thicknesses $\Delta \mathrm{z}_{1}, \Delta \mathrm{z}_{2} \ldots \Delta \mathrm{z}_{\mathrm{n}}$; vcont is then calculated from the following relationship:

$$
\operatorname{vcont}_{\mathrm{i}, \mathrm{j}, \mathrm{k}+1 / 2}=\frac{1}{\sum_{\mathrm{g}=1}^{\mathrm{n}} \frac{\Delta \mathrm{z}_{\mathrm{g}}}{\mathrm{K}_{\mathrm{vg}}}}
$$

Where:

$$
\begin{array}{lll}
\mathrm{g} & = & \text { HSU designator }[] ; \\
\mathrm{K}_{\mathrm{vg}} & = & \text { vertical hydraulic conductivity of HSU layer } \mathrm{g}[\mathrm{L} / \mathrm{T}] ; \text {; and } \\
\mathrm{i}, \mathrm{j}, \mathrm{k}+1 / 2 & = & \text { vertical interval between node } \\
&
\end{array}
$$

The vertical hydraulic conductivity, $K_{v g}$, is the product of the horizontal hydraulic conductivity value (determined by calculating the depth-corrected transmissivity of the HSU within the layer, as described above, and dividing by the HSU thickness) and the anisotropy ratio specified for each HSU. The anisotropy ratio is defined as the ratio of the vertical to horizontal hydraulic conductivities. The HSUs within the lower half of the current model layer and the upper half of the model layer below it are used to calculate vcont for the current layer. A more in-depth discussion and examples for the vcont calculation are included in the Groundwater Flow Model Documentation Package (IT, 1996f).

\subsection{Calibration Process}

Model calibration consists of iteratively adjusting various modeling parameters to develop an acceptable agreement between the model-related values and those values measured in the groundwater system. Modeling parameters are the model input values such as aquifer thickness, horizontal hydraulic conductivity projected to land surface $\left(K_{h}\right)$, and boundary conditions. 
Agreement is desired for values such as hydraulic head, boundary fluxes, and general flow direction. Steps taken to achieve calibration include the following tasks:

- Develop calibration criteria for the model.

- Assess the degree of agreement between simulated and measured water levels and boundary fluxes within an estimated range of uncertainty specified by the calibration criteria.

- Modify the hydraulic parameter values ( $K_{h}$, vertical anisotropy, and $\left.\lambda\right)$, the boundary conditions (recharge distribution, boundary heads, and Drain Package conductances), and the geologic model to achieve the calibration criteria.

The following text discusses the calibration procedure used for the regional flow model. The calibration was performed during three sequences. The initial model calibration sequence identified four geographic areas where changes to the digital geologic model were necessary to accurately simulate hydraulic head and flux distributions. The changes to the geologic model were summarized in Section 4.0. The revised geologic model was incorporated into the model during the second calibration sequence. An extensive peer review followed this calibration. The reviewers suggested, among other things, that the recharge dataset be reevaluated. This reevaluation concluded that the co-kriging process used in the earlier calibrations did not satisfactorily represent the distribution of precipitation in the northern part of the model area. A second precipitation dataset, based on older isohyetal maps of Nevada (Hardman, 1965) and on eastern California precipitation data included in a newer map by James (1993), was developed. The changes were used during the third and final calibration sequence. Sensitivity analyses were performed following the second and third model calibration sequences. Results of the sensitivity analyses were compared to the base cases for calibration sequences 2 and 3, termed "Base 2" and "Base 3," respectively.

\subsubsection{Development of Calibration Criteria}

The American Society for Testing Materials (ASTM) has identified several methods for evaluating the agreement between a model and the simulated flow system (ASTM, 1994). These procedures include qualitative and quantitative comparisons between model results and:

- Measured water levels

- Water-balance information (recharge and discharge fluxes)

- Flow-direction information

- Flow-system hydraulic parameters 
For the Nevada Test Site model, quantitative measures were designated to measure the goodnessof-fit between simulated and measured hydraulic heads. Quantitative measures were not calculated for the flux values, but the agreement between estimated and simulated fluxes was carefully monitored during calibration for each of the discharge and external boundary areas. Qualitative evaluations were used for the remaining two parameters since sufficient data were not available for the two parameters at the scale of the model to provide a constraint to model calibration.

\subsubsection{Target Hydraulic Heads}

One of the primary objectives of model calibration is to match simulated hydraulic heads calculated by the model with the measured, or target, hydraulic heads. A listing of the target heads is included in Appendix B. The list includes information on 928 wells or springs which fall within the model grid (797 of these wells fall within the active region of the model grid). The appendix also contains additional information necessary to calculate the statistical goodnessof-fit parameters for the calibration effort. As would be expected, some wells penetrate more than one model layer, and information on the completion interval is necessary for properly evaluating the goodness-of-fit.

Prior to beginning the calibration, the water-level database was evaluated to identify those measurements that were not representative of regional conditions. These data were not included in the material presented in this report. For example, water levels indicating perched conditions were flagged as not being representative. These included many springs at higher elevations in the northern part of the model area and in the Spring Mountains. Also excluded are measurements in NTS wells made during or shortly after drilling when it was questionable whether water levels had stabilized.

Additional measurements were eliminated from the set of target heads during the calibration process when inclusion of the measurement would bias the calibration process. For example, a well high in the Spring Mountains had a measured head of 2,454 m (8,051.6 ft), considerably higher than water levels at lower elevations. Neither the geologic nor hydrologic model was constructed to model the hydrology of the Spring Mountains because heads in this area would have little effect on predictions of transport from the weapons testing areas. Because of the high residual (measured minus simulated hydraulic head) associated with this high head, the mean residual and root mean square of the residuals would be greatly influenced by its inclusion in the target head database. As the calibration process was based, in part, on minimizing the mean and 
root mean square of the weighted head residuals, there would be a tendency to compensate for this high residual by simulating heads higher than present in the more important wells at lower elevations. To avoid this bias, the well was removed from the hydraulic head database. A similar decision to eliminate measurements from the target head database was made for five other wells. These wells are listed at the conclusion of Appendix B of the Groundwater Flow Model Documentation Package (IT, 1996f).

\subsubsection{Hydraulic Head Residuals}

There are several measures of fit that have been used in the modeling community. These are calculated, in part, from the head residual which is defined for this model as the difference between measured, or target, and model-calculated (simulated) hydraulic heads. A positive residual indicates that the model-calculated head is less than the measured value. The goals of calibration, with respect to water levels, are:

- Residual average close to zero

- Small residuals

- Normally distributed residuals, not spatially correlated

It is common to calculate weighted residuals, which consists of multiplying the residual by a weighting factor that is indicative of the reliability of the measurement. The greater the reliability of the measurement, the higher the weighting factor should be. The weighting factor was calculated as the inverse of the square root of the total variance associated with the mean value (in this case, hydraulic head) calculated for an observation point. For a low variance, the weighting factor is high, and the reliability of the mean target value will be high. The total variance was calculated as the sum of the variances associated with the elevation of the observation point, the variation in depth-to-water measurements (as discussed in Section 5.0), and the model error. The error associated with the model is difficult to quantify and is normally ignored. In this model, a model variance of $1 \mathrm{~m}^{2}\left(10.72 \mathrm{ft}^{2}\right)$ was used with the expectation that the model error is likely greater than this. For many wells, it was not possible to quantify the measurement variance because needed information was lacking. These measurements were assigned a variance of $100 \mathrm{~m}^{2}\left(1,072 \mathrm{ft}^{2}\right)$, which assumes that the combined error in the

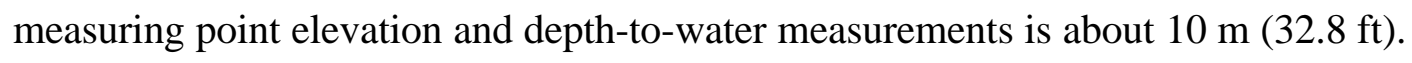

It should be noted that the model calculates hydraulic head values at the center of each grid cell, but the target wells are generally at locations other than the center of the cell. An interpolation routine from the code MODFLOWP (Hill, 1992) was used to calculate head values for the 
location of the well. Because the wells can extend over more than one model layer, the simulated head is calculated as the transmissivity-weighted average head for the layers the well penetrates. If the cell in which the measurement was made is dry, the hydraulic head in the layer below is used in calculating the residual.

There are many different ways to measure the goodness-of-fit between simulated and measured hydraulic heads. During model calibration, model fit was evaluated both by visual observation, and by evaluation of quantitative calibration criteria. Qualitative evaluation consisted of overlaying simulated heads and weighted residuals in a geographic information system (GIS) to identify locations of high residuals. Quantitative measures of the overall goodness-of-fit included generating the following items:

- Means of the weighted and nonweighted residuals for the overall model and for designated zones (described below) within the model

- Root-mean-square (RMS) of the weighted and nonweighted residuals for the overall model and for designated zones (described below) within the model

- Plots of measured versus simulated hydraulic head

\section{Delineation of Residual Zones}

Goodness-of-fit measures were developed for the overall model and were developed separately for 15 different areas, termed "residual zones," within the model. This approach allowed emphasis to be placed on the model characteristics expected to be important to solute transport from the testing areas. Each zone includes observation data from all model layers that fall within the zone. The 15 zones are shown in Figure 7-4, and the calibration goals for each of the zones are presented in Table 7-5. Areas such as the Spring Mountains and the area north of the NTS, while important with respect to the value of the groundwater resource in general, were thought to be less important with respect to solute transport than those areas within and downgradient from the testing areas. In addition, there are fewer subsurface data available for these areas; thus, the geologic model is correspondingly less well-defined. The goals are more stringent for the weapons testing areas and those areas downgradient from them. 
Table 7-5

Calibration Criteria for Weighted Hydraulic-Head Residuals by Zone

\begin{tabular}{|c|c|c|c|c|c|}
\hline \multirow{2}{*}{ Zone } & \multirow{2}{*}{$\begin{array}{c}\text { Residual Zone } \\
\text { Name }\end{array}$} & \multirow{2}{*}{$\begin{array}{c}\text { Residual Zone } \\
\text { Abbreviation }\end{array}$} & \multirow{2}{*}{$\begin{array}{c}\text { Mean } \\
\text { Weighted } \\
\text { Residual } \\
(\mathrm{m})\end{array}$} & \multirow{2}{*}{$\begin{array}{l}\text { Root Mean Square } \\
\text { of Weighted } \\
\text { Residuals } \\
(\mathrm{m})\end{array}$} & \multirow{2}{*}{$\begin{array}{c}\text { Range in } \\
\text { Measured Heads } \\
(\mathrm{m})\end{array}$} \\
\hline & & & & & \\
\hline & All & & 20 & 100 & 1687.4 \\
\hline 1 & Northern Area & NRTH & 100 & 150 & 202.7 \\
\hline 2 & Oasis Valley & OASI & 15 & 75 & 533.7 \\
\hline 3 & Pahute Mesa & PM & 25 & 35 & 230.7 \\
\hline 4 & Barrier & BARR & 300 & 350 & 565.3 \\
\hline 5 & W. Yucca Flat & WYF & 45 & 110 & 632.2 \\
\hline 6 & E. Yucca Flat & EYF & 35 & 80 & 101.3 \\
\hline 7 & Shoshone & SHON & 20 & 50 & 285.8 \\
\hline 8 & Death Valley & DV & 80 & 100 & 728.4 \\
\hline 9 & $\begin{array}{l}\text { Lower Carbonate } \\
\text { Aquifer }\end{array}$ & LCA & 5 & 40 & 205 \\
\hline 10 & $\begin{array}{l}\text { SW. of Pahranagat } \\
\text { Valley }\end{array}$ & PAHR & 40 & 40 & 15.3 \\
\hline 11 & Spring Mtn. & SPMT & 150 & 150 & 278.9 \\
\hline 12 & Sheep Range & SHRG & 100 & 100 & 39.9 \\
\hline 13 & Timber Mtn & TMBR & 100 & 100 & 220.7 \\
\hline 14 & Amargosa Farm & FARM & 10 & 50 & 58.3 \\
\hline 15 & Frenchman Flat & FF & 10 & 50 & 20.6 \\
\hline
\end{tabular}


The 15 zones and their abbreviations used in the corresponding tables and figures are defined as follows:

Zone 1: Northern Area (NRTH) - This zone consists of the area to the north of the Nevada Test Site and extends eastward to the high-gradient area east of Penoyer Valley. It includes several ranges where appreciable recharge occurs and high vertical gradients exist. The geologic model is not sufficiently complex in these areas to match these vertical gradients, and high residuals are expected and acceptable.

Zone 2: Oasis Valley (OASI) - This zone consists of the discharge area near Beatty and upgradient areas west of Timber Mountain. This area was delineated as a separate zone because of its importance as a possible downgradient receptor from the Pahute Mesa testing area.

Zone 3: Pahute Mesa (PM) - This area has been designated as a residual zone because it is a testing area from which radionuclide transport is of concern and because of the plan to perform more detailed modeling of this area. By calibrating the regional model to result in a "good fit" to hydraulic heads in this zone, subsequent development of the detailed model using the regional model for establishing boundary conditions will be more successful.

Zone 4: Belted Range Barrier (BARR) - This zone is a high-gradient area associated with the Lower Clastic Confining Unit northeast of the NTS. It has been designated as a residual zone because of the anticipated difficulty in accurately matching heads in this area. The important feature that needs to be simulated in the model is the existence of the high-gradient zone, rather than closely matching the individual head measurements.

Zone 5 and 6: Western Yucca Flat (WYF) and Eastern Yucca Flat (EYF) - The Yucca Flat testing area has been selected as an area of greater interest because it is also a testing area from which radionuclide transport is of concern. However, because Yucca Flat has higher heads in the western half (which is underlain by the Upper Clastic Confining Unit) than in the eastern half, it is divided into two separate zones. The Western Yucca Flat residual Zone is characterized by a wider range in heads and higher gradient than the Eastern Yucca Flat Zone.

Zone 7: Shoshone Mountain (SHON) - This zone, located west of Yucca Flat, is an area with relatively high water levels, presumably because of recharge in the area and the presence of the UCCU underlying the volcanic rocks. It is designated as a separate residual zone in order to prevent the heads in this area from affecting the residual statistics in Yucca Flat and Frenchman Flat.

Zone 8: Death Valley (DV) - This residual zone extends from the Amargosa Desert west of Death Valley Junction into Death Valley and includes the high-gradient area on the northeastern side of Death Valley. 
Zone 9: Lower Carbonate Aquifer (LCA) - This zone is underlain by the LCA and is generally characterized by low hydraulic gradients. It is the largest residual zone in the model, extending from the Amargosa Desert eastward to nearly the Sheep Range. This zone is separated from the Sheep Range, Spring Mountain, and Pahranagat Valley zones because of their higher gradient and from the Frenchman Flat zone because of its importance as an underground test area.

Zone 10: Southwest of Pahranagat Valley (PAHR) - This zone is east of the LCA residual zone and is characterized by shallower LCCU and higher hydraulic heads than in the LCA zone.

Zone 11: Spring Mountains (SPMT) - This zone covers the area south of and including the Las Vegas Valley Shear Zone. The heads in this area are higher than those to the north because of an apparent reduction in hydraulic conductivity associated with the shear zone.

Zone 12: Sheep Range (SHRG) - This zone is northeast of the Las Vegas Valley Shear Zone between the Sheep Range and the Spring Mountains. Because of the geometry of the LCCU and the high precipitation rate, the gradient within this zone is high.

Zone 13: Timber Mountain (TMBR) - The Timber Mountain zone lies between Pahute Mesa on the north and the high-gradient area north of Yucca Mountain and Jackass Flats to the south. The gradient within this zone is relatively low. It is separated from the Pahute Mesa zone because of its lower gradient and the occurrence of testing beneath Pahute Mesa.

Zone 14: Amargosa Farm Area (FARM) - This residual zone is in the northern part of the Amargosa Desert and contains a large number of target-head wells. It is defined as a separate zone within the LCA to keep the area from dominating the statistical measures for the LCA zone.

Zone 15: Frenchman Flat (FF) - The Frenchman Flat residual zone is separated from the LCA zone because of its importance as an underground test area and the plan to perform more detailed modeling of this underground test area.

\subsubsection{Fluxes}

The calibration procedure also compares computed fluxes with estimated and measured field fluxes. MODFLOW calculates the boundary fluxes for all individual flux boundary cells. Postprocessors were written to sum these fluxes for the eight internal discharge areas and the four external flux boundaries so that simulated flux values could be compared to the target flux ranges and flux values (Table 7-2). The calibration goal was to have the model-calculated fluxes fall within the target flux range as close as possible to the target value. 


\subsubsection{Hydraulic-Conductivity Zonations}

During the calibration process, it became clear that it would be necessary to subdivide some of the hydrostratigraphic units into several conductivity zones in order to achieve an acceptable calibration. Maps of the zones are presented in Figures 7-5 through 7-12, and a discussion of the zonations by HSU is presented below.

\section{Lower Carbonate Aquifer}

The Lower Carbonate Aquifer was separated into nine zones (Figure 7-5). Zone LCA(1) covers the eastern part of the NTS and the low gradient area to the east of the NTS. LCA(2) is a small area upgradient of the Ash Meadows discharge area which has been proposed as being very permeable based on the low gradients within this area and the high discharge at Ash Meadows (Winograd and Thordarson, 1975; Waddell, 1982). Winograd and Thordarson (1975) had also indicated that a barrier was present along the Las Vegas Valley Shear Zone (LVVSZ) (zone LCA(3)) on the basis of a high gradient developed across it near Indian Springs. Zone LCA(4) is beneath Jackass Flats, the Amargosa Desert, and Death Valley; model calibration indicates that a different transmissivity is needed here than in LCA(1). The zone covering the northern half of the model [LCA(5)] is defined to allow assignment of lower conductivities due to the greater shale content in the Paleozoic section in the northern part of the model. Another facies change occurs over a broad zone further to the west where there is a change to deep-water deposition. This latter facies change is represented in the geologic model by modeling the lower, more shaley, part of the lower carbonate section as LCCU. The sixth zone, LCA(6), represents the Spring Mountains south of the Las Vegas Valley Shear Zone where a lower hydraulic conductivity was needed to approximate heads in this area. However, there was no significant attempt to match water levels at higher elevations in the Spring Mountains, and the geologic model should be considered as approximate in this area. A seventh zone, $\operatorname{LCA}(7)$, is defined for the carbonate rock west of Timber Mountain so that sensitivity testing could be performed with respect to the presence of the LCA in this area. The eighth zone, $\operatorname{LCA}(8)$, is in the east central part of the model (Desert Valley) where there is an increase in gradient coincident with an increase in the shale content in the northeastern part of the model area, demonstrated by the Pilot and Chainman Shales. The ninth zone, $\operatorname{LCA}(9)$, is at the southeastern end of the Funeral Mountains. The properties of the LCA here have a significant impact on the simulated discharge in Death Valley. This area is zoned separately from Zone 4 to allow their independent adjustment. 


\section{Alluvial Aquifer}

The Alluvial Aquifer is divided into six zones (Figure 7-6). There are four zones (1, 4, 5, and 6) which represent coarser-grained alluvium and two (2 and 3) which represent finer-grained alluvium. The identification and distribution of the fine-grained vs. coarse-grained deposits were estimated from satellite imagery. Of the coarse-grained zones, Zone 1 represents all areas except for Zone 4 (Yucca Flat), Zone 5 (Frenchman Flat), and Zone 6 (Amargosa Desert). These are defined separately in order that sensitivity analyses could be performed for the respective areas. The fine-grained zones are divided into Zone 2 (Amargosa Desert and Death Valley) and Zone 3 (other areas). The responses noted during the calibration process indicate that Zone 2 primarily affects the rate of discharge at Ash Meadows and Alkali Flat, while Zone 3 affects the head gradient across the Las Vegas Valley Shear Zone.

\section{Timber Mountain Tuffs, Tuff Cone, Non-welded Tuffs, Welded Tuffs Above BCU, and Welded Tuffs}

The Timber Mountain Tuffs are zoned to allow for potential alteration effects on conductivity within the Timber Mountain and Black Mountain Calderas (Figure 7-7). TMA(1) comprises the extra-caldera tuffs. $\operatorname{TMA}(2), \operatorname{TMA}(3)$, and TMA(4) form approximately concentric cylinders with increasing radii from the center of the caldera. Zone 5 is in an area where TMA is absent, but the TC associated with the Claim Canyon caldera segment south of Timber Mountain is present. This zone $[\mathrm{TC}(5)]$ is altered in contrast to the TC that is present beneath Pahute Mesa [TC(1)]. A sixth zone surrounding Black Mountain has been added to account for alteration associated with heating during caldera formation. Hydrostratigraphic units TCB, TBA, BCU, and BAQ were rezoned identically to the TMA/TC in order to include the Black Mountain zonation.

\section{Volcanic Aquifer}

Three zones have been defined for the Volcanic Aquifer (Figure 7-8). VA(1) covers the southern part of the Nevada Test Site, and VA(2) covers Yucca Flat. The distinction was initially made to allow these two areas to be evaluated separately during the sensitivity analysis, but calibration results indicated that a slightly lower conductivity was necessary for VA(2) than VA(1) to improve the fit in Yucca Flat. A third zone beneath Crater Flat was defined to see if lower conductivities would result in higher simulated heads beneath Crater Flat. This approach was not successful, and the conductivities used in the current model for VA(3) are the same as those in Zone 2. 


\section{Lower Clastic Confining Unit}

The Lower Clastic Confining Unit has been divided into three zones (Figure 7-9). Zone 1 covers most of the LCCU. The LCCU beneath and near the Sheep Range is designated as Zone 2 so that a higher value of conductivity could be used to eliminate numerical problems associated with the steep gradient and large grid spacing there. A third zone is beneath and near the Amargosa Desert and Death Valley. Zone 3 was defined because adjusting the conductivity of the LCCU at Beatty affects the discharge rate in Oasis Valley and because of reported higher permeabilities encountered in a well drilled on the northeastern side of the Grapevine Mountains to monitor effects of water use at the Bullfrog Mine. This zone lies within the area affected by lateral shear related to Death Valley and Walker Lane tectonics; therefore, it may be more fractured than other areas of the LCCU as a result.

\section{Volcanic Confining Unit}

The Volcanic Confining Unit, which underlies an area from Yucca and Frenchman Flats westward beneath Crater Flat, has two zones defined (Figure 7-10). Nearly all of its occurrence is in Zone 1. Beneath Frenchman Flat, an interpretation of aeromagnetic data by the U.S. Geological Survey (Grauch and Hudson, 1995) indicates that the VCU is discontinuous along a northwestward trend through Frenchman Flat. Zone 2 has been defined to allow sensitivity analyses to be performed on particle movement beneath Frenchman Flat.

\section{Volcanics Undifferentiated}

The VU was separated into three zones (Figure 7-11). The first covers most of the model area. The second is coincident with Zone 6 for the TMA and TC to allow for inclusion of effects associated with Black Mountain. The third zone is the area between Pahute Mesa and Beatty to allow for better matching of heads in this area without impacting the model to the north.

\section{Tertiary Sediments/Death Valley Section}

Two different stratigraphic units have been combined in the TSDV hydrostratigraphic unit in the geologic model because they occur approximately at the same stratigraphic position and because they do not overlap. Zone 1 of TSDV comprises the Tertiary Sediments, while Zone 2 comprises the Death Valley sediments (Figure 7-12). 


\subsection{Flow Model Results and Sensitivity Analyses}

This section summarizes the calibrated groundwater flow modeling results including the distributions of areal recharge and hydraulic parameters, distributions of simulated hydraulic heads and corresponding residuals, and simulated fluxes. An overlay (Plate 4) that shows the study area general features in addition to the model boundary has been included to facilitate the following discussions on the areal recharge and potentiometric contour maps as well as the transmissivity and vertical leakance distribution maps. MODPATH particle-tracking results and sensitivity evaluations are also presented.

\subsubsection{Distribution of Recharge}

The final recharge coefficients used in the recharge model are shown in Table 7-6; the table also provides the Maxey-Eakin coefficients for comparative purposes. The corresponding recharge flux for the Nevada Test Site recharge model is $204,080 \mathrm{~m}^{3} / \mathrm{d}(60,396.6 \mathrm{ac}-\mathrm{ft} / \mathrm{y})$. It should be noted that this value is slightly different from that presented in Section 5.0 because the model grid boundary is an approximation of the hydrologic boundary within which the recharge flux was calculated. In Table 7-6, note that the lowest value below which precipitation is not projected to occur has been decreased from 20 to $16 \mathrm{~cm}$ (7.9 to $6.3 \mathrm{in}$.). This change was made to produce minor recharge in the higher areas of Yucca Flat, at Bullfrog Mountain, in the Wahmonie area, and the Funeral Mountains where perched water is present.

The model coefficients in Table 7-6 correspond to initial estimates of recharge used in the model $\left(191,000 \mathrm{~m}^{3} / \mathrm{d}[56,525.6 \mathrm{ac}-\mathrm{ft} / \mathrm{y}]\right)$; that estimate was later increased (to approximately $\left.204,000 \mathrm{~m}^{3} / \mathrm{d}[60,372.9 \mathrm{ac}-\mathrm{ft} / \mathrm{y}]\right)$ to account for larger estimated discharge fluxes in Oasis Valley and Ash Meadows. The larger flux was incorporated into the model by uniformly increasing the recharge at all model cells by a factor of 1.0678 , the ratio between the final and initial recharge estimates.

Figure 7-13 shows the distribution of recharge used in the model. Recharge primarily occurs in the northern mountains (Kawich, Reveille, and Quinn Canyon Ranges); the mountains immediately north and northwest of the NTS (Belted and Groom Ranges); Pahute Mesa, Shoshone Mountain, and Timber Mountain on the NTS; the Sheep Range to the east; and the Spring Mountains in the south. The effects of recharge redistribution from higher to lower elevations in and close to the NTS are apparent. For example, the recharge that is shown in the lower part of Fortymile Wash is due to this redistribution. 
Table 7-6

Comparison of Maxey-Eakin Coefficients and Coefficients Used in the Model

\begin{tabular}{||c|c||c|c||}
\hline \multicolumn{2}{|c||}{ Maxey-Eakin $^{\text {a }}$} & \multicolumn{2}{c||}{ Model } \\
\hline \hline $\begin{array}{c}\text { Precipitation } \\
(\mathrm{cm})\end{array}$ & $\begin{array}{c}\text { Maxey-Eakin } \\
\text { Coefficients } \\
(\%)\end{array}$ & $\begin{array}{c}\text { Precipitation } \\
(\mathrm{cm})\end{array}$ & $\begin{array}{c}\text { Coefficients } \\
\text { Used in Model } \\
(\%)\end{array}$ \\
\hline \hline$>50.8$ & 25 & $>50.8$ & 18 \\
\hline $38.1-50.8$ & 15 & $38.1-50.8$ & 11 \\
\hline $30.5-38.1$ & 7 & $30.5-38.1$ & 6 \\
\hline $20-30.5$ & 3 & $16-30.5$ & 1.5 \\
\hline$<20$ & 0 & $<16$ & 0 \\
\hline
\end{tabular}

a Source: Maxey and Eakin, 1949

\subsubsection{Hydraulic Parameters}

The final values for the hydraulic parameters included in the calibrated flow model for each model layer are presented in Table 7-7. For each hydrostratigraphic unit or zone within an HSU, there are three values that must be specified: the horizontal hydraulic conductivity projected to land surface $\left(K_{h}\right)$; the anisotropy ratio $\left(K_{\downarrow} / K_{h}\right)$, here defined as the vertical hydraulic conductivity divided by the horizontal hydraulic conductivity; and the exponential depth-decay parameter $(\lambda)$. The larger the $\lambda$ value, the more rapidly the hydraulic conductivity decreases with depth. When an HSU has been divided into different zones (e.g., the LCA), multiple sets of the three parameters are listed. The HSU descriptions and names are included in Table 4-3.

Figures 7-14, 7-15, and 7-16 compare the horizontal hydraulic conductivity values used in the model with conductivity values from aquifer tests for alluvium (AA), volcanic rocks, and carbonate rocks, respectively. The upper line for the AA (Figure 7-14) represents the zones $(1,4,5$, and 6$)$ of coarse-grained deposits. The next lower line is the zone of finer-grained sediments in the Amargosa Desert and Death Valley. The hydraulic conductivities for Zones 2 and 6 were well-constrained by the calibration, but a correlation between the hydraulic conductivity values for the AA and LCA units exists in this area. If a lower value were used for the LCA, a higher one would be needed for the Alluvial Aquifer. Additionally, the simulated heads and discharge rates are sensitive to the hydraulic conductivities of these two HSUs. 
Table 7-7

Final Hydraulic Parameters for the NTS Flow Model

(Page 1 of 2)

\begin{tabular}{|c|c|c|c|c|}
\hline $\begin{array}{l}\text { Model } \\
\text { Layer }\end{array}$ & $\begin{array}{c}\text { HSU \& } \\
\text { Zone No. }\end{array}$ & $\begin{array}{c}\boldsymbol{K}_{h} \\
(\mathrm{~m} / \mathrm{d})^{\mathrm{a}}\end{array}$ & $\begin{array}{l}\text { Anisotropy Ratio } \\
\left(K_{V} / K_{h}\right)^{\mathrm{b}}\end{array}$ & $\begin{array}{c}\text { Depth Decay } \\
\text { Parameter } \\
(\lambda)^{\mathrm{C}}\end{array}$ \\
\hline 20 & $\begin{array}{l}\text { AA } \\
\text { Zone 1,4,5,6 } \\
\text { Zone } 2 \\
\text { Zone 3 }\end{array}$ & $\begin{array}{l}11.0 \\
4.40 \\
0.01\end{array}$ & $\begin{array}{l}0.22 \\
0.16 \\
0.16\end{array}$ & $\begin{array}{l}0.0037 \\
0.0037 \\
0.0037\end{array}$ \\
\hline 19 & $\begin{array}{l}\text { TMA } \\
\text { Zone 1 } \\
\text { Zone } 2 \\
\text { Zone 3 } \\
\text { Zone 4 } \\
\text { Zone } 5 \\
\text { Zone 6 }\end{array}$ & $\begin{array}{l}35.0 \\
12.0 \\
16.0 \\
20.0 \\
1.20 \\
0.20\end{array}$ & $\begin{array}{l}0.08 \\
0.02 \\
0.02 \\
0.02 \\
0.02 \\
0.02\end{array}$ & $\begin{array}{l}0.0026 \\
0.0026 \\
0.0026 \\
0.0026 \\
0.0026 \\
0.0026\end{array}$ \\
\hline 18 & $\begin{array}{l}\text { TC } \\
\text { Zone 1 } \\
\text { Zone } 2 \\
\text { Zone 3 } \\
\text { Zone 4 } \\
\text { Zone 5 } \\
\text { Zone 6 }\end{array}$ & $\begin{array}{c}35.0 \\
12.0 \\
16.0 \\
20.0 \\
4.0 \\
0.20\end{array}$ & $\begin{array}{l}0.08 \\
0.02 \\
0.02 \\
0.02 \\
0.02 \\
0.02\end{array}$ & $\begin{array}{l}0.0026 \\
0.0026 \\
0.0026 \\
0.0026 \\
0.0026 \\
0.0026\end{array}$ \\
\hline 17 & $\begin{array}{l}\text { TCB } \\
\text { Zone 1 } \\
\text { Zones 2-5 } \\
\text { Zone } 6\end{array}$ & $\begin{array}{l}0.30 \\
0.03 \\
0.02\end{array}$ & $\begin{array}{l}0.02 \\
0.02 \\
0.02\end{array}$ & $\begin{array}{l}0.0026 \\
0.0026 \\
0.0026\end{array}$ \\
\hline 16 & $\begin{array}{l}\text { TBA } \\
\text { Zone 1 } \\
\text { Zones 2-5 } \\
\text { Zone } 6\end{array}$ & $\begin{array}{l}35.0 \\
2.0 \\
0.2\end{array}$ & $\begin{array}{l}0.02 \\
0.02 \\
0.02\end{array}$ & $\begin{array}{l}0.0026 \\
0.0026 \\
0.0026\end{array}$ \\
\hline 15 & $\begin{array}{l}\text { BCU } \\
\text { Zones 1-5 } \\
\text { Zone } 6\end{array}$ & $\begin{array}{l}0.3 \\
0.2\end{array}$ & $\begin{array}{l}0.02 \\
0.02\end{array}$ & $\begin{array}{l}0.0026 \\
0.0026\end{array}$ \\
\hline 14 & $\begin{array}{l}\text { BAQ } \\
\text { Zone 1 } \\
\text { Zones 2-5 } \\
\text { Zone } 6\end{array}$ & $\begin{array}{l}35.0 \\
2.0 \\
0.2\end{array}$ & $\begin{array}{l}0.02 \\
0.02 \\
0.02\end{array}$ & $\begin{array}{l}0.0026 \\
0.0026 \\
0.0026\end{array}$ \\
\hline 13 & $\begin{array}{l}\text { VA } \\
\text { Zone } 1 \\
\text { Zone } 2 \\
\text { Zone } 3\end{array}$ & $\begin{array}{l}2.0 \\
1.0 \\
8.0\end{array}$ & $\begin{array}{l}0.02 \\
0.02 \\
0.02\end{array}$ & $\begin{array}{l}0.0026 \\
0.0026 \\
0.0026\end{array}$ \\
\hline 12 & $\begin{array}{l}\text { VCU } \\
\text { Zones } 1,2\end{array}$ & 0.12 & 0.02 & 0.0026 \\
\hline
\end{tabular}


Table 7-7

Final Hydraulic Parameters for the NTS Flow Model

(Page 2 of 2)

\begin{tabular}{|c|c|c|c|c|}
\hline $\begin{array}{l}\text { Model } \\
\text { Layer }\end{array}$ & $\begin{array}{c}\text { HSU \& } \\
\text { Zone No. }\end{array}$ & $\begin{array}{c}K_{h} \\
(\mathrm{~m} / \mathrm{d})^{\mathrm{a}}\end{array}$ & $\begin{array}{c}\text { Anisotropy Ratio } \\
\left(K_{V} / K_{h}\right)^{\mathrm{b}}\end{array}$ & $\begin{array}{c}\text { Depth Decay } \\
\text { Parameter } \\
(\lambda)^{\mathrm{C}}\end{array}$ \\
\hline 11 & $\begin{array}{l}\text { VU } \\
\text { Zone } 194 \\
\text { Zone } 2 \\
\text { Zone } 3\end{array}$ & $\begin{array}{l}1.5 \\
0.2 \\
0.4\end{array}$ & $\begin{array}{l}0.02 \\
0.02 \\
0.02\end{array}$ & $\begin{array}{l}0.0026 \\
0.0026 \\
0.0026\end{array}$ \\
\hline 10 & $\begin{array}{l}\text { TSDVS } \\
\text { Zone } 1 \\
\text { Zone } 2\end{array}$ & $\begin{array}{l}0.50 \\
0.02\end{array}$ & $\begin{array}{l}0.02 \\
0.02\end{array}$ & $\begin{array}{l}0.004 \\
0.004\end{array}$ \\
\hline 9 & LCA3 & 0.1 & 0.02 & 0.001 \\
\hline 8 & UCCU & 0.002 & 0.02 & 0.0015 \\
\hline $7,5,3$ & $\begin{array}{l}\text { LCA } \\
\text { Zone 1,2 } \\
\text { Zone } 3 \\
\text { Zone } 4 \\
\text { Zone 5,8 } \\
\text { Zone 6 } 6 \\
\text { Zone } 7 \\
\text { Zone } 9\end{array}$ & $\begin{array}{l}110 . \\
0.01 \\
8.0 \\
0.8 \\
0.4 \\
2.0 \\
5.0\end{array}$ & $\begin{array}{l}0.015 \\
0.015 \\
0.015 \\
0.015 \\
0.015 \\
0.020 \\
0.015\end{array}$ & $\begin{array}{l}0.0010 \\
0.0010 \\
0.0010 \\
0.0010 \\
0.0010 \\
0.0026 \\
0.0010\end{array}$ \\
\hline 6 & $\begin{array}{l}\text { LCCU } \\
\text { Zone } 1 \\
\text { Zone } 2 \\
\text { Zone } 3\end{array}$ & $\begin{array}{l}0.02 \\
0.20 \\
0.10\end{array}$ & $\begin{array}{l}0.15 \\
0.15 \\
0.15\end{array}$ & $\begin{array}{l}0.0012 \\
0.0012 \\
0.0012\end{array}$ \\
\hline 4,2 & $\begin{array}{l}\text { LCCU1 } \\
\text { Zone } 1 \\
\text { Zone } 2 \\
\text { Zone } 3\end{array}$ & $\begin{array}{l}0.02 \\
0.20 \\
0.10\end{array}$ & $\begin{array}{l}0.15 \\
0.15 \\
0.15\end{array}$ & $\begin{array}{l}0.0015 \\
0.0012 \\
0.0012\end{array}$ \\
\hline 1 & 1 & 0.001 & 0.5 & 0.0015 \\
\hline
\end{tabular}

${ }_{\mathrm{b}}^{\mathrm{a}}$ Meters per day

b The parameter $K_{h}$ is the horizontal hydraulic conductivity that is projected to occur at the land surface, or a depth of zero.

The parameter $K_{v}$ is the vertical hydraulic conductivity that is projected to occur at the land surface, or a depth of zero.

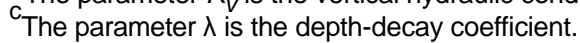


Higher values of hydraulic conductivity have been measured for the Alluvial Aquifer than were used in the calibrated model. The effects of using higher values of $K_{h}$ for Yucca and Frenchman Flat Zones 4 and 5, which are not as constrained by the calibration, were investigated through sensitivity analysis and are discussed below. The two lower lines in Figure 7-14 represent areas of low conductivities due to the formation of spring deposits. The values used in the model are consistent with values found in the reference literature for fine-grained sediments.

Figure 7-15 shows the comparison between measured and model hydraulic conductivity vs. depth for volcanic rocks. The lines represent the minimum and maximum values for both the volcanic aquifers and confining units represented in the model. The lines fit nicely within the measurements, but there are many measurements with higher conductivities than were used in the model. The maximum $K_{h}$ value (horizontal hydraulic conductivity projected to land surface) of $35 \mathrm{~m} / \mathrm{d}(114.8 \mathrm{ft} / \mathrm{d})$ was derived through calibration. Because of the paucity of data on conductivities for different volcanic aquifers, this value was assigned to all volcanic aquifers within the Timber Mountain/ Pahute Mesa area for consistency. Higher $K_{h}$ values could have been assigned to individual units locally without significantly affecting regional model results; however, increasing $K_{h}$ values for all of the volcanic aquifers in the western part of the NTS resulted in a significantly poorer model fit based on hydraulic head and flux residuals. There are several possible reasons for the differences between the high sample hydraulic conductivity measurements and the model values. These include:

- The aquifer-test results represent local effects rather than regional properties. The thickness of the volcanic units and the corresponding degree of welding and fracturing are greatly affected by pre-eruption topography and are, therefore, highly variable. Further, the conductivity measured in an aquifer test is greatly affected by the properties of fractures intercepted by the borehole, especially when the water level changes are measured in the stressed well. Thus, it would be expected that there would be many tests with higher conductivities than the regional average.

- The modeling results do not incorporate local barrier effects due to the presence of faults. Detailed mapping of hydrologic heads on Pahute Mesa suggests that faults may be barriers to flow in some areas. Moderately high gradients exist from one faultbounded block to another, and this is not incorporated in the regional model. The model-determined properties would then account for these barriers, resulting in lower simulated values for conductivity in comparison to those provided by aquifer tests.

The lines for the volcanic confining units in Figure 7-15 represent rocks that are nonwelded or that have been altered. 
The comparison for the LCA is presented in Figure 7-16; the lines for each of the nine LCA zones are displayed. The lines for LCA(1) and (2) are at the upper end of the range in measured values. Zone 2 is upgradient from Ash Meadows and is believed to be quite permeable as indicated by the very low gradient through this area and the high discharge rate at Ash Meadows. The measurements plotted at depths less than $200 \mathrm{~m}(656.2 \mathrm{ft})$ are from the tracer site located south of Point of Rocks within this zone, so there is supporting evidence for the high conductivity of Zone LCA(2). The remaining lines are consistent with the data. The values used for $\operatorname{LCA}(6)$ and LCA(3) in the model produced reasonable agreement with measured hydraulic head values, but the only basis for the value for $\operatorname{LCA}(3)$ was the need to simulate the observed gradient along the shear zone; this value is lower than occurs in the field. LCA Zones 5 and 8 were initially assigned different values of $K_{h}$; however, the model fit was not improved, and the two zones were reassigned the same values. Their values are the lowest of the LCA zones with the exceptions of Zones 3 and 6. Zone 7 is the zone west of Timber Mountain where the presence of LCA was predicted on the basis of an outcrop of Ordovician age. However, interpretations of gravity data suggest that the pre-Tertiary rocks are shallower than portrayed in the geologic model. Therefore, this zone was given properties similar to volcanic HSUs in the area as can be seen by the greater slope on the line.

As an example of the hydraulic parameter values included in the calibrated model, the HSU, transmissivity, and vcont (vertical leakance, defined in Section 7.3.4.2 and Equation 7-2) distributions for Model Layer 8 are shown in Figures 7-17 to 7-19, respectively. The structure of the geologic model, combined with the hydrologic properties of the HSUs, is apparent in the figures. The Lower Carbonate Aquifer is present in the southeastern part of the model, extending up into Yucca Flat. The LCA, readily apparent on the eastern side of the flat, is bounded to the west by the Upper Clastic Confining Unit which is, in turn, flanked to the west by the Lower Clastic Confining Unit and volcanics. The presence of the LCCU in this area is associated with thrusting along the Belted Range Thrust. The structural outline of the lower-conductivity volcanics associated with the Timber Mountain Aquifer and the Tuff Cone to the south of this aquifer is apparent.

The transmissivity and vcont figures show the logarithm (base 10) of the values used in the model. Although transmissivity and vcont data are calculated everywhere on the hydrologic grids, the figures only show values for those cells that remained active after the model had converged. If the water table is below the bottom of a cell, no value is shown. Thus, the figures also portray the distribution of active, wet cells in the converged model. 
Figures for the HSU, transmissivity, and vcont distributions for each of the model layers are included in the Groundwater Flow Model Documentation Package (IT, 1996f, Appendices D, E, and $\mathrm{F}$, respectively).

\subsubsection{Hydraulic-Head and Residual Distributions}

Simulated hydraulic head distributions and the corresponding residual hydraulic heads are presented in Appendix B of this report and are discussed in the following text.

\subsubsection{Hydraulic-Head Distributions}

Figure 7-20 is a map of the simulated water table for the calibrated model. This map was assembled by constructing an array of hydraulic heads where each entry in the array is the calculated head in the uppermost model layer that is active for each cell. In Figure 7-20, a steep gradient is present on the eastern side of Death Valley, caused by the Lower Clastic Confining Unit in the Funeral Range and the Tertiary Sediment/Death Valley Section in the Greenwater Range (see Plate 4). The Franklin Lake playa, also known as Alkali Flat, is present along the southern edge of the model. The playa provides a place for water to exit the model, and the 650-m (2,132.7-ft) contour line shows convergence of flow to this area. A low hydraulic gradient is present in the areas underlain by LCA(1) and LCA(2) and the western portions of LCA(4) and LCA(9) (Figure 7-5) with the exception of western Yucca Flat. In this area, the LCA(1) underlies the Upper Clastic Confining Unit which creates a higher water table because of its low conductivity and a much steeper gradient.

A steep gradient is also present along the Las Vegas Valley Shear Zone, a result of the lower conductivity used for LCA(3) and AA(2). South of the shear zone, heads rise because of the recharge in the Spring Mountains and the lower conductivity value used for LCA(6). The area in the western part of the Spring Mountains with a very high gradient has LCCU exposed at the surface. A high gradient is needed to transmit the water that is recharged in the model. In the field, this water probably travels as surface flow until encountering higher conductivity rocks.

A steeper gradient is also developed across the Desert Range because the LCCU is shallow along its axis as well as in the Sheep Range because of shallow LCCU and local recharge. The simulated hydraulic heads in this area are not reliable, but the estimated volume of recharge in the Sheep Range is incorporated accurately in the model. 
North of the junction of the Desert Range and the Pintwater Range, the hydraulic heads rise above $800 \mathrm{~m}(2,624.8 \mathrm{ft})$. This gradient is caused by the lower conductivity associated with LCA(8). There is a "ramp" in hydraulic heads as they increase to above 1,400 m $(4,593.4 \mathrm{ft})$ near Penoyer Valley. To the west of the ramp is a steep gradient caused by the LCCU underlying the Groom Range in addition to a local recharge mound at the northern end of the Groom Range.

The Nevada Test Site area is divided into three zones. The Lower Carbonate Aquifer underlies the first zone which is distinguished by the low hydraulic gradient present beneath eastern Yucca Flat, Frenchman Flat, Jackass Flats, and the Mercury area. This zone is separated from a second zone (which consists predominantly of volcanic rocks in the northwestern part of the NTS) by a third zone consisting of a pronounced high-gradient area that borders Yucca Flat on the east and west and curves around until it is oriented approximately east-west beneath Calico Hills and northern Yucca Mountain.

The high gradient east of Yucca Flat is caused by the structurally high Lower Clastic Confining Unit that borders northeastern Yucca Flat. The LCCU is also structurally high west of Yucca Flat (west of the trace of the Belted Range Thrust), but is located further west than the eastern margin of the high-gradient area. The higher water levels beneath western Yucca Flat are caused by the presence of the Upper Clastic Confining Unit which, in turn, causes a high vertical gradient between the rocks which overlie it and the underlying Lower Carbonate Aquifer. The overlying units include LCA3, several volcanic HSUs, and AA. The LCA3 is believed to consist of several isolated blocks of both pre- and post-Mississippian carbonate rocks; however, it is simulated as a single block within the model. When the LCA3 was assigned conductivity values that are representative of carbonate rocks, the water levels in western Yucca Flat dropped significantly. The calibrated model required a value much lower than expected for carbonate rock. This suggests that the LCA3 is not as well-connected as represented in the digital geologic model.

The high gradient across Calico Hills, northern Yucca Mountain, and northern Crater Flat is due to a combination of factors. The LCCU is uplifted north of the Belted Range Thrust, which prevents easy flow from the volcanic rocks southward into the LCA that underlies the UCCU to the south of the thrust fault. Second, the UCCU is structurally high in Calico Hills and in the northern part of Bare Mountain, helping to provide the barrier. Third, the volcanic rocks in the Claim Canyon caldera segment north of Yucca Mountain and in the northern part of Yucca 
Mountain have been altered and, thus, have a lower hydraulic conductivity than the volcanic rocks further to the south.

The Timber Mountain area has a lower hydraulic gradient than is present farther to the north beneath Pahute Mesa. There are two factors in the model which create this. Moderate conductivity values were assigned to the thick sequence of volcanic rocks in the Timber Mountain area in contrast to the inclusion of structurally offset interbedded units of both higher and lower hydraulic conductivity values in Pahute Mesa. The second factor is the recharge occurring at Timber Mountain, which reduces the gradient on the northern side of Timber Mountain.

Beneath Pahute Mesa, the hydraulic gradient indicates that flow is generally to the southwest. To the west of the mesa, the model hydraulic conductivity values in Black Mountain are approximately two orders of magnitude lower than those of the volcanic aquifers present beneath the Pahute Mesa testing area. This zonation resulted in higher simulated heads west of the Boxcar Fault and the development of the potentiometric trough within Area 20. It is yet not known whether or not this hypothesis is the correct explanation for the observed water levels.

The area north of the Nevada Test Site has moderate gradients with local divides due to recharge along the Kawich Range and the northern part of the Quinn Canyon Range. These divides are in agreement with the potentiometric map presented in Plate 3. The discharge area at Penoyer Valley is evident by the bend in the $1,450 \mathrm{~m}(4,757.5 \mathrm{ft})$ contour line that indicates flow into the discharge area from the south, west and north.

The hydraulic head distribution maps for Model Layers 5, 7, and 14 are reproduced in Figures 7-21, 7-22, and 7-23, respectively. Hydraulic-head contours are not drawn in areas where there are no active cells (e.g., where the bottoms of the cells are above the simulated water table). The contour plots include posting of all target well locations that fall within the active model domain. Single-layer and multiple-layer wells are identified with separate symbols on the plots. The measured hydraulic head value in each multiple-layer observation well is posted on each of the model layers over which the well is open. In areas with a dense population of points, only selected heads have been posted to minimize overprinting of data values. 
In Figure 7-21 (Model Layer 5, elevation range 1,050 to 1,200 $\mathrm{m}$ [3,445.1 to 3,937.2 ft]), the area north and west of the NTS is saturated. Effects of recharge are noted in the Kawich Range 1,500-m contour (4,921.5 ft), beneath Shoshone Mountain, in the Sheep Range, and in the Spring Mountains. To the west of Shoshone Mountain and north of Oasis Valley, the observed low hydraulic gradient (Plate 3) is apparent. The discharge in Oasis Valley is reflected in the contour lines in this layer. To the northeast of the NTS, the structural high present in the LCCU within the Groom Range is evident. Along the perimeter of Yucca Flat, the steep hydraulic gradient is apparent on the western side, but not to the north.

By Layer 7 (Figure 7-22), which includes the elevation range from 700 to $900 \mathrm{~m}$ (2,296.7 to 2,952.9 ft), many additional features are present. A steep gradient is present in the Sheep Range; this is caused by the Lower Clastic Confining Unit rising steeply from the valley west of the range to near the crest of the range over a short distance. A low gradient is present from Amargosa Desert eastward to Indian Springs Valley, a result of the high transmissivity in LCA Zones 1, 2, and 4 (Figure 7-5). Along the eastern edge of the model, the contours increase from south to north, varying from $750 \mathrm{~m}(2,460.8 \mathrm{ft})$ just west of Pahranagat Valley to more than $1,400 \mathrm{~m}(4,593.4 \mathrm{ft})$ in the north; this is a result of the lower conductivity assigned to LCA Zone 8. The low conductivity, needed to develop the gradient so that simulated heads would be high enough in Penoyer Valley and in the areas to the west of the Pahranagat and Sheep Ranges, is consistent with an increase in the shale content in the northeastern part of the model area. The effect of the zonation along the Las Vegas Valley Shear Zone (LCA Zone 3) is apparent in the $750-\mathrm{m}(2,460.8-\mathrm{ft})$ contour line, causing it to be oriented nearly east-west to the north of the Spring Mountains.

On the Nevada Test Site, several features are noteworthy. A low gradient associated with the LCA exists in the southern part of the NTS, extending up into the eastern part of Yucca Flat. The steep hydraulic gradient to the north of Yucca Flat is now well-developed. The steep gradient existing on the western part of Yucca Flat and westward toward the southeastern corner of Rainier Mesa is caused by the presence of the Upper Clastic Confining Unit which also creates a high vertical gradient between this layer and lower layers. The effect of recharge in Shoshone Mountain is still apparent. The high gradients to the south and southwest of the caldera complex, north of Yucca Mountain, are due to the presence of the Lower Clastic Confining Unit and low-conductivity volcanic units. In the Yucca Mountain area, the high measured head of $1,031 \mathrm{~m}(3,382.7 \mathrm{ft})$ is not well-matched because of the steep gradient, but the high gradient itself 
is well-defined, and the water level in Well UE-29a\#2 in Fortymile Canyon north of the gradient is well-matched (Appendix B).

In Model Layer 14 (Figure 7-23), the shelf caused by the UCCU is gone, and the low gradient area associated with the LCA beneath Yucca Flat is present farther to the west. The high gradient into Death Valley is well-defined, and an upward gradient is present below Franklin Lake. At Yucca Mountain, a downward gradient is modeled; the 750-m (2,460.8-ft) contour line is farther north in Layer 14 than it is in Layer 7. However, water-level data from USW-H1 (Appendix B) indicate that an upward gradient exists (Lobmeyer et al., 1995). The eastward gradient across the proposed repository block is also not present in the modeling results. Thus, the general features of the groundwater system near Yucca Mountain are modeled, but the detailed features are not.

The simulated hydraulic head distribution maps for the 20 model layers, including posted target head values, are included in Appendix G of the Groundwater Flow Model Documentation Package (IT, 1996f).

The simulated heads for the calibrated model are plotted against observed heads in Figure 7-24. The group of heads in the lower section of the graph represent Death Valley data. Following the line upward, the tight grouping of points represent data from the Amargosa farm area. The remainder of the line represents points from increasingly upgradient locations. Examination of the figure indicates that the fit of the model to measured data is very good.

\subsubsection{Head Residual Distributions by Zone}

One of the primary goals of calibration is to minimize weighted residuals in the areas of interest and to produce as small residuals as possible in the remaining areas. As explained in Section 7.4.1.2, simulated heads were interpolated from the centroid of each model cell to the target well location within the cell for each model layer in which the well is completed. The interpolated heads in each model layer were then used to calculate a single, transmissivityweighted average head for the layers that the well penetrates. The residual was calculated as measured minus the simulated, transmissivity-weighted average head. Finally, the weighted residual was calculated by dividing the residual by the square root of the total variance for that observation. 
Quantification of the calibration criteria included minimizing the weighted means and the Root Mean Square in each of the fifteen residual zones. The weighted and nonweighted means and RMSs by zone are provided in Table 7-8. It should be noted that the RMS will be larger than the standard deviation unless the mean-weighted residual is zero. The table also provides the range in measured heads observed within each residual zone. Normalized weighted and nonweighted means and RMSs can be calculated by dividing the zone parameters by the respective range in heads.

The following discussion includes statements that the measured hydraulic heads within a residual zone are either higher or lower than simulated hydraulic heads, based on whether the mean of the weighted residuals is positive or negative. It should be emphasized that there are both positive and negative residuals within each zone.

The mean-weighted residual for the 792 target heads is $7.9 \mathrm{~m}(25.9 \mathrm{ft})$. This is 0.47 percent of the range in measured heads, which indicates that, overall, the model provides an excellent approximation of regional hydraulic heads. The weighted root mean square of the residuals is $51.3 \mathrm{~m}(168.3 \mathrm{ft})$, which is approximately three percent of the range in measured heads. The highest mean-weighted residual occurs in the Barrier Zone which includes the high hydraulic gradient associated with the Lower Clastic Confining Unit. This zone was defined specifically because of the anticipated difficulty in matching heads in this area, and higher residuals are, therefore, not considered problematic. The Sheep Range Zone also has a high mean-weighted residual. Heads in this zone can not be considered reliable because of the zonation of the LCCU in this area to minimize convergence problems.

Observed hydraulic heads in the Northern Area Zone are slightly higher than simulated heads, possibly due to perched zones or the lack of detail in the geologic model. However, given the degree of refinement in the geologic model in this area, the fit to measured data is good. The remaining zones that are upgradient and distal from areas of interest, southwest of Pahranagat Valley Zone and Spring Mountains Zone, have satisfactory fits to measured data.

Mean residuals and RMS values within the LCA and Amargosa Farm Area are low, indicating a good fit to observed data within the regional carbonate aquifer. These values are also low for the Death Valley Zone, given the range in measured heads, which indicates that the geometry of the hydraulic barrier between Death Valley and the Amargosa Desert across the Funeral Mountains is reasonably well-defined. 
Table 7-8

Summary Statistics for Hydraulic-Head Residuals by Zone

\begin{tabular}{|c|c|c|c|c|c|c|c|c|}
\hline Zone & Area & Abbreviation & $\begin{array}{l}\text { Number of } \\
\text { Observations }\end{array}$ & $\begin{array}{c}\text { Mean } \\
\text { Residual } \\
(\mathrm{m})\end{array}$ & $\begin{array}{l}\text { RMS of } \\
\text { Residuals } \\
\text { (m) }\end{array}$ & $\begin{array}{c}\text { Mean } \\
\text { Weighted } \\
\text { Residual } \\
(\mathrm{m})\end{array}$ & $\begin{array}{l}\text { RMS of } \\
\text { Weighted } \\
\text { Residuals } \\
\text { (m) }\end{array}$ & $\begin{array}{l}\text { Range in } \\
\text { Measured } \\
\text { Heads } \\
\text { (m) }\end{array}$ \\
\hline & All & & 792 & 8.5 & 50.3 & 7.9 & 51.3 & 1687.4 \\
\hline 1 & Northern Area & NRTH & 61 & -6.5 & 38.8 & 5.8 & 42.9 & 202.7 \\
\hline 2 & Oasis Valley & OASI & 81 & 43.8 & 82.4 & 38.3 & 72.2 & 533.7 \\
\hline 3 & Pahute Mesa & PM & 83 & -10.2 & 37.3 & -5.8 & 35.7 & 230.7 \\
\hline 4 & Barrier & BARR & 13 & 147.4 & 181.5 & 107.2 & 146.8 & 565.3 \\
\hline 5 & W. Yucca Flat & WYF & 24 & 40.4 & 129.0 & 70.4 & 139.5 & 632.2 \\
\hline 6 & E. Yucca Flat & EYF & 91 & -1.1 & 21.5 & 1.3 & 22.9 & 101.3 \\
\hline 7 & Shoshone & SHON & 6 & 21.3 & 83.1 & 21.7 & 80.5 & 285.8 \\
\hline 8 & Death Valley & DV & 25 & 17.1 & 48.6 & 22.9 & 41.0 & 728.4 \\
\hline 9 & $\begin{array}{l}\text { Lower Carbonate } \\
\text { Aquifer }\end{array}$ & LCA & 213 & -1.0 & 19.7 & -7.3 & 28.8 & 205.0 \\
\hline 10 & $\begin{array}{l}\text { SW. of } \\
\text { Pahranagat Valley }\end{array}$ & PAHR & 5 & -11.3 & 12.9 & -9.9 & 11.4 & 15.3 \\
\hline 11 & Spring Mountains & SPMT & 23 & -7.3 & 47.2 & -1.7 & 53.3 & 278.9 \\
\hline 12 & Sheep Range & SHRG & 4 & 61.2 & 67.1 & 49.3 & 47.3 & 39.9 \\
\hline 13 & Timber Mountain & TMBR & 7 & 8.7 & 47.0 & 6.7 & 61.0 & 220.7 \\
\hline 14 & $\begin{array}{l}\text { Amargosa Farm } \\
\text { Area }\end{array}$ & FARM & 139 & 6.5 & 10.1 & 6.3 & 9.0 & 58.3 \\
\hline 15 & Frenchman Flat & $\mathrm{FF}$ & 16 & 0.7 & 4.9 & 0.8 & 5.2 & 20.6 \\
\hline
\end{tabular}

Note: Zones are shown in Figure 7-4.

The remaining seven zones (Oasis Valley, Pahute Mesa, Shoshone, Timber Mountain, Frenchman Flat, Western Yucca Flat, and Eastern Yucca Flat) are all within or immediately downgradient of underground nuclear testing locations. The model provides good-to-excellent fits for the Oasis Valley, Pahute Mesa, Shoshone Mountain, Timber Mountain, and Frenchman Flat Zones. Simulated hydraulic heads in the Oasis Valley Zone are, on average, lower than measured heads. The area where most of the mismatch occurs is on the northern side of the Grapevine Mountains and at Bullfrog Mountain where simulated water levels are too low. Within and upgradient of the Oasis Valley discharge area within the valley, the match is 
considerably better. Within the Timber Mountain Zone, the greatest mismatch is on the northeastern side of the caldera at WW8 and TW-1, where simulated heads are lower than measured ones. Agreement at the remaining five locations is much better. The fit in Frenchman Flat is excellent.

Western Yucca Flat has a high mean-weighted residual. It is adjoined by the eastern Yucca Flat Zone, which has a small mean-weighted residual. The WYF zone is structurally very complex, and high lateral and vertical hydraulic gradients are present. Because of the geologic complexity and the high gradients, heads are not easy to match in this area. The model was specifically calibrated to produce a mean-weighted residual for EYF near zero because of the importance of the flow paths from Yucca Flat southward into Frenchman Flat; however, this resulted in higher residuals in WYF as well as numerical instability in the high vertical gradient areas in the WYF and SHON residual zones. The instability is related to rewetting of model cells during the iterative process of solving the model equations. If higher residuals had been acceptable in EYF, the mean-weighted residual in WYF would have been lower, and the solution would have been more stable in the WYF and SHON residual zones. The particle-tracking results for a particle starting at Shoshone Mountain were very sensitive to this instability, but those for other particles were not.

\subsubsection{Boundary Flux Rates}

The hydraulic head values specified for the GHB (Pahrump Valley and Eagle Mountain) and Well Package (Pahranagat Valley and Sarcobatus Flat) boundary conditions for the calibrated model are provided in Table 7-9. The GHB heads assume no vertical gradient along the boundary, and the head values are consistent with the data provided in Plate 3. The elevations and conductances included in the Drain Package for the calibrated model are provided in the Groundwater Flow Model Documentation Package (IT, 1996f, Appendix C).

\section{Table 7-9}

\section{Hydraulic Head Values used in the GHB and Well Packages}

\begin{tabular}{||l|c||}
\hline \multicolumn{1}{|c|}{ Boundary Area } & $\begin{array}{c}\text { Boundary } \\
\text { Head }(\mathrm{m})\end{array}$ \\
\hline \hline Pahranagat Valley & 965.0 \\
\hline Sarcobatus Flat & 1215.0 \\
\hline Pahrump Valley & 775.0 \\
\hline Eagle Mountain & 599.0 \\
\hline
\end{tabular}


The model-calculated flux values associated with the four external model boundaries (GHB and Well Packages) and the eight surface-water discharge boundaries (Drain Package) are provided in Table 7-10. Positive values indicate flux into the model by underflow across model boundaries, while negative values indicate flux out of the model due to spring discharge/evapotranspiration or underflow.

Table 7-10

Comparison of Target and Simulated Boundary Fluxes

\begin{tabular}{||l|c|c|c||}
\hline \multicolumn{1}{|c|}{$\begin{array}{c}\text { Underflow or Discharge } \\
\text { Area }\end{array}$} & \multicolumn{1}{|c|}{$\begin{array}{c}\text { Target Flux } \\
\text { Range } \\
\left(\mathrm{m}^{3} / \mathrm{d}\right)\end{array}$} & $\begin{array}{c}\text { Target Flux Rate } \\
\left(\mathrm{m}^{3} / \mathrm{d}\right)\end{array}$ & $\begin{array}{c}\text { Simulated Rate } \\
\left(\mathrm{m}^{3} / \mathrm{d}\right)\end{array}$ \\
\hline \hline Pahranagat Valley & 5,400 to 60,800 & 27,000 & 27,000 \\
\hline Sarcobatus Flat & $-1,700$ to 1,700 & 0 & 0 \\
\hline Pahrump Valley & 5,000 to 7,600 & 5,000 & 1,720 \\
\hline Eagle Mountain & -850 to $-3,400$ & $-3,400$ & $-4,929$ \\
\hline Alkali Flat (Peter's Playa]) & $-5,000$ to $-7,300$ & $-6,100$ & $-5,233$ \\
\hline Amargosa River & $-2,040$ to $-5,100$ & $-2,500$ & -335 \\
\hline Ash Meadows & $-67,000$ to $-87,300$ & $-77,700$ & $-77,333$ \\
\hline Death Valley & $-17,500$ to $-60,200$ & $-60,100$ & $-59,783$ \\
\hline Franklin Lake/Alkali Flats & $-14,200$ to $-42,600$ & $-35,500$ & $-37,874$ \\
\hline Oasis Valley & $-17,000$ to $-27,000$ & $-25,000$ & $-25,785$ \\
\hline Penoyer Valley & $-13,000$ to $-27,000$ & $-20,300$ & $-19,106$ \\
\hline Indian Springs & $-1,600$ to $-2,400$ & $-2,400$ & $-2,456$ \\
\hline \hline
\end{tabular}

Overall, the calibrated model matches the target boundary fluxes very well. For example, the target for Ash Meadows discharge was $-77,700 \mathrm{~m}^{3} / \mathrm{d}$ (-22,995 ac-ft/y); the simulated discharge was $-77,332 \mathrm{~m}^{3} / \mathrm{d}(-22,886 \mathrm{ac}-\mathrm{ft} / \mathrm{y})$. Similarly, the target and simulated discharges for Oasis Valley were $-25,000 \mathrm{~m}^{3} / \mathrm{d}(-7,399 \mathrm{ac}-\mathrm{ft} / \mathrm{y})$ and $-25,784 \mathrm{~m}^{3} / \mathrm{d}(7,631 \mathrm{ac}-\mathrm{ft} / \mathrm{y})$, respectively. The simulated Death Valley discharge was $318 \mathrm{~m}^{3} / \mathrm{d}$ (94 ac-ft/y) lower than the target of $-60,100 \mathrm{~m}^{3} / \mathrm{d}$ (-17,786 ac-ft/y). Matches at Franklin Lake and Penoyer Valley are not as good, but are still within 7 percent of the estimates. 
In the smaller discharge areas, the simulated discharge rates are close to the targets, but the percentage differences are greater than in the larger discharge areas. There are four areas where the simulated flux was not within the target range. The poorest agreement is for the discharge at the Amargosa River discharge area (which apparently has not previously been measured or estimated). The simulated discharge was $-334 \mathrm{~m}^{3} / \mathrm{d}(-99 \mathrm{ac}-\mathrm{ft} / \mathrm{y})$, while the estimated range was $-2,040$ to $-5,100 \mathrm{~m}^{3} / \mathrm{d}(-604$ to $-1,509 \mathrm{ac}-\mathrm{ft} / \mathrm{y})$, and the target was $-2500 \mathrm{~m}^{3} / \mathrm{d}(-740 \mathrm{ac}-\mathrm{ft} / \mathrm{y})$. However, to put these numbers in perspective, the target represents only 1 percent of the estimated flux of water through the system.

At Eagle Mountain, the boundary flux was estimated to range from -850 to $-3,400 \mathrm{~m}^{3} / \mathrm{d}$ (-252 to $1,006 \mathrm{ac}-\mathrm{ft} / \mathrm{y})$ with a calibration target at the upper end. The simulated flux was $-4,928 \mathrm{~m}^{3} / \mathrm{d}(-1,458 \mathrm{ac}-\mathrm{ft} / \mathrm{y})$. The inflow from Pahrump Valley has been estimated to be between 5,000 and 7,000 $\mathrm{m}^{3} / \mathrm{d}$ (1,480 and 2,072 ac-ft/y); the simulated value was $1,719 \mathrm{~m}^{3} / \mathrm{d}(509 \mathrm{ac}-\mathrm{ft} / \mathrm{y})$. The fourth area with the simulated flux outside the target range is Indian Springs. Its range of estimates is from $-1,600$ to $-2,400 \mathrm{~m}^{3} / \mathrm{d}$ (-473 to $\left.-710 \mathrm{ac}-\mathrm{ft} / \mathrm{y}\right)$, with a target of $-2,400 \mathrm{~m}^{3} / \mathrm{d}$ $(-710 \mathrm{ac}-\mathrm{ft} / \mathrm{y})$. The simulated value $\left(-2,456 \mathrm{~m}^{3} / \mathrm{d}[-729 \mathrm{ac}-\mathrm{ft} / \mathrm{y}]\right)$, although outside the range of estimates, is very close to the target. The sum of the magnitudes of the difference between the simulated value and the target value for these four areas is $7,031 \mathrm{~m}^{3} / \mathrm{d}(2,081 \mathrm{ac}-\mathrm{ft} / \mathrm{y})$ or 3 percent of the total flux through the system.

In summary, the match of the simulated discharges to the targets is quite good. However, there is considerable uncertainty in the estimated and target discharges for individual areas and for the modeled area overall. Because of ongoing studies by the U.S. Geological Survey, the discharge at Ash Meadows is fairly well-known, but still has an uncertainty of approximately $20,000 \mathrm{~m}^{3} / \mathrm{d}$ (5,919 ac-ft/y); discharge in remaining areas is less well-known, especially in Death Valley. Model users should be aware of the lack of good discharge measurements, and they should interpret the results accordingly.

\subsubsection{Particle-Tracking Results}

The movement of contaminants in the groundwater system will be determined, in part, by the direction and rates of groundwater migration from contaminant sources to downgradient discharge areas. Particle tracking is a good method for evaluating the advective transport of contaminants and is easily implemented using head and flux distributions from the calibrated model. The computer code, MODPATH, Version 1.2 (Pollock, 1989) was used to calculate the locations of the particles along flow paths, and it was also used to incorporate information from 
the flow model into the subsequent transport calculations. The user starts the particles at desired locations, and the program calculates and records their location through time.

The procedure used to select the particle starting locations is described in detail in Section 9.0 of this report. As discussed in that section, 14 underground nuclear test locations were selected for the particle-tracking analysis. The 14 starting locations generally included the fastest moving particles from each of the testing areas: Pahute Mesa, Yucca Flat, Frenchman Flat, Rainier Mesa, Shoshone Mountain, and the Climax Stock located on the northern boundary of Yucca Flat. In Yucca Flat, particles were also selected to provide spatial coverage of the valley. It should be emphasized that the working points for the tests in Shoshone Mountain, Rainier Mesa, and Climax Stock were located above two-cavity radii of the water table; a single test from each of these areas was selected and assumed to originate at the water table to evaluate possible groundwater transport from these locations. This obviously does not take into account transport times through the unsaturated zone and will, therefore, underestimate the amount of time for contaminant migration from these three areas. The locations and names of the 14 selected tests are presented in Figure 7-25 which also shows the pathlines from the starting locations to the discharge points. It is very important to note that time information is not included as part of Figure 7-25; several of the particles originate in very low conductivity units, and residence times will be large.

To evaluate residence times, travel distances were calculated for the 14 particle-tracking locations after 25, 50, 100, and 200 years, taking into account the estimates of the effective porosities of the hydrostratigraphic units through which the particle migrates (Section 9.0). Because of the numerical instability problems affecting the Western Yucca Flat and Shoshone Mountain residual zones and the erratic particle-tracking results, the GUM DROP particle was deleted from the travel-time analysis. The following discussion will focus on the 25 -year travel distance for particles originating on western Pahute Mesa and the 100-year travel distances for the remaining particles. The 100-year travel distance is of interest because transport simulations indicate that concentrations that are high enough to cause concern typically occur in less than 100 years. However, the four particles originating on Pahute Mesa reached the discharge area in less than 50 years with one of the particles (from TYBO) discharging in less than 10 years. Therefore, the 25-year travel distances for the western Pahute Mesa particle were used in the sensitivity analysis. Table 7-11 shows the distances traveled by the 13 particles for the calibrated 
Table 7-11

\section{Estimated 25-Year (Western Pahute Mesa) and 100-Year (all Others) Particle Travel Distances Derived from Calibrated Model}

\begin{tabular}{|l|c|c||}
\hline \multicolumn{1}{|c|}{ Area } & \multicolumn{1}{|c|}{$\begin{array}{c}\text { Test Name and } \\
\text { Starting Location }\end{array}$} & $\begin{array}{c}\text { Particle Travel } \\
\text { Distance } \\
(\mathrm{m})\end{array}$ \\
\hline \hline Western Pahute Mesa & BULLION (WP) $^{\mathrm{a}}$ & 6,493 \\
\hline Western Pahute Mesa & DARWIN (B) & 4,947 \\
\hline Western Pahute Mesa & PURSE (WP) & 6,683 \\
\hline Western Pahute Mesa & TYBO (WP) & $30,918^{\mathrm{c}}$ \\
\hline Central Pahute Mesa & HOUSTON (B) & 42,344 \\
\hline Rainier Mesa & CLEARWATER & 1,546 \\
\hline Climax Stock & PILE DRIVER (WT) & 15,446 \\
\hline Yucca Flat & BOURBON (B) & 28,763 \\
\hline Yucca Flat & CORDUROY (WP) & 29,843 \\
\hline Yucca Flat & COULOMMIERS (B) & 8,000 \\
\hline Yucca Flat & CUMARIN (B) & 20,112 \\
\hline Yucca Flat & STRAIT (B) & 11,809 \\
\hline Frenchman Flat & DILUTED WATER (B) & 40 \\
\hline \hline
\end{tabular}

\footnotetext{
${ }_{b}^{a} W P=$ Working Point

$\mathrm{b}_{\mathrm{B}}=$ Bottom of sphere (starting location for tests)

${ }_{\mathrm{d}}^{\mathrm{C}}$ Reaches discharge point prior to 25 years

$\mathrm{d}_{\mathrm{WT}}=$ Water Table
}

model at a time of 25 years (western Pahute Mesa particles) and 100 years (all remaining particles).

It is very important to emphasize that the travel distances provided in Table 7-11 are the estimated distances that a conservative particle would move. Contaminant particles will move shorter distances because of attenuation processes which include sorption, ion exchange, and precipitation reactions, diffusion, and radioactive decay. Assuming that diffusion of tritiated water from the fractures into the rock matrix occurs, even tritium can be significantly retarded. Therefore, the distance calculated for the movement of the particles at 25 or 100 years should not be considered a reliable indicator of the rates of movement of contaminants. The effects of retardation on contaminant migration are evaluated as part of the transport modeling (Section 9.0). 
Table 7-11 also indicates the starting locations for each of the tests. The starting points are at one of four possible locations: the working point (WP); the water table (WT, applicable only for those tests in Rainier Mesa and the Climax Stock where the working point is located more than two cavity radii above the water table); at the top $(\mathrm{T})$ of a sphere with a radius twice that of the estimated cavity radius, centered on the working point; or at the bottom (B) of a sphere with a radius twice that of the estimated cavity radius, centered on the working point. In no case was the travel rate greatest at two cavity radii above the water table; therefore, "T" is not included as a starting point location.

The following discussion on the particle-tracking results refers both to the particle pathways shown in Figure 7-25 (no time component) and to the 25- and 100-year travel distances provided in Table 7-11. The pathline for the particle originating on Shoshone Mountain (GUM DROP) is shown on Figure 7-25, but the 100-year travel distance is not included in Table 7-11 due to the instability problems referred to earlier.

Five particles were started from underground test locations on Pahute Mesa. Four of these (DARWIN, PURSE, TYBO, and BULLION) originate on western Pahute Mesa, moving southwestward to discharge locations in Oasis Valley. They begin in either the Timber Mountain Aquifer or the Tuff Cone, but travel to the discharge area primarily in the TMA, discharging at Oasis Valley above the contact with the subcropping Lower Clastic Confining Unit. The fifth particle, HOUSTON, begins in Tuff Cone further to the east on central Pahute Mesa. HOUSTON's particle initially travels to the south along the east side of the Timber Mountain resurgent dome in the TMA. Leaving the moat, it reenters TC and travels a short distance before entering the Volcanic Confining Unit and the Volcanic Tuff Aquifer in northwestern Yucca Mountain. Beneath southern Crater Flat, it enters the LCA, crosses beneath the Amargosa Desert, and discharges into Death Valley through the Tertiary Sediments, Death Valley Section. The BULLION, DARWIN, and PURSE particles have 25-year travel distances ranging from about 5,000 to 6,600 m (16,405 to 21,655 ft). All three discharge at Oasis Valley prior to 50 years, while TYBO discharges before 10 years. The HOUSTON particle travels approximately 42,340 m (138,917 ft) in 100 years, reaching the contact between TC and VCU in northwestern Yucca Mountain.

Farther to the east, the particle originating on Rainier Mesa (CLEARWATER) begins in the Lower Clastic Confining Unit. The 100-year travel distance is about $1.5 \mathrm{~km}(0.9 \mathrm{mi})$ (note: this does not include the residence time within the unsaturated LCCU, which will be large). The 
particle travels through the LCCU, non-welded tuffs (BCU), and welded tuffs (BAQ) prior to entering the Timber Mountain Aquifer within the Timber Mountain moat. It travels southward within the moat, crosses the Lower Clastic Confining Unit where the Belted Range thrust raised these rocks, and moves through the LCA north of Calico Hills. It then passes through the Upper Clastic Confining Unit down into the LCA (near the east side of Yucca Mountain) and remains in the LCA until reaching the Funeral Mountains. It passes through the LCCU, the TSDV, and finally discharges from the Alluvial Aquifer.

The PILE DRIVER test in the Climax Stock was located more than two-cavity radii above the water table in intrusives located on the northern boundary of Yucca Flat. The hydraulic conductivity of the intrusive is lower than that of the Lower Clastic Confining Unit, and the transport distance should, therefore, be on the same order as that calculated for Rainier Mesa. However, examination of Table 7-11 indicates that the calculated travel distance for PILE DRIVER is approximately one order of magnitude greater than that for CLEARWATER. The difference is due to the process used to translate geologic data from the geologic grid to the hydrologic grid and the averaging of properties that sometimes results. In this case, the hydraulic properties of the cell representing the starting point for PILE DRIVER are a combination of the conductivities of the LCA and the intrusive, yielding a value considerably higher than that of the intrusive alone. Therefore, the calculated transport distance is not reliable for a particle starting within the intrusive body, but would be representative for a particle originating in the LCA in northern Yucca Flat. The PILE DRIVER particle pathway originates in the intrusive, passes through a small amount of UCCU, and enters the LCA beneath northern Yucca Flat. It travels along the upper part of the LCA, passing beneath Massachusetts Mountain which separates Yucca Flat from Frenchman Flat. Moving beneath the northwestern part of Frenchman Flat in the Lower Carbonate Aquifer, it moves down Rock Valley and enters the Alluvial Aquifer near Skeleton Hills. The particle continues to move southwestward to discharge at the Amargosa River discharge area.

Five particles were started in Yucca Flat. The COULOMMIERS and CORDUROY particles originate in the Volcanic Confining Unit and Lower Carbonate Aquifer, respectively, and have similar flowpaths to the PILE DRIVER particle, discharging from the Alluvial Aquifer at the Amargosa River discharge area. The BOURBON particle also starts within the LCA, but migrates southward farther to the east than the previous two particles, discharging in the AA at the Franklin Lake discharge area. The STRAIT particle moves eastward off the UCCU shelf within the VCU before migrating downward into the LCA. Because of the distribution of the 
LCA and UCCU in the central part and eastern side of Yucca Flat, the STRAIT particle is forced to migrate deeper within the flow system prior to entering the regional carbonate aquifer. The CUMARIN particle also begins in the VCU on the western side of Yucca Flat. Both the STRAIT and CUMARIN particles travel within the LCA into the Amargosa Desert, but are not captured by the Amargosa River discharge area. Instead, they move from the AA back into LCA and TSDV and discharge in Death Valley.

The particle in northern Frenchman Flat (DILUTED WATER) begins in AA, traveling only a few meters in 100 years. The particle migrates across the VCU and into the shallow part of the LCA. Near the western edge of Frenchman Flat, its path nearly coincides with that of the BOURBON particle, but is shallower, discharging at the Amargosa River discharge area.

The particle tracking results from Yucca Flat are different from earlier conceptual models that indicated that the water from Yucca Flat discharges at Ash Meadows. The numerical model does not support this conceptual model because of the inclusion of more detailed and recent geologic information. First, the simulated flow paths appear to be sensitive to the configuration of the top of the LCA, flowing through the shallower sections of the LCA. This is a consequence of the depth-decay model for conductivity that was used in the flow model. Second, the southern part of the Halfpint Range is underlain by the LCA which allows water flowing from the east to pass beneath the southern part of Yucca Flat. This is shown in the abrupt change in the particle paths toward the southwest. And finally, the older conceptual models were based on an interpretation that the Eleana argillite was 2,500 to 3,000 m (8,202 to 9,843 ft) thick beneath western Yucca Flat, which would tend to divert flow laterally around the Eleana, forcing it to the south underneath Frenchman Flat.

A more recent study of these rocks by Cashman and Trexler (1994) has shown that there are two distinct depositional environments present. This new interpretation places 1,000 to 1,500 m $(3,281$ to $4,921.5 \mathrm{ft})$ of Eleana argillite west of a similar thickness of the Chainman shale. These two units together comprise the UCCU. However, their position within the groundwater system allows water in the LCA to flow beneath them much farther to the west than previously interpreted. The net result is that water from the eastern part of the Nevada Test Site does not appear to flow to Ash Meadows; it is prevented from doing so by flow within the Lower Carbonate Aquifer coming from the east. Instead, this water discharges in the Amargosa Desert or Death Valley. 
The pathline results for the Yucca Flat particles indicate that the modeled flowpaths are greatly affected by the three-dimensional configuration of the LCA and the distribution of lowconductivity confining units. The details highlighted by the particle-tracking results would not be apparent in a two-dimensional model or one based on a greatly simplified geologic model. The results further demonstrate the need to develop an adequate understanding of the geology within the testing areas if the details of transport are important at that scale.

\subsubsection{Sensitivity Analyses}

Sensitivity analyses were performed at the conclusion of model calibration. The objectives of the sensitivity analysis were twofold:

- Evaluate the effects on model results of changes to the underlying geologic model and other parameters integral to development of the modeling approach (e.g., recharge redistribution to low-lying alluvial fans).

- Identify those hydraulic parameters (horizontal hydraulic conductivity, vertical anisotropy, and depth-decay coefficients) to which the model results are sensitive and, therefore, for which the model can provide information on the regional scale.

The effects of changes to the first set of parameters on model results cannot easily be evaluated in the traditional sense, which consists of modifying parameter values by a given amount and calculating the resultant change, or sensitivity, in heads or fluxes. For example, effects of implementing changes to the geologic model cannot be assessed in this manner. However, the effects on head and flux distributions due to modifications to the geologic model provide important information on the conceptual and calibrated model. This latter group is termed "special-case sensitivity analyses" and will be discussed first. Sensitivity analyses of the hydraulic parameters will be presented second.

\subsubsection{Special-Case Sensitivity Analyses}

Four types of special-case sensitivity analysis were conducted as part of the last modeling sequence. The first type of analysis was designed to evaluate the three geologic model interpretations presented in Section 4.0. The second type of sensitivity analysis was designed to test the effects of the assumptions made in the estimates of recharge rates and distribution. The third type was designed to evaluate the uncertainties associated with underflow from Pahranagat Valley and Sarcobatus Flat. The fourth and last type of special-case sensitivity analysis was designed to evaluate changes in hydraulic parameters that were greater or otherwise different from the systematic changes discussed later. 
The results of these special-case sensitivity analyses (Tables 7-12, 7-13, and 7-14) are compared to a selected base case. It should be emphasized that two different base cases were used. The geologic model sensitivity simulations were compared to Base 2 , while sensitivity simulations for the current (third) modeling sequence are compared to Base 3. The sensitivity analysis results are presented in terms of hydraulic head residuals and head-dependent boundary fluxes. The hydraulic-head residual comparison is presented for each hydraulic-head residual zone (Figure 7-4), whereas the boundary flux comparisons are made for each head-dependent boundary.

Each of the three tables (Tables 7-12, 7-13, and 7-14) includes the following: changes in meanweighted head residuals and the percentage change in the root mean square of weighted residuals for the 15 residual zones and the percentage change in discharge fluxes between the base (calibrated) case and each sensitivity run for the 10 head-dependent flux boundaries. All mean residual changes having an absolute value greater than or equal to $1 \mathrm{~m}(3.3 \mathrm{ft})$ are shaded in the table; flux and RMS percentage changes (absolute value) greater than or equal to 10 percent are also shaded. The discussion of the parameter sensitivities are grouped according to geologic model interpretations, recharge model evaluations, boundary flux evaluations, and conductivity evaluations. The effects of the parameter sensitivity runs on particle-tracking results are briefly discussed; a more detailed discussion of particle-tracking results for the special-case sensitivity runs are included in the Groundwater Flow Model Documentation Package (IT, 1996f).

\subsection{Geologic Model Interpretations}

Sensitivity analysis to the geology is important because of the significant impacts of the geology on hydraulic head and flux distributions and particle transport. Sensitivity analyses were performed using three interpretations of the digital geologic model which were based on changes made to the geologic model during the calibration process. The changes to the geologic model are discussed in Section 4.0.

The results of the three sensitivity analyses (Table 7-12) are compared to the results of the second calibration sequence (Base 2). The three sensitivity runs are identified in Table 7-12 by the term "GEOL," followed by the version number used internally for tracking changes to the geologic model. The first of these three runs, GEOL_6, included the geologic interpretation at the conclusion of the initial sequence of modeling. Based on those results, several areas within the geologic model were revised. The second sensitivity run, GEOL_10, incorporated changes to 
Table 7-12

Change in Hydraulic-Head Residuals and Boundary Fluxes Due to Different Geologic Model Interpretations

7-12a - Means of Weighted Head Residuals (m)

\begin{tabular}{|c|c|c|c|c|}
\hline Zone & Base 2 & Geol_6 & Geol_10 & Geol_12 \\
\hline OASI & 12.30 & -35.70 & 1.00 & 0.10 \\
\hline$\overline{\mathrm{PM}}$ & 4.00 & 42.10 & 10.00 & 2.10 \\
\hline BARR & 79.00 & -3.90 & -2.30 & 0.50 \\
\hline WYF & 35.00 & 105.90 & 111.50 & -0.70 \\
\hline EYF & -24.60 & 2.80 & 7.70 & -0.10 \\
\hline SHON & -9.00 & -51.80 & 5.00 & -0.20 \\
\hline$\overline{\mathrm{DV}}$ & -12.60 & -0.60 & 0.00 & -0.10 \\
\hline LCA & -5.10 & -11.40 & -0.30 & 0.00 \\
\hline PAHR & -13.60 & -2.50 & -0.60 & 0.00 \\
\hline SPMT & 19.50 & -1.90 & 0.50 & -1.40 \\
\hline SHRG & -45.70 & -0.70 & 1.20 & -1.90 \\
\hline TMBR & 9.10 & 156.40 & 41.60 & 1.20 \\
\hline
\end{tabular}

7-12b - Root Mean Square of Weighted Head Residuals

\begin{tabular}{||l|r|r|r|r||}
\hline \multicolumn{1}{|c|}{ Zone } & $\begin{array}{c}\text { Base 2 } \\
(\mathrm{m})\end{array}$ & $\begin{array}{c}\text { Geol_6 } \\
\text { \% Base 2) }\end{array}$ & $\begin{array}{c}\text { Geol_10 } \\
\text { \% Base 2) }\end{array}$ & $\begin{array}{c}\text { Geol_12 } \\
\text { \% Base 2) }\end{array}$ \\
\hline \hline NRTH & 61.00 & 8.69 & 5.57 & 1.48 \\
\hline OASI & 43.80 & 62.79 & 2.28 & -0.23 \\
\hline PM & 35.00 & 66.57 & -0.57 & -0.57 \\
\hline BARR & 136.90 & -1.97 & -0.80 & -0.07 \\
\hline WYF & 80.70 & 154.77 & -25.67 & -0.12 \\
\hline EYF & 41.30 & -16.46 & -3.91 & -0.24 \\
\hline SHON & 43.50 & 169.89 & 1.88 & 0.23 \\
\hline DV & 48.00 & 2.92 & 0.00 & 0.00 \\
\hline LCA & 17.20 & 136.05 & -0.44 & -1.00 \\
\hline PAHR & 67.50 & -1.19 & -1.05 & -0.15 \\
\hline SPMT & 57.40 & -2.96 & -0.58 & -0.35 \\
\hline SHRG & 51.40 & 2.14 & 53.47 & -1.56 \\
\hline TMBR & 50.50 & 244.95 & -0.59 \\
\hline \hline
\end{tabular}

7-12c - Boundary Fluxes $\left(\mathrm{m}^{3} / \mathrm{d}\right)$

\begin{tabular}{||l|r|r|r|r||}
\hline \multicolumn{1}{|c|}{ Zone } & $\begin{array}{c}\text { Base 2 } \\
\left(\mathrm{m}^{3} / \mathrm{d}\right)\end{array}$ & $\begin{array}{c}\text { Geol_6 } \\
\text { \% Base 2) }\end{array}$ & $\begin{array}{c}\text { Geol_10 } \\
\text { \% Base 2) }\end{array}$ & $\begin{array}{c}\text { Geol_12 } \\
\text { (\%Base 2) }\end{array}$ \\
\hline \hline DVal & -48327.00 & 0.95 & -0.14 & -0.19 \\
\hline OV & -15874.00 & -66.36 & -11.43 & 0.86 \\
\hline ARiv & -8508.00 & 19.95 & 2.82 & 0.19 \\
\hline AM & -69006.00 & 18.04 & 3.36 & 0.13 \\
\hline FL & -18088.00 & 5.88 & 10.86 & 0.86 \\
\hline AF & -5956.00 & 55.94 & 04.38 & 0.40 \\
\hline PV & -16138.00 & -0.87 & 1.01 & -2.21 \\
\hline IS & -1984.00 & 6.70 & -1.08 & 0.05 \\
\hline PP & 185.00 & -5.41 & 0.52 & 0.00 \\
\hline EM & -5982.00 & 3.49 & & 0.03 \\
\hline
\end{tabular}


Table 7-13

\section{Change in Hydraulic Head Residuals and Boundary Fluxes Due to Recharge Distributions and Subsurface Inflow}

7-13a - Means of Weighted Head Residuals (m)

\begin{tabular}{|c|c|c|c|c|c|c|c|c|}
\hline Zone & Base 3 & Rech1.5x & Rech0.75x & Rch_hdOr & Rch_hd.3r & Rch_me & $S F_{-1700}$ & $P V \_60000$ \\
\hline NRTH & 5.80 & 1.10 & -0.60 & -0.40 & 0.00 & 4.60 & 0.10 & 0.10 \\
\hline OASI & 38.30 & 1.10 & -0.40 & -0.20 & 0.10 & 0.70 & 0.70 & 3.00 \\
\hline PM & -5.80 & 1.50 & -0.80 & 1.50 & -1.70 & 8.10 & 0.70 & 0.00 \\
\hline BARR & 107.20 & -1.20 & 1.90 & 0.00 & 0.20 & 1.60 & 0.20 & 8.80 \\
\hline WYF & 70.40 & -3.00 & 2.40 & 5.00 & 2.00 & 0.80 & 1.30 & 1.50 \\
\hline EYF & 1.30 & -0.80 & 1.70 & 0.20 & 0.60 & 3.40 & 0.60 & 8.50 \\
\hline SHON & 21.70 & 2.10 & 1.80 & 1.10 & 0.20 & -12.70 & 0.30 & 6.50 \\
\hline DV & 22.90 & 8.50 & -4.30 & 0.00 & 0.10 & 3.50 & 0.00 & 1.10 \\
\hline LCA & -7.30 & 0.70 & -0.10 & -0.10 & 0.20 & -0.10 & 0.10 & 2.60 \\
\hline PAHR & -9.90 & -29.70 & 27.50 & -0.10 & -0.80 & -24.70 & 0.00 & 94.80 \\
\hline SPMT & -1.70 & -0.10 & 0.40 & 0.00 & 0.10 & -5.50 & 0.10 & 3.00 \\
\hline SHRG & 49.30 & -2.00 & 1.20 & 0.00 & 0.10 & -6.20 & 0.00 & 7.00 \\
\hline TMBR & 6.70 & 2.70 & -1.10 & 5.20 & -2.30 & 13.80 & 1.10 & 0.40 \\
\hline FARM & 6.30 & 0.50 & 0.10 & -0.20 & 0.10 & -2.00 & 0.00 & 3.80 \\
\hline $\mathrm{FF}$ & 0.80 & -1.30 & 1.70 & -0.10 & 0.20 & -2.00 & 0.10 & 8.60 \\
\hline
\end{tabular}

7-13b Root Mean Square of Weighted Head Residuals

\begin{tabular}{|c|c|c|c|c|c|c|c|c|}
\hline Zone & Base 3 & Rech1.5x & Rech0.75x & Rch_hdOr & (Rch_hd.3r & Rch_me & SF_1700 & $P V$ PV_60000 \\
\hline NRTH & 42.90 & -0.23 & 0.00 & 0.93 & -0.23 & 5.13 & -0.47 & 0.00 \\
\hline OASI & 72.20 & -1.11 & 0.28 & 0.14 & -0.14 & -2.35 & -0.42 & -1.94 \\
\hline PM & 35.70 & 0.84 & -0.28 & -0.84 & 0.56 & 5.60 & 0.28 & 0.00 \\
\hline BARR & 146.80 & 0.54 & -0.82 & 0.07 & -0.14 & 0.00 & -0.07 & -3.95 \\
\hline WYF & 139.50 & 0.07 & -0.29 & -2.72 & -1.65 & -25.16 & -1.08 & 0.07 \\
\hline EYF & 22.90 & 1.31 & -0.87 & 0.44 & 0.44 & 13.97 & 0.87 & 3.06 \\
\hline SHON & 80.50 & 2.86 & -0.87 & 1.37 & -0.25 & 1.37 & 0.37 & -4.47 \\
\hline DV & 41.00 & -4.15 & 1.95 & 0.24 & -0.24 & 7.07 & 0.00 & -4.63 \\
\hline LCA & 28.80 & 1.04 & -0.69 & -0.35 & 0.35 & 1.04 & 0.69 & 4.17 \\
\hline PAHR & 11.40 & 72.81 & 235.96 & -0.88 & -7.02 & 29.82 & -0.88 & 826.32 \\
\hline SPMT & 53.30 & -0.19 & 0.00 & 0.00 & 0.00 & -1.69 & 0.00 & -0.56 \\
\hline SHRG & 47.30 & 4.23 & -2.54 & 0.00 & -0.21 & 13.32 & 0.00 & -14.59 \\
\hline TMBR & 61.00 & 0.16 & 0.33 & -3.11 & 1.15 & -3.28 & 0.00 & 0.49 \\
\hline FARM & 9.00 & -4.44 & 0.00 & 2.22 & -1.11 & 18.89 & 0.00 & -23.33 \\
\hline FF & 5.20 & 7.69 & 1.92 & 1.92 & 0.00 & 13.46 & 0.00 & 80.77 \\
\hline
\end{tabular}

7-13c Boundary Fluxes $\left(\mathrm{m}^{3} / \mathrm{d}\right)$

\begin{tabular}{||l|r|r|r|r|r|r|r|r||}
\hline Zone & $\begin{array}{c}\text { Base 3 } \\
\left(\mathbf{m}^{3} / d\right)\end{array}$ & $\begin{array}{c}\text { Rech1.5x } \\
\text { (\% of Base 3) }\end{array}$ & $\begin{array}{c}\text { Rech0.75x } \\
\text { (\% of Base 3) }\end{array}$ & $\begin{array}{c}\text { Rch_hdOr } \\
\text { (\% of Base 3) }\end{array}$ & $\begin{array}{c}\text { Rch_hd.3r } \\
\text { (\% of Base 3) }\end{array}$ & $\begin{array}{c}\text { Rch_me } \\
\text { (\% of Base 3) })\end{array}$ & $\begin{array}{c}\text { SF_1700 } \\
\text { (\% of Base 3) }\end{array}$ & $\begin{array}{c}\text { PV_60000 } \\
\text { (\% of Base 3) }\end{array}$ \\
\hline \hline DVal & -59782.87 & 48.14 & -24.41 & -0.03 & 0.02 & 29.54 & 0.01 & 0.61 \\
\hline OV & -25784.95 & 47.18 & -24.30 & 3.52 & -1.95 & 46.01 & 5.63 & 0.22 \\
\hline ARiv & -334.81 & 43.21 & -19.14 & -1.52 & 1.28 & -4.41 & 0.65 & 40.00 \\
\hline AM & -77332.51 & 41.55 & -20.73 & -0.45 & 0.50 & 20.34 & 0.25 & 20.00 \\
\hline FL & -37873.70 & 41.04 & -22.16 & -0.11 & 0.09 & 22.30 & 0.05 & 2.89 \\
\hline AF & -5232.56 & 1.86 & 16.87 & -4.05 & 5.20 & -47.23 & 2.64 & 294.65 \\
\hline PV & -19105.90 & 45.57 & -24.86 & -1.59 & -1.16 & 79.62 & -0.70 & 0.73 \\
\hline IS & -2456.55 & 46.65 & -23.70 & -0.04 & 0.11 & -9.37 & 0.09 & 6.80 \\
\hline PP & 1719.51 & 49.84 & -24.93 & -0.01 & 0.01 & 33.18 & 0.01 & -0.54 \\
\hline EM & -4928.82 & 84.89 & -33.88 & -0.04 & 0.04 & 49.07 & 0.02 & 1.22 \\
\hline \hline
\end{tabular}

* PP and EM are GHB Fluxes. The remaining zones display Drain Fluxes. 
Table 7-14. Change in Hydraulic Head Residuals and Boundary Fluxes Due to Large Changes in Hydraulic Conductivities

7-14a - Means of Weighted Head Residuals (m)

\begin{tabular}{||l|r|r|r|r|r||}
\hline \multicolumn{1}{|c|}{ Zone } & \multicolumn{1}{c|}{ Base 3 } & VCU_ZN2 & LCA3_ZN1 & \multicolumn{1}{c|}{ AA_ZN4\&5 } & \multicolumn{1}{c|}{ TMA_ZN6 } \\
\hline \hline NRTH & 5.80 & 0.00 & -0.30 & 0.00 & -16.10 \\
\hline OASI & 38.30 & 0.00 & -0.90 & -0.10 & 8.10 \\
\hline PM & -5.80 & -0.20 & -3.00 & -0.10 & -64.00 \\
\hline BARR & 107.20 & 0.00 & 0.80 & -0.10 & -0.60 \\
\hline WYF & 70.40 & -43.10 & -65.30 & -1.50 & -26.40 \\
\hline EYF & 1.30 & 1.50 & -5.90 & -7.20 & 0.30 \\
\hline SHON & 21.70 & -0.60 & -21.00 & -0.80 & -2.80 \\
\hline DV & 22.90 & 0.00 & 0.10 & 0.00 & 0.90 \\
\hline LCA & -7.30 & 0.00 & -0.30 & 0.00 & -1.90 \\
\hline PAHR & -9.90 & 0.00 & -0.60 & -1.10 & 0.10 \\
\hline SPMT & -1.70 & 0.10 & 0.20 & 0.00 & 0.20 \\
\hline SHRG & 49.30 & 0.00 & 0.30 & 0.00 & 0.00 \\
\hline TMBR & 6.70 & -0.70 & -9.40 & 0.20 & -32.20 \\
\hline FARM & 6.30 & 0.00 & 0.30 & 0.00 & 1.60 \\
\hline FF & 0.80 & 0.40 & 0.70 & -0.20 & 0.10 \\
\hline \hline
\end{tabular}

7-14b - Root Mean Square of Weighted Head Residuals (m)

\begin{tabular}{||l|r|r|r|r|r||}
\hline \multicolumn{1}{|c|}{ Zone } & $\begin{array}{c}\text { Base 3 } \\
(\mathrm{m})\end{array}$ & $\begin{array}{c}\text { VCU_ZN2 } \\
\text { (\% of Base 3) }\end{array}$ & $\begin{array}{c}\text { LCA3_ZN1 } \\
\text { (\% of Base 3) }\end{array}$ & $\begin{array}{c}\text { AA_ZN4\&5 } \\
\text { (\% of Base 3) }\end{array}$ & $\begin{array}{c}\text { TMA_ZN6 } \\
\text { (\% of Base 3) }\end{array}$ \\
\hline \hline NRTH & 42.90 & 0.00 & 0.93 & 0.00 & 70.16 \\
\hline OASI & 72.20 & 0.00 & 0.83 & 0.00 & -16.07 \\
\hline PM & 35.70 & 0.00 & -1.12 & -0.28 & 89.64 \\
\hline BARR & 146.80 & 0.07 & -0.34 & 0.07 & 0.14 \\
\hline WYF & 139.50 & 3.58 & 75.13 & 7.46 & -8.75 \\
\hline EYF & 22.90 & 3.93 & -3.93 & 0.00 & 0.87 \\
\hline SHON & 80.50 & -0.12 & 2.24 & -0.25 & -1.49 \\
\hline DV & 41.00 & 0.00 & -0.24 & 0.00 & -3.41 \\
\hline LCA & 28.80 & -0.35 & -4.51 & -0.69 & -17.01 \\
\hline PAHR & 11.40 & -0.88 & -5.26 & -8.77 & 0.00 \\
\hline SPMT & 53.30 & 0.00 & 0.00 & 0.00 & 0.00 \\
\hline SHRG & 47.30 & 0.00 & -0.63 & 0.00 & 0.00 \\
\hline TMBR & 61.00 & 0.16 & 0.49 & 0.33 & 20.33 \\
\hline FARM & 9.00 & 0.00 & -2.22 & 0.00 & -14.44 \\
\hline FF & 5.20 & 0.00 & 0.00 & 1.92 & 0.00 \\
\hline \hline
\end{tabular}

7-14c - Boundary Fluxes $\left(\mathrm{m}^{3} / \mathrm{d}\right)^{\star}$

\begin{tabular}{||l|r|r|r|r|r||}
\hline \multicolumn{1}{|c|}{ Zone } & $\begin{array}{c}\text { Base 3 } \\
\text { ( } \mathrm{m}^{3} / \text { day) }\end{array}$ & $\begin{array}{c}\text { VCU_ZN2 } \\
\text { (\% of Base 3) }\end{array}$ & $\begin{array}{c}\text { LCA3_ZN1 } \\
\text { (\% ob Base 3) }\end{array}$ & $\begin{array}{c}\text { AA_ZN4\&5 } \\
\text { (\% of Base 3) }\end{array}$ & $\begin{array}{c}\text { TMA_ZN6 } \\
\text { (\% of Base 3) }\end{array}$ \\
\hline \hline DVal & -59782.87 & 0.01 & 0.04 & 0.00 & 0.74 \\
\hline OV & -25784.95 & -0.75 & -9.91 & -0.14 & -7.48 \\
\hline ARiv & -334.81 & 0.45 & 3.40 & 0.14 & 15.11 \\
\hline AM & -77332.51 & 0.27 & 1.89 & 0.07 & 2.33 \\
\hline FL & -37873.70 & 0.03 & 0.25 & 0.01 & 1.07 \\
\hline AF & -5232.56 & 3.17 & 21.80 & 0.81 & 10.40 \\
\hline PV & -19105.90 & -1.05 & -1.17 & -0.36 & -7.07 \\
\hline IS & -2456.55 & 0.07 & 0.40 & -0.09 & 0.27 \\
\hline PP & 1719.51 & 0.01 & 0.03 & 0.00 & 0.02 \\
\hline EM & -4928.82 & 0.01 & 0.11 & 0.00 & 0.41 \\
\hline
\end{tabular}

* PP and EM are GHB Fluxes. The remaining zones display Drain Fluxes. 
the geology in the vicinity of Penoyer Valley and in the area north of Yucca Mountain (Section 4.0). The changes implemented to the north of Yucca Mountain were necessary to develop a barrier to flow that is expressed in the higher hydraulic gradients present in this area (Figure 7-20). A final change to the geologic model making the Upper Clastic Confining Unit continuous beneath Tongue Wash on Rainier Mesa is investigated in the GEOL_12 sensitivity run.

The differences between the GEOL_O6 and the Base 2 sensitivity runs are significant (Table 7-12). The hydraulic heads in GEOL_O6 are considerably lower in the Timber Mountain, Pahute Mesa, and Western Yucca Flat residual zones than in Base 2. As a result of the lower hydraulic heads on Pahute Mesa, groundwater beneath Sarcobatus Flat flows into the model rather than out, which occurs in Base 2. In GEOL_06, more water moves through the area extending from Calico Hills to Bare Mountain, and the discharge in Oasis Valley is much lower than in the base case. The high gradient present in the northern part of Yucca Mountain is not simulated. The discharge at Penoyer Valley is similar in the two runs, but the heads in the northern Groom Range are considerably higher in the base case. This sensitivity run demonstrates that the geologic model used during the initial calibration sequence was not adequate to explain hydraulic head and flux distributions and needed modification.

Sensitivity run GEOL_10 produces a significantly better fit to hydraulic heads in Pahute Mesa, Timber Mountain, and Penoyer Valley in addition to a greater discharge at Oasis Valley as a result of the barrier north of Yucca Mountain. The model accurately simulates the high gradient at northern Yucca Mountain. Particles originating on western Pahute Mesa migrate southwestward to Oasis Valley rather than southward as they do in the GEOL_6 run. In addition to simulating the Oasis Valley discharge rates, the remaining boundary fluxes for GEOL_10 are also very similar to those calculated for Base 2 (Table 7-12). In the Penoyer Valley area, extending the Lower Clastic Confining Unit northward from the Groom Range along the eastern side of the valley improves model goodness-of-fit to hydraulic heads and discharge rates; however, a low value for the Lower Carbonate Aquifer in the northeastern part of the model is still necessary to maintain shallow heads in the valley.

Sensitivity run GEOL.10, while accurately calculating heads and fluxes over the majority of the study area, resulted in a depression within the potentiometric surface beneath Rainier Mesa, which is inconsistent with observed data. To address this, the UCCU was made continuous in this area, (geologic model version 12, run GEOL_12). The differences in regional water-table 
elevations and fluxes between this run and Base 2 are minor, but the hydraulic head differences between sensitivity runs GEOL_10 and GEOL_12 in Western Yucca Flat are significant. The base case interpretation provides a much better agreement with regional water-level data.

\subsection{Evaluation of Recharge Estimates}

Sensitivity analyses were performed to evaluate the assumptions in the amount and distribution of areal recharge from precipitation and by subsurface underflow. The sensitivity results, as compared to Base 3 results, are presented in Table 7-13.

\section{Areal Recharge}

There were five sensitivity runs performed on the areal recharge dataset. The sensitivity runs are identified in Table 7-13 by the term "RECH" or "RCH," followed by an identifier to indicate the change implemented in the dataset. The names of the five runs and the implemented change include:

Rech1.5x - Recharge rate and $K_{h} \mathrm{~s}$ (horizontal hydraulic conductivity values projected to land surface) increased by a factor of 1.5 times the corresponding values included in Base 3

Rech0.75x - Recharge rate and $K_{h}$ s set to 0.75 times the corresponding values included in Base 3 (25 percent decrease compared to Base 3)

Rch_hd0r - Same recharge rate as Base 3, but with no redistribution

Rch_hd.3r - Same recharge rate as Base 3, but with 30 percent redistribution versus 20 percent redistribution in Base 3

Rch_me - Maxey-Eakin recharge model, with the $K_{h} \mathrm{~s}$ increased by the Maxey-Eakin to Base 3 recharge ratio

The first two sensitivity runs were conducted to determine whether hydraulic heads behave in a linear fashion with respect to changes in recharge. It should be emphasized that some nonlinearity is to be expected, since drain and general-head boundary conductances and the Well Package flux rates were not changed correspondingly. The next two runs were conducted to evaluate the effect of recharge redistribution on heads and fluxes. The final run was included in the sensitivity analysis to evaluate the effects of incorporating the classical Maxey-Eakin approach (1949) on model heads and fluxes. 
In run Rech1.5x, the changes in the mean-weighted head residuals with respect to Base 3 are minor (Table 7-13) with the exception of the Pahranagat Valley and Death Valley residual zones (Figure 7-4). The anomalous values associated with these zones are a result of not increasing drain and GHB conductances and the Well Package flux rates by the 1.5 factor. With the exceptions of Alkali Flat and Eagle Mountain fluxes, the increases in the flux rates were all within the range of 41 to 50 percent (Table 7-13), which is similar to the increase in total flux into the model (44 percent). The small increase in the Alkali Flat discharge (1.9 percent) is due to the high negative sensitivity of this discharge area to the hydraulic conductivity of the underlying LCA(2) (Figure 7-5). The large percentage increase in discharge at Eagle Mountain (85 percent) resulted from increased inflow across Pahrump Valley due to the increase in LCCU conductivity. In run Rech0.75x, where the recharge and $K_{h}$ values were decreased by a factor of 0.25 , the results are similar, but generally opposite in direction to run Rech1.5x.

Increasing recharge and conductivities by a factor of 1.5 had significant impacts on particle travel distances (see Figure 7-25 for particle pathlines and Table 7-11 for base-case travel distances). For most particles, the 50 percent increase caused a large increase in travel distance. Doubling or tripling the travel distance at specified times was common. It is interesting to note that the percent change in distance can vary widely at different times, resulting from movement of particles through HSUs of different conductivities and effective porosities. Thus, those particles which were less sensitive to changes after one time period may have significantly greater sensitivities at other times. For example, the HOUSTON particle shows a very large increase in the 25-year travel distance over Base 3, during which time it travels in the Timber Mountain Aquifer, but only small increases at longer times after entry into the low-conductivity Volcanic Confining Unit.

Travel distances are less sensitive to a reduction in recharge and conductivities than to increases in these parameters. Typically, the percent reduction in travel distance was approximately the same as percent reduction in recharge.

In Base 3, 20 percent of the recharge on and near the NTS was redistributed to downstream areas. In sensitivity run $R c h \_h d 0 r$, the total amount of recharge remained the same, but no water was redistributed. The effects on hydraulic heads were minor, with less than 0.5-m (1.7-ft) change in the mean-weighted residual in all residual zones except Timber Mountain, Pahute Mesa, Shoshone Mountain, and Western Yucca Flat. Recharge in the first three zones increased since water was not redistributed downgradient. It is likely that the changes in Western Yucca Flat are 
due to numerical problems associated with the steep hydraulic gradient and may not be accurate. The changes in simulated discharge were also minor. The discharge in Oasis Valley increased by 3.5 percent and the discharge in the Amargosa Desert decreased by a similar volume. Recharge redistribution has only minor effects on particle movement.

In run $R c h \_h d .3 r$, recharge redistribution was increased from 20 to 30 percent. The changes to heads and discharge fluxes are small and generally opposite in direction to those observed in Rch_hdOr.

The final recharge sensitivity run, $R c h \_m e$, consisted of developing a recharge model using the original Maxey-Eakin coefficients; these coefficients and the corresponding precipitation ranges are listed in Table 7-6. The net recharge calculated for the modeled area by this method is $272,156 \mathrm{~m}^{3} / \mathrm{d}(80,543 \mathrm{ac}-\mathrm{ft} / \mathrm{y})$, compared with $204,080 \mathrm{~m}^{3} / \mathrm{d}(60,397 \mathrm{ac}-\mathrm{ft} / \mathrm{y})$ used in the base case model. In order to compare Maxey-Eakin results with those of the base case, the $K_{h} s$ of all hydrostratigraphic units were increased by a factor of 1.3336 , the ratio of the Maxey-Eakin to Base 3 recharge values. Again, boundary fluxes and conductances were not increased by an equivalent amount, which accounts for the anomalously low mean head residual in the Pahranagat Valley residual zone. Additionally, the Maxey-Eakin model does not include redistribution, which accounts for the higher residual heads in the Northern Pahute Mesa, and Timber Mountain residual zones. Overall, the Maxey-Eakin model resulted in an increase in the simulated discharge rates at almost all discharge locations with greater increases in higher gradient areas upgradient of the LCCU barrier (e.g., Penoyer Valley).

For particles starting on western Pahute Mesa (Figure 7-25), the approximately 33 percent increase in recharge increases 25-year travel distances from 91 percent (BULLION) to 326 percent (DARWIN); these results are similar to the results of the Rech1.5x sensitivity run. The 100-year travel distances for particles starting in Yucca Flat generally increase by less than 50 percent.

To summarize the recharge special-case sensitivity runs, when the recharge rate and $K_{h} s$ are increased by the same factor, the resulting heads are similar to those of the base case, and the fluxes increase nearly proportionately to the increase in the recharge, indicating that the model behaves linearly. Except for the Alkali Flat discharge [due to its negative sensitivity to $K_{h}$ of LCA(2)], the discharge in low-gradient areas is affected less than discharge fluxes in highgradient areas. Using the Maxey-Eakin recharge method increases the recharge amount by 
approximately one-third and produces simulated discharges that are higher than the target discharge rates listed in Table 7-10. This indicates that the Maxey-Eakin model results in discharge fluxes that are larger than estimated rates supported by existing data. Finally, changing the distribution of recharge within and near the Nevada Test Site has little effect on simulated heads and discharge fluxes since the total amount of recharge within the subbasins remains the same.

\section{Boundary Fluxes}

There is a large uncertainty in the boundary flux estimates for both Sarcobatus Flat and Pahranagat Valley. Two sensitivity runs were conducted to evaluate the effects of increasing the boundary fluxes at Pahranagat Valley and Sarcobatus Flat on head distributions, discharge rates, and particle travel distances. In run $S F_{-} 1700$ (Table 7-14), the flux at Sarcobatus Flat was increased from 0 to $1,700 \mathrm{~m}^{3} / \mathrm{d}$ (0 to $503 \mathrm{ac}-\mathrm{ft} / \mathrm{y}$ ) (the upper end of the estimated range, Table 7-10). Run $P V \_60000$ increased the influx at Pahranagat Valley from 27,000 to $60,000 \mathrm{~m}^{3} / \mathrm{d}$ (7,990 to $\left.17,756 \mathrm{ac}-\mathrm{ft} / \mathrm{y}\right)$, again the upper end of the estimated range. These were the only changes made for the respective runs; hydraulic parameters were not changed by corresponding amounts.

The changes in simulated heads between Base 3 and $S F_{-} 1700$ are very minor. With the exception of Oasis Valley, changes to the discharge fluxes are also minor. The discharge rate in nearby Oasis Valley increased by 5.6 percent, which is approximately 85 percent of the $1,700 \mathrm{~m}^{3} / \mathrm{d}$ (503 ac-ft/y) increase in flux at Sarcobatus Flat. Increasing the influx beneath Sarcobatus Flat had minimal impact on particle travel distances.

In sensitivity run $P V \_60000$, the mean-weighted head in the Pahranagat Valley residual zone increased nearly $95 \mathrm{~m}(311.7 \mathrm{ft})$; this is an artifact of not increasing the conductivity of adjoining LCA zones by an equivalent amount. The increase in the mean-weighted head residual was less than $10 \mathrm{~m}$ (33 ft) in the remaining 14 residual zones. With the increased flux across Pahranagat Valley, discharges increased considerably at Ash Meadows (AM - nearly 47 percent of the increase in Pahranagat Valley influx) and Alkali Flat (AF - also nearly 47 percent). Flux changes elsewhere were minor. The increase in the Pahranagat Valley flux affected particle travel distances in Yucca and Frenchman Flats, but had little effect on other particles. 


\subsection{Hydraulic Conductivity}

Four special-case sensitivity analyses were conducted on specific hydraulic parameters. The analysis names shown in Table 7-14 were selected to identify the hydrostratigraphic unit evaluated in each model simulation and the hydraulic conductivity zone within each HSU that was changed. For example, run $V C U_{-} Z N 2$ changed the hydraulic properties of Zone 2 in the Volcanic Confining Unit (Figure 7-10). The names of the four sensitivity runs and the figures that identify the zone locations for the corresponding HSUs include: $V C U \_Z N 2$ (Figure 7-10); LCA3_ZN1 (LCA3 has only one zone); AA_ZN4\&5 (Figure 7-6); and TMA_ZN6 (Figure 7-7). The following discussion summarizes the results for each of the four sensitivity runs.

Sensitivity Run VCU_ZN2: In Frenchman Flat, recently interpreted aeromagnetic data suggest that the volcanic rocks are not as continuous as incorporated in the geologic model, which would cause greater hydrologic communication between the Alluvial Aquifer and the underlying LCA than is currently represented in the geologic model. In run VCU_ZN2, the section of VCU in question was replaced with parameter values corresponding to the LCA. The resulting flux changes (Table 7-14) are very minor. The effect on heads is minor, with the exception of Western Yucca Flat; this change is believed to be due to numerical instability in this area. The travel distance for the DILUTED WATER particle, which originates in Frenchman Flat (Figure 7-25), increased from 10 to 15 percent; however, the overall travel distance remains small.

Sensitivity Run LCA3_ZN1: The $K_{h}$ for LCA3 is significantly lower than for the other carbonate rocks in the model. In run LCA3_ZNI, the $K_{h}$ was increased from 0.05 to $1.0 \mathrm{~m} / \mathrm{d}$ $(0.2$ to $3.3 \mathrm{ft} / \mathrm{d})$. The mean-weighted residuals decreased significantly in Western Yucca Flat, Shoshone Mountain, and Timber Mountain, indicating that the low $K_{h}$ value for LCA3 is necessary to maintain higher heads in these zones. The low conductivity value probably indicates that the LCA3 is not as continuous as represented in the geologic model. The major changes in fluxes were decreases in the discharge at Oasis Valley (nearly 10 percent) and Alkali Flat (22 percent increase). These changes indicate that the reduction in head in the above residual zones moved the location of the water-table divide westward, diverting water from the Oasis Valley system to the Ash Meadows system.

Sensitivity Run AA_ZN4\&5: The $K_{h}$ values for the coarser-grained zones in the Alluvial Aquifer were determined from calibration and were primarily constrained by the gradient and discharge rates in the Amargosa Desert. However, conductivity values for Zones 4 and 5 
(Yucca and Frenchman Flats, respectively, Figure 7-6) were not constrained by the gradient and discharge rates in the Amargosa Desert. In run $A A \_Z N 4 \& 5$, the conductivity value for AA Zones 4 and 5 was increased from 11 to $100 \mathrm{~m} / \mathrm{d}$ (36 to $328 \mathrm{ft} / \mathrm{d}$ ) (an 800 percent increase). Resulting changes in head were minor except in Eastern Yucca Flat where the mean-weighted residual decreased by $7.2 \mathrm{~m}(23.6 \mathrm{ft})$. The effects on boundary fluxes were very minor. The travel distance for the DILUTED WATER particle (which remains entirely in AA[5] for hundreds of years) increased approximately 600 percent, but was still less than $1 \mathrm{~km}(0.6 \mathrm{mi})$ at 200 years. Particles in Yucca Flat were also affected, but to a much smaller degree.

Sensitivity Run TMA_ZN6: A low conductivity zone was defined at the Black Mountain Caldera to help develop the potentiometric trough present in Area 20 of the Nevada Test Site (Figure 7-20). In run TMA_ZN6, the $K_{h}$ values of the volcanics in this zone were increased to those of the adjacent volcanic HSUs. The effect on heads was significant. Hydraulic heads in the Pahute Mesa, Timber Mountain, Western Yucca Flat, and Northern zones decreased by tens of meters, and the potentiometric trough was absent. With the reduction of heads in the north, the discharge at Penoyer Valley decreased, resulting in increased discharge at Alkali Flat and other areas in the Amargosa Desert as well as a lower discharge rate at Oasis Valley.

Because the conductivities in this zone were increased to those of adjacent volcanic HSUs, the area across which the flux moves is greater, and the flow rates in the Pahute Mesa testing area are decreased. This is illustrated by particle-tracking results for the particles originating on western Pahute Mesa.

\subsection{Summary of Special-Case Sensitivity Analyses}

Overall, the largest effects on particle travel distances were related to the recharge rate (and corresponding changes to hydraulic parameters) used in the model. Increases in the recharge rate (and hydraulic parameters) caused significant increases in travel distances. Based on currently available data, the discharge rates and, therefore, the calculated travel distances obtained in the Base 3 model are considered to be more representative of study area discharge values than rates calculated from either the Rech1.5x or Rch_me sensitivity runs; however, it must be emphasized that there is a large uncertainty in discharge rates within the study area. For example, the current estimates for discharge at Oasis Valley range from 17,000 to $27,000 \mathrm{~m}^{3} / \mathrm{d}(5,031$ to 7,990 ac-ft/y). The Rech1.5x and Rch_me runs both result in simulated discharges of approximately $38,000 \mathrm{~m}^{3} / \mathrm{d}(11,245 \mathrm{ac}-\mathrm{ft} / \mathrm{y})$, which are significantly higher than current estimates. 
Recharge redistribution and increased inflow at Sarcobatus Flat appear to have minimal impacts on head distributions, discharge fluxes, and particle-tracking results within the saturated zone. Increasing influx across Pahranagat Valley causes particles in Yucca and Frenchman Flats to move further westward. Decreasing the flux across Pahranagat was not investigated, but this may allow particles to discharge at Ash Meadows.

Changing the hydraulic conductivity values in the Black Mountain area caused significant changes in travel distance for particles starting on Pahute Mesa, but had minimal effect elsewhere. The movement of the DILUTED WATER particle in Frenchman Flat is significantly affected by the hydraulic conductivity of the valley-fill materials and is only minimally impacted by the continuity of the VCU beneath the basin. In all cases evaluated, however, its travel distance was limited.

\subsubsection{Sensitivity Analyses of Hydraulic Parameters}

The sensitivity of simulated hydraulic heads and fluxes to hydraulic parameters were evaluated by systematically changing individual hydraulic parameter values relative to the base case values (Base 3). All $K_{h}$ values (horizontal hydraulic conductivity projected to land surface) were increased by 100 percent and decreased by 50 percent over Base 3 values, and the depth-decay coefficients $(\lambda, \mathrm{ld})$ were increased and reduced by 10 percent over Base 3 values. Sensitivity testing during the second model calibration sequence indicated a general insensitivity to the anisotropy value, $K_{v}$, so those cases were not analyzed in the present model. There are 58 different $K_{h}$ parameters and 58 individual $\lambda$ parameters, resulting in 116 sensitivity runs with increased parameter values and an equal number of sensitivity runs with decreased values.

The mean-weighted residual and root mean square of the head residuals for each of the fifteen residual zones (Figure 7-4) were recorded for each run, as were the boundary fluxes for the ten different head-dependent flux areas. These data were then used to calculate the changes in these values between the base case and the sensitivity runs. Table C-1 (Appendix C) presents the changes in the mean-weighted residual (between the sensitivity run and the base case) per residual zone as a function of the 100 percent increase and 50 percent decrease in $K_{h}$ values and the 10 percent increase and decrease in the $\lambda$ parameter values. Changes with absolute values greater than or equal to one meter are shaded. A positive change indicates a general increase in water levels within the zone. Table C-2 presents the percentage change in the RMS of the weighted head residuals per zone for the same percentage changes in the parameter values listed above. A positive change indicates an increase in the RMS; shading indicates a change with an 
absolute value greater than or equal to 10 percent. The percentage changes in boundary flux rates between the calibrated model and the sensitivity runs are provided in Table C-3. Positive values indicate an increase in the recharge or discharge flux.

The convention used in naming the sensitivity run provides information on the parameter type ( $K_{h}$ or $\lambda$ ), the HSU identifier, and the HSU zone number, if applicable. For example, $\mathrm{Kh} \_\mathrm{LCA}(3)$ is the horizontal hydraulic conductivity parameter, projected to land surface, for Zone 3 of the LCA.

The effects of the sensitivity runs on simulated heads within each of the 15 residual zones and on the 10 head-dependent flux discharge areas are addressed in detail in the Groundwater Flow Model Documentation Package (IT, 1996f). The data have been included in Appendix C for reference, and a brief summary of results is provided.

Examination of Table C-1 indicates that increases in conductivity values for certain hydrostratigraphic units decrease hydraulic heads in residual zones in the vicinity of and upgradient from those HSUs. This is because downgradient discharge areas (e.g., Death Valley, Amargosa Desert, and Ash Meadows) control heads at the terminal points in the model. If upgradient conductivities are increased and the recharge flux is held constant, then upgradient hydraulic gradients will have to decrease to maintain mass balance, and the corresponding hydraulic heads will decrease.

Tables C-1 to C-3 in Appendix C indicate that individually changing most of the hydraulicconductivity parameters produced only small, local effects in the water levels and boundary fluxes because of the limited spatial distribution of the HSUs. The model was generally more sensitive to changes in $K_{h}$ than $\lambda$. An increase in $K_{h}$ produces a similar change as a decrease in $\lambda$ for the same HSU because each produces an increase in the transmissivity.

The simulated heads in western Yucca Flat behave erratically; this behavior is associated with the process used to simulate rewetting of the cells in this area. A high vertical gradient occurs across the Upper Clastic Confining Unit, and the success of the model in rewetting cells that become dry during the iterative model process appears to determine the value of the residuals. In the second model calibration sequence, the model was specifically calibrated to result in approximately equally weighted residuals in western and eastern Yucca Flat (WYF and EYF, respectively). This resulted in higher simulated hydraulic heads throughout Yucca Flat, which 
minimized the numerical instability associated with rewetting cells in Western Yucca Flat. During the third model calibration sequence, the heads in eastern Yucca Flat were more accurately simulated than in the second sequence because of the importance of gradients beneath eastern Yucca Flat and flow paths from this area. This resulted in a good fit to Eastern Yucca Flat hydraulic heads, but the resultant drop in water levels within Yucca Flat resulted in the inconsistent results for WYF mentioned above.

\subsubsection{Particle-Tracking Results for Hydraulic Parameter Sensitivities}

Because a major goal of the regional flow modeling effort was to provide information to facilitate analysis of contaminant transport from the weapons testing areas, it is important to analyze the effects of the hydraulic parameter sensitivity changes on transport distances and direction. This was done by running MODPATH 116 times using MODFLOW hydraulic head and flux data from 116 separate sensitivity runs. The runs included the 100 percent increase in $K_{h}$ parameters and the 10 percent decrease in the depth-decay coefficients $(\lambda)$. For each of the runs, the transport distances at times of 25, 50, 100, and 200 years from the start of the test for thirteen of the fourteen particle-tracking locations were compiled. Results from GUM DROP were not used because of the numerical sensitivity of the model in the Shoshone Mountain area and the resulting impacts on particle tracking results. These data and the corresponding distance for Base 3 are listed alphabetically by testing location in Appendix I of the Groundwater Flow Model Documentation Package (IT, 1996f).

The information contained in Appendix I (IT, 1996f) is unwieldy without some form of data reduction. To facilitate evaluation of the information, the travel distances were tabulated, and the percent change in distance between Base 3 and the sensitivity runs were calculated. All parameters with percent differences greater than or equal to plus or minus 10 percent of Base 3 values have been grouped by testing location and regional area and are listed in Table 7-15. Positive sensitivities are listed first from largest to smallest positive value. Parameters that fall within this category result in longer transport distances than particles associated with the base case. Negative sensitivities are listed second from largest negative value to smallest negative value. Parameters that fall within this category result in shorter transport distances than travel distances for the Base 3 run.

The 25-year (western Pahute Mesa) and 100-year (others) transport distances for the 116 hydraulic parameter sensitivity runs, plus the base case, are plotted for the thirteen testing locations in Figure 7-26. The points are overlaid on the particle pathlines calculated for the 
Table 7-15

Conductivity Parameters that Caused More than a $10 \%$ Change in the 25- or 100-Year Travel Distance

\begin{tabular}{|c|c|c|c|c|c|c|c|c|c|c|c|c|c|}
\hline \multicolumn{14}{|c|}{ Parameters with Positive Sensitivity*: } \\
\hline $\begin{array}{r}\text { Test } \\
\text { Name }\end{array}$ & DARWIN & PURSE & BULLION & & & CLEARWATER & PILE DRIVER & BOURBON & COULOMMIERS & CORDURO & CUMARIN & STRAIT & DILUTED WATER \\
\hline Area & $\begin{array}{l}\text { Pahute } \\
\text { Mesa }\end{array}$ & $\begin{array}{l}\text { Pahute } \\
\text { Mesa }\end{array}$ & $\begin{array}{l}\text { Pahute } \\
\text { Mesa }\end{array}$ & $\begin{array}{l}\text { Pahute } \\
\text { Mesa }\end{array}$ & $\begin{array}{l}\text { Pahute } \\
\text { Mesa }\end{array}$ & $\begin{array}{l}\text { Rainier } \\
\text { Mesa }\end{array}$ & $\begin{array}{l}\text { Climax } \\
\text { Stock }\end{array}$ & $\begin{array}{l}\text { Yucca } \\
\text { Flat }\end{array}$ & $\begin{array}{l}\text { Yucca } \\
\text { Flat }\end{array}$ & $\begin{array}{l}\text { Yucca } \\
\text { Flat }\end{array}$ & $\begin{array}{l}\text { Yucca } \\
\text { Flat }\end{array}$ & $\begin{array}{l}\text { Yucca } \\
\text { Flat }\end{array}$ & $\begin{array}{l}\text { Frenchman } \\
\text { Flat }\end{array}$ \\
\hline & $\begin{array}{l}\text { KH-TMA(1) } \\
\text { KH-TMA(4) } \\
\text { KH-TMA(3) }\end{array}$ & KH-TMA(1) & $\begin{array}{l}\text { KH-TC(1) } \\
\text { KH-TMA(4) }\end{array}$ & & $\begin{array}{l}\text { KH-VA(1) } \\
\text { KH-TBA(1) } \\
\text { LD-VCU(1) } \\
\text { LD-TMA(1) }\end{array}$ & & $\begin{array}{l}\text { KH-VU(1) } \\
\text { KH-LCCU(1) } \\
\text { KH-BCU(1) } \\
\text { KH-LCA(1) } \\
\text { KH-VA(3) } \\
\text { KH-TSDV(2) } \\
\end{array}$ & & $\overline{\mathrm{KH}-\mathrm{VU}(1)}$ & $\overline{\overline{K K H}-\mathrm{VU}(1)}$ & $\begin{array}{l}\text { KH-VU(1) } \\
\text { LD-LCA(1) } \\
\text { KH-AA(1) } \\
\text { KH-LCCU(1) } \\
\text { KH-LCA(2) } \\
\text { KH-BCU(1) } \\
\end{array}$ & $\begin{array}{l}\mathrm{KH}-\mathrm{VU}(1) \\
\text { LD-LCA(1) } \\
\text { KH-AA(1) }\end{array}$ & $\begin{array}{l}\text { KH-AA(5) } \\
\text { LD-LCA(1) }\end{array}$ \\
\hline \multirow{3}{*}{$\begin{array}{r}\text { Test } \\
\text { Name } \\
\text { Area }\end{array}$} & & & & & & $\underline{\text { Parameters }}$ & & & & & & & \\
\hline & & & BULLION & TYBO & HOUSTON & CLEARWATER & PILE DRIVER & BOURBON & COULOMMIERS & $\begin{array}{c}\text { CORDURO } \\
Y\end{array}$ & CUMARIN & STRAIT & DILUTED WATER \\
\hline & $\begin{array}{l}\text { W. Pahute } \\
\text { Mesa }\end{array}$ & $\begin{array}{l}\text { W. Pahute } \\
\text { Mesa }\end{array}$ & $\begin{array}{l}\text { W. Pahute } \\
\text { Mesa }\end{array}$ & $\begin{array}{l}\text { W. Pahute } \\
\text { Mesa }\end{array}$ & $\begin{array}{l}\text { Pahute } \\
\text { Mesa }\end{array}$ & $\begin{array}{l}\text { Rainier } \\
\text { Mesa }\end{array}$ & $\begin{array}{l}\text { Climax } \\
\text { Stock }\end{array}$ & $\begin{array}{c}\text { Yucca } \\
\text { Flat }\end{array}$ & $\begin{array}{l}\text { Yucca } \\
\text { Flat }\end{array}$ & $\begin{array}{c}\text { Yucca } \\
\text { Flat }\end{array}$ & $\begin{array}{c}\text { Yucca } \\
\text { Flat }\end{array}$ & $\begin{array}{l}\text { Yucca } \\
\text { Flat }\end{array}$ & $\begin{array}{l}\text { Frenchman } \\
\text { Flat }\end{array}$ \\
\hline & $\begin{array}{l}\text { LD-TMA(4) } \\
\text { LD-TMA(1) }\end{array}$ & $\overline{\mid L D-T M A(1)}$ & $\begin{array}{l}\text { LD-TC(1) } \\
\text { KH-TMA(1) }\end{array}$ & & $\begin{array}{l}\mathrm{KH}-\mathrm{VCU}(1) \\
\mathrm{KH}-\mathrm{LCCU}(1)\end{array}$ & & $\begin{array}{l}\text { KH-UCCU } \\
\text { LD-VU(1) } \\
\text { LD-LCA(1) } \\
\text { LD-LCCU(1) } \\
\text { LD-BCU(1) }\end{array}$ & $\overline{\mathrm{KH}-\mathrm{VU}(1)}$ & & & \begin{tabular}{|l} 
LD-VU(1) \\
KH-LCA(8) \\
LD-LCCU(1) \\
LD-TMA(1) \\
LD-AA(1)
\end{tabular} & $\overline{\mathrm{LD}-\mathrm{VU}(1)}$ & $\begin{array}{l}\text { KH-LCA(1) } \\
\text { LD-AA(5) }\end{array}$ \\
\hline
\end{tabular}

Note - For western Pahute Mesa particles, the sensitivities were evaluated for the 25-year travel distance. For other particles, sensitivities were evaluated for the 100 -year travel distance. 
calibrated model (Figure 7-25). It should be remembered that the particle pathlines show flow paths from testing locations to downgradient discharge areas independent of a time component. Additionally, the calculated travel distances displayed in Figure 7-26 do not incorporate retardation processes and will, therefore, overestimate the calculated travel distances (Section 9.0).

The four particles starting on western Pahute Mesa (PURSE, DARWIN, TYBO, and BULLION) traveled to the discharge area through the Timber Mountain Aquifer or Tuff Cone. For each of the particles, the travel distance at 25 years was most sensitive to the $K_{h}$ and/or $\lambda$ of the HSU in which the particle started (Table 7-15). For example, the DARWIN particle started in TMA(1); doubling the $K_{h}$ of TMA(1) resulted in a 228 percent increase in the 25 -year travel distance (furthest point along DARWIN flowpath in Figure 7-26). The starting HSUs for PURSE and BULLION are TMA(1) and TC(1), respectively (TYBO discharged in less than 25 years, and a sensitivity could not be calculated). The 25 -year travel distances are secondly most sensitive to the hydrologic properties of the HSUs immediately downgradient from the originating HSU. This sensitivity is usually greatly reduced when compared to the sensitivity of changes to the originating HSU. For example, doubling the $K_{h}$ of TC(1) (the second HSU encountered by the DARWIN particle along its flowpath) resulted in a change in the absolute value of the flowpath length of only 6 percent. The HOUSTON particle, which starts in the eastern part of Pahute Mesa and has a significantly different path, is discussed below.

The 100-year travel distance for CLEARWATER, starting on Rainier Mesa, is not very sensitive to any of the parameter changes evaluated. Even though the particle starts in the Lower Clastic Confining Unit (LCCU[1]), doubling its $K_{h}$ produced less than a 2 percent increase in the travel distance, perhaps because it resulted in a longer flow path within the LCCU. It should be emphasized that the working point is located more than two-cavity radii above the water table. Travel in the unsaturated zone, in conjunction with migration through the LCCU, indicates that this pathway is of minimal concern with respect to contaminant transport.

Four of the five particles originating within Yucca Flat (CORDUROY, COULOMMIERS, CUMARIN, and STRAIT) all have positive sensitivities to the $K_{h}$ of the Undifferentiated Volcanics (VU[1]). The VU(1) is present north of Yucca Flat and provides the pathway for underflow from Emigrant Valley into Yucca Flat; increasing its conductivity increases the underflow and the 100-year travel distances about 20 to 35 percent. The 100- and 200-year travel distances for the BOURBON particle, however, appear to decrease with an increase in $K_{h}$ 
of VU(1). The BOURBON particle migrates immediately below the contact between the overlying VCU and the underlying LCA, and the apparent decrease in flowpath length is probably due to an artifact of assigning effective porosity values to HSUs within the hydrologic model.

The travel distance for the CUMARIN particle, the fifth Yucca Flat particle, is sensitive to a larger number of parameters than the remaining Yucca Flat particles; the reason for this is not clear. In Base 3, the particle appears to frequently move between the LCA and VCU due to an artifact in assigning effective porosity values to HSUs within the hydrologic model; this behavior was also noted in the BOURBON particle. The movement of the CUMARIN particle between the LCA and VCU is not representative of the actual pathway of the particle since it would tend to migrate within the LCA below the LCA/VCU contact. It is, therefore, possible that the large number of sensitivities listed in Table 7-15 represent those parameters that affect the path length of the particle within the VCU and are also an artifact of the model and not representative of actual sensitivities.

When the $\lambda$ of LCA(1) is increased, indicating a greater reduction of conductivity with increasing depth, the travel distances of the Yucca Flat particles increase. This change in $\lambda$ effectively decreases the thickness of the LCA and forces flow into a thinner interval at the top of the LCA, resulting in a net increase in velocity and travel distance.

The movement of the PILE DRIVER particle is sensitive to a large number of parameters. Those with the greatest effect are those that control the flux across the barrier at the northern end of Yucca Flat, including the $K_{h} s$ and $\lambda$ s of the undifferentiated volcanics (VU[1]), Lower Clastic Confining Unit (LCCU[1]), Non-Welded Tuffs (BCU[1]), and LCA(1). Doubling the $K_{h}$ of the Upper Clastic Confining Unit resulted in no movement of the particle, which suggests that the originating cell desaturated.

The 100-year travel distance for the Frenchman Flat particle, DILUTED WATER, is increased when the conductivity of Zone 5 of the Alluvial Aquifer (AA[5]), the originating HSU, is increased or its $\lambda$ value is decreased. The travel distance is less sensitive to the $K_{h}$ of Zone 1 of the Undifferentiated Volcanics (VU[1]) than are particles within Yucca Flat, indicating that underflow across the barrier north of Yucca Flat is not as important to Frenchman Flat particles as the flux of water coming from the east. Because the DILUTED WATER particle does not travel far from its original location in 100 years, it remains within the Alluvial Aquifer. 
Increasing the LCA transmissivity reduces the gradient in the AA in northern Frenchman Flat and reduces the particle velocity by approximately 45 percent.

Perhaps the most important aspect to note in Figure 7-26 is that, despite the large changes in parameter values, nearly all particles representing the sensitivity runs plot on the pathlines calculated for Base 3. For these particles, the assumption used in the transport modeling (that the HSUs through which the particle passes for the base case can be used for the Monte Carlo runs) is reasonable. The HOUSTON particle, however, varies from its base-case pathline. This probably results from its proximity to the eastern boundary of the Oasis Valley groundwater subbasin; changing the model parameters changes the location of the simulated subbasin boundary. The approximate east-west alignment of the points for HOUSTON (Figure 7-26) coincides with the contact between the Tuff Cone and Volcanic Confining Unit at the southern edge of the Timber Mountain caldera.

The conductivity parameters that have the greatest effect on travel distance are not necessarily the ones that have the greatest effect on location. This is well-illustrated with the HOUSTON particle. The eastern-most point (Figure 7-26) is for the sensitivity run where the $K_{h}$ of VCU(1) was doubled. The VCU is part of the barrier at the northern end of Yucca Mountain; increasing its conductivity allows more water to flow through this area and moves the HOUSTON pathline eastward from the base case. The 100-year travel distance was increased 14.5 percent. The western-most points are for doubling the $K_{h} s$ of Zone 1 of the Volcanic Aquifer [VA(1)] and the Welded Tuff Aquifer [TBA(1)]. The 100-year travel distances were increased 13.9 and 12.5 percent, respectively. For those particles that lie along the base-case pathline, the correspondence between the parameters which affect travel distance and the plotted particle location is much closer. For example, the southern point for BULLION is the particle location for the sensitivity case where the $K_{h}$ of Zone 1 of the Tuff Cone [TC(1)] was doubled. This resulted in nearly a 200 percent increase in the 25 -year travel distance or a tripling of the distance traveled.

\subsection{Summary of Flow Model Results}

This report documents the development, calibration, and results of a regional three-dimensional, steady-state flow model of the Nevada Test Site regional groundwater flow system. The model is designed to provide a basis for predicting the movement of contaminants from the underground nuclear testing areas on a regional scale, constrained by estimates of the amount of water moving through the groundwater system. It is also intended to provide a means for 
evaluating the uncertainty in these predictions by allowing the easy modification of hydrologic parameters. The model can also be used to supply boundary conditions for more detailed models of the underground testing areas that are consistent with regional mass-balance information.

\subsubsection{Model Design}

The model is based on a complex geologic model of an even more complex geologic framework. It incorporates extensive hydrologic data and uses water levels from more than 900 sampling points. It was constructed to more accurately simulate the hydrology of the areas of concern, including the weapons testing areas and downgradient regions, than areas that are distant from the NTS. The modeling procedure was developed specifically to facilitate quality assurance checks by minimizing data entry errors and allowing reproducibility of results.

The groundwater system was modeled using MODFLOW. The model grid consists of 68 columns by 76 rows and 20 layers. The large number of layers was necessary to accurately simulate the geologic complexity of the thinner, hydrologically significant hydrostratigraphic units, primarily located in Pahute Mesa and Yucca Flat, and to increase numerical accuracy. The nonuniform grid is more finely spaced in the vicinity of the NTS and downgradient from it and is rotated 5 degrees clockwise to match the orientation of the average fracture direction in the primary testing areas of concern, Pahute Mesa and Yucca Flat. General-head boundary cells were used to simulate underflow across model boundaries in the southern part of the model where flux estimates are based solely on estimates of transmissivity and information of hydraulic gradients. A constant-flux boundary condition was used at Pahranagat Valley where geochemical data provide additional constraints on inflow rates. Drain cells were utilized to simulate discharge due to springs and evapotranspiration.

Distribution of recharge was based on a modification of the Maxey-Eakin approach. The ME coefficients imply that recharge does not occur when the annual precipitation is less than $20 \mathrm{~cm}$ (8 in.). In the recharge model used for the flow model, the lower threshold was reduced to $16 \mathrm{~cm}$ (6.3 in.), and coefficients lower than the ME coefficients were used. The net recharge to the model was approximately $204,000 \mathrm{~m}^{3} / \mathrm{d}(60,373 \mathrm{ac}-\mathrm{ft} / \mathrm{y})$, compared with approximately $270,000 \mathrm{~m}^{3} / \mathrm{d}(79,905 \mathrm{ac}-\mathrm{ft} / \mathrm{y})$ for the ME recharge model. In addition, 20 percent of the recharge water in the vicinity of the NTS was redistributed downstream to simulate infiltration along stream channels and on alluvial fans. The ME recharge model was evaluated in later sensitivity runs. 


\subsubsection{Model Calibration}

This report primarily addresses the results from the final of three model calibration sequences. Both hydraulic heads and fluxes were used as target criteria during model calibration. The target heads consisted of 798 sampling locations within the active cells of the model domain. Fifteen residual zones were defined for which the mean and RMSs of the weighted head residuals were calculated for comparison with previously determined calibration criteria. This approach allows flexibility in establishing calibration criteria to reflect the geohydrologic complexity and available data for different areas, and it is more sensitive to mismatches than applying calibration criteria on a model-wide basis.

The overall model has a mean-weighted residual of $7.9 \mathrm{~m}(25.9 \mathrm{ft})$ and an RMS of $51.3 \mathrm{~m}$ $(168.3 \mathrm{ft})$. The range in measured heads is nearly $1,690 \mathrm{~m}(5,545 \mathrm{ft})$, so the above values represent 0.4 and 3.0 percent of the range, respectively. The individual head calibration criteria were met in eleven of the fifteen zones. In two of the remaining four residual zones (LCA and OASI), the criteria were very tight. The achieved mean-weighted residuals for the calibrated model for these zones were 3.6 and 7.1 percent of the range in measured heads within the respective zones. For the other two zones (WYF and SHON) the criteria could have been met, but would have resulted in higher residuals in EYF. Because it was felt that minimizing Eastern Yucca Flat residuals was essential due to the importance of flow paths from Yucca Flat into Frenchman Flat, the EYF residual was minimized at the expense of higher residuals within Shoshone Mountain and Western Yucca Flat.

Estimates of the boundary fluxes in twelve areas were also used to set additional calibration goals. Discharge and recharge flux estimates within the model area are highly uncertain, and target flux ranges were established for each of the twelve areas to incorporate this uncertainty. The calibration goal was for the simulated fluxes to be within the range of estimates, but the calibration was performed to minimize the deviation between the simulated flux and a value considered to be the "best estimate" of the flux. The match to these target values is very good. For the largest two discharge areas (Ash Meadows and Death Valley), the simulated values are within 0.5 percent of their respective target values. The mismatch at Oasis Valley was only 3.1 percent. For four of the smaller discharge areas, the simulated values were outside the respective target ranges. However, the sum of the absolute value of the deviations from the target values for these areas was slightly over $7,000 \mathrm{~m}^{3} / \mathrm{d}(2,072 \mathrm{ac}-\mathrm{ft} / \mathrm{y})$ or about 3 percent of the total flux through the system. 
The calibrated model accurately simulates several observed hydrologic features present on the Nevada Test Site. The high gradient between Emigrant Valley and Yucca Flat is present as is the high gradient north of the Yucca Mountain area. The higher hydraulic heads in the western part of Yucca Flat above the Upper Clastic Confining Unit are present. A moderately low gradient across Timber Mountain, increasing to the north beneath Pahute Mesa, is well-simulated. The potentiometric trough located in Area 20 on Pahute Mesa is also present.

\subsubsection{Particle Tracking}

As part of the application of the model, particle-tracking calculations using the computer code MODPATH were performed. Additional postprocessing of the MODPATH results was done to include the different effective porosities of the HSUs through which the particle traveled. Particle starting locations were based on the locations of underground tests. From over 400 locations, which included tests where their working point was less than two cavity radii above the water table, fourteen particles were selected. These were chosen so that each testing area (Pahute Mesa, Rainier Mesa, Yucca Flat, Climax Stock, Shoshone Mountain, and Frenchman Flat) was represented. Further, particles with rapid estimated movement in each testing area were selected. Results indicate that particles originating in the Western Pahute Mesa testing area discharge in Oasis Valley. Particles originating in the eastern testing areas (Yucca Flat and Frenchman Flat) discharge in Death Valley or the Amargosa Desert, but not at Ash Meadows. The geologic model contains no effective barrier to prevent water from leaving Yucca or Frenchman Flats and traveling southwestward beneath Rock Valley and eastern Jackass Flats. Without a large volume of water coming into and leaving Yucca Flat to overwhelm water from the eastern part of the flow system, there is no reason to expect water from Yucca Flat or Frenchman Flat to discharge at Ash Meadows.

\subsubsection{Sensitivity Analysis}

Extensive sensitivity analyses were performed on both water level and boundary flux responses and on particle-tracking results. The sensitivity analysis was performed in two separate steps. The first step involved changing basic assumptions of the model such as using different versions of the digital geologic model and recharge models. The second step was a systematic variation of the hydraulic parameters; the $K_{h}$ (horizontal hydraulic conductivity projected to land surface) values and depth-decay coefficients were both increased and decreased by specified amounts.

The sensitivity analysis of the different geologic models confirmed that a barrier to flow in the area of Calico Hills westward to Bare Mountain is needed to match estimated discharge rates at 
Oasis Valley and observed gradients in this area. This barrier is based on structural relationships associated with the Belted Range Thrust and alteration of volcanic rocks in the Claim Canyon Caldera segment and northern Yucca Mountain. This interpretation is consistent with geologic and hydrologic information in the area. In addition, an interpretation that the UCCU is continuous beneath Rainier Mesa is consistent with hydraulic-head observations in Well ER-12-1 (Appendix B) and provides better agreement with head data elsewhere. The changes in the geologic model near Penoyer Valley resulted in an improvement in the hydrologic model, but lower hydraulic conductivities for LCA rocks in the northern part of the model were still needed to match water levels and estimated fluxes in that part of the model.

Sensitivity analyses were performed for several different recharge models. The results from the recharge sensitivity models include the following:

- When the recharge rates and hydraulic conductivities are increased or decreased by the same factor, the model behaves in an approximately linear fashion.

- Travel distances for particles on Western Pahute Mesa increase several-fold when the recharge rates and hydraulic conductances are increased while the increases for particles from other testing areas are moderate.

- Use of the Maxey-Eakin recharge model, and similarly increasing HSU hydraulic conductivities by the Maxey-Eakin-to-base case recharge ratio, produces effects similar to those described above. However, the distribution of the recharge differs. With the Maxey-Eakin approach, there was a greater percentage increase in discharge in higher gradient areas upgradient of the Lower Clastic Confining Unit barrier (e.g., Penoyer Valley). The Maxey-Eakin model results in discharge fluxes that are larger than estimated rates currently supported by existing data.

- Redistribution of recharge to downstream areas on and near the NTS has little effect on water levels, discharge rates, or particle movement.

Other sensitivity analyses were performed to evaluate the effects of uncertainty in the specified flux boundary conditions and in changes to hydraulic conductivity values other than those that were evaluated as part of the systematic analysis described in the following text. Findings from these "special-case" sensitivities include:

- The transport distance in Frenchman Flat is sensitive to the conductivity of the Alluvial Aquifer in Frenchman Flat, but the travel distances are likely to be short for reasonable values of $K_{h}$. 
- Removing the low-conductivity zonation in the vicinity of Black Mountain also removed the potentiometric trough located at Pahute Mesa. This indicates that the low conductivity zone can explain the presence of the trough, but there may be other interpretations that would provide similar results.

A systematic sensitivity analysis was performed on the $K_{h}$ and $\lambda$ values of the 58 different HSUs as well as on the sensitivities to changes in boundary fluxes. The majority of results indicated that increasing the conductivity value for a given HSU decreased heads in residual zones in the vicinity or upgradient of that HSU. This is because downgradient discharge areas control heads at the terminal point in the model; if upgradient conductivities increase and the recharge remains the same, then resultant heads must decrease to maintain mass balance. Travel distances of particles are generally most sensitive to changes in the hydraulic properties of the HSU in which they start. The increase in travel distance, expressed on a percentage basis, is usually less than the percentage change in $K_{h}$ for the starting HSU. In some instances, however, the percentage change in travel distances may be several times greater than the change in $K_{h}$. Sensitivity results also indicated the following:

- Lower LCA conductivity values are necessary in the northern part of the model than elsewhere to maintain necessary heads and fluxes;

- Particles originating on Western Pahute Mesa move quickly downgradient from the starting locations, discharging to the south and southwest at Oasis Valley.

- Particles within Yucca Flat discharge in either the Amargosa Desert or Death Valley, but not at Ash Meadows.

- Particles originating on Rainier Mesa or within Frenchman Flat do not migrate far from their starting locations within the 200-year time period evaluated.

- Particle travel distance commonly increased significantly when recharge was increased, suggesting that specific discharges increase downgradient.

- Despite the large changes in hydraulic parameter values, nearly all particles evaluated plot on the pathlines calculated for the base case simulation.

In summary, the NTS regional groundwater flow model incorporates a significant amount of detail at the regional scale and provides excellent agreement to observed head and flux data. The model will be able to provide initial estimates of boundary fluxes for future local scale transport modeling; however, the constraints placed by the regional model on hydrologically significant parameters specific to each underground test area should be evaluated prior to local-scale 
transport modeling. Additionally, the effects of the uncertainty in the regional model discharge fluxes on the uncertainty in the boundary fluxes for each of the underground test area models should also be evaluated. 


\subsection{Transport Parameters and Source Term}

The rate at which radioactive contaminants move in a groundwater flow system is a function of physical and chemical transport parameters such as porosity, dispersivity, sorption, matrix diffusion, and radioactive decay. Contaminant migration in groundwater is also a function of the contamination source. This section presents the objectives, general approach used, data types needed, data sources, and the process used in the generation of the dataset necessary for the modeling of tritium transport through the NTS regional groundwater flow system.

\subsection{Objectives}

The main objective of this task was to assemble all data necessary for the design of a onedimensional (1-D) tritium transport model within the regional groundwater flow system of the NTS. In addition to data from the groundwater flow model, the tritium transport model required information on transport parameters and source term. Further objectives were as follows:

- Assemble a dataset that provides representative values of matrix porosity of typical geologic units of the NTS region.

- Assemble a dataset that provides representative estimates of dispersivity values of typical geologic units of the NTS region.

- Compile readily available data on matrix diffusion of tritium.

- Estimate an average source term for tritium to be used in transport modeling.

\subsection{General Approach}

The general approach includes the following steps:

- Compile and qualify available porosity data.

- Perform statistical analysis to calculate mean porosity values and variances for hydrostratigraphic units.

- Compile and summarize the existing dispersivity data.

- Compile and summarize the existing data on matrix diffusion.

- Estimate an unclassified value of the average tritium source term. 


\subsection{Data Types}

Types of transport parameter data needed for modeling the migration of radionuclides include dispersivity, adsorption, matrix diffusion and radioactive decay. These data types and the corresponding processes are described in this section. Another important parameter that affects the adsorption and diffusion processes, matrix porosity, is also discussed as well as the source of contamination which also affects the migration of radionuclides in groundwater.

In fractured geologic media, the permeable fractures are separated by blocks of unfractured rock material called matrix. Typically, the matrix porosity of granular materials is on the order of 25 to 40 percent, whereas fracture porosity ranges from less than 0.01 to 10 percent (Freeze and Cherry, 1979). Radionuclides can diffuse into and sorb onto the rock matrix. Matrix porosity affects the adsorption and diffusion processes. In unconsolidated porous media such as the Alluvial Aquifer, the matrix porosity is equivalent to the effective porosity (see Section 5.0).

The spreading phenomenon of solutes in groundwater at a macroscopic level by the combined action of mechanical dispersion and molecular diffusion is called hydrodynamic dispersion (Van Der Heijde et al., 1988). Dispersion is a mixing process that causes dilution of the solute (Freeze and Cherry, 1979), and it is normally simulated as a Fickian diffusion process using a parameter called dispersivity to control the amount of spreading. Assessment of aquifer dispersivity is essential for predicting contaminant plume migration in groundwater. The dispersivities, both the longitudinal and transverse, are key input parameters to the governing transport equation used to estimate the concentration distribution of a solute in groundwater over time and space.

Adsorption occurs when a dissolved ion or molecule becomes attached to a preexisting solid substrate. The process includes cation exchange, surface complexation, and size-selective adsorption by zeolites. The adsorption process will not be discussed any further because tritium does not adsorb to the rock matrix to a significant degree. Thus, the adsorption coefficient for tritium is zero.

Matrix diffusion affects the rate of movement of contaminants in fractured media. It is a local transport phenomenon of the contaminant from the fracture to the rock matrix. As water and tritium flow along a fracture, a concentration gradient develops between the fracture and the water in the rock matrix immediately next to the fracture. This concentration gradient will cause tritium to diffuse from the fracture into the matrix where it remains for some period of time. At a later time, after the tritium front in the fracture has passed, the concentration gradient reverses, 
and tritium may move back into the fracture. During the time the tritium is in the matrix, the water in the fracture continues to move. Therefore, the mechanism of matrix diffusion slows the movement of the tritium with respect to the movement of the groundwater.

For radioisotopes such as tritium, radioactive decay is another process that affects the transport of contaminants in groundwater. Radioactive decay is incorporated into the contaminant transport code using a simple equation requiring the knowledge of the half-life of the radioactive agent of concern and the time when decay was initiated. Tritium decays to helium while emitting a beta particle; its radiological half-life is 12.3 years. The time when decay is initiated is discussed in Section 9.0. No data compilation was required for these two variables.

The initial volume and concentration of the source contaminant are necessary in simulating the transport of the contaminant in groundwater. Data relating to the Underground Test Area source terms are generally classified. Specifically, inventories of individual shots are classified; however, average tritium activities, which are unclassified, were available.

\subsection{Data Sources}

In general, sources of transport parameter data are limited. Sources of porosity data include a variety of geophysical logs (neutron, resistivity, and sonic logs) which are available from various reports and publications. The amount of site-specific dispersivity data available is limited to data obtained from a few transport experiments conducted on the NTS. Other sources of dispersivity data consist of only a few publications. Very little information was found to define the matrix diffusion characteristics of tritium into porous media at the NTS. Only one publication directly relevant to the diffusivity of tritium on NTS rocks was available (Triay et al., 1993). Unclassified data relating to the radiologic source term were obtained from a Los Alamos National Laboratory document (IT, 1996e).

\subsection{Matrix and Bulk Porosity}

Porosity is a significant component of the velocity of the groundwater and the tendency of the radionuclide to diffuse from the fractures into the rock matrix. Effective porosity data derived from tracer tests are discussed in Section 5.0. Matrix and bulk porosity data are discussed in this section.

\subsubsection{Data Compilation and Evaluation}

The porosity data were obtained from a variety of documents. The methods used to measure porosity include laboratory measurements on cores and interpretations of geophysical logs. For 
fractured consolidated geologic units, core data generally measure matrix porosity only because of the limited size of the cores, often only a few centimeters in length. For granular material, the matrix porosity may also be a reasonable estimate of the effective porosity.

A variety of geophysical logs (neutron, resistivity, and sonic) are used to determine the porosity of the formation near the borehole. The measurement scale of the geophysical logs can extend out to about a meter, depending on the type of $\log$ (Serra, 1984). The larger measurement scale for the geophysical logs will likely encompass fractures in the formation. Thus, the bulk porosity from the geophysical logs is more representative of the formation as a whole. In granular materials, the bulk porosity is also a good estimate of the effective porosity, but may not be as good a value in fractured media.

For many clastic hydrogeologic units, the matrix porosity is much larger than the fracture porosity; thus, the bulk porosity is considered a good estimate of the matrix porosity in those cases. In fractured units, the bulk porosity is still a good measure of formation porosity, but may not be as useful for separating the porosity into matrix and fracture (or effective) components. Data analysis results on bulk and matrix porosity studies are presented below.

\subsubsection{Data Analysis}

The porosity data from specific depths or locations, presented in the Transport Parameter and Source Term Data Documentation Package (IT, 1996e), were statistically summarized per HSU. Many records had multiple values of porosity obtained from different methods, such as multiple geophysical logs. In those cases, all the values per record were averaged to yield a single value. For each record, the average porosity was sorted by HSU and analyzed statistically to provide an estimate of the mean and variance of the matrix, and the bulk and fracture porosity of each HSU.

The detailed matrix and bulk data are summarized in Table 8-1. These values can be generalized even further by grouping the data into five generalized hydrogeologic units of Alluvial Aquifer (AA), Volcanic Aquifers (BAQ, TBA, TMA, VTA, WTA, WLA), Volcanic Confining Units (BCU, TCU, VCU), Carbonate Aquifer (LCA), and Clastic Aquitards (UCCU, LCCU). A weighted average porosity for each of the generalized hydrogeologic units is obtained from the mean values in Table 8-1, weighted by the number of data points (Table 8-2). These averages are compared to those derived by other authors, such as Burkhard (1989) for Yucca Flat. 
Table 8-1

Statistical Summary of Porosity

(Porosity is in percent)

\begin{tabular}{|c|c|c|c|c|c|}
\hline Hydrostratigraphic Unit & Type & Mean & Variance & $\begin{array}{l}\text { Range of Values } \\
\min / \max \end{array}$ & $\begin{array}{l}\text { Number } \\
\text { of Points }\end{array}$ \\
\hline Alluvial Aquifer & Bulk & 36.3 & 79.8 & $10-49$ & 126 \\
\hline Alluvial Aquifer & Matrix & 25.2 & 32.3 & $13.4-38.6$ & 18 \\
\hline Basil Aquifer & Bulk & 14.3 & 20.9 & $8.5-23$ & 9 \\
\hline Basil Aquifer & Matrix & 18.4 & 28.6 & $9.1-27.1$ & 25 \\
\hline Basil Confining Unit & Matrix & 38.3 & 13.4 & $33.2-45.2$ & 16 \\
\hline Belted Range Aquifer & Bulk & 28.4 & 66.6 & $19-39$ & 7 \\
\hline Lower Carbonate Aquifer & Bulk & 11.7 & 0.3 & $11-12$ & 3 \\
\hline Lower Carbonate Aquifer & Matrix & 3.8 & 7.5 & $0.3-9.9$ & 18 \\
\hline $\begin{array}{l}\text { Lower Clastic Confining } \\
\text { Unit }\end{array}$ & Matrix & 3.3 & 6.5 & $0.2-10$ & 31 \\
\hline Tuff Confining Unit & Matrix & 28.1 & 64 & $7.3-47.5$ & 75 \\
\hline $\begin{array}{l}\text { Topopah Spring Tuff } \\
\text { Aquifer }\end{array}$ & Matrix & 23.7 & NA & NA & 1 \\
\hline Timber Mountain Aquifer & Bulk & 16.2 & 132.5 & $3.4-58.3$ & 332 \\
\hline Timber Mountain Aquifer & Matrix & 23.2 & 172.8 & $7-54$ & 32 \\
\hline $\begin{array}{l}\text { Upper Clastic Confining } \\
\text { Unit }\end{array}$ & Matrix & 8.8 & 20.6 & $1.3-22.6$ & 34 \\
\hline Vitric Tuff Aquifer & Matrix & 34 & 84.3 & $19.9-44$ & 17 \\
\hline Welded Tuff Aquifer & Matrix & 20 & 138.1 & $1.4-65$ & 639 \\
\hline Wahmonie Lava Aquifer & Bulk & 16 & 2.8 & $14-18.7$ & 6 \\
\hline Wahmonie Lava Aquifer & Matrix & 27.4 & 13.8 & $22.3-33.5$ & 13 \\
\hline Volcanic Confining Unit & Matrix & 16 & 13 & $9.2-23.5$ & 28 \\
\hline
\end{tabular}


Table 8-2

Summary of Porosity Data for Major Hydrostratigraphic Units as Compared to Work by Others

\begin{tabular}{||l|c|c||}
\hline \multicolumn{1}{|c|}{ Hydrostratigraphic Unit } & Porosity from this Study & Porosity from Literature $^{\mathrm{a}}$ \\
\hline \hline Alluvial Aquifer & 34.9 & 34.8 \\
\hline Volcanic Aquifer & 19.1 & 36.2 \\
\hline Volcanic Confining Units & 26.8 & 45.1 \\
\hline Carbonate Aquifer & 4.9 & 2.5 \\
\hline Clastic Confining Units & 6.2 & 3.6 \\
\hline \hline
\end{tabular}

B Burkhard (1989)

Two major conclusions can be drawn from these statistical summaries. First, the alluvial and volcanic units have significantly larger porosities than the Paleozoic carbonate and clastic units. Second, the volcanic aquifers are less porous than the volcanic confining units. This is because the volcanic aquifer units tend to be welded, which reduces the porosity.

\subsection{Dispersivity}

The available dispersivity measurements were obtained from transport experiments that have been performed at or near the NTS. Additionally, other dispersivity data from the literature were used to evaluate the range of variability.

The data relating to the three site-specific transport experiments have been analyzed by various researchers to estimate longitudinal dispersivity values. The analysis methods used and results are provided in detail in the Transport Parameter and Source Term Data Documentation Package (IT, 1996e) and summarized in this section. The test data and results are presented in Table 8-3 which provides the aquifer type and geology, test method, tracer type, analytical method, and the derived dispersivities. The calculated site-specific dispersivity values range between 0.6 and $30 \mathrm{~m}$ ( 2 to $98 \mathrm{ft}$ ) for test scales ranging between 30 and $120 \mathrm{~m}$ (98 and $394 \mathrm{ft}$ ).

A critical review of dispersivity observations from 59 different field sites, domestic and abroad, was conducted by Gelhar et al. (1992). The review includes extensive tabulations of information on site location, geology, descriptions of aquifer material, average aquifer saturated thicknesses, hydraulic properties, effective porosity values, mean pore velocity values, flow configuration, dimensionality of monitoring network, tracer type, method of data interpretation, 
Table 8-3

\section{Longitudinal Dispersivity Information Summary}

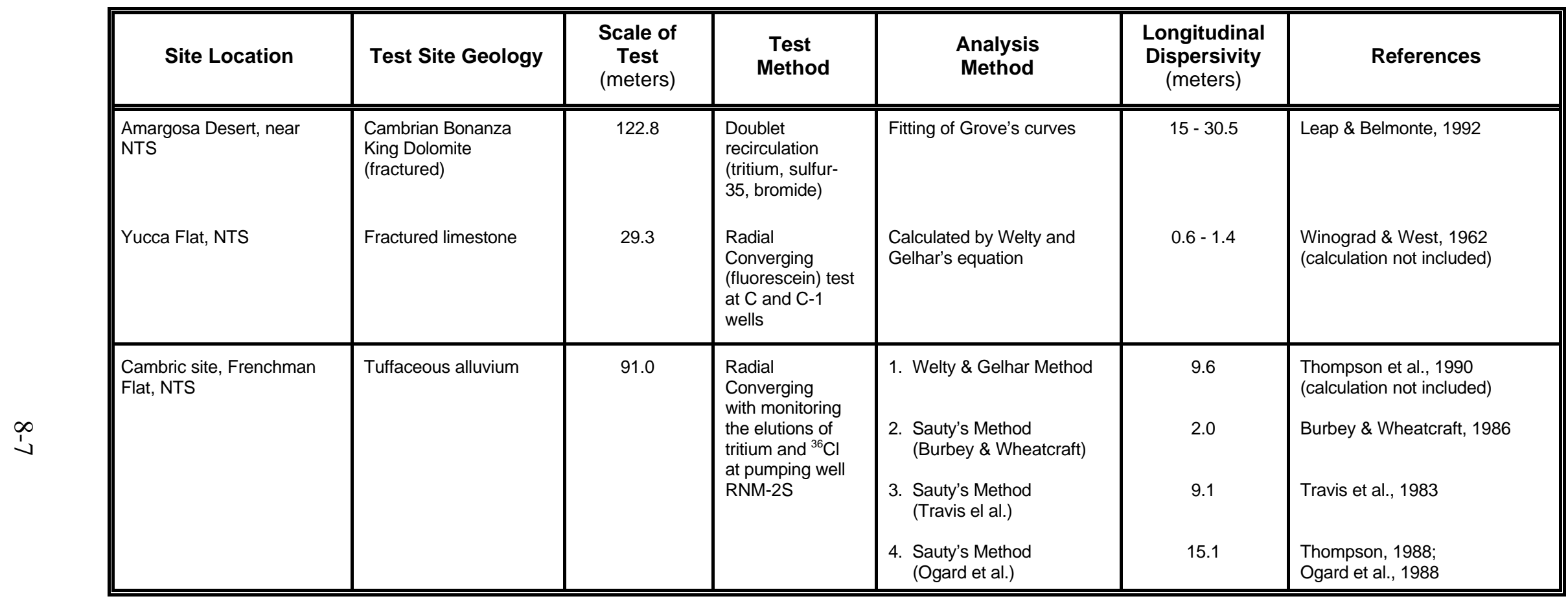


overall scale of observation, and longitudinal and transverse dispersivities from original sources. This information was used to classify the dispersivity data into three reliability classes. The analysis indicated a trend of systematic increases of the longitudinal dispersivity with observation scale, but the trend is much less clear when the reliability of the data is considered. The longitudinal dispersivities ranged from 0.01 to $10,000 \mathrm{~m}(0.03$ to $32,808 \mathrm{ft})$ for distances ranging from 0.1 to $100,000 \mathrm{~m}(0.33$ to $32,808 \mathrm{ft})$, but the largest distance with highly reliable data was only $250 \mathrm{~m}(820 \mathrm{ft})$. The corresponding longitudinal dispersivity was only $4 \mathrm{~m}(13 \mathrm{ft})$. Based on their review, Gelhar et al. (1992) concluded that dispersivity is scale-dependent. They also concluded from the data that, overall, dispersivity values did not appear to differ with lithology (porous versus fractured media).

The question of scale is still somewhat debated. The data summarized in Gelhar et al. (1992) should not be interpreted to suggest that dispersivity simply increases with distance for any particular plume. At two sites, Borden Air Force Base (AFB) (Canada) and Otis AFB (Mississippi), the dispersivity was observed to increase for a limited distance and then reach an asymptote (i.e., approach a constant value). Neuman (1990) believes that universal scaling is operative over large distances and that dispersivity may increase significantly as plumes migrate downgradient. The Neuman model yields ever increasing dispersivity values with travel distance, which are not realistic for large distances. However, many examples exist of long plumes that retain relatively modest dispersion, such as the Cape Cod sewage lagoon plume discussed by LeBlanc (1984). For this work, the assumption is made that dispersivity will not continue to increase as the length of transport increases, but rather, will reach an asymptotic

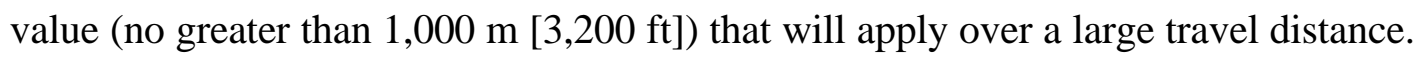

Several important conclusions related to the selection of longitudinal dispersivity and solute transport modeling for the NTS can be drawn based on the existing data and literature:

- The longitudinal dispersivity apparently increases with scale (distance from the contaminant source or the spacing between injection well and the monitoring well). However, it is not clear how increases occur for an individual plume. Data suggest that if dispersivity increases, it is not a smooth, monotonic function of travel distance.

- The dispersivity data derived from the NTS tracer tests are consistent with the range of data summarized by Gelhar et al. (1992). However, the dispersivity values for the NTS presented in Table 8-3 are too small to use in the regional transport simulations because of the scale effect. 
- The lithology, porous or fractured media, has no significant effect on the dispersivity tested. In other words, dispersivities used for porous media can also be used in fractured media.

Although the values of dispersivity derived from the NTS tracer studies are consistent with the data summarized by Gelhar et al. (1992), they are not appropriate for the regional evaluation. At the scale of the regional flow model, which is of the order of several tens of kilometers, larger dispersivities are more appropriate. Dispersivities on the order of 10 to $1,000 \mathrm{~m}$ (30 to 3,200 ft) have been used for the NTS region.

\subsection{Matrix Diffusion}

The main factor controlling the diffusion of tritium is the effective diffusion coefficient which is a function of the tritium diffusion coefficient in water, the tortuosity of the matrix (length of the flow path divided by the length of the sample), and the characteristics of fracture coatings. The limited site-specific data on tritium diffusion available were supplemented by values from the literature.

Very little information was found to define the matrix diffusion characteristics of tritium into the geologic media of the NTS subsurface. Site-specific data on tritium matrix diffusion are summarized in Table 8-4. The effective diffusion coefficient for tritium in the welded tuff aquifer is on the order of $1.0 \times 10^{-6}$ to $3.5 \times 10^{-6}$ square centimeters per second $\left(\mathrm{cm}^{2} / \mathrm{s}\right)$ $\left(1.1 \times 10^{-9}\right.$ to $3.8 \times 10^{-9}$ square feet per second $\left.\left[\mathrm{ft}^{2} / \mathrm{s}\right]\right)$. However, the data summarized in Table 8-4 are limited for several reasons. First, this represents a small set of data for only one hydrostratigraphic unit. Second, the range of porosity values is narrow compared with all the rock units at the NTS as a whole. Third, these tests were performed on fresh rock surfaces, whereas most in situ fractures have some mineral coating, especially in the saturated zone.

Diffusion data obtained from the literature consisted of effective diffusion coefficient measurements and values used in transport modeling studies. Feenstra et al. (1984) measured diffusion through intact sandstone cores and obtained a range of values from $3.4 \times 10^{-8}$ to $3.2 \times 10^{-7} \mathrm{~cm}^{2} / \mathrm{sec}\left(3.7 \times 10^{-11}\right.$ to $\left.3.4 \times 10^{-10} \mathrm{ft}^{2} / \mathrm{sec}\right)$ with a mean of $1.5 \times 10^{-7} \mathrm{~cm}^{2} / \mathrm{sec}$ $\left(1.6 \times 10^{-10} \mathrm{ft}^{2} / \mathrm{sec}\right)$. In mudstone, Barone et al. (1992) measured a diffusion coefficient of $1.5 \times 10^{-6}$ to $2.0 \times 10^{-6} \mathrm{~cm}^{2} / \mathrm{sec}\left(1.6 \times 10^{-9}\right.$ to $\left.2.2 \times 10^{-9} \mathrm{ft}^{2} / \mathrm{sec}\right)$. At the Grimsel site (Switzerland), Hadermann and Heer (1996) obtained diffusion coefficients of $2.5 \times 10^{-7} \mathrm{~cm}^{2} / \mathrm{sec}$ $\left(2.7 \times 10^{-10} \mathrm{ft}^{2} / \mathrm{sec}\right)$ to $1.7 \times 10^{-6} \mathrm{~cm}^{2} / \mathrm{sec}\left(1.8 \times 10^{-9} \mathrm{ft}^{2} / \mathrm{sec}\right)$. 
Table 8-4

Matrix Diffusion Coefficients for Tritium in the Welded Tuff Aquifer

\begin{tabular}{||l|c|c|c||}
\hline $\begin{array}{c}\text { Location } \\
\text { Or Well }\end{array}$ & $\begin{array}{c}\text { Sample } \\
\text { Number }\end{array}$ & $\begin{array}{c}\text { Porosity } \\
(\%)\end{array}$ & $\begin{array}{c}\text { Diffusion } \\
\text { Coefficient } \\
\left(10^{-6} \mathrm{~cm}^{2} / \mathrm{s}\right)\end{array}$ \\
\hline \hline USW G-4 & 737 & 7 & 2.2 \\
\hline USW GU-3 & $304 \# 1$ & 6 & 1.5 \\
\hline USW GU-3 & $304 \# 2$ & 6 & 1.6 \\
\hline USW GU-3 & 433 & 10 & 3.5 \\
\hline USW GU-3 & 1119 & 10 & 2.0 \\
\hline Topopah Outcrop & NA & 7 & 1.0 \\
\hline
\end{tabular}

Source: Triay et al. (1993)

Harrison et al. (1992) modeled diffusion of organic contaminants into clay till in Canada. They used effective diffusion coefficient values in the range of $1.5 \times 10^{-6} \mathrm{~cm}^{2} / \mathrm{sec}\left(1.6 \times 10^{-9} \mathrm{ft}^{2} / \mathrm{sec}\right)$. In modeling of diffusion of strontium and plutonium in fractured granite,

Krishnamoorthy et al. (1992) chose a range of values from $4.8 \times 10^{-7}$ to $1.9 \times 10^{-6} \mathrm{~cm}^{2} / \mathrm{sec}$ $\left(5.2 \times 10^{-10}\right.$ to $\left.2.1 \times 10^{-9} \mathrm{ft}^{2} / \mathrm{sec}\right)$. Although not comprehensive, the literature values help to bound the range of values that are plausible. The overall range of effective diffusion coefficient is $3.4 \times 10^{-8}$ to $2.0 \times 10^{-6} \mathrm{~cm}^{2} / \mathrm{s}\left(3.7 \times 10^{-11}\right.$ to $\left.2.2 \times 10^{-9} \mathrm{ft}^{2} / \mathrm{sec}\right)$.

Based on the majority of the available data, a range of effective diffusion coefficient values ranging from $1.0 \times 10^{-7}$ to $3.0 \times 10^{-6} \mathrm{~cm}^{2} / \mathrm{s}\left(1.1 \times 10^{-10}\right.$ to $\left.3.2 \times 10^{-9} \mathrm{ft}^{2} / \mathrm{sec}\right)$ is suitable for the NTS region. However, as demonstrated by the limited dataset on tritium diffusion, the uncertainties associated with this parameter are high.

\subsection{Tritium Source Term}

The tritium source term is part of the radiologic source term. Information on the radiologic source terms is classified and cannot be obtained for any specific shot. However, from the available data, an estimate of the radiohydrologic source term may be calculated for an average shot. The data and method of analysis are described below. 


\subsubsection{Data Compilation and Evaluation}

The radiologic source term is the total inventory of radionuclides contained in the subsurface of the NTS. This inventory is classified on a shot-by-shot basis; however, on a larger scale, the inventory has recently been declassified. A declassified inventory is presented for two groups of shots. The first group represents all shots on Pahute Mesa; the second group represents all shots in areas of the NTS other than Pahute Mesa. The total activity of each of the fission and fusion isotopes that are present in significant quantities in cavities deeper than $100 \mathrm{~m} \mathrm{(320 \textrm {ft } )}$ above the water table are totaled within each of the two groups.

While the radiologic source term provides information on the total inventory within the cavity, not all of the inventory for most of the isotopes is available for dissolution and transport with the groundwater flow system. This available inventory is called the radiohydrologic source term or hydrologic source term. The type of data relating to the hydrologic source term and required by the transport model is an activity per unit volume. Thus, an estimate of dissolution volume is also required.

In the case of tritium, a simplifying assumption has been made that the radiologic source term and the hydrologic source term are identical. The calculation of concentration requires only information on the saturated volume of the cavities. However, if other isotopes (cesium, strontium or plutonium) were to be modeled, the hydrologic source term would not be identical to the radiologic source term. Assumptions would be required to determine the quantity of the material contained within the glassy matrix of the shot melt, the leaching rates, the chemical speciation of the isotopes, and other similar factors. Until additional information that will be collected from the near-shot wells becomes available, reasonable estimates cannot be made on many of the other isotopes.

The source of the unclassified radiologic source term was Los Alamos National Laboratory. The unclassified information included data on fission and fission products (Pankratz, 1995), and unclassified average cavity volumes were estimated from cavity radius data.

\subsubsection{Data Analysis}

Because tritium was the only isotope modeled, the transformation from radiologic to hydrologic source term was a simple calculation. The only information required was an estimate of the cavity volumes for each of the two areas. Because cavity radius data were available for each of the shots, a volume was calculated for each cavity and totaled for the two areas. Each of the 
radiologic source terms for tritium was divided by the calculated volume resulting in the radiohydrologic source term. The values were $8.3 \times 10^{8} \mathrm{pCi} / \mathrm{L}$ for Pahute Mesa shots and $3.3 \times 10^{8} \mathrm{pCi} / \mathrm{L}$ for all other shots. Inherent in this calculation is the assumption that the porosity of the cavity is equal to one. Assuming lower porosities will result in higher concentrations.

The degree of uncertainty in the source term cannot be determined accurately from the unclassified data. For this work, the uncertainty is estimated from data presented by Daniels (1993) and Smith et al. (1996). For Tritium, concentrations as large as 7.56 x 109 pCi/L have been reported. This large value is certainly unusual, but was chosen as an upper bound for the simulations. The lower bound value for the simulations is approximately $7 \times 10^{6} \mathrm{pCi} / \mathrm{L}$. This large range of values is consistent with the limited, observed data. 


\subsection{Transport Model}

The transport model was designed to predict the regional migration of tritium in a very conservative manner. The transport model was used to calculate tritium concentrations in groundwater at selected receptor locations downgradient from major underground testing areas of the Nevada Test Site. The model serves as a tool to help guide future decisions with regard to NTS Environmental Restoration.

\subsection{Objectives}

The purpose of the transport model is to predict the regional-scale maximum migration of tritium in the groundwater flow system away from selected underground test locations. The simulations are limited to tritium because this radionuclide was produced in the greatest abundance during underground nuclear detonations and is mobile in a groundwater environment. The analysis is regional in extent and is intended to provide tritium migration information at the scale of tens of kilometers.

The tritium transport model objectives are as follows:

- Estimate the maximum extent of tritium contamination in groundwater moving through the underground testing areas, using conservative assumptions.

- Calculate the tritium concentration in groundwater downgradient from underground test locations. These concentrations are used in the ecological and human health risk assessment calculations to assess the current and near term potential risks.

- Assess the impacts of flow and transport parameter uncertainty on the predicted downgradient tritium concentration.

\subsection{Technical Approach}

The approach used to calculate the tritium concentration is presented in this section, followed by a description of the modeling data requirements. A general approach, defining the types of analyses, the steps involved, and the parameters needed is presented first. The transport modeling approach provides the details of the modeling. The approach descriptions will help the reader to understand the approximations inherent in the final results. 


\subsubsection{General Approach}

A three-step modeling approach was used in this study. First, a three-dimensional model of the groundwater flow system was developed from which groundwater flow paths were identified as described in Section 7.0. Second, advective transport along selected pathlines was simulated using a particle tracking technique, also as described in Section 7.0. This provided an assessment of the relative amount of downgradient migration from each underground test location. Third, tritium concentrations along three selected pathlines were simulated using a one-dimensional, finite-element model.

The transport model simulates tritium concentration along a one-dimensional pathway defined by the flow model. The one-dimensional, mobile/immobile, finite-element model, MC_TRANS, accounts for advection, dispersion, radioactive decay, and diffusion between the mobile and immobile phases. The mobile phase zone can be conceptualized as the portion of the aquifer through which the water flow occurs. This mobile phase zone may consist of fractures or the more permeable portions of a porous medium. The immobile phase zone is conceptualized as the matrix between the fractures or mobile phase zones. Advection is allowed only in the mobile phase zone. Uncertainty in model parameters is incorporated via either a Monte Carlo or Latin hypercube sampling technique (Iman et al., 1980).

The steps involved in modeling the transport of tritium are as follows:

- Calculate groundwater pathlines from underground test locations at or below the water table using the three-dimensional numerical groundwater flow model.

- Select three pathlines for transport simulations.

- Identify parameter uncertainty for flow and transport parameters.

- Determine the form of the source term and the uncertainty in values.

- Simulate the transport of tritium along the pathlines, accounting for uncertainty with a Monte Carlo or Latin hypercube approach.

- Determine the downgradient distance beyond which tritium concentration does not exceed 20,000 pCi/L. 
- Determine how uncertainty in selected input parameters impacts results.

- Provide tritium concentration data at preselected downgradient locations for risk assessment. The downgradient locations are chosen to aid in the presentation of results and to correspond to risk receptor locations.

\subsubsection{Transport Modeling Approach}

The hydrostratigraphic units of the Nevada Test Site groundwater flow system are quite variable, ranging from low permeability clastic rocks to high permeability fractured carbonates. The HSUs mapped in the geologic model are given in Table 4-3 for reference.

Some hydrostratigraphic units such as the alluvium can be treated as porous media while other units such as the welded tuffs and carbonates are better represented by fracture flow. In the fractured units, the matrix between fractures is porous and saturated with water. Diffusion of tritium between the matrix and fracture is a mechanism that has been proposed by other researchers (Grisak and Pickens, 1980; Harrison et al., 1992; and Maloszewski and Zuber, 1991) to account for slower mean velocities of solutes relative to water. Therefore, a model was required that allowed for matrix diffusion, advection, radioactive decay, and dispersion. In addition, it was recognized that if other radionuclides were to be considered at a later time, capabilities for adsorption and tracking of daughter products would also be required. A final consideration was the desire to use a Monte Carlo approach using Latin hypercube sampling to evaluate the impact of parameter uncertainty on the predicted tritium concentrations. The Latin hypercube approach was selected for the regional simulations because it reduced the number of realizations that were required and it incorporated correlation of parameters which was deemed necessary in some cases.

Monte Carlo is a technique for modeling a real-world situation in which one or more of the input parameters is either uncertain or may vary in a mathematically describable way. It employs random sampling from probability distributions to assign values to the uncertain parameters in the model. The Latin hypercube extension used in this study also allows for various parameters to be evaluated using a statistical technique called rank correlation. The Monte Carlo technique is typically used in cases where too many parameters are uncertain or the mathematics are too complex to be solved analytically. In this case, the model that describes the transport of tritium in the environment includes dozens of parameter values that are best described by probability distributions rather than single values. The probability distributions might include the normal, 1 og-normal, exponential, or one of a number of other mathematical expressions that meet the 
requirements of a probability distribution function. The Monte Carlo simulation randomly selects the parameter values from the corresponding probability distributions to obtain a single model result (or realization) that is specific to that set of the parameter values. If parameters are rank-correlated, the value of one parameter will depend on the randomly selected value of another parameter. This process is then repeated over a large number of trials until the probability distributions of the model results can be described.

Many of the physical processes (such as matrix diffusion and radioactive decay) may be simulated using existing three-dimensional computer codes (e.g., SWIFT or its successors). Unfortunately, these codes are typically very large, require large amounts of data, and are very difficult to implement efficiently in a Monte Carlo framework at the regional scale. Modeling the necessary transport mechanisms while providing a computationally efficient tool led to the creation of a one-dimensional model with Monte Carlo capabilities. The choice of a numerical approach over an analytical method was driven by the need to account for the complexity of the NTS geology and hydrology.

The one-dimensional model, MC_TRANS, was developed to simulate the transport of chains of dissolved chemical constituents within the groundwater system contained in fractured or porous media where the diffusion of solute mass into matrix or dead-end pore space is an important factor. The model can be used in a deterministic mode or probabilistic mode incorporating hydrologic uncertainty through the Monte Carlo method. In the deterministic mode, the input parameters are assigned fixed values, and a single solution is determined. In the probabilistic mode, selected parameters are treated as random variables and are allowed to vary within limits defined by the mean, standard deviation, and the probability distribution of the parameter. These selected parameters are varied via a Latin hypercube sampling approach, and numerous solutions are determined corresponding to the different parameter values.

The dual porosity representation of the groundwater system assumes complete mixing in the matrix and a mass transfer coefficient controls interaction between fracture and matrix (or interconnected and dead-end pore space) systems. The solutes are subject to advection, sorption, and first order radioactive decay in the fracture (or interconnected pore space) and sorption and first order radioactive decay in the matrix (or dead-end pore space) domain.

The Galerkin finite-element approach is used to solve the partial differential transport equations. The source input may be a prescribed concentration or mass flux. Parameter uncertainty allows 
for zonal variations of all input parameters using several types of statistical distributions. The inclusion of flow model sensitivity coefficients allows flow model parameter uncertainty to be incorporated in the transport simulations. A detailed documentation of the transport model MC_TRANS, including the governing equations, is given in the Tritium Transport Model documentation package (IT, 1996i).

The dual porosity formulation was chosen in favor of the discrete fracture/matrix formulation. The simulation of fractured geologic units is easily accomplished with either formulation, but the simulation of porous units (such as alluvium) is best accomplished with the dual porosity formulation.

The one-dimensional approach, which has been chosen for its versatility and efficiency, does have one drawback. The predicted concentrations will be overestimated because the effect of three-dimensional dispersion is not considered. As shown later in the text, the additional dilution due to three-dimensional dispersion is in the range of 5 to 200 times greater than in the case of one-dimensional dispersion. Thus, it is likely that the actual tritium concentrations will be less than those predicted with the one-dimensional approach.

\subsubsection{Data Requirements}

The transport model requires the following parameters to be defined at each node or element: initial tritium concentration in the mobile and immobile regions, radioactive decay coefficient, dispersivity, specific discharge, effective and matrix porosity, effective diffusion coefficient, grid spacing and time step. Grid spacing $(\Delta \mathrm{x})$ is controlled by the grid Peclet Number, $\mathrm{Pe}=\Delta \mathrm{x} / \alpha$, where $\alpha$ is the dispersivity. Huyakorn and Pinder (1983) suggest that the Peclet number be smaller than 2 to minimize numerical oscillations (overshoot and undershoot). For this work, the criteria of $\mathrm{Pe}=2.0$ was implemented using the minimum value for dispersivity of $50 \mathrm{~m}(164.1 \mathrm{ft})$. This fixed the grid spacing to be no larger than $100 \mathrm{~m}(328.1 \mathrm{ft})$. The time step is governed in part by the Courant Number, $\mathrm{Cr}=\mathrm{V} \Delta \mathrm{t} / \Delta \mathrm{x}$, where $\mathrm{V}$ is the velocity and $\Delta \mathrm{t}$ is the time step. Huyakorn and Pinder (1983) recommend a value of Cr less than one. However, experience has shown that larger values of $\mathrm{Cr}$ can be used without introducing significant numerical oscillations. The time step was adjusted to keep the Courant Number less than one for most of the simulations.

The maximum length of any of the pathlines used in the transport simulations was no greater than $99 \mathrm{~km}$ (61.5 mi), based on preliminary scoping simulations. The maximum simulation time 
of 250 years was selected because it represents approximately 20 tritium half-lives. Assuming an initial cavity concentration of $1 \times 10^{9}$ picoCuries per liter, the concentration decays below $20,000 \mathrm{pCi} / \mathrm{L}$, the regulatory limit, in slightly less than 200 years. This source term value is deliberately chosen to be larger than the average value provided in the Transport Parameter and Source Term Documentation Package (IT, 1996e) in order to define an appropriate upper bound on the simulation time.

\subsection{Data Flow}

The process of generating the tritium breakthrough curves involved six main tasks with several smaller steps within each task. The tasks are:

- Select particle starting locations.

- Determine groundwater pathways.

- Identify effective porosity along the pathline.

- Identify parameter values and uncertainty.

- Define model grid system and create input files.

- Calculate tritium breakthrough curves along each path.

A complete description of each task is given in the Tritium Transport Model Documentation Package (IT, 1996g). A brief description is provided in the following text.

\subsubsection{Overview}

Groundwater pathways are determined by tracking the movement of groundwater through the three-dimensional groundwater flow system starting at underground test locations that are at or below the water table. A particle tracking computer code, MODPATH (Pollock, 1989), takes the output of the MODFLOW computer code and calculates the groundwater pathways. In MODPATH, an imaginary particle is followed as it flows through the groundwater system as defined by the numerical groundwater flow model. Using the PATHLINE output option of MODPATH, the location coordinates of the particle in model space are recorded where the particle crosses a grid cell boundary. Intermediate locations along the pathline within cells are determined and compared with the geologic model to identify the hydrostratigraphic unit at each intermediate location. Effective porosity values, appropriate for each hydrostratigraphic unit, are assigned to each point along the pathline, and travel times are computed. The travel times and travel distances from each starting location are summarized for each of the pathlines. Tritium transport simulations were then performed for selected underground nuclear tests representative 
of the major test areas. The pathlines were then discretized (broken into small segments) in preparation for MC_TRANS transport simulations.

\subsubsection{Selection of Particle Starting Locations}

The first step in the selection process is to identify all the events that may have encountered the water table. A database containing underground test location information was provided by Lawrence Livermore National Laboratory. The database was refined by the DOE and was modified to include estimated water table elevations at each test location as determined by the U.S. Geological Survey. Three vertical locations were identified for each nuclear test: the working point and two locations, the first location at an estimated distance of two cavity radii above and the second at an estimated distance of two cavity radii below the working point (Figure 9-1). Each point was compared to the estimated water table elevation, and only those points below the water table were selected as particle starting locations. If only the bottom point was below the water table, then only one starting location would be used for that nuclear test. If the top point was below the water table, then all three points were used as particle starting locations. For this analysis, 415 flowpaths from 254 shots were examined.

\subsubsection{MODPATH Simulations}

The starting locations defined using the above-mentioned process were used in the particle tracking code, MODPATH, to simulate the movement of particles through the groundwater flow system. To define these pathlines, the required MODFLOW files from the calibrated flow model were used along with a porosity of 1.0 for all points in the groundwater flow model domain. The PATHLINE option of MODPATH generates an output file (pathline) giving the location and travel time where a particle crosses a cell boundary. Because the porosity of 1.0 was used, the distance traveled across a MODFLOW grid cell divided by the travel time is not the velocity, but rather the specific discharge. The calculation of solute velocity is part of a later step.

\subsubsection{Identification of Hydrostratigraphic Units along a Pathline}

To determine the velocity along a pathline, it is necessary to assign an effective porosity value to each point along the pathline. For the regional simulations, the effective porosity of each HSU is treated as a spatially uniform value. Thus, the porosity at any point along the pathline is uniquely defined by the hydrostratigraphic unit. Figure 9-2 is a schematic diagram of a pathline segment through a model cell in which an HSU boundary is crossed. In this figure, the porosity could differ in each HSU, and the velocity could change within the cell due to HSU changes. 
Along each pathline segment, such as the one in Figure 9-2, points were located approximately every $100 \mathrm{~m}(328.1 \mathrm{ft})$ laterally or $10 \mathrm{~m}(32.8 \mathrm{ft})$ vertically to allow for changes in the HSU. The HSU for each point is assumed to extend to the midpoint between neighboring points. To assign a porosity, the HSU at each point along the pathway was determined from the geological model used in the regional groundwater flow simulations.

\subsubsection{Calculation of Advective Velocity along a Flow Path}

The velocity along each flow path is used to compute the travel time along each path. The paths with the more rapid travel times were selected for transport simulations. It is recognized that paths through the aquifer units will be more rapid than paths through the confining units. Therefore the emphasis in this section is on the aquifer units.

The advective velocity at each point along the flow path was determined as the specific discharge divided by the effective porosity at that point. The travel time between any two points is the distance between points divided by the velocity. The cumulative travel time to any downgradient point is determined by summing the travel times along the intermediate points. The effective porosity at each point is defined as a function of each HSU. The effective porosity corresponding to each HSU was discussed in Section 5.0 of this report and in the Transport Parameter and Source Term Data Documentation Package (IT, 1996e).

For porous units such as alluvium, the effective porosity is assumed to be approximately equal to the matrix or bulk porosity. For units such as the carbonates, that are dominated by fracture flow, the effective porosity is more closely approximated by the fracture porosity. The effective porosity values used for the pathline velocity calculations are given in Table 9-1. These values have been optimized to emphasize the most important aquifer units. The Lower and Upper Carbonate Aquifers and the Timber Mountain, Belted Range, and Basal Volcanic Aquifers are given small effective porosities to correspond to fracture porosity values. Several of the volcanic confining units were given smaller effective porosities than the matrix porosity values typically associated with the effective porosity of porous units. These changes were made to reduce the impact of a path that was predominantly in an aquifer unit, but may have crossed a small section of confining unit. As noted in the Transport Model Documentation Package (IT, 1996g), differences in the discretization of the geologic model and the groundwater flow model occasionally led to a situation where a path appeared to enter a confining unit for a short distance and then return to an aquifer. In many cases, the flow through the confining unit was 
Table 9-1

Effective Porosity Values for Each Hydrostratigraphic Unit used to Calculate Travel Times Along Pathlines

\begin{tabular}{|c|c|c|c|c|}
\hline HSU No. & Hydrostratigraphic Unit & Abbreviation & $\begin{array}{l}\text { Effective } \\
\text { Porosity }\end{array}$ & Source \\
\hline 20 & Alluvial Aquifer & AA & 0.30 & Cambric Expmnt. \\
\hline 19 & Timber Mountain Aquifer & TMA & 0.0005 & Cubic Law Estimate \\
\hline 18 & Tuff Cones & $\mathrm{TC}$ & 0.01 & Professional Judgement \\
\hline 17 & Non-Welded Tuffs & TCBCU & 0.06 & Professional Judgement \\
\hline 16 & Belted Range Aquifer & TBAQ & 0.0005 & Cubic Law Estimate \\
\hline 15 & Basal Confining Unit & $\mathrm{BCU}$ & 0.07 & Professional Judgement \\
\hline 14 & Welded Tuffs & $\mathrm{BAQ}$ & 0.0005 & Cubic Law Estimate \\
\hline 13 & Volcanic Tuff Aquifer & VA & 0.001 & Professional Judgement \\
\hline 12 & Volcanic Tuff Confining Unit & VCU & 0.03 & Professional Judgement \\
\hline 11 & Volcanics Undifferentiated & VU & 0.19 & Professional Judgement \\
\hline 10 & $\begin{array}{c}\text { Tertiary Sediments/Death } \\
\text { Valley Section }\end{array}$ & TSDVS & 0.30 & Cambric Expmnt. \\
\hline 9 & $\begin{array}{c}\text { Lower Carbonate Aquifer } \\
\text { (Yucca Flat Upper Plate), } \\
\text { Upper Carbonate Aquifer in } \\
\text { the NTS Area }\end{array}$ & LCA3 & 0.005 & Cubic Law Estimate \\
\hline 8 & Upper Clastic Confining Unit & UCCU & 0.02 & Professional Judgement \\
\hline 7 & Lower Carbonate Aquifer & LCA & 0.005 & Cubic Law Estimate \\
\hline 6 & Lower Clastic Confining Unit & LCCU & 0.01 & Professional Judgement \\
\hline 5 & $\begin{array}{l}\text { Lower Carbonate Aquifer } \\
\text { (Upper Plate) }\end{array}$ & LCA1 & 0.005 & Cubic Law Estimate \\
\hline 4 & $\begin{array}{c}\text { Lower Clastic Confining Unit } \\
\text { (Upper Plate) }\end{array}$ & LCCU1 & 0.01 & Professional Judgement \\
\hline 3 & $\begin{array}{l}\text { Lower Carbonate Aquifer } \\
\text { (Lower Plate) }\end{array}$ & LCA2 & 0.005 & Cubic Law Estimate \\
\hline 2 & $\begin{array}{l}\text { Lower Clastic Confining Unit } \\
\text { (Lower Plate) }\end{array}$ & LCCU2 & 0.01 & Professional Judgement \\
\hline 1 & Intrusives & 1 & 0.0005 & Cubic Law Estimate \\
\hline
\end{tabular}


not physically realistic. Therefore, using a smaller effective porosity for some of the confining units reduced the impact of the differences in discretization.

\subsubsection{Selection of Starting Locations for Regional Modeling}

The purpose of the regional transport modeling is to provide an assessment of the likely travel distance for tritium over a period of approximately 200 years. Using this approach, travel distances over a 100- and 200-year period were calculated for each underground test below the water table. Figure 9-3 shows the pathlines for the nuclear tests at or below the water table for a travel time of 200 years. The travel distances are summarized for each of the pathlines in the Tritium Transport Model Documentation Package (IT, 1996g). The three nuclear tests chosen for regional scale modeling are TYBO in Western Pahute Mesa, HOUSTON in Central Pahute Mesa, and BOURBON in Yucca Flat. Shots with greater particle velocities, which were closer to the southern boundary of an area, were given priority. However, other factors such as the geology of the shot or the ability of the shot to represent a general flow area were also considered.

The groundwater flow velocity along the paths originating from these three locations is greater than the velocity along paths originating from most of the surrounding test locations; therefore, the calculated tritium concentrations are significantly more conservative than average. The selected paths will portray downgradient migration of tritium to distances greater than would be expected from the majority of other test locations.

\subsubsection{Evaluation of Upgradient and Downgradient Nuclear Tests Along the Same Pathline}

Prior to selecting the starting locations, an evaluation of upgradient and downgradient nuclear tests along the three chosen pathlines was performed. If more than one nuclear test is along the same pathline, the plume may overlap and lead to greater downgradient migration than if only one nuclear test is considered. Two situations were considered: pathlines from upgradient nuclear tests that pass through TYBO, HOUSTON, or BOURBON; and downgradient nuclear tests that are along the pathline from TYBO, HOUSTON, or BOURBON. The determination of whether a pathline intersected another nuclear test location is based on the size of plumes originating from each of the nuclear tests and is presented in the Tritium Transport Model Documentation Package (IT, 1996g).

For the TYBO location, two nuclear tests upgradient (KASH and PEPATO) were found to have paths that passed very close to the TYBO working point. The location of KASH is $6.7 \mathrm{~km}$ (4.2 mi) upgradient of TYBO, and PEPATO is $7.8 \mathrm{~km}$ (4.8 mi) upgradient. For BOURBON, one 
nuclear test upgradient (KANKAKEE, $9 \mathrm{~km}$ [5.6 mi]) and one pair of nuclear tests downgradient (MICKEY AND TORRIDO, $2.6 \mathrm{~km}$ [1.6 mi]) were determined as likely interacting plume sources. An approximate assessment of the interaction of the plumes was performed by allowing the TYBO path to originate at PEPATO with KASH and TYBO both included. Additionally, the BOURBON path originated at KANKAKEE with BOURBON and MICKEY/TORRIDO included downgradient. A more complete analysis of the interaction of plumes will be performed as part of local-scale modeling at a later time. The three pathlines chosen for these simulations beginning at PEPATO/TYBO, KANKAKEE/BOURBON, and HOUSTON are given in Figure 9-4. The locations of the other nuclear tests (BOURBON, MICKEY/TORRIDO, $\mathrm{KASH}$, and TYBO) are also shown on Figure 9-4.

\subsection{Transport Parameters and Uncertainty}

Concurrent with the selection of the pathline starting locations, parameter values specific to the transport model such as porosity, dispersivity, and tritium concentrations were tabulated and uncertainties assigned. Three pieces of information are required for each parameter: the probability distribution representing the parameter variability, the mean value, and the standard deviation.

Five options are available in the transport model to describe the probability distribution:

- Constant

- Normal

- Log-normal

- Uniform

- User-defined

A parameter that is constant is defined by a single value. An example is the radioactive decay coefficient which is the same at all locations and all times for a specific radionuclide. The normal distribution is defined by its mean and standard deviation. For a log-normally distributed parameter, the transport model requires the mean of the $\log _{10}$ value and the standard deviation of the $\log _{10}$ value. A uniform distribution is defined by the lower and upper bounds of the range of values. A userdefined probability distribution may be derived based on site-specific data.

\subsubsection{Porosity}

The effective porosity (defined for the fractures or mobile phase) and the matrix porosity (defined for the matrix between fractures, the immobile phase) are required for each HSU. The mobile and immobile zone porosity information for each HSU is given in Table 9-2. These 
Table 9-2

Porosity Data and Uncertainty for Each HSU

\begin{tabular}{|c|c|c|c|c|c|c|c|}
\hline & & Mobile & Phase & Porosity & Immobile & Phase & Porosity \\
\hline $\begin{array}{l}\text { HSU } \\
\text { No. }\end{array}$ & HSU & Distribution & Mean $^{a}$ & $\begin{array}{l}\text { Standard } \\
\text { Deviation }^{\text {a }}\end{array}$ & Distribution & Mean & $\begin{array}{l}\text { Standard } \\
\text { Deviation }\end{array}$ \\
\hline 20 & AA & Uniform & 0.25 & 0.35 & None & 0 & 0 \\
\hline 19 & TMA & Log-normal & -2.87 & 0.21 & Uniform & 0.08 & 0.50 \\
\hline 18 & TC & Log-normal & -2.87 & 0.21 & Uniform & 0.12 & 0.45 \\
\hline 17 & TCBCU & Uniform & 0.07 & 0.47 & None & 0 & 0 \\
\hline 16 & TBAQ & Log-normal & -2.87 & 0.21 & Uniform & 0.19 & 0.39 \\
\hline 15 & $\mathrm{BCU}$ & Uniform & 0.33 & 0.45 & None & 0 & 0 \\
\hline 14 & BAQ & Log-normal & -2.87 & 0.21 & Uniform & 0.09 & 0.27 \\
\hline 13 & VA & Log-normal & -2.87 & 0.21 & Uniform & 0.08 & 0.45 \\
\hline 12 & VCU & Uniform & 0.07 & 0.47 & None & 0 & 0 \\
\hline 11 & VU & Uniform & 0.01 & 0.36 & None & 0 & 0 \\
\hline 10 & TSDVS & Uniform & 0.25 & 0.35 & None & 0 & 0 \\
\hline 9 & LCA3 & Log-normal & -2.46 & 0.25 & Uniform & 0.01 & 0.15 \\
\hline 8 & UCCU & Uniform & 0.01 & 0.23 & None & 0 & 0 \\
\hline 7 & LCA & Log-normal & -2.46 & 0.25 & Uniform & 0.01 & 0.15 \\
\hline 6 & LCCU & Log-normal & -4.50 & 0.39 & Uniform & 0.01 & 0.09 \\
\hline 5 & LCA1 & Log-normal & -2.46 & 0.25 & Uniform & 0.01 & 0.15 \\
\hline 4 & LCCU1 & Log-normal & -4.50 & 0.39 & Uniform & 0.01 & 0.09 \\
\hline 3 & LCA2 & Log-normal & -2.46 & 0.25 & Uniform & 0.01 & 0.15 \\
\hline 2 & LCCU2 & Log-normal & -4.50 & 0.39 & Uniform & 0.01 & 0.09 \\
\hline 1 & I & Log-normal & -4.50 & 0.39 & Uniform & 0.001 & 0.01 \\
\hline
\end{tabular}

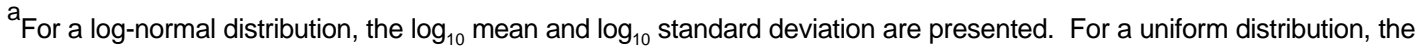
mean and standard deviation represent the lower and upper bounds, respectively. 
values differ somewhat from the values in Table 9-1 for several reasons. The values in Table 9-1 were optimized to accentuate the influence of aquifer units, whereas in Table 9-2 the effects of high-porosity confining units were included explicitly. The effective porosity of the fractured volcanic units were set to the same value because of the similarities in the fracture porosity of those units.

The effective porosity of the fractured units was assumed to be log-normally distributed to avoid the problem of negative values during Latin hypercube sampling while allowing for a rather large range of variation. In addition, the effective porosity in fractured media is a function of the fracture aperture which has been assumed to be log-normally distributed by other investigators such as Long and Billaux (1987). The $\log _{10}$ standard deviation of 0.21 to 0.25 is based on the criterion that the lower bound of the distribution should not produce a value so low as to be physically unrealistic. The chosen range of variability is based, in part, on the sensitivity of the calculated hydraulic conductivity to aperture where a factor of 25 change in aperture (and effective porosity if the spacing is held constant at 1 meter) produces more than a three-order-ofmagnitude change in bulk hydraulic conductivity. The three-order-of-magnitude range in hydraulic conductivity is consistent with measured data presented in both the Hydrologic Parameter Data Documentation Package (IT, 1996d) and the Groundwater Flow Model Documentation Package (IT, 1996f).

The effective porosity of the porous units and the matrix porosity of the fractured units were characterized by a uniformly distributed porosity. The uniform distribution assigns equal probability to all values, in contrast to a normal distribution which gives greater probability to values near the mean. The uniform distribution was chosen to provide a greater emphasis to values at the ends of the range of matrix porosity values.

\subsubsection{Dispersion Coefficient}

The dispersion coefficient in the mobile zone is the product of the dispersivity and the solute velocity where the parameter required as input for the transport model is the dispersivity. For these regional simulations, a mean dispersivity of $550 \mathrm{~m}(1,804.6 \mathrm{ft})$ and a range of 100 to $1,000 \mathrm{~m} \mathrm{(328.1} \mathrm{to} \mathrm{3,281} \mathrm{ft)} \mathrm{was} \mathrm{chosen} \mathrm{for} \mathrm{the} \mathrm{carbonate} \mathrm{aquifer} \mathrm{and} \mathrm{the} \mathrm{volcanic} \mathrm{aquifers.} \mathrm{For}$ the Clastic and Volcanic Confining Units, the range of dispersivity values was 100 to $500 \mathrm{~m}$ (328.1 to $1,640.5 \mathrm{ft}$ ) with a mean of $300 \mathrm{~m}(984.3 \mathrm{ft})$. The Alluvial Aquifer and the Death Valley Sediments were given a range of 50 to $500 \mathrm{~m}$ (164 to $1,640.5 \mathrm{ft})$. The larger dispersivities of the aquifer units reflect the larger fluxes in those units when compared with the confining units and 
alluvium. The range of values is consistent with the range reported in the literature and documented in Section 8.0 and in the Transport Parameter and Source Term Data Documentation Package (IT, 1996e). Despite the wide range of values chosen, the model predictions are not very sensitive to the value of the dispersivity as will be shown later when the results of sensitivity analyses are presented.

\subsubsection{Advective Velocity}

The advective velocity is determined in the transport model as the specific discharge divided by the effective porosity. The specific discharge is calculated from the calibrated regional groundwater flow model. The variation in specific discharge along the flow path due to variations in hydraulic conductivity and recharge are included in the transport model via flow sensitivity coefficients determined from the groundwater flow model.

The uncertainty in hydraulic conductivity parameters is incorporated into the transport model via the specific discharge. To do so, the sensitivity of the three components of the specific discharge vector at each node in the flow model to changes in the hydraulic conductivity parameters of each HSU (or zone) was determined. In the Latin hypercube portion of the transport model, different hydraulic conductivity parameters were allowed to vary simultaneously, and the resulting change in specific discharge was calculated as the sum of the parameters times the sensitivities.

The hydraulic conductivity and the coefficient to decrease the conductivity with depth $(\lambda)$ of each HSU or zone within each HSU were considered variable and were included in the flow parameter sensitivity. A total of 117 parameters (58 HSUs or zones times two parameters plus the recharge parameter) were included in the transport model. From the Hydrologic Parameter Data Documentation Package (IT, 1996d), it is known that variations in hydraulic conductivity can be quite large, up to four orders of magnitude in many HSUs. The large variation in measured values is representative of local scale variation and likely does not reflect the range of variation at the HSU scale as used in the flow model. Van Marcke (1983) addresses the question of averaging spatially variable processes and shows that the variation of the averaged parameter is smaller than the variation of the measured values. The range of variation of the hydraulic conductivity is conservatively assumed to be about one order of magnitude for the transport calculations. A corresponding $\log _{10}$ standard deviation of 0.25 was assigned for the $\log _{10}$ standard deviation of the horizontal hydraulic conductivity for all HSUs. The other flow parameter was assigned a uniform distribution with a range of values consistent with the 
uncertainty in the slope of the log hydraulic conductivity with depth as given in the Hydrologic Parameter Data Documentation Package (IT, 1996d).

Finally, it is recognized that recharge is also uncertain. As recharge increases, more water will flow through the groundwater flow system. To keep the model in calibration, the calibrated hydraulic conductivity would need to increase a proportional amount to keep the hydraulic gradient the same. Therefore, the dominant effect of changes in recharge can be approximated by multiplying the specific discharge by a recharge factor. The recharge factor was allowed to vary between 0.17 and 5.92, with 90 percent of the values between 0.4 and 2.6.

\subsubsection{Diffusion Coefficient}

The diffusion coefficient is an important parameter controlling the rate of mass transfer between the mobile and immobile regions. The limited site-specific data as well as values from the literature are available in the Transport Parameter and Source Term Data Documentation Package (IT, 1996e).

The data that were available from NTS site measurements (Triay et al, 1993), as presented in Section 8.0, represented diffusion experiments into fresh rock surfaces and probably overestimate values that might occur under natural conditions. Natural fracture surfaces have mineral coatings that may reduce the efficiency of diffusion into the rock matrix. Other published data, noted in the Transport Parameter and Source Term Data Documentation Package (IT, 1996e), are somewhat lower.

A range of values of $2.6 \times 10^{-4}$ to $7.9 \times 10^{-3}$ square meters per year $\left(\mathrm{m}^{2} / \mathrm{yr}\right)(0.003$ to 0.08 square feet per year $\left[\mathrm{ft}^{2} / \mathrm{yr}\right]$ ) was used in the transport simulations. This range was intended to represent a balance between NTS-specific data and published values from other sites. A log-normal distribution was chosen to describe the variation in the diffusion coefficient with a $\log _{10}$ mean of 2.84 and $\log _{10}$ standard deviation of 0.24 .

\subsubsection{Fracture Spacing}

The spacing of water conducting fractures has been estimated for both the carbonate aquifers and several of the volcanic units. Two recent reports, one for the carbonates (IT, 1996j) and one for the volcanics (IT, 1996k), summarize data on conducting fractures. The reports provide 
information on apparent fracture spacing along the borehole and fracture dips. The true fracture spacing is determined from the equation:

$$
\mathrm{B}=B^{\prime} \sin (90-\alpha)
$$

Where:

$\mathrm{B}=$ true fracture spacing $[\mathrm{L}]$

$\mathrm{B}^{\prime}=$ apparent fracture spacing along the borehole [L]; and

$\alpha=$ dip angle of the fracture where 0 is horizontal and 90 is vertical.

If $\alpha=90$, then B is undefined because $\mathrm{B}^{\prime}$ is indeterminate.

Using ranges for the spacing and the dip angle from the above-cited reports, a range of values for the true fracture spacing was defined. For the carbonates, the range of values is 0.03 to $1.5 \mathrm{~m}$ $(0.1$ to $4.9 \mathrm{ft})$. For the fractured volcanics, excluding the tuff cones, fracture spacing values range between 0.7 to $2.5 \mathrm{~m}$ ( 2.3 to $8.2 \mathrm{ft}$ ). For the tuff cones, a range of 0.3 to $1.3 \mathrm{~m}$ ( 1 to $4.3 \mathrm{ft}$ ) was used. These ranges are all based on measured spacing of open fractures in core and from measured dip angles.

\subsubsection{Initial Tritium Concentrations}

The initial concentrations of tritium for individual shots are classified data. However, averaged values, which are not considered classified information, were obtained. Two average values have been calculated and presented in Section 8.0: one for Pahute Mesa $\left(8.31 \times 10^{8} \mathrm{pCi} / \mathrm{L}\right)$ and one for all other shots $\left(3.28 \times 10^{8} \mathrm{pCi} / \mathrm{L}\right)$. The averaged values were determined by summing the total tritium inventory for all the shots in each region and dividing by the sum of the estimated cavity volumes, assuming the cavities were spherical and that the porosity of the cavities was 1.0.

For the transport modeling, it was assumed that the tritium is evenly spread over the entire rock volume occupied by a sphere of radius equal to approximately two times the cavity radius. This assumption allows for a prompt injection zone around the actual cavity. Borg (1972) suggests that the zone of pervasive fracturing around a nuclear test is about three times the cavity radius in the horizontal direction and two times in the vertical direction. The assumption of two times will result in larger initial concentrations which are believed to be conservative. The volume of the initial region in the model is, thus, about eight times the cavity volume. To maintain a consistent representation of the total mass of tritium, the initial tritium concentration for the simulations is calculated as described in the Tritium Transport Model Documentation Package (IT, 1996g). 
The initial concentration is placed in both the fractures and the matrix at the source. Thus, for the purposes of the modeling, the sum of the fracture and matrix porosities will represent the porosity of the initial contaminant volume. A sensitivity simulation will be presented later where all the tritium was confined to the fractured region.

It is anticipated that there will be uncertainty in the source term concentration. The degree of uncertainty is estimated from data presented by Daniels (1993) and Smith et al. (1996). For tritium, concentrations as large as $7.56 \times 10^{9} \mathrm{pCi} / \mathrm{L}$ have been reported. This large value is certainly unusual, but it was chosen as an upper bound for the simulations. The lower bound value for the simulations is approximately $7 \times 10^{6} \mathrm{pCi} / \mathrm{L}$. The initial condition is modeled with a log-normal distribution to accommodate the large range in values.

\subsubsection{Correlation of Parameters}

The Latin hypercube sampling randomly selects parameter values for each realization. Typically, the selection of one parameter value is statistically independent of another. In some cases, however, it is necessary to correlate several parameters so that the value of one parameter is dependent on the value of another.

Examples of such cases are the relationships between fracture porosity and fracture spacing, and between fracture porosity and hydraulic conductivity. In the first example, fracture porosity can be estimated as the fracture aperture divided by the fracture spacing. Therefore, as fracture spacing increases, the fracture porosity tends to decrease. In this case, fracture porosity and fracture spacing are inversely correlated. In the second example, fracture porosity increases if aperture increases or spacing decreases. Both processes increase the cross-sectional area to flow and hydraulic conductivity also increases. In this case, fracture porosity and hydraulic conductivity are positively correlated.

In the transport simulations, the pairs of parameters shown on Table 9-3 were considered correlated. The correlation coefficient for each pair of parameters is 0.80 or -0.80 . The 80 percent level is somewhat arbitrary but is based on a desire to have a relatively strong correlation among certain parameters. The importance of correlation will be examined as part of sensitivity analyses that are presented later. 
Table 9-3

Correlation of Input Parameters

\begin{tabular}{||l|l|c||}
\hline \multicolumn{1}{|c|}{ Parameter 1 } & \multicolumn{1}{c|}{ Parameter 2 } & Correlation Coefficient \\
\hline \hline Effective porosity & Hydraulic conductivity & 0.8 \\
\hline Effective porosity & Fracture spacing & -0.8 \\
\hline Matrix porosity & Diffusion coefficient & 0.8 \\
\hline Hydraulic conductivity & Conductivity-depth coeff. & 0.8 \\
\hline
\end{tabular}

\subsubsection{Other Parameters}

The half-life of tritium is well-known to be 12.3 years. The radioactive decay coefficient as used in the modeling is calculated with the expression " $\ln (2) /$ half-life." Using the half-life of tritium, the radioactive decay coefficient is $5.64 \times 10^{-2}\left(\mathrm{yr}^{-1}\right)$. This value is assumed constant throughout the simulations.

\subsection{Transport Calculations}

MC_TRANS was used to simulate tritium movement along the three selected pathways defined from the groundwater flow model. Some of those parameters were uncertain and were varied using a Latin hypercube sampling technique. Receptor locations were specified for breakthrough curve calculations at selected distances downgradient from the sources. For all three paths, the first receptor location was within the source area.

An additional uncertainty that was not included in the transport calculations is the time that tritium migration begins. Transport may start immediately following the detonation of the nuclear device (the most conservative case) or be delayed by years, depending upon the integrity of the cavity structure to groundwater flow. Because of this, the reader should be aware that predicted arrival times at receptor locations will be affected by this lag. For the regional simulations, the most conservative case of zero delay is assumed.

\subsubsection{Pathlines}

The three pathlines chosen for this study began at separate shot locations: one each on Western Pahute Mesa (TYBO), Central Pahute Mesa (HOUSTON), and Yucca Flat (BOURBON). The pathlines for these three locations are presented in the plan view in Figure 9-4. Figures 9-5 through 9-7 show the vertical position of the pathline and the hydrostratigraphy where the top 
of each HSU is shown as a function of downgradient distance for shots BOURBON, HOUSTON, and TYBO, respectively.

The BOURBON pathline begins in the Lower Carbonate Aquifer and is dominated by the structural relationship of the Lower Carbonate Aquifer to other hydrostratigraphic units. The Lower Carbonate Aquifer, being the most permeable HSU, is the primary conduit for flow. The path closely follows the structural changes in the position of the Lower Carbonate Aquifer. In Frenchman Flat (downgradient distance of $30 \mathrm{~km}$ [18.6 mi]), where the top of the Lower Carbonate Aquifer is just above sea level, the pathline also goes near sea level. The pathline rises up and over clastic units that have been uplifted in the vicinity of the Specter Range at the northern edge of Amargosa Desert at a distance of about $60 \mathrm{~km}(37.3 \mathrm{mi})$. At $80 \mathrm{~km}(49.7 \mathrm{mi})$, the pathline enters the Alluvial Aquifer of Amargosa Desert and remains in that unit until it discharges in the vicinity of Ash Meadows.

The pathline from the BOURBON nuclear test location appears to leave the Lower Carbonate Aquifer and enter into the overlying Volcanic Confining Unit at downgradient distances near $30 \mathrm{~km}(18.6 \mathrm{mi})$. This apparent skipping of the pathline in and out of a confining unit is artificial and stems from the inclusion of geologic model details at scales smaller than the flow model grids. These artificial conditions were corrected prior to transport modeling.

The path from the HOUSTON nuclear test location begins in the Tuff Cones, then enters the Timber Mountain Aquifer at a downgradient distance of $6 \mathrm{~km}(3.7 \mathrm{mi})$. At $38.5 \mathrm{~km}(23.9 \mathrm{ft})$ downgradient, the path leaves the Timber Mountain Aquifer and enters the Tuff cones again for the next $4.1 \mathrm{~km}(2.5 \mathrm{mi})$. After that, the path enters the Volcanic Confining Unit for $11 \mathrm{~km}$ (6.8 mi). The remainder of the flow path is through a variety of units on its way to Death Valley.

The pathline from TYBO moves downward from the point of origin to the discharge areas of Oasis Valley. The flow path begins in the Timber Mountain Aquifer and remains in that unit for $30 \mathrm{~km}$ (18.6 mi) until it discharges at Oasis Valley.

\subsubsection{Tritium Transport Simulations - General}

Tritium concentrations were calculated at selected potential receptor points located on each pathline downgradient from the shot, using the MC-TRANS computer code. These calculations result in what are known as "breakthrough curves" which show the tritium concentration at a specific location as a function of time. At each receptor point, a breakthrough curve is calculated 
corresponding to different sets of input parameters for each of the Latin hypercube trials. Each Latin hypercube trial results in a "realization" or a breakthrough curve for each downgradient location. Two hundred realizations were performed for each pathline, resulting in 200 breakthrough curves for each location on the pathline.

The results of the transport simulations are presented in three different ways to summarize the Latin hypercube simulations. First, contour plots of tritium concentration as a function of downgradient distance and time are presented for different levels from 5 to 95 percent of the realizations. To create these plots, the tritium concentration at each fixed location and time is recorded for each realization. These values are then sorted from smallest to largest and summarized in the form of contour plots at selected percentage levels. The levels can range from 0 to 100 percent and describe the percentage of realizations for which the tritium concentration was less than the corresponding activity value. For example, if the 50 percent frequency value is at $100 \mathrm{pCi} / \mathrm{L}$, it means that 50 percent of the Latin hypercube trials for that location and time resulted in tritium concentrations of less than $100 \mathrm{pCi} / \mathrm{L}$. Contour plots were prepared which show the tritium concentration as a function of distance and time for any selected percentage level.

Histograms of all tritium values for the 30-year period surrounding the peak tritium concentration at the 95 percent level and cumulative density plots of maximum tritium concentration at each receptor location are also presented. For the maximum tritium concentration plots, the maximum concentration at each downgradient receptor was recorded, sorted from smallest to largest, and plotted as a cumulative density function to demonstrate the range of possible outcomes. These latter figures were reserved for presentation of some of the uncertainty analyses. The transport calculations are presented separately for each of the three pathlines beginning with BOURBON.

\subsubsection{Tritium Transport Simulations - BOURBON (Yucca Flat)}

Contour plots of tritium concentration as a function of distance and time were created to depict the model results. For each of the 200 realizations, the model calculates tritium concentrations at fixed distances and times. Therefore, at each distance and time, there are 200 values, each representing a different realization. These 200 values at each location in distance and time are sorted from smallest to largest. The position of a value in the sorted list represents the concentration for which a specified percentage of the realizations are smaller. For example, the concentration between the 100th and 101st value represents the 50 percent level and indicates that 50 percent of the realizations produced a larger value and 50 percent produced a smaller 
value. At the 95 percent level, 95 percent of the realizations produced a smaller value and 5 percent a larger value. By choosing the same level (for example 95 percent) for all points in distance and time, it is possible to contour tritium concentrations that represent the value for which 95 percent of all realizations yielded a smaller value.

The 5, 50, 85, and 95 percent level contour plots for the pathline that originates at the KANKAKEE nuclear test location and passes through the BOURBON and MICKEY/TORRIDO nuclear test locations are shown on Figure 9-8. The 5 percent level (Figure 9-8a) represents the cases of small initial concentration and smaller groundwater movement. The two source areas are clearly seen on the figure: one for KANKAKEE and the other combination of BOURBON and MICKEY/ TORRIDO. The 50 percent level is the median case and represents where one half of the realizations produced smaller values and one half produced larger (Figure 9-8b). At the 50 percent level, the distance to the $20,000 \mathrm{pCi} / \mathrm{L}$ point is approximately $20 \mathrm{~km}$ from KANKAKEE or $10.5 \mathrm{~km}$ (6.5 mi) downgradient from BOURBON. At the larger levels, such as 95 percent (Figure 9-8d), the amount of downgradient movement as represented by the $20,000 \mathrm{pCi} / \mathrm{L}$ line is approximately $36 \mathrm{~km}(22.4 \mathrm{mi})$, which is greater than at the 50 percent level. For reference, the $36 \mathrm{~km}(22.4 \mathrm{mi})$ distance is a point at the northern edge of Frenchman Flat, well within the boundaries of the NTS. The $20,000 \mathrm{pCi} / \mathrm{L}$ contour reaches its maximum extent at approximately 25 years from the time of release and then begins to recede gradually over the next 125 years.

As the tritium moves downgradient in the fracture flow system, some of it diffuses in the matrix. As the main pulse of tritium moves farther downgradient, tritium in the matrix behind the pulse will begin to diffuse back into the fractures. When the mass flux from diffusion into the fractures is less than the mass loss due to radioactive decay, the boundary recedes.

A second method of presenting the results of the 200 realizations is with histograms of tritium concentration. To support the human health risk assessment, the tritium concentration from all 200 trials was summarized in a noncontinuous histogram for the 30-year period (the exposure time of the hypothetical future land user) surrounding the year when the maximum tritium concentration occurred in the contour plot at the 95 percent frequency level. From Figure 9-8, it can be seen that the time of peak concentration at any downgradient location generally decreases as the level increases. This occurs because the higher level plots depict the more extreme cases with larger tritium velocity. As a result, the tritium migrates further downgradient in a shorter amount of time. Larger concentration values at any downgradient location occur at the 95 percent level than at the lower levels. 
To be conservative in the analyses, the time of peak concentration used to choose the 30 -year interval for the histogram analysis was defined on the basis of the 95 percent level plots. However, the interval chosen is not \pm 15 years around the year of the maximum tritium concentration. The interval chosen is -5 years to +25 years around the year of the maximum concentration because the distribution of the tritium concentration is not symmetrical, but rather it is skewed. A skewed distribution of contaminants in groundwater is typical in matrix diffusion-dominated flow systems. Choosing the -5 to +25 years around the year of the maximum tritium concentration in groundwater will ensure that the calculated dose and risk to a potential dose receptor is conservative and bounding. The concentration values from each realization over the 30-year period are used to create a non-continuous histogram of tritium concentrations for each dose location along the flow path.

The histograms are a presentation of the relative frequency of occurrence of tritium concentration in groundwater over the 30-year period surrounding the maximum tritium concentration. The histogram approximates the distribution of tritium activity at a location resulting from inclusion of parameter uncertainty in the groundwater transport model. The histogram lists the fraction of realizations within a specific tritium concentration range. Each tritium concentration range is known as a bin, with 25 bins used in the risk assessment. The smallest bin includes tritium concentrations of less than $100 \mathrm{pCi} / \mathrm{L}$, whereas the largest bin consists of tritium concentrations ranging between $4.6 \times 10^{9}$ and $1.0 \times 10^{10} \mathrm{pCi} / \mathrm{L}$.

Figure 9-9 is the histogram of tritium concentration in the 30-year period around the peak for each downgradient distance. Each tritium concentration bin represents approximately one-third of an order of magnitude with the upper bound of the bin range presented on the axis. The distances increase from back to front in the plot so that the histogram for the $0.1-\mathrm{km}(0.6-\mathrm{mi})$ distance is in the back of the figure. Yearly tritium concentration data over the 30 -year period are summarized for all realizations in each histogram. Thus, at each distance, there are 6,200 values summarized: 31 yearly values (including the two end points of the 30-year period) times 200 realizations. The smallest interval in Figure 9-9 is the interval of 100 to 220 pCi/L. Any concentration less than $100 \mathrm{pCi} / \mathrm{L}$ is not plotted, but is included in the calculation of the histogram frequencies. The relative frequency represents the proportion of 6,200 values that fall within a particular tritium concentration range. The histogram defines the relative percentage of the time that a particular range in tritium concentration will occur over the 30 -year time period. This representation captures all the uncertainty in the Latin hypercube simulations and provides a balanced view of the true range of outcomes. 
The results shown in the histograms are interesting from several aspects. Near the source, the tritium concentrations are large and have a narrower range of values than at larger distances. At a greater distance away from the source, nearly all the tritium concentration values fall below $100 \mathrm{pCi} / \mathrm{L}$. For example, beyond $40 \mathrm{~km}(24.9 \mathrm{mi})$, more than 90 percent of the tritium values are less than $100 \mathrm{pCi} / \mathrm{L}$. At intermediate distances, the influence of parameter uncertainty is evident by the wide range of tritium concentration values that occur. These results indicate that parameter uncertainty has a significant influence on the predicted transport of tritium.

To investigate the role of individual parameters on the uncertainty, a series of sensitivity simulations was performed. These simulations took two forms: one in which only a single variable was allowed to vary and the other where all parameters varied, but a major component of the conceptual model was changed.

In the first case, selected individual parameters were allowed to vary within the Latin hypercube portion of MC_TRANS while all other parameters were set equal to their mean value. In Figure 9-10, the cumulative density of maximum tritium concentration was plotted for each parameter. This figure was developed by retaining the peak concentration that occurred at the 1-km (0.6-mi) downgradient distance for each of the 200 realizations. The 200 peak concentration values were sorted from smallest to largest and assigned a number (n) from 1 to 200. The cumulative density function was calculated as $(n /(200+1)) \times 100$ to plot the density as a percentage. Each curve in Figure 9-10 represents the peak concentration for each of 200 realizations when only a single parameter was varied. The transport parameters that were varied individually included: source term, dispersivity, effective porosity, matrix porosity, block width, and diffusion coefficient. Additionally, the sensitivity of several flow parameters was also examined.

Only the most significant flow sensitivity parameters were chosen to be included in the sensitivity analyses. Of the 116 flow sensitivity parameters, the most sensitive were identified in Section 7.0 in the flow model discussion. For the BOURBON path, the selected flow sensitivity parameter was horizontal hydraulic conductivity, $K_{h}$, for the Volcanics Undifferentiated. The final variable to be included in the sensitivity analyses was the recharge coefficient.

The results of the sensitivity runs are presented in Figures 9-10 through 9-12 for the 1-km (0.6-mi), 10-km (6.2-mi), and 20-km (12.4-mi) distances. The source term dominates the uncertainty near the nuclear test location. Further downgradient, the most important parameters 
are those related to matrix diffusion (matrix porosity, block width, and diffusion coefficient) and the recharge coefficient. These results indicate that the uncertainty in the total amount of water flowing through Yucca Flat and the diffusion properties of the Lower Carbonate Aquifer are important contributors to the uncertainty in downgradient tritium concentration.

Additional considerations in the interpretation of the predicted concentrations revolve around several key aspects of the conceptual model. Three aspects were investigated: the importance of multiple nuclear tests along the same pathline, the influence of parameter correlation on the results, and the resulting concentrations if all the initial tritium were in the fractures only.

The impact of multiple sources was investigated by simulating the transport from the location of BOURBON alone and comparing the results to the previous simulations with multiple nuclear tests. Figure $9-13 \mathrm{a}$ is the contour plot of tritium concentration from just the BOURBON nuclear test at the 95 percent level. The maximum extent of the $20,000 \mathrm{pCi} / \mathrm{L}$ contour is about $22 \mathrm{~km}(13.7 \mathrm{mi})$. Recall that the BOURBON test is $9.5 \mathrm{~km}(5.9 \mathrm{mi})$ along the path given in Figure 9-8d. If that distance is added to $22 \mathrm{~km}(13.7 \mathrm{mi})$, the distance is $31.5 \mathrm{~km}(19.6 \mathrm{mi})$. This is about $4.5 \mathrm{~km}(2.8 \mathrm{mi})$ less travel distance than in the multiple source case. Part of the difference is made up by the third source placed $2.6 \mathrm{~km}(1.6 \mathrm{mi})$ downgradient of BOURBON in the original simulation (Figure 9-8a). This would suggest that the additive effect of multiple tritium sources in these one-dimensional simulations may not be a significant factor in the estimation of concentrations downgradient in the carbonate.

Not all parameters were allowed to vary independently of the other parameters. This second case examined a scenario where all correlation among parameters was zero, thus allowing all parameters to vary independently. At the 95 percent level (Figure 9-13b), this result produces a maximum distance of about $17 \mathrm{~km}(10.6 \mathrm{mi}), 5 \mathrm{~km}$ (3.1 mi) less than when correlation was included (Figure 9-13a). This suggests that an increase in one parameter is offset by a decrease in another when parameters are uncorrelated. This reduction is significant and indicates that correlation of parameters cannot be ignored.

The final simulation examined the assumption that the initial tritium mass was distributed between the fracture and matrix porosity. The matrix porosity is generally much larger than the fracture porosity and serves as a storage reservoir for tritium. If all the initial tritium mass were to be in the fractures alone, the concentration (mass/volume) would be much greater. To account for the tritium mass in the fractures alone, the range of initial tritium concentration was 
set to $3.0 \times 10^{8}$ to $1.0 \times 10^{11} \mathrm{pCi} / \mathrm{L}$. The large values were required to maintain the same initial tritium mass as in the base case. Figure $9-13 \mathrm{c}$ is the 95 percent level for the case of tritium in fractures alone. The maximum downgradient extent is $25 \mathrm{~km}(15.5 \mathrm{mi})$, about $3 \mathrm{~km}$ (1.9 mi) larger than the base case. Additionally, the 20,000 pCi/L line persists over approximately a 50 -year period at that distance; whereas, in the base case, the distance to the $20,000 \mathrm{pCi} / \mathrm{L}$ concentration decreases shortly after reaching its maximum extent.

\subsubsection{Tritium Transport Simulations - HOUSTON (Central Pahute Mesa)}

The HOUSTON test is located on Central Pahute Mesa and was chosen to represent expected migration of tritium from many of the nearby shots that will follow a path around the east side of Timber Mountain (Figure 9-3). Recall from Figure 9-6 that the pathline from the HOUSTON $t$ est began in the Tuff Cones, then in succession entered the Welded Tuff Aquifer, the Tuff Cones again, and then into the Volcanic Confining Unit.

The contours of the tritium concentration as a function of distance and time are given in Figure 9-14 for the 5, 50, 85, and 95 percent levels. Again, the distance downgradient of the 20,000 $\mathrm{pCi} / \mathrm{L}$ contour increases and the time of peak decreases as the percentage level increases. The maximum distance to the $20,000 \mathrm{pCi} / \mathrm{L}$ contour at the 50 percent level is approximately $14 \mathrm{~km}(8.7 \mathrm{mi})$. At the 95 percent level, the rapid transport in the fractured Welded Tuff Aquifer yields tritium at $20,000 \mathrm{pCi} / \mathrm{L} 42 \mathrm{~km}(26.1 \mathrm{mi})$ downgradient in less than 25 years from the time of release. At approximately $45 \mathrm{~km}$ (28 mi), the pathline enters the Volcanic Confining Unit and slows down substantially. This reduction in velocity, caused by the larger effective porosity of the confining unit, allows radioactive decay to completely remove the tritium before appreciable additional transport takes place. The simulated tritium concentration exceeds $20,000 \mathrm{pCi} / \mathrm{L}$ at all dose receptor locations until $45 \mathrm{~km}$ (28 mi) along this pathline. The peak tritium concentration at the 95th percent level in the HOUSTON pathline is expected to reach the NTS border in 16 years and the western border of Nellis Air Force Range in 22 years, assuming that release of tritium to the environment occurred immediately following detonation.

The histogram of tritium concentration along the pathline from the HOUSTON test is presented in Figure 9-15. As before, these data represent all the concentration data for a 30-year period which is determined from the 95 percent level tritium contour plot in Figure 9-14. The relative proportion of tritium concentration values that are above $20,000 \mathrm{pCi} / \mathrm{L}$ decreases substantially as the distance from the nuclear test location increases. 
The sensitivity of the results to variability in different parameters is presented in Figures 9-16 through 9-18 for distances of 1, 5, and $20 \mathrm{~km}(0.6,3.1$, and $12.4 \mathrm{mi})$, respectively. The parameters that are varied are the source term concentration, dispersivity, effective porosity, matrix porosity, block width, and diffusion, recharge coefficient. In addition, sensitivity runs were performed for four flow parameters: the hydraulic conductivity Zone 1 of the Tuff Cones, that of the Welded Tuff Aquifer, the coefficients describing the decrease of hydraulic conductivity with depth for Zone 1 of the Tuff Cones; and that of the Welded Tuff Aquifer. Near the source the most important parameter is the source term concentration. Further downgradient, at $5 \mathrm{~km}(3.1 \mathrm{mi})$, the importance of the source term concentration is similar to the diffusion parameters (matrix porosity, block width, and diffusion coefficient) and the recharge coefficient. At the $20-\mathrm{km}$ distance, the variability in the diffusion parameters and the recharge dominate the uncertainty in predicted values.

Figure 9-19 is a contour plot of tritium concentration for the case where the initial mass of tritium was placed in the fractures only. This result is only slightly different from the base case in Figure 9-14d in terms of maximum extent. The primary differences occur at early time near the source where concentrations are much larger than in the base case.

For the pathline from Central Pahute Mesa, the most important aspect is that the paths do not discharge into Oasis Valley, but pass through the Volcanic Confining Unit which substantially slows the rate of migration and allows radioactive decay to remove the tritium.

\subsubsection{Tritium Transport Simulations - TYBO (Western Pahute Mesa)}

The TYBO pathline begins at the upgradient location of the PEPATO test, passes through the KASH test location, and then through TYBO at a distance of $7.8 \mathrm{~km}$ (4.8 mi). The tritium contour plots for the 5, 50, 85, and 95 percent levels are given in Figure 9-20. The pathway from TYBO is entirely in the Welded Tuff Aquifer, and as a result, rapid fracture flow and transport dominates the outcome. The discharge area of Oasis Valley is located at about $37 \mathrm{~km} \mathrm{(23} \mathrm{mi)} \mathrm{on}$ these figures. At the 50 percent level, the distance to the $20,000 \mathrm{pCi} / \mathrm{L}$ contours is approximately $30 \mathrm{~km}$ (18.6 mi). The tritium concentrations at Oasis Valley do not exceed 20,000 p Ci/L. For the larger percentage cases (85 percent, 95 percent), tritium concentrations discharging at Oasis Valley are greater than $10^{6} \mathrm{pCi} / \mathrm{L}$ spanning as many as 40 years. At the 95 percent level, the tritium concentration at Oasis Valley exceeds $20,000 \mathrm{pCi} / \mathrm{L}$ from a time of just a few years following release from the cavity until 115 years. The calculated tritium concentration for the 95th percent level exceeds the limit of $20,000 \mathrm{pCi} / \mathrm{L}$ at all dose receptor locations along this 
pathline. Based on the simulations, the peak tritium concentration at the 95-percent level reaches the NTS border $(9.8 \mathrm{~km}$ [6.1 mi]) in two years, the northern edge of Oasis Valley $(29.4 \mathrm{~km}$ [18.3 mi]) in nine years, and the Nellis Air Force Range border (31.8 km [19.8 mi]) in ten years from the time of the nuclear test.

The histogram of tritium values that fall within the 30-year period, as defined by the peak concentrations in the 95-percent contour plot, are given in Figure 9-21. The range of tritium concentrations at the downgradient discharge point (Oasis Valley at $37.1 \mathrm{~km}$ [23.2 mi]) is quite large and encompasses values larger than $2.2 \times 10^{7} \mathrm{pCi} / \mathrm{L}$. More than 27 percent of the values in the histogram at Oasis Valley are above 20,000 pCi/L.

The sensitivity results for distances of 1,10 , and $30 \mathrm{~km}(0.6,6.2$, and $18.6 \mathrm{mi})$ are presented in Figures 9-22 through 9-24. At a distance of $10 \mathrm{~km}$ (6.2 mi), the uncertainty in source term, diffusion parameters, and the recharge coefficient are all of about equal importance. Source term concentration dominates the uncertainty at $1 \mathrm{~km}(0.6 \mathrm{ft})$. By $30 \mathrm{~km}(18.6 \mathrm{mi})$, the recharge coefficient and matrix diffusion parameters are more important than the source term.

Two other simulations to address the impact of multiple sources and initial tritium mass in the fractures are shown in Figure 9-25. Figure 9-25a is a contour plot of tritium concentration for the case of transport from TYBO alone with no other upgradient nuclear tests. The shorter pathline means that the Oasis Valley discharge area is located about $30 \mathrm{~km}$ downgradient. Tritium concentrations for the 95 percent level are nearly as large as in Figure 9-20d and remain above $20,000 \mathrm{pCi} / \mathrm{L}$ for approximately 100 years. Thus, the comparison of the one-source versus the multiple-source cases suggests that the multiple sources are not the controlling factor in the large tritium values predicted at Oasis Valley for the 95 percent level case. The final example is of all the initial tritium mass in fractures case. This result, Figure 9-25b, yields tritium concentrations in excess of $1 \times 10^{7} \mathrm{pCi} / \mathrm{L}$ at the discharge boundary which are larger than in the base case (Figure 9-20d). Changes in the conceptual model of the source are important considerations in the predictions.

All the simulations for the TYBO only nuclear test produce large tritium concentrations at the Oasis Valley groundwater discharge area for the 95 percent level. At the 50 percent level (Figure 9-20b), concentrations are between 1,000 and 10,000 pCi/L. These results must be viewed in relation to the Latin hypercube methodology that was used. Many of the parameters that govern the transport of tritium are uncertain. The parameter ranges that were used in this 
study were intentionally quite large to ensure that the actual tritium transport does not fall outside of the range of predicted concentrations. This means that the 5 percent level results should predict less impact than reality, and the 95 percent level should predict greater impact than reality.

The results from the PEPATO/KASH/TYBO simulations are used as an example. At the 95-percent level, the predicted tritium concentrations at Oasis Valley should have exceeded $1 \times 10^{6} \mathrm{pCi} / \mathrm{L}$ after about two years and remained above $1 \times 10^{6} \mathrm{pCi} / \mathrm{L}$ for nearly 40 years. The time of travel in the simulations begins when the tritium begins to migrate away from a nuclear test location. There is a lag time between when a nuclear test occurs and the time that groundwater fills the cavity and begins to carry tritium downgradient. This time lag is unknown, but is expected to be less than the 21 years since the TYBO nuclear test was conducted. If the 95 percent level contours were a reality, the concentration of tritium in Oasis Valley should have reached $1 \times 10^{6} \mathrm{pCi} / \mathrm{L}$ by now. To date, no tritium concentrations above environmental levels (approximately $50 \mathrm{pCi} / \mathrm{L}$ ) have been detected at any monitoring site in Oasis Valley (DOE, 1995). This suggests that the 85 percent and 95 percent results for Oasis Valley overestimate concentrations that would occur in reality.

Another consideration in the interpretation of these results is the limitations of the onedimensional modeling approach. In the actual groundwater flow system, dispersion causes a plume to disperse in three dimensions. The one-dimensional approach allows dispersion in one direction only and, therefore, limits the amount of dilution that can occur. The amount of additional dilution from a three-dimensional approach was estimated using the analytical model AT123D (IT, 1996g). The additional dilution is likely to be on the order of a factor of 5 to 200. An additional source of dilution occurs at the spring discharge locations. It is not clear how much dilution may occur at the springs because different sources of water converge at the discharge locations. Subsequent simulations to be performed as part of later scale investigations will be designed to address questions of three-dimensional dilution.

\subsection{Summary}

One-dimensional tritium transport simulations were performed along three pathlines originating from underground test locations: BOURBON, on Yucca Flat; HOUSTON, on Central Pahute 
Mesa; and TYBO, on Western Pahute Mesa. Several observations can be made based on these results:

- The regional geology, as depicted in the geologic model, is the dominant factor controlling the horizontal and vertical position of paths.

- At many downgradient receptor locations, the range of maximum tritium concentration is quite large, often exceeding over five orders of magnitude.

- Matrix diffusion is an important mechanism governing the migration of tritium in fractured carbonate and volcanic rocks.

- Source term concentration uncertainty is most important near the nuclear test locations and decreases in importance as the travel distance increases.

- The recharge coefficient which accounts for the total groundwater flux uncertainty is as important as matrix diffusion at downgradient locations.

- The downgradient distances, beyond which tritium concentration does not exceed $20,000 \mathrm{pCi} / \mathrm{L}$ at the 5, 50 and 95 percent levels, are summarized in Table 9-4. These distances are similar for the BOURBON and HOUSTON pathlines. For the TYBO pathline, the $20,000 \mathrm{pCi} / \mathrm{L}$ concentration level ranges between $14 \mathrm{~km}(9 \mathrm{mi})$ at the 5 percent level and $37 \mathrm{~km}(23 \mathrm{mi})$ at the 95 percent level, at which point groundwater is discharged to the surface (Oasis Valley discharge area).

- The results presented at the 95 percent level are expected to be an overestimate of what will occur in reality.

Table 9-4

Approximate Distances Beyond Which Tritium Concentration Does Not Exceed 20,000 pCi/L

\begin{tabular}{||c|c|c|c|c||}
\hline Nuclear Test & Location & $\begin{array}{c}\text { Distance at 5 } \\
\text { Percent Level }\end{array}$ & $\begin{array}{c}\text { Distance at 50 } \\
\text { Percent Level }\end{array}$ & $\begin{array}{c}\text { Distance at 95 } \\
\text { Percent Level }\end{array}$ \\
\hline \hline BOURBON & Yucca Flat & $15 \mathrm{~km}(9 \mathrm{mi})$ & $20 \mathrm{~km}(12 \mathrm{mi})$ & $35 \mathrm{~km}(22 \mathrm{mi})$ \\
\hline HOUSTON & $\begin{array}{c}\text { Central Pahute } \\
\text { Mesa }\end{array}$ & $2 \mathrm{~km}(1.2 \mathrm{mi})$ & $14 \mathrm{~km}(8.7 \mathrm{mi})$ & $42 \mathrm{~km}(26 \mathrm{mi})$ \\
\hline TYBO & $\begin{array}{c}\text { Western Pahute } \\
\text { Mesa }\end{array}$ & $14 \mathrm{~km}(9 \mathrm{mi})$ & $30 \mathrm{~km}(19 \mathrm{mi})$ & $\begin{array}{c}37 \mathrm{~km}(23 \mathrm{mi}) \\
\text { (Oasis Valley) }\end{array}$ \\
\hline
\end{tabular}


Risk assessment provides estimates relative to the radiological dose and associated risk due to tritium contamination in the groundwater resulting from underground nuclear testing activities on the NTS. The human health risk assessment provides a conservative and bounding estimate of potential health risk to individuals from tritium in the groundwater. The ecological risk assessment evaluates whether the tritium concentration in groundwater could adversely affect aquatic and semiaquatic populations, groundwater microorganisms, and special status species. The risks to hypothetical dose receptors located near the TYBO, HOUSTON, or BOURBON pathlines were conservatively evaluated based on the tritium transport predictions described in Section 9.0.

This section contains a summary of the human health and ecological risk assessments. The objectives and general assumptions are described first, followed by descriptions of the human health and ecological risk assessment. The associated uncertainties and conclusions are discussed last. The approach and results are described in detail in the Risk Assessment Documentation Package (IT, 1996h).

\subsection{Objectives}

The purpose of the risk assessment is to aid in evaluating the highest, credible current and nearterm risk to human health and the environment from underground nuclear testing at the NTS.

The objectives of the risk assessment are as follows:

- Determine if the conservative tritium concentrations predicted by the regional transport model could result in estimated doses to individuals that exceed the regulatory limits.

- Estimate and evaluate the maximum risk associated with various hypothetical, conservative land-use scenarios at several dose receptor locations along the fastest transport pathlines.

- Evaluate the maximum risk to selected ecological receptors of contaminated groundwater.

\subsection{Assumptions}

The human health and ecological risk assessments evaluate the relationship between the tritium concentration in groundwater and the estimated effects it may have on human health and 
ecological dose receptors. To ensure that risks are not underestimated, several conservative assumptions were made.

A major assumption was that the probability of encountering groundwater contaminated to the extent estimated (pessimistically) by the transport model is one (1). In other words, the chance of encountering maximally contaminated water is $100 \%$. However, note that in reality, the probability of a well encountering such contamination is less than 1 , maybe even close to zero, because the flow path at the concentration used in the risk assessment has to be very narrow. If the flow path were wider, thus, increasing the probability of drilling into it, concentrations would drop rapidly owing to lateral dispersion (not accounted for in the transport model). Therefore, predicted concentration (from the transport model) and the predicted chance of encountering contamination (from the risk assessment) are, in fact, inversely correlated. In other words, as one goes up, the other has to go down. In this study, both were assumed to be high. This results in a purposefully significant overestimation of risk. Other specific assumptions that add conservatism to the calculated risks are presented throughout the following text.

\subsection{Human Health Risk Assessment}

The general approach to human health risk assessment is briefly described in this section, followed by descriptions of the three major components of the assessment: exposure assessment, dose assessment, and risk characterization.

\subsubsection{General Approach}

The human health risk assessment evaluates the mechanisms that enable tritium to be transported to a human receptor under various land use scenarios. Human metabolic rates and consumption rates of various foods and water are the links between the tritium source term in the groundwater, the tritium concentration in a transport medium available to a human, and the actual intake and subsequent dose to which the human body may be subjected. The exposure mechanisms involve several environmental media: air, water, soil, and food. Once the exposure mechanisms are determined, the dose and the resulting risk to human health are calculated.

The human health risk assessment was conducted to determine if the conservative, pessimistic tritium concentrations predicted by the transport analyses (Section 9.0) could result in estimated doses to individuals that exceed the limits established in DOE Order 5400.5, Radiation Protection of the Public and the Environment (DOE, 1993). In addition, the risks associated with each land-use scenario at appropriate dose receptor locations were estimated. The 
computed risk addresses the lifetime fatal cancer risk and lifetime cancer incidence risk. The lifetime fatal cancer risk is compared to values based on recommendations for protection to members of the public promulgated by the International Commission on Radiological Protection (ICRP, 1991). In addition, the lifetime risk of cancer incidence is compared to cancer estimates using EPA slope factors which are required to be used for evaluation of risk at Superfund hazardous waste sites.

This approach to the assessment of risk to human health was performed using the GW.RISK code (IT, 1996h) for selected exposure locations along the groundwater pathlines from their point of origin on the Nevada Test Site to potential off-site discharge areas.

The human health risk assessment consisted of the following steps:

- Conduct an exposure assessment which includes the identification of land use scenarios at the exposure locations along the selected pathlines and calculation of the exposure, which includes identification of the exposure pathway and scenario, identification of the potential receptors, and the quantification of the tritium intake.

- Conduct a dose assessment which consists of a description of the toxicity of the constituent of potential concern, and quantification of the dose associated with exposure to the constituent of potential concern.

- Characterize risks to human health by calculating the risk values for each type of receptor at each location along the three fastest pathlines.

\subsubsection{Exposure Assessment}

Exposure of human receptors to tritiated groundwater was assessed at the selected locations along the three fastest pathlines described earlier. Exposure assessment consisted of identifying potential future land uses and the associated tritium exposure scenarios.

\subsubsection{Land Use Scenarios}

The specific land uses considered were developed from input from stakeholder groups such as the Citizens Advisory Board (CAB). The CAB requested that each land use be considered independently to avoid assigning a subjective probability to each land use and potentially biasing the results. Land uses evaluated in the risk assessment are shown on Table 10-1. For each scenario, the tritium exposure mechanisms, intake, dose, and resultant risk to human health were evaluated. The land uses evaluated in this assessment are discussed in greater detail in the Risk Assessment Documentation Package (IT, 1996h). 
Table 10-1

Land-Use Scenarios and Receptors Considered in the Human Health Risk Assessment

\begin{tabular}{|c|c|}
\hline Land-Use Scenario & Receptor \\
\hline \hline Agricultural & Adults/Children \\
\hline Industrial & Adults \\
\hline Mining & Adults \\
\hline Recreational & Adults/Children \\
\hline Residential & Adults/Children \\
\hline Tourism & Adults/Children \\
\hline
\end{tabular}

These land-use scenarios were formulated to be very conservative to ensure that the calculated doses would bound any realistic dose received by individuals. For example, even scenarios that are known to be highly unlikely in the near future on the Nevada Test Site, such as tourism, were considered for added conservatism.

\subsubsection{Exposure Scenarios}

A description of the potential exposure scenarios, including the analytical methods for calculating the tritium concentrations in the environmental transport media and the tritium intake by humans, are presented in this section.

\subsection{Calculation of Tritium Concentrations}

The environmental transport media considered include air, water, soil, and food. Methods of calculating tritium concentrations derived from tritiated groundwater in these media are presented. The concentration of tritium in water is assumed to be equal to that of the groundwater at the exposure location and is not further discussed in this section.

\section{Tritium Concentration in Air}

Atmospheric concentration of tritium contained in water vapor is calculated as a function of the total groundwater production on the Nevada Test Site $\left(2.46 \times 10^{6} \mathrm{~m}^{3} / \mathrm{yr}[1,995 \mathrm{ac}-\mathrm{ft} / \mathrm{yr}]\right)$, the tritium concentration in groundwater, the land area of the NTS $\left(3.5 \times 10^{9} \mathrm{~m}^{2}\left[3.8 \times 10^{10} \mathrm{ft}^{2}\right]\right)$ (DOE, 1996), and a mixing height of $2 \mathrm{~m}$ (6.6 ft) (Yu et al., 1993a). 


\section{Tritium Concentration in Soil}

The model for calculating tritium concentration in soil was originally designed by Argonne National Laboratory to determine the flux of contaminated surface water to the saturated zone (Yu et al., 1993a). The model provides an appropriate relationship between the tritium concentration in soil water and the tritium concentration in the soil.

The concentration of tritium in soil from tritiated irrigation water is calculated as a function of the concentration of tritium in irrigation water, the retardation function for tritium in soil, saturated water content in soil, the bulk density of soil, the hydraulic conductivity of the soil, a soil-specific exponential parameter, the evapotranspiration coefficient of the soil, the NTS precipitation rate, and the assumed irrigation rate.

The average evapotranspiration coefficient (unitless) was the value provided for southern Nevada by Yu et al. (1993b), giving a normal distribution with a mean of 1.1 and a standard deviation of 0.2. The precipitation rate is based on NTS data and was fitted to a normal distribution with a mean of 0.13 meters per year $(\mathrm{m} / \mathrm{yr})(0.4 \mathrm{ft} / \mathrm{yr})$ and a standard deviation of 0.1 . The irrigation rate is based on the quantity needed to support agricultural activities. A normal distribution was assigned with a mean of $1.2 \mathrm{~m} / \mathrm{yr}$ ( $3.9 \mathrm{ft} / \mathrm{yr}$ ), a standard deviation of 0.1 , and a range of 1.0 to $1.8 \mathrm{~m} / \mathrm{yr}$ ( 3.3 to $5.9 \mathrm{ft} / \mathrm{yr}$ ). The range and distribution were selected based on the NTS rainfall and temperature patterns and the way they affect the need for irrigation.

\section{Tritium Concentration in Food}

Methods of calculating tritium concentrations in foods such as food crops, beef, milk, and their by-products are provided.

The tritium concentration in food crops is due to both tritium in irrigation water and tritium in the air. The tritium concentration in food crops due to tritium in irrigation water is the product of the tritium concentration in irrigation water and the mass fraction of hydrogen in food crops. The mass fraction of hydrogen $(\mathrm{H})$ in food crops was obtained from a report by Yu et al. (1993a). This hydrogen fraction is conservative for many crops having significantly lower water content. The concentration of tritium in food crops due to tritium in the atmosphere is adapted from the methodology developed at the Savannah River Laboratory (Hamby, 1993). It is a function of the tritium concentration in the atmosphere, the fraction of food crop that is water, the ratio of plant tritium concentration to atmospheric tritium, and the annual average absolute humidity. The value for the fraction of food crops that is water was obtained from a report by Yu et al. (1993a). 
The ratio of plant tritium concentration to atmospheric tritium is modeled as a triangular distribution with a peak of 0.8 and a range of 0.4 to 1.2 (Hamby, 1993). The annual, average absolute humidity has been derived from temperature and relative humidity data provided by the Las Vegas office of the National Oceanic and Atmospheric Administration for Pahute Mesa, Yucca Flat, and Mercury (Soule, 1995; 1996).

The concentration of tritium in beef and beef by-products includes contributions from tritium in feed crops, drinking water, and ingested soil. The modeling of tritium concentration in beef is based upon Savannah River Laboratory research (Hamby, 1993). The tritium concentration in beef due to tritium in feed crops is a product of the equilibrium ratio of tritium in beef to the cattle's daily feed ingestion rate, the tritium concentration in cattle feed, and a correction factor for the radiological decay of tritium during the time from slaughter to consumption. The analytical variables were modeled as log-normal distributions.

The concentration of tritium in beef due to the cattle's ingestion of drinking water is a product of the tritium concentration in drinking water, the transfer coefficient from water to cattle, the beef cattle water ingestion rate, and a correction factor for tritium decay for the time from slaughter to consumption.

The concentration of tritium in beef due to cattle ingestion of soil is a product of the tritium concentration in soil, the cattle soil ingestion rate, and the tritium transfer rate from soil to beef. The ingestion rate of soil by cattle and dairy cows is from a review performed at the Idaho National Engineering Laboratory (INEL) and is modeled as a normal distribution with a mean of 0.5 kilogram per day $(\mathrm{kg} / \mathrm{d})(11$ pounds per day [lbs/d]) and a standard deviation of 0.08 (Rope and Adams, 1983). The tritium transfer coefficient from soil to beef was assumed to be a normal distribution with a mean of 0.01 days per kilogram $(\mathrm{d} / \mathrm{kg})(0.005$ days per pound $[\mathrm{d} / \mathrm{lb}])$ and a standard deviation of 0.001 .

The total concentration of tritium in beef and its by-products is the sum of the contributions from feed, drinking water, and soil. The concentration of tritium in beef is typically on the order of the concentration in tritiated groundwater.

The concentration of tritium in milk and its by-products is calculated in a manner analogous to the method used to calculate tritium concentration in beef. Dairy cows ingest tritium from feed, drinking water, and soil. The most significant difference is that dairy cows ingest greater 
quantities of water. In this risk assessment, a mean value of 27.7 gallons per day (gpd) (105 liters per day [L/d]) was assumed with a standard deviation of 18.3 and a range from 13.2 to $42.3 \mathrm{gpd}(50$ to $160 \mathrm{~L} / \mathrm{d}$ ) (Yu et al., 1993b). The tritium concentration in milk is approximately equal to the tritium concentration in groundwater.

\subsection{Calculation of Intakes}

Tritium may be taken into the body through inhalation or skin absorption of tritiated water vapor, ingestion or skin absorption of tritiated water, and ingestion of contaminated soil or foods.

\section{Exposure to Tritium in Air}

Exposure to air contaminated with tritiated water vapor results in intakes of tritium both by skin absorption and by inhalation.

The model used to calculate the intake of tritium due to skin absorption is that presented in ICRP Publication 30, which is based on the investigations of Osborne (1966, 1968). Individuals are assumed to absorb tritium water vapor through their skin at all times while on site. Absorption of tritium through the skin is directly proportional to the tritium concentration in the air and exposure time with a constant of proportionality of 0.01 picoCuries per minute per picoCuries per cubic meters $\left(\mathrm{pCi} / \mathrm{min}\right.$ per $\left.\mathrm{pCi} / \mathrm{m}^{3}\right)$ of tritium in the atmosphere.

Inhalation intakes are the product of the breathing rates, the time over which the activity takes place, and the concentration of tritium in the atmosphere. Breathing rates are controlled primarily by the amount of oxygen required in the metabolic conversion of food nutrients to the energy to support the frequency and duration of various physical activities (McLean and Tobin, 1987). Secondary influences are age, weight, gender, and health. Breathing rates coupled to food-energy intakes needed to sustain the assumed physical activity levels for the land-use scenarios for various age and gender groups are from Layton (1993). The mix of physical activities used in this analysis was for individuals performing outdoor activities as recommended in the Residual Radioactive Material Guideline (RESRAD) code manual (Yu et al., 1993b).

\section{Exposure to Tritium in Water}

Exposure of human individuals to tritiated water results in intakes of tritium both by skin absorption and by ingestion. 
The analytical expression that quantifies skin intake through wet skin is that of Osborne (1968) and is a function of skin surface area, intake rate for skin, humidity of air at skin temperature, specific activity of tritium in water vapor, intake rate due to the blotter effect, and exposure time. The total skin intake of tritium is the sum of the intakes from the atmosphere and wet skin. Individuals are assumed to shower, bathe, and otherwise get their skin wet with water having a tritium concentration equal to that of groundwater.

The calculation method for ingestion intake of tritiated water is analogous to the method for calculating the inhalation of tritium in air. It is the product of the drinking water ingestion rate, the tritium concentration in drinking water, and the time that the tritiated water is being ingested. The rate of drinking water ingestion was obtained from a study by the U.S. Food and Drug Administration's total diet study (Pennington, 1983). Ingested tritiated water was assumed to be completely and instantaneously absorbed from the gastrointestinal tract and to mix rapidly with the total body water so that, at all times following ingestion, the concentration of tritium in all body fluids is equal. Tritiated water was assumed to then be uniformly distributed among all soft tissue at any time following the intake.

\section{Exposure to Tritium in Soil}

Individuals are assumed to inadvertently ingest soil. The tritium intake from soil ingestion for individuals is modeled like that for dairy and beef cattle. The average ingestion rate is 0.1 grams per day (g/d) (0.004 ounces [oz.] per day) except for individuals in the agricultural, industrial, and mining land-use scenarios who are assumed to ingest $0.48 \mathrm{~g} / \mathrm{d}(0.02 \mathrm{oz}$. per day) (Yu et al., 1993b). These ingestion rates are slightly higher than the guidance given by EPA (1991a), but are justified due to the particularly dusty conditions in the desert.

\section{Exposure to Tritium in Food}

The intakes from tritium-contaminated food crops, beef, milk, and their by-products were calculated using southern Nevada-specific consumption rates (Whicker et al., 1990). To provide a thorough description of the potential tritium intake, the concentration of tritium in pork, eggs, and poultry was assumed to be the same as in beef. For all land-use scenarios except agriculture, individuals are assumed to receive 20 percent of their food from farms and ranches using tritiated water for irrigation and drinking water. The individuals participating in the agricultural land-use scenario were conservatively assumed to get all of their food from their farm and dairy operations. 
It was assumed that all food crops were irrigated with tritiated groundwater and that the fraction of food grown on site is representative for rural areas in the vicinity of the NTS. The types and amounts of food ingested are representative of average southern Nevada residents

(Whicker et al., 1990). It was also conservatively assumed that ingesting tritium-contaminated food stuffs results in the tritium being absorbed across the gastrointestinal tract and rapidly and uniformly mixing with the body fluids.

\subsubsection{Dose Assessment}

Dose assessment provides dose values that can be compared to benchmark values and/or can be used to calculate risk values to human health. Tritium intake and dose for each scenario at each dose receptor location were calculated. Descriptions of the specific approach used in dose assessment and the resulting doses along the three selected pathlines are provided in this section.

\subsubsection{Dose Assessment Approach}

Descriptions of the radiological effects of tritium, tritium dosimetry theory, and the analytical methods used in calculating tritium doses are provided in this section.

Tritium, an isotope of the element hydrogen, is both naturally occurring and manufactured. The radiological half-life of tritium is 12.3 years (Unterweger et al., 1980), decaying to helium while emitting a beta particle. Tritium beta particles, while of very low energy $\left(18.6 \times 10^{-2}\right.$ megaelectron volts $[\mathrm{MeV}]$ maximum, $5.7 \times 10^{-3} \mathrm{MeV}$ average), have enough energy to ionize and excite molecules in their path. Tritium poses no direct external hazard. The penetration range in tissue of the beta particles released during tritium decay is on the average less than 1 micrometer $(\mu \mathrm{m})$, and the maximum range is only $6 \mu \mathrm{m}$ (ICRP, 1983). Because of their small range in tissue, the tritium betas cannot penetrate through an average size cell in the body nor through the outer layer of dead skin cells. Therefore, the fundamental issue in tritium dosimetry is its uptake and distribution within soft tissue in the body.

The amount of energy actually absorbed from radiation by living cells per unit mass of tissue is known as the absorbed dose. The amount of internal radiation dose is a function of the type and energy of the emitted radiation and the amount and distribution of the radiation in the body. Tritium beta particles do not leave the organ in which they originate and, therefore, deposit all of their energy in that organ. The quantitative measure of energy absorption is the Gray (Gy), where $1 \mathrm{~Gy}$ is taken to represent one joule $(\mathrm{J})$ of energy deposited per kilogram of material. 
The dose is taken to be the average dose over a tissue or organ and is used as an indicator for the probability of stochastic effects occurring after irradiation.

An example of a stochastic effect is cancer. The biological effects of radiation are brought about through chemical changes in the cells caused by ionization, excitations, dissociations, and atom displacements. When determining radiation effects on living organisms, it is necessary to consider not only the total dosages of ionization produced within the organism, but also such factors as the density of the ionization, the dose rate, the localization effect, and the rates of both uptake and elimination of radioactive material.

The dose due to the tritium intakes was calculated by adding all intakes and multiplying the sum by a dose conversion factor (DCF). The dose conversion factor is calculated using the definition for absorbed dose stated above. The energy from the tritium beta is assumed to be absorbed in the soft tissue of the body from which it is eliminated with an average half-time of 8.69 days. The analytical expression for calculating the DCF is listed below:

$$
\mathrm{DCF}=\frac{\left(5.12 \times 10^{-5} \times \mathrm{Q} \times \mathrm{E} \times \mathrm{f} \times \mathrm{T}_{\mathrm{e}}\right)}{\ln (2) \times \mathrm{S}}
$$

where:

$\mathrm{DCF}=$ Dose conversion factor from $\mathrm{pCi}$ intake to rem;

$\mathrm{Q}=$ Quality factor for tritium beta emissions (1);

$\mathrm{E} \quad=$ Average energy of tritium betas (5.685E-3 MeV/disintegration);

$\mathrm{f} \quad=$ Fraction of energy absorbed in soft tissue (10);

$\mathrm{T}_{\mathrm{e}} \quad=$ Biological half-life in the body (8.692 days);

$\mathrm{S}=$ Soft tissue mass of the body $(70,200$ grams $[\mathrm{g}])$; and

$5.12 \times 10^{-5}=$ Unit conversion factor $(\mathrm{rem} \times \mathrm{g} / \mathrm{pCi} \times[\mathrm{MeV} /$ disintegration $] \times$ day $)$.

The biological half-life, $\mathrm{T}_{\mathrm{e}}$, was modeled as a log-normal distribution with a geometric mean of 8.69 days with a geometric standard deviation of 0.27 for the adult dose receptor (Hamby, 1993). For the child, the distribution is normally distributed with a mean of 4.95 days and a standard deviation of 0.35 (Hill and Johnson, 1993). The mass of the soft tissue, S, was modeled for the adult as a log-normal distribution with a geometric mean of 70,200 $\mathrm{g}$ (155 lbs) and a geometric standard deviation of 0.14 (Hamby, 1993). The mass of soft tissue, S, for the child was modeled 
at a constant, 30,000 $\mathrm{g}$ (Lioy et al., 1992). The tritium intakes for each land-use scenario from all exposure mechanisms at each exposure location were summed and then multiplied by the DCF.

\subsubsection{Dose Assessment Results}

The dose assessment was performed for each receptor location on the three selected pathlines, for each of the land use scenarios (Table 10-1) by comparing the calculated doses with the requirements in DOE Order 5400.5 (DOE, 1993). The DOE Order 5400.5 requires that doses to members of the public not exceed 100 millirems per year (mrem/yr) above natural background level from DOE activities.

The calculated doses at the 5th, 50th and 95th percent levels at selected receptor locations along the BOURBON, HOUSTON, and TYBO pathlines are presented. The estimated doses for the agricultural and residential scenarios are listed in Tables 10-2 and 10-3. The agriculture and residential land-use exposure scenarios were chosen because they resulted in the maximum dose. The dose from the other four land-use exposure scenarios are significantly lower. Emphasis of the following discussion is on whether the dose exceeds regulatory limits off the NTS.

\subsection{BOURBON Pathline}

Analysis of the BOURBON pathline demonstrates that the tritium concentration and radiation dose do not exceed the limits established in DOE Order 5400.5 (DOE, 1993) at dose receptor locations past the NTS boundary. Details on the radiation doses in regard to the BOURBON pathline are discussed in this section.

The 5th and 50th percentile doses for the adult do not exceed the 100-mrem/yr limit at any dose location beyond the NTS boundary. The maximum dose to the adult at the 5th and 50th percentiles from the agriculture exposure scenario is less than $100 \mathrm{mrem} / \mathrm{yr}$ at distances past $12.5 \mathrm{~km}(7.8 \mathrm{mi})$ from the nuclear test location. The 95th percentile doses for the adult does not exceed the 100-mrem/yr limit at locations beyond $17.5 \mathrm{~km}(10.9 \mathrm{mi})$.

The 5th and 50th percentile doses for the child do not exceed the 100-mrem/yr limit at any locations past the NTS boundary. The maximum dose to the child at the 5th and 50th percentiles, from the agriculture exposure scenario, is less than $100 \mathrm{mrem} / \mathrm{yr}$ at distance past $12.5 \mathrm{~km}(7.8 \mathrm{mi})$. The 95th percentile dose for the child does not exceed the $100-\mathrm{mrem} / \mathrm{yr}$ limit at any dose receptor location past the NTS boundary. The maximum dose at the 95th percentile 
is received in the agriculture scenario and does not exceed $100 \mathrm{mrem} / \mathrm{yr}$ at locations past $17.5 \mathrm{~km}$ (7.8 mi).

\subsection{HOUSTON Pathline}

Analysis of the HOUSTON pathline demonstrates that the tritium concentration and radiation doses do not exceed the limits established in DOE Order 5400.5 (DOE, 1993) at dose receptor locations past the NTS and Nellis Air Force Range boundaries. At the 5th, 50th and 95th percentile, the dose to the adult or child for all exposure scenarios did not exceed the limit of $100 \mathrm{mrem} / \mathrm{yr}$ at any dose receptor location past the NTS boundary (Tables 10-2 and 10-3).

Table 10-2

\section{Estimated Dose for Potential Agricultural Scenario at the Nevada Test Site ${ }^{a}$}

\begin{tabular}{|c|c|c|c|c|c|c|c|}
\hline \multirow[t]{2}{*}{$\begin{array}{l}\text { Distance } \\
\text { (kilometers) }\end{array}$} & \multirow[t]{2}{*}{ Location } & \multicolumn{3}{|c|}{$\begin{array}{l}\text { Adult Annual Dose } \\
\text { (percentile) } \\
\text { (mrem/yr) }\end{array}$} & \multicolumn{3}{|c|}{$\begin{array}{l}\text { Child Annual Dose } \\
\text { (percentile) } \\
\text { (mrem/yr) }\end{array}$} \\
\hline & & 5 & 50 & 95 & 5 & 50 & 95 \\
\hline \multicolumn{8}{|c|}{ BOURBON Pathline - Agricultural Scenario } \\
\hline 0.1 & KANKAKEE & $3.2 \times 10^{1}$ & $7.1 \times 10^{2}$ & $1.3 \times 10^{4}$ & $3.1 \times 10^{1}$ & $6.8 \times 10^{2}$ & $1.3 \times 10^{4}$ \\
\hline 10 & BOURBON & $2.1 \times 10^{1}$ & $4.1 \times 10^{2}$ & $4.0 \times 10^{3}$ & $2.0 \times 10^{1}$ & $3.9 \times 10^{2}$ & $3.7 \times 10^{3}$ \\
\hline 70 & NTS Boundary & $2.4 \times 10^{-4}$ & $2.2 \times 10^{-3}$ & $5.5 \times 10^{-3}$ & $2.4 \times 10^{-4}$ & $2.1 \times 10^{-3}$ & $4.7 \times 10^{-3}$ \\
\hline \multicolumn{8}{|c|}{ HOUSTON Pathline - Agricultural Scenario } \\
\hline 0.1 & HOUSTON & $9.2 \times 10^{1}$ & $1.1 \times 10^{3}$ & $1.2 \times 10^{4}$ & $9.0 \times 10^{1}$ & $1.0 \times 10^{3}$ & $1.2 \times 10^{4}$ \\
\hline 30 & NTS Boundary & $3.7 \times 10^{-4}$ & $3.3 \times 10^{-3}$ & $6.7 \times 10^{0}$ & $3.5 \times 10^{-4}$ & $3.1 \times 10^{-3}$ & $6.3 \times 10^{0}$ \\
\hline 40 & $\begin{array}{l}\text { Nellis Air Force } \\
\text { Range Boundary }\end{array}$ & $2.5 \times 10^{-4}$ & $2.7 \times 10^{-3}$ & $9.1 \times 10^{-1}$ & $2.4 \times 10^{-4}$ & $2.5 \times 10^{-3}$ & $9.0 \times 10^{-1}$ \\
\hline \multicolumn{8}{|c|}{ TYBO Pathline - Agricultural Scenario } \\
\hline 0.1 & PEPATO & $7.7 \times 10^{0}$ & $1.3 \times 10^{2}$ & $1.7 \times 10^{3}$ & $7.1 \times 10^{0}$ & $1.3 \times 10^{2}$ & $1.7 \times 10^{3}$ \\
\hline 9.8 & $\begin{array}{c}\text { TYBO \& NTS } \\
\text { Boundary }\end{array}$ & $1.7 \times 10^{1}$ & $3.7 \times 10^{2}$ & $2.6 \times 10^{3}$ & $1.7 \times 10^{1}$ & $3.5 \times 10^{2}$ & $2.5 \times 10^{3}$ \\
\hline 31.8 & $\begin{array}{l}\text { Nellis Air Force } \\
\text { Range Boundary }\end{array}$ & $5.7 \times 10^{-4}$ & $1.3 \times 10^{-1}$ & $1.8 \times 10^{2}$ & $5.2 \times 10^{-4}$ & $1.2 \times 10^{-1}$ & $1.7 \times 10^{2}$ \\
\hline 37.1 & $\begin{array}{l}\text { Oasis Valley } \\
\text { Discharge Area }\end{array}$ & $5.7 \times 10^{-4}$ & $1.2 \times 10^{-1}$ & $1.4 \times 10^{2}$ & $5.5 \times 10^{-5}$ & $1.2 \times 10^{-1}$ & $1.4 \times 10^{2}$ \\
\hline
\end{tabular}

\footnotetext{
$\mathrm{a}_{\mathrm{mrem} / \mathrm{yr}}=$ Millirems per year
} 


\section{Table 10-3}

Estimated Dose for Potential Residential Scenario at the Nevada Test Site ${ }^{a}$

\begin{tabular}{|c|c|c|c|c|c|c|c|}
\hline \multirow{2}{*}{$\begin{array}{c}\text { Distance } \\
\text { (kilometers) }\end{array}$} & \multirow[t]{2}{*}{ Location } & \multicolumn{3}{|c|}{$\begin{array}{l}\text { Adult Annual Dose } \\
\text { (percentile) } \\
\text { (mrem/yr) }\end{array}$} & \multicolumn{3}{|c|}{$\begin{array}{c}\text { Child Annual Dose } \\
\text { (percentile) } \\
\text { (mrem/yr) }\end{array}$} \\
\hline & & 5 & 50 & 95 & 5 & 50 & 95 \\
\hline \multicolumn{8}{|c|}{ BOURBON Pathline - Residential Scenario } \\
\hline 0.1 & KANKAKEE & $2.1 \times 10^{1}$ & $4.5 \times 10^{2}$ & $8.2 \times 10^{3}$ & $1.2 \times 10^{1}$ & $2.4 \times 10^{2}$ & $4.4 \times 10^{3}$ \\
\hline 10 & BOURBON & $1.2 \times 10^{1}$ & $2.5 \times 10^{2}$ & $2.7 \times 10^{3}$ & $6.6 \times 10^{0}$ & $1.4 \times 10^{2}$ & $1.4 \times 10^{3}$ \\
\hline 70 & NTS Boundary & $1.6 \times 10^{-4}$ & $1.4 \times 10^{-3}$ & $3.7 \times 10^{-3}$ & $8.6 \times 10^{-5}$ & $7.6 \times 10^{-4}$ & $1.8 \times 10^{-3}$ \\
\hline \multicolumn{8}{|c|}{ HOUSTON Pathline - Residential Scenario } \\
\hline 0.1 & HOUSTON & $5.8 \times 10^{1}$ & $6.8 \times 10^{2}$ & $7.9 \times 10^{3}$ & $3.3 \times 10^{1}$ & $3.7 \times 10^{2}$ & $4.1 \times 10^{3}$ \\
\hline 30 & NTS Boundary & $2.3 \times 10^{-4}$ & $2.1 \times 10^{-3}$ & $4.3 \times 10^{0}$ & $1.3 \times 10^{-4}$ & $1.1 \times 10^{-3}$ & $2.3 \times 10^{0}$ \\
\hline 40 & $\begin{array}{l}\text { Nellis Air Force Range } \\
\text { Boundary }\end{array}$ & $1.6 \times 10^{-4}$ & $1.7 \times 10^{-3}$ & $5.8 \times 10^{-1}$ & $1.0 \times 10^{-4}$ & $9.1 \times 10^{-4}$ & $3.2 \times 10^{-1}$ \\
\hline \multicolumn{8}{|c|}{ TYBO Pathline - Residential Scenario } \\
\hline 0.1 & PEPATO & $5.3 \times 10^{0}$ & $8.1 \times 10^{1}$ & $1.1 \times 10^{3}$ & $2.9 \times 10^{0}$ & $4.4 \times 10^{1}$ & $6.0 \times 10^{2}$ \\
\hline 9.8 & $\begin{array}{c}\text { TYBO \& NTS } \\
\text { Boundary }\end{array}$ & $1.2 \times 10^{1}$ & $2.4 \times 10^{2}$ & $1.7 \times 10^{3}$ & $6.8 \times 10^{0}$ & $1.3 \times 10^{2}$ & $9.1 \times 10^{2}$ \\
\hline 31.8 & $\begin{array}{c}\text { Nellis Air Force Range } \\
\text { Boundary }\end{array}$ & $3.4 \times 10^{-4}$ & $6.0 \times 10^{-2}$ & $1.2 \times 10^{2}$ & $1.9 \times 10^{-4}$ & $3.1 \times 10^{-2}$ & $6.4 \times 10^{1}$ \\
\hline 37.1 & $\begin{array}{c}\text { Oasis Valley } \\
\text { Discharge Area }\end{array}$ & $3.5 \times 10^{-4}$ & $1.2 \times 10^{-1}$ & $1.4 \times 10^{2}$ & $1.9 \times 10^{-4}$ & $4.7 \times 10^{-2}$ & $6.4 \times 10^{1}$ \\
\hline
\end{tabular}

$a_{\mathrm{mrem} / \mathrm{yr}}=$ Millirems per year

\subsection{TYBO Pathline}

Analysis of the TYBO pathline indicates that tritium concentrations and radiation doses exceed the $100 \mathrm{mrem} / \mathrm{yr}$ limit established in DOE Order 5400.5 (DOE, 1993) at dose receptor locations downgradient of the NTS border.

At the 5th percentile, the $100-\mathrm{mrem} / \mathrm{y}$ limit was not exceeded past a distance of $0.1 \mathrm{~km}(0.06 \mathrm{mi})$ for both of the agricultural and residential scenarios. However, for the agriculture exposure scenario at locations less than $14.7 \mathrm{~km}(9.1 \mathrm{mi})$ and for the residential exposure scenario at 
location less than $12.2 \mathrm{~km}(7.6 \mathrm{mi})$, the 50th percentile dose for the adult receptors exceeded the 100-mrem/yr limit. These include locations that are off the NTS but not beyond the Nellis Air Force Range boundary. The 50th percentile dose did not exceed the 100-mrem/yr limit for any other adult dose receptors at locations off the NTS.

At the 95th percentile, the 100-mrem/yr limit is exceeded at all dose receptor locations for the agricultural exposure scenario. For the adult residential exposure scenario, the 95 th percentile dose exceeds 100-mrem/yr at locations beyond both the NTS and the Nellis Air Force Range boundaries. The 95th percentile dose for the industrial, mining, and recreation exposure scenarios exceed the 100-mrem/yr limit at locations off the NTS, but it is not exceeded beyond the Nellis Air Force Range boundary. The 95th percentile dose for the adult tourist exposure scenario does not exceed the $100 \mathrm{mrem} / \mathrm{yr}$ limit at locations beyond $2.9 \mathrm{~km}$ (1.8 $\mathrm{mi})$ from the TYBO test location; this is located on the NTS.

The dose to the child is slightly less than the dose to the adult at the 50th percentile for all exposure scenarios. Despite the difference in dose, the location where the dose to the child is less than $100 \mathrm{mrem} / \mathrm{yr}$ occurs close to the same location as for the adult.

\subsubsection{Risk Characterization}

The risk results are presented in terms of maximum simulated distances to points along the pathlines representing regulatory guidelines relating to Superfund sites. The guidelines are as follows:

- The $10^{-4}$ lifetime total cancer incidence represents the risk level above which an immediate interim remedial action must be taken at Superfund sites.

- The $10^{-6}$ lifetime total cancer incidence represents the risk level below which no corrective action is needed at Superfund sites.

These limits were used for comparison purposes only. They do not constitute regulatory limits that are applicable to DOE operations in Nevada.

The calculated risks at the 5th, 50th and 95th percent levels at selected receptor locations along the BOURBON, HOUSTON, and TYBO pathlines are presented. The estimated risks for the 
agricultural and residential scenarios are listed in Tables 10-4 through 10-7. Again, the agriculture and residential land-use exposure scenarios were chosen because they resulted in the maximum doses and risks. The doses and risks from the other four land-use exposure scenarios are significantly lower. Emphasis of the following discussion is on whether the risk exceeds $10^{-4}$ lifetime total cancer incidence.

\subsubsection{Risk Characterization Approach}

Risk is expressed as the lifetime probability of a latent cancer fatality (LCF), a total cancer incidence (TCI), nonfatal cancer incidence, and a severe hereditary or genetic detriment. The last two risks are combined in this analysis and defined as the radiological detriment. A risk factor is a distribution that provides a numerical correlation between a dose and the effect the dose will have on a person. Radiological risk factors are based largely on epidemiological data, primarily from studies examining the radiological health effects of high doses and high dose rates of external exposure. Risk is not a direct function of the absorbed dose. An absorbed dose can result in different risk based upon the characteristics of the radiation and the type of tissue irradiated. When comparing the relative toxicities or damage potential of different radiations, equal energy absorption is assumed.

The predominant risk from radiation exposure is cancer incidence. Radiation-induced cancers may have a latency period, that is, delayed onset, of 20 years or longer. Therefore, cancer death is referred to as latent cancer fatality. The radiological risk estimates include the lifetime risk for latent cancer fatality and the total cancer incidence.

\subsubsection{Risk Characterization Results}

This section describe the lifetime risks at the 5th, 50th and 95th percentiles at locations along the TYBO, HOUSTON, and BOURBON pathlines. The estimated risks for the agricultural and residential scenarios are listed in Tables 10-4 through 10-7. Tables 10-4 and 10-6 list the risks to adult receptors and Tables 10-5 and 10-7 list the risks to child receptors.

\subsection{BOURBON Pathline}

Analysis of the BOURBON pathline demonstrates that the lifetime cancer incidence risk does not exceed $1 \times 10^{-4}$ at any dose receptor location beyond the NTS boundary. Results are summarized in Tables 10-4 through 10-7. 
Table 10-4

Estimated Risk for Potential Agricultural Adult Scenario at the Nevada Test Site ${ }^{a}$

\begin{tabular}{|c|c|c|c|c|c|c|c|}
\hline \multirow{2}{*}{$\begin{array}{c}\text { Distance } \\
\text { (kilometers) }\end{array}$} & \multirow[t]{2}{*}{ Location } & \multicolumn{3}{|c|}{$\begin{array}{l}\text { Lifetime Fatal } \\
\text { Cancer Risk } \\
\text { (percentile) }\end{array}$} & \multicolumn{3}{|c|}{$\begin{array}{l}\text { Lifetime Cancer Incidence } \\
\text { (Slope Factor) } \\
\text { (percentile) }\end{array}$} \\
\hline & & 5 & 50 & 95 & 5 & 50 & 95 \\
\hline \multicolumn{8}{|c|}{ BOURBON Pathline } \\
\hline 0.1 & KANKAKEE & $4.8 \times 10^{-4}$ & $1.1 \times 10^{-2}$ & $2.0 \times 10^{-1}$ & $1.3 \times 10^{-3}$ & $2.9 \times 10^{-2}$ & $5.5 \times 10^{-1}$ \\
\hline 10 & BOURBON & $3.2 \times 10^{-4}$ & $6.1 \times 10^{-3}$ & $6.0 \times 10^{-2}$ & $9.0 \times 10^{-4}$ & $1.7 \times 10^{-2}$ & $1.6 \times 10^{-1}$ \\
\hline 70 & NTS Boundary & $3.6 \times 10^{-9}$ & $3.3 \times 10^{-8}$ & $8.2 \times 10^{-8}$ & $1.0 \times 10^{-8}$ & $9.1 \times 10^{-8}$ & $2.0 \times 10^{-7}$ \\
\hline \multicolumn{8}{|c|}{ HOUSTON Pathline } \\
\hline 0.1 & HOUSTON & $1.4 \times 10^{-3}$ & $1.6 \times 10^{-2}$ & $1.9 \times 10^{-1}$ & $3.9 \times 10^{-3}$ & $4.4 \times 10^{-2}$ & $5.0 \times 10^{-1}$ \\
\hline 30 & NTS Boundary & $5.6 \times 10^{-9}$ & $4.9 \times 10^{-8}$ & $1.0 \times 10^{-4}$ & $1.5 \times 10^{-8}$ & $1.3 \times 10^{-7}$ & $2.7 \times 10^{-4}$ \\
\hline 40 & Nellis Air Force Range Boundary & $3.6 \times 10^{-9}$ & $4.0 \times 10^{-8}$ & $1.4 \times 10^{-5}$ & $1.0 \times 10^{-8}$ & $1.1 \times 10^{-7}$ & $3.9 \times 10^{-5}$ \\
\hline \multicolumn{8}{|c|}{ TYBO Pathline } \\
\hline 0.1 & PEPATO & $1.2 \times 10^{-4}$ & $2.0 \times 10^{-3}$ & $2.6 \times 10^{-2}$ & $3.1 \times 10^{-4}$ & $5.4 \times 10^{-3}$ & $7.1 \times 10^{-2}$ \\
\hline 9.8 & TYBO \& NTS Boundary & $2.6 \times 10^{-4}$ & $5.5 \times 10^{-3}$ & $3.8 \times 10^{-2}$ & $7.2 \times 10^{-4}$ & $1.5 \times 10^{-2}$ & $1.1 \times 10^{-1}$ \\
\hline 31.8 & Nellis Air Force Range Boundary & $8.5 \times 10^{-9}$ & $2.0 \times 10^{-6}$ & $2.7 \times 10^{-3}$ & $2.3 \times 10^{-8}$ & $5.4 \times 10^{-6}$ & $7.4 \times 10^{-3}$ \\
\hline 37.1 & Oasis Valley Discharge Area & $8.5 \times 10^{-9}$ & $1.9 \times 10^{-6}$ & $2.1 \times 10^{-3}$ & $2.3 \times 10^{-8}$ & $5.1 \times 10^{-6}$ & $5.8 \times 10^{-3}$ \\
\hline
\end{tabular}

${ }_{b}^{a}$ This table reflects potential risks for the Agricultural Exposure Scenario for an adult receptor.

$\mathrm{mrem} / \mathrm{yr}=$ Millirems per year 
Table 10-5

Estimated Risk for Potential Agricultural Child Scenario at the Nevada Test Site ${ }^{a}$

\begin{tabular}{|c|c|c|c|c|c|c|c|}
\hline \multirow{2}{*}{$\begin{array}{c}\text { Distance } \\
\text { (kilometers) }\end{array}$} & \multirow[t]{2}{*}{ Location } & \multicolumn{3}{|c|}{$\begin{array}{l}\text { Lifetime Fatal } \\
\text { Cancer Risk } \\
\text { (percentile) }\end{array}$} & \multicolumn{3}{|c|}{$\begin{array}{l}\text { Lifetime Cancer Incidence } \\
\text { (Slope Factor) } \\
\text { (percentile) }\end{array}$} \\
\hline & & 5 & 50 & 95 & 5 & 50 & 95 \\
\hline \multicolumn{8}{|c|}{ BOURBON Pathline } \\
\hline 0.1 & KANKAKEE & $1.4 \times 10^{-4}$ & $3.1 \times 10^{-3}$ & $5.7 \times 10^{-2}$ & $2.9 \times 10^{-4}$ & $6.4 \times 10^{-3}$ & $1.2 \times 10^{-1}$ \\
\hline 10 & BOURBON & $9.1 \times 10^{-5}$ & $1.7 \times 10^{-3}$ & $1.7 \times 10^{-2}$ & $2.0 \times 10^{-4}$ & $3.6 \times 10^{-3}$ & $3.5 \times 10^{-2}$ \\
\hline 70 & NTS Boundary & $1.1 \times 10^{-9}$ & $9.5 \times 10^{-9}$ & $2.1 \times 10^{-8}$ & $2.2 \times 10^{-9}$ & $2.0 \times 10^{-8}$ & $4.3 \times 10^{-8}$ \\
\hline \multicolumn{8}{|c|}{ HOUSTON Pathline } \\
\hline 0.1 & HOUSTON & $4.1 \times 10^{-2}$ & $4.6 \times 10^{-3}$ & $5.2 \times 10^{-2}$ & $8.4 \times 10^{-4}$ & $9.4 \times 10^{-3}$ & $1.1 \times 10^{-1}$ \\
\hline 30 & NTS Boundary & $1.6 \times 10^{-9}$ & $1.4 \times 10^{-8}$ & $2.8 \times 10^{-5}$ & $3.3 \times 10^{-9}$ & $2.9 \times 10^{-8}$ & $5.9 \times 10^{-5}$ \\
\hline 40 & Nellis Air Force Range Boundary & $1.1 \times 10^{-9}$ & $1.1 \times 10^{-8}$ & $4.0 \times 10^{-6}$ & $2.2 \times 10^{-9}$ & $2.4 \times 10^{-8}$ & $8.4 \times 10^{-6}$ \\
\hline \multicolumn{8}{|c|}{ TYBO Pathline } \\
\hline 0.1 & PEPATO & $3.2 \times 10^{-5}$ & $5.7 \times 10^{-4}$ & $7.4 \times 10^{-3}$ & $6.7 \times 10^{-5}$ & $1.2 \times 10^{-3}$ & $1.5 \times 10^{-2}$ \\
\hline 9.8 & TYBO \& NTS Boundary & $7.4 \times 10^{-5}$ & $1.6 \times 10^{-3}$ & $1.1 \times 10^{-2}$ & $1.5 \times 10^{-4}$ & $3.3 \times 10^{-3}$ & $2.3 \times 10^{-2}$ \\
\hline 31.8 & Nellis Air Force Range Boundary & $2.3 \times 10^{-9}$ & $5.6 \times 10^{-7}$ & $7.8 \times 10^{-4}$ & $4.9 \times 10^{-9}$ & $1.2 \times 10^{-6}$ & $1.6 \times 10^{-3}$ \\
\hline 37.1 & Oasis Valley Discharge Area & $2.5 \times 10^{-9}$ & $5.2 \times 10^{-7}$ & $6.1 \times 10^{-4}$ & $5.1 \times 10^{-9}$ & $1.1 \times 10^{-6}$ & $1.3 \times 10^{-3}$ \\
\hline
\end{tabular}

${ }^{\mathrm{a}}$ This table reflects potential risks for the Agricultural Exposure Scenario for a child receptor. 
Table 10-6

Estimated Risk for Potential Residential Adult Scenario at the Nevada Test Site ${ }^{a}$

\begin{tabular}{|c|c|c|c|c|c|c|c|}
\hline \multirow{2}{*}{$\begin{array}{c}\text { Distance } \\
\text { (kilometers) }\end{array}$} & \multirow[t]{2}{*}{ Location } & \multicolumn{3}{|c|}{$\begin{array}{l}\text { Lifetime Fatal } \\
\text { Cancer Risk } \\
\text { (percentile) }\end{array}$} & \multicolumn{3}{|c|}{$\begin{array}{l}\text { Lifetime Cancer Incidence } \\
\text { (Slope Factor) } \\
\text { (percentile) }\end{array}$} \\
\hline & & 5 & 50 & 95 & 5 & 50 & 95 \\
\hline \multicolumn{8}{|c|}{ BOURBON Pathline } \\
\hline 0.1 & KANKAKEE & $3.2 \times 10^{-4}$ & $6.8 \times 10^{-3}$ & $1.2 \times 10^{-1}$ & $8.8 \times 10^{-4}$ & $1.8 \times 10^{-2}$ & $3.3 \times 10^{-1}$ \\
\hline 10 & BOURBON & $1.8 \times 10^{-4}$ & $3.8 \times 10^{-3}$ & $4.1 \times 10^{-2}$ & $5.2 \times 10^{-4}$ & $1.0 \times 10^{-2}$ & $1.1 \times 10^{-1}$ \\
\hline 70 & NTS Boundary & $2.4 \times 10^{-9}$ & $2.1 \times 10^{-8}$ & $5.5 \times 10^{-8}$ & $6.4 \times 10^{-9}$ & $5.7 \times 10^{-8}$ & $1.3 \times 10^{-7}$ \\
\hline \multicolumn{8}{|c|}{ HOUSTON Pathline } \\
\hline 0.1 & HOUSTON & $8.7 \times 10^{-4}$ & $1.0 \times 10^{-2}$ & $1.2 \times 10^{-1}$ & $2.4 \times 10^{-3}$ & $2.8 \times 10^{-2}$ & $3.2 \times 10^{-1}$ \\
\hline 30 & NTS Boundary & $3.4 \times 10^{-9}$ & $3.1 \times 10^{-8}$ & $6.4 \times 10^{-5}$ & $9.4 \times 10^{-9}$ & $8.4 \times 10^{-8}$ & $1.7 \times 10^{-4}$ \\
\hline 40 & Nellis Air Force Range Boundary & $2.3 \times 10^{-9}$ & $2.5 \times 10^{-8}$ & $8.6 \times 10^{-6}$ & $6.5 \times 10^{-9}$ & $6.9 \times 10^{-8}$ & $2.5 \times 10^{-5}$ \\
\hline \multicolumn{8}{|c|}{ TYBO Pathline } \\
\hline 0.1 & PEPATO & $7.9 \times 10^{-5}$ & $1.2 \times 10^{-3}$ & $1.7 \times 10^{-2}$ & $2.2 \times 10^{-4}$ & $3.3 \times 10^{-3}$ & $4.6 \times 10^{-2}$ \\
\hline 9.8 & TYBO \& NTS Boundary & $1.7 \times 10^{-4}$ & $3.7 \times 10^{-3}$ & $2.5 \times 10^{-2}$ & $4.9 \times 10^{-4}$ & $9.9 \times 10^{-3}$ & $6.8 \times 10^{-2}$ \\
\hline 31.8 & Nellis Air Force Range Boundary & $5.1 \times 10^{-9}$ & $9.0 \times 10^{-7}$ & $1.8 \times 10^{-3}$ & $1.4 \times 10^{-8}$ & $2.4 \times 10^{-6}$ & $4.8 \times 10^{-3}$ \\
\hline 37.1 & Oasis Valley Discharge Area & $5.2 \times 10^{-9}$ & $1.3 \times 10^{-6}$ & $1.4 \times 10^{-3}$ & $1.4 \times 10^{-8}$ & $3.6 \times 10^{-6}$ & $3.8 \times 10^{-3}$ \\
\hline
\end{tabular}

${ }^{\mathrm{a}}$ This table reflects potential risks for the Residential Exposure Scenario for an adult receptor. 
Table 10-7

Estimated Risk for Potential Residential Child Scenario at the Nevada Test Site ${ }^{a}$

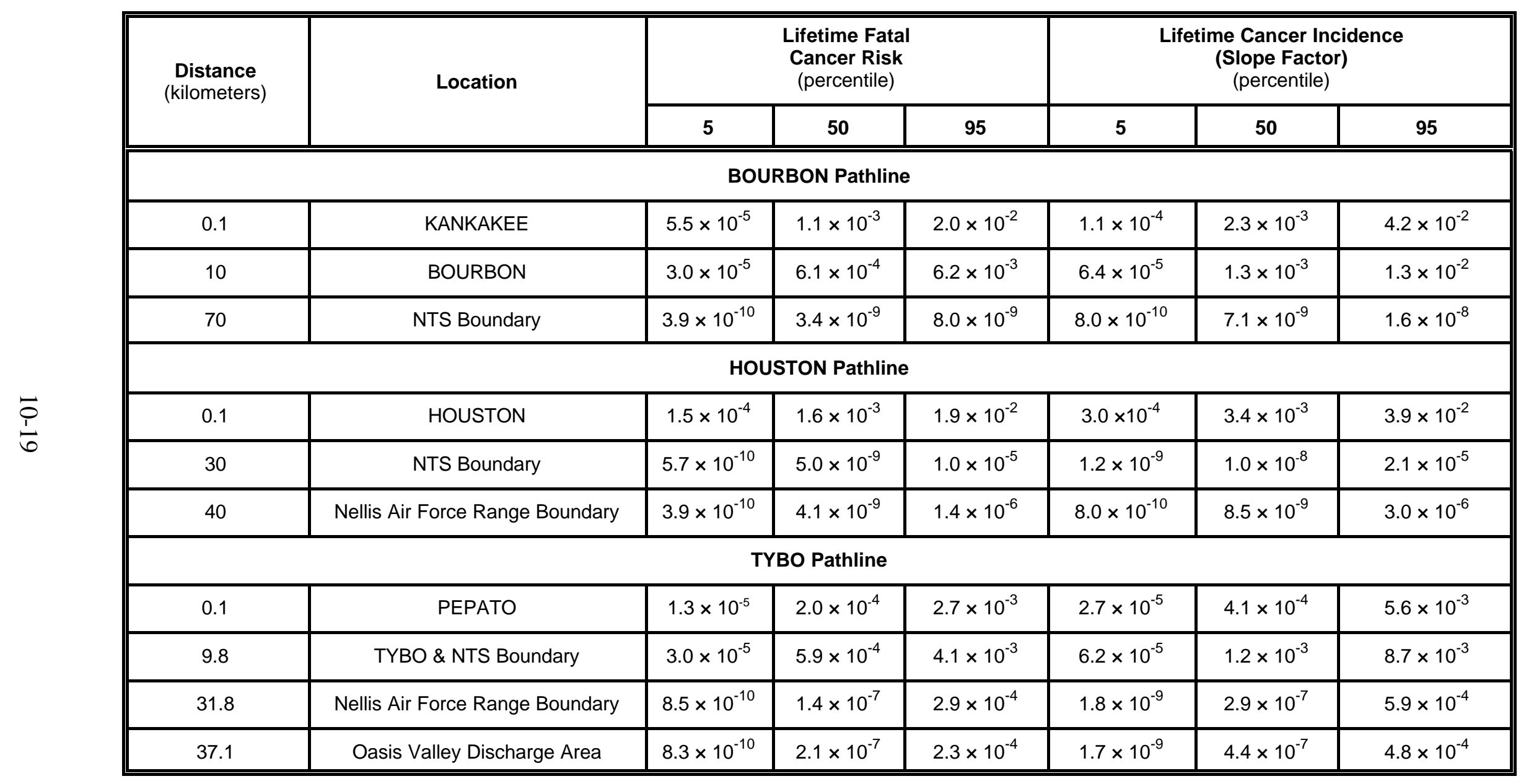

${ }^{\mathrm{a}}$ This table reflects potential risks for the Residential Exposure Scenario for a child receptor. 
The estimated lifetime cancer incidence risk to adults at the 5th and 50th percentiles does not exceed $1 \times 10^{-4}$ at dose receptor locations past $15 \mathrm{~km}(9 \mathrm{mi})$ for the agriculture exposure scenario. The 95th percentile estimated lifetime cancer incidence risk to adults does not exceed $1 \times 10^{-4}$ at dose receptor locations for the agriculture exposure scenario beyond the NTS boundary. For all exposure scenarios, the 95th percentile estimated lifetime cancer incidence risk for adults does not exceed $1 \times 10^{-4}$ at any dose receptor location beyond $30 \mathrm{~km}$ (19 mi) downgradient.

The lifetime radiation detriment and fatal cancer risk to adults at the 50th percentile do not exceed $1 \times 10^{-4}$ at any dose receptor location past the NTS boundary. The maximum lifetime radiation detriment and fatal cancer risk to adults at the 50th percentile are from the agriculture exposure scenario, and neither exceeds $1 \times 10^{-4}$ at distances beyond $15 \mathrm{~km}(9 \mathrm{mi})$. At the $95 \mathrm{th}$ percentile, the lifetime radiation detriment and fatal cancer risk do not exceed $1 \times 10^{-4}$ at any dose receptor locations beyond $30 \mathrm{~km}(19 \mathrm{mi})$.

The estimated lifetime cancer incidence risk to the child at the 5th, 50th and 95th percentile does not exceed $1 \times 10^{-4}$ for any dose receptor location past the NTS boundary. The maximum estimated lifetime cancer incidence at the 95th percentile is from the agriculture exposure scenario. The risk does not exceed $1 \times 10^{-4}$ for distance beyond $25 \mathrm{~km}(15.5 \mathrm{mi})$.

The estimated lifetime fatal cancer risks to the child do not exceed $1 \times 10^{-4}$ at the 5th, 50th and 95th percentile for any dose receptor location past the NTS boundary.

\subsection{HOUSTON Pathline}

Analysis of the HOUSTON pathline demonstrates that the estimated cancer incidence risks do not exceed $1 \times 10^{-4}$ for any dose receptor location beyond the Nellis Air Force Range boundary. The risk for the HOUSTON pathline are discussed in this section. These details are summarized in Tables 10-4 through 10-7.

At the 5th and 50th percentiles, the estimated lifetime cancer incidence risk to the adult or child for all exposure scenarios did not exceed $1 \times 10^{-4}$ at any location past the NTS boundary. At the 95th percentile, the estimated lifetime cancer incidence risk to the adult does not exceed $1 \times 10^{-4}$ at locations past $35 \mathrm{~km}$ (21.7 mi), which is beyond the NTS boundary but still on the Nellis Air Force Range. At the 95th percentile, the lifetime cancer incidence, lifetime fatal cancer, or lifetime radiation detriment risk to the child does not exceed $1 \times 10^{-4}$ at any dose receptor location beyond the NTS for any exposure scenario. At the 95 th percentile, the lifetime fatal 
cancer risks to the adult and the child do not exceed $1 \times 10^{-4}$ at any location beyond the Nellis Air Force Range boundary.

\subsection{TYBO Pathline}

Analysis of the TYBO pathline indicates that the estimated cancer incidence risks exceed $1 \times 10^{-4}$ for some land-use exposure scenarios at locations beyond the Nevada Test Site. Details on the risk for the TYBO pathline are discussed in this section. Results are summarized in Tables 10-4 through 10-7.

The estimated lifetime cancer incidence risk to the adult at the 5th percentile for the agricultural and residential exposure scenarios exceeds $1 \times 10^{-4}$ at all dose receptor locations within a distance of $12.2 \mathrm{~km}$ (7.6 mi) of the nuclear test location. The estimated lifetime cancer incidence risk to adults at the 50th percentile for the agricultural, residential, industrial, and mining exposure scenarios exceeds $1 \times 10^{-4}$ at all dose receptor locations on the NTS. This risk level is also exceeded at dose receptor locations on the Nellis Air Force Range up to $24.5 \mathrm{~km}$ (15.2 mi), but not at locations beyond the Nellis Air Force Range boundary. For the recreational and tourism exposure scenarios at the 50th percentile, the cancer incident risk is less than $1 \times 10^{-4}$ at all locations past $19.6 \mathrm{~km}(12.2 \mathrm{mi})$ and $12.2 \mathrm{~km}$ (7.6 mi) respectively, within the Nellis Air Force Range boundary. At the 95th percentile, the lifetime cancer incidence risk to adults exceeds $1 \times 10^{-4}$ for all exposure scenarios at all dose receptor locations beyond the Nellis Air Force Range boundary except for tourism.

The estimated lifetime cancer incidence risk to the child at the 5 th percentile exceeds $1 \times 10^{-4}$ at all dose receptor locations up to $2.9 \mathrm{~km}(1.8 \mathrm{mi})$ for the agricultural exposure scenario, and up to $0.1 \mathrm{~km}(0.06 \mathrm{mi})$ for all other scenarios. The estimated lifetime cancer incidence risk to the child at the 50th percentile exceeds $1 \times 10^{-4}$ at all dose receptor locations up to $19.6 \mathrm{~km}$ (12.2 mi) for the agricultural exposure scenarios. For the child participating in the tourism exposure scenario the estimated lifetime cancer incidence risk at the 50th percentile does not exceed $1 \times 10^{-4}$ at any dose receptor location. The 95th percentile estimated lifetime cancer incidence risk for the child participating in the agriculture and residential exposure scenarios exceed $1 \times 10^{-4}$ at all dose receptor locations.

The lifetime fatal cancer risk and radiation detriment to the adult at the 5th and 50th percentiles exceed $1 \times 10^{-4}$ at locations past the NTS boundary, but within the Nellis Air Force Range boundary. At the 95th percentile, the lifetime fatal cancer risk and radiation detriment to the 
adult exceeds $1 \times 10^{-4}$ at all locations beyond the Nellis Air Force Range boundaries for the agriculture and residential exposure scenarios.

The lifetime fatal cancer risk and radiation detriment to the child participating in the agriculture and residential exposure scenarios at the 5th and 50th percentiles exceeds $1 \times 10^{-4}$ at all locations on the NTS, but not beyond the Nellis Air Force Range boundary. At the 50th percentile, the lifetime fatal cancer risk and radiation detriment to the child tourist is less than $1 \times 10^{-4}$ at all dose receptor locations. The lifetime fatal cancer risk and radiation detriment to the child at the 95th percentile exceeds $1 \times 10^{-4}$ at all dose receptor locations past the NTS boundary and at all locations for the agriculture and resident exposure scenario. At the 95th percentile, the lifetime fatal cancer risk and radiation detriment to the child for the recreation and tourism exposure scenarios do not exceed $1 \times 10^{-4}$ at dose locations past the Nellis Air Force Range boundary.

\subsection{Ecological Evaluation}

This section contains an overview of the ecological risk assessment performed for the regional evaluation of the Underground Test Area. The comprehensive ecological risk assessment is contained within the Risk Assessment Documentation Package (IT, 1996h). The ecological risk assessment is divided into site description, problem formulation, exposure characterization, and risk evaluation.

\subsubsection{General Approach}

The ecological risk assessment was conducted following the general guidance of the Risk Assessment Guidance for Superfund, Volume II, Environmental Evaluation Manual (EPA, 1989) and is organized in a manner consistent with the format suggested in the Framework for Ecological Risk Assessment (EPA, 1992). The ecological risk assessment calculates the tritium concentration in groundwater that would result in a specific dose rate to the selected ecological receptors.

To estimate risk to these receptors, a toxicological benchmark was used. The toxicological benchmark is a maximum dose rate recommended by the National Council on Radiation Protection and Measurements Scientific Committee on the Effects of Ionizing Radiation on Aquatic Organisms (NCRP, 1991 as cited in Kahn, 1992). This benchmark is expected to provide protection to aquatic and semiaquatic populations. The tritium concentration in groundwater that would result in the toxicological benchmark dose rate is known as the threshold value. The ecological risk assessment estimates the threshold value and compares it to the 
modeled tritium concentration in groundwater where the selected ecological receptors are located.

Risk calculations are dependent upon many factors that are either not well quantified or vary unpredictably over space and time. A degree of uncertainty is associated with each step of the risk assessment. In this risk assessment, elements of uncertainty are described for each step in the process, and uncertainty is considered in the final evaluation of risk. In addition, because a large amount of uncertainty is associated with modeling groundwater flow, quantifying exposure, and the estimating of dose and resultant risk, Monte Carlo analysis techniques have been employed to quantitatively assess the effect of uncertainty on the modeling results.

The ecological risk assessment consisted of the following steps:

- Formulate the problem by identifying the constituent of concern, the study site, exposure pathways, and ecological endpoints

- Characterize the ecological exposure by identifying contaminant transport, flow phenomena, and specific ecological receptors and quantifying exposure point concentrations for both primary and secondary exposure pathways

- Characterize the ecological effects by defining quantitative links between contaminant concentrations and their effects on receptors

- Characterize the risk by describing potential risks to ecological receptors and populations of interest.

\subsubsection{Problem Formulation}

Problem formulation is the first step of the ecological risk assessment process. The process begins with the initial stages of characterizing exposure and describing the relationships among assessment and measurement endpoints, data required, and methodology used to analyze the data.

The UGTA study area is defined as impacted groundwater created by underground nuclear testing. Therefore, any way in which the groundwater may contact an ecological receptor was evaluated for the potential to present a risk to the NTS and surrounding ecosystems. Points of contact were eliminated from further consideration where an element necessary to complete an exposure pathway was determined to be lacking. 


\subsubsection{Study Site Identification}

Site features that are important to the ecological risk evaluation include topography, groundwater and surface hydrology, climate, and biota. These physical and biological characteristics of the NTS region are summarized in Section 2.0 of this report. The biological characteristics are described in greater detail in the Risk Assessment Documentation Package (IT, 1996h). These characteristics provide the building blocks from which the conceptual model of the site was developed. There are several areas where groundwater flowing under the NTS discharges to the surface, downgradient from the NTS. These discharge areas were considered as study sites where potential exists for the completion of a pathway from the contaminant source to an ecological receptor. In addition, groundwater both on and off site was considered a study site for groundwater microorganisms.

\section{Conceptual Site Model}

A conceptual site model (Figure 10-1) was developed describing sources of constituents present, constituent release and transport mechanisms, potential routes of migration, and potential ecological receptors.

\section{Study Site Descriptions}

Study sites consists of exposure points which correspond to areas on and downgradient from the NTS where aquatic and semiaquatic biota may come in contact with tritium-contaminated groundwater, originating from the underground test areas. These study sites consist of areas where groundwater discharges to the surface under natural or man-made conditions. In addition, all regional groundwater located on the NTS and downgradient from the underground test areas, was considered a medium of concern for groundwater microorganisms.

\section{On-Site Exposure Points}

Although several springs exist on the NTS, they are known to originate from perched water zones and not from the regional groundwater flow system (Laczniak et al., 1996).

Contamination associated with these springs is, therefore, not likely to be associated with underground testing activities conducted at or below the water table. However, these springs may be affected by nuclear testing conducted at the surface or in the unsaturated zone. Because this report relates to the regional groundwater flow system, the NTS springs were not considered as potential ecological exposure locations. 


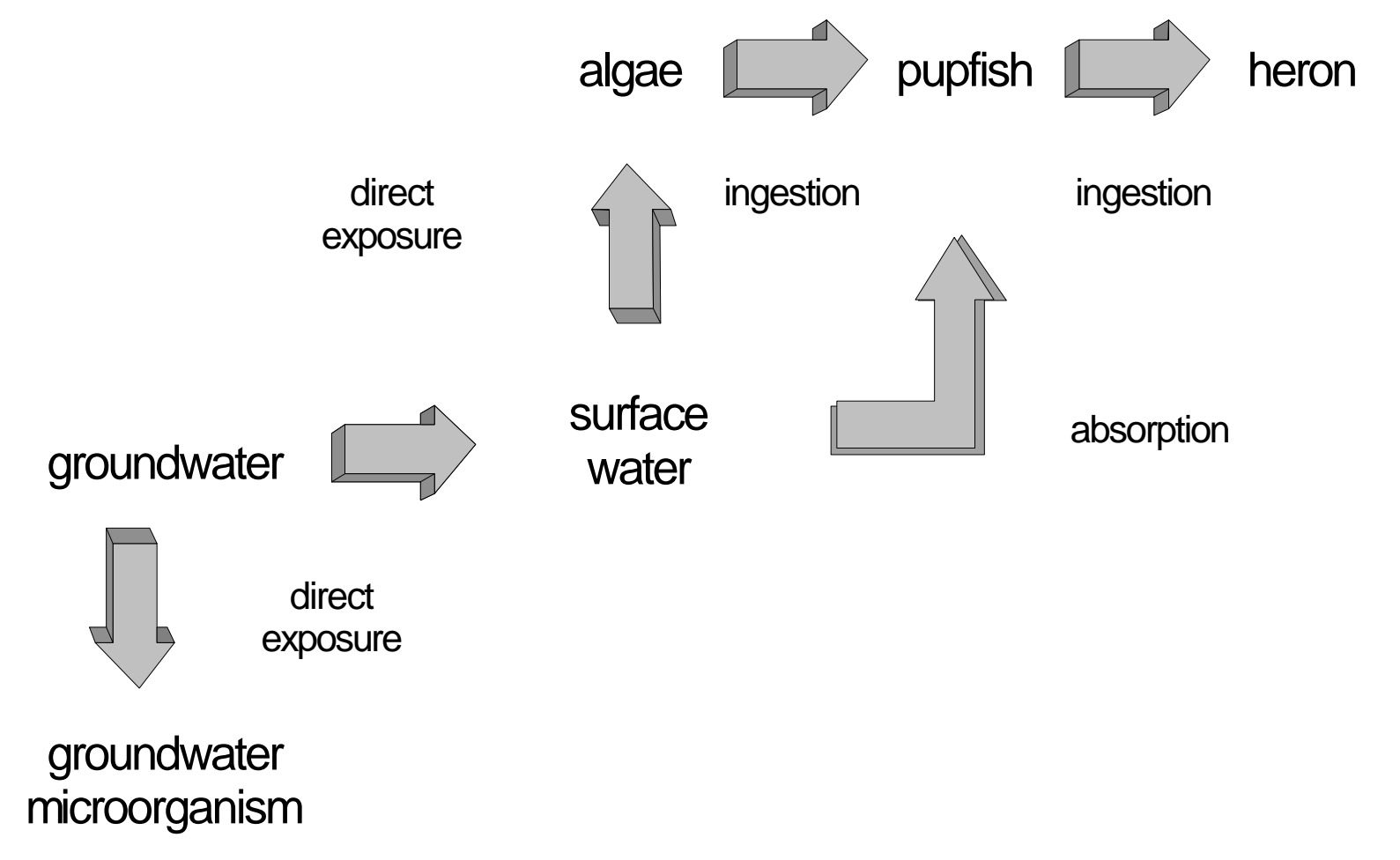

\section{Figure 10-1 \\ Simplified Ecological Exposure Pathway Model}

Animals inhabiting the NTS may, however, be exposed to contaminated groundwater under manmade conditions, such as pumping of highly contaminated (above regulatory limits) groundwater, and storing it in surface facilities that are accessible to wildlife, such as sumps. Although these conditions are highly unlikely at the present time, they constitute one of the future possibilities.

\section{Off-Site Exposure Points}

Several areas where the NTS regional groundwater flow system discharges through springs and seeps constitute ecological exposure points outside of the NTS. These discharge areas are Ash Meadows, Oasis Valley, Furnace Creek, and Amargosa Canyon.

Ash Meadows is a large, spring-fed lowland area where the NTS groundwater flow system is known to discharge. Ash Meadows is a unique riparian ecosystem located in southwestern Nye County, Nevada, and southeastern Inyo County, California. It is approximately $150 \mathrm{~km}$

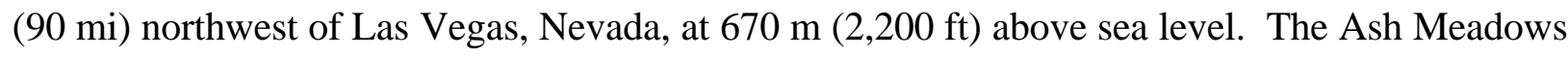


soils are silts and clays with slow internal drainage and high salt content, and the water table is near the surface in much of the area. Approximately 25 springs exist in the northern and eastern parts of Ash Meadows. Many of the springs are in lime-encrusted pools. There are also numerous small streams, meadows with continuously moist soils, and groves of small ash trees, hence the name Ash Meadows. Ash Meadows is characterized by more than thirty seeps and springs which discharge in the range of 20 to $25 \times 10^{7}$ cubic meters $\left(\mathrm{m}^{3}\right)\left(5.3\right.$ to $6.6 \times 10^{10}$ gallons) of water annually (AMNWR, 1989). This discharge may be described as "fossil" water, having taken over 10,000 years to reach its Ash Meadows destination (Baugh and Deacon, 1983). Aside from groundwater discharge, the only other source of water to this area is rain, averaging less than $0.06 \mathrm{~m}$ (2.4 in.) per annum. As is typical of the desert environment, the annual evaporation rate is quite high, averaging $2.5 \mathrm{~m}(8.2 \mathrm{ft})$ (Sada, 1990). This area supports a wide variety of biota, including more than 25 endemic species.

Ash Meadows was designated as a National Wildlife Refuge in June 1984. That designation followed decades of groundwater pumping and habitat destruction, to which it is believed the extinction of two, and possibly more, species may be directly attributed. While the refuge wholly encompasses much of the critical habitat for several of the sensitive species of the area, many of the plant species are more widespread and are not entirely protected within the confines of the refuge. In an uncommon arrangement, the refuge houses a small portion of the Death Valley National Monument (the Devil's Hole area) which was incorporated into the monument in the late 1950s. The U.S. Fish and Wildlife Service manages the National Wildlife Refuge at Ash Meadows, and the U.S. Park Service has authority over the Devil's Hole area.

The Oasis Valley and headwaters of the Amargosa River form the second largest spring-fed area in the region, and vegetation is similar between the two areas. Oasis Valley is located in southwestern Nevada, adjacent to the Nevada-California border. Both small and large springs are found in Oasis Valley. The larger springs include the Beatty Springs which are used as the municipal water supply for Beatty, an unnamed spring north of the Ranch Trueba headquarters, Goss Springs, an unnamed spring at the Fleur-de-lis Ranch, and an unnamed spring in the Amargosa Narrows just south of Beatty. Other springs include Indian Springs, Crystal Springs, Long Spring, and several hot springs. The average depth to water below the land surface in areas with phreatophyte vegetation (e.g., salt grass, Bermuda grass, greasewood, and salt brush) is 2 to $3 \mathrm{~m}(6.5$ to $10 \mathrm{ft})$. The high rate of evaporation and poor drainage characteristics of the soil have resulted in soils of high salinity, evidenced by soils encrusted by a salt efflorescence at the surface (Malmberg and Eakin, 1962). 


\section{Furnace Creek}

Springs in the Furnace Creek area of Death Valley include Travertine Springs and Texas Spring. Travertine Springs consists of open soil ditches that collect the water and convey it to a concretelined ditch and a sump intercepting water that is not collected by the ditch system. This water is piped for human usage. Some of the water from the springs recharges the fan at Furnace Creek

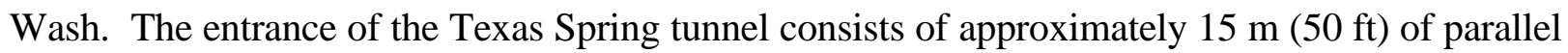
rock-retaining walls shored up by timber. As of 1974, plans existed to further alter the spring for human usage (Douglas and Sanchez, 1974).

\section{Amargosa Canyon}

Amargosa Canyon along the Amargosa River may be an area that receives UGTA-impacted groundwater. It is one of the three segments of the 264-km (164-mi) Amargosa River that contains permanently flowing water. It lies approximately $65 \mathrm{~km}$ (40 mi) north of the town of Baker in San Bernardino County, California. Just north of the canyon is Tecopa Hot Springs. The flow entering the canyon emanates from subterranean flows where numerous minor springs and seeps feed the river.

\subsubsection{Exposure Pathways}

By definition, the Underground Test Area has only one transport medium: groundwater. The groundwater discharge areas form points of potential environmental contact for plant and animal receptors. Still to be determined is whether there is a source and mechanism and whether there may be an exposure route at the exposure point. Exposure routes by which fish and semiaquatic wildlife, algea, and microorganisms may be exposed to contaminated groundwater are described.

Possible exposure routes by which fish and semiaquatic wildlife may be exposed to tritium from the underground test areas include consumption of contaminated animal or plant tissues and consumption of contaminated abiotic media (groundwater). However, because desert species are often adapted to survive in water-limited environments, direct consumption of water was considered a pathway of secondary importance and was not evaluated.

Some contaminants may be bioaccumulated in plants or animal tissues and passed through food web interactions to higher trophic levels. The ability of contaminants to be passed from lower to higher trophic levels is dependent on their flow inside the plant or prey animal. If the contaminant is solely ingested and excreted by the prey, without absorption from the gastrointestinal tract and storage in its tissues, then the exposure of higher trophic levels is 
minimized. The dose received by the predator is dependent upon the contaminant concentration in the prey, its ingestion rate, and the amount of contaminated matter consumed. This route of exposure is believed to be the major exposure route for fish and semiaquatic receptors associated with the underground test areas.

Algae have been studied at several of the natural springs, and these lower plants may directly absorb tritium, as water would be absorbed, across the cellular membrane. Submerged portions and the roots of vascular wetland plants may also be exposed to tritium either by absorption or through root uptake. Exposure of algae to tritium was evaluated. Passive or active transport of contaminants across cellular membranes is the route by which deep subsurface microorganisms may be exposed to groundwater within aquifers. This pathway was also addressed.

\subsubsection{Endpoints}

This section contains a discussion of the assessment and measurement endpoints used. Some individual organisms may be more sensitive to tritium than others; therefore, protection of individuals would not be a practical goal. The exception is those instances where a special status or protected species is involved. In this case, individual organisms must also be protected from environmental perturbations. The overall assessment endpoint for this risk assessment is the protection of aquatic and semiaquatic populations, groundwater microorganisms, and special status individuals from adverse effects that may be associated with exposure to tritium in the environment.

Adverse effects to biota were assessed or measured through the use of available groundwater and surface-water monitoring data, flow and transport modeling results, and toxicity-based benchmark toxicity values. Current monitoring data were used to address present impacts, and data obtained through flow and transport modeling were used to evaluate potential future impacts to aquatic and semiaquatic biota. Radiological benchmarks have been established for terrestrial animal and plant populations by the International Atomic Energy Agency (IAEA, 1991, as cited in Kahn, 1992) and for aquatic populations by the National Council for Radiation Protection and Measurements (NCRP, 1991). In addition, radiation effects data were gleaned to obtain benchmarks specific to sensitive life stages of protected species. Monitoring data and modeling results were compared to the benchmark values. Adverse impacts were predicted to occur when benchmarks were exceeded. 


\subsubsection{Exposure Assessment}

To characterize the ecological exposure, the contaminant transport from groundwater to the receptors, the specific receptors, and the tritium exposure models used are described.

Exposure point concentrations are tritium concentrations in both on- and off-site groundwater wells. Concentrations of tritium in groundwater at surface discharge points were also used as exposure point concentrations. In both cases, current concentrations were obtained from monitoring data (maximum concentrations), and simulated concentrations (the 95 percent value of each of the Monte Carlo realizations) were obtained the results of the transport model.

Four specific receptors were selected to evaluate possible adverse effects on biota that are closely associated with the discharge points. These receptors are the great blue heron (Ardea herodias), a predatory bird assumed to feed exclusively on fish; a generic pupfish (adult and eggs) to represent the protected fish within the surface water systems; a generic algae that represents a plant maximally exposed to surface water; and a generic groundwater microorganism to represent the bacteria and protozoans in groundwater.

Two complementary radioecological dose models were used in the evaluation of risk to fish and wildlife. An aquatic dose model created by Pacific Northwest Laboratory was used to estimate the concentration of tritium in water necessary to produce a dose of $1 \mathrm{rad} / \mathrm{d}$ to the pupfish and a dose of $0.1 \mathrm{rad} / \mathrm{d}$ to the heron (Baker and Soldat, 1992). In addition, an aquatic dose model developed by Blaylock et al. (1993) was used to estimate the concentration in surface water that would result in a dose of $0.04 \mathrm{rad} / \mathrm{d}$ to fish eggs. The external dose from tritium to the pupfish, fish eggs, and heron was not considered because the external dose rate from immersion and sediment is zero (Baker and Soldat, 1992). Consequently, tritium will not pose an external threat to an organism. Exposure to tritium will, however, result in an internal dose to these receptors. Tritium is a unique radioactive threat because it is found as part of the water molecule itself. The tritium will, therefore, distribute itself uniformly and quickly throughout the body of an organism. More comprehensive discussions of the models and their associated assumptions are presented in the Risk Assessment Documentation Package (IT, 1996h).

\subsubsection{Effect Assessment}

Because tritium is a radionuclide, adverse effects associated with exposure to tritium will be attributed to radiation. Tritium is not a chemically toxic compound. Consequently, the discussion that follows will focus on the effects of radiation exposure. 
The dosage and biological effectiveness of radiation due to tritium incorporated in biological tissues has been studied primarily in laboratory animals and cell cultures, although some data exist for aquatic organisms. A major concern for tritium is incorporation into deoxyribonucleic acid (DNA). The radioactive decay of tritium in a DNA molecule can result in breakdown or rearrangement of the molecule, resulting in genetic or somatic defects. However, the ionizing radiation of decaying tritium in cells is probably more likely (NCRP, 1979). Radiotoxic effects of tritiated water exposure to embryos and fetuses are consistent with those expected from an equivalent, absorbed dose of external radiation (NCRP, 1979). These effects include tumors (NCRP, 1979) and chromosome aberrations (Straume and Carsten, 1993).

The radioactive hydrogen isotope tritium enters aquatic systems in the form of tritiated water. Tritium can be exchanged just as hydrogen between the tissue-water compartment and the tissuebound compartment. Tritium bioaccumulation factors are approximately one (1), reflecting equilibration between ambient water and tissue water. Another pathway for entry of tritium into the nonexchangeable component for animals is the ingestion and incorporation of food molecules containing nonexchangeable tritium. In studies on a herbivorous fish, calculations showed 60 percent of nonexchangeable hydrogen came from tissue-water hydrogen and 40 percent from food. However, food-chain transfer of exchangeable tritium hydrogens is unimportant because equilibrium conditions with ambient water exist in both consumer and food items, and turnover occurs more rapidly than food intake. In plants, photosynthesis and other reduction reactions incorporate tritium into the nonexchangeable component of plants (Vanderploeg et al., 1975).

Information regarding the responses of groundwater organisms to toxicants is very limited (Notenboom et al., 1994). Such information is primarily focused on heavy metals and organic contaminants. Because specific data on potential adverse impacts of radiation on groundwater fauna could not be found in the open literature, impacts on UGTA groundwater receptors will be assessed qualitatively based on information on radiation effects on freshwater microorganisms. According to Whicker and Schultz (1982), ranges of acute lethal doses (LD) to bacteria and protozoans are approximately 4,000 to 90,000 rads and 8,000 to 30,000 rads, respectively. The lethal $\mathrm{LD}_{50}$ (dose at which 50 percent of exposed individuals die in 60 days) range for aquatic microorganisms under acute radiation exposure is 10,000 to 500,000 rads (NCRP, 1991, as cited in Kahn, 1992).

A dose rate of $1 \mathrm{rad} / \mathrm{d}$ was used as the toxicological benchmark for the protection of aquatic life with emphasis on adult pupfish. This value has been recommended by the NCRP Scientific 
Committee on the Effects of Ionizing Radiation on Aquatic Organisms (NCRP, 1991, as cited in Kahn, 1992) and is expected to provide protection to aquatic populations. Radioecologists have, however, shown differential sensitivities of fish to radiation as a function of age (e.g., Polikarpov, 1966; NCRP, 1991). According to Ophel and his colleagues (IAEA, 1976), teleost fish (bony fish), and their eggs and young in particular, are the most sensitive aquatic organisms known. A compilation of $\mathrm{LD}_{50}$ data for rainbow trout (Salmo gaudnerii) exposed to radiation during various stages of development indicate adult fish with an $\mathrm{LD}_{50}$ of 1,500 rad and the egg at the one-cell stage (the most sensitive stage for this species) with an $\mathrm{LD}_{50}$ of $58 \mathrm{rad}$ (Polikarpov, 1966). Based on these studies, a benchmark for pupfish eggs was set at 26 times less than the benchmark of $1 \mathrm{rad} / \mathrm{d}$ set for adult pupfish, or $0.04 \mathrm{rad} / \mathrm{d}$. The lowest concentration of tritiated water to which developing eggs have been exposed and biological effects reported is $1.0 \times 10^{12} \mathrm{pCi} / \mathrm{L}$ (Strand et al., 1973). This value is associated with rainbow trout eggs exposed six hours after fertilization, and a suppression of the immune response (antibody production) was noted in fish fry.

A comparison of acute lethal doses to primitive plants, higher plants, bacteria, fish, and birds indicates that algae and bacteria are considerably less sensitive to the adverse effects of radiation than either birds or fish (Whicker and Schultz, 1982). Based on this information, the value of $1 \mathrm{rad} / \mathrm{d}$ is expected to provide sufficient protection to each of the aquatic receptor species selected with the exception of fish eggs. Because the heron is a semiaquatic species, a more conservative benchmark (pessimistic) value was used to provide sufficient protection to the bird. The IAEA Committee on the Effects of Ionizing Radiations on Plants and Animals recommends a dose of $0.1 \mathrm{rad} / \mathrm{d}$ for the protection of terrestrial populations (IAEA, 1992).

\subsubsection{Ecological Risk Evaluation}

To provide sufficient protection to pupfish (all life stages), heron, algae, and microorganisms that may be exposed to tritium, the concentrations of tritium in groundwater should not exceed $9.32 \times 10^{7} \mathrm{pCi} / \mathrm{L}$. This concentration would result in a dose of $0.028 \mathrm{rad} / \mathrm{d}$ to adult pupfish, $0.027 \mathrm{rad} / \mathrm{d}$ to pupfish eggs, and $0.1 \mathrm{rad} / \mathrm{d}$ to the heron that ingests the fish. In contrast, a dose of $1 \mathrm{rad} / \mathrm{d}$ to the pupfish and a dose of $3.61 \mathrm{rad} / \mathrm{d}$ to the heron would result from a tritium concentration in water of $3.37 \times 10^{9} \mathrm{pCi} / \mathrm{L}$. A concentration of $1.38 \times 10^{8} \mathrm{pCi} / \mathrm{L}$ was estimated as the concentration of tritium in groundwater that would result in a dose of $0.04 \mathrm{rad} / \mathrm{d}$ to pupfish eggs. Because this concentration would not offer suitable protection to the heron, the more protective threshold concentration for the aquatic and semiaquatic receptors associated with the springs, or $9.37 \times 10^{7} \mathrm{pCi} / \mathrm{L}$, was used as the threshold value below which adverse impacts to 
birds and fish would not be expected. Because algae and microorganisms are less sensitive to the effects of radiation than fish and birds, protection of the pupfish and the heron should allow for sufficient protection to algae, higher plants, and microorganisms exposed to tritium. The tritium concentration of $9.32 \times 10^{7} \mathrm{pCi} / \mathrm{L}$ should, therefore, be the threshold concentration for protection of the spring ecosystems.

The transport model results indicate that tritium concentrations in groundwater both on and off site may exceed the toxicity-based benchmark set for heron by less than an order of magnitude. For the TYBO groundwater pathline, potentially hazardous concentrations of tritium are expected to occur from the TYBO nuclear test location to about $10 \mathrm{~km}(6.2 \mathrm{mi})$ downgradient. This distance is off the NTS, but still within the Nellis Air Force Range. Along the HOUSTON pathline, groundwater tritium concentrations in excess of $9.3 \times 10^{7} \mathrm{pCi} / \mathrm{L}$ are expected to occur from the source to about $2 \mathrm{~km}(1.2 \mathrm{mi})$ downgradient from the HOUSTON nuclear test location. Finally, tritium concentrations from the BOURBON pathline through Yucca Flat area to Amargosa Valley/Ash Meadows are expected to exceed the toxicological benchmark for groundwater microorganisms from the source to about $2 \mathrm{~km}$ (1.2 mi) downgradient. It is, therefore, possible that future tritium concentrations in groundwater might adversely impact the populations of groundwater organisms located within a few kilometers of the underground test locations.

In contrast, transport modeling results indicate that tritium concentrations in excess of $9.3 \times 10^{7}$ $\mathrm{pCi} / \mathrm{L}$ are not expected to reach the off-site springs. Concentrations at the three discharge points modeled range from $8 \times 10^{6} \mathrm{pCi} / \mathrm{L}$ for the TYBO pathline down to $0.9 \mathrm{pCi} / \mathrm{L}$ for the BOURBON pathline. Future concentrations of tritium at the surface water discharge points are, therefore, not expected to adversely impact fish, heron, algae, or groundwater microorganisms.

\subsection{Uncertainties}

The results of any risk assessment contain uncertainties due to the following general sources:

- Parameter uncertainties

- Completeness uncertainties

- Model uncertainties

The parameter uncertainty, such as exposure and toxicity factors, contains a combination of parameter uncertainty and model uncertainty. Parameter uncertainty is the dominant contributor to the total uncertainty of an exposure estimate. 
Completeness uncertainty relates to whether all major pathways, contaminants, and release mechanisms have been included in the risk assessment. It is unlikely that a significant pathway has been excluded altogether; more likely, a pathway may have been assumed to be present when it actually is not. Completeness uncertainty is not expected to be a large contributor to the total uncertainty of a given risk estimate.

Model uncertainties are the most difficult to address due to the unknown nature of its sources. Examples of model uncertainties include the derivation of the latent cancer fatality and cancer incidence risk responses in human health risk assessment and postulated mechanisms of action used to quantify toxicity for the ecological risk receptors. Additional sources of model uncertainty include dispersion estimates which are usually theoretical in nature, not analytical.

Two major types of uncertainties should be considered when reviewing the results of the exposure assessment: uncertainties associated with determining the tritium concentration at the receptor location (i.e., transport mechanism) and those associated with the assumptions used in the exposure models. These uncertainties are described in the following paragraphs.

The uncertainties in the transport mechanisms were bounded by using Monte Carlo techniques, applying Latin hypercube sampling of the distributions, and choosing the 95th percentile tritium concentration distribution at all dose receptor locations.

Uncertainties associated with the assumptions used in the exposure models include the selecting of the 95th percentile tritium concentration distribution as input, assuming a probability of one for all land use exposure scenarios at all dose receptor locations, assuming a receptor inhabits a single location for thirty years, and that the computed tritium concentration is accurately modeled over the thirty year exposure time.

For exposure parameters such as exposure time, exposure frequency, and exposure duration, the potential to overestimate is high, and the potential to underestimate risk is low. These qualitative ratings are based on best professional judgment and do not represent actual quantitative analysis of uncertainty. The greatest contributor to uncertainty in the tritium intake by the dose receptor for each land use is associated with the uncertainty in the concentration of tritium in groundwater. 


\subsection{Summary}

Projected tritium concentrations in groundwater, the estimated radiation doses received by individuals from chronic exposure to tritium, and the corresponding human health risks for six potential land-use scenarios have been calculated. The land-use scenarios were formulated to be very conservative to ensure that the calculated exposures would bound any realistic dose received by individuals. Estimated doses and risks are summarized in Tables 10-2 through 10-7. These calculations are representative of the conservative scenarios evaluated for tritium exposure. Complete sets of dose and risk estimations for each of the land-use scenarios can be found in the Risk Assessment Documentation Package (IT, 1996h).

The TYBO pathline has the greatest potential for off-site release, with a projected groundwater discharge at Oasis Valley. Fate and transport calculations indicate that the peak tritium concentration may have reached the end of the TYBO pathline 14 years after the release of tritium. The time of release could have occurred in 1974. Therefore, the risk estimates developed for the TYBO pathline may be considered to exist now, and they are bounded by the 95th percentile values.

The agriculture adult scenario is the most conservative of the four scenarios presented here. The following summarizes the results of that scenario. The results focus on concentrations, doses, and risks that are predicted to occur beyond the active control boundary, which for the TYBO and HOUSTON pathlines is the Nellis Air Force Range boundary and for the BOURBON pathline is the NTS boundary.

Along the TYBO pathline, concentrations are not predicted to exceed 20,000 $\mathrm{pCi} / \mathrm{L}$ beyond the Nellis Air Force Range boundary. Doses are predicted to exceed the 100-mrem/yr limit at the 95th percentile. Lifetime cancer incidence and fatal cancer risks are predicted to exceed the $10^{-4}$ level at the 95th percentile and the fatal cancer risk at the 50th percentile for the $10^{-6}$ level are predicted for receptor locations beyond the Nellis Air Force Range boundary.

Along the HOUSTON pathline, concentrations at the 95th percentile are predicted to exceed the 20,000-pCi/L level beyond the Nellis Air Force Range boundary. Doses are not predicted to exceed the 100-mrem/yr level beyond the boundary. Lifetime cancer incidence and fatal cancer risk exceeding $10^{-6}$ at the 95th percentile level are predicted beyond the Nellis Air Force Range boundary. 
Along the BOURBON pathline, no concentrations exceeding 20,000 $\mathrm{pCi} / \mathrm{L}$, no doses exceeding $100 \mathrm{mrem} / \mathrm{yr}$, and no cancer incidence or fatal cancer risks exceeding $10^{-6}$ are predicted to occur beyond the NTS boundary.

Two complementary radiological dose models were used to evaluate risk to fish and wildlife. A tritium concentration of $9.32 \times 10^{7} \mathrm{pCi} / \mathrm{L}$ was selected as the threshold level for protection of pupfish eggs in the spring ecosystems. Also, a dose of $1 \mathrm{rad} / \mathrm{d}$ to pupfish and a dose of $3.6 \mathrm{rad} / \mathrm{d}$ for the heron are calculated as exposure thresholds both corresponding to a tritium concentration of $3.37 \times 10^{9} \mathrm{pCi} / \mathrm{L}$ in spring discharge or irrigation ditch water. Estimated tritium concentrations, calculated through fate and transport modeling at the 95th percentile, were not projected to go beyond $6.2 \times 10^{6} \mathrm{pCi} / \mathrm{L}$ at the spring discharge points.

The dose and risk calculations demonstrate the following:

- Within the next several years, quantifiable potential risks from long-term exposure of tritium in groundwater were simulated to occur at receptor points along the TYBO pathway.

- In the near term, tritium migration from HOUSTON and BOURBON do not contribute to human health hazards off the NTS.

- As a result of the high ecotoxicological thresholds associated with tritium exposure, future ecological risks are not anticipated to occur. 


\subsection{Summary and Conclusions}

This report documents the results of the regional evaluation of groundwater flow, tritium migration, and risk assessment performed for the underground test areas of the NTS. The regional evaluation comprised data analysis and hydrologic and risk modeling, which were necessary steps in developing an understanding of the migration of tritium in groundwater from the underground test areas to potential human and ecological receptors. The hydrologic models that were used to understand and predict the migration of tritium included a regional threedimensional groundwater flow model and a conservative (pessimistic), one-dimensional tritium transport model. The risk evaluation was also conservative and focused solely on the human health and ecological effects of tritium in the groundwater.

\subsection{Summary}

Historical testing activities, particularly nuclear tests conducted near or below the water table, contaminated groundwater within the Nevada Test Site. Tritium was selected as the primary contaminant of concern for this phase of the project because it is abundant, highly mobile, and represents the most significant contributor to the dose for the short term. It was assumed that the predicted risk to human health and the environment from tritium exposure would reasonably represent the risk from other, less mobile radionuclides within the same time frame. Other radionuclides will be investigated at a later date.

Existing and newly collected data were compiled for a large area of southern Nevada and California, encompassing the NTS regional groundwater flow system. These data were used to develop numerical groundwater flow and tritium transport models to be used in the prediction of tritium concentrations at potential human and ecological receptor locations for a 200 -year time frame.

Groundwater velocities derived from the calibrated steady-state regional groundwater flow model were used to predict the movement of contaminants from the underground testing areas on a regional scale. The range of uncertainty in these predictions due to uncertainties associated with the hydrologic parameters was also evaluated. 
Sensitivity analyses were performed during the groundwater flow model calibration process to evaluate basic flow model assumptions such as the geologic model, the recharge distributions, and the hydraulic-conductivity parameters.

The sensitivity analyses of the different geologic models confirmed that a modeling barrier to flow in the area of Calico Hills westward to Bare Mountain resulted in matching estimated discharge rates at Oasis Valley and observed gradients in that area. In addition, an interpretation that the Upper Clastic Confining Unit is continuous beneath Rainier Mesa was consistent with water levels observed in this area and provided good agreement with water-level data near Rainier Mesa and in western Yucca Flat. The sensitivity analysis performed on 116 hydraulic conductivity values showed that the effect on water levels and boundary fluxes was small. The response in an area was dependent on local conditions such as the geometric relationships between hydrostratigraphic units and the three-dimensional extent of the HSU.

The numerical groundwater flow model results were also used in conjunction with a particletracking code to define the pathlines followed by groundwater particles originating from 415 points associated with 253 nuclear test locations. The locations selected were BOURBON on Yucca Flat, HOUSTON on Central Pahute Mesa, and TYBO on Western Pahute Mesa.

One-dimensional stochastic tritium transport simulations were performed for the three pathlines, using the Monte Carlo method with Latin hypercube sampling. For the BOURBON and TYBO pathlines, sources of tritium from other nuclear tests located along the same pathline were included in the simulations. Sensitivity analyses were also performed on the transport model to evaluate the uncertainties associated with the geologic model, recharge, the tritium source, and the transport parameters.

For many of the downgradient receptor locations, the simulated range of maximum tritium concentrations was quite large, often extending over five orders of magnitude. Simulated tritium concentrations were high $\left(5 \times 10^{8} \mathrm{pCi} / \mathrm{L}\right)$ in the vicinity of the nuclear test locations for all three pathlines. For the BOURBON pathline, the simulated tritium concentration was low ( $<100 \mathrm{pCi} / \mathrm{L})$ outside the NTS boundary. For HOUSTON, the concentration $15 \mathrm{~km}(9 \mathrm{mi})$ outside the Nevada Test Site boundary is less than $100 \mathrm{pCi} / \mathrm{L}$. However, for the TYBO pathline, transport simulations indicate that the peak tritium concentration reached the end of the TYBO pathline 14 years after the release of tritium. The time of release might have been as early as 1974. 
Based on sensitivity analysis, the regional geology as depicted in the geologic model is the dominant factor controlling the horizontal and vertical position of transport pathways. Matrix diffusion is an important mechanism governing the migration of tritium in fractured carbonate and volcanic rocks. Source term concentration uncertainty is most important near the nuclear test locations and decreases in importance as the travel distance increases. The recharge coefficient, which accounts for the total groundwater flux uncertainty, is as important as matrix diffusion at downgradient locations.

The risk assessment was performed to provide conservative and bounding estimates of the potential risks to human health and ecological receptors from tritium in groundwater. Risk models were designed by coupling scenario-specific tritium intake with tritium dose models and cancer and genetic risk estimates using the Monte Carlo method.

Estimated radiation doses received by individuals from chronic exposure to tritium and the corresponding human health risks at selected key point-of-use locations along each of the pathlines were calculated for six potential land-use scenarios. Conservative land-use scenarios were postulated to ensure that the calculated exposures would bound any realistic dose received by individuals. For each pathline, the selected point-of-use locations corresponded to a point near the source, the location where the pathline crosses the NTS boundary, the location where the pathline crosses the Nellis Air Force Range boundary, and the point of discharge to the surface in the case of the TYBO pathline only.

Based on the human-health risk estimates, tritium exposures associated with the HOUSTON and BOURBON pathlines do not present a hazard to human health off the Nevada Test Site in the present, the near term, or in the future. However, the estimates show that the TYBO pathline has the greatest potential for off-site release with a projected groundwater discharge at Oasis Valley. Using the most conservative scenario evaluating tritium exposure demonstrates that dose could exceed the 100-mrem/yr limit at locations along the TYBO pathline.

For the TYBO pathline the limiting land-use scenarios resulting in the highest estimated risk and dose are agriculture and residential. At the 50th percentile the estimated dose to adult and child receptors do not exceed the 100-mrem/yr limit at locations beyond $12.2 \mathrm{~km}(7.6 \mathrm{mi})$ from the PEPATO test location. This includes locations off the NTS, but not beyond the Nellis Air Force Range boundary. The dose to the residential adult and child dose receptor, at the 50th percentile, does not exceed the 100-mrem/yr limit at any location beyond the NTS boundary. At the $95^{\text {th }}$ 
percentile the estimated dose to dose receptors exceeds the 100-mrem/yr limit at locations beyond the Nellis Air Force Range boundary.

For the TYBO pathline, the estimated lifetime total cancer incidence risk, at the 50th percentile, does not exceed $10^{-4}$ at locations beyond $19.6 \mathrm{~km}$ (12.2 mi) for the adult and child dose receptors engaged in the agriculture land-use scenario. This location is off the NTS, but is not beyond the Nellis Air Force Range boundary. At the 95th percentile the estimated risk to all dose receptors exceeds $10^{-4}$ at locations beyond the Nellis Air Force Range boundary.

Two complementary radiological dose models were used to evaluate risk to fish and wildlife. A tritium concentration of $9.32 \times 10^{7}$ picoCuries per liter was selected as the threshold level for protection of pupfish eggs in the spring ecosystems. Also, a dose of $1 \mathrm{rad} /$ day to pupfish and a dose of $3.6 \mathrm{rad} /$ day for the heron were calculated as exposure thresholds, both corresponding to a tritium concentration of $3.37 \times 10^{9} \mathrm{pCi} / \mathrm{L}$ in spring discharge or irrigation ditch water. Estimated tritium concentrations, calculated through fate and transport modeling at the 95 th percentile, were not projected to exceed $6.2 \times 10^{6} \mathrm{pCi} / \mathrm{L}$ at the spring discharge points.

\subsection{Conclusions}

Near-term risks to human health and ecological receptors were conservatively calculated based on tritium migration predictions from nuclear test locations associated with the BOURBON, HOUSTON, and TYBO pathlines. The conclusions are as follows:

- In the near term, tritium migration from HOUSTON and BOURBON does not constitute a human health hazard off the NTS.

- As a result of the high ecotoxicological thresholds associated with estimated tritium exposure, future ecological risks are not expected to occur.

- Based on transport simulations and the incorporation of several conservative assumptions, a potential risk from long-term exposure to tritium in groundwater may exist at off-site receptor locations along the TYBO pathline.

The estimated risks from the TYBO pathline are not supported by results from the existing environmental monitoring network. Long-term monitoring of water samples from the Oasis Valley springs and groundwater wells west and south of the Pahute Mesa do not show tritium levels above the background levels. As the transport model was intended to predict contaminant 
levels if multiple, pessimistic conditions existed, monitoring results support the conclusion that tritium is migrating at a more normal, non-exceptional rate. In other words, the conservative assumptions used to predict tritium transport to Oasis Valley do not appear to be valid in reality. 


\subsection{References}

AMNWR, see Ash Meadows National Wildlife Refuge.

ASTM, see American Society of Testing Materials.

American Society for Testing Materials. 1994. Standard Guide for Comparing Ground-Water Flow Model Simulations to Site-Specific Information, D 5490-93. Philadelphia, PA.

Armstrong, R.L. 1968. "Sevier Organic Belt in Nevada and Utah." In Geological Society of America Bulletin, 79 (40): 429-458.

Arteaga, F.E., C.S. Savard, M.E. Johnson, and J.C. Stone. 1991. Hydrogeologic Data from Selected Wells and Test Holes In and Adjacent to the Nevada Test Site, Nye County, Nevada, Through 1986, U.S. Geological Survey Open-File Report 87-356.

Ash Meadows National Wildlife Refuge. 1989. "An Oasis of Life in the Desert," Fact Sheet. Ash Meadows National Wildlife Refuge, NV.

BN, see Bechtel Nevada.

Baker, D.A., and J.K. Soldat. 1992. Methods for Estimating Doses to Organisms from Radioactive Materials Released into the Aquatic Environment, PNL-8150. Richland, WA: Pacific Northwest Laboratory.

Barone, F.S., R.K. Rowe, and R.M. Quigley. 1992. "Estimation of Chloride Diffusion Coefficient and Tortuosity Factor for Mudstone." In ASCE Journal of Geotechnical Engineering, 118 (7): 1031-1045.

Baugh, T.M., and J. Deacon. 1983. "Daily and Yearly Movement of the Devil's Hole Pupfish, Cyprinodon diabolis, Wales in Devil's Hole, Nevada." In Great Basin Naturalist, 43: 592.

Bear, J. 1979. Hydraulics of Groundwater. New York, NY: McGraw-Hill.

Bechtel Nevada. 1996. “Nevada Test Site Region Image Map,” SIGIS-NTS-96038. Las Vegas, NV: Remote Sensing Laboratory.

Blankennagel, R.K., and J.E. Weir. 1973. Geohydrology of the Eastern Part of the Pahute Mesa, Nevada Test Site, Nye County, Nevada, U.S. Geological Survey Professional Paper 712B. 
Blaylock, B.G., M.L. Frank, and B.R. O’Neal. 1993. Methodology for Estimating Radiation Dose Rates to Freshwater Biota Exposed to Radionuclides in the Environment, ES/ER/TM-78. Oak Ridge, TN: Oak Ridge National Laboratory.

Borg, T.Y. 1972. Extent of Prevasive Fracturing Around Underground Nuclear Explosions, UCRL-73831. Livermore, CA: Lawrence Livermore Laboratory.

Borg, I.R., R.Stone, H.B. Levy, and L.D. Ramspott. 1976. Information Pertinent to the Migration of Radionuclides in Ground Water at the Nevada Test Site, Part 1: Review and Analysis of Existing Information, UCRL-52078. Livermore, CA: Lawrence Livermore National Laboratory.

Bryant, E.A., and J. Fabrika-Martin. 1991. Survey of Hazardous Materials used in Nuclear Testing, LA-12014-MS. Los Alamos, NM: Los Alamos National Laboratory.

Burbey, T.J., and S.W. Wheatcraft. 1986. Tritium and Chlorine-36 Migration from a Nuclear Explosion Cavity, Publication No. 45050. Las Vegas, NV: Desert Research Institute.

Burkhard, N.R. 1989. Physical Properties in LLNL Yucca Flat Areas: The ROCK PILE Concept. Livermore CA: Lawrence Livermore National Laboratory.

Cashman, P.H., and J.H. Trexler, Jr. 1994. "The Case for Two, Coeval, Mississippian Sections at the Nevada Test Site." In Geological Investigations of an Active Margin, 27th Annual Meeting, San Bernardino, CA, March 21-23, 1994: 76-81. S. F. Mc Gill and T.M. Ross, eds. Geological Society of America.

Caskey, S.J., and R.A. Schweickert. 1992. "Mesozoic Deformation in the Nevada Test Site and Vicinity: Framework of the Cordilleran Fold and Thrust Belt and Tertiary Extension North of Las Vegas Valley." In Tectonics, 11 (6): 1314-1331.

Cole, J.C., R.R. Wash, and M.R. Hudson. 1989. "Structural Relations Within the Paleozoic Basement of the Mine Mountain Block; Implications for Interpretation of Gravity Data in Yucca Flat, Nevada Test Site." In Proceedings from the fifth Symposium on Containment of Underground Nuclear Explosions, held on September 19-21, 1989 at Santa Barbara, CA, CONF-8909163, 2: 431-456. Santa Barbara, CA: Mission Research Corporation.

Cole, J.C., J.H. Trexler, Cashman, P.H., and M.R. Hudson. 1994. "Structural and Stratigraphic Relations of the Mississippian Rocks at the Nevada Test Site." In Geological Investigations of an Active Margin, 27th Annual Meeting, San Bernardino, CA, March 21-23, 1994: 66-75. Cordilleran Section Guidebook. S.F. McGill and T.M. Ross, eds. Geological Society of America.

Czarnecki, J.B. 1985. Simulated Effects of increased Recharge on the Ground-Water Flow System of Yucca Mountain and Vicinity, Nevada-California, U.S. Geological Survey WaterResources Investigations Report 84-4344. 
Czarnecki, J. B. 1990. Geohydrology and Evapotranspiration at Franklin Lake Playa, Inyo County, California, U.S. Geological Survey Open-File Report 90-356.

DOE, see U.S. Department of Energy.

DOE/NV, see U.S. Department of Energy, Nevada Operations Office.

D’Agnese, F.A. 1994. “Using Geoscientific Information Systems for Three-Dimensional Modeling of Regional Groundwater Flow Systems, Death Valley Region, Nevada and California." Unpublished PH.D. thesis. Golden, CO: Colorado School of Mines.

Daniels, J.I, ed. 1993. Pilot Study Risk Assessment for Selected Problems at the Nevada Test Site (NTS), UCRL-LR-113891. Livermore, CA: Lawrence Livermore National Laboratory.

Decision Engineering. 1995. Crystal Ball Software, Version 4.0 for Windows. Denver, CO.

Dettinger, M.D., J.R. Harrill, and D.L. Schmidt. 1995. Distribution of Carbonate-Rock Aquifers and the Potential for Their Development, Southern Nevada and Adjacent Parts of California, Arizona, and Utah, U.S. Geological Survey Water-Resources Investigations Report 91-4146.

Douglas, C., and P. Sanchez. 1974. Potential Environmental Impacts of Proposed Water Supply Systems in Furnace Creek and Cow Creek, Death Valley National Monument. National Park Service.

EPA, see U.S. Environmental Protection Agency.

ERDA, see U.S. Energy Research and Development Administration.

Eakin, T.E., G.B. Maxey, T.W. Robinson, J.C. Fredericks, and O.J. Loeltz. 1951. "Estimated Annual Increment to Groundwater, in Contributions to the Hydrology of Eastern Nevada." In Water Resources Bulletin 12, 26-27. State of Nevada, Nevada State Engineers Office.

FFACO, see Federal Facility Agreement and Consent Order of 1996.

Federal Facility Agreement and Consent Order. 1996. Agreed to by the State of Nevada, the U.S. Department of Energy, and the U.S. Department of Defense.

Feenstra, S., J.A. Cherry, E.A. Sudicky, and Z. Hag. 1984. "Matrix Diffusion Effects on Contaminant Migration from an Injection Well in Fractured Sandstone." In Groundwater, 22 (3): 307-316.

Ferguson, J.F., A. H. Cogbill, and R. G. Warren. 1994. "A Geophysical-Geological Transect of the Silent Canyon Caldera Complex, Pahute Mesa, Nevada." In Journal of Geophysical Research, 99 (B3): 4323-4339. American Geophysical Union. 
Freeze, R.A., and J.A. Cherry. 1979. Groundwater. Englewood Cliffs, NJ: Prentice Hall.

Gelhar, L.W. 1982. Analysis of Two-Well Tracer Tests with a Pulse Input, RHO-BW-CR-131P. Richland, WA: Rockwell Hanford Operations.

Gelhar, L.W., C. Welty, and K.R. Rehfeldt. 1992. "A Critical Review of Data on Field-Scale Dispersion in Aquifers." In Water Resources Research, 28 (7): 1954-1974.

Grauch, V.J.S., and M.R. Hudson. 1995. Preliminary Analysis of Major Structures and Lithologic Boundaries for the Frenchman Flat Model Area. Denver, CO: U.S. Geological Survey.

Grisak, G.E., and J.F. Pickens. 1980. "Solute Transport Through Fractured Media 1: The Effect of Matrix Diffusion.” In Water Resources Research, 16 (4): 719-730.

Grose, T.L.T. 1983. Thirty-Two Geologic Cross-Sections, Clark, Esmeralda, Lincoln, Mineral and Nye Counties, Nevada, and Adjacent Areas in California, Open-File Report 83-13. Carson City, NV: Nevada Bureau of Mines and Geology.

Guth, P.L. 1981. "Tertiary Extension North of the Las Vegas Valley Shear Zone, Sheep and Desert Ranges, Clark County, Nevada.” In Geological Society of American Bulletin, Part I, 92 (10): 763-771.

Hadermann, J., and W. Heer. 1996. "The Grimsel (Switzerland) Migration Experiment Integrating Field Experiments, Laboratory Investigations and Modeling." In Journal of Contaminant Hydrology, 21: 87-100.

Hamby, D.M. 1993. “A Probabilistic Estimation of Atmospheric Tritium Dose.” In Health Physics, 65 (6): 628-647. Baltimore, MD: Williams and Wilkins.

Hardman, G. 1936. Nevada Precipitation and Acreages of Land by Rainfall Zones. Reno, NV: U.S. Department of Agriculture Experimental Station, University of Nevada.

Hardman, G. 1965. Nevada Precipitation and Acreages of Land by Rainfall Zones. Reno, NV: U.S. Department of Agriculture Experimental Station, University of Nevada.

Harrill, J.R. 1986. Ground-Water Storage Depletion in Pahrump Valley, Nevada-California 1962-1975, U.S, Geological Survey Water Supply Paper 2279.

Harrill, J.R., J.S. Gates, and J.M. Thomas. 1988. "Major Ground-Water Flow systems in the Great Basin Region of Nevada, Utah, and Adjacent States," U.S. Geological Survey Atlas HA-694-C. 
Harrison, B., E.A. Sudicky, and J.A. Cherry. 1992. "Numerical Analysis of Solute Migration Through Fractured Clayey Deposits Into Underlying Aquifers." In Water Resources Research, 28 (2): 515-526.

Hill, M.C. 1990. Preconditioned Conjugate-Gradient 2 (PCG2), A Computer Program for Solving Ground-Water Flow Equations, U.S. Geological Survey Water-Resources Investigation Report 90-4048.

Hill, M.C. 1992. A Computer Program (MODFLOWP) for Estimating Parameters of a Transient, Three-Dimensional, Ground-Water Flow Model Using Nonlinear Regression, U.S. Geological Open-File Report 91-84.

Hill, R.L., and J.R. Johnson. 1993. "Metabolism and Dosimetry of Tritium. In Health Physics 65: 628-647. New York: Pergamon Press.

Hughes, J.L. 1966. Some Aspects of the Hydrology of the Spring Mountains and Pahrump Valley, Nevada, and Environs, as Determined by Spring Evaluation. Reno, NV: McKay School of Mines, University of Nevada-Reno.

Hunt, G.B., T.W. Robinson, W.A. Bowles, and A.L. Washburn. 1966. Hydrologic Basin Death Valley, California, U.S. Geological Professional Paper 494-B.

Huyakorn, P.S., and G.F. Pinder. 1983. Computational Methods in Subsurface Flow. Orlando, FL: Academic Press.

IAEA, see International Atomic Energy Agency.

ICRP, see International Commission on Radiological Protection.

IT, see IT Corporation.

Iman, R.L., J.M. Davenport, and D.K. Ziegler. 1980. Latin Hypercube Sampling (Program User's Guide), SAND79-1473. Albuquerque, NM: Sandia National Laboratories.

International Atomic Energy Agency. 1976. Effects of Ionizing Radiation on Aquatic Organisms and Ecosystems, Technical Report Series No. 172. Vienna, Austria.

International Atomic Energy Agency. 1991. Airborne Gamma Ray Spectrometer Surveying, Technical Reports Series No. 323. Vienna, Austria.

International Atomic Energy Agency. 1992. Effects of Ionizing Radiation on Plants and Animals at Levels Implied by Current Radiation Protection Standards, Technical Report Series 332. Vienna, Austria. 
International Commission on Radiological Protection. 1978. Limits for Intakes of Radionuclides by Workers, Publication 30, Part 1. New York, NY: Pergamon Press.

International Commission on Radiological Protection. 1983. Radionuclide Transformations: Energy and Intensity of Emissions, Publication 38. New York, NY: Pergamon Press.

International Commission on Radiological Protection. 1991. 1990 Recommendations of the International Commission on Radiological Protection, Publication 60. New York, NY: Pergamon Press.

IT Corporation. 1996a. Regional Geologic Model Documentation Package (Phase I Data Analysis Documentation, Volume I). Prepared for DOE/NV. Las Vegas, NV.

IT Corporation. 1996b. Potentiometric Data Documentation Package (Phase I Data Analysis Documentation, Volume II). Prepared for DOE/NV. Las Vegas, NV.

IT Corporation. 1996c. Groundwater Recharge and Discharge Data Documentation Package (Phase I Data Analysis Documentation, Volume III). Prepared for DOE/NV. Las Vegas, NV.

IT Corporation. 1996d. Hydrologic Parameter Data Documentation Package (Phase I Data Analysis Documentation, Volume IV). Prepared for DOE/NV. Las Vegas, NV.

IT Corporation. 1996e. Transport Parameter and Source Term Data Documentation Package (Phase I Data Analysis Documentation, Volume V). Prepared for DOE/NV, Las Vegas, NV.

IT Corporation. 1996f. Groundwater Flow Model Documentation Package (Phase I Data Analysis Documentation, Volume VI). Prepared for DOE/NV. Las Vegas, NV.

IT Corporation. 1996g. Tritium Transport Model Documentation Package (Phase I Data Analysis Documentation, Volume VII). Prepared for DOE/NV. Las Vegas, NV.

IT Corporation. 1996h. Risk Assessment Documentation Package (Phase I Data Analysis Documentation, Volume VIII). Prepared for DOE/NV. Las Vegas, NV.

IT Corporation. 1996i. MC_TRANS: A Stochastic Advective-Dispersive Transport Code for Multiple Constituents in Dual Porosity or Fractured Geological Media. Prepared for the U.S. Department of Energy. Las Vegas, NV.

IT Corporation. 1996j. Wells ER-6-1 and ER-6-2 Core Fracture Analyses and Geophysical Log Comparisons, ITLV/10972/171. Prepared for the U.S. Department of Energy. Las Vegas, NV. 
IT Corporation. 1996k. Underground Test Area Fracture Analysis Report: Analysis of Fractures in Volcanic Cores from Pahute Mesa. Prepared for the U.S. Department of Energy. Las Vegas, NV.

Jacobson, B. Desert Research Institute, Reno NV. 1996. Personal communication to O. Drici, IT Corporation, Las Vegas, NV, regarding precipitation data, 20 September. Reno, NV.

James, J.W. 1993. Climate of the Death Valley Region, Nevada/California. Prepared for the National Park Service. Reno, NV: State of Nevada, Office of the State Climatologist.

Kahn, B. 1992. "Ecological Risks Associated with Radioactive Material." In Predicting Ecosystem Risk, 289-326. Princeton, NJ: Scientific Publishing Co., Inc.

Krishnamoorthy, T.M., R.N. Nair, and T.P. Sarma. 1992. "Migration of Radionuclides from a Granite Repository." In Water Resources Research, 28 (7): 1927-1934.

La Camera, R.J., and C.L. Westenburg. 1994. Selected Ground-Water Data for Yucca Mountain Region, Southern Nevada, and Eastern California, Through December, 1992, U.S..Geological Open-File Report 94-54.

Laczniak, R.J. U.S. Geological Survey, Las Vegas, NV. 1996a. Personal communication to O. Drici, IT Corporation, Las Vegas, NV, regarding groundwater discharge in Ash Meadows and Oasis Valley, 13 February.

Laczniak, R.J. U.S. Geological Survey, Las Vegas, NV. 1996b. Personal communication to R. Waddell, GeoTrans, Boulder, CO, regarding evapotranspiration study at Ash Meadows, 12 September.

Laczniak, R.J., J.C. Cole, D.A. Sawyer, and D.A. Trudeau. 1996. Summary of Hydrogeologic Controls on Ground-Water Flow at the Nevada Test Site, Nye County, Nevada, U.S. Geological Survey Water-Resources Investigation Report 96-4109. Carson City, NV.

Las Vegas Valley Water District. 1992. Evaluation of Maxey-Eakin Method for Calculating Recharge to Ground-Water Basins in Nevada, Cooperative Water Project Report No. 7. Las Vegas, NV.

Layton, D.W. 1993. "Metabolically Consistent Breathing Rates for Use in Dose Assessments." In Health Physics, 64 (1): 23-36. Baltimore, MD: Williams and Wilkins.

Leap, D.I., and P.M. Belmonte. 1992. "Influence of Pore Pressure on Apparent Dispersivity of a Fissured Dolomitic Aquifer." In Groundwater, 30 (1): 87-95.

LeBlanc, D.R. 1984. Sewage Plume in a Sand and Gravel Aquifer, Cape Cod, Massachusetts, U.S. Geological Survey, Water Supply Paper 2218. 
Lee, C.H., and I. Farmer. 1993. Fluidflow in Discontinuous Rocks. London, UK: Chapman and Hall.

Lioy et al. 1992. "Microenvironmental Analysis of Residential Exposure to Chromium-Laden Waste in and Around New Jersey Homes." In Risk Analysis 12(2): 287-299.

Lobmeyer, D.H., R.R. Luckey, G.M. O’Brien, and D.J. Burkhardt. 1995. Water Levels in Continuously Monitored Wells in the Yucca Mountain Area, Nevada, 1989, U.S. Geological Survey Open-File Report 93-098.

Loeltz, O.J. 1960. Abstract, "Source of Water Issuing from Springs in Ash Meadows Valley, Nye County, Nevada.” In Geological Society of America Bulletin, 71 (12): 1917-1918.

Long, J.C.S., and D.M. Billaux. 1987. "From Field Data to Fracture Network Modeling: An Example Incorporating Spatial Structure.” In Water Resources Research, 23 (7): 1201-1216.

Malmberg, G.T. 1967. Hydrology of the Valley-Fill and Carbonate-Rock Reservoirs, Pahrump Valley, Nevada-California, U.S. Geological Survey Water Supply Paper 1832.

Malmberg, G.T., and T.E. Eakin. 1962. Ground-Water Appraisal of Sarcobatus Flat and Oasis Valley, Nye County and Esmeralda Counties, Nevada, U.S. Geological Survey GroundWater-Reconnaissance Series Report 10. Carson City, NV.

Maloszewski, P., and A. Zuber. 1991. "Influence of Matrix Diffusion and Exchange Reactions on Radiocarbon Ages in Fissured Carbonate Aquifers." In Water Resources Research, 27 (8): 1937-1945.

Maxey, G.B., and T.E. Eakin. 1949. Groundwater in White River Valley, White Pine, Nye and Lincoln Counties, Nevada, U.S. Geological Survey Water-Resources Bulletin No. 8.

Maxey, G.B., and C.H. Jameson. 1948. Geology and Water Resources of Las Vegas, Pahrump and Indian Spring Valleys, Clark and Nye Counties, Nevada, U.S. Geological Survey Water Resources Bulletin No. 5.

McDonald, M.G., and A.W. Harbaugh. 1988. "A Modular Three-Dimensional, Finite Difference Ground-Water Flow Model.” In U.S. Geological Survey Techniques of Water Resources Investigations, Book 6, Chapter A1.

McDonald, M.G., and A.W. Harbaugh. 1991. A Method of Converting No-Flow Cells to Variable-Head Cells for the U.S. Geological Survey Modular Finite-Difference GroundWater Flow Model, U.S. Geological Survey Open-File Report 91-356.

McLean, J.A., and G. Tobin. 1987. Animal and Human Calorimetry. Cambridge, MA: Cambridge University. 
Miller, G.A. 1977. Appraisal of the Water Resources of Death Valley California-Nevada, U.S. Geological Survey Open-File Report 77-728.

Moench, A.F. 1984. "Double-Porosity Models for a Fissured Groundwater Reservoir With Fracture Skin.” In Water Resources Research, 20 (7): 831-846.

NCRP, see National Council on Radiation Protection and Measurements.

NOAA, see National Oceanic and Atmospheric Administration.

National Council on Radiation Protection and Measurements. 1979. Tritium in the Environment, Report No. 62. Bethesda, MD.

National Council on Radiation Protection and Measurements. 1991. Effects of Ionizing Radiation on Aquatic Organisms, Report No. 109. Bethesda, MD.

National Oceanic and Atmospheric Administration. 1991. "Local Climatological DataAnnual." In Summaries for 1990, Part IV-Western Region. Washington, DC: U.S. Department of Commerce.

Neretnieks, I., H. Abelin, and L. Birgersson. 1989. "Some Recent Observations of Channeling in Fractured rocks - Its Potential Impact on Radionuclide Migration." In Proceedings of the Conference on Geostatistical, Sensitivity, and Uncertainty Methods for Ground-Water Flow and Radionuclide Transport Modeling, September 15-17, 1987, San Francisco, CA, 387-410. Battell Press.

Neuman, S.P. 1990. "Universal Scaling of Hydraulic Conductivities and Dispersivities in Geologic Media." In Water Resources Research, 26 (8): 1749-1758.

Notenboom, J., S. Plénet, and M.J. Turquin. 1994. “Groundwater Contamination and its Impact on Groundwater Animals and Ecosystems.” In Groundwater Ecology, 477-504.

J.D. Gilbert, D.L. Danielopol, and J.A. Stanford, eds. San Diego, CA: Academic Press.

Ogard, A.E., J.L. Thompson, R.S. Rundberg, K. Wolfsberg, P.W. Kubik, D. Elmore, and H.W. Bentley. 1988. "Migration of Chlorine -36 and Tritium from an Underground Nuclear Test.” In Radiochimica Acta, 44/45: 213-217. Munich, Germany: R. Oldenbourg, Verlag.

Osborne, R.V. 1966. “Absorption of Tritiated Water Vapour by People." In Health Physics, 12 (11): 1527-1538. New York, NY: Pergamon Press.

Osborne, R.V. 1968. "Intake of Tritium When Skin is Splashed With Tritiated Water." In Health Physics, 15 (2): 155-156. New York, NY: Pergamon Press.

PAL Consultants. 1995. A Conceptual Model of the Death Valley Ground-Water Flow Systems. Nevada, California. Prepared for U.S. Department of the Interior National Park Service. 
Pankratz, M. Los Alamos National Laboratory. 1995. Personal Communication To J. Willie, IT Corporation, regarding events that were detonated below or within 100 meters of the water table at the Nevada Test Site. Los Alamos, NM.

Pennington, J.A.T. 1983. "Revision of the Total Diet Study Food List and Diets." In Journal of the American Dietetic Association, 82: 166-173.

Polikarpov, G.G. 1966. Radioecology of Aquatic Organisms. New York, NY: Reinhold Book Division.

Pollock, D.W. 1989. Documentation of Computer Programs to Compute and Display Pathlines Using Results from the U.S. Geological Survey Modular Three-Dimensional, FiniteDifference Ground-Water Flow Model, U.S. Geological Survey Open-File Report 89-381.

Prudic, D.E., J. R. Harrill, and T.J. Burbey. 1993. Conceptual Evaluation of Regional GroundWater Flow in the Carbonate-Rock Province of the Great Basin, Nevada, Utah, and Adjacent States, U.S. Geological Survey Open-File Report 93-170.

Quiring, R.F. 1968. Climatological Data Nevada Test Site and Nuclear Rocket Development Station, Environmental Science Services Administration Research Report ERLTM-AR17. Washington, DC: U.S. Department of Commerce.

Rope, S.K., and S.R. Adams. 1983. "Screening Levels for Radionuclides in Soil: Application to Decontamination and Decommissioning (D\&D) Criteria." In Proceedings of the Fourth DOE Environmental Protection Information Meeting, CONF-821215. Denver, CO.

Russell, C.E. Desert Research Institute. 1996. Personal communication about Novel species in aquifers and aquitards beneath the NTS.

Sada, D.W. 1990. Recovery Plan for the Endangered and Threatened Species of Ash Meadows, Nevada. U.S. Fish and Wildlife Service.

Saltus, R. 1994. "Regional Map of Southern Nevada Showing Thickness of Cenozoic Stratigraphy, Based on Gravity Interpretation," scale 1:500,000, unpublished map. U.S. Geological Survey.

Savard, C.S. 1994. "Groundwater Recharge in Fortymile Wash near Yucca Mountain, Nevada, 1992-1993." In High Level Radioactive Waste Management, 4: 1805-1813.

Sawyer, D.A., R.J. Fleck, M.A. Lanphere, R.G. Warren, and D.A. Broxton. 1990. "Episodic Volcanism in the Southwest Nevada Volcanic field: New 40AR/39AR Geochronologic Results." In EOS Transactions, AGU, 71 (43): 1296. 
Scott, B.R., T.J. Smales, F.E. Rush, and A.S. Van Denburgh. 1971. Water for Nevada, Nevada's Water Resources, State of Nevada Water Planning Report, Report No. 3. State of Nevada, Department of Conservation and Natural Resources, Division of Water Resources.

Serra, O. 1984. Fundamentals of Well Log Interpretation. Elsevier, NY.

Smith, D.K. et al., compilers. 1996. Hydrologic Resources Management Program FY1995 Progress Report. Livermore, CA: Lawrence Livermore National Laboratory.

Soule, D. Chief, Technical Support Branch, ARL/SORD. 1995. Personal communication about temperature, relative humidity, and wind direction and speed for Pahute Mesa and Frenchman Flat. Las Vegas, NV: National Oceanic and Atmospheric Administration.

Soule, D., Chief, Technical Support Branch, ARL/SORD. 1996. Personal communication about temperature, relative humidity, and wind direction and speed for Yucca Flat (Area 20). Las Vegas, NV: National Oceanic and Atmospheric Administration.

Stead, F.W. 1963. "Tritium Distribution in Groundwater and Large Underground Fusion Explosions.” In Science, 142: 3596.

Stewart, J.H., and J.E. Carlson. 1977. "Geologic Map of Nevada, Southern Half, "Map 57, scale 1;500,000, U.S. Geological Survey and the Nevada Bureau of Mines.

Strand, J.A., W.L. Templeton, and E.G. Tangen. 1973. "Accumulation and Retention of Tritium (Tritiated Water) in Embryonic and Larval Fish, and Radiation Effect." In Radionuclides in Ecosystems, 1: 445-451, D.J. Nelson, ed. Washington, DC: U.S. Atomic Energy Commission.

Straume, T., and A.L. Carsten. 1993. "Tritium Radiobiology and Relative Biological Effectiveness." In Health Physics, 65 (6): 657-672. Baltimore, MD: Williams and Wilkins.

Thomas, J.M. 1988. Delineation of Regional Flow Systems in Southern Nevada, Geological Society of America, 20 (7).

Thomas, J.M. 1996. "Geochemical and Isotopic Interpretation of Groundwater Flow, Geochemical Processes, and Age Dating of Groundwater in the Carbonate-Rock Aquifers of the Southern Basin and Range." A dissertation. Reno NV: University of Nevada-Reno.

Thordarson, W. 1965. Perched Ground Water in Zeolitized Bedded Tuff, Rainier Mesa and Vicinity, Nevada Test Site, U.S. Geological Survey Trace Elements Investigation Report TEI-862. Washington, DC. 
Tomasko, D., M. Reeves, V.A. Kelley, and J.F. Pickens. 1989. "Parameter Sensitivity and Importance for Radionuclide Transport in Double-Porosity Systems." In Proceedings of the Conference on Geostatistical Sensitivity, and Uncertainty Methods for Ground-Water Flow and Radionuclide Transport Modeling, pp. 279-321, September 15-17, 1987, B.E. Bufton, ed. San Francisco, CA: Battell Press.

Triay, I.R., K.H. Birdsell, A.J. Mitchell, and M.A. Ott. 1993. "Diffusion of Sorbing and NonSorbing Radionuclides." In Proceedings of the Fourth Annual International High Level Radioactive Waste Management Conference, Las Vegas, NV, April 26-30, 1993, American Nuclear Society, Inc., and American Society of Civil Engineers.

USGS, see U.S. Geological Survey.

Unterweger, M.P., B.M. Coursey, R.J. Shima, and W.B. Mann. 1980. "Preparation and Calibration of the 1978 National Bureau of Standards Tritiated Water Standards." In International Journal of Applied Radiation Isotopes, 31: 611-614.

U.S. Department of Energy. 1991. Interim Guidance for the Office of Environmental Restoration and Waste Management (EM) Data Quality Objectives Process. Washington, DC: U.S. Government Printing Office.

U.S. Department of Energy. 1992a. Nevada Field Office Annual Site Environmental Report for 1991, DOE/NV/10630-33, 1 and 2. Las Vegas, NV: DOE/NV.

U.S. Department of Energy. 1992b. Announced United States Nuclear Tests, DOE/NV/209 (Rev. 12). Las Vegas, NV: DOE/NV.

U.S. Department of Energy. 1992c. Environmental Assessment for the Groundwater Characterization Project, Nevada Test Site, Nye County, Nevada, DOE/EA-0532. Las Vegas, NV: DOE/NV.

U.S. Department of Energy. 1992d. Nevada Test Site Defense Waste Acceptance Criteria, Certification, and Transfer Requirements, NV-325. Las Vegas, NV: DOE/NV.

U.S. Department of Energy. 1993. Radiation Protection of the Public and Environment, DOE Order 5400.5, Change 2, January 7. Washington, DC: U.S. Government Printing Office.

U.S. Department of Energy. 1994. Announced United States Nuclear Tests, DOE/NV-209 (Rev 14). Las Vegas, NV: DOE/NV.

U.S. Department of Energy. 1995. Nevada Field Office Annual Site Environmental Report for 1994, DOE/NV/11432-175. Las Vegas, NV: DOE/NV. 
U.S. Department of Energy. 1996. The Environmental Impact Statement for the Nevada Test Site and Off-Site Locations in the State of Nevada, DOE/EIS/0243, 1 and 2. Las Vegas, NV: $\mathrm{DOE} / \mathrm{NV}$.

U.S. Energy Research and Development Administration, Nevada Operations Office. 1977. Final Environmental Impact Statement, Nye County, Nevada, ERDA-1551. Las Vegas, NV.

U.S. Environmental Protection Agency. 1989. Risk Assessment Guidance for Superfund, Volume II: Environmental Evaluation Manual, EPA/540/1-89/001. Washington, DC: U.S. Government Printing Office

U.S. Environmental Protection Agency. 1991a. Risk Assessment Guidance for Superfund, Human Health Evaluation Manual (Part B), Development of Risk-Based Preliminary Remediation Goals, EPA/540/R-92/003. Washington DC: U.S. Government Printing Office.

U.S. Environmental Protection Agency. 1991b. Risk Assessment Guidance for Superfund, Vol. 1: Human Health Evaluation Manual, Supplemental Guidance - Standard Default Exposure Factors, OSWER Directive 9285.6-03. Washington, DC: U.S. Government Printing Office.

U.S. Environmental Protection Agency. 1992. Framework for Ecological Risk Assessment, EPA/630/R-92/00, Washington, DC: U.S. Government Printing Office.

U.S. Environmental Protection Agency. 1995. Health Effects Assessment Summary Tables FY-1995 Annual, EPA/540/R-95/036. Washington, DC: Office of Solid Waste and Emergency Response.

U.S. Geological Survey. 1987. Digital Elevation Models: U.S. Geological Survey, National Mapping Program Technical Instructions Data User's Guide 5.

U.S. Geological Survey. 1989. National Water Information System User's Manual, Vol. 2, Chapter 4, Ground-Water Site Inventory System, U.S. Geological Survey Open-File Report 89-587, Version 90.1. S.B. Mathey, ed. Reston, VA.

Van der Heijde, P.K.M., A.I. El-Kadi, and S.A. Williams. 1988. Groundwater Modeling: an Overview and Status Report, EPA600/2-89-028. Ada, Oklahoma: R.S. Kerr Environmental Research Laboratory.

Van Denburgh, A.S., and F.E. Rush. 1974. Water-Resources Appraisal of Railroad and Penoyer Valleys, East-Central Nevada, Water-Resources Reconnaissance Series Report 60. U.S. Geological Survey.

Vanderploeg, H.A., D.C. Parzyck, W.H. Wilcox, J.R. Kercher, and S.V. Kaye. 1975. Bioaccumulation Factors for Radionuclides in Freshwater Biota, ORNL-5002.

Oak Ridge TN: Oak Ridge National Laboratory. 
Van Marke, E. 1983. Random Fields: Analysis and Synthesis. Cambridge, MA: The MIT Press.

Waddell, R.K. 1982. Two-Dimensional Steady-State Model of Ground-Water Flow, Nevada Test Site and Vicinity, Nevada-California, U.S. Geological Survey Water- Resources Investigation Report 82-4085.

Waddell, R.K., J. H. Robison, and R.K. Blankennagel. 1984. Hydrology of Yucca Mountain and Vicinity, Nevada-California: Investigative Results Through Mid-1983, U.S. Geological Water-Resources Investigation Report 84-4267. Denver, CO.

Walker, G.E., and T.E. Eakin. 1963. Geology and Ground-Water of the Amargosa Desert, Nevada-California, Department of Conservation and Natural Resources, Nevada, and U.S. Geological Survey Ground-Water Resources - Reconnaissance Series Report 14. U.S. Geological Survey.

Warren, R.G., D.A. Sawyer, and H.R. Covington. 1989. "Stratigraphy of the Southwestern Nevada Volcanic Field." In Proceedings from the Fifth Symposium on Containment of Underground Nuclear Explosives, held on September 19-21, 1989 at Santa Barbara, CA., CONF-8909163, 2: 387. Livermore, CA: Lawrence Livermore Laboratory.

Welty, C., and L.W. Gelhar. 1989. Evaluation of Longitudinal Dispersity from Tracer Test Data, R89-05. Cambridge, MA: Massachusetts Institute of Technology.

Wernicke, B., G.J. Axen, and J.K. Snow. 1988. "Basin and Range Extensional Tectonics at the Latitude of Las Vegas.” In Geologic Society of America Bulletin, 100: 1738-1757.

Whicker, F.W., T.B. Kirchner, D.B. Breshears, and M.D. Otis. 1990. "Estimation of Radionuclide Ingestion: The 'PATHWAY' Food Chain Model." In Health Physics, Special Issue, "Evaluation of Environmental Radiation Exposures from Nuclear Testing in Nevada," 59 (5): 645-657. New York, NY: Pergamon Press.

Whicker, F.W., and V. Schultz. 1982. Radioecology: Nuclear Energy and the Environment, Boca Raton, FL: CRC Press.

Winograd, I.J., and W. Thordardson. 1975. Hydrogeologic and Hydrochemical Framework, South-Central Great Basin, Nevada-California, with Special Reference to the Nevada Test Site, U.S. Geological Survey Professional Paper 712-C. Washington, DC.

Winograd, I.J., and I. Friedman. 1972. "Deuterium as a Tracer of Regional Ground-Water Flow, Southern Great Basin, Nevada and California." In Geological Society of America Bulletin, 83 (12): 3691-3708. 
Winograd, I.J., and L.R. West. 1962. Preliminary Tracer Experiment to Demonstrate Hydraulic Continuity Between Water Wells C and C-1, Yucca Flat, Nevada Test Site, U.S. Geological Survey Technical Letter, NTS-20.

Yu, C., A.J. Zielen, J.-J. Cheng, Y.C. Yuan, L.G. Jones, D.J. LePoire, Y.Y. Wang, C.O. Loureiro, E. Gnanpragasam, E. Faillace, A. Wallo III, W.A. Williams, and H. Peterson. 1993a. Manual for Implementing Residual Radioactive Material Guidelines Using RESRAD, Version 5.0, ANL/EAD/LD-2. Argonne, IL: Argonne National Laboratory.

Yu, C., C. Loureiro, J.-J. Cheng, L.G. Jones, Y.Y. Wang, Y.P. Chia, and E. Faillace. 1993b. Data Collection Handbook to Support Modeling the Impacts of Radioactive Material in Soil, ANL/EAIS-8. Argonne, IL: Argonne National Laboratory. 


\section{Appendix A Quality Control}




\section{A.1.0 Quality Control}

A Quality Assurance (QA) program has been developed for all activities performed under the Environmental Restoration (ER) Project, including the UGTA project. QA measures taken to control quality during the process of generating the products under the different data analysis subtasks include data documentation evaluation, data quality evaluation, checking procedures, software quality assurance, use of standard methodologies, technical and peer reviews, and corroboration through the models.

\section{A.1.1 Data Documentation Evaluation}

During the documentation evaluation process of data, flags are assigned. The five levels of Data Documentation Evaluation Flags (DDE_F) are briefly presented here:

Level 1: Data are collected in accordance with Nevada Environmental Restoration Project (ERP) subproject quality assurance plans, approved Nevada procedures, and/or participant-specific procedures. This ranking indicates that all supporting documentation for the data is on file and is available for review by data users.

Level 2: Data are collected in accordance with approved plans and procedures as required for Level 1, with the exception that one or more documentation requirements may be deficient in some way. Examples of data documentation deficiencies may include lost or destroyed field-data collection forms or data acquired using interim or draft procedures.

Level 3: Data are collected using accepted scientific methodology (e.g., American Society of Testing Materials [ASTM], EPA methods, USGS procedures) and accompanied by supporting and corroborative documentation such as testing apparatus diagrams, field or laboratory notes, and procedures. Documents referenced to qualify submitted data under the Level 3 category are noted and described in Part II of the Data Information Form (DIF).

Level 4: Data are collected by a participating Nevada ERP organization or another organization not associated with the Nevada ERP prior to the issuance and implementation of project-approved standard policies, procedures, or practices governing data acquisition and qualification. The methods of data collection are documented and traceable; however, the validity and prudency of data use or compliance with referenced procedures is indeterminate. Supporting documentation may or may not exist. Documentation provided to qualify submitted data under Level 4 shall be noted and described in Part II of the Data Information Form. 
Level 5: Data are obtained under unknown, undesirable, or uncertain conditions. When data documentation is unknown, any available supporting or helpful descriptions of the intended use and conditions of data capture should be described and listed in Part II of the Data Information Form.

\section{A.1.2 Data Quality Evaluation}

The criteria used to evaluate the different types of required data were dependent on the type of data and the intended use of the data. Thus, various criteria were used to evaluate data quality. The general procedure assigned one or more flags to each record compiled in the database, indicating the data quality or suitability of the individual data record for the intended usage. Subtask-specific data quality evaluation procedures are described in detail in the corresponding subtask documentation package.

\section{A.1.3 Checking Procedures}

Various checking procedures were designed for quality control purposes. Checking procedures applicable to the UGTA data analysis subtasks include those developed for transcription of data, generation of figures, tables and logs, and performance of calculations. Data compiled by project personnel were subjected to the checking procedures before being added to the ER database. However, the bulk of the ER database is comprised of external digital databases developed by agencies external to the UGTA project, mainly the National Water Information System (NWIS) data from the USGS. Internal procedures do not govern other ER database participants; therefore, their data were not subjected to the checking procedures described here.

\section{A.1.4 Software Quality Assurance}

Various computer codes were developed in-house to aid in the data analysis subtasks. Codes developed specifically for the UGTA project were subjected to software quality assurance requirements such as validation/verification, preparation of operating manuals, and documentation of the theoretical basis for the calculations. Codes developed to load data and perform unit conversion codes used on the ERDBMS were also checked.

\section{A.1.5 Standard Methodologies}

Only standard and widely accepted methodologies were used in the development of the interpretive products. The various methodologies used are too numerous to list here; however, they are described and referenced, where appropriate, in the sections discussing their use in the data analysis process. 


\section{A.1.6 Technical and Peer Reviews}

The review process constitutes an important measure of product quality, and was used throughout the performance of the data analysis activities. The review process consists of both technical and peer reviews. The technical review process is internal and is performed by qualified personnel. The peer review process is intended to complement the technical review process and is usually performed by individuals who are independent of the project.

Products generated under the Data Analysis Task were subjected to a continual review process to identify any major flaws in the conceptual model of the groundwater flow system at an early stage. The geologic cross sections and maps were subjected to technical and peer reviews several times during their development.

The hydrogeologic cross sections were also subjected to technical and peer reviews during their generation. The peer reviews were conducted during periodic meetings involving the IT Corporation (IT) geologists and hydrogeologists and representatives from Raytheon Services Nevada (RSN), the USGS, DRI, Los Alamos National Laboratory (LANL), and Lawrence Livermore National Laboratory (LLNL). Comments were recorded, evaluated, and incorporated into the process of defining the hydrostratigraphy.

The map products were internally reviewed by project personnel and submitted for peer review along with this documentation package. Following receipt of comments from the peer reviewers about the documentation packages and the map products, comments were resolved either by explanation or by modification of the products. Formal responses were prepared.

\section{A.1.7 Corroboration of Data through the Models}

This step was completed as the groundwater flow model was calibrated. During the calibration process, interpretations were tested and modified as required. This step particularly applied to the geologic model where extensive interpretation was necessary. The geologic model was modified during the calibration of the flow model because the initial interpretations in some areas did not allow for the duplication of the observed hydraulic heads within the existing levels of uncertainties. 


\section{Appendix B}

Comparison of Simulated and Observed Hydraulic Heads 


\section{Description of Appendix Contents}

This appendix contains a comparison of the simulated and observed hydraulic heads for those wells completed within the Nevada Test Site regional groundwater flow system. This dataset were derived from various databases and reports. The data are presented in table form. The data may be used in conjunction with Plate 3, using the map reference number. The table (Table B-1) is provided on pages B-4 through B-70. 


\section{Table B-1 \\ Comparison of Simulated and Observed Hydraulic Heads}

The following provides a description of each of the fields and the codes used in the table:

Map Ref. No Site reference number for cross-referencing between Table B-1 and Plate 3.

Official ID Unique site identification number (may or may not be a USGS ID).

Common name REDBOOK reporting name for wells on the NTS.

Northing NAD 27, UTM Zone 11 coordinate, in meters

Easting NAD 27, UTM Zone 11 coordinate, in meters

Observed Hyd. Mean predevelopment hydraulic head, in meters above mean sea level Head (amsl).

Simulated Hyd. Mean predevelopment hydraulic head simulated by the groundwater flow Head model.

Weighted Residual The difference between observed and simulated hydraulic heads, weighted by the inverse of the square root of the variance of the observed hydraulic head. 
Table B-1

Comparison of Simulated and Observed Hydraulic Heads

\begin{tabular}{|c|c|c|c|c|c|c|c|}
\hline $\begin{array}{c}\text { Map Ref. } \\
\text { No. }\end{array}$ & Official ID & Common Name & $\begin{array}{l}\text { Northing }{ }^{a} \\
\quad(\mathrm{~m})^{\mathrm{b}}\end{array}$ & $\begin{array}{l}\text { Easting }^{a} \\
(\mathrm{~m})\end{array}$ & $\begin{array}{l}\text { Observed } \\
\text { Hyd. Head } \\
(\mathrm{m})\end{array}$ & $\begin{array}{c}\text { Simulated } \\
\text { Hyd. Head } \\
(\mathrm{m})\end{array}$ & $\begin{array}{l}\text { Weighted } \\
\text { Residual }\end{array}$ \\
\hline 106 & 361158116240501 & & 4006033.8 & 553820.5 & 584 & 605.6 & -6.7 \\
\hline 107 & 361158116240502 & & 4006033.8 & 553820.5 & 579.9 & 605.5 & -8 \\
\hline 114 & 361210116225701 & & 4006414 & 555516.4 & 607.2 & 605.1 & 0.6 \\
\hline 115 & 361210116225702 & & 4006414 & 555516.4 & 607.6 & 602.7 & 1.5 \\
\hline 170 & 361406116173900 & W-10 & 4010177.3 & 556166.4 & 605.5 & 606.8 & -0.1 \\
\hline 172 & 361413116221201 & & 4010211 & 556615.5 & 605.8 & 606.4 & -0.6 \\
\hline 173 & 361413116221202 & & 4010211 & 556615.5 & 606.3 & 606.4 & -0.1 \\
\hline 174 & 361413116221203 & & 4010211 & 556615.5 & 606.7 & 606.4 & 0.3 \\
\hline 178 & 361415116222101 & & 4010271.3 & 556390.4 & 607.2 & 606.7 & 0.5 \\
\hline 179 & 361415116222102 & & 4010271.3 & 556390.4 & 607.2 & 606.7 & 0.4 \\
\hline 180 & 361415116222103 & & 4010271.3 & 556390.4 & 607.7 & 606.7 & 1 \\
\hline 181 & 361415116230200 & W-14 & 4010264.5 & 555367.1 & 608.9 & 607.7 & 1.2 \\
\hline 183 & 361417116224001 & & 4010329.8 & 555915.8 & 606.3 & 607.3 & -1 \\
\hline 198 & 361451116170800 & GS-18 & 4011168.5 & 556983.7 & 607.1 & 607.6 & 0 \\
\hline 202 & 361457116183400 & W-13 & 4011122.8 & 554637.8 & 608 & 610.8 & -0.3 \\
\hline 217 & 361516116220101 & GS-16 & 4012154 & 556877.4 & 608.4 & 609.3 & -0.1 \\
\hline 218 & 361516116220102 & GS-17 & 4012154 & 556877.4 & 608.3 & 609.3 & -0.1 \\
\hline 230 & 361527116171300 & GS-15 & 4012154 & 556877.4 & 608.3 & 609.3 & -0.1 \\
\hline 255 & 361553116212101 & GS-5 & 4013300.5 & 557868.1 & 610.2 & 610.7 & -0.1 \\
\hline 256 & 361553116212102 & GS-6 & 4013300.5 & 557868.1 & 610.4 & 610.7 & 0 \\
\hline 267 & 361605116212701 & GS-1 & 4013669.3 & 557715.9 & 611.6 & 611.3 & 0.2 \\
\hline 268 & 361605116212702 & GS-2 & 4013700 & 557715.7 & 611.4 & 611.3 & 0.1 \\
\hline 275 & 361610116223701 & GS-19 & 4013811.8 & 555968.3 & 607.6 & 613 & -5.4 \\
\hline 289 & 361627116221202 & GS-14 & 4014339.8 & 556588.7 & 613 & 613.1 & 0 \\
\hline 300 & 361640116315501 & & 4014657.8 & 542041.2 & 613.3 & 653.2 & -4 \\
\hline 330 & 361745116215502 & & 4016745.8 & 556997 & 617.6 & 617.4 & 0 \\
\hline 339 & 361808116273501 & & 4017402.8 & 548512.6 & 628.9 & 629.9 & -0.9 \\
\hline 346 & 361817116244701 & DEATH VLY JCT W & 4017704.5 & 552700.9 & 621.1 & 626 & -4.9 \\
\hline 353 & 361835116220301 & & 4018223.5 & 556812.8 & 619.7 & 622.1 & -0.7 \\
\hline 354 & 361835116224501 & & 4018278 & 555740 & 619.5 & 623.2 & -0.4 \\
\hline 356 & 361840116184001 & GA-8K & 4018617.3 & 560376.4 & 647.1 & 626.4 & 6.5 \\
\hline 357 & 361840116184002 & GA-8B & 4018740 & 560300.8 & 651.9 & 626.7 & 7.8 \\
\hline 358 & 361840116184003 & GA-8C & 4018771.5 & 560400.3 & 650 & 627 & 7.2 \\
\hline 359 & 361840116184004 & GA-8D & 4018771.5 & 560400.3 & 649.7 & 627 & 7.1 \\
\hline 360 & 361840116184005 & GA-8E & 4018772 & 560475.1 & 648.3 & 627.2 & 6.6 \\
\hline 361 & 361840116184006 & GA-8F & 4018772.3 & 560525 & 646.2 & 627.2 & 5.9 \\
\hline 362 & 361840116184007 & GA-8M & 4018772.3 & 560525 & 646.7 & 627.2 & 6 \\
\hline 363 & 361845116193707 & GA-8J RATHOLE & 4018617.5 & 560426.3 & 651 & 626.5 & 7.6 \\
\hline 394 & 361954116181201 & GS-3 W & 4020854.5 & 563028.6 & 648.2 & 652.5 & -4.3 \\
\hline 395 & 361954116181202 & & 4020854.5 & 563028.6 & 692 & 648.1 & 33.7 \\
\hline 398 & 362014116133901 & GS-1 W & 4021644 & 569554.6 & 716.2 & 693.2 & 23 \\
\hline 399 & 362014116134902 & & 4021644 & 569554.6 & 715.9 & 693.3 & 22.6 \\
\hline 401 & 362033116255202 & & 4021885 & 551055.2 & 628.1 & 635.3 & -0.7 \\
\hline 404 & 362113116160101 & GS-2 DEEP & 4022909 & 565805.5 & 694.8 & 687.9 & 2.1 \\
\hline 405 & 362113116160102 & GS-2 SHALLOW & 4022909 & 565805.5 & 694.9 & 686.2 & 2.7 \\
\hline 406 & 362120116162201 & & 4023428.5 & 565253.2 & 693.4 & 683.3 & 1 \\
\hline
\end{tabular}


Table B-1

Comparison of Simulated and Observed Hydraulic Heads

\begin{tabular}{|c|c|c|c|c|c|c|c|}
\hline $\begin{array}{c}\text { Map Ref. } \\
\text { No. }\end{array}$ & Official ID & Common Name & $\begin{array}{l}\text { Northing }{ }^{a} \\
\quad(m)^{b}\end{array}$ & $\begin{array}{l}\text { Easting } \\
\quad(\mathrm{m})\end{array}$ & $\begin{array}{l}\text { Observed } \\
\text { Hyd. Head } \\
(\mathrm{m})\end{array}$ & $\begin{array}{c}\text { Simulated } \\
\text { Hyd. Head } \\
(\mathrm{m})\end{array}$ & $\begin{array}{l}\text { Weighted } \\
\text { Residual }\end{array}$ \\
\hline 407 & 362140116261001 & & 4023947 & 550594.5 & 625.1 & 639 & -4.3 \\
\hline 408 & 362142116154701 & & 4024113 & 566120.3 & 701 & 689.1 & 1.2 \\
\hline 409 & 362145116161301 & & 4024200.5 & 565471.6 & 693.4 & 686.4 & 0.7 \\
\hline 410 & 362153116171502 & & 4024435.5 & 563924.7 & 672.6 & 674 & -0.4 \\
\hline 411 & 362154116162001 & & 4024435.5 & 563924.7 & 674.2 & 674 & 0 \\
\hline 413 & 362230116162001 & Big Spring & 4025554 & 565162.4 & 682.8 & 686.7 & -0.4 \\
\hline 414 & 362230116392901 & TRAVERTINE POINT $1 \mathrm{~W}$ & 4025394 & 530676.6 & 649.1 & 610.2 & 38.9 \\
\hline 416 & 362250116175001 & & 4026185.5 & 563039.7 & 671.9 & 673.5 & -0.2 \\
\hline 417 & 362250116175301 & & 4026184.8 & 562964.9 & 671.2 & 672.9 & -1.3 \\
\hline 418 & 362250116265101 & & 4026097.8 & 549560.4 & 641.5 & 643.3 & -0.6 \\
\hline 419 & 362250116265102 & & 4026097.8 & 549560.4 & 642.2 & 643.3 & -0.4 \\
\hline 420 & 362252116425301 & Navel Spring & 4026055.5 & 525591.5 & 634 & 523.5 & 11 \\
\hline 421 & 362303116174502 & & 4026586.8 & 563161.4 & 674.7 & 676.5 & -0.5 \\
\hline 422 & 362314116160101 & & 4026809 & 564056.7 & 687.3 & 684 & 0.3 \\
\hline 423 & 362343116160802 & & 4027837.3 & 565568.7 & 716.3 & 693.7 & 2.3 \\
\hline 424 & 362343116160803 & & 4027837.3 & 565568.7 & 716.3 & 693.7 & 2.3 \\
\hline 425 & 362343116160805 & & 4027837.3 & 565568.7 & 716.3 & 693.7 & 2.3 \\
\hline 430 & 362358116163301 & SPR MEADOWS 4 & 4028480 & 565015.9 & 702.9 & 693.9 & 2.8 \\
\hline 431 & 362400116161701 & & 4028298 & 565390.9 & 696.2 & 694.2 & 0.6 \\
\hline 432 & 362401116181101 & & 4028369.3 & 562500.7 & 685.8 & 680.3 & 0.6 \\
\hline 433 & 362401116181102 & & 4028369.3 & 562500.7 & 684.3 & 680.3 & 0.4 \\
\hline 434 & 362401116181103 & & 4028369.3 & 562500.7 & 685.8 & 680.3 & 0.6 \\
\hline 435 & 362402116172201 & & 4028409 & 563721 & 688.2 & 688.9 & -0.1 \\
\hline 437 & 362405116161305 & & 4026999.8 & 564827.7 & 701 & 688.9 & 1.2 \\
\hline 438 & 362406116154001 & SPR MEADOWS 17 & 4028520.5 & 566286 & 706.2 & 697.1 & 2.8 \\
\hline 439 & 362407116162401 & & 4028267 & 565366.2 & 716.3 & 694.1 & 2.2 \\
\hline 441 & 362408116154001 & SPR MEADOWS 16 & 4028519.5 & 566136.5 & 705.2 & 696.8 & 2.6 \\
\hline 442 & 362409116155601 & SPR MEADOWS 2 & 4028269 & 565640.2 & 699.7 & 694.8 & 1.5 \\
\hline 443 & 362410116160901 & SPR MEADOWS 1 & 4028518 & 565962.2 & 705.7 & 696.1 & 3 \\
\hline 444 & 362410116161002 & POINT OF ROCKS SPR & 4028514 & 565414.1 & 707.1 & 694.7 & 1.2 \\
\hline 446 & 362415116270501 & & 4028714.8 & 549196.6 & 650.7 & 648.2 & 0.2 \\
\hline 447 & 362417116163600 & POINT OF ROCKS S W & 4028971.8 & 564837.8 & 707.3 & 694.6 & 12.7 \\
\hline 448 & 362425116164901 & & 4029123.5 & 564537.7 & 696.5 & 694.2 & 0.2 \\
\hline 449 & 362425116181001 & SPR MEADOWS 9 & 4029386 & 562493.3 & 678.1 & 684.1 & -1.9 \\
\hline 450 & 362432116165701 & POINT OF ROCKS N W & 4029337.8 & 564336.9 & 699.6 & 693.9 & 5.7 \\
\hline 452 & 362443116263602 & & 4029581.5 & 549914 & 650.8 & 650.2 & 0.1 \\
\hline 453 & 362444116251001 & & 4029871.5 & 552054.3 & 642.8 & 651.5 & -0.9 \\
\hline 457 & 362502116192301 & CRYSTAL POOL & 4030574 & 560592 & 669 & 673.7 & -0.5 \\
\hline 458 & 362505116223001 & & 4035749 & 555777.1 & 661.7 & 672 & -3.2 \\
\hline 462 & 362521116160801 & & 4030856.8 & 565545.8 & 715.8 & 702 & 4.3 \\
\hline 464 & 362525116274301 & NA-9 W & 4030866.3 & 548238.1 & 665.2 & 653.4 & 11.8 \\
\hline 465 & 362525116274302 & & 4030866.3 & 548238.1 & 659.6 & 653.5 & 1.9 \\
\hline 466 & 362525116274501 & & 4030866 & 548188.3 & 662.2 & 653.4 & 0.9 \\
\hline 467 & 362526116181801 & & 4030987 & 562307.5 & 690.1 & 689.4 & 0.1 \\
\hline 469 & 362529116155801 & & 4031105 & 565793 & 718.4 & 701.7 & 1.7 \\
\hline 470 & 362529116160501 & SPR MEADOWS 12 & 4031041.5 & 565544.4 & 718.8 & 701.8 & 5.3 \\
\hline
\end{tabular}

${ }^{a}$ UTM Coordinates; Zone 11; NAD 27

${ }^{\mathrm{b}} \operatorname{Meter(}(\mathrm{s})$ 
Table B-1

Comparison of Simulated and Observed Hydraulic Heads

\begin{tabular}{|c|c|c|c|c|c|c|c|}
\hline $\begin{array}{c}\text { Map Ref. } \\
\text { No. }\end{array}$ & Official ID & Common Name & $\begin{array}{l}\text { Northing }{ }^{a} \\
\quad(m)^{b}\end{array}$ & $\begin{array}{l}\text { Easting }^{a} \\
\quad(\mathrm{~m})\end{array}$ & $\begin{array}{l}\text { Observed } \\
\text { Hyd. Head } \\
(\mathrm{m})\end{array}$ & $\begin{array}{c}\text { Simulated } \\
\text { Hyd. Head } \\
(\mathrm{m})\end{array}$ & $\begin{array}{l}\text { Weighted } \\
\text { Residual }\end{array}$ \\
\hline 471 & 362529116171100 & DEVILS HOLE W & 4031121.5 & 563875.4 & 717.9 & 698.3 & 19.6 \\
\hline 473 & 362532116172700 & DEVILS HOLE & 4031181 & 563576.1 & 718.3 & 697 & 21.3 \\
\hline 475 & 362532116181501 & & 4031172.3 & 562380.8 & 716.3 & 690.5 & 2.6 \\
\hline 476 & 362535116244801 & & 4031199.8 & 552594.1 & 670.6 & 655.4 & 1.5 \\
\hline 477 & 362554116184101 & & 4031845.5 & 561728.5 & 701 & 689.6 & 1.1 \\
\hline 478 & 362554116204001 & & 4031825 & 558765.6 & 662.6 & 666.4 & -0.4 \\
\hline 479 & 362555116205301 & GARNERS W & 4031853.5 & 558441.6 & 655.1 & 664.7 & -9.6 \\
\hline 480 & 362557116181301 & & 4031943 & 562425.1 & 723.9 & 693.9 & 3 \\
\hline 483 & 362627116213501 & & 4033296.3 & 557635.3 & 659 & 666.4 & -0.7 \\
\hline 485 & 362648116201401 & PETERSON & 4033493 & 559401.5 & 673.7 & 679.1 & -1.7 \\
\hline 486 & 362648116274601 & & 4033423 & 548149.1 & 676 & 660.7 & 1.5 \\
\hline 487 & 362650116311501 & & 4033457.3 & 542945.9 & 671.4 & 657.4 & 1.4 \\
\hline 488 & 362702116322201 & & 4033819 & 541276.3 & 671.2 & 657.5 & 11.2 \\
\hline 489 & 362705116300901 & & 4033927.8 & 544586.6 & 673.7 & 659.6 & 1.4 \\
\hline 490 & 362705116315001 & & 4033915.3 & 542072.4 & 673.3 & 658 & 1.5 \\
\hline 491 & 362705116322301 & & 4033911.3 & 541250.9 & 675.3 & 657.7 & 1.8 \\
\hline 494 & 362715116322301 & & 4034219.5 & 541249.5 & 673.3 & 658.4 & 6.7 \\
\hline 495 & 362723116184101 & & 4034587.8 & 561709 & 731.5 & 697.2 & 3.4 \\
\hline 496 & 362725116305901 & & 4034537.8 & 543338.8 & 673 & 660.2 & 8.2 \\
\hline 497 & 362726116314401 & & 4034563 & 542218.6 & 672.2 & 659.6 & 1.3 \\
\hline 498 & 362727116322201 & & 4034589.3 & 541272.6 & 670.9 & 659.3 & 1.2 \\
\hline 499 & 362728116501101 & TEXAS SPR & 4034534 & 514664.3 & 121.9 & 87.6 & 3.4 \\
\hline 501 & 362736116285701 & & 4034892.5 & 546373.7 & 674.7 & 663.5 & 8.8 \\
\hline 502 & 362736116285702 & & 4034892.5 & 546373.7 & 675.4 & 663.9 & 8.5 \\
\hline 503 & 362740116112601 & & 4035142 & 573453.9 & 715.8 & 709 & 5.4 \\
\hline 504 & 362745116204001 & & 4035245 & 558742.3 & 680.3 & 677.5 & 0.3 \\
\hline 506 & 362751116192701 & LONGSTREET SPR & 4035811.3 & 560430.8 & 704.1 & 693.5 & 1.1 \\
\hline 509 & 362755116202001 & & 4035556.5 & 559237.9 & 682.1 & 681.8 & 0.1 \\
\hline 510 & 362757116202401 & & 4035617.5 & 559138 & 679.1 & 682 & -0.3 \\
\hline 511 & 362757116202402 & & 4035617.5 & 559138 & 680.6 & 681.7 & -0.1 \\
\hline 513 & 362809116213101 & & 4035976 & 557468 & 664.8 & 675 & -3.1 \\
\hline 514 & 362811116202401 & & 4036048.8 & 559135 & 679.3 & 682.9 & -1 \\
\hline 516 & 362830115270501 & USAF W 2372-1 & 4037549.8 & 638942 & 904.5 & 944.6 & -12.5 \\
\hline 517 & 362835116192101 & ROGERS SPR & 4037136.3 & 560421.6 & 693.4 & 696.5 & -0.3 \\
\hline 518 & 362835116264101 & Gilgans South Well & 4036729 & 549748.3 & 673.9 & 672.2 & 0.5 \\
\hline 520 & 362848116195901 & & 4037193 & 559749.3 & 670.6 & 691.1 & -2 \\
\hline 521 & 362848116264201 & GILGANS NORTH W & 4037129 & 549621.6 & 673.3 & 673.4 & -0.1 \\
\hline 522 & 362848116291101 & & 4037815.5 & 545586.7 & 683.6 & 672.4 & 1.1 \\
\hline 523 & 362848116301501 & & 4037717 & 544417.7 & 685.5 & 670.8 & 1.5 \\
\hline 524 & 362850116202601 & & 4037250 & 559077 & 680.9 & 688.1 & -2.2 \\
\hline 525 & 362852116281401 & & 4037794.5 & 547428 & 686.6 & 673.9 & 7 \\
\hline 526 & 362852116294901 & & 4037812.8 & 545064.2 & 687.6 & 671.8 & 1.6 \\
\hline 527 & 362856116284201 & & 4037760 & 546731.6 & 685.8 & 673.3 & 6.8 \\
\hline 528 & 362858116091501 & & 4036946 & 575404.7 & 719.5 & 711.6 & 0.8 \\
\hline 529 & 362858116091502 & & 4037627 & 575771.9 & 719.4 & 712.3 & 0.7 \\
\hline 530 & 362858116195301 & ROGERS SPR W & 4037410.5 & 559971.7 & 689.4 & 693.7 & -4.3 \\
\hline
\end{tabular}


Table B-1

Comparison of Simulated and Observed Hydraulic Heads

\begin{tabular}{|c|c|c|c|c|c|c|c|}
\hline $\begin{array}{c}\text { Map Ref. } \\
\text { No. }\end{array}$ & Official ID & Common Name & $\begin{array}{l}\text { Northing }{ }^{a} \\
\quad(m)^{b}\end{array}$ & $\begin{array}{l}\text { Easting }^{a} \\
\quad(\mathrm{~m})\end{array}$ & $\begin{array}{l}\text { Observed } \\
\text { Hyd. Head } \\
(\mathrm{m})\end{array}$ & $\begin{array}{c}\text { Simulated } \\
\text { Hyd. Head } \\
(\mathrm{m})\end{array}$ & $\begin{array}{l}\text { Weighted } \\
\text { Residual }\end{array}$ \\
\hline 531 & 362858116195302 & & 4037472.5 & 560046 & 691.1 & 695.3 & -1.3 \\
\hline 533 & 362902116304701 & & 4037528 & 543622.4 & 674.8 & 669.3 & 0.6 \\
\hline 534 & 362905116092301 & & 4037841 & 575571 & 719.3 & 712.4 & 0.7 \\
\hline 535 & 362905116274001 & & 4037645 & 548274.9 & 673.5 & 674.1 & -0.1 \\
\hline 537 & 362917116294601 & & 4038520 & 544811.7 & 688.6 & 672.9 & 1.6 \\
\hline 538 & 362917116304701 & & 4037990 & 543620 & 683.5 & 670.6 & 1.3 \\
\hline 539 & 362921116280401 & & 4038596 & 547473.5 & 678 & 675.4 & 2 \\
\hline 540 & 362921116302501 & & 4038547.5 & 544164.7 & 688.2 & 672.3 & 1.6 \\
\hline 542 & 362923116291101 & & 4038647 & 545507.7 & 684.3 & 673.9 & 5.8 \\
\hline 543 & 362924116203001 & Fairbanks Spring & 4038359 & 559019.7 & 685.8 & 692.3 & -0.7 \\
\hline 544 & 362925116253301 & & 4038649.5 & 551429.1 & 675.9 & 678 & -1 \\
\hline 546 & 362929116085701 & CHERRY PATCH W & 4038586.3 & 576211.4 & 719.2 & 713.3 & 5.9 \\
\hline 547 & 362930116295901 & & 4038396.8 & 544812.3 & 676.2 & 672.7 & 0.4 \\
\hline 549 & 362938116270001 & & 4038667.5 & 549264.4 & 672.8 & 676.8 & -2.2 \\
\hline 551 & 362939116265401 & & 4038699.3 & 549413.6 & 667.7 & 676.9 & -0.9 \\
\hline 552 & 362946116254101 & & 4039387.8 & 551225.6 & 677 & 679.7 & -0.3 \\
\hline 553 & 362946116270301 & & 4038910.8 & 548665.9 & 677.7 & 676.9 & 0.4 \\
\hline 554 & 362946116302201 & & 4039256.5 & 544235.6 & 688.4 & 673.7 & 7.9 \\
\hline 555 & 362946116302301 & & 4038886.8 & 544212.6 & 688.9 & 673 & 1.6 \\
\hline 556 & 362946116302302 & & 4038886.8 & 544212.6 & 686.7 & 673 & 1.4 \\
\hline 557 & 362947116252001 & MOUNTAIN VIEW HOMES & 4038959.5 & 551750.7 & 673.8 & 679 & -3.5 \\
\hline 558 & 362957116254901 & & 4039263.3 & 551027.4 & 673.7 & 679.2 & -0.6 \\
\hline 559 & 363002116304801 & & 4039376.5 & 543588.2 & 680.6 & 673.2 & 0.7 \\
\hline 560 & 363002116310701 & & 4039374.3 & 543115.6 & 681.2 & 672.7 & 2.6 \\
\hline 561 & 363005116291001 & & 4039481.5 & 546025.7 & 683.1 & 675.9 & 0.7 \\
\hline 562 & 363009116291101 & & 4040219.3 & 545673.5 & 686.1 & 677 & 0.9 \\
\hline 563 & 363009116302701 & HALLOW W & 4039595 & 544109.5 & 686.7 & 674.2 & 12.5 \\
\hline 564 & 363011116280401 & & 4040230 & 547663.4 & 681.3 & 678.7 & 1.3 \\
\hline 565 & 363017116253001 & & 4040221.3 & 551494.3 & 676 & 682 & -3.1 \\
\hline 566 & 363017116253002 & & 4039882.3 & 551496.4 & 684.3 & 681.1 & 0.3 \\
\hline 567 & 363020116290001 & & 4039945 & 546272 & 681.5 & 677 & 0.5 \\
\hline 568 & 363026116160401 & & 4040255.3 & 565574.1 & 686.6 & 708.2 & -6.7 \\
\hline 569 & 363026116160402 & & 4040255.3 & 565574.1 & 680.8 & 708.2 & -8.5 \\
\hline 570 & 363026116275601 & & 4040138.8 & 547862.9 & 677.4 & 678.6 & -0.1 \\
\hline 571 & 363027116270001 & & 4040177.5 & 549255.8 & 677.3 & 679.9 & -0.3 \\
\hline 573 & 363028116270201 & & 4040208 & 549205.8 & 677.3 & 679.9 & -1.4 \\
\hline 574 & 363030116104501 & & 4040472.8 & 573458.3 & 714.1 & 713.2 & 0.3 \\
\hline 575 & 363030116280001 & & 4040261.5 & 547762.8 & 685.5 & 678.8 & 0.7 \\
\hline 576 & 363039116303501 & & 4040518.3 & 543905.8 & 686.2 & 675.8 & 3.2 \\
\hline 580 & 363045115280201 & USAF ALPHA 2 & 4041684 & 637258.1 & 894.4 & 902.4 & -6.3 \\
\hline 581 & 363046116281401 & & 4041183.8 & 547409.4 & 686.1 & 680.1 & 4.6 \\
\hline 582 & 363046116285701 & & 4041116.5 & 546340.3 & 687.2 & 679.1 & 2.5 \\
\hline 583 & 363050116105001 & & 4041057.5 & 573378.7 & 714.8 & 713.7 & 0.1 \\
\hline 584 & 363053116271001 & & 4040977 & 549002.5 & 677 & 681.2 & -0.4 \\
\hline 585 & 363053116272001 & & 4040975.5 & 548753.7 & 681.6 & 681 & 0.4 \\
\hline 586 & 363054116270401 & & 4041008.8 & 549151.5 & 678.8 & 681.4 & -0.3 \\
\hline
\end{tabular}

${ }^{a}$ UTM Coordinates; Zone 11; NAD 27

${ }^{\mathrm{b}} \operatorname{Meter}(\mathbf{s})$ 
Table B-1

Comparison of Simulated and Observed Hydraulic Heads

\begin{tabular}{|c|c|c|c|c|c|c|c|}
\hline $\begin{array}{c}\text { Map Ref. } \\
\text { No. }\end{array}$ & Official ID & Common Name & $\begin{array}{l}\text { Northing }{ }^{a} \\
\quad(\mathrm{~m})^{\mathrm{b}}\end{array}$ & $\begin{array}{l}\text { Easting }^{a} \\
(\mathrm{~m})\end{array}$ & $\begin{array}{l}\text { Observed } \\
\text { Hyd. Head } \\
(\mathrm{m})\end{array}$ & $\begin{array}{c}\text { Simulated } \\
\text { Hyd. Head } \\
(\mathrm{m})\end{array}$ & $\begin{array}{l}\text { Weighted } \\
\text { Residual }\end{array}$ \\
\hline 587 & 363058116270501 & & 4041131.8 & 549126 & 682 & 681.6 & 0.3 \\
\hline 589 & 363109116252601 & & 4041485 & 551586.3 & 677.7 & 684.9 & -2.2 \\
\hline 590 & 363109116253101 & & 4042069.8 & 551458.4 & 687.6 & 686.1 & 0.2 \\
\hline 591 & 363111116275601 & & 4041525.3 & 547855.2 & 688.3 & 681.1 & 5.5 \\
\hline 592 & 363111116290201 & & 4041516.3 & 546213.8 & 692.5 & 679.6 & 1.3 \\
\hline 593 & 363111116300001 & & 4041878.5 & 544769.3 & 687.9 & 678.7 & 0.9 \\
\hline 594 & 363115116242001 & & 4041680 & 553226.6 & 704 & 688.1 & 1.6 \\
\hline 595 & 363117116303601 & & 4041689 & 543875 & 688.7 & 677.6 & 6.1 \\
\hline 596 & 363120116300001 & BETTLES & 4041786 & 544769.8 & 687 & 678.6 & 8.4 \\
\hline 597 & 363121116112301 & & 4042006 & 572549.9 & 714.7 & 714.3 & 0 \\
\hline 598 & 363129116241701 & & 4042111.8 & 553298.6 & 677.2 & 689.3 & -3.8 \\
\hline 599 & 363129116242501 & & 4042110.5 & 553099.7 & 674.9 & 688.9 & -10.7 \\
\hline 600 & 363129116252901 & & 4042101 & 551508 & 677.3 & 686.2 & -4.4 \\
\hline 601 & 363132116285201 & & 4042164.8 & 546459 & 685.3 & 680.8 & 0.4 \\
\hline 602 & 363133116250101 & & 4042228.5 & 552203.6 & 675.3 & 687.4 & -1.2 \\
\hline 603 & 363134116292001 & & 4042222.5 & 545762.3 & 684.9 & 680.2 & 3.7 \\
\hline 604 & 363135115281401 & USAF ALPHA 3 & 4043220 & 636935.1 & 890.5 & 890.6 & -0.1 \\
\hline 605 & 363136116271501 & & 4042608.8 & 548744.5 & 687.5 & 684 & 1.1 \\
\hline 606 & 363138116142701 & & 4042494.5 & 568243 & 701.2 & 713.4 & -1.2 \\
\hline 609 & 363138116252101 & & 4042625 & 551554.6 & 692.2 & 687.4 & 4.1 \\
\hline 610 & 363138116290201 & & 4042164 & 546334.6 & 688.6 & 680.7 & 6.7 \\
\hline 611 & 363138116310101 & & 4042700.8 & 542875.1 & 688.8 & 677.9 & 1.1 \\
\hline 612 & 363138116323801 & & 4042629.3 & 540836.2 & 688 & 676.1 & 7.7 \\
\hline 613 & 363140116275301 & & 4042172.8 & 547926.3 & 687.9 & 682.3 & 5.3 \\
\hline 614 & 363145116310601 & & 4042548 & 543124.6 & 689.5 & 678 & 3.6 \\
\hline 615 & 363148116251001 & & 4042689.3 & 551977.1 & 676.1 & 688.1 & -8.7 \\
\hline 616 & 363155116323301 & & 4042845.5 & 540959.5 & 689.5 & 676.5 & 1.3 \\
\hline 617 & 363157116221201 & & 4042870.5 & 556303 & 693.9 & 700.6 & -5 \\
\hline 618 & 363200116304401 & & 4043353.3 & 543966 & 689.1 & 679.9 & 2.9 \\
\hline 620 & 363200116323301 & & 4042999.5 & 540958.8 & 693.7 & 676.7 & 1.7 \\
\hline 621 & 363203116295801 & & 4043604 & 544810.1 & 689.1 & 681.3 & 5.2 \\
\hline 622 & 363205115335601 & USAF W 2278-1 & 4044013.3 & 628415.4 & 941.3 & 967.3 & -2.6 \\
\hline 623 & 363205116271801 & & 4043564 & 548788.9 & 687.9 & 685.8 & 1.1 \\
\hline 624 & 363209116314001 & & 4043283.3 & 542275.4 & 678.1 & 678.2 & -0.1 \\
\hline 625 & 363210116313801 & & 4043314.3 & 542325 & 689.9 & 678.3 & 9.2 \\
\hline 626 & 363211116294601 & & 4043359.3 & 545109.8 & 689.5 & 681.2 & 2.6 \\
\hline 627 & 363212115240301 & SBH-1 S BLK HILLS-1 & 4044461.5 & 643158.9 & 882.2 & 834.1 & 26.5 \\
\hline 628 & 363212116270401 & & 4043567 & 549286.2 & 688.5 & 686.4 & 1.1 \\
\hline 629 & 363213116133700 & & 4043580.8 & 569204.3 & 719.7 & 715.4 & 1.3 \\
\hline 630 & 363213116133800 & TRACER W 3 & 4043580.5 & 569179.5 & 719.5 & 715.4 & 4.1 \\
\hline 631 & 363213116133901 & & 4043580.3 & 569154.6 & 719.4 & 715.4 & 1.2 \\
\hline 632 & 363213116134001 & & 4043580 & 569129.7 & 719.9 & 715.4 & 1.4 \\
\hline 633 & 363214116284801 & & 4043459.3 & 546551.5 & 688.2 & 683 & 2.1 \\
\hline 634 & 363217116320001 & & 4044049 & 541351.6 & 692.6 & 678.4 & 6 \\
\hline 636 & 363223116292201 & & 4044440.8 & 545700.9 & 690.2 & 683.6 & 0.7 \\
\hline 637 & 363223116295501 & & 4044310 & 544284.3 & 687.9 & 681.8 & 5 \\
\hline
\end{tabular}


Table B-1

Comparison of Simulated and Observed Hydraulic Heads

\begin{tabular}{|c|c|c|c|c|c|c|c|}
\hline $\begin{array}{c}\text { Map Ref. } \\
\text { No. }\end{array}$ & Official ID & Common Name & $\begin{array}{l}\text { Northing }{ }^{a} \\
\quad(m)^{b}\end{array}$ & $\begin{array}{l}\text { Easting }^{a} \\
\quad(\mathrm{~m})\end{array}$ & $\begin{array}{l}\text { Observed } \\
\text { Hyd. Head } \\
(\mathrm{m})\end{array}$ & $\begin{array}{c}\text { Simulated } \\
\text { Hyd. Head } \\
(\mathrm{m})\end{array}$ & $\begin{array}{l}\text { Weighted } \\
\text { Residual }\end{array}$ \\
\hline 638 & 363223116303801 & & 4044154.3 & 543936.9 & 690.7 & 681.1 & 3 \\
\hline 639 & 363223116345901 & & 4043691.8 & 537325.2 & 693.9 & 675.1 & 16.5 \\
\hline 640 & 363225116260901 & & 4044156.3 & 549954.2 & 688.1 & 688.5 & -0.3 \\
\hline 641 & 363225116282401 & & 4044323.3 & 546770.6 & 687.6 & 684.7 & 0.3 \\
\hline 642 & 363225116310901 & & 4044211.5 & 543041.6 & 689.8 & 680.2 & 1 \\
\hline 643 & 363230116260501 & & 4043975 & 550601.7 & 686.5 & 689 & -0.3 \\
\hline 644 & 363231115322201 & USBLM & 4044849.8 & 630740.9 & 907.7 & 955.7 & -48 \\
\hline 645 & 363237116292901 & & 4044162.5 & 545528.3 & 690.4 & 683 & 4.1 \\
\hline 646 & 363238115464601 & ARMY 3 & 4044766 & 609254.3 & 1014.7 & 1006.5 & 8.2 \\
\hline 647 & 363243116354101 & & 4044303.5 & 536278.3 & 687.8 & 675.4 & 1.2 \\
\hline 648 & 363244116320701 & & 4044911.5 & 541322.7 & 690.1 & 679.7 & 1 \\
\hline 650 & 363248116302801 & & 4044493.8 & 544059.6 & 685.9 & 681.8 & 0.4 \\
\hline 651 & 363248116303101 & & 4045325.5 & 543980.8 & 692.8 & 683 & 3.1 \\
\hline 652 & 363250116251301 & & 4044999.5 & 551888.4 & 700 & 693.4 & 5.1 \\
\hline 653 & 363252116265001 & & 4045170.3 & 549475.9 & 691.3 & 689.8 & 1.1 \\
\hline 654 & 363252116292501 & & 4044963.5 & 545524 & 691.4 & 684.2 & 2.2 \\
\hline 655 & 363254116295501 & & 4044959.5 & 544728.5 & 690 & 683.3 & 2.1 \\
\hline 657 & 363255115515801 & ARMY 2 & 4045195 & 601490.3 & 1010 & 1005.8 & 4.2 \\
\hline 658 & 363256116282101 & & 4045157.5 & 547213.5 & 687.4 & 686.7 & 0.6 \\
\hline 659 & 363310116294001 & USBLM W & 4045178 & 545249.5 & 691.5 & 684.2 & 7.3 \\
\hline 660 & 363316116362401 & & 4045315.8 & 535205 & 688.9 & 676.3 & 9.7 \\
\hline 661 & 363317116293001 & & 4045980.3 & 545493.8 & 691 & 685.8 & 0.5 \\
\hline 662 & 363332115244001 & DR-1 & 4046789 & 642249.8 & 842.3 & 805.1 & 20.5 \\
\hline 663 & 363332116323501 & & 4045832.3 & 540522.8 & 692.1 & 680.3 & 7.5 \\
\hline 664 & 363338116303101 & & 4046034 & 543977.1 & 691.3 & 684.1 & 1.6 \\
\hline 665 & 363340116332901 & & 4046815.5 & 539971.3 & 694.1 & 681.2 & 4 \\
\hline 666 & 363340116362801 & & 4046424.5 & 535101.1 & 692.9 & 677.8 & 12 \\
\hline 667 & 363342116325101 & & 4046819.5 & 540791.5 & 693.9 & 681.9 & 3.7 \\
\hline 668 & 363342116335701 & & 4046842.8 & 539150.9 & 696.5 & 680.5 & 1.6 \\
\hline 669 & 363342116345401 & & 4046710 & 537038.7 & 690.7 & 679.1 & 7.4 \\
\hline 670 & 363344116304501 & & 4046496 & 543925 & 691.2 & 684.7 & 5.1 \\
\hline 671 & 363346116322801 & & 4046700.3 & 541612.3 & 694.2 & 682.5 & 3.7 \\
\hline 672 & 363348116254901 & & 4046380.8 & 550985.2 & 695 & 694.9 & 0.1 \\
\hline 674 & 363348116292701 & & 4046594.5 & 545117.7 & 691 & 686.4 & 3.3 \\
\hline 675 & 363350116252101 & & 4046880.5 & 552100.8 & 699.5 & 698.3 & 0.7 \\
\hline 676 & 363354115400601 & & 4047239.8 & 619167.8 & 970.2 & 964 & 0.6 \\
\hline 677 & 363355116254901 & & 4046596.5 & 550984 & 691.3 & 695.4 & -2.6 \\
\hline 678 & 363356115400501 & INDIAN SPRS-3 & 4047301.8 & 619191.7 & 969.3 & 963 & 0.6 \\
\hline 679 & 363356115400601 & INDIAN SPRS- 1 & 4047270.5 & 619167.3 & 969.3 & 963.6 & 0.6 \\
\hline 680 & 363402116344201 & & 4046744 & 537734.6 & 689.6 & 679.5 & 1 \\
\hline 681 & 363405116321501 & & 4047561.8 & 541384.5 & 705.6 & 683.5 & 6.6 \\
\hline 683 & 363407115215301 & COW CAMP & 4048059.5 & 646331.5 & 865.8 & 813.7 & 28.7 \\
\hline 684 & 363407116243501 & & 4047683.5 & 552394.3 & 709 & 700.8 & 0.8 \\
\hline 685 & 363407116273301 & AMARGOSA VLY WATER & 4046951.5 & 548396.8 & 701.3 & 691.6 & 1 \\
\hline 686 & 363407116342501 & & 4047668.3 & 537730.5 & 691.4 & 680.7 & 3.2 \\
\hline 687 & 363409116233701 & & 4047430.8 & 551351.8 & 713.2 & 697.9 & 1.5 \\
\hline
\end{tabular}


Table B-1

Comparison of Simulated and Observed Hydraulic Heads

\begin{tabular}{|c|c|c|c|c|c|c|c|}
\hline $\begin{array}{c}\text { Map Ref. } \\
\text { No. }\end{array}$ & Official ID & Common Name & $\begin{array}{l}\text { Northing }{ }^{a} \\
\quad(\mathrm{~m})^{\mathrm{b}}\end{array}$ & $\begin{array}{c}\text { Easting }^{a} \\
\quad(\mathrm{~m})\end{array}$ & $\begin{array}{l}\text { Observed } \\
\text { Hyd. Head } \\
(\mathrm{m})\end{array}$ & $\begin{array}{c}\text { Simulated } \\
\text { Hyd. Head } \\
(\mathrm{m})\end{array}$ & $\begin{array}{l}\text { Weighted } \\
\text { Residual }\end{array}$ \\
\hline 690 & 363410116261101 & & 4047055.5 & 550434.4 & 691.2 & 695.3 & -0.4 \\
\hline 691 & 363411116264701 & & 4047666.5 & 549536.1 & 689.5 & 694.8 & -0.5 \\
\hline 692 & 363411116272901 & AMARGOSA TWN COMPLEX & 4047075.3 & 548495.5 & 688.9 & 692 & -0.3 \\
\hline 693 & 363415116275101 & & 4047780.8 & 547944.7 & 696.2 & 692.3 & 0.4 \\
\hline 694 & 363417116271801 & & 4047260 & 548469.7 & 690.1 & 692.2 & -1 \\
\hline 696 & 363422115433701 & CACTUS SPRG 3 & 4048031.5 & 613911.3 & 984.6 & 977.7 & 3.8 \\
\hline 697 & 363428116234701 & COOKS EAST W & 4047631.8 & 554010.1 & 719.3 & 705.2 & 14.1 \\
\hline 698 & 363428116240301 & Cooks West W & 4047629.5 & 553612.5 & 720.1 & 704.1 & 5 \\
\hline 699 & 363428116281201 & AMARGOSA WATER & 4047593 & 547423.9 & 690.4 & 691.2 & -0.1 \\
\hline 700 & 363429116233401 & & 4047664.8 & 554332.9 & 715.7 & 706.2 & 0.9 \\
\hline 701 & 363429116315901 & & 4047594.5 & 541781.9 & 690.8 & 683.9 & 3.7 \\
\hline 702 & 363430115400501 & & 4048349.5 & 619177.2 & 940.9 & 949 & -0.8 \\
\hline 703 & 363434116354001 & DEFIR W & 4048403 & 536658.6 & 692.4 & 681.1 & 11.3 \\
\hline 704 & 363436116333201 & & 4048449 & 540038.2 & 693 & 683.4 & 2.9 \\
\hline 705 & 363436116342301 & & 4048440.8 & 538199.2 & 706.9 & 682 & 7.5 \\
\hline 706 & 363436116345901 & & 4048375 & 537304.9 & 726 & 681.4 & 4.5 \\
\hline 707 & 363437116010801 & ARMY 6 A & 4048187.5 & 587783.8 & 735.8 & 735.2 & 0.6 \\
\hline 708 & 363438116324601 & & 4048082 & 540611.6 & 696.6 & 683.4 & 7.1 \\
\hline 710 & 363440116282401 & & 4047961 & 547123.7 & 686.4 & 691.3 & -0.5 \\
\hline 711 & 363442116363301 & & 4047964.8 & 534970.5 & 689.1 & 679.6 & 0.9 \\
\hline 712 & 363447115404601 & USAF W 106-2 & 4048858.3 & 618076.4 & 934.1 & 947 & -9.9 \\
\hline 713 & 363452115404401 & USAF W 62-1 & 4049014 & 618198.5 & 938.9 & 914 & 16.4 \\
\hline 714 & 363452115405101 & USAF W 3 & 4048918.5 & 617976.1 & 933.3 & 918.3 & 4.6 \\
\hline 715 & 363454116314201 & & 4048890.8 & 542198.2 & 693.4 & 686.1 & 5.8 \\
\hline 716 & 363456116335501 & & 4048998.5 & 538892.6 & 707.4 & 683.2 & 18.6 \\
\hline 717 & 363500115400001 & & 4046539.8 & 619799.1 & 958.9 & 969 & -1 \\
\hline 718 & 363503116284001 & & 4048667.5 & 546722.1 & 693.6 & 691.8 & 1 \\
\hline 719 & 363503116351501 & & 4048620 & 536906.3 & 690.9 & 681.5 & 7 \\
\hline 720 & 363508115391701 & USAF MW-22 & 4049537 & 620353.9 & 932.5 & 924.7 & 7.8 \\
\hline 721 & 363511116335101 & & 4048875.5 & 538992.5 & 690.8 & 683.1 & 0.8 \\
\hline 722 & 363514115475001 & TW-4 & 4049553 & 607602.8 & 835.8 & 963.1 & -127.3 \\
\hline 724 & 363519116322001 & & 4049935 & 541522.2 & 693.7 & 686.7 & 2.2 \\
\hline 725 & 363521116352501 & & 4049173.5 & 536655.4 & 691 & 682.1 & 6.5 \\
\hline 726 & 363523116353701 & & 4050004 & 536353.7 & 693.7 & 682.9 & 8.3 \\
\hline 728 & 363527115510901 & TW-10 & 4049893 & 602652.7 & 832.3 & 964.5 & -13.2 \\
\hline 729 & 363527116292501 & & 4049401 & 545599.9 & 697.8 & 691.2 & 4.3 \\
\hline 730 & 363529115391301 & USAF MW-21 & 4050185.5 & 620444.2 & 930 & 855.8 & 74.2 \\
\hline 731 & 363529115392101 & USAF MW-20 & 4050182.8 & 620245.5 & 930 & 853.5 & 76.5 \\
\hline 732 & 363530116021401 & Army 1 WW & 4049804 & 586127.1 & 721.7 & 721.2 & 0 \\
\hline 733 & 363540116240801 & & 4049847 & 553474.4 & 721.9 & 707.1 & 8.2 \\
\hline 734 & 363549116305001 & & 4050068 & 543484.4 & 695.9 & 689.1 & 2.1 \\
\hline 736 & 363621116263201 & & 4052320.3 & 549683.2 & 704.4 & 701.5 & 0.3 \\
\hline 737 & 363709116264601 & & 4052566 & 549532.7 & 704 & 701.4 & 0.3 \\
\hline 738 & 363711116263701 & & 4053645.5 & 549750 & 707.7 & 702.9 & 2.6 \\
\hline 739 & 363742116263201 & & 4054909.5 & 549866.8 & 706.7 & 704.3 & 1.6 \\
\hline 740 & 363750115394099 & S15E5621 & 4054522.5 & 619709 & 737.8 & 733.9 & 0.4 \\
\hline
\end{tabular}

${ }^{a}$ UTM Coordinates; Zone 11; NAD 27

${ }^{\mathrm{b}} \operatorname{Meter}(\mathrm{s})$ 
Table B-1

Comparison of Simulated and Observed Hydraulic Heads

\begin{tabular}{|c|c|c|c|c|c|c|c|}
\hline $\begin{array}{c}\text { Map Ref. } \\
\text { No. }\end{array}$ & Official ID & Common Name & $\begin{array}{l}\text { Northing }{ }^{a} \\
\quad(\mathrm{~m})^{\mathrm{b}}\end{array}$ & $\begin{array}{l}\text { Easting }^{a} \\
(\mathrm{~m})\end{array}$ & $\begin{array}{l}\text { Observed } \\
\text { Hyd. Head } \\
(\mathrm{m})\end{array}$ & $\begin{array}{c}\text { Simulated } \\
\text { Hyd. Head } \\
(\mathrm{m})\end{array}$ & $\begin{array}{l}\text { Weighted } \\
\text { Residual }\end{array}$ \\
\hline 742 & 363815116175901 & TW-5 & 4054685 & 562608.2 & 725.1 & 716.1 & 9 \\
\hline 744 & 363830116241401 & AIRPORT W & 4054927.3 & 552821.9 & 705.4 & 710.1 & -4.7 \\
\hline 745 & 363835116234001 & NDOT W & 4055243.5 & 554136.1 & 705.4 & 712.9 & -7.5 \\
\hline 746 & 363836116234001 & & 4055457.3 & 553811.9 & 702.8 & 712.4 & -3.3 \\
\hline 748 & 363840116233501 & & 4055335.3 & 554011.4 & 701.6 & 712.7 & -1.1 \\
\hline 749 & 363840116234001 & & 4055397.8 & 554135.2 & 705.6 & 713 & -0.7 \\
\hline 750 & 363840116235000 & & 4055396 & 553886.8 & 704.1 & 712.5 & -0.8 \\
\hline 751 & 363907116235701 & & 4056227 & 553707.8 & 718.4 & 712.8 & 0.6 \\
\hline 752 & 363910115300099 & S15E5817 & 4057200.5 & 634076.2 & 843 & 735.3 & 10.8 \\
\hline 755 & 364141116351401 & NA-6 W BGMW-10 & 4060510.8 & 527995.8 & 718.9 & 706.8 & 12.1 \\
\hline 756 & 364141116351402 & & 4060510.8 & 527995.8 & 722.5 & 707.8 & 3.1 \\
\hline 757 & 364215116362701 & S14 E47 25AAD & 4062692.5 & 534410.7 & 716 & 707.2 & 0.9 \\
\hline 758 & 364243116432401 & & 4062750 & 524713.6 & 730.1 & 710.8 & 6 \\
\hline 759 & 364246116445701 & & 4062836 & 522406.1 & 743.2 & 711.8 & 9.8 \\
\hline 760 & 364247116442301 & & 4062869.3 & 523249.6 & 736.6 & 710.9 & 8 \\
\hline 762 & 364457116231201 & & 4067332.8 & 550736.8 & 729.7 & 721.3 & 0.8 \\
\hline 763 & 364514116482901 & & 4067384.3 & 517137.5 & 873.4 & 726 & 45.9 \\
\hline 766 & 364534116065902 & TW-F & 4068347.3 & 578873.7 & 729.3 & 723.1 & 6.2 \\
\hline 767 & 364550116472701 & & 4068496.8 & 518672.5 & 799.6 & 730 & 7 \\
\hline 768 & 364552116413301 & & 4068582 & 527448.7 & 737.9 & 718.7 & 6 \\
\hline 769 & 364554116232401 & J-12 WW & 4068773 & 554447.3 & 727.7 & 728.9 & -1.2 \\
\hline 772 & 364557116410901 & MW 309 & 4068738 & 528043.3 & 751.5 & 718.5 & 33 \\
\hline 773 & 364557116411101 & MW 317 & 4068738 & 527993.7 & 751.3 & 718.5 & 32.8 \\
\hline 774 & 364557116411201 & & 4068737.8 & 527968.9 & 763.9 & 718.5 & 4.5 \\
\hline 775 & 364557116411401 & MW 311 & 4068737.5 & 527919.3 & 752 & 718.6 & 33.4 \\
\hline 776 & 364557116411501 & U.S. ECOLOCY - MW604 & 4068737.5 & 527894.5 & 746.1 & 718.6 & 2.7 \\
\hline 777 & 364557116411801 & MW 315 & 4068737.3 & 527820.2 & 751.8 & 718.7 & 33.1 \\
\hline 778 & 364557116413701 & U.S. ECOLOGY-W002 & 4068735.8 & 527349.1 & 738.3 & 719 & 1.9 \\
\hline 779 & 364557116434501 & & 4068726.3 & 524175.7 & 755.9 & 722.3 & 10.4 \\
\hline 780 & 364559116521901 & & 4068761.3 & 511432.7 & 1001.4 & 732.1 & 26.9 \\
\hline 782 & 364600116412001 & MW 314 & 4068829.5 & 527770.2 & 754 & 718.9 & 35.1 \\
\hline 783 & 364600116413001 & & 4068736.3 & 527522.6 & 751.3 & 718.9 & 3.2 \\
\hline 785 & 364601116414101 & U.S. ECOLOGY-W001 & 4068858.8 & 527249.5 & 744.4 & 719.3 & 2.5 \\
\hline 786 & 364603116410801 & MW 316 & 4068923 & 528067.4 & 757.3 & 718.8 & 38.5 \\
\hline 787 & 364603116412101 & MW 312 & 4068922 & 527745.1 & 760.3 & 719 & 41.3 \\
\hline 788 & 364607116410701 & MW 310 & 4069046.3 & 528091.8 & 759.7 & 719 & 40.7 \\
\hline 789 & 364615116412401 & MW 313 & 4069291.5 & 527669.6 & 761.2 & 719.7 & 41.5 \\
\hline 790 & 364615116412402 & U.S. ECOLOGY - MW600 & 4069291.5 & 527669.6 & 755.8 & 719.7 & 3.6 \\
\hline 792 & 364635115572901 & WW-5A & 4070369 & 592986.3 & 725.8 & 728.4 & -0.3 \\
\hline 793 & 364649116280201 & USW WT-11 & 4070426.5 & 547545.6 & 730.5 & 722.3 & 8.2 \\
\hline 794 & 364656116261601 & UE-25 WT 12 & 4070657.5 & 550171.8 & 729.4 & 730.6 & -1.2 \\
\hline 795 & 364706116170601 & J-11 WW & 4071056.5 & 563802.3 & 732.2 & 739.7 & -7.5 \\
\hline 796 & 364708115574401 & WW-5C & 4071750.5 & 592475.5 & 727.7 & 728.5 & -0.7 \\
\hline 797 & 364732116330701 & USW VH-1 & 4071713 & 539979.3 & 779.4 & 722 & 57.4 \\
\hline 798 & 364757116245801 & UE-25 WT 3 & 4072548.5 & 552093.7 & 729.5 & 743.4 & -13.9 \\
\hline 799 & 364758116331701 & USW VH-1 & 4072512.8 & 539727.7 & 789.4 & 723.9 & 6.6 \\
\hline
\end{tabular}


Table B-1

Comparison of Simulated and Observed Hydraulic Heads

\begin{tabular}{|c|c|c|c|c|c|c|c|}
\hline $\begin{array}{c}\text { Map Ref. } \\
\text { No. }\end{array}$ & Official ID & Common Name & $\begin{array}{l}\text { Northing }{ }^{a} \\
\quad(\mathrm{~m})^{\mathrm{b}}\end{array}$ & $\begin{array}{l}\text { Easting }^{a} \\
(\mathrm{~m})\end{array}$ & $\begin{array}{l}\text { Observed } \\
\text { Hyd. Head } \\
(\mathrm{m})\end{array}$ & $\begin{array}{c}\text { Simulated } \\
\text { Hyd. Head } \\
(\mathrm{m})\end{array}$ & $\begin{array}{l}\text { Weighted } \\
\text { Residual }\end{array}$ \\
\hline 800 & 364804115580801 & $W W-5 B$ & 4073101 & 591990 & 734.2 & 728.7 & 0.5 \\
\hline 801 & 364805115580801 & WW-5B & 4073132 & 591989.6 & 734.2 & 728.7 & 5.5 \\
\hline 802 & 364814116485401 & & 4072929.3 & 516506.9 & 791.1 & 742.3 & 4.9 \\
\hline 803 & 364822116262601 & UE-25 WT 17 & 4073306 & 549908.4 & 729.6 & 744.8 & -15.2 \\
\hline 804 & 364825116290501 & USW WT-10 & 4073376 & 545968.1 & 775.9 & 729 & 46.9 \\
\hline 805 & 364828116234001 & $\mathrm{~J}-13 \mathrm{WW}$ & 4073515.8 & 554020.6 & 728.2 & 741.4 & -13.2 \\
\hline 807 & 364830115512601 & TW-3 & 4074015.5 & 601942.7 & 728.7 & 731.6 & -2.9 \\
\hline 809 & 364844115541301 & WW-1 & 4074398.5 & 597799.5 & 727.3 & 730.8 & -0.3 \\
\hline 810 & 364905116280101 & USW G-3 & 4074617.5 & 547547 & 730.4 & 741.1 & -10.7 \\
\hline 811 & 364915115574101 & UE-5n & 4075296.3 & 592635.3 & 733.8 & 730 & 3.8 \\
\hline 812 & 364916116265601 & USW WT- 1 & 4074965.5 & 549155.4 & 730.5 & 752.4 & -21.9 \\
\hline 813 & 364922115580101 & RNM-2S & 4075475.8 & 592137.9 & 733.9 & 730 & 3.9 \\
\hline 814 & 364923115575701 & RNM-2 & 4075538.5 & 592236.3 & 733.8 & 730 & 3.6 \\
\hline 815 & 364928115580101 & RNM-1 & 4075691.5 & 592135.5 & 715.6 & 730.1 & -14.5 \\
\hline 816 & 364933116285701 & USW WT- 7 & 4075472.5 & 546154.9 & 775.7 & 739.7 & 36 \\
\hline 817 & 364938116252102 & UE-25p 1 PTH & 4075657.3 & 551504.9 & 752.3 & 719.7 & 32.6 \\
\hline 818 & 364942116280001 & USW H-3 HTH & 4075757.5 & 547565.4 & 731.4 & 748.9 & -16.7 \\
\hline 819 & 364942116280002 & USW H-3 HTH & 4075757.5 & 547565.4 & 732.6 & 748.7 & -16.1 \\
\hline 820 & 364942116280003 & USW H-3 HTH & 4075757.5 & 547565.4 & 754.3 & 748.8 & 5.5 \\
\hline 821 & 364942116280004 & USW H-3 HTH & 4075757.5 & 547565.4 & 731.1 & 748.7 & -17.6 \\
\hline 822 & 364942116280005 & USW H-3 HTH & 4075757.5 & 547565.4 & 772.2 & 748.9 & 23.3 \\
\hline 823 & 364945116235001 & UE-25 WT 13 & 4075825 & 553733.5 & 729 & 766.4 & -37.4 \\
\hline 824 & 364947116254300 & UE- $25 \mathrm{c} 1 \mathrm{HTH}$ & 4075931.3 & 550958.3 & 730.1 & 764.5 & -3.4 \\
\hline 825 & 364947116254301 & UE-25c 2 HTH & 4075869.8 & 550958.6 & 729.3 & 764 & -3.5 \\
\hline 826 & 365011115584701 & UE-5c WW & 4077004.3 & 590981.7 & 734.3 & 730.6 & 3.7 \\
\hline 827 & 365023116271801 & USW WT-2 & 4077027 & 548598.7 & 730.6 & 764.1 & -33.5 \\
\hline 828 & 365032116243501 & UE-25 WT 14 & 4077328.3 & 552634.2 & 730 & 779.7 & -49.7 \\
\hline 829 & 365032116265401 & USW H-4 HTH & 4077307.5 & 549191.5 & 729.8 & 771.4 & -41.6 \\
\hline 830 & 365032116265402 & USW H-4 HTH & 4077307.5 & 549191.5 & 730 & 771 & -41 \\
\hline 831 & 365032116265403 & USW H-4 HTH & 4077307.5 & 549191.5 & 730.1 & 771 & -40.9 \\
\hline 832 & 365049116285501 & USW H-6 HTH & 4077814.5 & 546191.9 & 775.1 & 752.3 & 2.3 \\
\hline 833 & 365049116285502 & USW H-6 HTH & 4077814.5 & 546191.9 & 775.8 & 752.6 & 23.2 \\
\hline 834 & 365049116285503 & USW H-6 HTH & 4077814.5 & 546191.9 & 777.8 & 752.6 & 25.2 \\
\hline 835 & 365049116285504 & USW H-6 HTH & 4077814.5 & 546191.9 & 7775.5 & 752.6 & 22.9 \\
\hline 836 & 365049116285505 & USW H-6 HTH & 4077814.5 & 546191.9 & 775.3 & 752.6 & 22.7 \\
\hline 837 & 365105115565801 & UE-5 PW-1 & 4078697.5 & 593663.4 & 733.7 & 731.9 & 1.8 \\
\hline 838 & 365105116262401 & UE-25a 1 & 4078328.8 & 549928.6 & 731 & 783.3 & -52.3 \\
\hline 839 & 365108116262301 & UE-25b $1 \mathrm{HTH}$ & 4078421.3 & 549952.8 & 730.3 & 761.6 & -31.3 \\
\hline 840 & 365108116262302 & UE-25b 1 HTH & 4078421.3 & 549952.8 & 728.3 & 784.7 & -56.4 \\
\hline 841 & 365108116262303 & UE-25b $1 \mathrm{HTH}$ & 4078421.3 & 549952.8 & 730.5 & 784.8 & -54.3 \\
\hline 842 & 365114116270401 & USW G-4 & 4078600.3 & 548936.4 & 730.1 & 779.6 & -49.5 \\
\hline 843 & 365116116233801 & UE-25 WT 15 & 4078692.8 & 554037.3 & 728.9 & 798.3 & -69.4 \\
\hline 844 & 365122116275501 & USW H-5 HTH & 4078839.8 & 547672 & 774.8 & 770.9 & 3.9 \\
\hline 845 & 365122116275502 & USW H-5 HTH & 4078839.8 & 547672 & 775.2 & 770.8 & 4.4 \\
\hline 846 & 365122116275503 & USW H-5 HTH & 4078839.8 & 547672 & 775.1 & 770.8 & 4.3 \\
\hline 847 & 365140116260301 & UE-25 WT 4 & 4079410.3 & 550442.2 & 730.6 & 797.1 & -66.5 \\
\hline
\end{tabular}

${ }^{a}$ UTM Coordinates; Zone 11; NAD 27

${ }^{\mathrm{b}} \operatorname{Meter}(\mathrm{s})$ 
Table B-1

Comparison of Simulated and Observed Hydraulic Heads

\begin{tabular}{|c|c|c|c|c|c|c|c|}
\hline $\begin{array}{c}\text { Map Ref. } \\
\text { No. }\end{array}$ & Official ID & Common Name & $\begin{array}{l}\text { Northing }{ }^{a} \\
\quad(m)^{b}\end{array}$ & $\begin{array}{l}\text { Easting }^{a} \\
\quad(\mathrm{~m})\end{array}$ & $\begin{array}{l}\text { Observed } \\
\text { Hyd. Head } \\
(\mathrm{m})\end{array}$ & $\begin{array}{c}\text { Simulated } \\
\text { Hyd. Head } \\
(\mathrm{m})\end{array}$ & $\begin{array}{l}\text { Weighted } \\
\text { Residual }\end{array}$ \\
\hline 848 & 365147116185301 & UE-25a 3 & 4079695.8 & 561088.1 & 748.3 & 815 & -6.7 \\
\hline 849 & 365152115565701 & UE-5 PW-2 & 4080146 & 593672.2 & 733.5 & 732.3 & 1.2 \\
\hline 850 & 365157116271201 & USW H-1 HTH & 4079924.3 & 548730.7 & 730.9 & 728.2 & 2.7 \\
\hline 851 & 365157116271202 & USW H-1 HTH & 4079924.3 & 548730.7 & 784.9 & 792 & -7.1 \\
\hline 852 & 365157116271203 & USW H-1 HTH & 4079924.3 & 548730.7 & 731.1 & 791.4 & -60.3 \\
\hline 853 & 365157116271204 & USW H-1 HTH & 4079924.3 & 548730.7 & 730.1 & 791.3 & -61.2 \\
\hline 854 & 365157116271205 & USW H-1 HTH & 4079924.3 & 548730.7 & 730.4 & 791.3 & -60.9 \\
\hline 855 & 365201115581601 & UE-5 PW-3 & 4080402 & 591713.1 & 733.5 & 732.1 & 1.4 \\
\hline 856 & 365213115564401 & UE- $5 f$ & 4080796.8 & 593986.9 & 734.9 & 732.6 & 0.2 \\
\hline 857 & 365239116020901 & UE-5j & 4081512.8 & 585932.2 & 848 & 744.3 & 10.4 \\
\hline 858 & 365239116253401 & UE-25 WT 16 & 4081232.5 & 551149.4 & 738.3 & 825 & -86.7 \\
\hline 860 & 365259115571601 & UE-11a & 4082205.5 & 593179.2 & 736.2 & 733 & 2.9 \\
\hline 862 & 365322116273501 & USW G-2 & 4082540 & 548146.4 & 1030.7 & 884.3 & 123.7 \\
\hline 864 & 365340116264601 & UE-25 WT 6 & 4083101.8 & 549356 & 1034.1 & 1108.5 & -74.4 \\
\hline 867 & 365412116013901 & WW-4A & 4084386 & 586645.6 & 844.4 & 744.8 & 99.6 \\
\hline 868 & 365418116012601 & WW-4 & 4084574.3 & 586965.5 & 843.3 & 744.8 & 93.9 \\
\hline 869 & 365437116384401 & S12 E48 07ad & 4084775 & 531574.9 & 1174 & 868.1 & 30.6 \\
\hline 870 & 365445116383901 & GEXA W 3 & 4085020.5 & 531701.4 & 1194.8 & 878.3 & 316.5 \\
\hline 871 & 365500116003901 & WW-C-1 & 4085880.5 & 588115.2 & 724.6 & 744.3 & -19.7 \\
\hline 872 & 365502115134101 & DDL-2 & 4086951.5 & 657846 & 940.5 & 940.3 & 0.1 \\
\hline 873 & 365503116444101 & & 4085546.5 & 522742.5 & 1027.2 & 971.1 & 5.6 \\
\hline 874 & 365506115142499 & S12E60 10AD & 4087056.5 & 656775.9 & 925.2 & 939.8 & -1.5 \\
\hline 875 & 365508116003501 & WW-C & 4086128 & 588211.6 & 725.6 & 744.1 & -17.6 \\
\hline 876 & 365508116003502 & WW-C & 4086128 & 588211.6 & 724.7 & 744 & -1.9 \\
\hline 877 & 365517116365801 & S12 E48 04ca & 4086017.8 & 534193 & 990 & 890.8 & 9.9 \\
\hline 878 & 365520116370301 & GEXA W 4 & 4086108.3 & 534072.6 & 1009.2 & 908.5 & 100.7 \\
\hline 879 & 365527116475301 & BEATTY SUMMIT W & 4086274.5 & 517990.2 & 1161.3 & 903.9 & 25.7 \\
\hline 881 & 365550116091101 & UE-14b & 4087299.3 & 575432.5 & 819.1 & 851.7 & -32.6 \\
\hline 885 & 365636116430801 & & 4088416 & 524169.4 & 1085.1 & 1039.2 & 4.6 \\
\hline 887 & 365709116481101 & BEATTY INDIAN SPR W & 4089416.8 & 517538.4 & 1238.4 & 992.3 & 24.6 \\
\hline 888 & 365711115115101 & Desert Valley Well & 4090978 & 660492.9 & 929.1 & 941.5 & -1.2 \\
\hline 889 & 365711115115201 & DDL-1 & 4090977.8 & 660468.1 & 929.4 & 941.4 & -9.5 \\
\hline 890 & 365731116425501 & & 4090114.3 & 525351.5 & 1085.1 & 1078.1 & 0.7 \\
\hline 891 & 365740116043501 & ER-6-2 & 4090753.8 & 582224.1 & 745 & 763.2 & -1.8 \\
\hline 892 & 365749116431101 & & 4090667.8 & 524954.3 & 1085.1 & 1079 & 0.6 \\
\hline 894 & 365804116432101 & & 4091129.3 & 524705.6 & 1083.6 & 1081.5 & 0.2 \\
\hline 895 & 365810116425101 & & 4091869 & 524777.6 & 1097.3 & 1091.9 & 0.5 \\
\hline 897 & 365821116343701 & USW VH-2 & 4073212.5 & 537742.1 & 810.4 & 725.9 & 8.5 \\
\hline 899 & 365849116002101 & TW-B & 4092811.3 & 587796 & 739.1 & 737.6 & 1.5 \\
\hline 900 & 365856116453701 & & 4093217.3 & 522029.7 & 1249.7 & 1097.8 & 15.2 \\
\hline 904 & 365905116012001 & UE-6e & 4093419.8 & 587023.2 & 739.7 & 735.2 & 4.5 \\
\hline 905 & 365905116012002 & UE-6e & 4093420 & 587023.2 & 739.4 & 738.4 & 1 \\
\hline 906 & 365905116033201 & UE-6d & 4093386.8 & 583759.9 & 741.2 & 738 & 0.3 \\
\hline 907 & 365930115075499 & S11E61 & 4095376.3 & 666267.3 & 930.2 & 948.1 & $\begin{array}{l}-1.8 \\
\end{array}$ \\
\hline 910 & 365943116032901 & WW-3 & 4094558.5 & 583822.4 & 730.1 & 744.2 & -13.4 \\
\hline 911 & 370002116430101 & & 4094210.3 & 524573 & 1127.8 & 1122.6 & 0.5 \\
\hline
\end{tabular}

${ }^{a}$ UTM Coordinates; Zone 11; NAD 27

${ }^{\mathrm{b}}$ Meter(s) 
Table B-1

Comparison of Simulated and Observed Hydraulic Heads

\begin{tabular}{|c|c|c|c|c|c|c|c|}
\hline $\begin{array}{c}\text { Map Ref. } \\
\text { No. }\end{array}$ & Official ID & Common Name & $\begin{array}{l}\text { Northing }{ }^{a} \\
\quad(\mathrm{~m})^{\mathrm{b}}\end{array}$ & $\begin{array}{c}\text { Easting }^{a} \\
\quad(\mathrm{~m})\end{array}$ & $\begin{array}{l}\text { Observed } \\
\text { Hyd. Head } \\
(\mathrm{m})\end{array}$ & $\begin{array}{c}\text { Simulated } \\
\text { Hyd. Head } \\
(\mathrm{m})\end{array}$ & $\begin{array}{l}\text { Weighted } \\
\text { Residual }\end{array}$ \\
\hline 912 & 370003116424501 & & 4094800.5 & 526128.4 & 1188.7 & 1157.5 & 3.1 \\
\hline 913 & 370005116040301 & UE-1h & 4095228.3 & 582975.4 & 743.1 & 737.5 & 5.6 \\
\hline 914 & 370017116014201 & U-3jg & 4095632.8 & 586456.7 & 735.4 & 741.4 & -5.7 \\
\hline 916 & 370020116003701 & U-3kv & 4095742 & 588062.3 & 738.4 & 736.9 & 1.5 \\
\hline 918 & 370053116002901 & U-3ks & 4096760.8 & 588249.3 & 736.9 & 736.9 & 0 \\
\hline 920 & 370116115561301 & ER-3-1-1 & 4097539.3 & 594564.2 & 729.2 & 735.7 & -0.6 \\
\hline 921 & 370116115561302 & ER-3-1-2 & 4097539.3 & 594564.2 & 729.1 & 735.7 & -0.7 \\
\hline 922 & 370142116021100 & WW-A & 4099200.5 & 585728.5 & 732.1 & 751.3 & -1.9 \\
\hline 923 & 370142116021101 & WW-A & 4099200.5 & 585728.5 & 729.7 & 751.2 & -18.8 \\
\hline 925 & 370154116430201 & & 4097786.5 & 525155.7 & 1204 & 1169.4 & 3.5 \\
\hline 927 & 370208116092401 & UE-16f & 4098944.5 & 575007.8 & 1174.6 & 1079 & 9.6 \\
\hline 928 & 370208116092402 & UE-16f & 4098944.5 & 575007.8 & 1306 & 1079 & 227 \\
\hline 931 & 370214116021002 & ER-3-2-2 & 4099232.5 & 585724.4 & 731.2 & 743.8 & -1.3 \\
\hline 933 & 370214116452701 & & 4098424.5 & 521843.2 & 1213.1 & 1183 & 3 \\
\hline 934 & 370218116033101 & UE-1k & 4099334.5 & 583725.8 & 745.9 & 759.2 & -13.3 \\
\hline 935 & 370246116064901 & UE-1f & 4100150.3 & 578826.3 & 1112.1 & 984.1 & 12.8 \\
\hline 936 & 370253116055201 & UE-1C & 4100379.3 & 580232.2 & 886.7 & 835.5 & 51.2 \\
\hline 937 & 370254116064201 & UE-1b & 4100398.5 & 578996.9 & 1105.9 & 980.9 & 125 \\
\hline 938 & 370254116070601 & UE-1a & 4100393 & 578404 & 1145.6 & 981 & 164.6 \\
\hline 940 & 370254116082002 & UE-1L & 4100376 & 576576.1 & 1199.8 & 1011.2 & 188.6 \\
\hline 941 & 370301116065301 & UE-1d & 4100611.5 & 578723.2 & 1146 & 980.4 & 16.6 \\
\hline 942 & 370301116185801 & ER-30-1-1 & 4100465.3 & 560811.5 & 1280 & 1272.6 & 0.7 \\
\hline 943 & 370301116185802 & ER-30-1-2 & 4100465.3 & 560811.5 & 1280 & 1272.6 & 0.7 \\
\hline 944 & 370311115591901 & TH-9 & 4101031.8 & 589958.8 & 728.8 & 736.8 & -0.8 \\
\hline 945 & 370320116012001 & U-3en 5 & 4101708.8 & 586913.3 & 729 & 738.1 & -9.1 \\
\hline 946 & 370321115594201 & TW-E & 4101333.8 & 589362.7 & 748.2 & 736.9 & 11.3 \\
\hline 947 & 370321115594202 & TW-E & 4101333.8 & 589362.7 & 743.7 & 736.9 & 6.8 \\
\hline 949 & 370326116021101 & U-3jn 1 & 4101449.8 & 585680.9 & 731.5 & 755.9 & -23.3 \\
\hline 950 & 370334116012100 & U-3cn 5 HTH & 4101709 & 586938 & 727.6 & 738.1 & -10.5 \\
\hline 952 & 370337116033001 & UE-1q & 4101769 & 583726.4 & 770.4 & 769.2 & 1.2 \\
\hline 953 & 370337116033002 & UE-1q & 4101769 & 583726.4 & 739.5 & 761.9 & -22.4 \\
\hline 954 & 370338116011801 & U-3cn 1 & 4101832.8 & 586986.1 & 732.8 & 739.1 & -0.6 \\
\hline 956 & 370339116011901 & U-3cn 3 & 4101863.5 & 586961.2 & 732.5 & 739.3 & -0.7 \\
\hline 958 & 370348116024301 & U-3mt & 4102119.5 & 584883.8 & 771.1 & 761.6 & 9.5 \\
\hline 959 & 370353116000601 & U-3jq 1 & 4102313.5 & 588759.5 & 750.7 & 738.5 & 12.2 \\
\hline 960 & 370353116020201 & TW-7 & 4102284 & 585894.8 & 730.4 & 744.9 & -14.5 \\
\hline 961 & 370353116021401 & U-3an 3 & 4102311.8 & 585598.2 & 724.1 & 738.3 & -1.4 \\
\hline 962 & 370355116013001 & U-3cn 4 HTH & 4102353.5 & 586684.4 & 732 & 742.1 & -9.6 \\
\hline 963 & 370406116095600 & UE-16d WW & 4102759.5 & 574307.2 & 1198.5 & 1379.1 & -18.1 \\
\hline 965 & 370411116025901 & UE-3e & 4102824.5 & 584481.6 & 770.1 & 766 & 4.1 \\
\hline 969 & 370411116025905 & UE-3e & 4102824.5 & 584481.6 & 774.8 & 765.6 & 8.7 \\
\hline 976 & 370411116025912 & UE-3e 4-3 & 4102824.5 & 584481.6 & 771.3 & 766 & 5.3 \\
\hline 977 & 370412115593601 & UE-7aa & 4102907 & 589494.2 & 729.6 & 737.3 & -7.7 \\
\hline 978 & 370412116095101 & UE-16d WW & 4102759.5 & 574307.2 & 1198.2 & 1273 & -7.5 \\
\hline 979 & 370418116044501 & TW-D & 4103326 & 582229.3 & 740.5 & 794.9 & -5.4 \\
\hline 980 & 370419116101700 & UE-17a & 4103158.8 & 574130.8 & 1236.9 & 1399.8 & -162.9 \\
\hline
\end{tabular}


Table B-1

Comparison of Simulated and Observed Hydraulic Heads

\begin{tabular}{|c|c|c|c|c|c|c|c|}
\hline $\begin{array}{c}\text { Map Ref. } \\
\text { No. }\end{array}$ & Official ID & Common Name & $\begin{array}{l}\text { Northing }{ }^{a} \\
\quad(\mathrm{~m})^{\mathrm{b}}\end{array}$ & $\begin{array}{l}\text { Easting }^{a} \\
(\mathrm{~m})\end{array}$ & $\begin{array}{l}\text { Observed } \\
\text { Hyd. Head } \\
(\mathrm{m})\end{array}$ & $\begin{array}{c}\text { Simulated } \\
\text { Hyd. Head } \\
(\mathrm{m})\end{array}$ & $\begin{array}{l}\text { Weighted } \\
\text { Residual }\end{array}$ \\
\hline 981 & 370425116095801 & UE-17a & 4103158.8 & 574130.8 & 1237.2 & 1399.2 & -162 \\
\hline 982 & 370428116043001 & TW-D & 4103326 & 582229.3 & 740 & 796 & -56 \\
\hline 983 & 370434116040702 & UE-4ae & 4103516.5 & 582795.4 & 763.2 & 785.1 & -13.1 \\
\hline 984 & 370435116040701 & U-4ak & 4103547.5 & 582795.1 & 766.4 & 787.2 & -19.8 \\
\hline 985 & 370436116000201 & U-7ca & 4103639.8 & 588844.4 & 774.2 & 739.7 & 34.5 \\
\hline 986 & 370444116001801 & U-7bc & 4103882 & 588446.8 & 757.4 & 739.8 & 17.6 \\
\hline 987 & 370447116030501 & U-7au & 4103932.3 & 584322.3 & 764.3 & 767.9 & $\begin{array}{l}-0.4 \\
\end{array}$ \\
\hline 990 & 370451116024102 & U-7cd 1 & 4104061.5 & 584913.7 & 820.9 & 762.2 & 58.7 \\
\hline 991 & 370454116003201 & U-7bd & 4104186.5 & 588097.8 & 754.2 & 738.1 & 13.6 \\
\hline 992 & 370501116041301 & UE-4ah & 4104347.5 & 582663.8 & 760.9 & 751.7 & 8 \\
\hline 994 & 370509116040301 & U-4au & 4104595 & 582784.8 & 763.5 & 789.2 & -25.7 \\
\hline 996 & 370513116025101 & U-4u PS 2A & 4104735.5 & 584511.8 & 756.1 & 744.6 & 11.5 \\
\hline 997 & 370514116000601 & U-7cb & 4104809.5 & 588733.3 & 761.9 & 739.6 & 22.3 \\
\hline 998 & 370514116024101 & U-7ba & 4104770.3 & 584906.6 & 800.2 & 759.6 & 4.1 \\
\hline 999 & 370520116025701 & U-4u & 4104951.3 & 584509.7 & 740.5 & 763.3 & -2.3 \\
\hline 1002 & 370547116041101 & UE-4av & 4105765 & 582674.6 & 795.6 & 790.5 & 0.5 \\
\hline 1003 & 370547116041102 & UE-4av & 4105765 & 582674.6 & 777.5 & 749.7 & 2.8 \\
\hline 1005 & 370547116041104 & UE-4av & 4105765 & 582674.6 & 794.5 & 790.2 & 0.4 \\
\hline 1007 & 370556116000901 & UE-7nS & 4106103 & 588645.7 & 731.5 & 738.6 & -7.1 \\
\hline 1008 & 370556116025401 & UE- $4 \mathrm{t}$ & 4106061.3 & 584572.6 & 775.3 & 758.4 & 1.7 \\
\hline 1015 & 370601116030102 & UE-4a & 4106213.8 & 584398.3 & 773.6 & 739.3 & 34.3 \\
\hline 1016 & 370601116030103 & UE-4a & 4106213.8 & 584398.3 & 772.9 & 746 & 26.9 \\
\hline 1019 & 370605116012401 & U-7cc & 4106361.3 & 586791.4 & 825.4 & 739.1 & 86.3 \\
\hline 1021 & 370608116043102 & UE-4ab & 4106407.5 & 582174.5 & 784.8 & 791.3 & -6.2 \\
\hline 1023 & 370616116090801 & UE-17c & 4106590.3 & 575335 & 1318.1 & 1169.7 & 148.4 \\
\hline 1024 & 370626116015601 & U-7a & 4107000.3 & 585994.9 & 727.4 & 739.4 & -1.2 \\
\hline 1029 & 370645116031901 & U-2gh & 4107565 & 583940.4 & 793.5 & 766.5 & 27 \\
\hline 1030 & 370648116473001 & & 4107260.3 & 518513.3 & 1202.4 & 1229.5 & -14.9 \\
\hline 1031 & 370700116474001 & & 4107629.5 & 518265.7 & 1220.4 & 1230.1 & -1 \\
\hline 1032 & 370704116474201 & & 4107384 & 518784.5 & 1236.1 & 1229.5 & 0.7 \\
\hline 1033 & 370712116073901 & UE-2s & 4108335.8 & 577515.9 & 805.1 & 961.9 & -15.7 \\
\hline 1034 & 370720116041601 & U-2gk & 4108629.8 & 582523.1 & 748.8 & 775.9 & -27.1 \\
\hline 1035 & 370723116033101 & U-2bs & 4108733.3 & 583632.7 & 763.1 & 767.7 & -4.6 \\
\hline 1036 & 370726116040302 & UE-2ar & 4108818 & 582842.1 & 746.7 & 771.6 & -2.5 \\
\hline 1037 & 370728116042001 & U-2gf & 4108875.5 & 582422 & 754.2 & 774.7 & -19.5 \\
\hline 1038 & 370736116050301 & UE-2fb & 4109111.5 & 581358.5 & 763.8 & 775.2 & -10.9 \\
\hline 1039 & 370737116035901 & U-2v & 4109157.8 & 582937.5 & 741.1 & 767.6 & -2.6 \\
\hline 1041 & 370741116194501 & UE-18t & 4109083.8 & 559593.4 & 1306.3 & 1282.6 & 2.4 \\
\hline 1043 & 370758116040601 & UE-2aw & 4109803.3 & 582758.4 & 748.2 & 758.2 & -8.8 \\
\hline 1044 & 370802116050301 & U-2dr & 4109912.8 & 581350.8 & 748.4 & 771.3 & -22.9 \\
\hline 1045 & 370806116264001 & UE-18r & 4109757 & 549324.3 & 1271.9 & 1284.2 & -12.3 \\
\hline 1046 & 370815116032701 & U-9ct & 4110336.5 & 583715.5 & 787.9 & 751.3 & 28.9 \\
\hline 1047 & 370819116022901 & U-9 ITS UE-S- 25 & 4110474.5 & 585169.9 & 740.3 & 741.6 & -1.3 \\
\hline 1049 & 370823116050001 & UE-2dj & 4110560.5 & 581418.6 & 745.7 & 760 & -14.3 \\
\hline 1052 & 370831116080701 & UE-2ce & 4110764 & 576802.7 & 1010.9 & 1022.3 & -11.4 \\
\hline 1055 & 370836116035001 & U-2av & 4110978 & 583141.6 & 740.7 & 749.1 & -0.8 \\
\hline
\end{tabular}

${ }^{a}$ UTM Coordinates; Zone 11; NAD 27

${ }^{\mathrm{b}} \operatorname{Meter(}(\mathrm{s})$ 
Table B-1

Comparison of Simulated and Observed Hydraulic Heads

\begin{tabular}{|c|c|c|c|c|c|c|c|}
\hline $\begin{array}{c}\text { Map Ref. } \\
\text { No. }\end{array}$ & Official ID & Common Name & $\begin{array}{l}\text { Northing }{ }^{a} \\
\quad(m)^{b}\end{array}$ & $\begin{array}{l}\text { Easting }^{a} \\
\quad(\mathrm{~m})\end{array}$ & $\begin{array}{l}\text { Observed } \\
\text { Hyd. Head } \\
(\mathrm{m})\end{array}$ & $\begin{array}{c}\text { Simulated } \\
\text { Hyd. Head } \\
(\mathrm{m})\end{array}$ & $\begin{array}{l}\text { Weighted } \\
\text { Residual }\end{array}$ \\
\hline 1056 & 370840116510101 & TPJ-1 & 4110701.8 & 513300.5 & 1203.2 & 1234.9 & -30.2 \\
\hline 1057 & 370846116030851 & U-9ca 1 & 4111296.5 & 584174.8 & 750.8 & 742.5 & 7.6 \\
\hline 1059 & 370904116040301 & U-2ei & 4111837.8 & 582812.4 & 740.4 & 743.9 & -3.5 \\
\hline 1060 & 370909116041901 & UE-2aa & 4111988 & 582416.3 & 734.1 & 743.2 & -0.9 \\
\hline 1061 & 370909116041951 & UE-2aa & 4111988 & 582416.3 & 739.3 & 743.2 & -3.9 \\
\hline 1062 & 370910116045901 & UE-2ax 2 & 4112009.3 & 581429.2 & 740.2 & 744.1 & -0.4 \\
\hline 1063 & 370917116023701 & U-10l 1 & 4112259.5 & 584929.9 & 735 & 742.2 & -4.8 \\
\hline 1067 & 370929116132304 & TW-1 & 4112483.8 & 568992 & 1271.6 & 1276.4 & -0.5 \\
\hline 1069 & 370929116132306 & TW-1 & 4112483.8 & 568992 & 1276.8 & 1259.3 & 1.7 \\
\hline 1070 & 370929116132307 & TW-1 & 4112483.8 & 568992 & 1437.1 & 1297.4 & 139.7 \\
\hline 1071 & 370929116132308 & TW-1 & 4112483.8 & 568992 & 1437.3 & 1297.4 & 139.9 \\
\hline 1072 & 370929116132309 & TW-1 & 4112483.8 & 568992 & 1277 & 1259.3 & 17.7 \\
\hline 1074 & 370929116132311 & TW-1 & 4112483.8 & 568992 & 1429.6 & 1297.4 & 132.2 \\
\hline 1075 & 370953116030801 & U-10k 1 & 4113361.3 & 584154.1 & 734.5 & 742.7 & -8.2 \\
\hline 1076 & 370956116172101 & WW-8 & 4113269.8 & 563115.4 & 1407.6 & 1298.6 & 109 \\
\hline 1077 & 370958116051501 & WW-2 & 4113484.5 & 581020.3 & 759.9 & 743.1 & 13.3 \\
\hline 1078 & 370958116051503 & WW-2 & 4113484.5 & 581020.3 & 760.2 & 743 & 12.4 \\
\hline 1079 & 370958116051508 & WW-2 & 4113484.5 & 581020.3 & 735.8 & 743 & -0.7 \\
\hline 1080 & 370958116051511 & WW-2 & 4113484.5 & 581020.3 & 736.5 & 742.9 & -0.6 \\
\hline 1081 & 370958116051512 & WW-2 & 4113484.5 & 581020.3 & 736.2 & 742.9 & -6.3 \\
\hline 1082 & 371014116051601 & UE-8e & 4113977.5 & 580990.9 & 785.8 & 743.6 & 42.2 \\
\hline 1083 & 371014116051602 & UE-8e & 4113977.5 & 580990.9 & 785.8 & 743.5 & 42.3 \\
\hline 1086 & 371043116142101 & ER-19-1-1 & 4114754 & 567539.5 & 1325.9 & 1293.8 & 3.2 \\
\hline 1090 & 371052116125201 & U-12e.06-1 R/C & 4115047.8 & 569735.6 & 1416.6 & 1348.9 & 57.3 \\
\hline 1091 & 371106116110401 & ER-12-1 & 4115501.5 & 572394.9 & 1302.4 & 1419.5 & -11.7 \\
\hline 1092 & 371108116045301 & UE-10j & 4115647 & 581542 & 735.2 & 743.5 & -8 \\
\hline 1094 & 371109116024702 & UE-10 ITS 3 & 4115708.5 & 584648.4 & 762.2 & 743.5 & 17.8 \\
\hline 1095 & 371123116025201 & UE-10bf & 4116138.5 & 584520.8 & 759.6 & 743.7 & 14.5 \\
\hline 1096 & 371123116025202 & UE-10bf & 4116138.5 & 584520.8 & 763.9 & 743.7 & 15.1 \\
\hline 1097 & 371131116021501 & UE-10aa & 4116425.5 & 585455 & 992.5 & 743.8 & 118.5 \\
\hline 1099 & 371154116024601 & UE-10 ITS 1 & 4117095.5 & 584659.2 & 996.7 & 744.1 & 230.6 \\
\hline 1100 & 371154116024602 & UE-10 ITS 1 & 4117095.5 & 584659.2 & 994.9 & 744.1 & 250.8 \\
\hline 1101 & 371155116031401 & UE-10 ITS 5 & 4117119.3 & 583968.6 & 757.3 & 744.1 & 12.6 \\
\hline 1102 & 371155116031402 & UE-10 ITS 5 & 4117119.3 & 583968.6 & 772.6 & 744.1 & 27.2 \\
\hline 1110 & 371313116274201 & U-20as & 4119239.5 & 547765.3 & 1284.5 & 1316.5 & -32 \\
\hline 1111 & 371315116282701 & U-20y & 4119295 & 546655.9 & 1276.9 & 1313.7 & -35.1 \\
\hline 1112 & 371321116292301 & ER-20-1 & 4119473.8 & 545271.1 & 1278.1 & 1307.5 & -2.9 \\
\hline 1113 & 371329116220301 & UE-19fS & 4119784.3 & 556116.7 & 1350 & 1350.1 & 0 \\
\hline 1116 & 371332116254101 & U-20be & 4119842.5 & 550743.8 & 1303.8 & 1329.8 & -26 \\
\hline 1119 & 371339116221601 & U-19az & 4120090.3 & 555794.3 & 1424.6 & 1356.6 & 68 \\
\hline 1122 & 371341116222901 & U-19aq & 4120149.8 & 555473.5 & 1429 & 1355.5 & 56.3 \\
\hline 1126 & 371349116222001 & U-19bh & 4120397.8 & 555693.7 & 1423.3 & 1356.2 & 64 \\
\hline 1127 & 371350116264701 & U-20ax & 4120387.5 & 549114.1 & 1329.7 & 1330.2 & -0.5 \\
\hline 1129 & 371352116281801 & UE-20c & 4120436.3 & 546871.4 & 1267.1 & 1324.4 & -5.7 \\
\hline 1130 & 371353116282501 & U-20c & 4120466 & 546698.7 & 1275.3 & 1323.3 & -4.8 \\
\hline 1131 & 371359116252301 & U-20av & 4120677.3 & 551182.3 & 1336.8 & 1339.8 & -2.8 \\
\hline
\end{tabular}


Table B-1

Comparison of Simulated and Observed Hydraulic Heads

\begin{tabular}{|c|c|c|c|c|c|c|c|}
\hline $\begin{array}{c}\text { Map Ref. } \\
\text { No. }\end{array}$ & Official ID & Common Name & $\begin{array}{l}\text { Northing }{ }^{a} \\
\quad(\mathrm{~m})^{\mathrm{b}}\end{array}$ & $\begin{array}{l}\text { Easting }^{a} \\
(\mathrm{~m})\end{array}$ & $\begin{array}{l}\text { Observed } \\
\text { Hyd. Head } \\
(\mathrm{m})\end{array}$ & $\begin{array}{c}\text { Simulated } \\
\text { Hyd. Head } \\
(\mathrm{m})\end{array}$ & $\begin{array}{l}\text { Weighted } \\
\text { Residual }\end{array}$ \\
\hline 1132 & 371401116220601 & U-19x & 4120769.8 & 556036.2 & 1392 & 1361.8 & 3 \\
\hline 1133 & 371401116252001 & UE-20av & 4120739.3 & 551255.9 & 1319.5 & 1340.7 & -21.2 \\
\hline 1134 & 371410116221301 & U-19ae & 4121046 & 555861.8 & 1369.8 & 1364 & 5.5 \\
\hline 1136 & 371416116282201 & U-20ao & 4121175.3 & 546768.7 & 1317.3 & 1331.4 & -1.4 \\
\hline 1138 & 371421116333701 & PM-3 & 4121289.8 & 539006.6 & 1331.3 & 1314.4 & 16.9 \\
\hline 1139 & 371421116333702 & PM-3 & 4121289.8 & 539006.6 & 1330.3 & 1311.1 & 19.2 \\
\hline 1140 & 371421116333703 & PM-3-1 & 4121289.8 & 539006.6 & 1329.8 & 1308 & 21.8 \\
\hline 1141 & 371421116333704 & PM-3-2 & 4121289.8 & 539006.6 & 1330.5 & 1314.4 & 16.1 \\
\hline 1143 & 371425116210101 & U-20n PS 1DD-H & 4121478.3 & 551152.8 & 1324.7 & 1345.5 & -20.8 \\
\hline 1144 & 371425116251901 & UE-20n 1 & 4121479 & 551276 & 1318.8 & 1349 & -3 \\
\hline 1145 & 371425116251902 & UE-20n 1 & 4121479 & 551276 & 1349.4 & 1349.2 & 0.2 \\
\hline 1147 & 371433116251301 & U-20n PS 1DD-H & 4121478.3 & 551152.8 & 1349.1 & 1345.5 & 3.5 \\
\hline 1148 & 371434116251601 & U-20a 2 WW & 4121756.8 & 551348.2 & 1343.7 & 1352.3 & -8.6 \\
\hline 1149 & 371434116255101 & U-20a & 4121751.5 & 550485.9 & 1328.7 & 1349.3 & -2.1 \\
\hline 1150 & 371439115480001 & Watertown 2 WW & 4122428.5 & 606437.3 & 1079.3 & 953.4 & 12.6 \\
\hline 1151 & 371440115483401 & Watertown $1 \mathrm{WW}$ & 4122448.8 & 605599.3 & 1204.1 & 973.1 & 23.1 \\
\hline 1153 & 371444116263001 & U-20bf & 4122054 & 549523.2 & 1338.1 & 1349.7 & -11.6 \\
\hline 1156 & 371452116284901 & UE-20D & 4122281 & 546097.3 & 1273.9 & 1342.7 & -62.8 \\
\hline 1157 & 371452116292101 & U-20ak & 4122276.8 & 545309 & 1278.5 & 1339.5 & -61 \\
\hline 1160 & 371452116293903 & U-20bb 1 & 4122274.3 & 544865.5 & 1280.9 & 1336.5 & -30.6 \\
\hline 1161 & 371452116303301 & U-20at 1 & 4122267.3 & 543535.2 & 1284.4 & 1329.7 & -35.8 \\
\hline 1163 & 371459116204801 & UE-19i & 4122600.8 & 557921 & 1396.3 & 1387.5 & 0.9 \\
\hline 1164 & 371505116254501 & U-20 WW & 4122707.8 & 550628 & 1344.6 & 1360.2 & -15.6 \\
\hline 1165 & 371505116254502 & U-20 WW & 4122707.8 & 550628 & 1351.5 & 1360.3 & -8.8 \\
\hline 1167 & 371509116223601 & U-19au & 4122860.5 & 555283.1 & 1358.5 & 1380.3 & -17.2 \\
\hline 1168 & 371509116223602 & U-19au 1 & 4122860.5 & 555283.1 & 1358.8 & 1380.3 & -21.5 \\
\hline 1169 & 371512116193101 & U-19ab & 4122984 & 559839.9 & 1495 & 1405.5 & 89.5 \\
\hline 1170 & 371513116193001 & U-19ab 2 & 4123015 & 559864.3 & 1497.8 & 1406 & 87.6 \\
\hline 1172 & 371519116223301 & U-19av & 4123169 & 555355.1 & 1369 & 1383.3 & -1.4 \\
\hline 1173 & 371521116252001 & U-20ah & 4123204.5 & 551240.9 & 1354 & 1367.8 & -13.2 \\
\hline 1179 & 371537115555001 & Watertown 4 WW & 4124174 & 603064.5 & 1320.7 & 1081.4 & 23.9 \\
\hline 1180 & 371539115500301 & Watertown 3 WW & 4124239.5 & 603384 & 1322.6 & 1084 & 23.9 \\
\hline 1182 & 371542116251202 & U-20bd 2 & 4123853 & 551433.9 & 1375.3 & 1375 & 0.3 \\
\hline 1183 & 371542116251203 & U-20bd & 4123853 & 551433.9 & 1355.8 & 1374.9 & -19.1 \\
\hline 1184 & 371542116251301 & U-20bd 1 & 4123852.8 & 551409.3 & 1355.5 & 1374.8 & -19.3 \\
\hline 1185 & 371545115495401 & WNGM W & 4124427.3 & 603603.4 & 1322.5 & 1089.6 & 23.3 \\
\hline 1186 & 371547116292601 & U-20bc & 4123971 & 545176.7 & 1303.1 & 1363.1 & -60 \\
\hline 1188 & 371551116262501 & U-20ai & 4124119.5 & 549634.2 & 1356.2 & 1372.5 & -15.6 \\
\hline 1190 & 371554116185301 & U-19c & 4124285 & 560766.7 & 1429.2 & 1417.9 & 1.1 \\
\hline 1192 & 371604116243801 & U-20am & 4124536 & 552267.1 & 1357 & 1383.2 & -25 \\
\hline 1193 & 371608116191001 & UE-19c & 4124713.5 & 560344.8 & 1428.9 & 1418.1 & 1.1 \\
\hline 1194 & 371608116191002 & UE-19c WW & 4124713.5 & 560344.8 & 1431.1 & 1418.1 & 9.5 \\
\hline 1195 & 371617116291701 & UE-20f & 4124896.5 & 545393.3 & 1322.9 & 1372.1 & -40.2 \\
\hline 1196 & 371617116291702 & UE-20f & 4124896.5 & 545393.3 & 1268.7 & 1373.8 & -10.5 \\
\hline 1197 & 371617116291801 & U-20f & 4124896.5 & 545368.8 & 1276.2 & 1373.9 & -9.8 \\
\hline 1198 & 371618116260201 & UE-20h WW & 4124985.5 & 550195.5 & 1355.5 & 1380.9 & -17.5 \\
\hline
\end{tabular}


Table B-1

Comparison of Simulated and Observed Hydraulic Heads

\begin{tabular}{|c|c|c|c|c|c|c|c|}
\hline $\begin{array}{c}\text { Map Ref. } \\
\text { No. }\end{array}$ & Official ID & Common Name & $\begin{array}{l}\text { Northing }{ }^{a} \\
\quad(\mathrm{~m})^{\mathrm{b}}\end{array}$ & $\begin{array}{c}\text { Easting }^{a} \\
\quad(\mathrm{~m})\end{array}$ & $\begin{array}{l}\text { Observed } \\
\text { Hyd. Head } \\
(\mathrm{m})\end{array}$ & $\begin{array}{c}\text { Simulated } \\
\text { Hyd. Head } \\
(\mathrm{m})\end{array}$ & $\begin{array}{l}\text { Weighted } \\
\text { Residual }\end{array}$ \\
\hline 1199 & 371620116213501 & U-19bg 1 & 4125058.3 & 556771.1 & 1394.5 & 1401.4 & -6.9 \\
\hline 1202 & 371623116243701 & UE-20ab & 4125121.5 & 552288.1 & 1356.1 & 1387.9 & -25.2 \\
\hline 1204 & 371630116221202 & U-19aS & 4125360.5 & 555857.8 & 1392.7 & 1399.1 & -0.6 \\
\hline 1205 & 371632116211301 & U-19ay & 4125431.8 & 557310.4 & 1396.9 & 1405.7 & -8.8 \\
\hline 1207 & 371643116212001 & U-19ar & 4125769.5 & 557135.6 & 1398.9 & 1406.5 & -0.8 \\
\hline 1209 & 371648116242001 & TW-9 & 4125894.5 & 552702 & 1349.2 & 1394 & -4.5 \\
\hline 1210 & 371649116242101 & PM-1 & 4125925.3 & 552677.2 & 1354.5 & 1394.1 & -36.2 \\
\hline 1211 & 371649116242102 & PM-1 & 4125925.3 & 552677.2 & 1359.3 & 1390.4 & -31.1 \\
\hline 1214 & 371658116244401 & U-20aw & 4126199 & 552109.1 & 1371.4 & 1395.3 & -18.9 \\
\hline 1220 & 371714116230301 & U-19bk & 4126708 & 554592.9 & 1427.8 & 1402.5 & 25.3 \\
\hline 1225 & 371746116184601 & U-19ba & 4127737.8 & 560914 & 1488.8 & 1430.7 & 58.1 \\
\hline 1230 & 371750116195901 & UE-19e WW & 4127848 & 559115.8 & 1432 & 1423.9 & 6.4 \\
\hline 1231 & 371750116262701 & U-20an & 4127786.3 & 549563.3 & 1363.1 & 1402.2 & -39.1 \\
\hline 1233 & 371758116193601 & UE-19z & 4128098.5 & 559680.3 & 1429.7 & 1427.6 & 0.2 \\
\hline 1234 & 371801116320301 & UE-20j WW & 4128080.3 & 541289.3 & 1412 & 1418.4 & -0.6 \\
\hline 1236 & 371802116320301 & U-20m & 4128111 & 541289.1 & 1412.1 & 1408.8 & 0.3 \\
\hline 1237 & 371807116243001 & U-20g & 4128327.5 & 552440.5 & 1357.3 & 1409.6 & -5.2 \\
\hline 1239 & 371830116215301 & UE-19gS WW & 4129061.5 & 556300.8 & 1424.9 & 1417.8 & 6.8 \\
\hline 1241 & 371836116215101 & U-19g & 4129246.5 & 556348.8 & 1424.2 & 1418.8 & 4.9 \\
\hline 1242 & 371851116273801 & $\mathrm{U}-20 \mathrm{e}$ & 4129655.8 & 547804.5 & 1360.3 & 1412.3 & -5.2 \\
\hline 1243 & 371852116175701 & UE-19b 1 WW & 4129780.5 & 562105.3 & 1427.9 & 1436 & -8.1 \\
\hline 1244 & 371852116281701 & U-20ar 1 & 4129681.3 & 546844.3 & 1364.4 & 1412.3 & -47.9 \\
\hline 1246 & 371901116272501 & UE-20e 1 & 4129965.8 & 548122.8 & 1364.1 & 1414.3 & -39.7 \\
\hline 1247 & 371929116185501 & U-19ai & 4130910.3 & 560669.4 & 1429 & 1434.2 & -4.1 \\
\hline 1253 & 372034116222501 & UE-19h & 4132877.5 & 555487.8 & 1422.8 & 1427.1 & -0.4 \\
\hline 1254 & 372034116222503 & UE-19h & 4132877.5 & 555487.8 & 1472.2 & 1427.1 & 45.1 \\
\hline 1255 & 372034116222504 & UE-19h & 4132877.5 & 555487.8 & 1423.1 & 1427.2 & -4.1 \\
\hline 1256 & 372042116340501 & PM-2 & 4133027.5 & 538263.1 & 1443 & 1435.3 & 7.7 \\
\hline 1258 & 372054116191901 & U-19d 2 & 4133525.3 & 560060 & 1428 & 1434.7 & -6.1 \\
\hline 1277 & 372543116363501 & GOLD FLAT 2 & 4142287 & 534534.1 & 1523 & 1451.8 & 56.3 \\
\hline 1279 & 372642116281301 & Gold Flat 1 & 4144165.5 & 546861.5 & 1421.2 & 1449.9 & -2.9 \\
\hline 1318 & 373624115434101 & & 4162460.8 & 610611.9 & 1405.4 & 1435.1 & -3 \\
\hline 1320 & 373635115450101 & & 4162807.3 & 608841.6 & 1406 & 1450.4 & -4.4 \\
\hline 1321 & 373704115465701 & & 4163478 & 605890.2 & 1446 & 1453.5 & -0.7 \\
\hline 1322 & 373704115490401 & & 4163467.5 & 602604.5 & 1428 & 1451.5 & -2.3 \\
\hline 1323 & 373708115482201 & & 4163995.3 & 605368.6 & 1439.9 & 1452 & -6.6 \\
\hline 1325 & 373721115470102 & & 4164421.5 & 607349.2 & 1442 & 1451.1 & -0.9 \\
\hline 1326 & 373721115473401 & & 4164411 & 606540.2 & 1440 & 1451.5 & -3.6 \\
\hline 1327 & 373721115483901 & & 4164390.5 & 604946.8 & 1438.8 & 1451 & -5.4 \\
\hline 1328 & 373729115442601 & & 4164328.5 & 609679.8 & 1449.1 & 1445.3 & 0.4 \\
\hline 1329 & 373729115454301 & & 4164425 & 607618.8 & 1456 & 1450.9 & 0.5 \\
\hline 1330 & 373741115480601 & & 4164780.5 & 604083.7 & 1431 & 1450.4 & -1.9 \\
\hline 1335 & 373813115454001 & & 4165747.3 & 607381 & 1463 & 1447.3 & 1.6 \\
\hline 1336 & 373815115434601 & & 4166034 & 610441.7 & 1450.8 & 1444.7 & 0.6 \\
\hline 1337 & 373817115483301 & & 4165818.5 & 603286.3 & 1449.3 & 1449.8 & 0 \\
\hline 1338 & 373819115465201 & & 4165820 & 605835.6 & 1449.6 & 1448.3 & 0.1 \\
\hline
\end{tabular}


Table B-1

Comparison of Simulated and Observed Hydraulic Heads

\begin{tabular}{|c|c|c|c|c|c|c|c|}
\hline $\begin{array}{c}\text { Map Ref. } \\
\text { No. }\end{array}$ & Official ID & Common Name & $\begin{array}{l}\text { Northing }{ }^{a} \\
\quad(m)^{b}\end{array}$ & $\begin{array}{l}\text { Easting }^{a} \\
\quad(\mathrm{~m})\end{array}$ & $\begin{array}{l}\text { Observed } \\
\text { Hyd. Head } \\
(\mathrm{m})\end{array}$ & $\begin{array}{c}\text { Simulated } \\
\text { Hyd. Head } \\
(\mathrm{m})\end{array}$ & $\begin{array}{l}\text { Weighted } \\
\text { Residual }\end{array}$ \\
\hline 1340 & 373833115441101 & USGS-MX & 4166695.5 & 611486.8 & 1456.2 & 1443.5 & 1 \\
\hline 1341 & 373838115424001 & & 4166829.5 & 612269.4 & 1442.3 & 1442.7 & 0 \\
\hline 1342 & 373851115472001 & & 4167189 & 606847.6 & 1432.6 & 1446 & -1.3 \\
\hline 1343 & 373907115461701 & & 4167432.8 & 606623.9 & 1447.1 & 1445.9 & 0.1 \\
\hline 1344 & 373907115472901 & & 4167663.8 & 605395.5 & 1450.5 & 1447.3 & 0.3 \\
\hline 1345 & 373943115495701 & & 4168534.8 & 601095.8 & 1444.2 & 1450.7 & -0.6 \\
\hline 1346 & 373944115454101 & & 4168854.3 & 609252.2 & 1440.4 & 1443.6 & -0.3 \\
\hline 1348 & 373955115490201 & & 4169199 & 602484.4 & 1447.2 & 1449.6 & -0.2 \\
\hline 1349 & 373955115512901 & & 4169085 & 600721.5 & 1439.3 & 1450.9 & -1.2 \\
\hline 1350 & 373957115440501 & & 4169323 & 609736.1 & 1448 & 1443.6 & 0.4 \\
\hline 1352 & 374020115494101 & & 4169680 & 601498.3 & 1445.3 & 1450.2 & -0.5 \\
\hline 1353 & 374024115502901 & & 4171705.3 & 600738.6 & 1450.3 & 1450.6 & 0 \\
\hline 1354 & 374029115501901 & & 4169854.5 & 600638.6 & 1444.4 & 1450.8 & -0.6 \\
\hline 1356 & 374051115420802 & & 4170989.8 & 614442.5 & 1446 & 1442.6 & 1.8 \\
\hline 1357 & 374052115403001 & & 4170787.3 & 615400.8 & 1445.1 & 1440.9 & 0.4 \\
\hline 1359 & 374140115490401 & & 4172185.3 & 602178 & 1445.8 & 1449.4 & -0.4 \\
\hline 1363 & 374230115491701 & & 4174696.3 & 603322.3 & 1457.3 & 1450.1 & 0.7 \\
\hline 1364 & 374241116264601 & TTR CEDAR PASS R-1 W & 4173731.8 & 548825 & 1608.1 & 1509.5 & 9.9 \\
\hline 1366 & 374244115420801 & & 4174481.3 & 612802.2 & 1443.3 & 1447.7 & -0.4 \\
\hline 1367 & 374247115433202 & & 4174536.5 & 612336.2 & 1440.8 & 1447.6 & -0.7 \\
\hline 1368 & 374247115474001 & & 4174340 & 604404.2 & 1446.8 & 1448.9 & -0.2 \\
\hline 1373 & 374345115415501 & USGS-MX & 4176356.8 & 614686.4 & 1446.3 & 1451.3 & -0.5 \\
\hline 1374 & 374356115422601 & & 4176685.3 & 613922.9 & 1446.6 & 1452.1 & -3 \\
\hline 1376 & 374419115453001 & & 4177333.3 & 609409.4 & 1464.6 & 1451.1 & 1.3 \\
\hline 1379 & 374506116292300 & TTR CEDAR PASS WW & 4177627 & 545571.4 & 1568 & 1520 & 26.1 \\
\hline 1380 & 374523115440901 & USGS-MX & 4179332.3 & 611365.3 & 1483.6 & 1457.4 & 2.1 \\
\hline 1383 & 374530115455201 & USGS-MX & 4179514.3 & 608842 & 1446.4 & 1457.4 & -1.1 \\
\hline 1385 & 374536115445901 & & 4179716.5 & 610136.5 & 1446.4 & 1458.2 & -6.5 \\
\hline 1387 & 374619116435401 & TTR EH-4 & 4180339.5 & 523636 & 1567.4 & 1525.7 & 23 \\
\hline 1393 & 374703116445701 & TTR SANDIA MAIN WW & 4181691.3 & 522091.1 & 1564.9 & 1524.9 & 4 \\
\hline 1396 & 374725116452701 & TTR SANDIA 2 & 4182367.5 & 521355.6 & 1564 & 1525.1 & 38.9 \\
\hline 1397 & 374729115483301 & USGS-MX & 4183112.3 & 603388.1 & 1444.4 & 1465 & -1.7 \\
\hline 1398 & 374739116453401 & TTR SANDIA 4 & 4182798.5 & 521183.3 & 1563.8 & 1525.3 & 38.5 \\
\hline 1399 & 374806115413601 & & 4184479.8 & 613595 & 1452.4 & 1464.7 & -1.2 \\
\hline 1402 & 374910116373001 & TTR DEAD HORSE W & 4185641.8 & 533009.1 & 1578.7 & 1527.7 & 28.1 \\
\hline 1406 & 374946115460101 & & 4187509.5 & 586463.3 & 1460.1 & 1520.7 & -6.1 \\
\hline 1411 & 375051115445301 & & 4189742.8 & 608413.4 & 1451.8 & 1472.8 & -2.1 \\
\hline 1414 & 375103115463001 & & 4189765 & 607777.6 & 1445.5 & 1472.9 & -2.7 \\
\hline 1430 & 375357115465101 & & 4195106.5 & 584869 & 1456.6 & 1522.1 & -6.6 \\
\hline 1442 & 375751116030201 & FALLINI BROS & 4194324 & 583753.4 & 1469.1 & 1522.5 & -53.4 \\
\hline 1444 & 375820115442301 & REPORT 60 P1 & 4161645.3 & 588966.4 & 1457.6 & 1465.1 & -0.7 \\
\hline 1446 & 375937115414701 & USGS-MX & 4205700.5 & 614472.4 & 1443.5 & 1535.9 & -9.2 \\
\hline 1450 & 380054115472601 & USGS-MX & 4207962.5 & 606172.6 & 1441.7 & 1569 & -12.7 \\
\hline 1457 & 380235115475501 & USGS-MX & 4211066 & 605425.2 & 1448.7 & 1593.4 & -14.5 \\
\hline 2279 & ASH-B-1 & ASH-B-1 & 4064213 & 529046.6 & 719.1 & 710.8 & 0.8 \\
\hline 2280 & ASH-B-2 & ASH-B-2 & 4064213 & 529046.6 & 719.5 & 710.8 & 0.9 \\
\hline
\end{tabular}

${ }^{a}$ UTM Coordinates; Zone 11; NAD 27

${ }^{\mathrm{b}}$ Meter(s) 
Table B-1

Comparison of Simulated and Observed Hydraulic Heads

\begin{tabular}{|c|c|c|c|c|c|c|c|}
\hline $\begin{array}{c}\text { Map Ref. } \\
\text { No. }\end{array}$ & Official ID & Common Name & $\begin{array}{l}\text { Northing }{ }^{a} \\
\quad(m)^{b}\end{array}$ & $\begin{array}{l}\text { Easting }^{a} \\
\qquad(\mathrm{~m})\end{array}$ & $\begin{array}{l}\text { Observed } \\
\text { Hyd. Head } \\
(\mathrm{m})\end{array}$ & $\begin{array}{c}\text { Simulated } \\
\text { Hyd. Head } \\
(\mathrm{m})\end{array}$ & $\begin{array}{l}\text { Weighted } \\
\text { Residual }\end{array}$ \\
\hline 2283 & BT004 & & 4045680.8 & 508451.8 & -79.3 & -34.7 & -4.5 \\
\hline 2284 & BT005 & & 4041060.8 & 509948.7 & -79.3 & -33.2 & -4.6 \\
\hline 2285 & BT006 & & 4042909 & 509697.9 & -79.3 & -32.1 & -4.7 \\
\hline 2286 & BT007 & Salt & 4042909.5 & 510195.2 & -79.3 & -30.3 & -4.9 \\
\hline 2287 & BT008 & & 4039523 & 512189.3 & 3.1 & -10.2 & 1.3 \\
\hline 2288 & BT009 & Cow & 4039216.8 & 513433.6 & 61 & 28.8 & 3.2 \\
\hline 2289 & BT010 & & 4040142.5 & 514427.2 & 158.5 & 59.4 & 9.9 \\
\hline 2290 & BT012 & Nevares & 4040144.5 & 515422.1 & 219.5 & 123.7 & 9.6 \\
\hline 2291 & BT013 & Nevares & 4040454 & 516167.8 & 158.5 & 118.6 & 4 \\
\hline 2294 & BT120 & & 4088233 & 524240.4 & 1060.7 & 1037.1 & 2.4 \\
\hline 2295 & BT128 & & 4089160.3 & 525227 & 1060.7 & 1062.3 & -0.2 \\
\hline 2296 & BT139 & & 4090699.5 & 524727.9 & 1082 & 1076 & 0.6 \\
\hline 2298 & BT172 & & 4093783 & 525460.5 & 1112.5 & 1128.7 & -1.6 \\
\hline 2314 & DV008 & & 4009345 & 520968.9 & -79.3 & -65.7 & -1.4 \\
\hline 2316 & DV010 & & 4032748.3 & 514688.5 & 97.5 & 52.5 & 4.5 \\
\hline 2317 & DV011 & Travertine & 4032749.3 & 515186.4 & 97.5 & 65.6 & 3.2 \\
\hline 2318 & DV012 & & 4033056.5 & 514688 & 97.5 & 54.7 & 4.3 \\
\hline 2319 & DV013 & Travertine & 4032749.5 & 515435.3 & 121.9 & 77.9 & 4.4 \\
\hline 2320 & DV016 & & 4033057.8 & 515434.8 & 121.9 & 84.8 & 3.7 \\
\hline 2321 & DV017 & DV Hotel Tunnel & 4033978.8 & 513441.8 & 15.2 & 25.4 & -1 \\
\hline 2323 & DV019 & & 4033672.3 & 514438 & 48.8 & 52 & -0.3 \\
\hline 2324 & DV021 & & 4033672.8 & 514686.9 & 121.9 & 73.4 & 4.8 \\
\hline 2325 & DV022 & & 4033980.5 & 514437.5 & 48.8 & 54 & -0.5 \\
\hline 2327 & DV027 & & 4037056.8 & 511197.5 & -73.2 & -38.4 & -3.5 \\
\hline 2328 & DV030 & & 4038597 & 510946.7 & -73.2 & -34 & -3.9 \\
\hline 2329 & DV031 & & 4038600 & 513185.8 & 30.5 & 22.7 & 0.8 \\
\hline 2330 & DV114 & & 4028341.8 & 562771.2 & 684.3 & 682.4 & 0.2 \\
\hline 2331 & DV121 & Last Chance & 4023738.5 & 565296.9 & 686.7 & 684.2 & 0.3 \\
\hline 2332 & DV127 & & 4032338.3 & 561497.2 & 702.6 & 690 & 1.3 \\
\hline 2333 & DV138 & & 4032033.8 & 561997.4 & 709.6 & 692.1 & 1.8 \\
\hline 2334 & DV141 & & 4031421 & 562499.8 & 713.2 & 692.2 & 2.1 \\
\hline 2335 & DV145 & Big Spring & 4025554 & 565162.4 & 682.5 & 686.7 & -0.4 \\
\hline 2336 & DV154 & Jack Rabbit & 4027124 & 564773.2 & 691.9 & 689.1 & 0.3 \\
\hline 2337 & DV165 & & 4024362.3 & 566289.2 & 693.4 & 690.1 & 0.3 \\
\hline 2338 & DV170 & Bell & 4038178.5 & 559465.1 & 692.5 & 693.3 & -0.1 \\
\hline 2339 & DV180 & & 4035417.8 & 561226.4 & 714.8 & 696.8 & 1.8 \\
\hline 2340 & DV204 & & 4028668.3 & 565259.8 & 704.1 & 694.7 & 0.9 \\
\hline 2341 & DV212 & Indian Rock (King) & 4028670.3 & 565508.9 & 708.7 & 695.3 & 1.3 \\
\hline 2342 & ER-20-2-1S & ER-20-2-1S & 4118446.3 & 553210.3 & 1349.8 & 1325.4 & 2.4 \\
\hline 2343 & ETW-I-4 & PW-1 & 4078907.3 & 515798.2 & 811.6 & 753.8 & 5.8 \\
\hline 2344 & ETW-II-1 & PW-2 & 4078167.3 & 515601.5 & 780.8 & 752.4 & 2.8 \\
\hline 2345 & ETW-II-2 & PW-3 & 4078171 & 517483.6 & 783.4 & 750.7 & 3.3 \\
\hline 2346 & ETW-II-5 & PW-4 & 4076195.8 & 515828 & 779.9 & 748.6 & 3.1 \\
\hline 2350 & IS017 & Indian & 4046815.3 & 619567.7 & 967.7 & 958.7 & 0.9 \\
\hline 2353 & LWS-A-1 & LWS-A-1 & 4045693 & 549021.7 & 693.6 & 690.2 & 0.3 \\
\hline 2354 & LWS-A-2 & LWS-A-2 & 4045693 & 549021.7 & 685.8 & 690.2 & -0.4 \\
\hline
\end{tabular}


Table B-1

Comparison of Simulated and Observed Hydraulic Heads

\begin{tabular}{|c|l|l|c|c|c|c|c|}
\hline $\begin{array}{c}\text { Map Ref. } \\
\text { No. }\end{array}$ & Official ID & \multicolumn{1}{|c|}{ Common Name } & $\begin{array}{c}\text { Northing } \\
(\mathrm{m})\end{array}$ & $\begin{array}{c}\text { Easting } \\
(\mathrm{m})\end{array}$ & $\begin{array}{c}\text { Observed } \\
\text { Hyd. Head } \\
(\mathrm{m})\end{array}$ & $\begin{array}{c}\text { Simulated } \\
\text { Hyd. Head } \\
(\mathrm{m})\end{array}$ & $\begin{array}{c}\text { Weighted } \\
\text { Residual }\end{array}$ \\
\hline 2355 & MSH-C-1 & MSH-C-1 & 4039731 & 565375.3 & 710.2 & 707.5 & 0.3 \\
\hline 2356 & MSH-C-2 & MSH-C-2 & 4039731 & 565375.3 & 711.1 & 707.4 & 0.4 \\
\hline 2357 & PM011 & & 4096243.8 & 523970.3 & 1133.9 & 1160.6 & -2.7 \\
\hline 2358 & PM013 & & 4095629 & 524466.4 & 1121.7 & 1148.4 & -2.7 \\
\hline 2359 & PM015 & Long Spring & 4097787.5 & 524954.3 & 1182.6 & 1170 & 1.3 \\
\hline 2360 & PM018 & & 4095325.3 & 525950.1 & 1170.4 & 1159.2 & 1.1 \\
\hline 2373 & UE-29a-1 & UE-29a-1 & 4088340.8 & 555757.6 & 1191.6 & 1228.8 & -35.5 \\
\hline 2374 & UE-29a-2 & UE-29a-2 & 4088345.5 & 555749.1 & 1186.9 & 1223.6 & -36.7 \\
\hline SM23-1 & SM23-1 & SM23-1 & 4055901 & 587967 & 724.8 & 723.3 & 0.2 \\
\hline
\end{tabular}


Appendix C

\section{Numerical Groundwater Flow Model Sensitivity Analysis Results}




\section{Description of Appendix Contents}

This appendix presents data from the numerical groundwater flow model sensitivity analysis. The data are presented in three tables: Table C-1, Table C-2, and Table C-3. The tables provide the results from numerous sensitivity runs for the $\mathrm{Kh}$ or $\lambda$ parameters types.

The convention used in naming the sensitivity run provides information on the parameter type (Kh or $\lambda$ ), the HSU identifier, and the HSU zone number, if applicable. For example,

$\mathrm{Kh} \_\mathrm{LCA}(3)$ is the horizontal hydraulic conductivity parameter, projected to land surface, for zone 3 of the LCA.

The following tables list the calibration zones for the sensitivity analyses.

\section{Abbreviations for Zones Used in Table C-1 and Table C-2}

\begin{tabular}{|c|c|}
\hline Residual Zone Identifier & Residual Zone Name \\
\hline NRTH & Northern Area \\
\hline OASI & Oasis Valley \\
\hline PM & Pahute Mesa \\
\hline BARR & Barrier \\
\hline WYF & Western Yucca Flat \\
\hline EYF & Eastern Yucca Flat \\
\hline SHON & Shoshone \\
\hline DV & Death Valley \\
\hline LCA & Lower Carbonate Aquifer \\
\hline PAHR & Southwest of Pahranagat \\
\hline SPMT & Salley \\
\hline SHRG & Sheep Range \\
\hline TMBR & Timber Mountain \\
\hline FARM & Amargosa Farm \\
\hline FF & Frenchman Flat \\
\hline & \\
\hline & \\
\hline SHain \\
\hline
\end{tabular}




\section{Abbreviations for Zones Used in Table C-3}

\begin{tabular}{|c|c|}
\hline $\begin{array}{c}\text { Boundary Flux Zone } \\
\text { Identifier }\end{array}$ & $\begin{array}{c}\text { Boundary Flux Zone } \\
\text { Name }\end{array}$ \\
\hline DV & Death Valley \\
\hline OV & Oasis Valley \\
\hline ARiv & Amargosa River \\
\hline AM & Ash Meadows \\
\hline FL & Franklin Lake/Alkali Flats \\
\hline AF & Alkali Flats (Peter's Playa) \\
\hline PV & Penoyer Valley \\
\hline IS & Indian Springs \\
\hline PP & Pahrump Valley \\
\hline EM & Eagle Mountain \\
\hline
\end{tabular}

The following are brief descriptions of the contents of each table in this appendix.

\section{Table C-1: Changes in Mean Weighted Residuals Between Sensitivity Runs and Calibration Run}

Table C-1 presents the changes in the mean weighted residual (between the sensitivity run and the base case) per residual zone as a function of the 100 percent increase and 50 percent decrease in Kh values, and the 10 percent increase and decrease in the lambda parameter values. Changes with absolute values greater than or equal to one meter are shaded. A positive change indicates a general increase in water levels within the zone.

\section{Table C-2: Percentage Change in Roots Mean Square of Mean Weighted Residuals Between Sensitivity Runs and Calibration Run}

Table C-2 presents the percentage change in the RMS of the weighted head residuals per zone. A positive change indicates an increase in the RMS; shading indicates a change with an absolute value greater than or equal to 10 percent. 


\section{Table C-3: Percentage Changes in Discharge Rates Between Sensitivity Runs and Calibration Run}

Table C-3 presents the percentage changes in boundary flux rates between the calibrated model and the sensitivity runs. Positive values indicate an increase in the recharge or discharge flux.

The effects of the sensitivity runs on simulated heads within each of the 15 residual zones, and on the 10 head-dependent flux discharge areas are addressed in detail in the Groundwater Flow Model Documentation Package (IT, 1996f). The tables (Table C-1 thru C-3) are provided on pages $\mathrm{C}-4$ through $\mathrm{C}-27$. 
Table C-1

Changes in Mean Weighted Residuals Between Sensitivity Runs and Calibration Run

\begin{tabular}{|c|c|c|c|c|c|c|c|c|c|c|c|c|c|c|c|c|}
\hline \multicolumn{2}{|c|}{ Calibration Zones and Base Data ${ }^{a}$ : } & \multirow{2}{*}{$\begin{array}{c}\text { NRTH } \\
5.80 \\
\end{array}$} & \multirow{2}{*}{$\begin{array}{l}\text { OASI } \\
38.30 \\
\end{array}$} & \multirow{2}{*}{$\begin{array}{l}\text { PM } \\
-5.80 \\
\end{array}$} & \multirow{2}{*}{$\begin{array}{c}\text { BARR } \\
107.20\end{array}$} & \multirow{2}{*}{$\begin{array}{l}\text { WYF } \\
70.40\end{array}$} & \multirow{2}{*}{$\begin{array}{l}\text { EYF } \\
1.30\end{array}$} & \multirow{2}{*}{$\begin{array}{c}\text { SHON } \\
21.70\end{array}$} & \multirow{2}{*}{$\frac{\text { DV }}{22.90}$} & \multirow{2}{*}{\begin{tabular}{|l|} 
LCA \\
-7.30 \\
\end{tabular}} & \multirow{2}{*}{$\begin{array}{c}\text { PAHR } \\
-9.90\end{array}$} & \multirow{2}{*}{$\begin{array}{c}\text { SPMT } \\
-1.70\end{array}$} & \multirow{2}{*}{$\begin{array}{c}\text { SHRG } \\
49.30 \\
\end{array}$} & \multirow{2}{*}{$\begin{array}{c}\text { TMBR } \\
6.70\end{array}$} & \multirow{2}{*}{\begin{tabular}{c|} 
FARM \\
6.30
\end{tabular}} & \multirow{2}{*}{$\begin{array}{c}\text { FF } \\
0.80\end{array}$} \\
\hline Parameter & $\%$ Change & & & & & & & & & & & & & & & \\
\hline Kh_I & 100 & -0.10 & 0.00 & -0.20 & 0.10 & 2.50 & 0.40 & 1.00 & 0.00 & 0.10 & 0.00 & 0.10 & 0.10 & -0.30 & 0.00 & 0.10 \\
\hline Kh_LCCU(1) & 100 & -1.90 & 1.10 & -4.10 & -1.00 & -5.20 & 1.30 & 0.20 & 0.20 & 0.10 & -3.90 & -3.40 & -0.90 & -5.70 & 0.70 & 1.10 \\
\hline Kh_LCCU(2) & 100 & -0.10 & 0.00 & -0.20 & 0.20 & 8.30 & 1.00 & 1.10 & 0.10 & 0.00 & -28.20 & -4.30 & -12.40 & 0.00 & 0.00 & 0.20 \\
\hline Kh_LCCU(3) & 100 & 0.00 & -9.20 & -0.30 & -0.70 & -42.40 & 0.90 & -0.60 & 3.80 & -1.30 & -0.60 & -0.20 & -0.50 & -0.80 & -3.20 & -0.90 \\
\hline Kh_LCA(1) & 100 & -0.20 & -0.10 & -0.50 & -12.20 & 2.70 & -8.30 & -4.10 & 0.70 & -0.10 & -10.20 & -4.30 & -22.60 & -0.60 & 0.40 & -5.40 \\
\hline Kh_LCA(2) & 100 & 0.00 & -1.90 & 0.10 & -5.00 & -47.10 & -4.20 & -4.00 & -0.50 & -1.20 & -2.50 & -1.60 & -2.70 & 0.10 & -1.90 & -5.50 \\
\hline Kh_LCA(3) & 100 & 0.00 & 0.20 & -0.10 & 0.70 & 2.40 & 0.90 & 1.10 & 0.10 & 0.20 & -0.70 & -18.50 & -6.40 & -0.20 & 0.20 & 0.60 \\
\hline Kh_LCA(4) & 100 & -0.10 & -3.90 & -0.30 & -5.20 & 1.80 & -4.60 & -2.60 & 3.90 & -2.20 & -2.50 & -1.60 & -2.70 & -0.50 & -2.00 & -5.60 \\
\hline Kh_LCA(5) & 100 & -4.50 & 0.20 & -3.20 & 2.80 & 2.10 & 2.20 & 1.90 & 0.70 & 0.40 & 2.30 & 1.00 & 0.90 & -1.60 & 0.60 & 1.80 \\
\hline Kh_LCA(6) & 100 & -0.10 & -0.10 & -0.20 & 0.20 & -3.10 & 0.60 & 1.80 & 0.00 & 0.00 & -0.90 & -4.40 & 0.30 & -0.30 & 0.00 & 0.10 \\
\hline Kh_LCA(7) & 100 & -1.40 & 0.10 & -2.80 & 0.10 & 2.60 & 0.40 & 0.50 & 0.00 & 0.00 & -0.10 & 0.10 & 0.00 & -1.50 & 0.00 & 0.00 \\
\hline Kh_LCA(8) & 100 & -2.80 & 0.90 & -0.50 & 0.70 & 3.30 & 2.60 & 2.00 & 0.30 & 0.80 & -60.80 & 0.60 & -0.10 & -0.40 & 1.10 & 2.50 \\
\hline Kh_LCA(9) & 100 & -0.10 & -3.90 & -0.10 & -1.80 & 8.80 & -1.10 & -0.80 & 8.30 & -2.30 & -0.90 & -0.50 & -1.00 & 0.00 & -7.50 & -2.00 \\
\hline Kh_UCCU & 100 & -0.20 & -0.30 & -0.90 & 0.40 & -29.00 & 2.20 & -4.30 & 0.00 & -0.10 & -0.80 & 0.10 & 0.10 & -2.10 & 0.00 & 0.30 \\
\hline Kh_LCA3 & 100 & -0.10 & -0.10 & -0.30 & 0.20 & -46.40 & 0.10 & -13.20 & 0.00 & 0.00 & -0.90 & 0.10 & 0.00 & -0.70 & 0.00 & 0.10 \\
\hline Kh_TSDV(1) & 100 & 0.00 & -0.20 & -0.10 & 0.00 & 2.90 & 0.40 & 0.70 & 0.10 & 0.10 & -0.10 & 0.00 & 0.00 & -0.20 & -0.10 & 0.00 \\
\hline Kh_TSDV(2) & 100 & 0.00 & -0.70 & -0.20 & 0.00 & -42.50 & 1.60 & -0.30 & -3.70 & -0.30 & -0.20 & 0.00 & -0.10 & -0.80 & -1.10 & -0.20 \\
\hline Kh_VU(1) & 100 & -10.00 & 0.60 & -5.10 & 3.40 & -1.30 & 2.70 & 0.70 & 0.00 & 0.40 & -0.70 & 0.80 & 0.70 & -2.50 & 0.70 & 1.80 \\
\hline Kh_VU(2) & 100 & -0.10 & 0.00 & -0.40 & 0.30 & -41.80 & 1.90 & -0.90 & 0.00 & 0.00 & 0.10 & 0.10 & 0.00 & -0.80 & 0.00 & 0.10 \\
\hline Kh_VU(3) & 100 & -1.00 & 4.70 & -6.20 & 0.30 & -1.00 & 0.60 & -2.90 & 0.50 & 0.00 & -0.80 & 0.10 & 0.20 & -10.70 & 0.90 & 0.30 \\
\hline Kh_VCU(1) & 100 & -0.40 & 8.80 & -4.20 & 0.90 & -6.90 & -0.10 & -4.90 & 0.50 & 5.20 & -0.50 & 0.30 & 0.50 & -15.50 & 1.50 & 0.90 \\
\hline Kh_VCU(2) & 100 & 0.00 & -0.10 & -0.30 & 0.30 & -39.80 & 2.00 & -0.90 & 0.00 & 0.00 & 0.00 & 0.10 & 0.00 & -0.80 & 0.00 & 0.10 \\
\hline Kh_VA(1) & 100 & 0.10 & -4.70 & 0.90 & -0.10 & 4.10 & 0.10 & -2.20 & 0.00 & -6.20 & -0.20 & 0.00 & -0.10 & 6.00 & -0.20 & -0.30 \\
\hline Kh_VA(2) & 100 & 0.00 & 0.00 & -0.10 & 0.20 & -3.00 & -1.80 & -1.10 & 0.00 & 0.00 & 0.00 & 0.10 & 0.00 & -0.30 & 0.00 & 0.10 \\
\hline Kh_VA(3) & 100 & 0.00 & -8.90 & -0.20 & 0.20 & -39.80 & 1.90 & -1.30 & 0.10 & -2.60 & -0.10 & 0.10 & 0.00 & -0.70 & 0.40 & 0.00 \\
\hline Kh_BAQ(1) & 100 & -0.30 & 0.10 & -2.10 & 0.20 & 1.20 & 0.70 & 1.10 & 0.00 & 0.10 & 0.00 & 0.10 & 0.00 & -0.40 & 0.00 & 0.10 \\
\hline Kh_BAQ(3) & 100 & 0.00 & 0.00 & 0.00 & 0.20 & -43.20 & 0.70 & -0.40 & 0.00 & 0.00 & 0.00 & 0.10 & 0.00 & -0.30 & 0.00 & 0.10 \\
\hline Kh_BAQ(4) & 100 & -0.10 & 0.00 & -0.30 & 0.20 & -43.10 & 1.70 & -0.40 & 0.00 & 0.00 & 0.00 & 0.10 & 0.00 & -0.90 & 0.00 & 0.10 \\
\hline Kh_BAQ(5) & 100 & 0.00 & 0.00 & 0.00 & 0.20 & -26.50 & 0.40 & 1.30 & 0.00 & 0.00 & 0.00 & 0.10 & 0.00 & -0.30 & 0.00 & 0.10 \\
\hline Kh_BAQ(6) & 100 & 0.00 & 0.00 & -0.10 & 0.20 & 1.40 & 0.40 & 0.20 & 0.00 & 0.00 & 0.00 & 0.10 & 0.00 & -0.10 & 0.00 & 0.10 \\
\hline Kh_BCU(1) & 100 & -0.70 & -0.10 & -2.80 & 0.60 & -1.30 & 0.70 & 0.70 & 0.10 & 0.10 & 0.10 & 0.10 & 0.20 & -1.40 & 0.10 & 0.30 \\
\hline Kh_BCU(3) & 100 & 0.10 & 0.00 & 0.10 & 0.00 & -33.20 & 0.00 & -0.70 & 0.00 & 0.00 & 0.00 & 0.00 & 0.00 & 0.10 & 0.00 & 0.00 \\
\hline Kh_BCU(4) & 100 & 0.00 & 0.00 & -0.20 & 0.30 & -41.90 & 1.80 & -0.60 & 0.00 & 0.00 & 0.00 & 0.10 & 0.00 & -0.70 & 0.00 & 0.10 \\
\hline
\end{tabular}


Table C-1

Changes in Mean Weighted Residuals Between Sensitivity Runs and Calibration Run

\begin{tabular}{|c|c|c|c|c|c|c|c|c|c|c|c|c|c|c|c|c|}
\hline \multicolumn{2}{|c|}{ Calibration Zones and Base Data ${ }^{\mathrm{a}}$ : } & \multirow{2}{*}{$\begin{array}{c}\text { NRTH } \\
5.80 \\
\end{array}$} & \multirow{2}{*}{$\begin{array}{l}\text { OASI } \\
38.30 \\
\end{array}$} & \multirow{2}{*}{$\begin{array}{c}\text { PM } \\
-5.80 \\
\end{array}$} & \multirow{2}{*}{$\begin{array}{c}\text { BARR } \\
107.20 \\
\end{array}$} & \multirow{2}{*}{$\begin{array}{l}\text { WYF } \\
70.40\end{array}$} & \multirow{2}{*}{$\begin{array}{l}\text { EYF } \\
1.30\end{array}$} & \multirow{2}{*}{$\begin{array}{c}\text { SHON } \\
21.70\end{array}$} & \multirow{2}{*}{$\frac{\text { DV }}{22.90}$} & \multirow{2}{*}{\begin{tabular}{|l|} 
LCA \\
-7.30 \\
\end{tabular}} & \multirow{2}{*}{$\begin{array}{c}\text { PAHR } \\
-9.90 \\
\end{array}$} & \multirow{2}{*}{$\begin{array}{c}\text { SPMT } \\
-1.70 \\
\end{array}$} & \multirow{2}{*}{$\begin{array}{c}\text { SHRG } \\
49.30 \\
\end{array}$} & \multirow{2}{*}{$\begin{array}{c}\text { TMBR } \\
6.70 \\
\end{array}$} & \multirow{2}{*}{\begin{tabular}{|c|} 
FARM \\
6.30 \\
\end{tabular}} & \multirow{2}{*}{$\begin{array}{c}F F \\
0.80\end{array}$} \\
\hline Parameter & $\%$ Change & & & & & & & & & & & & & & & \\
\hline Kh_BCU(5) & 100 & 0.00 & 0.00 & -0.20 & 0.30 & -41.80 & 1.90 & -0.90 & 0.00 & 0.00 & 0.00 & 0.10 & 0.00 & -0.70 & 0.00 & 0.10 \\
\hline Kh_BCU(6) & 100 & -0.10 & -0.10 & -0.20 & 0.20 & -20.00 & 1.40 & -0.40 & 0.00 & 0.00 & 0.00 & 0.10 & 0.10 & -0.60 & 0.00 & 0.10 \\
\hline Kh_TBA(1) & 100 & -1.00 & -0.20 & -3.20 & 0.40 & -42.30 & 0.30 & -0.40 & 0.30 & 0.00 & -1.10 & 0.10 & 0.10 & 1.60 & -0.10 & 0.10 \\
\hline Kh_TBA(3) & 100 & 0.00 & -0.10 & -0.30 & 0.30 & -42.30 & 1.80 & 0.60 & 0.00 & 0.00 & 0.00 & 0.10 & 0.10 & -0.80 & 0.00 & 0.10 \\
\hline Kh_TBA(4) & 100 & 0.00 & -0.10 & -0.30 & 0.20 & -43.90 & 1.80 & -1.30 & 0.00 & 0.00 & 0.00 & 0.10 & 0.00 & -0.80 & 0.00 & 0.10 \\
\hline Kh_TBA(6) & 100 & 0.00 & -0.10 & -0.20 & 0.30 & -41.30 & 1.90 & -0.90 & 0.00 & 0.00 & 0.00 & 0.10 & 0.00 & -0.70 & 0.00 & 0.10 \\
\hline Kh_TCB(1) & 100 & -0.10 & 0.00 & -0.30 & 0.30 & -43.80 & 1.70 & -0.40 & 0.00 & 0.00 & -0.80 & 0.10 & 0.00 & -0.70 & 0.00 & 0.10 \\
\hline Kh_TCB(4) & 100 & -0.10 & -0.10 & -0.30 & 0.30 & -42.80 & 1.80 & -0.20 & 0.00 & 0.00 & -0.80 & 0.10 & 0.00 & -0.80 & 0.00 & 0.10 \\
\hline Kh_TCB(6) & 100 & 0.00 & -0.10 & -0.30 & 0.30 & -39.80 & 2.00 & -0.90 & 0.00 & 0.00 & 0.00 & 0.10 & 0.00 & -0.80 & 0.00 & 0.10 \\
\hline Kh_TC(1) & 100 & -5.70 & 0.10 & -15.80 & -1.00 & 0.10 & 1.30 & 1.30 & 0.00 & 0.00 & 0.00 & 0.00 & -0.10 & 1.90 & -0.10 & -0.10 \\
\hline Kh_TC(3) & 100 & 0.00 & -0.10 & -0.40 & 0.30 & -44.30 & 1.80 & -0.90 & 0.00 & 0.00 & 0.00 & 0.10 & 0.00 & -0.80 & 0.00 & 0.10 \\
\hline Kh_TC(4) & 100 & -0.30 & 0.30 & -2.70 & 0.20 & 0.70 & 0.40 & 1.00 & 0.00 & 0.20 & 0.00 & 0.10 & 0.00 & -2.40 & 0.00 & 0.10 \\
\hline Kh_TC(5) & 100 & -0.10 & 0.60 & -0.50 & 0.30 & -41.90 & 1.90 & 1.50 & 0.10 & 0.30 & 0.00 & 0.10 & 0.10 & -1.40 & 0.10 & 0.20 \\
\hline Kh_TC(6) & 100 & -0.10 & -0.10 & -0.70 & 0.20 & -44.00 & 1.80 & -0.90 & 0.00 & 0.00 & 0.00 & 0.10 & 0.00 & -0.70 & 0.00 & 0.10 \\
\hline Kh_TMA(1) & 100 & -3.00 & -0.40 & -13.80 & 0.20 & -4.60 & 1.20 & -0.10 & 0.00 & -0.30 & 0.20 & 0.10 & 0.10 & -5.70 & -0.10 & 0.10 \\
\hline Kh_TMA(2) & 100 & -0.20 & -0.10 & -2.00 & 0.10 & 1.30 & 0.40 & -0.20 & 0.00 & -0.10 & -0.10 & 0.10 & 0.00 & -3.80 & -0.10 & 0.00 \\
\hline Kh_TMA(3) & 100 & -0.50 & -0.40 & -5.20 & 0.00 & 2.70 & 0.50 & 0.00 & 0.00 & -0.30 & -0.10 & 0.00 & 0.00 & -7.30 & -0.10 & 0.00 \\
\hline Kh_TMA(4) & 100 & -1.00 & -0.40 & -9.70 & 0.00 & -3.60 & 0.50 & 0.30 & 0.00 & -0.20 & 0.00 & 0.10 & 0.00 & -7.00 & -0.10 & 0.00 \\
\hline Kh_TMA(6) & 100 & -0.40 & 0.00 & -2.10 & 0.10 & 3.80 & 0.40 & 0.90 & 0.00 & 0.00 & 0.00 & 0.10 & 0.00 & -0.60 & 0.00 & 0.10 \\
\hline Kh_AA(1) & 100 & -12.00 & -0.20 & -1.60 & -2.30 & 0.80 & 0.50 & -2.20 & -2.60 & 0.40 & -2.10 & -11.70 & 8.30 & -2.70 & 1.40 & -0.30 \\
\hline Kh_AA(2) & 100 & -0.10 & -4.50 & -0.40 & -8.20 & -4.90 & -7.10 & -5.80 & -5.00 & -4.40 & -4.30 & -2.60 & -4.30 & -0.70 & -6.00 & -8.90 \\
\hline Kh_AA(3) & 100 & 0.00 & 0.00 & 0.00 & 0.30 & -43.40 & 0.70 & -0.40 & 0.00 & 0.10 & 0.00 & -1.60 & -0.30 & -0.30 & 0.00 & 0.20 \\
\hline Kh_AA(4) & 100 & 0.00 & 0.20 & -0.20 & 0.10 & 2.50 & -2.20 & -0.70 & 0.40 & 0.00 & 0.10 & 0.10 & 0.00 & -0.40 & -0.10 & 0.00 \\
\hline Kh_AA(5) & 100 & 0.00 & -0.10 & -0.20 & 0.20 & -40.90 & 1.90 & -1.10 & 0.00 & 0.00 & 0.00 & 0.10 & 0.00 & -0.70 & 0.00 & 0.00 \\
\hline Kh_AA(6) & 100 & -0.10 & -7.80 & -0.20 & -3.00 & 4.80 & -2.10 & -1.00 & -0.10 & -2.20 & -1.50 & -0.90 & -1.60 & -0.20 & -2.50 & -3.20 \\
\hline Id_I & 10 & 0.00 & -0.10 & -0.20 & 0.20 & -41.60 & 1.80 & -0.60 & 0.00 & 0.00 & 0.00 & 0.10 & 0.00 & -0.70 & 0.00 & 0.10 \\
\hline Id_LCCU(1) & 10 & 0.50 & -0.20 & 1.30 & 0.20 & 3.90 & 0.10 & 0.30 & 0.00 & 0.00 & -0.80 & 1.30 & 0.00 & 1.90 & -0.20 & -0.30 \\
\hline Id_LCCU(2) & 10 & -0.10 & 0.00 & -0.40 & 0.10 & 4.30 & 1.40 & -0.20 & 0.00 & 0.00 & 2.40 & 1.60 & 4.20 & -0.50 & 0.00 & 0.10 \\
\hline Id_LCCU(3) & 10 & 0.00 & 1.70 & 0.00 & 0.40 & -10.00 & 0.80 & 0.40 & -2.00 & 0.30 & -0.70 & 0.50 & -0.10 & -0.10 & 0.70 & 0.30 \\
\hline Id_LCA(1) & 10 & 0.10 & 0.00 & -0.10 & 6.60 & 4.30 & 5.20 & 2.90 & 0.00 & 0.10 & 2.60 & 1.40 & 2.90 & -0.10 & -0.20 & 2.60 \\
\hline Id_LCA(2) & 10 & 0.00 & 0.50 & 0.10 & 1.60 & -32.60 & 1.80 & 0.30 & 0.20 & 0.40 & -0.10 & 0.90 & 0.60 & -0.10 & 0.50 & 1.60 \\
\hline Id_LCA(3) & 10 & 0.00 & -0.10 & -0.10 & 0.00 & 2.50 & 0.30 & 0.10 & 0.00 & 0.00 & -0.10 & 3.80 & 0.70 & -0.20 & -0.10 & 0.00 \\
\hline Id_LCA(4) & 10 & 0.00 & 0.60 & -0.10 & 1.10 & 4.20 & 1.40 & 0.20 & -1.40 & 0.40 & -0.60 & 0.70 & 0.20 & -0.20 & 0.20 & 1.00 \\
\hline
\end{tabular}


Table C-1

Changes in Mean Weighted Residuals Between Sensitivity Runs and Calibration Run

\begin{tabular}{|c|c|c|c|c|c|c|c|c|c|c|c|c|c|c|c|c|}
\hline \multicolumn{2}{|c|}{ Calibration Zones and Base Data ${ }^{a}$ : } & \multirow{2}{*}{\begin{tabular}{|c|} 
NRTH \\
5.80 \\
\end{tabular}} & \multirow{2}{*}{\begin{tabular}{|l|} 
OASI \\
38.30 \\
\end{tabular}} & \multirow{2}{*}{$\begin{array}{c}\text { PM } \\
-5.80 \\
\end{array}$} & \multirow{2}{*}{$\begin{array}{c}\text { BARR } \\
107.20 \\
\end{array}$} & \multirow{2}{*}{$\begin{array}{l}\text { WYF } \\
70.40\end{array}$} & \multirow{2}{*}{$\begin{array}{l}\text { EYF } \\
1.30\end{array}$} & \multirow{2}{*}{$\begin{array}{c}\text { SHON } \\
21.70 \\
\end{array}$} & \multirow{2}{*}{$\begin{array}{c}\text { DV } \\
22.90 \\
\end{array}$} & \multirow{2}{*}{$\begin{array}{l}\text { LCA } \\
-7.30 \\
\end{array}$} & \multirow{2}{*}{\begin{tabular}{|c|} 
PAHR \\
-9.90 \\
\end{tabular}} & \multirow{2}{*}{$\begin{array}{c}\text { SPMT } \\
-1.70 \\
\end{array}$} & \multirow{2}{*}{$\begin{array}{c}\text { SHRG } \\
49.30 \\
\end{array}$} & \multirow{2}{*}{$\begin{array}{c}\text { TMBR } \\
6.70 \\
\end{array}$} & \multirow{2}{*}{\begin{tabular}{|c|} 
FARM \\
6.30 \\
\end{tabular}} & \multirow{2}{*}{$\begin{array}{c}\text { FF } \\
0.80\end{array}$} \\
\hline Parameter & $\%$ Change & & & & & & & & & & & & & & & \\
\hline Id_LCA(5) & 10 & 1.20 & 0.30 & 0.70 & -0.70 & 2.00 & -0.10 & 0.40 & 0.00 & -0.10 & -0.90 & 0.30 & -0.50 & 0.20 & -0.20 & -0.40 \\
\hline Id_LCA(6) & 10 & 0.00 & 0.00 & -0.30 & 0.20 & -43.40 & 1.70 & -0.20 & 0.00 & 0.00 & 0.00 & 1.60 & -0.50 & -0.70 & 0.00 & 0.10 \\
\hline Id_LCA(7) & 10 & 0.50 & 0.00 & 0.90 & 0.20 & -1.00 & 0.90 & 1.80 & 0.00 & 0.10 & -0.90 & 0.40 & -0.20 & 0.10 & 0.00 & 0.10 \\
\hline Id_LCA(8) & 10 & 0.50 & -0.30 & -0.20 & 0.00 & -3.30 & -0.10 & 1.50 & 0.00 & -0.20 & 14.70 & 0.30 & -0.40 & 0.20 & -0.30 & -0.50 \\
\hline Id_LCA(9) & 10 & 0.00 & 1.00 & -0.20 & 0.60 & 2.60 & 0.90 & 1.30 & -2.20 & 0.60 & -0.60 & 0.60 & 0.00 & -0.30 & 2.10 & 0.60 \\
\hline Id_UCCU & 10 & 0.00 & 0.10 & 0.10 & 0.10 & 7.90 & 0.40 & 1.70 & 0.00 & 0.10 & -0.90 & 0.40 & -0.20 & 0.10 & 0.00 & 0.00 \\
\hline Id_LCA3 & 10 & 0.00 & 0.00 & -0.10 & 0.10 & 3.60 & 0.60 & 1.90 & 0.00 & 0.10 & -0.10 & 0.40 & -0.20 & -0.10 & 0.00 & 0.10 \\
\hline Id_TSDV(1) & 10 & 0.00 & 0.00 & -0.20 & 0.30 & -44.20 & 1.60 & -0.50 & 0.00 & 0.00 & -0.80 & 0.40 & -0.20 & -0.60 & 0.00 & 0.10 \\
\hline Id_TSDV(2) & 10 & 0.00 & 0.10 & -0.30 & 0.30 & -41.70 & 2.00 & -0.80 & 1.00 & 0.10 & 0.00 & 0.40 & -0.20 & -0.70 & 0.30 & 0.20 \\
\hline Id_VU(1) & 10 & 2.70 & -0.50 & 1.90 & -0.90 & 2.20 & -0.40 & 1.10 & 0.10 & -0.20 & -0.10 & 0.30 & -0.50 & 1.50 & -0.40 & -0.50 \\
\hline Id_VU(2) & 10 & 0.00 & 0.00 & -0.10 & 0.10 & 3.20 & 0.50 & -0.20 & 0.00 & 0.00 & 0.00 & 0.40 & -0.20 & -0.10 & 0.00 & 0.10 \\
\hline Id_VU(3) & 10 & 0.10 & -1.00 & 0.40 & 0.10 & 5.80 & 1.10 & 2.10 & 0.00 & 0.00 & -0.10 & 0.40 & -0.20 & 0.70 & -0.20 & 0.00 \\
\hline Id_VCU(1) & 10 & 0.10 & -2.60 & 0.90 & -0.10 & 3.10 & 1.30 & 4.50 & -0.10 & -1.50 & -0.10 & 0.40 & -0.30 & 3.90 & -0.40 & -0.10 \\
\hline Id_VCU(2) & 10 & 0.00 & 0.00 & -0.10 & 0.10 & 3.90 & 0.40 & -0.50 & 0.00 & 0.00 & 0.10 & 0.40 & -0.30 & -0.20 & 0.00 & 0.00 \\
\hline Id_VA(1) & 10 & 0.00 & 0.70 & 0.00 & 0.20 & -27.10 & 1.30 & 5.20 & 0.00 & 1.70 & 0.00 & 0.40 & -0.20 & 0.60 & -0.10 & 0.10 \\
\hline Id_VA(2) & 10 & -0.10 & 0.00 & -0.50 & 0.30 & 7.20 & 6.40 & -0.80 & 0.00 & 0.00 & -0.10 & 0.50 & 0.00 & -1.10 & 0.00 & 0.10 \\
\hline Id_VA(3) & 10 & 0.00 & 3.40 & -0.20 & 0.30 & -39.80 & 2.00 & -0.50 & 0.00 & 1.10 & 0.00 & 0.40 & -0.20 & -0.70 & -0.10 & 0.10 \\
\hline Id_BAQ(1) & 10 & -0.20 & 0.00 & -0.80 & 0.00 & 2.60 & 0.30 & 1.30 & 0.00 & 0.10 & -0.10 & 0.40 & -0.20 & 1.40 & 0.00 & 0.00 \\
\hline Id_BAQ(3) & 10 & 0.00 & -0.10 & -0.20 & 0.30 & -41.70 & 1.90 & -0.90 & 0.00 & 0.00 & 0.10 & 0.40 & -0.20 & -0.70 & 0.00 & 0.10 \\
\hline Id_BAQ(4) & 10 & 0.00 & 0.00 & -0.10 & 0.10 & 2.80 & 0.40 & 0.90 & 0.00 & 0.00 & 0.00 & 0.40 & -0.20 & -0.20 & 0.00 & 0.10 \\
\hline Id_BAQ(5) & 10 & 0.00 & -0.10 & -0.20 & 0.30 & -41.60 & 1.90 & -0.90 & 0.00 & 0.00 & 0.00 & 0.40 & -0.20 & -0.70 & 0.00 & 0.10 \\
\hline Id_BAQ(6) & 10 & 0.00 & -0.10 & -0.20 & 0.30 & -40.10 & 2.00 & -0.90 & 0.00 & 0.00 & 0.00 & 0.40 & -0.20 & -0.80 & 0.00 & 0.10 \\
\hline Id_BCU(1) & 10 & 0.30 & 0.00 & 1.20 & -0.10 & 5.00 & 0.30 & -0.50 & 0.00 & 0.00 & -0.90 & 0.40 & -0.30 & 0.40 & -0.10 & 0.00 \\
\hline Id_BCU(3) & 10 & 0.00 & 0.00 & -0.10 & 0.10 & 4.10 & 0.50 & -0.50 & 0.00 & 0.00 & 0.00 & 0.40 & -0.20 & -0.20 & 0.00 & 0.10 \\
\hline Id_BCU(4) & 10 & -0.10 & -0.10 & -0.20 & 0.30 & -42.30 & 1.80 & -0.10 & 0.00 & 0.00 & -0.80 & 0.40 & -0.20 & -0.80 & 0.00 & 0.10 \\
\hline Id_BCU(5) & 10 & 0.00 & -0.10 & -0.20 & 0.30 & -41.70 & 1.90 & -0.90 & 0.00 & 0.00 & 0.10 & 0.40 & -0.20 & -0.70 & 0.00 & 0.10 \\
\hline Id_BCU(6) & 10 & 0.00 & 0.00 & -0.10 & 0.10 & 4.20 & 0.50 & 0.20 & 0.00 & 0.00 & 0.00 & 0.40 & -0.20 & -0.20 & 0.00 & 0.10 \\
\hline Id_TBA(1) & 10 & 0.50 & -0.10 & 2.00 & 0.00 & -45.00 & 0.60 & -0.20 & 0.00 & -0.10 & -0.10 & 0.40 & -0.30 & -0.60 & -0.10 & 0.00 \\
\hline Id_TBA(3) & 10 & 0.00 & -0.10 & -0.20 & 0.30 & -41.30 & 1.90 & -0.90 & 0.00 & 0.00 & 0.00 & 0.40 & -0.20 & -0.70 & 0.00 & 0.10 \\
\hline Id_TBA(4) & 10 & 0.00 & 0.00 & 0.10 & 0.20 & -42.70 & 0.70 & -0.80 & 0.00 & 0.00 & 0.00 & 0.40 & -0.20 & -0.20 & 0.00 & 0.10 \\
\hline Id_TBA(6) & 10 & 0.00 & -0.10 & -0.20 & 0.30 & -39.80 & 2.00 & -0.90 & 0.00 & 0.00 & 0.00 & 0.40 & -0.20 & -0.80 & 0.00 & 0.10 \\
\hline Id_TCB(1) & 10 & 0.00 & -0.10 & -0.20 & 0.30 & -41.60 & 1.90 & -0.70 & 0.00 & 0.00 & 0.00 & 0.40 & -0.20 & -0.70 & 0.00 & 0.10 \\
\hline Id_TCB(4) & 10 & 0.00 & 0.00 & -0.10 & 0.10 & 3.90 & 0.40 & -0.50 & 0.00 & 0.00 & 0.10 & 0.40 & -0.30 & -0.20 & 0.00 & 0.00 \\
\hline
\end{tabular}


Table C-1

Changes in Mean Weighted Residuals Between Sensitivity Runs and Calibration Run

\begin{tabular}{|c|c|c|c|c|c|c|c|c|c|c|c|c|c|c|c|c|}
\hline \multicolumn{2}{|c|}{ Calibration Zones and Base Data ${ }^{a}$ : } & \multirow{2}{*}{\begin{tabular}{|c|} 
NRTH \\
5.80 \\
\end{tabular}} & \multirow{2}{*}{\begin{tabular}{|l|} 
OASI \\
38.30 \\
\end{tabular}} & \multirow{2}{*}{$\begin{array}{c}\text { PM } \\
-5.80 \\
\end{array}$} & \multirow{2}{*}{$\begin{array}{c}\text { BARR } \\
107.20\end{array}$} & \multirow{2}{*}{$\begin{array}{l}\text { WYF } \\
70.40\end{array}$} & \multirow{2}{*}{$\begin{array}{l}\text { EYF } \\
1.30\end{array}$} & \multirow{2}{*}{$\begin{array}{c}\text { SHON } \\
21.70 \\
\end{array}$} & \multirow{2}{*}{$\begin{array}{c}\text { DV } \\
22.90 \\
\end{array}$} & \multirow{2}{*}{$\begin{array}{l}\text { LCA } \\
-7.30 \\
\end{array}$} & \multirow{2}{*}{\begin{tabular}{|c|} 
PAHR \\
-9.90 \\
\end{tabular}} & \multirow{2}{*}{$\begin{array}{c}\text { SPMT } \\
-1.70 \\
\end{array}$} & \multirow{2}{*}{$\begin{array}{c}\text { SHRG } \\
49.30 \\
\end{array}$} & \multirow{2}{*}{$\begin{array}{c}\text { TMBR } \\
6.70 \\
\end{array}$} & \multirow{2}{*}{\begin{tabular}{|c|} 
FARM \\
6.30 \\
\end{tabular}} & \multirow{2}{*}{$\begin{array}{c}\text { FF } \\
0.80\end{array}$} \\
\hline Parameter & $\%$ Change & & & & & & & & & & & & & & & \\
\hline Id_TCB(6) & 10 & 0.00 & 0.00 & -0.10 & 0.10 & 2.80 & 0.40 & 0.50 & 0.00 & 0.00 & 0.00 & 0.40 & -0.20 & -0.20 & 0.00 & 0.10 \\
\hline Id_TC(1) & 10 & 3.30 & 0.10 & 9.50 & 0.50 & 2.50 & 0.60 & 0.30 & 0.10 & 0.00 & -1.10 & 0.40 & -0.20 & -2.00 & 0.00 & 0.20 \\
\hline Id_TC(3) & 10 & 0.00 & -0.10 & -0.20 & 0.30 & -41.40 & 1.90 & -0.90 & 0.00 & 0.00 & 0.00 & 0.40 & -0.20 & -0.70 & 0.00 & 0.10 \\
\hline Id_TC(4) & 10 & 0.10 & -0.20 & 1.10 & 0.10 & 4.00 & 0.40 & 0.00 & 0.00 & -0.10 & -0.10 & 0.40 & -0.20 & 0.70 & 0.00 & 0.10 \\
\hline Id_TC(5) & 10 & 0.00 & -0.30 & 0.20 & 0.10 & -35.00 & 0.20 & -1.00 & 0.00 & -0.10 & -0.10 & 0.40 & -0.20 & 0.20 & -0.10 & 0.00 \\
\hline Id_TC(6) & 10 & 0.00 & -0.10 & 0.00 & 0.20 & -41.70 & 1.80 & -0.60 & 0.00 & 0.00 & 0.00 & 0.40 & -0.20 & -0.70 & 0.00 & 0.10 \\
\hline Id_TMA(1) & 10 & 1.20 & 0.30 & 5.30 & 0.10 & 1.60 & 0.30 & 1.40 & 0.10 & 0.10 & -1.20 & 0.40 & -0.30 & 2.00 & 0.00 & 0.00 \\
\hline Id_TMA(2) & 10 & 0.10 & 0.00 & 0.90 & 0.20 & 4.90 & 0.50 & 0.20 & 0.00 & 0.10 & 0.00 & 0.40 & -0.20 & 1.70 & 0.00 & 0.10 \\
\hline Id_TMA(3) & 10 & 0.00 & 0.40 & 1.10 & 0.10 & 4.30 & 0.50 & 0.00 & 0.10 & 0.10 & 0.00 & 0.40 & -0.20 & 3.20 & 0.00 & 0.10 \\
\hline Id_TMA(4) & 10 & 0.40 & 0.40 & 3.70 & 0.10 & 3.00 & 0.40 & -0.40 & 0.10 & 0.10 & 0.00 & 0.40 & -0.20 & 2.40 & 0.10 & 0.10 \\
\hline Id_TMA(6) & 10 & 0.20 & 0.00 & 0.80 & 0.20 & -43.30 & 0.70 & -0.50 & 0.00 & 0.00 & 0.00 & 0.40 & -0.20 & -0.20 & 0.00 & 0.10 \\
\hline Id_AA(1) & 10 & 3.30 & -0.10 & 0.00 & 0.80 & 4.00 & 0.20 & 1.00 & 0.90 & 0.00 & -0.20 & 3.10 & -2.10 & 0.30 & -0.20 & 0.00 \\
\hline Id_AA(2) & 10 & -0.10 & 0.40 & -0.20 & 1.10 & -41.60 & 2.60 & 0.00 & 0.90 & 0.50 & -0.30 & 0.70 & 0.30 & -0.70 & 0.70 & 1.00 \\
\hline Id_AA(3) & 10 & 0.00 & 0.00 & -0.10 & 0.20 & 2.80 & 0.40 & 0.50 & 0.00 & 0.00 & 0.00 & 0.70 & -0.20 & -0.20 & 0.00 & 0.00 \\
\hline Id_AA(4) & 10 & -0.10 & 0.00 & -0.10 & 0.10 & 2.10 & 1.80 & -0.30 & 0.00 & 0.00 & 0.00 & 0.40 & -0.20 & -0.10 & 0.00 & 0.10 \\
\hline Id_AA(5) & 10 & 0.00 & -0.10 & -0.20 & 0.30 & -44.00 & 1.80 & -0.90 & 0.00 & 0.00 & 0.00 & 0.40 & -0.20 & -0.70 & 0.00 & 0.10 \\
\hline Id_AA(6) & 10 & 0.10 & 1.30 & 0.20 & 0.50 & -32.60 & 0.40 & -0.40 & 0.00 & 0.30 & 0.30 & 0.50 & 0.00 & 0.10 & 0.10 & 0.40 \\
\hline Kh_I & -50 & -0.10 & -0.10 & -0.30 & 0.20 & -42.00 & 1.90 & 0.10 & 0.00 & 0.00 & 0.00 & 0.10 & 0.00 & -0.90 & 0.00 & 0.10 \\
\hline Kh_LCCU(1) & -50 & 1.00 & -0.80 & 2.10 & 0.40 & 5.30 & -0.20 & 1.50 & -0.10 & -0.10 & 0.70 & 2.30 & 0.60 & 3.10 & -0.40 & -0.50 \\
\hline Kh_LCCU(2) & -50 & 0.00 & -0.20 & -0.10 & 0.10 & 2.60 & 0.30 & 1.00 & 0.00 & -0.10 & 14.10 & 3.10 & 10.70 & 0.20 & -0.10 & 0.00 \\
\hline Kh_LCCU(3) & -50 & 0.00 & 2.60 & 0.10 & 0.60 & -41.60 & 2.20 & 0.30 & -2.50 & 0.30 & -0.70 & 0.20 & 0.20 & 0.00 & 1.20 & 0.40 \\
\hline Kh_LCA(1) & -50 & 0.10 & 0.00 & 0.20 & 21.40 & 5.40 & 17.60 & 7.40 & -0.20 & 0.30 & 14.30 & 7.70 & 27.00 & 0.10 & -0.60 & 9.90 \\
\hline Kh_LCA(2) & -50 & 0.00 & 2.40 & -0.10 & 7.20 & 3.50 & 7.60 & 6.40 & 0.70 & 1.50 & 2.20 & 2.40 & 4.00 & -0.10 & 2.50 & 7.60 \\
\hline Kh_LCA(3) & -50 & -0.10 & -0.20 & -0.20 & -0.20 & -0.20 & 0.20 & 1.60 & 0.00 & -0.10 & -0.20 & 12.20 & 3.80 & -0.30 & -0.20 & -0.30 \\
\hline Kh_LCA(4) & -50 & 0.00 & 3.00 & -0.10 & 3.40 & -2.70 & 3.50 & 4.10 & -3.40 & 1.30 & -0.10 & 1.20 & 1.80 & 0.00 & 1.30 & 3.50 \\
\hline Kh_LCA(5) & -50 & 4.90 & -0.70 & 3.20 & -2.80 & 2.60 & -1.40 & -0.30 & 0.10 & -0.50 & -2.40 & -0.40 & -0.90 & 1.90 & -1.00 & -1.70 \\
\hline Kh_LCA(6) & -50 & 0.00 & -0.30 & 0.00 & 0.10 & 9.50 & 0.60 & 0.50 & 0.30 & -0.10 & 0.20 & 6.50 & -1.20 & 0.10 & -0.20 & 0.00 \\
\hline Kh_LCA(7) & -50 & 0.90 & 0.00 & 1.80 & 0.20 & 4.50 & 0.50 & 0.50 & 0.00 & 0.10 & -1.10 & 0.10 & 0.00 & 0.70 & 0.00 & 0.10 \\
\hline Kh_LCA(8) & -50 & 2.00 & -0.80 & 0.10 & -0.60 & 0.60 & -1.30 & -1.20 & -0.20 & -0.70 & 71.40 & -0.40 & -0.20 & 0.40 & -0.90 & -1.80 \\
\hline Kh_LCA(9) & -50 & 0.00 & 2.80 & 0.10 & 1.60 & 3.50 & 1.80 & 1.90 & -7.60 & 1.70 & 0.00 & 0.50 & 0.80 & 0.30 & 5.90 & 1.60 \\
\hline Kh_UCCU & -50 & 0.10 & 0.30 & 0.80 & -0.10 & -31.40 & -1.00 & -8.50 & 0.00 & 0.20 & -0.10 & 0.00 & -0.10 & 1.70 & -0.10 & -0.10 \\
\hline Kh_LCA3 & -50 & 0.00 & 0.10 & 0.20 & 0.10 & 11.10 & 0.60 & 3.40 & 0.00 & 0.10 & -0.10 & 0.00 & 0.00 & 0.60 & 0.00 & 0.00 \\
\hline Kh_TSDV(1) & -50 & 0.00 & 0.10 & -0.10 & 0.20 & 3.70 & 0.50 & -0.70 & 0.00 & 0.00 & 0.00 & 0.10 & 0.10 & -0.10 & 0.00 & 0.10 \\
\hline
\end{tabular}


Table C-1

Changes in Mean Weighted Residuals Between Sensitivity Runs and Calibration Run

\begin{tabular}{|c|c|c|c|c|c|c|c|c|c|c|c|c|c|c|c|c|}
\hline \multicolumn{2}{|c|}{ Calibration Zones and Base Data ${ }^{a}$ : } & \multirow{2}{*}{$\begin{array}{c}\text { NRTH } \\
5.80\end{array}$} & \multirow{2}{*}{$\begin{array}{l}\text { OASI } \\
38.30 \\
\end{array}$} & \multirow{2}{*}{$\begin{array}{l}\text { PM } \\
-5.80 \\
\end{array}$} & \multirow{2}{*}{$\begin{array}{l}\text { BARR } \\
107.20\end{array}$} & \multirow{2}{*}{$\begin{array}{l}\text { WYF } \\
70.40\end{array}$} & \multirow{2}{*}{$\begin{array}{c}\text { EYF } \\
1.30\end{array}$} & \multirow{2}{*}{$\begin{array}{c}\text { SHON } \\
21.70\end{array}$} & \multirow{2}{*}{$\begin{array}{c}\text { DV } \\
22.90\end{array}$} & \multirow{2}{*}{$\begin{array}{l}\text { LCA } \\
-7.30 \\
\end{array}$} & \multirow{2}{*}{$\begin{array}{c}\text { PAHR } \\
-9.90\end{array}$} & \multirow{2}{*}{$\begin{array}{c}\text { SPMT } \\
-1.70 \\
\end{array}$} & \multirow{2}{*}{$\begin{array}{c}\text { SHRG } \\
49.30\end{array}$} & \multirow{2}{*}{$\begin{array}{c}\text { TMBR } \\
6.70\end{array}$} & \multirow{2}{*}{$\begin{array}{c}\text { FARM } \\
6.30\end{array}$} & \multirow{2}{*}{$\begin{array}{c}\text { FF } \\
0.80\end{array}$} \\
\hline Parameter & $\%$ Change & & & & & & & & & & & & & & & \\
\hline Kh_TSDV(2) & -50 & 0.00 & 0.40 & 0.10 & 0.30 & -34.70 & 0.40 & -0.20 & 3.60 & 0.30 & -0.80 & 0.10 & 0.10 & -0.10 & 0.70 & 0.20 \\
\hline Kh_VU(1) & -50 & 8.10 & -0.20 & 4.40 & -3.00 & 6.90 & -1.20 & 0.00 & 0.00 & -0.30 & -0.60 & -0.30 & -0.60 & 3.90 & -0.60 & -1.20 \\
\hline Kh_VU(2) & -50 & 0.00 & -0.10 & -0.10 & 0.20 & -44.00 & 1.80 & -0.90 & 0.00 & 0.00 & 0.00 & 0.10 & 0.00 & -0.60 & 0.00 & 0.10 \\
\hline Kh_VU(3) & -50 & 0.60 & -4.50 & 4.20 & -0.10 & 4.40 & -0.10 & 1.90 & -0.30 & 0.10 & -0.20 & 0.00 & -0.10 & 8.50 & -0.80 & -0.20 \\
\hline Kh_VCU(1) & -50 & 0.30 & -9.80 & 3.30 & -0.70 & 8.70 & 0.70 & 10.70 & -0.40 & -6.80 & -0.50 & -0.20 & -0.40 & 17.20 & -1.40 & -0.80 \\
\hline Kh_VCU(2) & -50 & -0.10 & 0.00 & -0.20 & 0.10 & 2.50 & 0.40 & 0.90 & 0.00 & 0.10 & 0.00 & 0.10 & 0.00 & -0.30 & 0.00 & 0.10 \\
\hline Kh_VA(1) & -50 & 0.00 & 2.60 & 0.50 & 0.10 & -45.80 & 0.60 & -3.30 & 0.00 & 5.30 & 0.00 & 0.10 & 0.00 & 3.00 & -0.20 & 0.10 \\
\hline Kh_VA(2) & -50 & -0.10 & 0.00 & -0.40 & 0.30 & -21.20 & 6.40 & 0.50 & 0.00 & 0.00 & 0.00 & 0.10 & 0.10 & -1.20 & 0.00 & 0.20 \\
\hline Kh_VA(3) & -50 & 0.00 & 8.10 & -0.10 & 0.20 & 3.90 & 0.60 & 1.50 & -0.10 & 2.50 & 0.00 & 0.10 & 0.10 & -0.20 & -0.40 & 0.20 \\
\hline Kh_BAQ(1) & -50 & -0.20 & 0.00 & -0.10 & 0.10 & 6.30 & 0.40 & 0.90 & 0.00 & 0.00 & -1.10 & 0.10 & 0.00 & 1.80 & 0.00 & 0.10 \\
\hline Kh_BAQ(3) & -50 & 0.00 & -0.10 & -0.20 & 0.30 & -39.80 & 2.00 & -0.90 & 0.00 & 0.00 & 0.00 & 0.10 & 0.00 & -0.80 & 0.00 & 0.10 \\
\hline Kh_BAQ(4) & -50 & 0.00 & -0.10 & -0.20 & 0.20 & -42.20 & 1.70 & -0.50 & 0.00 & 0.00 & 0.00 & 0.10 & 0.00 & -0.50 & 0.00 & 0.10 \\
\hline Kh_BAQ(5) & -50 & 0.00 & 0.00 & 0.10 & 0.10 & -33.40 & 0.00 & 0.20 & 0.00 & 0.00 & -0.10 & 0.10 & 0.00 & 0.00 & 0.00 & 0.00 \\
\hline Kh_BAQ(6) & -50 & 0.00 & -0.10 & -0.20 & 0.20 & -42.40 & 1.70 & -0.50 & 0.00 & 0.00 & 0.00 & 0.10 & 0.00 & -0.70 & 0.00 & 0.10 \\
\hline Kh_BCU(1) & -50 & 0.30 & 0.00 & 1.40 & -0.10 & 7.00 & 0.60 & -0.40 & 0.00 & 0.00 & -0.90 & 0.00 & -0.10 & 0.30 & -0.10 & -0.10 \\
\hline Kh_BCU(3) & -50 & 0.00 & 0.00 & 0.10 & 0.10 & -33.10 & 0.40 & -0.20 & 0.00 & 0.00 & 0.00 & 0.10 & 0.00 & -0.10 & 0.00 & 0.10 \\
\hline Kh_BCU(4) & -50 & 0.00 & 0.00 & 0.00 & 0.20 & -44.30 & 0.80 & -0.50 & 0.00 & 0.00 & 0.00 & 0.10 & 0.00 & -0.30 & 0.00 & 0.10 \\
\hline Kh_BCU(5) & -50 & 0.00 & 0.00 & -0.10 & 0.10 & 3.20 & 0.40 & 0.00 & 0.00 & 0.00 & 0.00 & 0.10 & 0.00 & -0.20 & 0.00 & 0.10 \\
\hline Kh_BCU(6) & -50 & 0.10 & 0.00 & 0.00 & 0.00 & 0.00 & 0.00 & 0.00 & 0.00 & 0.00 & 0.00 & 0.00 & 0.00 & 0.00 & 0.00 & 0.00 \\
\hline Kh_TBA(1) & -50 & 0.80 & -0.10 & 3.20 & -0.30 & 3.60 & 0.20 & -0.30 & 0.00 & 0.00 & -0.10 & 0.00 & 0.00 & -0.60 & -0.10 & -0.10 \\
\hline Kh_TBA(3) & -50 & 0.00 & 0.00 & -0.20 & 0.10 & 2.70 & 0.40 & 1.00 & 0.00 & 0.00 & 0.00 & 0.10 & 0.00 & -0.30 & 0.00 & 0.10 \\
\hline Kh_TBA(4) & -50 & 0.00 & 0.00 & -0.10 & 0.20 & -43.00 & 1.70 & -0.60 & 0.00 & 0.00 & 0.00 & 0.10 & 0.00 & -0.60 & 0.00 & 0.10 \\
\hline Kh_TBA(6) & -50 & 0.00 & 0.00 & -0.10 & 0.20 & 1.90 & 0.40 & 0.50 & 0.00 & 0.00 & 0.00 & 0.10 & 0.00 & -0.20 & 0.00 & 0.10 \\
\hline Kh_TCB(1) & -50 & 0.00 & 0.00 & -0.10 & 0.10 & 3.80 & 0.40 & -0.40 & 0.00 & 0.00 & 0.10 & 0.00 & 0.00 & -0.20 & 0.00 & 0.00 \\
\hline Kh_TCB(4) & -50 & 0.00 & -0.10 & -0.20 & 0.20 & -41.90 & 1.80 & -0.60 & 0.00 & 0.00 & 0.00 & 0.10 & 0.00 & -0.70 & 0.00 & 0.10 \\
\hline Kh_TCB(6) & -50 & 0.00 & -0.10 & -0.30 & 0.30 & -39.80 & 2.00 & -0.90 & 0.00 & 0.00 & 0.00 & 0.10 & 0.00 & -0.80 & 0.00 & 0.10 \\
\hline Kh_TC(1) & -50 & 5.90 & -0.40 & 13.60 & 0.60 & 3.40 & 0.90 & 0.20 & 0.00 & -0.10 & -1.00 & 0.10 & 0.10 & -3.50 & 0.00 & 0.20 \\
\hline Kh_TC(3) & -50 & 0.00 & 0.00 & -0.10 & 0.30 & -43.50 & 1.70 & -0.30 & 0.00 & 0.00 & 0.00 & 0.10 & 0.00 & -0.60 & 0.00 & 0.10 \\
\hline Kh_TC(4) & -50 & 0.20 & -0.50 & 2.00 & 0.10 & 3.00 & 0.40 & -0.30 & 0.00 & -0.30 & 0.00 & 0.10 & 0.00 & 1.70 & -0.10 & 0.00 \\
\hline Kh_TC(5) & -50 & 0.00 & -0.80 & 0.10 & 0.20 & -39.40 & 2.00 & -2.90 & 0.00 & -0.40 & -0.10 & 0.10 & 0.00 & 0.00 & -0.10 & 0.00 \\
\hline Kh_TC(6) & -50 & 0.00 & -0.10 & 0.10 & 0.30 & -42.50 & 1.80 & 0.70 & 0.00 & 0.00 & 0.00 & 0.10 & 0.00 & -0.80 & 0.00 & 0.10 \\
\hline Kh_TMA(1) & -50 & 2.20 & 0.50 & 9.40 & 0.30 & 6.10 & 0.50 & 0.60 & 0.10 & 0.30 & -1.10 & 0.50 & -0.10 & 5.50 & 0.10 & 0.10 \\
\hline Kh_TMA(2) & -50 & 0.10 & 0.00 & 1.50 & 0.20 & 3.40 & 0.40 & 0.20 & 0.00 & 0.10 & -0.90 & 0.10 & 0.00 & 3.00 & 0.00 & 0.10 \\
\hline
\end{tabular}


Table C-1

Changes in Mean Weighted Residuals Between Sensitivity Runs and Calibration Run

\begin{tabular}{|c|c|c|c|c|c|c|c|c|c|c|c|c|c|c|c|c|}
\hline \multicolumn{2}{|c|}{ Calibration Zones and Base Data ${ }^{a}$ : } & \multirow{2}{*}{$\begin{array}{c}\text { NRTH } \\
5.80 \\
\end{array}$} & \multirow{2}{*}{$\begin{array}{l}\text { OASI } \\
38.30 \\
\end{array}$} & \multirow{2}{*}{$\begin{array}{c}\text { PM } \\
-5.80 \\
\end{array}$} & \multirow{2}{*}{$\begin{array}{c}\text { BARR } \\
107.20 \\
\end{array}$} & \multirow{2}{*}{$\begin{array}{l}\text { WYF } \\
70.40\end{array}$} & \multirow{2}{*}{$\begin{array}{l}\text { EYF } \\
1.30\end{array}$} & \multirow{2}{*}{$\begin{array}{c}\text { SHON } \\
21.70 \\
\end{array}$} & \multirow{2}{*}{$\frac{\text { DV }}{22.90}$} & \multirow{2}{*}{$\begin{array}{l}\text { LCA } \\
-7.30 \\
\end{array}$} & \multirow{2}{*}{\begin{tabular}{|c|} 
PAHR \\
-9.90 \\
\end{tabular}} & \multirow{2}{*}{$\begin{array}{c}\text { SPMT } \\
-1.70 \\
\end{array}$} & \multirow{2}{*}{$\begin{array}{c}\text { SHRG } \\
49.30 \\
\end{array}$} & \multirow{2}{*}{$\begin{array}{c}\text { TMBR } \\
6.70 \\
\end{array}$} & \multirow{2}{*}{\begin{tabular}{|c|} 
FARM \\
6.30 \\
\end{tabular}} & \multirow{2}{*}{$\begin{array}{c}F F \\
0.80\end{array}$} \\
\hline Parameter & $\%$ Change & & & & & & & & & & & & & & & \\
\hline Kh_TMA(3) & -50 & 0.20 & 0.40 & 3.60 & 0.20 & 5.60 & 0.40 & 1.00 & 0.10 & 0.20 & -0.80 & 0.10 & 0.00 & 7.30 & 0.10 & 0.10 \\
\hline Kh_TMA(4) & -50 & 0.80 & 0.10 & 8.50 & 0.10 & 7.90 & 0.50 & 1.70 & 0.40 & 0.20 & 0.30 & 0.10 & 0.00 & 8.20 & -0.10 & 0.10 \\
\hline Kh_TMA(6) & -50 & 0.30 & 0.00 & 1.40 & 0.20 & -43.60 & 1.80 & -0.60 & 0.00 & 0.00 & 0.00 & 0.10 & 0.00 & -0.50 & 0.00 & 0.10 \\
\hline $\mathrm{Kh} \_\mathrm{AA}(1)$ & -50 & 14.20 & 0.30 & 0.90 & 1.60 & 3.90 & 0.70 & 2.00 & 2.60 & 0.50 & 0.80 & 19.30 & -7.00 & 1.40 & -1.10 & 0.60 \\
\hline Kh_AA(2) & -50 & 0.00 & 2.20 & 0.00 & 4.40 & 3.90 & 4.50 & 3.40 & 4.40 & 2.10 & 0.50 & 1.50 & 2.40 & 0.00 & 3.00 & 4.60 \\
\hline Kh_AA(3) & -50 & 0.00 & -0.10 & -0.10 & 0.10 & 0.00 & 0.50 & 0.20 & 0.00 & 0.00 & -0.10 & 1.00 & 0.20 & -0.20 & 0.00 & 0.00 \\
\hline Kh_AA(4) & -50 & 0.00 & 0.00 & -0.10 & 0.10 & -0.10 & 2.80 & 0.40 & 0.00 & 0.00 & 0.00 & 0.10 & 0.00 & -0.10 & 0.00 & 0.10 \\
\hline Kh_AA(5) & -50 & -0.10 & -0.10 & -0.20 & 0.30 & -41.80 & 1.90 & -0.80 & 0.00 & 0.00 & -0.80 & 0.10 & 0.00 & -0.70 & 0.00 & 0.20 \\
\hline $\mathrm{Kh} \_\mathrm{AA}(6)$ & -50 & 0.00 & 7.20 & -0.10 & 2.20 & 3.80 & 2.40 & 1.90 & -0.50 & 2.30 & -0.50 & 0.70 & 1.10 & -0.10 & 0.40 & 2.20 \\
\hline Id_I & -10 & 0.00 & 0.00 & -0.10 & 0.10 & 1.10 & 0.40 & 1.10 & 0.00 & 0.10 & 0.00 & 0.10 & 0.00 & -0.20 & 0.00 & 0.10 \\
\hline Id_LCCU(1) & -10 & -0.80 & 0.10 & -2.10 & -0.40 & 1.20 & 1.00 & -0.20 & 0.10 & 0.00 & -0.90 & -0.60 & -0.50 & -3.10 & 0.20 & 0.50 \\
\hline Id_LCCU(2) & -10 & 0.00 & -0.10 & -0.20 & 0.20 & 0.20 & 1.10 & 0.90 & 0.00 & 0.00 & -7.50 & -0.70 & -3.50 & 0.00 & 0.00 & 0.10 \\
\hline Id_LCCU(3) & -10 & -0.10 & -2.50 & -0.30 & 0.00 & -41.90 & 1.60 & -1.10 & 2.00 & -0.30 & -0.10 & 0.30 & -0.40 & -0.90 & -1.00 & -0.20 \\
\hline Id_LCA(1) & -10 & 0.00 & -0.20 & -0.20 & -5.30 & -1.00 & -3.50 & -1.50 & 0.10 & -0.10 & -2.90 & -0.50 & -3.10 & 0.20 & 0.20 & -2.20 \\
\hline Id_LCA(2) & -10 & 0.00 & -0.50 & -0.10 & -1.30 & 3.90 & -0.90 & -1.70 & -0.10 & -0.30 & -0.80 & -0.10 & -1.00 & -0.30 & -0.60 & -1.50 \\
\hline Id_LCA(3) & -10 & 0.00 & 0.00 & -0.20 & 0.30 & -43.20 & 1.80 & -0.30 & 0.10 & 0.10 & 0.00 & -3.30 & -1.30 & -0.70 & 0.00 & 0.20 \\
\hline Id_LCA(4) & -10 & -0.10 & -1.00 & 0.00 & -1.10 & 3.10 & -0.70 & 0.40 & 2.00 & -0.50 & -0.40 & 0.00 & -0.90 & 0.00 & -0.30 & -1.20 \\
\hline Id_LCA(5) & -10 & -1.20 & 0.00 & -0.90 & 0.90 & 2.40 & 0.90 & 0.90 & 0.10 & 0.20 & -0.60 & 0.60 & 0.00 & -0.40 & 0.20 & 0.50 \\
\hline Id_LCA(6) & -10 & 0.00 & 0.00 & -0.20 & 0.20 & -0.60 & 0.30 & 1.80 & 0.00 & 0.00 & 0.00 & -0.50 & 0.00 & -0.20 & 0.00 & 0.10 \\
\hline Id_LCA(7) & -10 & -0.80 & 0.00 & -1.70 & 0.10 & 3.60 & 0.50 & 0.80 & 0.00 & -0.10 & 0.00 & 0.40 & -0.20 & -0.60 & 0.00 & 0.10 \\
\hline Id_LCA(8) & -10 & -0.80 & 0.30 & -0.20 & -0.20 & 4.00 & 1.10 & 1.20 & 0.10 & 0.30 & -14.70 & 0.60 & 0.00 & -0.40 & 0.30 & 0.80 \\
\hline Id_LCA(9) & -10 & -0.10 & -1.50 & -0.10 & -0.50 & 1.20 & -0.20 & 1.20 & 2.60 & -0.70 & -0.10 & 0.20 & -0.60 & 0.10 & -2.40 & -0.60 \\
\hline Id_UCCU & -10 & -0.10 & -0.10 & -0.40 & 0.20 & -2.70 & 0.40 & -0.20 & 0.00 & 0.00 & 0.10 & 0.40 & -0.20 & -0.70 & 0.00 & 0.10 \\
\hline Id_LCA3 & -10 & 0.00 & 0.00 & -0.20 & 0.20 & 1.20 & 0.30 & -0.30 & 0.00 & 0.00 & 0.00 & 0.40 & -0.20 & -0.40 & 0.00 & 0.10 \\
\hline Id_TSDV(1) & -10 & -0.10 & -0.10 & -0.20 & 0.20 & -41.10 & 1.90 & -1.20 & 0.00 & 0.00 & 0.00 & 0.40 & -0.20 & -0.70 & 0.00 & 0.10 \\
\hline Id_TSDV(2) & -10 & 0.00 & -0.20 & -0.10 & 0.10 & 3.90 & 0.40 & -0.30 & -1.10 & -0.10 & -0.10 & 0.40 & -0.30 & -0.20 & -0.50 & -0.10 \\
\hline Id_VU(1) & -10 & -3.30 & 0.40 & -2.30 & 1.00 & 3.80 & 1.40 & 1.10 & 0.10 & 0.10 & -0.70 & 0.60 & 0.10 & -1.20 & 0.30 & 0.70 \\
\hline Id_VU(2) & -10 & -0.10 & -0.10 & -0.30 & 0.30 & -41.80 & 1.90 & -0.80 & 0.00 & 0.00 & -0.80 & 0.40 & -0.20 & -0.70 & 0.00 & 0.10 \\
\hline Id_VU(3) & -10 & -0.20 & 0.90 & -0.90 & 0.10 & 0.20 & 0.40 & 1.20 & 0.40 & 0.00 & 0.30 & 0.40 & -0.20 & -1.20 & 0.00 & 0.10 \\
\hline Id_VCU(1) & -10 & -0.10 & 2.80 & -1.20 & 0.40 & -27.90 & -0.20 & -3.60 & 0.20 & 1.60 & -0.70 & 0.50 & -0.10 & -5.10 & 0.50 & 0.40 \\
\hline Id_VCU(2) & -10 & 0.00 & 0.00 & -0.10 & 0.10 & 2.60 & 0.40 & -0.10 & 0.00 & 0.00 & 0.00 & 0.40 & -0.20 & -0.20 & 0.00 & 0.10 \\
\hline Id_VA(1) & -10 & -0.10 & -1.00 & -0.40 & 0.20 & -3.90 & 0.80 & -4.60 & 0.10 & -1.60 & -0.80 & 0.40 & -0.20 & -1.70 & 0.10 & 0.10 \\
\hline Id_VA(2) & -10 & 0.00 & 0.00 & 0.10 & 0.20 & -30.30 & -0.80 & -0.10 & 0.00 & 0.00 & 0.00 & 0.40 & -0.20 & -0.30 & 0.00 & 0.10 \\
\hline
\end{tabular}


Table C-1

Changes in Mean Weighted Residuals Between Sensitivity Runs and Calibration Run

\begin{tabular}{|c|c|c|c|c|c|c|c|c|c|c|c|c|c|c|c|c|}
\hline \multicolumn{2}{|c|}{ Calibration Zones and Base Data ${ }^{a}$ : } & \multirow{2}{*}{\begin{tabular}{|c|} 
NRTH \\
5.80 \\
\end{tabular}} & \multirow{2}{*}{$\begin{array}{l}\text { OASI } \\
38.30 \\
\end{array}$} & \multirow{2}{*}{$\begin{array}{c}\text { PM } \\
-5.80\end{array}$} & \multirow{2}{*}{\begin{tabular}{|c|} 
BARR \\
107.20 \\
\end{tabular}} & \multirow{2}{*}{$\begin{array}{l}\text { WYF } \\
70.40\end{array}$} & \multirow{2}{*}{$\begin{array}{l}\text { EYF } \\
1.30\end{array}$} & \multirow{2}{*}{$\begin{array}{c}\text { SHON } \\
21.70 \\
\end{array}$} & \multirow{2}{*}{$\begin{array}{c}\text { DV } \\
22.90\end{array}$} & \multirow{2}{*}{$\begin{array}{l}\text { LCA } \\
-7.30\end{array}$} & \multirow{2}{*}{$\begin{array}{c}\text { PAHR } \\
-9.90 \\
\end{array}$} & \multirow{2}{*}{$\begin{array}{c}\text { SPMT } \\
-1.70 \\
\end{array}$} & \multirow{2}{*}{$\begin{array}{c}\text { SHRG } \\
49.30 \\
\end{array}$} & \multirow{2}{*}{$\begin{array}{c}\text { TMBR } \\
6.70 \\
\end{array}$} & \multirow{2}{*}{\begin{tabular}{|c|} 
FARM \\
6.30 \\
\end{tabular}} & \multirow{2}{*}{$\begin{array}{c}F F \\
0.80\end{array}$} \\
\hline Parameter & $\%$ Change & & & & & & & & & & & & & & & \\
\hline Id_VA(3) & -10 & 0.00 & -3.60 & -0.20 & 0.20 & -43.10 & 1.70 & -0.60 & 0.10 & -1.10 & 0.00 & 0.40 & -0.20 & -0.60 & 0.10 & 0.10 \\
\hline Id_BAQ(1) & -10 & -0.20 & 0.00 & -1.40 & 0.10 & 1.80 & 0.40 & -0.20 & 0.20 & 0.10 & 0.00 & 0.40 & -0.20 & 0.00 & 0.00 & 0.10 \\
\hline Id_BAQ(3) & -10 & 0.00 & -0.10 & -0.20 & 0.20 & -41.90 & 1.80 & -0.60 & 0.00 & 0.00 & 0.00 & 0.40 & -0.20 & -0.70 & 0.00 & 0.10 \\
\hline Id_BAQ(4) & -10 & 0.00 & 0.00 & 0.00 & 0.10 & 1.10 & 0.10 & 0.00 & 0.00 & 0.10 & -0.10 & 0.40 & -0.20 & -0.10 & 0.00 & 0.00 \\
\hline Id_BAQ(5) & -10 & 0.00 & 0.00 & -0.10 & 0.10 & 3.60 & 0.40 & 0.90 & 0.00 & 0.00 & 0.00 & 0.40 & -0.20 & -0.30 & 0.00 & 0.10 \\
\hline Id_BAQ(6) & -10 & -0.10 & 0.00 & -0.20 & 0.10 & 2.40 & 0.40 & 1.00 & 0.00 & 0.10 & 0.00 & 0.40 & -0.20 & -0.30 & 0.00 & 0.10 \\
\hline Id_BCU(1) & -10 & -0.50 & -0.10 & -2.10 & 0.50 & 4.10 & 0.90 & 0.70 & 0.10 & 0.10 & 0.10 & 0.50 & -0.10 & -1.20 & 0.10 & 0.30 \\
\hline Id_BCU(3) & -10 & 0.00 & 0.00 & 0.10 & 0.10 & -48.10 & 0.60 & -0.40 & 0.00 & 0.00 & 0.00 & 0.40 & -0.20 & -0.20 & 0.00 & 0.10 \\
\hline Id_BCU(4) & -10 & 0.00 & -0.10 & -0.30 & 0.20 & -39.30 & 2.10 & -0.90 & 0.00 & 0.00 & 0.00 & 0.40 & -0.20 & -0.80 & 0.00 & 0.10 \\
\hline Id_BCU(5) & -10 & 0.00 & 0.00 & -0.20 & 0.30 & -41.70 & 1.90 & -0.90 & 0.00 & 0.00 & 0.00 & 0.40 & -0.20 & -0.80 & 0.00 & 0.10 \\
\hline Id_BCU(6) & -10 & -0.10 & 0.00 & -0.20 & 0.10 & 2.40 & 0.40 & 1.00 & 0.00 & 0.00 & 0.00 & 0.40 & -0.20 & -0.30 & 0.00 & 0.10 \\
\hline Id_TBA(1) & -10 & -0.70 & -0.20 & -2.20 & 0.20 & 1.40 & 0.40 & 0.80 & 0.30 & 0.00 & 0.30 & 0.40 & -0.20 & 1.10 & -0.20 & 0.10 \\
\hline Id_TBA(3) & -10 & 0.00 & -0.10 & -0.20 & 0.30 & -41.90 & 1.80 & -0.60 & 0.00 & 0.00 & 0.00 & 0.40 & -0.20 & -0.70 & 0.00 & 0.10 \\
\hline Id_TBA(4) & -10 & -0.10 & -0.10 & -0.30 & 0.30 & -41.50 & 1.90 & -0.80 & 0.00 & 0.00 & -0.80 & 0.40 & -0.20 & -0.80 & 0.00 & 0.10 \\
\hline Id_TBA(6) & -10 & 0.00 & -0.10 & -0.20 & 0.30 & -41.30 & 1.90 & -0.90 & 0.00 & 0.00 & 0.00 & 0.40 & -0.20 & -0.70 & 0.00 & 0.10 \\
\hline Id_TCB(1) & -10 & -0.10 & 0.00 & -0.10 & 0.10 & 1.70 & 0.40 & 0.10 & 0.00 & 0.10 & 0.00 & 0.40 & -0.20 & -0.10 & 0.00 & 0.10 \\
\hline Id_TCB(4) & -10 & 0.00 & 0.00 & 0.00 & 0.20 & -42.60 & 0.70 & -0.80 & 0.00 & 0.00 & 0.00 & 0.40 & -0.20 & -0.30 & 0.00 & 0.10 \\
\hline Id_TCB(6) & -10 & 0.00 & -0.10 & -0.20 & 0.20 & -44.10 & 1.80 & -0.90 & 0.00 & 0.00 & 0.00 & 0.40 & -0.20 & -0.70 & 0.00 & 0.10 \\
\hline Id_TC(1) & -10 & -3.50 & 0.10 & -10.90 & -0.30 & 3.00 & 0.20 & 1.30 & 0.00 & 0.10 & -0.10 & 0.40 & -0.30 & 1.40 & -0.10 & -0.10 \\
\hline Id_TC(3) & -10 & -0.10 & 0.00 & -0.30 & 0.10 & 3.60 & 0.40 & 0.50 & 0.00 & 0.00 & 0.00 & 0.40 & -0.20 & -0.40 & 0.00 & 0.10 \\
\hline Id_TC(4) & -10 & -0.20 & 0.10 & -1.60 & 0.20 & 2.60 & 0.40 & 1.20 & 0.00 & 0.10 & 0.20 & 0.40 & -0.20 & -1.40 & 0.00 & 0.10 \\
\hline Id_TC(5) & -10 & 0.00 & 0.20 & -0.40 & 0.30 & -42.10 & 1.90 & 0.40 & 0.10 & 0.20 & 0.00 & 0.40 & -0.20 & -1.10 & 0.00 & 0.10 \\
\hline Id_TC(6) & -10 & -0.10 & -0.10 & -0.50 & 0.20 & -41.70 & 1.80 & -0.60 & 0.00 & 0.00 & 0.00 & 0.40 & -0.20 & -0.70 & 0.00 & 0.10 \\
\hline Id_TMA(1) & -10 & -1.50 & -0.50 & -7.00 & 0.30 & 1.00 & 0.60 & 0.40 & 0.00 & -0.20 & 0.00 & 0.40 & -0.10 & -3.80 & 0.00 & 0.20 \\
\hline Id_TMA(2) & -10 & -0.20 & -0.10 & -1.20 & 0.10 & 3.00 & 0.40 & 0.70 & 0.00 & -0.10 & -0.90 & 0.40 & -0.20 & -2.30 & 0.00 & 0.10 \\
\hline Id_TMA(3) & -10 & -0.20 & -0.20 & -2.10 & 0.10 & -0.50 & 0.30 & -0.30 & 0.00 & -0.10 & -0.10 & 0.40 & -0.20 & -3.40 & -0.10 & 0.00 \\
\hline Id_TMA(4) & -10 & -0.40 & -0.30 & -3.90 & 0.10 & -0.20 & 0.40 & 0.30 & 0.00 & -0.10 & -0.10 & 0.40 & -0.20 & -2.90 & -0.10 & 0.10 \\
\hline Id_TMA(6) & -10 & -0.20 & 0.00 & -0.80 & 0.20 & -44.20 & 0.80 & -0.90 & 0.00 & 0.00 & 0.00 & 0.40 & -0.20 & -0.40 & 0.00 & 0.10 \\
\hline Id_AA(1) & -10 & -3.50 & 0.00 & -0.30 & -1.40 & 7.40 & 1.10 & 0.10 & -1.10 & 0.00 & -1.20 & -2.30 & 1.60 & -0.40 & 0.20 & 0.10 \\
\hline Id_AA(2) & -10 & 0.00 & -0.60 & 0.00 & -0.80 & -44.30 & -0.10 & -1.60 & -0.90 & -0.50 & -0.60 & 0.10 & -0.80 & -0.30 & -0.70 & -1.00 \\
\hline Id_AA(3) & -10 & 0.00 & 0.00 & -0.10 & 0.10 & 3.60 & 0.50 & -0.40 & 0.00 & 0.00 & 0.00 & 0.10 & -0.30 & -0.20 & 0.00 & 0.10 \\
\hline Id_AA(4) & -10 & 0.00 & 0.00 & 0.10 & 0.10 & -26.10 & -0.90 & 0.30 & 0.00 & 0.00 & 0.00 & 0.40 & -0.20 & -0.30 & 0.00 & 0.10 \\
\hline Id_AA(5) & -10 & 0.00 & 0.00 & -0.10 & 0.10 & 3.80 & 0.40 & -0.30 & 0.00 & 0.00 & 0.00 & 0.40 & -0.30 & -0.20 & 0.00 & 0.00 \\
\hline Id_AA(6) & -10 & -0.10 & -1.50 & -0.30 & -0.20 & -41.90 & 1.40 & -1.20 & 0.10 & -0.30 & -0.30 & 0.30 & -0.50 & -0.80 & -0.20 & -0.40 \\
\hline
\end{tabular}


Table C-2

Percentage Change in Roots Mean Square of Mean Weighted Residuals Between Sensitivity Runs and Calibration Run

\begin{tabular}{|c|c|c|c|c|c|c|c|c|c|c|c|c|c|c|c|c|}
\hline \multicolumn{2}{|c|}{ Calibration Zones and Base Data ${ }^{a}$ : } & \multirow{2}{*}{\begin{tabular}{|c|} 
NRTH \\
42.90 \\
\end{tabular}} & \multirow{2}{*}{\begin{tabular}{|l|} 
OASI \\
72.20 \\
\end{tabular}} & \multirow{2}{*}{$\begin{array}{c}\text { PM } \\
35.70\end{array}$} & \multirow{2}{*}{$\begin{array}{c}\text { BARR } \\
146.80\end{array}$} & \multirow{2}{*}{$\begin{array}{c}\text { WYF } \\
139.50\end{array}$} & \multirow{2}{*}{$\begin{array}{c}\text { EYF } \\
22.90\end{array}$} & \multirow{2}{*}{\begin{tabular}{|c|} 
SHON \\
80.50
\end{tabular}} & \multirow{2}{*}{$\begin{array}{c}\text { DV } \\
41.00\end{array}$} & \multirow{2}{*}{$\begin{array}{l}\text { LCA } \\
28.80\end{array}$} & \multirow{2}{*}{$\begin{array}{c}\text { PAHR } \\
11.40\end{array}$} & \multirow{2}{*}{\begin{tabular}{|c|} 
SPMT \\
53.30
\end{tabular}} & \multirow{2}{*}{\begin{tabular}{|c|} 
SHRG \\
47.30
\end{tabular}} & \multirow{2}{*}{\begin{tabular}{|c|} 
TMBR \\
61.00
\end{tabular}} & \multirow{2}{*}{\begin{tabular}{|c|} 
FARM \\
9.00
\end{tabular}} & \multirow{2}{*}{$\begin{array}{c}\text { FF } \\
5.20\end{array}$} \\
\hline Parameter & $\%$ Change & & & & & & & & & & & & & & & \\
\hline Kh_I & 100 & 0.00 & 0.00 & 0.00 & -0.07 & -0.86 & 0.44 & 0.37 & 0.00 & 0.00 & 0.00 & 0.00 & -0.21 & 0.16 & 0.00 & 0.00 \\
\hline $\mathrm{Kh} \_\mathrm{LCCU}(1)$ & 100 & 0.93 & -1.94 & -0.28 & -0.34 & -0.57 & -0.87 & -1.61 & -0.98 & -2.08 & -30.70 & -2.44 & 2.11 & 1.64 & -5.56 & 0.00 \\
\hline Kh_LCCU(2) & 100 & 0.00 & 0.00 & 0.00 & -0.14 & -11.18 & 1.75 & 0.37 & 0.00 & -0.69 & 62.28 & -1.50 & 27.48 & 0.49 & 0.00 & 0.00 \\
\hline Kh_LCCU(3) & 100 & 0.00 & 15.10 & -0.28 & 0.34 & 3.08 & 4.37 & 0.75 & 10.49 & -3.13 & -5.26 & 0.00 & 1.06 & 0.16 & 31.11 & 5.77 \\
\hline Kh_LCA(1) & 100 & 0.23 & 0.28 & 0.00 & 5.65 & -0.50 & 12.23 & 4.22 & 0.98 & -0.69 & -64.04 & 2.06 & 48.41 & 0.16 & -3.33 & 55.77 \\
\hline Kh_LCA(2) & 100 & -0.23 & 1.25 & 0.00 & 2.38 & 7.60 & 6.11 & 3.35 & 2.20 & -3.47 & -21.05 & 0.56 & 5.50 & 0.33 & 16.67 & 57.69 \\
\hline Kh_LCA(3) & 100 & 0.00 & -0.14 & 0.00 & -0.27 & -1.51 & 0.44 & 0.12 & -0.24 & 0.35 & -6.14 & -3.00 & 13.95 & 0.00 & -2.22 & 0.00 \\
\hline Kh_LCA(4) & 100 & 0.00 & 2.91 & 0.00 & 2.52 & -0.65 & 5.68 & 3.98 & -8.54 & -3.82 & -21.93 & 0.56 & 5.50 & 0.16 & 16.67 & 59.62 \\
\hline Kh_LCA(5) & 100 & -0.93 & -0.28 & -1.12 & -1.09 & -1.22 & 0.00 & -0.62 & 0.98 & 0.00 & 18.42 & 0.38 & -1.90 & 0.66 & -3.33 & 1.92 \\
\hline Kh_LCA(6) & 100 & 0.00 & 0.00 & 0.00 & -0.07 & 1.43 & 0.87 & 0.87 & 0.00 & 0.00 & -7.02 & -3.56 & -0.63 & 0.16 & 0.00 & 0.00 \\
\hline Kh_LCA(7) & 100 & 5.36 & 0.00 & -1.40 & 0.00 & -1.29 & 0.44 & 0.12 & 0.00 & -0.35 & -0.88 & 0.00 & 0.00 & 0.49 & 0.00 & 0.00 \\
\hline Kh_LCA(8) & 100 & -0.93 & -0.69 & -0.28 & -0.89 & -1.36 & 0.00 & -1.37 & -1.46 & 1.04 & 342.98 & -0.38 & 0.63 & 0.16 & -7.78 & 5.77 \\
\hline Kh_LCA(9) & 100 & 0.00 & 2.49 & 0.00 & 0.89 & -5.52 & 2.18 & 1.74 & 6.34 & -2.43 & -7.89 & 0.19 & 1.90 & 0.16 & 76.67 & 13.46 \\
\hline Kh_UCCU & 100 & 0.23 & 0.14 & -0.28 & -0.20 & -6.09 & 4.37 & -1.86 & 0.00 & -1.39 & -7.02 & 0.00 & -0.21 & 0.66 & 0.00 & 0.00 \\
\hline Kh_LCA3 & 100 & 0.00 & 0.00 & 0.00 & -0.07 & 10.18 & -0.44 & -0.37 & 0.00 & -0.69 & -7.02 & 0.00 & 0.00 & 0.00 & 0.00 & 0.00 \\
\hline Kh_TSDV(1) & 100 & 0.00 & 0.14 & 0.00 & 0.00 & -1.72 & 0.44 & 0.37 & 0.00 & -0.35 & -1.75 & 0.00 & 0.00 & 0.00 & 1.11 & 1.92 \\
\hline Kh_TSDV(2) & 100 & 0.00 & 0.42 & 0.00 & 0.00 & 3.15 & 4.37 & 0.00 & 15.12 & -0.69 & -1.75 & 0.00 & 0.21 & 0.16 & 10.00 & 1.92 \\
\hline Kh_VU(1) & 100 & 18.41 & -0.55 & 0.00 & -1.63 & -1.22 & -0.44 & -1.74 & 0.24 & -0.69 & -7.02 & 0.19 & -1.48 & 1.48 & -5.56 & 1.92 \\
\hline Kh_VU(2) & 100 & 0.23 & 0.00 & -0.28 & -0.07 & 2.72 & 4.37 & -0.50 & 0.00 & -0.35 & 0.00 & 0.00 & 0.00 & 0.16 & 0.00 & 0.00 \\
\hline Kh_VU(3) & 100 & 3.50 & -8.59 & -0.84 & -0.14 & 0.00 & 0.44 & -3.35 & -1.46 & -2.08 & -7.02 & 0.00 & -0.42 & 1.48 & -8.89 & 0.00 \\
\hline Kh_VCU(1) & 100 & 1.40 & -6.65 & -1.40 & -0.41 & 2.44 & -1.31 & -3.60 & -1.95 & 34.38 & -4.39 & -0.19 & -1.06 & -0.16 & -12.22 & 0.00 \\
\hline Kh_VCU(2) & 100 & 0.00 & 0.00 & 0.00 & -0.07 & 1.36 & 4.80 & -0.50 & 0.00 & -0.35 & -0.88 & 0.00 & 0.00 & 0.16 & 0.00 & 0.00 \\
\hline Kh_VA(1) & 100 & -0.47 & 2.77 & 0.56 & 0.07 & -1.86 & 0.44 & 10.56 & 0.24 & -42.36 & -1.75 & 0.00 & 0.21 & 4.26 & 1.11 & 1.92 \\
\hline Kh_VA(2) & 100 & 0.00 & 0.00 & 0.00 & -0.07 & 1.15 & -3.06 & 1.49 & 0.00 & 0.00 & -0.88 & 0.00 & 0.00 & 0.16 & 0.00 & 0.00 \\
\hline Kh_VA(3) & 100 & 0.00 & 11.22 & 0.00 & -0.07 & 1.36 & 4.80 & -0.75 & -0.49 & -15.63 & -0.88 & 0.00 & 0.00 & 0.16 & -3.33 & 0.00 \\
\hline Kh_BAQ(1) & 100 & 0.70 & -0.14 & 0.56 & -0.07 & -2.08 & 1.31 & 0.62 & 0.00 & 0.35 & -0.88 & 0.00 & 0.00 & 2.95 & 0.00 & 0.00 \\
\hline Kh_BAQ(3) & 100 & -0.23 & 0.00 & 0.00 & -0.07 & 5.45 & 1.31 & -0.25 & 0.00 & 0.00 & 0.00 & 0.00 & 0.00 & 0.00 & 0.00 & 0.00 \\
\hline Kh_BAQ(4) & 100 & 0.00 & 0.00 & 0.00 & -0.07 & 3.73 & 3.93 & -0.37 & 0.00 & -0.35 & -0.88 & 0.00 & 0.00 & 0.98 & 0.00 & 0.00 \\
\hline Kh_BAQ(5) & 100 & -0.23 & 0.00 & 0.00 & -0.07 & 1.65 & 0.87 & 0.62 & 0.00 & 0.00 & -0.88 & 0.00 & 0.00 & 0.00 & 0.00 & 0.00 \\
\hline Kh_BAQ(6) & 100 & 0.00 & 0.00 & 0.00 & -0.07 & -1.43 & 0.44 & 0.12 & 0.00 & 0.00 & -0.88 & 0.00 & 0.00 & 0.00 & 0.00 & 0.00 \\
\hline Kh_BCU(1) & 100 & 1.40 & 0.00 & -0.28 & -0.34 & -1.86 & 0.00 & 0.00 & -0.24 & -0.35 & 0.00 & 0.00 & -0.42 & 0.33 & 0.00 & 0.00 \\
\hline $\mathrm{Kh} \_\mathrm{BCU}(3)$ & 100 & 0.00 & 0.00 & 0.00 & 0.00 & -8.10 & -0.44 & -0.25 & 0.00 & 0.00 & 0.00 & 0.00 & 0.00 & -0.16 & 0.00 & 1.92 \\
\hline
\end{tabular}

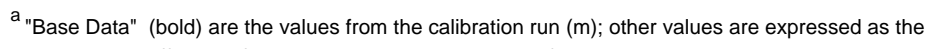


Table C-2

Percentage Change in Roots Mean Square of Mean Weighted Residuals Between Sensitivity Runs and Calibration Run

\begin{tabular}{|c|c|c|c|c|c|c|c|c|c|c|c|c|c|c|c|c|}
\hline \multicolumn{2}{|c|}{ Calibration Zones and Base Data ${ }^{\mathrm{a}}$ : } & \multirow{2}{*}{\begin{tabular}{|c|} 
NRTH \\
42.90 \\
\end{tabular}} & \multirow{2}{*}{\begin{tabular}{|l|} 
OASI \\
72.20 \\
\end{tabular}} & \multirow{2}{*}{$\begin{array}{c}\text { PM } \\
35.70\end{array}$} & \multirow{2}{*}{$\begin{array}{c}\text { BARR } \\
146.80\end{array}$} & \multirow{2}{*}{$\begin{array}{c}\text { WYF } \\
139.50\end{array}$} & \multirow{2}{*}{$\begin{array}{c}\text { EYF } \\
22.90\end{array}$} & \multirow{2}{*}{\begin{tabular}{|c|} 
SHON \\
80.50
\end{tabular}} & \multirow{2}{*}{$\begin{array}{c}\text { DV } \\
41.00\end{array}$} & \multirow{2}{*}{$\begin{array}{l}\text { LCA } \\
28.80\end{array}$} & \multirow{2}{*}{$\begin{array}{c}\text { PAHR } \\
11.40\end{array}$} & \multirow{2}{*}{\begin{tabular}{|c|} 
SPMT \\
53.30 \\
\end{tabular}} & \multirow{2}{*}{$\begin{array}{c}\text { SHRG } \\
47.30\end{array}$} & \multirow{2}{*}{$\begin{array}{c}\text { TMBR } \\
61.00\end{array}$} & \multirow{2}{*}{\begin{tabular}{|c|} 
FARM \\
9.00 \\
\end{tabular}} & \multirow{2}{*}{$\begin{array}{c}\text { FF } \\
5.20\end{array}$} \\
\hline Parameter & $\%$ Change & & & & & & & & & & & & & & & \\
\hline Kh_BCU(4) & 100 & 0.00 & 0.00 & 0.00 & -0.07 & 3.08 & 3.93 & -0.37 & 0.00 & -0.35 & -0.88 & 0.00 & 0.00 & 0.16 & 0.00 & 0.00 \\
\hline Kh_BCU(5) & 100 & 0.00 & 0.00 & 0.00 & -0.07 & 2.72 & 4.37 & -0.50 & 0.00 & -0.35 & -0.88 & 0.00 & 0.00 & 0.16 & 0.00 & 0.00 \\
\hline Kh_BCU(6) & 100 & 0.23 & 0.00 & -0.28 & -0.07 & 0.86 & 3.06 & -0.25 & 0.00 & -0.35 & -0.88 & 0.00 & -0.21 & 0.16 & 0.00 & 0.00 \\
\hline Kh_TBA(1) & 100 & 2.56 & -0.14 & 1.40 & -0.20 & 1.36 & 0.00 & 0.12 & 3.17 & 0.00 & -9.65 & 0.00 & -0.21 & -1.48 & 1.11 & 0.00 \\
\hline Kh_TBA(3) & 100 & 0.00 & 0.00 & -0.28 & -0.07 & 3.01 & 4.37 & 0.12 & 0.00 & -0.35 & -0.88 & 0.00 & -0.21 & 0.16 & 0.00 & 0.00 \\
\hline Kh_TBA(4) & 100 & 0.00 & 0.00 & 0.00 & -0.07 & 4.80 & 3.93 & -0.62 & 0.00 & -0.35 & -0.88 & 0.00 & 0.00 & 0.66 & 0.00 & 0.00 \\
\hline Kh_TBA(6) & 100 & 0.00 & 0.00 & -0.28 & -0.07 & 2.37 & 4.37 & -0.50 & 0.00 & -0.35 & -0.88 & 0.00 & 0.00 & 0.16 & 0.00 & 0.00 \\
\hline Kh_TCB(1) & 100 & 0.00 & 0.00 & 0.00 & -0.07 & 4.09 & 3.93 & -0.37 & 0.00 & 0.00 & -7.02 & 0.00 & 0.00 & 0.16 & 0.00 & 0.00 \\
\hline Kh_TCB(4) & 100 & 0.00 & 0.00 & 0.00 & -0.14 & 3.37 & 3.93 & -0.25 & 0.00 & -0.35 & -7.02 & 0.00 & 0.00 & 0.16 & 0.00 & 0.00 \\
\hline Kh_TCB(6) & 100 & 0.00 & 0.00 & 0.00 & -0.07 & 1.36 & 4.80 & -0.50 & 0.00 & -0.35 & -0.88 & 0.00 & 0.00 & 0.16 & 0.00 & 0.00 \\
\hline Kh_TC(1) & 100 & 21.91 & -0.28 & 10.08 & 0.20 & -7.17 & 3.49 & 1.24 & 0.00 & 0.35 & -0.88 & 0.00 & 0.21 & 0.98 & 1.11 & 1.92 \\
\hline Kh_TC(3) & 100 & 0.00 & 0.00 & -0.28 & -0.07 & 5.02 & 3.93 & -0.50 & 0.00 & -0.35 & -0.88 & 0.00 & 0.00 & 0.16 & 0.00 & 0.00 \\
\hline Kh_TC(4) & 100 & 0.93 & -0.28 & -1.40 & -0.07 & -1.08 & 0.44 & 0.99 & 0.00 & 1.04 & 0.00 & 0.00 & 0.00 & 1.48 & 0.00 & 0.00 \\
\hline Kh_TC(5) & 100 & 0.00 & -0.83 & -0.28 & -0.14 & 2.72 & 4.37 & 1.74 & -0.24 & 1.74 & -0.88 & 0.00 & -0.21 & 0.33 & -1.11 & 0.00 \\
\hline Kh_TC(6) & 100 & 0.23 & 0.00 & 0.28 & -0.07 & 4.87 & 3.93 & -0.50 & 0.00 & -0.35 & -0.88 & 0.00 & 0.00 & 0.16 & 0.00 & 0.00 \\
\hline Kh_TMA(1) & 100 & 11.19 & -0.28 & -0.84 & -0.07 & 1.15 & 2.62 & -0.62 & 0.00 & -2.08 & 0.88 & 0.00 & -0.21 & 3.11 & 1.11 & 0.00 \\
\hline Kh_TMA(2) & 100 & 0.70 & 0.00 & -1.12 & 0.00 & -1.08 & 0.44 & -0.12 & 0.00 & -1.04 & -0.88 & 0.00 & 0.00 & 2.46 & 1.11 & 0.00 \\
\hline Kh_TMA(3) & 100 & 1.63 & 0.00 & -0.84 & 0.00 & -3.30 & 0.87 & 0.00 & 0.24 & -1.74 & -1.75 & 0.00 & 0.00 & 5.57 & 1.11 & 1.92 \\
\hline Kh_TMA(4) & 100 & 3.50 & -0.14 & -1.68 & 0.00 & 2.29 & 0.87 & -0.25 & 0.24 & -1.39 & -0.88 & 0.00 & 0.00 & 6.72 & 1.11 & 0.00 \\
\hline Kh_TMA(6) & 100 & 1.63 & 0.00 & 0.84 & -0.07 & -1.00 & 0.44 & 0.37 & 0.00 & 0.00 & -0.88 & 0.00 & 0.00 & 0.33 & 0.00 & 0.00 \\
\hline Kh_AA(1) & 100 & 26.57 & 0.14 & -0.56 & 0.14 & -1.36 & 0.44 & -1.37 & 5.85 & -3.13 & -17.54 & -2.81 & -17.55 & 1.15 & -8.89 & 1.92 \\
\hline Kh_AA(2) & 100 & 0.00 & 3.19 & 0.00 & 3.95 & 6.95 & 10.48 & 5.47 & 11.22 & -2.78 & -35.09 & 0.94 & 8.67 & 0.16 & 55.56 & 111.54 \\
\hline Kh_AA(3) & 100 & 0.00 & -0.14 & 0.00 & -0.14 & 5.73 & 1.31 & -0.25 & 0.00 & 0.00 & 0.00 & -1.31 & 0.63 & 0.00 & 0.00 & 0.00 \\
\hline Kh_AA(4) & 100 & 0.00 & -0.28 & 0.00 & -0.07 & 2.72 & -2.62 & -0.25 & 2.68 & -0.35 & 0.00 & 0.00 & 0.00 & 0.16 & 1.11 & 0.00 \\
\hline Kh_AA(5) & 100 & 0.00 & 0.00 & 0.00 & -0.07 & 2.08 & 4.37 & -0.62 & 0.00 & -0.35 & -0.88 & 0.00 & 0.00 & 0.16 & 0.00 & 1.92 \\
\hline Kh_AA(6) & 100 & 0.00 & 6.09 & 0.00 & 1.43 & -2.44 & 3.49 & 2.61 & 0.24 & -4.86 & -13.16 & 0.19 & 3.17 & 0.16 & 16.67 & 26.92 \\
\hline Id_I & 10 & 0.00 & 0.00 & 0.00 & -0.07 & 2.87 & 4.37 & -0.37 & 0.00 & -0.35 & -0.88 & 0.00 & 0.00 & 0.16 & 0.00 & 0.00 \\
\hline Id_LCCU(1) & 10 & -0.47 & 0.28 & 0.28 & 0.07 & -1.72 & 0.87 & 0.75 & 0.24 & 0.69 & -7.02 & 1.13 & 0.00 & -0.16 & 2.22 & 1.92 \\
\hline Id_LCCU(2) & 10 & 0.23 & 0.00 & 0.00 & -0.07 & -2.29 & 3.06 & -0.12 & 0.00 & 0.00 & 18.42 & 0.94 & -9.30 & 0.16 & 0.00 & 0.00 \\
\hline Id_LCCU(3) & 10 & 0.00 & -2.91 & 0.00 & -0.14 & -18.14 & 0.87 & 0.00 & -1.22 & 0.35 & -6.14 & 0.38 & 0.21 & 0.00 & -6.67 & 0.00 \\
\hline Id_LCA(1) & 10 & 0.00 & -0.14 & 0.00 & -3.00 & -2.65 & 0.00 & -1.37 & 0.24 & 0.35 & 21.05 & 0.19 & -5.92 & 0.00 & 2.22 & 5.77 \\
\hline Id_LCA(2) & 10 & -0.23 & -0.42 & 0.00 & -0.75 & -8.39 & 0.00 & -1.24 & -0.73 & 0.69 & -0.88 & 0.38 & -1.06 & 0.00 & -4.44 & 1.92 \\
\hline
\end{tabular}

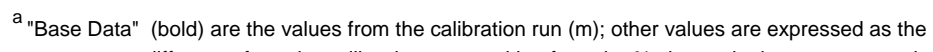

percentage difference from the calibration run resulting from the $\%$ change in the parameter value. 
Table C-2

Percentage Change in Roots Mean Square of Mean Weighted Residuals Between Sensitivity Runs and Calibration Run

\begin{tabular}{|c|c|c|c|c|c|c|c|c|c|c|c|c|c|c|c|c|}
\hline \multicolumn{2}{|c|}{ Calibration Zones and Base Data ${ }^{a}$ : } & \multirow{2}{*}{\begin{tabular}{|c|} 
NRTH \\
42.90 \\
\end{tabular}} & \multirow{2}{*}{\begin{tabular}{|l|} 
OASI \\
72.20 \\
\end{tabular}} & \multirow{2}{*}{$\begin{array}{c}\text { PM } \\
35.70\end{array}$} & \multirow{2}{*}{$\begin{array}{c}\text { BARR } \\
146.80\end{array}$} & \multirow{2}{*}{$\begin{array}{c}\text { WYF } \\
139.50\end{array}$} & \multirow{2}{*}{$\begin{array}{c}\text { EYF } \\
22.90\end{array}$} & \multirow{2}{*}{\begin{tabular}{|c|} 
SHON \\
80.50
\end{tabular}} & \multirow{2}{*}{$\begin{array}{c}\text { DV } \\
41.00\end{array}$} & \multirow{2}{*}{$\begin{array}{l}\text { LCA } \\
28.80\end{array}$} & \multirow{2}{*}{$\begin{array}{c}\text { PAHR } \\
11.40\end{array}$} & \multirow{2}{*}{$\begin{array}{r}\text { SPMT } \\
53.30\end{array}$} & \multirow{2}{*}{$\begin{array}{c}\text { SHRG } \\
47.30\end{array}$} & \multirow{2}{*}{$\begin{array}{c}\text { TMBR } \\
61.00\end{array}$} & \multirow{2}{*}{\begin{tabular}{|c|} 
FARM \\
9.00 \\
\end{tabular}} & \multirow{2}{*}{$\begin{array}{c}\text { FF } \\
5.20\end{array}$} \\
\hline Parameter & $\%$ Change & & & & & & & & & & & & & & & \\
\hline Id_LCA(3) & 10 & 0.00 & 0.00 & 0.00 & 0.00 & -1.86 & 0.44 & 0.12 & 0.00 & 0.00 & -1.75 & 3.38 & -1.48 & 0.00 & 1.11 & 1.92 \\
\hline Id_LCA(4) & 10 & 0.00 & -0.55 & 0.00 & -0.48 & -2.58 & 0.44 & -0.87 & 2.68 & 0.69 & -5.26 & 0.38 & -0.42 & 0.00 & -1.11 & 0.00 \\
\hline Id_LCA(5) & 10 & 0.47 & -0.42 & 0.28 & 0.27 & -1.43 & 0.87 & 0.62 & 0.24 & 0.00 & -7.89 & 0.56 & 1.06 & 0.00 & 2.22 & 1.92 \\
\hline Id_LCA(6) & 10 & 0.00 & 0.00 & 0.00 & -0.07 & 4.16 & 3.93 & -0.25 & 0.00 & -0.35 & -0.88 & 1.88 & 1.06 & 0.16 & 0.00 & 0.00 \\
\hline Id_LCA(7) & 10 & -2.33 & 0.00 & 0.56 & -0.07 & -0.72 & 1.31 & 0.87 & 0.00 & 0.00 & -7.02 & 0.38 & 0.42 & -0.16 & 0.00 & 0.00 \\
\hline Id_LCA(8) & 10 & 0.23 & 0.14 & 0.00 & 0.14 & 0.07 & 0.87 & 1.24 & 0.24 & -0.69 & 124.56 & 0.56 & 0.85 & 0.33 & 2.22 & 1.92 \\
\hline Id_LCA(9) & 10 & 0.00 & -0.69 & 0.00 & -0.27 & -0.86 & 0.44 & 0.12 & 1.46 & 0.69 & -5.26 & 0.38 & 0.00 & 0.16 & -17.78 & 0.00 \\
\hline Id_UCCU & 10 & -0.23 & -0.14 & 0.00 & 0.00 & -0.50 & 0.87 & 0.87 & 0.00 & 0.35 & -7.89 & 0.38 & 0.42 & 0.00 & 0.00 & 0.00 \\
\hline Id_LCA3 & 10 & 0.00 & 0.00 & 0.00 & -0.07 & -1.00 & 1.31 & 0.87 & 0.00 & 0.00 & -0.88 & 0.38 & 0.42 & 0.00 & 0.00 & 0.00 \\
\hline Id_TSDV(1) & 10 & 0.00 & 0.00 & 0.00 & -0.14 & 5.38 & 3.49 & -0.37 & 0.00 & 0.00 & -7.02 & 0.38 & 0.42 & 0.16 & 0.00 & 0.00 \\
\hline Id_TSDV(2) & 10 & 0.00 & -0.14 & 0.00 & -0.14 & 2.65 & 4.37 & -0.62 & -4.15 & 0.00 & 0.00 & 0.38 & 0.42 & 0.16 & -3.33 & 0.00 \\
\hline Id_VU(1) & 10 & -2.80 & 0.00 & 0.28 & 0.48 & -1.51 & 0.87 & 1.61 & -0.49 & -0.69 & -1.75 & 0.56 & 1.06 & -0.33 & 3.33 & 3.85 \\
\hline Id_VU(2) & 10 & -0.23 & 0.00 & 0.00 & -0.07 & -1.94 & 0.44 & -0.12 & 0.00 & 0.00 & 0.00 & 0.38 & 0.42 & 0.00 & 0.00 & 0.00 \\
\hline Id_VU(3) & 10 & -0.47 & 1.80 & 0.28 & -0.07 & -3.58 & 2.18 & 1.24 & 0.24 & 0.00 & -0.88 & 0.38 & 0.42 & 0.16 & 2.22 & 0.00 \\
\hline Id_VCU(1) & 10 & -0.47 & 1.94 & 0.56 & 0.07 & -2.01 & 3.06 & 4.10 & 0.49 & -9.72 & -1.75 & 0.38 & 0.63 & 1.48 & 4.44 & 1.92 \\
\hline Id_VCU(2) & 10 & 0.00 & 0.00 & 0.00 & -0.07 & -2.51 & 0.87 & -0.25 & 0.00 & 0.00 & 0.00 & 0.38 & 0.63 & 0.00 & 0.00 & 0.00 \\
\hline Id_VA(1) & 10 & 0.00 & -0.55 & 0.00 & -0.07 & 1.08 & 2.62 & 2.11 & 0.00 & 13.19 & 0.00 & 0.38 & 0.42 & 0.66 & 1.11 & 0.00 \\
\hline Id_VA(2) & 10 & 0.00 & 0.00 & 0.00 & -0.14 & -23.94 & 20.96 & -1.24 & 0.00 & -0.35 & -0.88 & 0.38 & 0.00 & 0.66 & 0.00 & 0.00 \\
\hline Id_VA(3) & 10 & 0.00 & -3.60 & 0.00 & -0.14 & 1.36 & 4.80 & -0.12 & 0.24 & 6.60 & -0.88 & 0.38 & 0.42 & 0.16 & 1.11 & 0.00 \\
\hline Id_BAQ(1) & 10 & 0.47 & -0.14 & 0.28 & 0.00 & -2.58 & 0.44 & 0.75 & 0.00 & 0.00 & -0.88 & 0.38 & 0.42 & -3.28 & 0.00 & 0.00 \\
\hline Id_BAQ(3) & 10 & 0.00 & 0.00 & 0.00 & -0.14 & 2.65 & 4.37 & -0.50 & 0.00 & -0.35 & 0.00 & 0.38 & 0.42 & 0.16 & 0.00 & 0.00 \\
\hline Id_BAQ(4) & 10 & 0.00 & 0.00 & 0.00 & -0.07 & -0.86 & 0.44 & 0.37 & 0.00 & 0.00 & -0.88 & 0.38 & 0.42 & -0.16 & 0.00 & 0.00 \\
\hline Id_BAQ(5) & 10 & 0.00 & 0.00 & 0.00 & -0.07 & 2.44 & 4.37 & -0.50 & 0.00 & -0.35 & -0.88 & 0.38 & 0.42 & 0.16 & 0.00 & 0.00 \\
\hline Id_BAQ(6) & 10 & 0.00 & 0.00 & 0.00 & -0.07 & 1.58 & 4.37 & -0.50 & 0.00 & -0.35 & -0.88 & 0.38 & 0.42 & 0.16 & 0.00 & 0.00 \\
\hline Id_BCU(1) & 10 & -0.70 & -0.14 & 0.00 & 0.07 & -2.37 & 0.87 & 0.00 & 0.00 & 0.00 & -7.89 & 0.38 & 0.63 & 0.00 & 1.11 & 1.92 \\
\hline Id_BCU(3) & 10 & 0.00 & 0.00 & 0.00 & -0.07 & -2.51 & 0.87 & -0.25 & 0.00 & 0.00 & -0.88 & 0.38 & 0.42 & 0.00 & 0.00 & 0.00 \\
\hline Id_BCU(4) & 10 & 0.00 & 0.00 & 0.00 & -0.14 & 3.30 & 3.93 & -0.25 & 0.00 & -0.35 & -7.02 & 0.38 & 0.42 & 0.16 & 0.00 & 0.00 \\
\hline Id_BCU(5) & 10 & 0.00 & 0.00 & 0.00 & -0.07 & 2.65 & 4.37 & -0.50 & 0.00 & -0.35 & 0.00 & 0.38 & 0.42 & 0.16 & 0.00 & 0.00 \\
\hline Id_BCU(6) & 10 & 0.00 & 0.00 & 0.00 & -0.07 & -1.36 & 0.44 & 0.12 & 0.00 & 0.00 & -0.88 & 0.38 & 0.42 & 0.16 & 0.00 & 0.00 \\
\hline Id_TBA(1) & 10 & -1.40 & 0.00 & -0.56 & 0.00 & 7.10 & 1.75 & -0.12 & 0.00 & -0.69 & -0.88 & 0.38 & 0.63 & 1.15 & 1.11 & 1.92 \\
\hline Id_TBA(3) & 10 & 0.00 & 0.00 & 0.00 & -0.07 & 2.37 & 4.37 & -0.50 & 0.00 & -0.35 & -0.88 & 0.38 & 0.42 & 0.16 & 0.00 & 0.00 \\
\hline Id_TBA(4) & 10 & -0.23 & 0.00 & 0.00 & -0.07 & 5.09 & 1.31 & -0.37 & 0.00 & 0.00 & -0.88 & 0.38 & 0.42 & -0.16 & 0.00 & 0.00 \\
\hline
\end{tabular}


Table C-2

Percentage Change in Roots Mean Square of Mean Weighted Residuals Between Sensitivity Runs and Calibration Run

\begin{tabular}{|c|c|c|c|c|c|c|c|c|c|c|c|c|c|c|c|c|}
\hline \multicolumn{2}{|c|}{ Calibration Zones and Base Data ${ }^{a}$ : } & \multirow{2}{*}{\begin{tabular}{|c|} 
NRTH \\
42.90 \\
\end{tabular}} & \multirow{2}{*}{\begin{tabular}{|l|} 
OASI \\
72.20 \\
\end{tabular}} & \multirow{2}{*}{$\begin{array}{c}\text { PM } \\
35.70\end{array}$} & \multirow{2}{*}{$\begin{array}{c}\text { BARR } \\
146.80\end{array}$} & \multirow{2}{*}{$\begin{array}{c}\text { WYF } \\
139.50\end{array}$} & \multirow{2}{*}{$\begin{array}{c}\text { EYF } \\
22.90\end{array}$} & \multirow{2}{*}{\begin{tabular}{|c|} 
SHON \\
80.50
\end{tabular}} & \multirow{2}{*}{$\begin{array}{c}\text { DV } \\
41.00\end{array}$} & \multirow{2}{*}{$\begin{array}{l}\text { LCA } \\
28.80\end{array}$} & \multirow{2}{*}{$\begin{array}{c}\text { PAHR } \\
11.40\end{array}$} & \multirow{2}{*}{$\begin{array}{r}\text { SPMT } \\
53.30\end{array}$} & \multirow{2}{*}{$\begin{array}{c}\text { SHRG } \\
47.30\end{array}$} & \multirow{2}{*}{$\begin{array}{c}\text { TMBR } \\
61.00\end{array}$} & \multirow{2}{*}{\begin{tabular}{|c|} 
FARM \\
9.00 \\
\end{tabular}} & \multirow{2}{*}{$\begin{array}{c}\text { FF } \\
5.20\end{array}$} \\
\hline Parameter & $\%$ Change & & & & & & & & & & & & & & & \\
\hline Id_TBA(6) & 10 & 0.00 & 0.00 & 0.00 & -0.07 & 1.36 & 4.80 & -0.50 & 0.00 & -0.35 & -0.88 & 0.38 & 0.42 & 0.16 & 0.00 & 0.00 \\
\hline Id_TCB(1) & 10 & 0.00 & 0.00 & 0.00 & -0.07 & 2.58 & 4.37 & -0.37 & 0.00 & -0.35 & -0.88 & 0.38 & 0.42 & 0.16 & 0.00 & 0.00 \\
\hline Id_TCB(4) & 10 & 0.00 & 0.00 & 0.00 & -0.07 & -2.51 & 0.87 & -0.25 & 0.00 & 0.00 & 0.00 & 0.38 & 0.63 & 0.00 & 0.00 & 0.00 \\
\hline Id_TCB(6) & 10 & 0.00 & 0.00 & 0.00 & -0.07 & -1.51 & 0.44 & 0.25 & 0.00 & 0.00 & -0.88 & 0.38 & 0.42 & 0.16 & 0.00 & 0.00 \\
\hline Id_TC(1) & 10 & -11.42 & -0.14 & 5.04 & -0.20 & -1.72 & 0.44 & -0.25 & 0.00 & -0.69 & -8.77 & 0.38 & 0.42 & -0.33 & 0.00 & 0.00 \\
\hline Id_TC(3) & 10 & 0.00 & 0.00 & 0.00 & -0.07 & 2.44 & 4.37 & -0.50 & 0.00 & -0.35 & -0.88 & 0.38 & 0.42 & 0.16 & 0.00 & 0.00 \\
\hline Id_TC(4) & 10 & -0.47 & 0.14 & 0.84 & -0.07 & -2.01 & 0.44 & -0.25 & 0.00 & -0.69 & -0.88 & 0.38 & 0.42 & -0.49 & 0.00 & 0.00 \\
\hline Id_TC(5) & 10 & -0.23 & 0.28 & 0.00 & -0.07 & -6.45 & 0.00 & -0.87 & 0.00 & -1.04 & -0.88 & 0.38 & 0.42 & 0.00 & 1.11 & 0.00 \\
\hline Id_TC(6) & 10 & 0.00 & 0.00 & -0.28 & -0.07 & 2.94 & 3.93 & -0.37 & 0.00 & -0.35 & -0.88 & 0.38 & 0.42 & 0.16 & 0.00 & 0.00 \\
\hline Id_TMA(1) & 10 & -4.66 & 0.14 & 4.48 & 0.00 & -1.22 & 0.44 & 0.99 & 0.00 & 0.35 & -9.65 & 0.38 & 0.63 & -0.82 & 0.00 & 0.00 \\
\hline Id_TMA(2) & 10 & -0.47 & 0.00 & 0.56 & -0.07 & -2.72 & 0.87 & 0.12 & 0.00 & 0.35 & -0.88 & 0.38 & 0.42 & -0.66 & 0.00 & 0.00 \\
\hline Id_TMA(3) & 10 & -0.23 & -0.42 & 1.40 & -0.07 & -1.94 & 0.44 & 0.12 & 0.00 & 0.35 & -0.88 & 0.38 & 0.42 & -1.97 & 0.00 & 0.00 \\
\hline Id_TMA(4) & 10 & -1.40 & -0.28 & 3.08 & -0.07 & -2.08 & 0.44 & 0.00 & 0.00 & 0.69 & -0.88 & 0.38 & 0.42 & -2.13 & 0.00 & 0.00 \\
\hline Id_TMA(6) & 10 & -0.70 & 0.00 & -0.28 & -0.07 & 5.59 & 1.31 & -0.25 & 0.00 & 0.00 & -0.88 & 0.38 & 0.42 & -0.16 & 0.00 & 0.00 \\
\hline Id_AA(1) & 10 & -4.66 & 0.00 & 0.00 & 0.00 & -2.15 & 0.87 & 0.62 & -2.44 & 0.00 & -1.75 & 2.25 & 4.44 & 0.33 & 2.22 & 0.00 \\
\hline Id_AA(2) & 10 & 0.00 & -0.28 & 0.00 & -0.48 & 2.87 & 3.93 & -0.87 & -2.20 & 0.35 & -3.51 & 0.38 & -0.42 & 0.16 & -5.56 & 0.00 \\
\hline Id_AA(3) & 10 & 0.00 & 0.00 & 0.00 & -0.07 & -1.51 & 0.44 & 0.25 & 0.00 & 0.00 & -0.88 & 0.56 & 0.42 & 0.00 & 0.00 & 0.00 \\
\hline Id_AA(4) & 10 & 0.00 & 0.00 & 0.00 & -0.07 & -1.51 & 3.93 & -0.25 & 0.00 & 0.00 & -0.88 & 0.38 & 0.42 & 0.00 & 0.00 & 0.00 \\
\hline Id_AA(5) & 10 & 0.00 & 0.00 & 0.00 & -0.07 & 4.87 & 3.93 & -0.50 & 0.00 & -0.35 & -0.88 & 0.38 & 0.42 & 0.16 & 0.00 & 0.00 \\
\hline Id_AA(6) & 10 & -0.23 & -1.11 & 0.00 & -0.20 & -8.46 & -0.44 & -0.50 & 0.49 & 0.69 & 1.75 & 0.38 & 0.21 & -0.16 & 1.11 & 0.00 \\
\hline Kh_I & -50 & 0.00 & 0.00 & -0.28 & -0.14 & 2.87 & 4.37 & -0.12 & 0.00 & -0.35 & -0.88 & 0.00 & 0.00 & 0.16 & 0.00 & 0.00 \\
\hline Kh_LCCU(1) & -50 & -0.47 & 1.25 & 0.56 & 0.20 & -1.36 & 0.87 & 1.74 & 0.49 & 0.35 & 4.39 & 1.88 & -1.48 & -0.33 & 3.33 & 1.92 \\
\hline Kh_LCCU(2) & -50 & 0.00 & 0.00 & 0.00 & 0.00 & -0.65 & 0.44 & 0.50 & 0.00 & -0.69 & 117.54 & 1.69 & -23.47 & 0.49 & 1.11 & 1.92 \\
\hline Kh_LCCU(3) & -50 & -0.23 & -6.65 & 0.00 & -0.27 & 2.65 & 3.93 & 0.00 & -4.88 & 0.00 & -6.14 & 0.00 & -0.42 & 0.16 & -10.00 & 0.00 \\
\hline Kh_LCA(1) & -50 & -0.23 & -0.14 & 0.00 & -9.47 & -7.81 & 20.52 & -6.58 & 0.98 & 1.04 & 121.93 & 2.06 & -54.55 & 0.16 & 4.44 & 103.85 \\
\hline Kh_LCA(2) & -50 & 0.00 & -1.66 & 0.00 & -3.27 & -4.23 & 3.06 & -3.48 & -3.17 & 4.51 & 16.67 & -0.38 & -8.03 & 0.16 & -17.78 & 65.38 \\
\hline Kh_LCA(3) & -50 & 0.00 & 0.14 & 0.00 & 0.14 & 0.50 & 0.87 & 1.12 & 0.24 & -0.35 & -1.75 & 12.95 & -8.03 & 0.16 & 1.11 & 1.92 \\
\hline Kh_LCA(4) & -50 & 0.00 & -2.22 & 0.00 & -1.57 & -0.22 & 0.00 & -0.99 & 8.29 & 3.47 & -1.75 & -0.19 & -3.59 & 0.00 & -11.11 & 13.46 \\
\hline Kh_LCA(5) & -50 & 3.50 & 0.14 & 1.68 & 1.09 & -1.72 & 1.75 & 1.86 & 4.88 & -0.69 & -20.18 & 0.19 & 1.90 & -0.49 & 8.89 & 9.62 \\
\hline Kh_LCA(6) & -50 & 0.00 & 0.00 & 0.00 & -0.07 & -4.95 & 0.87 & 0.50 & 3.17 & -0.35 & 1.75 & 10.32 & 2.54 & 0.16 & 2.22 & 0.00 \\
\hline Kh_LCA(7) & -50 & -3.73 & -0.14 & 1.12 & -0.07 & -2.51 & 0.87 & 0.37 & 0.00 & 0.35 & -9.65 & 0.00 & 0.00 & -0.16 & 0.00 & 0.00 \\
\hline Kh_LCA(8) & -50 & 0.93 & 0.42 & 0.00 & 0.68 & -1.51 & 1.31 & 1.12 & 0.98 & -1.74 & 621.05 & 0.19 & 0.21 & 0.33 & 6.67 & 11.54 \\
\hline
\end{tabular}


Table C-2

Percentage Change in Roots Mean Square of Mean Weighted Residuals Between Sensitivity Runs and Calibration Run

\begin{tabular}{|c|c|c|c|c|c|c|c|c|c|c|c|c|c|c|c|c|}
\hline \multicolumn{2}{|c|}{ Calibration Zones and Base Data ${ }^{a}$ : } & \multirow{2}{*}{\begin{tabular}{|c|} 
NRTH \\
42.90 \\
\end{tabular}} & \multirow{2}{*}{\begin{tabular}{|l|} 
OASI \\
72.20 \\
\end{tabular}} & \multirow{2}{*}{$\begin{array}{c}\text { PM } \\
35.70 \\
\end{array}$} & \multirow{2}{*}{\begin{tabular}{|l|} 
BARR \\
146.80 \\
\end{tabular}} & \multirow{2}{*}{$\begin{array}{c}\text { WYF } \\
139.50 \\
\end{array}$} & \multirow{2}{*}{$\begin{array}{l}\text { EYF } \\
22.90 \\
\end{array}$} & \multirow{2}{*}{$\begin{array}{c}\text { SHON } \\
80.50 \\
\end{array}$} & \multirow{2}{*}{$\begin{array}{c}\text { DV } \\
41.00 \\
\end{array}$} & \multirow{2}{*}{$\begin{array}{l}\text { LCA } \\
28.80 \\
\end{array}$} & \multirow{2}{*}{$\begin{array}{c}\text { PAHR } \\
11.40 \\
\end{array}$} & \multirow{2}{*}{$\begin{array}{c}\text { SPMT } \\
53.30 \\
\end{array}$} & \multirow{2}{*}{$\begin{array}{c}\text { SHRG } \\
47.30 \\
\end{array}$} & \multirow{2}{*}{\begin{tabular}{c|} 
TMBR \\
61.00 \\
\end{tabular}} & \multirow{2}{*}{\begin{tabular}{|c|} 
FARM \\
9.00 \\
\end{tabular}} & \multirow{2}{*}{$\begin{array}{c}\text { FF } \\
5.20\end{array}$} \\
\hline Parameter & $\%$ Change & & & & & & & & & & & & & & & \\
\hline Kh_LCA(9) & -50 & -0.23 & -2.08 & 0.00 & -0.75 & -1.43 & 0.00 & -0.25 & 3.66 & 2.43 & -0.88 & -0.19 & -1.69 & 0.16 & -37.78 & 1.92 \\
\hline Kh_UCCU & -50 & -0.47 & -0.28 & 0.28 & 0.07 & -2.44 & -1.31 & -1.24 & 0.00 & 1.39 & -1.75 & 0.00 & 0.21 & -0.33 & 1.11 & 1.92 \\
\hline Kh_LCA3 & -50 & -0.23 & -0.14 & 0.00 & 0.00 & 0.14 & 2.18 & 1.37 & 0.00 & 0.69 & -0.88 & 0.00 & 0.00 & 0.16 & 0.00 & 0.00 \\
\hline Kh_TSDV(1) & -50 & 0.00 & -0.14 & 0.00 & -0.07 & -0.93 & 0.44 & -0.37 & 0.00 & 0.00 & -0.88 & 0.00 & -0.21 & 0.16 & 0.00 & 0.00 \\
\hline Kh_TSDV(2) & -50 & -0.23 & -0.28 & 0.00 & -0.14 & -6.74 & 0.00 & -0.25 & -9.02 & 0.35 & -7.02 & 0.00 & -0.21 & 0.00 & -6.67 & 0.00 \\
\hline Kh_VU(1) & -50 & -5.13 & -0.28 & 1.68 & 1.23 & -2.72 & 2.18 & 1.99 & -0.24 & 0.00 & -5.26 & 0.19 & 1.27 & -1.64 & 5.56 & 7.69 \\
\hline Kh_VU(2) & -50 & -0.23 & 0.00 & 0.00 & -0.07 & 4.87 & 3.93 & -0.50 & 0.00 & -0.35 & -0.88 & 0.00 & 0.00 & 0.16 & 0.00 & 0.00 \\
\hline Kh_VU(3) & -50 & -2.56 & 8.59 & 3.36 & 0.07 & -4.59 & 0.00 & 2.73 & 1.22 & 1.74 & -1.75 & 0.00 & 0.21 & -0.33 & 7.78 & 1.92 \\
\hline Kh_VCU(1) & -50 & -1.17 & 9.97 & 2.52 & 0.34 & -4.16 & 2.62 & 15.40 & 1.95 & -41.32 & -5.26 & 0.00 & 0.85 & 9.67 & 12.22 & 3.85 \\
\hline Kh_VCU(2) & -50 & 0.00 & 0.00 & 0.00 & -0.07 & -0.86 & 0.44 & 0.37 & 0.00 & 0.00 & 0.00 & 0.00 & 0.00 & 0.16 & 0.00 & 0.00 \\
\hline Kh_VA(1) & -50 & -0.23 & -1.52 & 0.28 & -0.07 & 7.17 & 1.31 & -7.20 & 0.24 & 42.71 & -0.88 & 0.00 & 0.00 & 1.97 & 2.22 & 0.00 \\
\hline Kh_VA(2) & -50 & 0.23 & 0.00 & -0.28 & -0.20 & -12.54 & 20.96 & -1.86 & 0.00 & -0.35 & -0.88 & 0.00 & -0.21 & 0.49 & 0.00 & 0.00 \\
\hline Kh_VA(3) & -50 & 0.00 & -8.31 & 0.00 & -0.07 & -1.51 & 0.44 & 0.99 & 0.49 & 15.63 & -0.88 & 0.00 & -0.21 & 0.16 & 4.44 & 0.00 \\
\hline $\mathrm{Kh} \_B A Q(1)$ & -50 & 0.23 & 0.00 & 0.00 & 0.00 & -3.66 & 0.44 & 0.50 & 0.00 & 0.00 & -9.65 & 0.00 & 0.00 & -5.41 & 0.00 & 0.00 \\
\hline Kh_BAQ(3) & -50 & 0.00 & 0.00 & 0.00 & -0.07 & 1.36 & 4.80 & -0.50 & 0.00 & -0.35 & -0.88 & 0.00 & 0.00 & 0.16 & 0.00 & 0.00 \\
\hline Kh_BAQ(4) & -50 & 0.00 & 0.00 & 0.00 & -0.07 & 3.15 & 3.93 & -0.37 & 0.00 & -0.35 & -0.88 & 0.00 & 0.00 & -0.33 & 0.00 & 0.00 \\
\hline Kh_BAQ(5) & -50 & -0.23 & 0.00 & 0.00 & -0.07 & -7.81 & -0.44 & 0.12 & 0.00 & 0.00 & -0.88 & 0.00 & 0.00 & -0.16 & 0.00 & 0.00 \\
\hline Kh_BAQ(6) & -50 & 0.00 & 0.00 & 0.00 & -0.07 & 3.23 & 3.93 & -0.37 & 0.00 & -0.35 & -0.88 & 0.00 & 0.00 & 0.16 & 0.00 & 0.00 \\
\hline Kh_BCU(1) & -50 & -0.93 & -0.14 & 0.28 & 0.07 & -3.66 & 1.75 & 0.00 & 0.00 & 0.00 & -7.89 & 0.00 & 0.21 & 0.00 & 1.11 & 1.92 \\
\hline Kh_BCU(3) & -50 & -0.23 & 0.00 & 0.00 & -0.07 & -8.10 & 0.44 & -0.12 & 0.00 & 0.00 & -0.88 & 0.00 & 0.00 & 0.00 & 0.00 & 0.00 \\
\hline Kh_BCU(4) & -50 & 0.00 & 0.00 & 0.00 & -0.07 & 6.09 & 1.31 & -0.25 & 0.00 & 0.00 & -0.88 & 0.00 & 0.00 & 0.00 & 0.00 & 0.00 \\
\hline Kh_BCU(5) & -50 & 0.00 & 0.00 & 0.00 & -0.07 & -1.22 & 0.44 & 0.00 & 0.00 & 0.00 & -0.88 & 0.00 & 0.00 & 0.16 & 0.00 & 0.00 \\
\hline Kh_BCU(6) & -50 & -0.23 & 0.00 & 0.00 & 0.00 & 0.00 & 0.00 & 0.00 & 0.00 & 0.00 & 0.00 & 0.00 & 0.00 & 0.00 & 0.00 & 0.00 \\
\hline Kh_TBA(1) & -50 & -2.33 & 0.00 & -0.56 & 0.07 & -1.22 & 0.87 & 0.00 & 0.00 & 0.00 & -1.75 & 0.00 & 0.00 & 0.98 & 1.11 & 1.92 \\
\hline Kh_TBA(3) & -50 & 0.00 & 0.00 & 0.00 & -0.07 & -0.79 & 0.44 & 0.37 & 0.00 & 0.00 & -0.88 & 0.00 & 0.00 & 0.16 & 0.00 & 0.00 \\
\hline Kh_TBA(4) & -50 & 0.00 & 0.00 & 0.00 & -0.07 & 3.51 & 3.93 & -0.37 & 0.00 & -0.35 & -0.88 & 0.00 & 0.00 & -0.16 & 0.00 & 0.00 \\
\hline Kh_TBA(6) & -50 & 0.00 & 0.00 & 0.00 & -0.07 & -1.65 & 0.44 & 0.25 & 0.00 & 0.00 & -0.88 & 0.00 & 0.00 & 0.00 & 0.00 & 0.00 \\
\hline $\mathrm{Kh} \_\mathrm{TCB}(1)$ & -50 & 0.00 & 0.00 & 0.00 & -0.07 & -2.51 & 0.87 & -0.12 & 0.00 & 0.00 & 0.00 & 0.00 & 0.00 & 0.00 & 0.00 & 0.00 \\
\hline Kh_TCB(4) & -50 & 0.00 & 0.00 & 0.00 & -0.07 & 3.01 & 3.93 & -0.37 & 0.00 & -0.35 & -0.88 & 0.00 & 0.00 & 0.16 & 0.00 & 0.00 \\
\hline $\mathrm{Kh} \_\mathrm{TCB}(6)$ & -50 & 0.00 & 0.00 & 0.00 & -0.07 & 1.36 & 4.80 & -0.50 & 0.00 & -0.35 & -0.88 & 0.00 & 0.00 & 0.16 & 0.00 & 0.00 \\
\hline Kh_TC(1) & -50 & -19.35 & 0.42 & 8.40 & -0.27 & -4.09 & 0.87 & -0.50 & 0.00 & -1.04 & -8.77 & -0.19 & -0.21 & -0.33 & 0.00 & 0.00 \\
\hline Kh_TC(3) & -50 & 0.00 & 0.00 & 0.00 & -0.07 & 3.87 & 3.93 & -0.25 & 0.00 & 0.00 & -0.88 & 0.00 & 0.00 & 0.16 & 0.00 & 0.00 \\
\hline
\end{tabular}

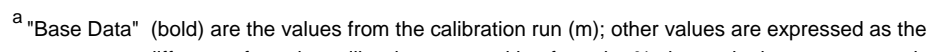

percentage difference from the calibration run resulting from the $\%$ change in the parameter value.

C-16 
Table C-2

Percentage Change in Roots Mean Square of Mean Weighted Residuals Between Sensitivity Runs and Calibration Run

\begin{tabular}{|c|c|c|c|c|c|c|c|c|c|c|c|c|c|c|c|c|}
\hline \multicolumn{2}{|c|}{ Calibration Zones and Base Data ${ }^{a}$ : } & \multirow{2}{*}{\begin{tabular}{|c|} 
NRTH \\
42.90 \\
\end{tabular}} & \multirow{2}{*}{\begin{tabular}{|l|} 
OASI \\
72.20 \\
\end{tabular}} & \multirow{2}{*}{$\begin{array}{c}\text { PM } \\
35.70\end{array}$} & \multirow{2}{*}{$\begin{array}{c}\text { BARR } \\
146.80\end{array}$} & \multirow{2}{*}{$\begin{array}{c}\text { WYF } \\
139.50\end{array}$} & \multirow{2}{*}{$\begin{array}{c}\text { EYF } \\
22.90\end{array}$} & \multirow{2}{*}{\begin{tabular}{|c|} 
SHON \\
80.50
\end{tabular}} & \multirow{2}{*}{$\begin{array}{c}\text { DV } \\
41.00\end{array}$} & \multirow{2}{*}{$\begin{array}{l}\text { LCA } \\
28.80\end{array}$} & \multirow{2}{*}{$\begin{array}{c}\text { PAHR } \\
11.40\end{array}$} & \multirow{2}{*}{$\begin{array}{r}\text { SPMT } \\
53.30\end{array}$} & \multirow{2}{*}{$\begin{array}{c}\text { SHRG } \\
47.30\end{array}$} & \multirow{2}{*}{$\begin{array}{c}\text { TMBR } \\
61.00\end{array}$} & \multirow{2}{*}{\begin{tabular}{|c|} 
FARM \\
9.00 \\
\end{tabular}} & \multirow{2}{*}{$\begin{array}{c}F F \\
5.20\end{array}$} \\
\hline Parameter & $\%$ Change & & & & & & & & & & & & & & & \\
\hline Kh_TC(4) & -50 & -0.70 & 0.42 & 1.12 & -0.07 & -1.72 & 0.44 & -0.99 & 0.00 & -2.43 & -0.88 & 0.00 & 0.00 & -1.31 & 1.11 & 0.00 \\
\hline Kh_TC(5) & -50 & 0.00 & 0.69 & 0.00 & -0.07 & 1.15 & 4.80 & -2.61 & 0.24 & -2.78 & -0.88 & 0.00 & 0.00 & 0.16 & 1.11 & 0.00 \\
\hline Kh_TC(6) & -50 & 0.00 & 0.00 & -0.56 & -0.07 & 3.44 & 3.93 & 0.25 & 0.00 & -0.35 & -0.88 & 0.00 & 0.00 & 0.16 & 0.00 & 0.00 \\
\hline Kh_TMA(1) & -50 & -8.16 & 0.28 & 10.08 & -0.07 & -3.37 & 0.44 & 0.87 & -0.24 & 1.39 & -9.65 & 0.38 & 0.21 & -2.30 & 0.00 & 0.00 \\
\hline Kh_TMA(2) & -50 & -0.70 & 0.00 & 0.84 & -0.07 & -2.80 & 0.44 & 0.25 & 0.00 & 0.35 & -7.02 & 0.00 & 0.00 & -1.31 & 0.00 & 0.00 \\
\hline Kh_TMA(3) & -50 & -1.17 & -0.14 & 3.36 & -0.07 & -3.15 & 0.44 & 0.75 & -0.24 & 1.04 & -7.02 & 0.00 & 0.00 & -4.92 & -1.11 & 0.00 \\
\hline Kh_TMA(4) & -50 & -3.26 & -0.28 & 10.36 & -0.07 & -4.44 & 0.44 & 1.86 & 3.17 & 1.04 & 1.75 & 0.00 & 0.00 & -6.39 & 1.11 & 0.00 \\
\hline Kh_TMA(6) & -50 & -1.40 & 0.00 & -0.56 & -0.07 & 4.01 & 3.93 & -0.37 & 0.00 & 0.00 & -0.88 & 0.00 & 0.00 & 0.00 & 0.00 & 0.00 \\
\hline Kh_AA(1) & -50 & -9.79 & -0.28 & 0.28 & -0.27 & -2.58 & 0.44 & 0.87 & -2.68 & 2.78 & 5.26 & 18.20 & 15.22 & -0.82 & 8.89 & 0.00 \\
\hline Kh_AA(2) & -50 & 0.00 & -1.39 & 0.00 & -2.04 & -2.80 & 0.00 & -2.48 & 0.24 & 2.78 & 3.51 & -0.38 & -4.86 & 0.00 & -20.00 & 25.00 \\
\hline Kh_AA(3) & -50 & 0.00 & 0.00 & 0.00 & 0.00 & -0.43 & 0.87 & 0.12 & 0.00 & 0.00 & -0.88 & 0.38 & -0.42 & 0.00 & 0.00 & 0.00 \\
\hline Kh_AA(4) & -50 & 0.00 & 0.00 & 0.00 & -0.07 & -3.37 & 6.55 & 0.12 & 0.00 & 0.00 & -0.88 & 0.00 & 0.00 & 0.00 & 0.00 & 0.00 \\
\hline Kh_AA(5) & -50 & 0.00 & 0.00 & 0.00 & -0.14 & 2.72 & 4.37 & -0.37 & 0.00 & -0.35 & -7.02 & 0.00 & 0.00 & 0.16 & 0.00 & 0.00 \\
\hline Kh_AA(6) & -50 & 0.00 & -5.12 & 0.00 & -1.02 & -0.86 & 0.00 & -0.99 & 3.41 & 4.86 & -5.26 & -0.19 & -2.33 & 0.16 & 10.00 & 3.85 \\
\hline Id_I & -10 & 0.00 & 0.00 & 0.00 & -0.07 & -1.22 & 0.44 & 0.50 & 0.00 & 0.00 & -0.88 & 0.00 & 0.00 & 0.00 & 0.00 & 0.00 \\
\hline Id_LCCU(1) & -10 & 0.47 & -0.42 & -0.56 & -0.20 & -0.86 & 0.00 & -0.99 & -0.24 & -1.39 & -8.77 & -0.38 & 1.06 & 1.15 & -1.11 & 0.00 \\
\hline Id_LCCU(2) & -10 & 0.00 & 0.00 & 0.00 & -0.07 & 0.29 & 2.18 & 0.37 & 0.00 & -0.69 & -53.51 & 0.00 & 7.61 & 0.49 & 0.00 & 0.00 \\
\hline Id_LCCU(3) & -10 & 0.00 & 4.02 & -0.28 & 0.07 & 2.80 & 4.37 & -0.37 & 2.44 & -1.04 & -1.75 & 0.38 & 0.63 & 0.16 & 8.89 & 1.92 \\
\hline Id_LCA(1) & -10 & 0.23 & 0.14 & 0.00 & 2.52 & 0.50 & 4.80 & 1.74 & -0.24 & -1.04 & -24.56 & 0.75 & 6.55 & 0.49 & -1.11 & 15.38 \\
\hline Id_LCA(2) & -10 & 0.00 & 0.28 & 0.00 & 0.61 & -2.44 & 1.75 & 0.62 & 0.73 & -1.04 & -7.02 & 0.56 & 2.11 & 0.00 & 4.44 & 9.62 \\
\hline Id_LCA(3) & -10 & 0.00 & 0.00 & 0.00 & -0.14 & 3.66 & 3.93 & -0.25 & 0.00 & 0.00 & 0.00 & -2.06 & 2.75 & 0.16 & 0.00 & 0.00 \\
\hline Id_LCA(4) & -10 & 0.00 & 0.55 & 0.00 & 0.54 & -2.08 & 1.31 & 1.61 & 0.00 & -1.39 & -3.51 & 0.56 & 1.69 & 0.16 & 2.22 & 7.69 \\
\hline Id_LCA(5) & -10 & -0.70 & 0.00 & -0.28 & -0.34 & -1.72 & 0.44 & 0.12 & -0.24 & 0.00 & -5.26 & 0.38 & 0.00 & 0.16 & -1.11 & 0.00 \\
\hline Id_LCA(6) & -10 & 0.00 & 0.00 & 0.00 & -0.07 & -1.15 & 0.44 & 0.87 & 0.00 & 0.00 & -0.88 & -0.56 & 0.00 & 0.00 & 0.00 & 0.00 \\
\hline Id_LCA(7) & -10 & 3.03 & 0.00 & -0.56 & -0.07 & -2.01 & 0.87 & 0.25 & 0.00 & -0.69 & -0.88 & 0.38 & 0.42 & 0.66 & 0.00 & 0.00 \\
\hline Id_LCA(8) & -10 & -0.23 & -0.28 & 0.00 & -0.20 & -1.22 & 0.44 & -0.12 & -0.49 & 0.35 & -48.25 & 0.38 & 0.00 & 0.16 & -2.22 & 0.00 \\
\hline Id_LCA(9) & -10 & 0.00 & 0.83 & 0.00 & 0.20 & -2.58 & 0.87 & 1.49 & 2.68 & -1.04 & -0.88 & 0.56 & 1.06 & 0.00 & 23.33 & 3.85 \\
\hline Id_UCCU & -10 & 0.00 & 0.00 & 0.00 & -0.07 & -0.93 & 0.44 & -0.12 & 0.00 & -0.35 & 0.00 & 0.38 & 0.42 & 0.16 & 0.00 & 0.00 \\
\hline Id_LCA3 & -10 & 0.00 & 0.00 & 0.00 & -0.07 & -3.08 & 0.00 & 0.00 & 0.00 & -0.35 & 0.00 & 0.38 & 0.42 & 0.00 & 0.00 & 0.00 \\
\hline Id_TSDV(1) & -10 & 0.00 & 0.14 & 0.00 & -0.07 & 2.22 & 4.37 & -0.62 & 0.00 & -0.35 & -0.88 & 0.38 & 0.42 & 0.16 & 0.00 & 0.00 \\
\hline Id_TSDV(2) & -10 & 0.00 & 0.14 & 0.00 & 0.00 & -1.94 & 0.87 & 0.00 & 5.37 & -0.35 & -1.75 & 0.38 & 0.63 & 0.16 & 4.44 & 1.92 \\
\hline Id_VU(1) & -10 & 4.43 & -0.42 & -0.28 & -0.61 & -4.44 & 0.00 & -0.25 & 0.00 & -0.35 & -6.14 & 0.38 & 0.00 & 0.82 & -2.22 & 0.00 \\
\hline
\end{tabular}


Table C-2

Percentage Change in Roots Mean Square of Mean Weighted Residuals Between Sensitivity Runs and Calibration Run

\begin{tabular}{|c|c|c|c|c|c|c|c|c|c|c|c|c|c|c|c|c|}
\hline \multicolumn{2}{|c|}{ Calibration Zones and Base Data ${ }^{a}$ : } & \multirow{2}{*}{\begin{tabular}{|c|} 
NRTH \\
42.90 \\
\end{tabular}} & \multirow{2}{*}{\begin{tabular}{|l|} 
OASI \\
72.20 \\
\end{tabular}} & \multirow{2}{*}{$\begin{array}{c}\text { PM } \\
35.70\end{array}$} & \multirow{2}{*}{$\begin{array}{c}\text { BARR } \\
146.80\end{array}$} & \multirow{2}{*}{$\begin{array}{c}\text { WYF } \\
139.50\end{array}$} & \multirow{2}{*}{$\begin{array}{c}\text { EYF } \\
22.90\end{array}$} & \multirow{2}{*}{\begin{tabular}{|c|} 
SHON \\
80.50
\end{tabular}} & \multirow{2}{*}{$\begin{array}{c}\text { DV } \\
41.00\end{array}$} & \multirow{2}{*}{$\begin{array}{l}\text { LCA } \\
28.80\end{array}$} & \multirow{2}{*}{$\begin{array}{c}\text { PAHR } \\
11.40\end{array}$} & \multirow{2}{*}{$\begin{array}{r}\text { SPMT } \\
53.30\end{array}$} & \multirow{2}{*}{$\begin{array}{c}\text { SHRG } \\
47.30\end{array}$} & \multirow{2}{*}{$\begin{array}{c}\text { TMBR } \\
61.00\end{array}$} & \multirow{2}{*}{\begin{tabular}{|c|} 
FARM \\
9.00 \\
\end{tabular}} & \multirow{2}{*}{$\begin{array}{c}\text { FF } \\
5.20\end{array}$} \\
\hline Parameter & $\%$ Change & & & & & & & & & & & & & & & \\
\hline Id_VU(2) & -10 & 0.00 & 0.00 & -0.28 & -0.07 & 2.72 & 4.37 & -0.50 & 0.00 & -0.35 & -7.02 & 0.38 & 0.42 & 0.16 & 0.00 & 0.00 \\
\hline Id_VU(3) & -10 & 0.47 & -2.08 & -0.28 & -0.07 & -1.94 & 0.44 & 0.62 & 2.93 & -0.35 & 1.75 & 0.38 & 0.42 & 0.00 & 0.00 & 0.00 \\
\hline Id_VCU(1) & -10 & 0.47 & -2.22 & -0.56 & -0.20 & -0.43 & -0.87 & -3.23 & -0.73 & 10.07 & -6.14 & 0.38 & 0.21 & -0.98 & -4.44 & 0.00 \\
\hline Id_VCU(2) & -10 & 0.00 & 0.00 & 0.00 & -0.07 & -1.15 & 0.44 & -0.12 & 0.00 & 0.00 & -0.88 & 0.38 & 0.42 & 0.00 & 0.00 & 0.00 \\
\hline Id_VA(1) & -10 & 0.00 & 0.69 & -0.28 & -0.07 & 1.29 & 1.31 & -1.49 & 0.00 & -12.85 & -7.02 & 0.38 & 0.42 & -0.49 & 0.00 & 0.00 \\
\hline Id_VA(2) & -10 & -0.23 & 0.00 & 0.00 & -0.07 & 1.72 & -1.75 & 0.75 & 0.00 & 0.00 & -0.88 & 0.38 & 0.42 & -0.16 & 0.00 & 0.00 \\
\hline Id_VA(3) & -10 & 0.00 & 4.16 & 0.00 & -0.07 & 3.58 & 3.93 & -0.37 & -0.24 & -7.29 & -0.88 & 0.38 & 0.42 & 0.16 & -1.11 & 0.00 \\
\hline Id_BAQ(1) & -10 & 0.47 & -0.14 & 0.28 & -0.07 & -1.51 & 0.44 & 0.00 & -0.98 & 0.35 & -0.88 & 0.38 & 0.42 & 1.31 & 0.00 & 0.00 \\
\hline Id_BAQ(3) & -10 & 0.00 & 0.00 & 0.00 & -0.07 & 3.08 & 3.93 & -0.37 & 0.00 & -0.35 & -0.88 & 0.38 & 0.42 & 0.16 & 0.00 & 0.00 \\
\hline Id_BAQ(4) & -10 & 0.00 & 0.00 & 0.00 & -0.07 & 0.00 & 0.00 & 0.00 & 0.00 & 0.00 & -0.88 & 0.38 & 0.42 & 0.33 & 0.00 & 0.00 \\
\hline Id_BAQ(5) & -10 & 0.00 & 0.00 & 0.00 & -0.07 & -0.79 & 0.44 & 0.37 & 0.00 & 0.00 & -0.88 & 0.38 & 0.42 & 0.16 & 0.00 & 0.00 \\
\hline Id_BAQ(6) & -10 & 0.00 & 0.00 & 0.00 & -0.07 & -0.79 & 0.44 & 0.37 & 0.00 & 0.00 & 0.00 & 0.38 & 0.42 & 0.16 & 0.00 & 0.00 \\
\hline Id_BCU(1) & -10 & 0.93 & 0.00 & -0.28 & -0.27 & -5.45 & 0.44 & 0.00 & 0.00 & -0.35 & 0.00 & 0.38 & 0.21 & 0.33 & 0.00 & 0.00 \\
\hline Id_BCU(3) & -10 & -0.23 & 0.00 & 0.00 & -0.07 & 9.39 & 1.31 & -0.12 & 0.00 & 0.00 & -0.88 & 0.38 & 0.42 & 0.00 & 0.00 & 0.00 \\
\hline Id_BCU(4) & -10 & 0.00 & 0.00 & -0.28 & -0.14 & 1.08 & 4.80 & -0.50 & 0.00 & -0.35 & -0.88 & 0.38 & 0.42 & 0.16 & 0.00 & 0.00 \\
\hline Id_BCU(5) & -10 & 0.00 & 0.00 & 0.00 & -0.07 & 2.65 & 4.37 & -0.50 & 0.00 & -0.35 & -0.88 & 0.38 & 0.42 & 0.16 & 0.00 & 0.00 \\
\hline Id_BCU(6) & -10 & 0.00 & 0.00 & 0.00 & -0.07 & -0.72 & 0.44 & 0.37 & 0.00 & 0.00 & -0.88 & 0.38 & 0.42 & 0.16 & 0.00 & 0.00 \\
\hline Id_TBA(1) & -10 & 1.63 & -0.14 & 1.12 & -0.07 & -2.08 & 0.44 & 0.75 & 3.17 & 0.00 & 1.75 & 0.38 & 0.42 & -0.98 & 1.11 & 0.00 \\
\hline Id_TBA(3) & -10 & 0.00 & 0.00 & 0.00 & -0.07 & 3.01 & 3.93 & -0.37 & 0.00 & -0.35 & -0.88 & 0.38 & 0.42 & 0.16 & 0.00 & 0.00 \\
\hline Id_TBA(4) & -10 & 0.00 & 0.00 & 0.00 & -0.14 & 2.80 & 4.37 & -0.50 & 0.00 & -0.35 & -7.02 & 0.38 & 0.42 & 0.33 & 0.00 & 0.00 \\
\hline Id_TBA(6) & -10 & 0.00 & 0.00 & -0.28 & -0.07 & 2.37 & 4.37 & -0.50 & 0.00 & -0.35 & -0.88 & 0.38 & 0.42 & 0.16 & 0.00 & 0.00 \\
\hline Id_TCB(1) & -10 & 0.00 & 0.00 & 0.00 & -0.07 & -1.43 & 0.44 & 0.00 & 0.00 & 0.00 & -0.88 & 0.38 & 0.42 & 0.00 & 0.00 & 0.00 \\
\hline Id_TCB(4) & -10 & -0.23 & 0.00 & 0.00 & -0.07 & 5.23 & 1.31 & -0.37 & 0.00 & 0.00 & 0.00 & 0.38 & 0.42 & 0.00 & 0.00 & 0.00 \\
\hline Id_TCB(6) & -10 & 0.00 & 0.00 & 0.00 & -0.07 & 4.95 & 3.93 & -0.50 & 0.00 & -0.35 & -0.88 & 0.38 & 0.42 & 0.16 & 0.00 & 0.00 \\
\hline Id_TC(1) & -10 & 13.29 & -0.14 & 4.48 & 0.07 & -2.37 & 0.87 & 1.24 & 0.00 & 0.35 & -0.88 & 0.38 & 0.63 & 0.66 & 1.11 & 1.92 \\
\hline Id_TC(3) & -10 & 0.00 & 0.00 & 0.00 & -0.07 & -1.36 & 0.44 & 0.25 & 0.00 & 0.00 & -0.88 & 0.38 & 0.42 & 0.16 & 0.00 & 0.00 \\
\hline Id_TC(4) & -10 & 0.47 & -0.14 & -1.12 & -0.07 & -1.65 & 0.44 & 0.87 & 0.00 & 0.35 & 0.88 & 0.38 & 0.42 & 0.66 & 0.00 & 0.00 \\
\hline Id_TC(5) & -10 & 0.00 & -0.28 & -0.28 & -0.14 & 2.94 & 4.37 & 0.50 & 0.00 & 0.69 & -0.88 & 0.38 & 0.42 & 0.16 & 0.00 & 0.00 \\
\hline Id_TC(6) & -10 & 0.00 & 0.00 & 0.28 & -0.07 & 2.94 & 3.93 & -0.37 & 0.00 & -0.35 & -0.88 & 0.38 & 0.42 & 0.16 & 0.00 & 0.00 \\
\hline Id_TMA(1) & -10 & 5.59 & 0.14 & -2.80 & -0.14 & -0.14 & 0.44 & -0.25 & 0.00 & -1.74 & 0.00 & 0.38 & 0.42 & 1.97 & 1.11 & 0.00 \\
\hline Id_TMA(2) & -10 & 0.23 & 0.00 & -0.84 & -0.07 & -1.22 & 0.44 & 0.25 & 0.00 & -0.69 & -7.89 & 0.38 & 0.42 & 1.48 & 0.00 & 0.00 \\
\hline Id_TMA(3) & -10 & 0.70 & 0.00 & -1.40 & 0.00 & -0.93 & 0.44 & -0.12 & 0.00 & -1.04 & -0.88 & 0.38 & 0.42 & 1.64 & 1.11 & 0.00 \\
\hline
\end{tabular}


Table C-2

Percentage Change in Roots Mean Square of Mean Weighted Residuals Between Sensitivity Runs and Calibration Run

\begin{tabular}{|c|c|c|c|c|c|c|c|c|c|c|c|c|c|c|c|c|}
\hline \multicolumn{2}{|c|}{ Calibration Zones and Base Data ${ }^{a}$ : } & \multirow{2}{*}{$\begin{array}{c}\text { NRTH } \\
42.90 \\
\end{array}$} & \multirow{2}{*}{$\begin{array}{l}\text { OASI } \\
72.20 \\
\end{array}$} & \multirow{2}{*}{$\begin{array}{c}\text { PM } \\
35.70 \\
\end{array}$} & \multirow{2}{*}{\begin{tabular}{|l} 
BARR \\
146.80 \\
\end{tabular}} & \multirow{2}{*}{$\begin{array}{c}\text { WYF } \\
139.50\end{array}$} & \multirow{2}{*}{$\begin{array}{c}\text { EYF } \\
22.90 \\
\end{array}$} & \multirow{2}{*}{$\begin{array}{c}\text { SHON } \\
80.50 \\
\end{array}$} & \multirow{2}{*}{$\begin{array}{c}\text { DV } \\
41.00 \\
\end{array}$} & \multirow{2}{*}{$\begin{array}{l}\text { LCA } \\
28.80 \\
\end{array}$} & \multirow{2}{*}{$\begin{array}{c}\text { PAHR } \\
11.40 \\
\end{array}$} & \multirow{2}{*}{$\begin{array}{c}\text { SPMT } \\
53.30 \\
\end{array}$} & \multirow{2}{*}{$\begin{array}{c}\text { SHRG } \\
47.30 \\
\end{array}$} & \multirow{2}{*}{$\begin{array}{c}\text { TMBR } \\
61.00 \\
\end{array}$} & \multirow{2}{*}{$\begin{array}{c}\text { FARM } \\
9.00 \\
\end{array}$} & \multirow{2}{*}{$\begin{array}{c}\text { FF } \\
5.20\end{array}$} \\
\hline Parameter & $\%$ Change & & & & & & & & & & & & & & & \\
\hline Id_TMA(4) & -10 & 1.40 & -0.14 & -2.24 & -0.07 & -0.79 & 0.44 & 0.12 & 0.00 & -0.69 & -0.88 & 0.38 & 0.42 & 2.46 & 1.11 & 0.00 \\
\hline Id_TMA(6) & -10 & 0.70 & 0.00 & 0.28 & -0.07 & 6.59 & 1.75 & -0.37 & 0.00 & 0.00 & -0.88 & 0.38 & 0.42 & 0.00 & 0.00 & 0.00 \\
\hline Id_AA(1) & -10 & 6.29 & 0.00 & 0.00 & 0.00 & -5.81 & 1.31 & 0.00 & 3.17 & -0.35 & -9.65 & -0.94 & -3.38 & 0.16 & -1.11 & 0.00 \\
\hline Id_AA(2) & -10 & 0.00 & 0.42 & 0.00 & 0.41 & 6.45 & 2.18 & 0.25 & 2.20 & -0.69 & -6.14 & 0.56 & 1.48 & 0.00 & 6.67 & 5.77 \\
\hline Id_AA(3) & -10 & 0.00 & 0.00 & 0.00 & -0.07 & -1.72 & 0.44 & -0.25 & 0.00 & 0.00 & -0.88 & 0.38 & 0.63 & 0.00 & 0.00 & 0.00 \\
\hline Id_AA(4) & -10 & -0.23 & 0.00 & 0.00 & -0.07 & -1.36 & -1.75 & 0.25 & 0.00 & 0.00 & -0.88 & 0.38 & 0.42 & 0.00 & 0.00 & 0.00 \\
\hline Id_AA(5) & -10 & 0.00 & 0.00 & 0.00 & 0.00 & -2.51 & 0.87 & -0.12 & 0.00 & 0.00 & 0.00 & 0.38 & 0.63 & 0.00 & 0.00 & 0.00 \\
\hline Id_AA(6) & -10 & 0.00 & 1.11 & 0.00 & 0.14 & 2.80 & 4.37 & -0.25 & -0.49 & -1.04 & -2.63 & 0.56 & 1.06 & 0.16 & 0.00 & 1.92 \\
\hline
\end{tabular}


Table C-3

Percentage Changes in Discharge Rates Between Sensitivity Runs and Calibration Run

\begin{tabular}{|c|c|c|c|c|c|c|c|c|c|c|c|}
\hline \multirow{2}{*}{\multicolumn{2}{|c|}{ Calibration Zones and Base Data ${ }^{\mathrm{a}}$ : }} & \multicolumn{8}{|c|}{ Drain Fluxes } & \multicolumn{2}{|c|}{ GHB Fluxes } \\
\hline & & \multirow{2}{*}{$\begin{array}{c}\text { DV } \\
-59782.87\end{array}$} & \multirow{2}{*}{$\begin{array}{c}\text { OV } \\
-25784.95\end{array}$} & \multirow{2}{*}{$\begin{array}{c}\text { Ariv } \\
-334.81\end{array}$} & \multirow{2}{*}{$\begin{array}{c}\text { AM } \\
-77332.51\end{array}$} & \multirow{2}{*}{$\begin{array}{c}\text { FL } \\
-37873.7\end{array}$} & \multirow{2}{*}{$\begin{array}{c}\text { AF } \\
-5232.56\end{array}$} & \multirow{2}{*}{$\begin{array}{c}\text { PV } \\
-19105.9\end{array}$} & \multirow{2}{*}{$\begin{array}{c}\text { IS } \\
-2456.55\end{array}$} & \multirow{2}{*}{$\begin{array}{c}\text { PP } \\
1719.51\end{array}$} & \multirow{2}{*}{$\begin{array}{c}\text { EM } \\
-4928.82\end{array}$} \\
\hline Parameter & $\%$ Change & & & & & & & & & & \\
\hline Kh_I & 100 & 0.04 & -0.35 & 0.39 & 0.22 & -0.02 & 2.54 & -1.18 & 0.07 & 0.01 & -0.03 \\
\hline Kh_LCCU(1) & 100 & 0.15 & -9.15 & 7.23 & 3.82 & 0.55 & 36.34 & -7.84 & -12.08 & 60.83 & 0.24 \\
\hline Kh_LCCU(2) & 100 & 0.01 & -0.38 & 0.92 & 0.52 & 0.07 & 6.06 & -1.09 & -18.23 & 0.02 & 0.03 \\
\hline Kh_LCCU(3) & 100 & 16.91 & -6.30 & -39.34 & -6.93 & -2.58 & -40.87 & -0.82 & -0.52 & 0.21 & 5.85 \\
\hline Kh_LCA(1) & 100 & 0.85 & -0.72 & 3.02 & 0.62 & 0.15 & -2.84 & -1.96 & -17.44 & 0.01 & 0.06 \\
\hline Kh_LCA(2) & 100 & -0.30 & -0.30 & -15.27 & 6.78 & -0.78 & -82.59 & -1.01 & -3.24 & 2.32 & -0.24 \\
\hline Kh_LCA(3) & 100 & 0.04 & -0.22 & 2.93 & 1.54 & 0.21 & 17.62 & -0.87 & -81.94 & 0.08 & 0.09 \\
\hline Kh_LCA(4) & 100 & 7.41 & -0.78 & 34.52 & -4.54 & 7.22 & -100.00 & -1.15 & -3.31 & -2.50 & 38.92 \\
\hline Kh_LCA(5) & 100 & 0.78 & -2.38 & 5.25 & 3.93 & 0.36 & 49.09 & -29.65 & 1.39 & 0.04 & 0.16 \\
\hline Kh_LCA(6) & 100 & 0.01 & -0.40 & 0.55 & 0.27 & 0.04 & 3.06 & -1.04 & -4.19 & 0.04 & 0.02 \\
\hline Kh_LCA(7) & 100 & 0.01 & 0.55 & 0.22 & 0.09 & 0.02 & 0.97 & -1.46 & 0.03 & 0.00 & 0.01 \\
\hline Kh_LCA(8) & 100 & 0.18 & -0.57 & 11.80 & 6.16 & 0.86 & 74.19 & -47.24 & 1.03 & 0.02 & 0.36 \\
\hline Kh_LCA(9) & 100 & 37.70 & 0.20 & -100.00 & -17.83 & -10.24 & -78.69 & -1.31 & -1.14 & -0.46 & -4.16 \\
\hline Kh_UCCU & 100 & 0.01 & -2.30 & 0.90 & 0.57 & 0.07 & 6.87 & -1.32 & 0.13 & 0.01 & 0.03 \\
\hline Kh_LCA3 & 100 & 0.01 & -0.80 & 0.54 & 0.30 & 0.04 & 3.41 & -1.19 & 0.12 & 0.01 & 0.02 \\
\hline Kh_TSDV(1) & 100 & 0.05 & -0.29 & 1.62 & -0.81 & 2.45 & -3.13 & -0.91 & 0.00 & 0.24 & 1.81 \\
\hline Kh_TSDV(2) & 100 & 6.42 & -0.88 & -22.32 & -2.75 & -1.96 & -9.45 & -0.81 & -0.07 & -0.02 & -0.43 \\
\hline Kh_VU(1) & 100 & 0.07 & -4.31 & 8.20 & 4.25 & 0.58 & 49.88 & -26.77 & 0.67 & 0.04 & 0.25 \\
\hline Kh_VU(2) & 100 & 0.01 & -0.78 & 0.47 & 0.27 & 0.03 & 3.21 & -1.09 & 0.11 & 0.01 & 0.01 \\
\hline Kh_VU(3) & 100 & 0.41 & -9.67 & 9.09 & 1.94 & 0.64 & 13.99 & -1.48 & 0.19 & 0.02 & 0.25 \\
\hline Kh_VCU(1) & 100 & 0.39 & -20.99 & 14.14 & 4.00 & 0.99 & 35.32 & -1.17 & 0.55 & 0.04 & 0.40 \\
\hline Kh_VCU(2) & 100 & 0.01 & -0.85 & 0.39 & 0.23 & 0.03 & 2.77 & -0.79 & 0.11 & 0.01 & 0.01 \\
\hline Kh_VA(1) & 100 & -0.03 & 4.30 & -1.29 & -0.66 & -0.09 & -7.34 & -0.82 & -0.10 & -0.02 & -0.04 \\
\hline Kh_VA(2) & 100 & 0.00 & -0.35 & 0.30 & 0.17 & 0.02 & 1.99 & -0.82 & 0.08 & 0.00 & 0.01 \\
\hline Kh_VA(3) & 100 & 0.04 & -0.70 & 3.59 & 0.30 & 0.25 & -0.82 & -0.78 & 0.05 & 0.00 & 0.09 \\
\hline Kh_BAQ(1) & 100 & 0.01 & -0.30 & 0.44 & 0.21 & 0.03 & 2.42 & -1.22 & 0.10 & 0.00 & 0.01 \\
\hline Kh_BAQ(3) & 100 & 0.00 & -0.36 & 0.36 & 0.20 & 0.03 & 2.36 & -1.03 & 0.10 & 0.00 & 0.01 \\
\hline Kh_BAQ(4) & 100 & 0.01 & -0.81 & 0.44 & 0.25 & 0.03 & 2.95 & -0.85 & 0.12 & 0.01 & 0.01 \\
\hline Kh_BAQ(5) & 100 & 0.00 & -0.39 & 0.29 & 0.17 & 0.02 & 1.95 & -0.76 & 0.10 & 0.00 & 0.01 \\
\hline Kh_BAQ(6) & 100 & 0.00 & -0.17 & 0.25 & 0.14 & 0.02 & 1.59 & -0.83 & 0.09 & 0.00 & 0.01 \\
\hline
\end{tabular}


Table C-3

Percentage Changes in Discharge Rates Between Sensitivity Runs and Calibration Run

\begin{tabular}{|c|c|c|c|c|c|c|c|c|c|c|c|}
\hline \multirow{2}{*}{\multicolumn{2}{|c|}{ Calibration Zones and Base Data ${ }^{a}$ : }} & \multicolumn{8}{|c|}{ Drain Fluxes } & \multicolumn{2}{|c|}{ GHB Fluxes } \\
\hline & & \multirow{2}{*}{$\begin{array}{c}\text { DV } \\
-59782.87\end{array}$} & \multirow{2}{*}{$\begin{array}{c}\text { OV } \\
-25784.95\end{array}$} & \multirow{2}{*}{$\begin{array}{c}\text { Ariv } \\
-334.81\end{array}$} & \multirow{2}{*}{$\begin{array}{c}\text { AM } \\
-77332.51\end{array}$} & \multirow{2}{*}{$\begin{array}{c}\mathbf{F L} \\
-37873.7\end{array}$} & \multirow{2}{*}{$\begin{array}{c}\text { AF } \\
-5232.56\end{array}$} & \multirow{2}{*}{$\begin{array}{c}\text { PV } \\
-19105.9\end{array}$} & \multirow{2}{*}{$\begin{array}{c}\text { IS } \\
-2456.55\end{array}$} & \multirow{2}{*}{$\begin{array}{c}\text { PP } \\
1719.51\end{array}$} & \multirow{2}{*}{$\begin{array}{c}\text { EM } \\
-4928.82\end{array}$} \\
\hline Parameter & $\%$ Change & & & & & & & & & & \\
\hline $\mathrm{Kh} \_\mathrm{BCU}(1)$ & 100 & 0.02 & -2.30 & 1.42 & 0.78 & 0.10 & 9.12 & -2.86 & 0.21 & 0.02 & 0.04 \\
\hline Kh_BCU(3) & 100 & 0.00 & 0.10 & -0.06 & -0.03 & 0.00 & -0.31 & 0.05 & 0.01 & 0.00 & 0.00 \\
\hline Kh_BCU(4) & 100 & 0.01 & -0.80 & 0.41 & 0.24 & 0.03 & 2.80 & -0.76 & 0.12 & 0.01 & 0.01 \\
\hline Kh_BCU(5) & 100 & 0.01 & -0.84 & 0.43 & 0.25 & 0.03 & 2.88 & -0.73 & 0.11 & 0.01 & 0.01 \\
\hline Kh_BCU(6) & 100 & 0.00 & -0.67 & 0.38 & 0.22 & 0.03 & 2.61 & -0.78 & 0.07 & 0.01 & 0.01 \\
\hline Kh_TBA(1) & 100 & 0.69 & 0.65 & -2.17 & 0.01 & -0.20 & 2.90 & -3.41 & 0.09 & 0.00 & 0.00 \\
\hline Kh_TBA(3) & 100 & 0.01 & -0.94 & 0.45 & 0.26 & 0.03 & 3.12 & -0.79 & 0.08 & 0.01 & 0.01 \\
\hline Kh_TBA(4) & 100 & 0.01 & -0.75 & 0.40 & 0.23 & 0.03 & 2.74 & -0.78 & 0.11 & 0.00 & 0.00 \\
\hline Kh_TBA(6) & 100 & 0.01 & -0.76 & 0.39 & 0.23 & 0.03 & 2.73 & -0.76 & 0.10 & 0.01 & 0.02 \\
\hline Kh_TCB(1) & 100 & 0.01 & -0.76 & 0.48 & 0.27 & 0.04 & 3.18 & -1.10 & 0.10 & 0.00 & 0.00 \\
\hline $\mathrm{Kh} \_\mathrm{TCB}(4)$ & 100 & 0.01 & -0.87 & 0.48 & 0.28 & 0.04 & 3.29 & -1.06 & 0.09 & 0.00 & 0.00 \\
\hline Kh_TCB(6) & 100 & 0.01 & -0.85 & 0.42 & 0.25 & 0.03 & 2.91 & -0.79 & 0.13 & -0.01 & -0.02 \\
\hline Kh_TC(1) & 100 & -0.01 & 4.44 & -0.66 & -0.32 & -0.05 & -3.68 & -3.54 & -0.07 & 0.00 & 0.00 \\
\hline Kh_TC(3) & 100 & 0.00 & -0.68 & 0.36 & 0.21 & 0.03 & 2.51 & -0.75 & 0.08 & 0.00 & 0.01 \\
\hline Kh_TC(4) & 100 & 0.01 & -0.22 & 0.49 & 0.21 & 0.04 & 2.25 & -1.29 & 0.06 & 0.01 & 0.04 \\
\hline Kh_TC(5) & 100 & 0.02 & -2.02 & 1.24 & 0.47 & 0.09 & 4.89 & -0.81 & 0.08 & 0.01 & 0.01 \\
\hline Kh_TC(6) & 100 & 0.01 & -0.70 & 0.39 & 0.23 & 0.03 & 2.68 & -0.80 & 0.13 & 0.01 & -0.01 \\
\hline Kh_TMA(1) & 100 & -0.02 & 1.06 & -0.36 & 0.16 & -0.02 & 2.91 & -2.80 & 0.07 & 0.00 & 0.00 \\
\hline Kh_TMA(2) & 100 & 0.00 & 0.67 & -0.10 & 0.00 & -0.01 & 0.19 & -0.94 & 0.02 & 0.00 & -0.02 \\
\hline Kh_TMA(3) & 100 & -0.02 & 1.92 & -0.90 & -0.18 & -0.06 & -1.23 & -1.29 & 0.01 & 0.00 & -0.02 \\
\hline Kh_TMA(4) & 100 & -0.02 & 1.74 & -0.72 & -0.07 & -0.05 & 0.18 & -1.94 & 0.05 & 0.00 & 0.00 \\
\hline Kh_TMA(6) & 100 & 0.00 & -0.03 & 0.26 & 0.15 & 0.02 & 1.76 & -1.11 & 0.05 & 1.36 & 80.73 \\
\hline Kh_AA(1) & 100 & 3.93 & 0.68 & 12.13 & 3.81 & -14.23 & 16.91 & -18.69 & -56.93 & 1.78 & 6.56 \\
\hline $\mathrm{Kh} \_\mathrm{AA}(2)$ & 100 & 2.97 & -0.93 & 28.02 & -0.87 & 11.58 & -100.00 & -1.40 & -5.09 & 0.01 & 0.02 \\
\hline Kh_AA(3) & 100 & 0.01 & -0.34 & 0.70 & 0.39 & 0.05 & 4.50 & -0.72 & -13.73 & 0.00 & -0.08 \\
\hline Kh_AA(4) & 100 & 0.71 & -0.64 & -2.06 & -0.21 & -0.20 & -0.35 & 0.01 & 0.05 & 0.01 & 0.01 \\
\hline Kh_AA(5) & 100 & 0.01 & -0.78 & 0.41 & 0.24 & 0.03 & 2.82 & -0.79 & 0.11 & 10.66 & 87.81 \\
\hline Kh_AA(6) & 100 & -0.21 & -0.63 & -50.95 & -17.33 & 40.19 & -100.00 & -1.16 & -1.95 & 0.01 & -0.07 \\
\hline Id_I & 10 & -0.01 & -0.79 & 0.39 & 0.23 & 0.06 & 2.77 & -0.76 & 0.11 & 0.01 & 0.04 \\
\hline Id_LCCU(1) & 10 & -0.03 & 2.66 & -1.53 & -0.80 & -0.12 & -8.06 & 0.91 & 3.49 & -9.29 & -0.05 \\
\hline
\end{tabular}


Table C-3

Percentage Changes in Discharge Rates Between Sensitivity Runs and Calibration Run

\begin{tabular}{|c|c|c|c|c|c|c|c|c|c|c|c|}
\hline \multirow{2}{*}{\multicolumn{2}{|c|}{ Calibration Zones and Base Data ${ }^{a}$ : }} & \multicolumn{8}{|c|}{ Drain Fluxes } & \multicolumn{2}{|c|}{ GHB Fluxes } \\
\hline & & \multirow{2}{*}{$\begin{array}{c}\text { DV } \\
-59782.87\end{array}$} & \multirow{2}{*}{$\begin{array}{c}\text { OV } \\
-25784.95\end{array}$} & \multirow{2}{*}{$\begin{array}{c}\text { Ariv } \\
-334.81\end{array}$} & \multirow{2}{*}{$\begin{array}{c}\text { AM } \\
-77332.51\end{array}$} & \multirow{2}{*}{$\begin{array}{c}\text { FL } \\
-37873.7\end{array}$} & \multirow{2}{*}{$\begin{array}{c}\text { AF } \\
-5232.56\end{array}$} & \multirow{2}{*}{$\begin{array}{c}\text { PV } \\
-19105.9\end{array}$} & \multirow{2}{*}{$\begin{array}{c}\text { IS } \\
-2456.55\end{array}$} & \multirow{2}{*}{$\begin{array}{c}\text { PP } \\
1719.51\end{array}$} & \multirow{2}{*}{$\begin{array}{c}\text { EM } \\
-4928.82 \\
\end{array}$} \\
\hline Parameter & $\%$ Change & & & & & & & & & & \\
\hline Id_LCCU(2) & 10 & 0.00 & -0.62 & 0.28 & 0.17 & 0.02 & 1.96 & -1.22 & 5.31 & 0.00 & 0.01 \\
\hline Id_LCCU(3) & 10 & -4.38 & 1.82 & 10.32 & 1.95 & 0.69 & 11.88 & -1.11 & 0.21 & -0.13 & -1.41 \\
\hline Id_LCA(1) & 10 & -0.03 & -0.19 & -1.73 & -0.19 & -0.11 & 1.86 & 0.46 & 2.98 & -0.01 & -0.04 \\
\hline Id_LCA(2) & 10 & 0.09 & -0.08 & 4.42 & -1.68 & 0.20 & 24.18 & -0.68 & 1.07 & -0.16 & 0.05 \\
\hline Id_LCA(3) & 10 & 0.00 & -0.25 & -0.15 & -0.07 & -0.01 & -0.86 & -0.89 & 13.96 & -0.02 & 0.00 \\
\hline Id_LCA(4) & 10 & -2.76 & -0.17 & -13.06 & 0.82 & -3.22 & 46.86 & 0.06 & 0.64 & 0.06 & -3.25 \\
\hline Id_LCA(5) & 10 & -0.02 & 0.27 & -1.72 & -0.96 & -0.13 & -11.48 & 7.07 & -0.22 & -0.03 & -0.05 \\
\hline Id_LCA(6) & 10 & 0.01 & -0.83 & 0.39 & 0.23 & 0.03 & 2.75 & -0.83 & 1.44 & -0.01 & 0.01 \\
\hline Id_LCA(7) & 10 & 0.01 & -0.85 & 0.55 & 0.27 & 0.04 & 3.07 & -0.94 & 0.11 & 0.00 & 0.02 \\
\hline Id_LCA(8) & 10 & -0.04 & -0.17 & -2.44 & -1.23 & -0.18 & -14.58 & 9.69 & -0.27 & -0.04 & -0.08 \\
\hline Id_LCA(9) & 10 & -9.69 & -0.29 & 34.09 & 4.85 & 2.14 & 24.77 & -0.83 & 0.39 & 0.03 & 0.85 \\
\hline Id_UCCU & 10 & 0.00 & 0.11 & 0.26 & 0.12 & 0.02 & 1.36 & -1.11 & 0.06 & 0.00 & 0.01 \\
\hline Id_LCA3 & 10 & 0.00 & -0.11 & 0.25 & 0.13 & 0.02 & 1.55 & -0.89 & 0.04 & 0.00 & 0.01 \\
\hline Id_TSDV(1) & 10 & -0.01 & -0.69 & 0.36 & 0.43 & -0.40 & 4.09 & -1.08 & 0.08 & -0.04 & -0.34 \\
\hline Id_TSDV(2) & 10 & -2.01 & -0.82 & 7.48 & 1.20 & 0.64 & 6.95 & -0.85 & 0.15 & 0.01 & 0.19 \\
\hline Id_VU(1) & 10 & -0.02 & 2.65 & -3.17 & -1.34 & -0.21 & -15.04 & 6.44 & -0.20 & -0.04 & -0.09 \\
\hline Id_VU(2) & 10 & 0.00 & -0.19 & 0.33 & 0.19 & 0.02 & 2.14 & -1.17 & 0.09 & 0.00 & 0.01 \\
\hline Id_VU(3) & 10 & -0.05 & 1.15 & -1.19 & -0.11 & -0.08 & 0.27 & -0.84 & 0.08 & 0.00 & -0.03 \\
\hline Id_VCU(1) & 10 & -0.09 & 5.44 & -3.59 & -0.86 & -0.25 & -6.80 & -1.12 & -0.04 & -0.02 & -0.10 \\
\hline Id_VCU(2) & 10 & 0.00 & -0.24 & 0.05 & 0.04 & 0.00 & 0.45 & 0.04 & 0.05 & 0.00 & 0.00 \\
\hline Id_VA(1) & 10 & -0.01 & 0.19 & -0.13 & 0.10 & -0.01 & 1.58 & -1.05 & 0.04 & 0.00 & 0.00 \\
\hline Id_VA(2) & 10 & 0.00 & -0.58 & 0.28 & 0.18 & 0.02 & 2.14 & -0.89 & 1.56 & 0.00 & 0.01 \\
\hline Id_VA(3) & 10 & -0.01 & -0.73 & -0.69 & 0.20 & -0.05 & 3.85 & -0.78 & 0.08 & 0.00 & -0.02 \\
\hline Id_BAQ(1) & 10 & 0.00 & 0.34 & 0.21 & 0.10 & 0.02 & 1.12 & -1.21 & 0.06 & 0.00 & 0.01 \\
\hline Id_BAQ(3) & 10 & 0.01 & -0.82 & 0.49 & 0.28 & 0.04 & 3.32 & -1.06 & 0.09 & 0.00 & 0.02 \\
\hline Id_BAQ(4) & 10 & 0.00 & -0.37 & 0.33 & 0.18 & 0.02 & 2.11 & -0.87 & 0.07 & 0.00 & 0.01 \\
\hline Id_BAQ(5) & 10 & 0.01 & -0.76 & 0.39 & 0.23 & 0.03 & 2.70 & -0.74 & 0.10 & 0.00 & 0.01 \\
\hline Id_BAQ(6) & 10 & 0.01 & -0.85 & 0.42 & 0.25 & 0.03 & 2.94 & -0.78 & 0.09 & 0.00 & 0.01 \\
\hline Id_BCU(1) & 10 & 0.00 & 0.73 & -0.17 & -0.09 & -0.01 & -1.10 & -0.28 & 0.02 & -0.01 & -0.01 \\
\hline Id_BCU(3) & 10 & 0.00 & -0.27 & 0.29 & 0.16 & 0.02 & 1.89 & -0.90 & 0.11 & 0.00 & 0.01 \\
\hline
\end{tabular}


Table C-3

Percentage Changes in Discharge Rates Between Sensitivity Runs and Calibration Run

\begin{tabular}{|c|c|c|c|c|c|c|c|c|c|c|c|}
\hline \multirow{2}{*}{\multicolumn{2}{|c|}{ Calibration Zones and Base Data ${ }^{a}$ : }} & \multicolumn{8}{|c|}{ Drain Fluxes } & \multicolumn{2}{|c|}{ GHB Fluxes } \\
\hline & & \multirow{2}{*}{$\begin{array}{c}\text { DV } \\
-59782.87\end{array}$} & \multirow{2}{*}{$\begin{array}{c}\text { OV } \\
-25784.95\end{array}$} & \multirow{2}{*}{$\begin{array}{c}\text { Ariv } \\
-334.81\end{array}$} & \multirow{2}{*}{$\begin{array}{c}\text { AM } \\
-77332.51\end{array}$} & \multirow{2}{*}{$\begin{array}{c}\mathbf{F L} \\
-37873.7\end{array}$} & \multirow{2}{*}{$\begin{array}{c}\text { AF } \\
-5232.56\end{array}$} & \multirow{2}{*}{$\begin{array}{c}\text { PV } \\
-19105.9\end{array}$} & \multirow{2}{*}{$\begin{array}{c}\text { IS } \\
-2456.55\end{array}$} & \multirow{2}{*}{$\begin{array}{c}\text { PP } \\
1719.51\end{array}$} & \multirow{2}{*}{$\begin{array}{c}\text { EM } \\
-4928.82\end{array}$} \\
\hline Parameter & $\%$ Change & & & & & & & & & & \\
\hline Id_BCU(4) & 10 & 0.01 & -0.85 & 0.49 & 0.29 & 0.04 & 3.36 & -1.07 & 0.15 & 0.00 & 0.02 \\
\hline Id_BCU(5) & 10 & 0.01 & -0.79 & 0.45 & 0.27 & 0.03 & 3.17 & -1.02 & 0.11 & 0.00 & 0.01 \\
\hline Id_BCU(6) & 10 & 0.00 & -0.31 & 0.30 & 0.17 & 0.02 & 1.94 & -0.87 & 0.08 & 0.00 & 0.01 \\
\hline Id_TBA(1) & 10 & 0.00 & -0.13 & -0.16 & -0.04 & -0.01 & -0.37 & 0.48 & 0.06 & 0.00 & 0.00 \\
\hline Id_TBA(3) & 10 & 0.01 & -0.77 & 0.40 & 0.24 & 0.03 & 2.79 & -0.74 & 0.10 & 0.00 & 0.01 \\
\hline Id_TBA(4) & 10 & 0.00 & -0.29 & 0.24 & 0.14 & 0.02 & 1.64 & -0.69 & 0.05 & 0.00 & 0.01 \\
\hline Id_TBA(6) & 10 & 0.01 & -0.86 & 0.43 & 0.25 & 0.03 & 2.97 & -0.78 & 0.10 & 0.00 & 0.01 \\
\hline Id_TCB(1) & 10 & 0.01 & -0.83 & 0.42 & 0.25 & 0.03 & 2.92 & -0.77 & 0.08 & 0.00 & 0.01 \\
\hline Id_TCB(4) & 10 & 0.00 & -0.24 & 0.05 & 0.04 & 0.00 & 0.44 & 0.04 & 0.06 & 0.00 & 0.00 \\
\hline Id_TCB(6) & 10 & 0.00 & -0.29 & 0.29 & 0.16 & 0.02 & 1.90 & -0.90 & 0.07 & 0.00 & 0.01 \\
\hline Id_TC(1) & 10 & 0.01 & -3.56 & 0.89 & 0.42 & 0.06 & 4.70 & 1.56 & 0.14 & 0.01 & 0.03 \\
\hline Id_TC(3) & 10 & 0.01 & -0.85 & 0.43 & 0.25 & 0.03 & 2.95 & -0.77 & 0.06 & 0.00 & 0.01 \\
\hline Id_TC(4) & 10 & 0.00 & -0.10 & 0.10 & 0.10 & 0.01 & 1.34 & -0.80 & 0.06 & 0.00 & 0.00 \\
\hline Id_TC(5) & 10 & -0.01 & 0.50 & -0.19 & 0.01 & -0.01 & 0.47 & -0.79 & 0.07 & 0.00 & 0.00 \\
\hline Id_TC(6) & 10 & 0.01 & -0.78 & 0.40 & 0.24 & 0.03 & 2.78 & -0.76 & 0.10 & 0.00 & 0.01 \\
\hline Id_TMA(1) & 10 & 0.09 & -0.87 & 0.67 & 0.13 & 0.05 & 0.82 & 0.00 & 0.04 & 0.00 & 0.02 \\
\hline Id_TMA(2) & 10 & 0.01 & -0.56 & 0.39 & 0.19 & 0.03 & 2.11 & -0.69 & 0.07 & 0.00 & 0.01 \\
\hline Id_TMA(3) & 10 & 0.01 & -0.89 & 0.73 & 0.29 & 0.05 & 3.01 & -0.96 & 0.10 & 0.00 & 0.02 \\
\hline Id_TMA(4) & 10 & 0.02 & -1.00 & 0.87 & 0.26 & 0.06 & 2.40 & -0.59 & 0.06 & 0.00 & 0.02 \\
\hline Id_TMA(6) & 10 & 0.00 & -0.41 & 0.25 & 0.15 & 0.02 & 1.73 & -0.60 & 0.06 & 0.00 & 0.01 \\
\hline Id_AA(1) & 10 & -1.68 & -0.05 & 1.40 & -0.16 & 0.07 & -3.92 & 5.23 & 12.44 & -0.05 & 0.03 \\
\hline Id_AA(2) & 10 & -1.12 & -0.73 & -8.73 & -1.32 & -1.65 & 52.72 & -1.06 & 0.68 & -0.07 & -0.92 \\
\hline Id_AA(3) & 10 & 0.00 & -0.26 & 0.22 & 0.13 & 0.02 & 1.46 & -0.81 & 1.66 & 0.00 & 0.01 \\
\hline Id_AA(4) & 10 & 0.00 & -0.17 & 0.33 & 0.18 & 0.02 & 2.06 & -1.15 & 0.09 & 0.00 & 0.01 \\
\hline Id_AA(5) & 10 & 0.01 & -0.73 & 0.39 & 0.23 & 0.03 & 2.70 & -0.77 & 0.10 & 0.00 & 0.01 \\
\hline Id_AA(6) & 10 & -0.02 & 0.30 & 4.65 & 2.22 & -6.47 & 19.60 & 0.18 & 0.31 & -0.60 & -8.68 \\
\hline Kh_I & -50 & -0.02 & -0.97 & 0.43 & 0.27 & 0.09 & 3.26 & -0.83 & 0.12 & 0.01 & 0.07 \\
\hline Kh_LCCU(1) & -50 & -0.09 & 5.03 & -3.75 & -1.86 & -0.29 & -16.98 & 1.96 & 8.04 & -36.67 & -0.13 \\
\hline Kh_LCCU(2) & -50 & 0.00 & -0.12 & -0.23 & -0.09 & -0.02 & -1.00 & -1.07 & 13.41 & -0.01 & -0.01 \\
\hline Kh_LCCU(3) & -50 & -10.13 & 9.89 & 18.12 & 3.17 & 1.18 & 17.17 & -1.02 & 0.30 & -0.32 & -3.37 \\
\hline
\end{tabular}


Table C-3

Percentage Changes in Discharge Rates Between Sensitivity Runs and Calibration Run

\begin{tabular}{|c|c|c|c|c|c|c|c|c|c|c|c|}
\hline \multirow{2}{*}{\multicolumn{2}{|c|}{ Calibration Zones and Base Data ${ }^{a}$ : }} & \multicolumn{8}{|c|}{ Drain Fluxes } & \multicolumn{2}{|c|}{ GHB Fluxes } \\
\hline & & \multirow{2}{*}{$\begin{array}{c}\text { DV } \\
-59782.87\end{array}$} & \multirow{2}{*}{$\begin{array}{c}\text { OV } \\
-25784.95\end{array}$} & \multirow{2}{*}{$\begin{array}{c}\text { Ariv } \\
-334.81\end{array}$} & \multirow{2}{*}{$\begin{array}{c}\text { AM } \\
-77332.51\end{array}$} & \multirow{2}{*}{$\begin{array}{c}\mathbf{F L} \\
-37873.7\end{array}$} & \multirow{2}{*}{$\begin{array}{c}\text { AF } \\
-5232.56\end{array}$} & \multirow{2}{*}{$\begin{array}{c}\text { PV } \\
-19105.9\end{array}$} & \multirow{2}{*}{$\begin{array}{c}\text { IS } \\
-2456.55\end{array}$} & \multirow{2}{*}{$\begin{array}{c}\text { PP } \\
1719.51\end{array}$} & \multirow{2}{*}{$\begin{array}{c}\text { EM } \\
-4928.82\end{array}$} \\
\hline Parameter & $\%$ Change & & & & & & & & & & \\
\hline Kh_LCA(1) & -50 & -0.12 & 0.12 & -5.02 & -0.81 & -0.33 & 1.70 & 0.27 & 26.55 & -0.02 & -0.13 \\
\hline Kh_LCA(2) & -50 & 0.42 & -0.14 & 20.94 & -8.07 & 1.06 & 105.54 & -0.74 & 4.79 & -2.46 & 0.32 \\
\hline Kh_LCA(3) & -50 & -0.02 & -0.40 & -1.54 & -0.79 & -0.11 & -9.15 & -1.08 & 59.36 & -0.06 & -0.05 \\
\hline Kh_LCA(4) & -50 & -5.86 & 0.04 & -30.50 & -4.60 & -6.10 & 204.73 & -0.98 & 2.23 & -0.16 & -22.81 \\
\hline Kh_LCA(5) & -50 & 1.00 & 3.54 & -11.94 & -4.38 & -0.92 & -48.85 & 25.44 & -1.01 & -0.18 & -0.38 \\
\hline Kh_LCA(6) & -50 & 0.68 & 0.48 & -2.78 & -0.30 & -0.24 & -0.49 & -1.11 & 1.70 & -0.07 & -0.09 \\
\hline Kh_LCA(7) & -50 & 0.00 & -0.89 & 0.40 & 0.20 & 0.03 & 2.25 & -0.36 & 0.05 & 0.00 & 0.01 \\
\hline Kh_LCA(8) & -50 & -0.13 & 0.11 & -8.56 & -4.26 & -0.63 & -51.84 & 32.97 & -0.85 & -0.20 & -0.27 \\
\hline Kh_LCA(9) & -50 & -27.20 & 0.84 & 144.28 & 13.34 & 4.53 & 69.05 & -1.07 & 0.97 & 0.02 & 1.79 \\
\hline Kh_UCCU & -50 & 0.00 & 1.77 & -0.29 & -0.23 & -0.02 & -2.93 & -0.59 & -0.02 & -0.01 & -0.01 \\
\hline Kh_LCA3 & -50 & 0.00 & 0.57 & 0.03 & -0.01 & 0.00 & -0.13 & -0.71 & 0.02 & 0.00 & 0.00 \\
\hline Kh_TSDV(1) & -50 & -0.03 & -0.18 & -0.65 & 0.85 & -1.65 & 4.93 & -0.89 & 0.08 & -0.18 & -1.18 \\
\hline Kh_TSDV(2) & -50 & -4.42 & -0.09 & 15.66 & 2.17 & 1.43 & 9.74 & -0.79 & 0.20 & 0.02 & 0.44 \\
\hline Kh_VU(1) & -50 & -0.05 & 5.14 & -5.73 & -2.75 & -0.40 & -33.03 & 14.43 & -0.63 & -0.10 & -0.17 \\
\hline Kh_VU(2) & -50 & 0.01 & -0.76 & 0.39 & 0.23 & 0.03 & 2.68 & -0.76 & 0.12 & 0.01 & 0.01 \\
\hline Kh_VU(3) & -50 & -0.28 & 7.74 & -7.00 & -1.34 & -0.49 & -8.65 & -0.65 & -0.07 & -0.02 & -0.19 \\
\hline Kh_VCU(1) & -50 & -0.28 & 19.72 & -12.51 & -3.45 & -0.88 & -32.08 & -0.85 & -0.44 & -0.10 & -0.35 \\
\hline Kh_VCU(2) & -50 & 0.01 & -0.37 & 0.38 & 0.21 & 0.03 & 2.43 & -1.17 & 0.11 & 0.00 & 0.01 \\
\hline Kh_VA(1) & -50 & -0.03 & 1.65 & -1.25 & -0.18 & -0.09 & -0.72 & -1.00 & 0.05 & 0.00 & -0.03 \\
\hline Kh_VA(2) & -50 & 0.01 & -1.13 & 0.68 & 0.37 & 0.05 & 4.36 & -1.30 & 0.10 & 0.01 & 0.02 \\
\hline Kh_VA(3) & -50 & -0.04 & -0.07 & -3.04 & 0.05 & -0.21 & 5.00 & -0.87 & 0.11 & 0.01 & -0.08 \\
\hline Kh_BAQ(1) & -50 & 0.00 & 0.28 & 0.26 & 0.14 & 0.02 & 1.60 & -1.46 & 0.02 & 0.00 & 0.01 \\
\hline Kh_BAQ(3) & -50 & 0.01 & -0.86 & 0.42 & 0.25 & 0.03 & 2.92 & -0.78 & 0.12 & 0.01 & 0.01 \\
\hline Kh_BAQ(4) & -50 & 0.01 & -0.75 & 0.39 & 0.23 & 0.03 & 2.68 & -0.75 & 0.12 & 0.01 & 0.01 \\
\hline Kh_BAQ(5) & -50 & 0.00 & 0.02 & 0.18 & 0.10 & 0.01 & 1.14 & -0.79 & 0.08 & 0.00 & 0.01 \\
\hline Kh_BAQ(6) & -50 & 0.01 & -0.75 & 0.39 & 0.23 & 0.03 & 2.71 & -0.76 & 0.08 & 0.01 & 0.01 \\
\hline Kh_BCU(1) & -50 & 0.00 & 0.79 & -0.24 & -0.14 & -0.02 & -1.57 & -0.03 & 0.00 & 0.00 & -0.01 \\
\hline Kh_BCU(3) & -50 & 0.00 & -0.14 & 0.23 & 0.13 & 0.02 & 1.49 & -0.80 & 0.09 & 0.00 & 0.01 \\
\hline Kh_BCU(4) & -50 & 0.00 & -0.35 & 0.29 & 0.17 & 0.02 & 2.01 & -1.03 & 0.09 & 0.00 & 0.01 \\
\hline Kh_BCU(5) & -50 & 0.00 & -0.25 & 0.29 & 0.16 & 0.02 & 1.88 & -0.90 & 0.05 & 0.00 & 0.01 \\
\hline
\end{tabular}


Table C-3

Percentage Changes in Discharge Rates Between Sensitivity Runs and Calibration Run

\begin{tabular}{|c|c|c|c|c|c|c|c|c|c|c|c|}
\hline \multirow{2}{*}{\multicolumn{2}{|c|}{ Calibration Zones and Base Data ${ }^{a}$ : }} & \multicolumn{8}{|c|}{ Drain Fluxes } & \multicolumn{2}{|c|}{ GHB Fluxes } \\
\hline & & \multirow{2}{*}{$\begin{array}{c}\text { DV } \\
-59782.87\end{array}$} & \multirow{2}{*}{$\begin{array}{c}\text { OV } \\
-25784.95\end{array}$} & \multirow{2}{*}{$\begin{array}{c}\text { Ariv } \\
-334.81\end{array}$} & \multirow{2}{*}{$\begin{array}{c}\text { AM } \\
-77332.51\end{array}$} & \multirow{2}{*}{$\begin{array}{c}\text { FL } \\
-37873.7\end{array}$} & \multirow{2}{*}{$\begin{array}{c}\text { AF } \\
-5232.56\end{array}$} & \multirow{2}{*}{$\begin{array}{c}\text { PV } \\
-19105.9\end{array}$} & \multirow{2}{*}{$\begin{array}{c}\text { IS } \\
-2456.55\end{array}$} & \multirow{2}{*}{$\begin{array}{c}\text { PP } \\
1719.51\end{array}$} & \multirow{2}{*}{$\begin{array}{c}\text { EM } \\
-4928.82 \\
\end{array}$} \\
\hline Parameter & $\%$ Change & & & & & & & & & & \\
\hline Kh_BCU(6) & -50 & 0.00 & -0.01 & -0.02 & -0.01 & 0.00 & -0.13 & 0.01 & 0.02 & 0.00 & 0.00 \\
\hline Kh_TBA(1) & -50 & -0.01 & 0.52 & -0.44 & -0.23 & -0.03 & -2.57 & 1.01 & -0.07 & -0.01 & -0.01 \\
\hline Kh_TBA(3) & -50 & 0.00 & -0.39 & 0.32 & 0.18 & 0.02 & 2.07 & -0.87 & 0.06 & 0.00 & 0.01 \\
\hline Kh_TBA(4) & -50 & 0.01 & -0.71 & 0.39 & 0.23 & 0.03 & 2.65 & -0.79 & 0.11 & 0.01 & 0.01 \\
\hline Kh_TBA(6) & -50 & 0.00 & -0.21 & 0.27 & 0.15 & 0.02 & 1.70 & -0.83 & 0.05 & 0.00 & 0.01 \\
\hline Kh_TCB(1) & -50 & 0.00 & -0.25 & 0.05 & 0.04 & 0.00 & 0.45 & 0.05 & -0.01 & 0.00 & 0.00 \\
\hline Kh_TCB(4) & -50 & 0.01 & -0.77 & 0.39 & 0.23 & 0.03 & 2.70 & -0.76 & 0.12 & 0.01 & 0.01 \\
\hline Kh_TCB(6) & -50 & 0.01 & -0.86 & 0.42 & 0.25 & 0.03 & 2.94 & -0.79 & 0.12 & 0.01 & 0.01 \\
\hline Kh_TC(1) & -50 & 0.01 & -5.46 & 0.83 & 0.50 & 0.06 & 6.00 & 3.38 & 0.13 & 0.01 & 0.03 \\
\hline Kh_TC(3) & -50 & 0.01 & -0.78 & 0.40 & 0.23 & 0.03 & 2.74 & -0.75 & 0.11 & 0.01 & 0.01 \\
\hline Kh_TC(4) & -50 & -0.01 & 0.51 & -0.22 & 0.03 & -0.01 & 0.80 & -1.01 & 0.08 & 0.00 & -0.01 \\
\hline Kh_TC(5) & -50 & -0.02 & 0.66 & -0.65 & -0.05 & -0.04 & 0.35 & -0.76 & 0.08 & 0.00 & -0.02 \\
\hline Kh_TC(6) & -50 & 0.01 & -0.93 & 0.45 & 0.26 & 0.03 & 3.08 & -0.77 & 0.12 & 0.01 & 0.01 \\
\hline Kh_TMA(1) & -50 & 0.09 & -2.03 & 1.03 & 0.28 & 0.07 & 2.40 & 0.41 & 0.29 & 0.00 & 0.03 \\
\hline Kh_TMA(2) & -50 & 0.01 & -0.53 & 0.45 & 0.21 & 0.03 & 2.39 & -0.94 & 0.10 & 0.00 & 0.01 \\
\hline Kh_TMA(3) & -50 & 0.02 & -1.62 & 1.19 & 0.44 & 0.08 & 4.44 & -1.10 & 0.12 & 0.01 & 0.03 \\
\hline Kh_TMA(4) & -50 & 0.69 & -0.64 & -2.27 & -0.12 & -0.20 & 1.18 & -0.68 & 0.04 & 0.00 & -0.08 \\
\hline Kh_TMA(6) & -50 & 0.01 & -1.02 & 0.47 & 0.27 & 0.03 & 3.12 & -0.69 & 0.11 & 0.01 & 0.01 \\
\hline Kh_AA(1) & -50 & -2.84 & -1.30 & -2.14 & -0.47 & -0.68 & -2.34 & 11.73 & 21.98 & -0.92 & -0.25 \\
\hline Kh_AA(2) & -50 & 0.16 & 0.00 & -58.83 & -12.87 & -10.67 & 275.34 & -0.90 & 2.86 & -2.55 & -5.45 \\
\hline Kh_AA(3) & -50 & 0.00 & -0.29 & 0.07 & 0.04 & 0.00 & 0.43 & -0.92 & 7.78 & 0.00 & 0.00 \\
\hline Kh_AA(4) & -50 & 0.00 & -0.18 & 0.27 & 0.15 & 0.02 & 1.73 & -0.88 & 0.03 & 0.00 & 0.01 \\
\hline Kh_AA(5) & -50 & 0.01 & -0.82 & 0.48 & 0.28 & 0.04 & 3.24 & -1.06 & 0.11 & 0.01 & 0.02 \\
\hline Kh_AA(6) & -50 & -0.09 & 0.48 & 27.75 & 11.29 & -40.22 & 100.30 & -1.04 & 1.37 & -17.36 & 19.40 \\
\hline Id_I & -10 & 0.03 & -0.30 & 0.28 & 0.16 & -0.01 & 1.92 & -0.90 & 0.05 & 0.00 & -0.02 \\
\hline Id_LCCU(1) & -10 & 0.05 & -4.43 & 2.85 & 1.51 & 0.21 & 16.06 & -3.69 & -4.13 & 10.98 & 0.09 \\
\hline Id_LCCU(2) & -10 & 0.00 & -0.29 & 0.40 & 0.24 & 0.03 & 2.90 & -0.85 & -4.92 & 0.00 & 0.01 \\
\hline Id_LCCU(3) & -10 & 5.56 & -3.07 & -12.43 & -2.00 & -0.85 & -9.71 & -1.05 & -0.04 & 0.12 & 1.84 \\
\hline Id_LCA(1) & -10 & 0.04 & -0.18 & 2.02 & 0.27 & 0.13 & -1.28 & -0.63 & -2.46 & 0.00 & 0.05 \\
\hline Id_LCA(2) & -10 & -0.08 & -0.32 & -3.94 & 1.87 & -0.18 & -22.88 & -0.08 & -0.91 & 0.13 & -0.05 \\
\hline
\end{tabular}


Table C-3

Percentage Changes in Discharge Rates Between Sensitivity Runs and Calibration Run

\begin{tabular}{|c|c|c|c|c|c|c|c|c|c|c|c|}
\hline \multirow{2}{*}{\multicolumn{2}{|c|}{ Calibration Zones and Base Data ${ }^{a}$ : }} & \multicolumn{8}{|c|}{ Drain Fluxes } & \multicolumn{2}{|c|}{ GHB Fluxes } \\
\hline & & \multirow{2}{*}{$\begin{array}{c}\text { DV } \\
-59782.87\end{array}$} & \multirow{2}{*}{$\begin{array}{c}\text { OV } \\
-25784.95\end{array}$} & \multirow{2}{*}{$\begin{array}{c}\text { Ariv } \\
-334.81\end{array}$} & \multirow{2}{*}{$\begin{array}{c}\text { AM } \\
-77332.51\end{array}$} & \multirow{2}{*}{$\begin{array}{c}\text { FL } \\
-37873.7\end{array}$} & \multirow{2}{*}{$\begin{array}{c}\text { AF } \\
-5232.56\end{array}$} & \multirow{2}{*}{$\begin{array}{c}\text { PV } \\
-19105.9\end{array}$} & \multirow{2}{*}{$\begin{array}{c}\text { IS } \\
-2456.55\end{array}$} & \multirow{2}{*}{$\begin{array}{c}\text { PP } \\
1719.51\end{array}$} & \multirow{2}{*}{$\begin{array}{c}\text { EM } \\
-4928.82\end{array}$} \\
\hline Parameter & $\%$ Change & & & & & & & & & & \\
\hline Id_LCA(3) & -10 & 0.01 & -0.76 & 0.90 & 0.50 & 0.07 & 5.76 & -0.79 & -15.10 & 0.02 & 0.03 \\
\hline Id_LCA(4) & -10 & 3.86 & 0.37 & 14.42 & -1.26 & 3.82 & -54.43 & -1.26 & -0.70 & -0.29 & 3.62 \\
\hline Id_LCA(5) & -10 & 0.03 & -0.66 & 2.29 & 1.29 & 0.17 & 15.02 & -9.02 & 0.44 & 0.02 & 0.07 \\
\hline Id_LCA(6) & -10 & 0.00 & -0.28 & 0.32 & 0.17 & 0.02 & 1.95 & -0.76 & -1.55 & 0.01 & 0.01 \\
\hline Id_LCA(7) & -10 & 0.00 & 0.26 & 0.26 & 0.14 & 0.02 & 1.62 & -1.44 & 0.04 & 0.00 & 0.01 \\
\hline Id_LCA(8) & -10 & 0.06 & -0.45 & 3.66 & 1.92 & 0.27 & 22.00 & -14.04 & 0.50 & 0.03 & 0.11 \\
\hline Id_LCA(9) & -10 & 11.59 & 0.43 & -40.38 & -5.39 & -2.88 & -25.61 & -1.24 & -0.32 & -0.08 & -1.14 \\
\hline Id_UCCU & -10 & 0.01 & -0.83 & 0.53 & 0.31 & 0.04 & 3.65 & -1.24 & 0.07 & 0.00 & 0.02 \\
\hline Id_LCA3 & -10 & 0.01 & -0.42 & 0.38 & 0.21 & 0.03 & 2.48 & -1.07 & 0.07 & 0.00 & 0.01 \\
\hline Id_TSDV(1) & -10 & 0.02 & -0.81 & 0.51 & 0.06 & 0.60 & 1.84 & -1.07 & 0.13 & 0.06 & 0.48 \\
\hline Id_TSDV(2) & -10 & 2.60 & -0.28 & -8.83 & -1.06 & -0.77 & -3.24 & -0.84 & 0.00 & -0.01 & -0.23 \\
\hline Id_VU(1) & -10 & 0.04 & -2.27 & 3.35 & 1.74 & 0.25 & 19.89 & -10.17 & 0.51 & 0.03 & 0.10 \\
\hline Id_VU(2) & -10 & 0.01 & -0.81 & 0.48 & 0.28 & 0.04 & 3.29 & -1.08 & 0.11 & 0.00 & 0.02 \\
\hline Id_VU(3) & -10 & 0.75 & -1.62 & -0.80 & 0.14 & -0.10 & 2.75 & -1.29 & 0.09 & 0.00 & -0.04 \\
\hline Id_VCU(1) & -10 & 0.11 & -7.11 & 5.06 & 1.46 & 0.36 & 13.10 & -1.14 & 0.27 & 0.02 & 0.14 \\
\hline Id_VCU(2) & -10 & 0.00 & -0.21 & 0.27 & 0.15 & 0.02 & 1.73 & -0.89 & 0.11 & 0.00 & 0.01 \\
\hline Id_VA(1) & -10 & 0.02 & -1.46 & 1.12 & 0.42 & 0.08 & 4.38 & -1.21 & 0.12 & 0.00 & 0.03 \\
\hline Id_VA(2) & -10 & 0.00 & -0.29 & 0.24 & 0.14 & 0.02 & 1.67 & -0.69 & 0.09 & 0.00 & 0.01 \\
\hline Id_VA(3) & -10 & 0.02 & -0.69 & 1.48 & 0.25 & 0.10 & 1.47 & -0.80 & 0.06 & 0.00 & 0.04 \\
\hline Id_BAQ(1) & -10 & 0.04 & -0.18 & 0.29 & 0.17 & 0.04 & 1.96 & -1.22 & 0.10 & 0.00 & 0.02 \\
\hline Id_BAQ(3) & -10 & 0.01 & -0.77 & 0.39 & 0.23 & 0.03 & 2.73 & -0.77 & 0.10 & 0.00 & 0.01 \\
\hline Id_BAQ(4) & -10 & 0.00 & -0.04 & 0.22 & 0.12 & 0.02 & 1.37 & -0.87 & 0.09 & 0.00 & 0.01 \\
\hline Id_BAQ(5) & -10 & 0.00 & -0.31 & 0.31 & 0.17 & 0.02 & 1.99 & -0.89 & 0.08 & 0.00 & 0.01 \\
\hline Id_BAQ(6) & -10 & 0.01 & -0.36 & 0.39 & 0.22 & 0.03 & 2.49 & -1.19 & 0.13 & 0.00 & 0.01 \\
\hline Id_BCU(1) & -10 & 0.02 & -1.92 & 1.16 & 0.65 & 0.08 & 7.51 & -2.36 & 0.21 & 0.01 & 0.04 \\
\hline Id_BCU(3) & -10 & 0.00 & -0.24 & 0.24 & 0.14 & 0.02 & 1.64 & -0.77 & 0.07 & 0.00 & 0.01 \\
\hline Id_BCU(4) & -10 & 0.01 & -0.96 & 0.48 & 0.28 & 0.04 & 3.28 & -0.85 & 0.10 & 0.00 & 0.02 \\
\hline Id_BCU(5) & -10 & 0.01 & -0.85 & 0.43 & 0.25 & 0.03 & 2.91 & -0.78 & 0.06 & 0.00 & 0.01 \\
\hline Id_BCU(6) & -10 & 0.00 & -0.39 & 0.32 & 0.18 & 0.02 & 2.07 & -0.87 & 0.07 & 0.00 & 0.01 \\
\hline Id_TBA(1) & -10 & 0.69 & 0.58 & -2.39 & -0.11 & -0.21 & 1.59 & -2.46 & 0.08 & 0.00 & -0.08 \\
\hline
\end{tabular}


Table C-3

Percentage Changes in Discharge Rates Between Sensitivity Runs and Calibration Run

\begin{tabular}{|c|c|c|c|c|c|c|c|c|c|c|c|}
\hline \multirow{2}{*}{\multicolumn{2}{|c|}{ Calibration Zones and Base Data ${ }^{a}$ : }} & \multicolumn{8}{|c|}{ Drain Fluxes } & \multicolumn{2}{|c|}{ GHB Fluxes } \\
\hline & & \multirow{2}{*}{$\begin{array}{c}\text { DV } \\
-59782.87\end{array}$} & \multirow{2}{*}{$\frac{\text { OV }}{-25784.95}$} & \multirow{2}{*}{$\begin{array}{c}\text { Ariv } \\
-334.81\end{array}$} & \multirow{2}{*}{$\begin{array}{c}\text { AM } \\
-77332.51\end{array}$} & \multirow{2}{*}{$\begin{array}{c}\text { FL } \\
-37873.7\end{array}$} & \multirow{2}{*}{$\begin{array}{c}\text { AF } \\
-5232.56\end{array}$} & \multirow{2}{*}{$\begin{array}{c}\mathbf{P V} \\
-19105.9\end{array}$} & \multirow{2}{*}{$\begin{array}{c}\text { IS } \\
-2456.55\end{array}$} & \multirow{2}{*}{$\begin{array}{c}\text { PP } \\
1719.51\end{array}$} & \multirow{2}{*}{$\begin{array}{c}\text { EM } \\
-4928.82\end{array}$} \\
\hline Parameter & $\%$ Change & & & & & & & & & & \\
\hline Id_TBA(3) & -10 & 0.00 & -0.76 & 0.38 & 0.22 & 0.03 & 2.63 & -0.71 & 0.07 & 0.00 & 0.01 \\
\hline Id_TBA(4) & -10 & 0.01 & -0.86 & 0.49 & 0.29 & 0.04 & 3.35 & -1.06 & 0.13 & 0.00 & 0.02 \\
\hline Id_TBA(6) & -10 & 0.01 & -0.76 & 0.39 & 0.23 & 0.03 & 2.71 & -0.75 & 0.09 & 0.00 & 0.01 \\
\hline Id_TCB(1) & -10 & 0.00 & -0.19 & 0.34 & 0.18 & 0.02 & 2.11 & -1.19 & 0.11 & 0.00 & 0.01 \\
\hline Id_TCB(4) & -10 & 0.00 & -0.34 & 0.34 & 0.19 & 0.03 & 2.27 & -1.03 & 0.07 & 0.00 & 0.01 \\
\hline Id_TCB(6) & -10 & 0.01 & -0.73 & 0.39 & 0.23 & 0.03 & 2.68 & -0.78 & 0.09 & 0.00 & 0.01 \\
\hline Id_TC(1) & -10 & -0.01 & 3.19 & -0.51 & -0.23 & -0.04 & -2.61 & -2.54 & -0.01 & -0.01 & -0.02 \\
\hline Id_TC(3) & -10 & 0.00 & -0.28 & 0.29 & 0.16 & 0.02 & 1.90 & -0.89 & 0.07 & 0.00 & 0.01 \\
\hline Id_TC(4) & -10 & 0.01 & -0.25 & 0.34 & 0.16 & 0.02 & 1.83 & -0.92 & 0.08 & 0.00 & 0.01 \\
\hline Id_TC(5) & -10 & 0.01 & -1.43 & 0.83 & 0.36 & 0.06 & 3.87 & -0.80 & 0.11 & 0.00 & 0.02 \\
\hline Id_TC(6) & -10 & 0.01 & -0.75 & 0.39 & 0.23 & 0.03 & 2.73 & -0.79 & 0.06 & 0.00 & 0.01 \\
\hline Id_TMA(1) & -10 & -0.01 & -1.19 & 0.22 & 0.44 & 0.02 & 6.05 & -1.91 & 0.17 & 0.01 & 0.01 \\
\hline Id_TMA(2) & -10 & 0.00 & 0.22 & 0.14 & 0.11 & 0.01 & 1.43 & -1.21 & 0.04 & 0.00 & 0.00 \\
\hline Id_TMA(3) & -10 & -0.01 & 0.66 & -0.24 & 0.01 & -0.02 & 0.57 & -1.05 & 0.06 & 0.00 & -0.01 \\
\hline Id_TMA(4) & -10 & -0.01 & 0.54 & -0.41 & 0.05 & -0.03 & 1.29 & -1.18 & 0.10 & 0.00 & -0.01 \\
\hline Id_TMA(6) & -10 & 0.00 & -0.16 & 0.22 & 0.13 & 0.02 & 1.53 & -0.78 & 0.05 & 0.00 & 0.01 \\
\hline Id_AA(1) & -10 & 1.99 & -0.43 & -1.51 & 0.49 & -0.09 & 8.44 & -8.06 & -12.90 & 0.05 & -0.04 \\
\hline Id_AA(2) & -10 & 1.25 & -0.38 & 10.53 & 2.01 & 1.93 & -54.76 & -0.76 & -0.53 & -0.24 & 1.07 \\
\hline Id_AA(3) & -10 & 0.00 & -0.20 & 0.33 & 0.18 & 0.02 & 2.13 & -0.89 & -1.69 & 0.00 & 0.01 \\
\hline Id_AA(4) & -10 & 0.00 & -0.31 & 0.27 & 0.16 & 0.02 & 1.82 & -0.77 & 0.10 & 0.00 & 0.01 \\
\hline Id_AA(5) & -10 & 0.00 & -0.24 & 0.04 & 0.03 & 0.00 & 0.42 & 0.04 & 0.06 & 0.00 & 0.00 \\
\hline Id_AA(6) & -10 & 0.02 & -1.07 & -4.94 & -2.17 & 7.19 & -19.90 & -1.10 & -0.21 & 0.50 & 10.18 \\
\hline
\end{tabular}




\section{Distribution List}

Copies

Ralph Lightner

1 (CD ROM)

U.S. Department of Energy

Office of Southwestern Area Program, EM-45

19901 Germantown Road

Germantown, MD 20874-1290

Robert M. Bangerter, Jr.

2 (1 Paper \& 1 CD ROM)

DOE/Nevada Operations Office

Environmental Restoration Division

P.O. Box 98518, M/S 505

Las Vegas, NV 89193-8518

Runore Wycoff, Director

1 (CD ROM)

Waste Management Division

DOE/Nevada Operations Office

P.O. Box 98518, M/S 505

Las Vegas, NV 89193-8518

Steve Mellington

1 (CD ROM)

Environmental Restoration Division

DOE/Nevada Operations Office

P.O. Box 98518, M/S 505

Steve Lawrence

1 (CD ROM)

DOE/Nevada Operations Office

Engineering Division

P.O. Box 98518, M/S 505

Las Vegas, NV 89193-8518

Public Reading Room, Nevada

DOE/ Nevada Operations Office

U.S. Department of Energy

2621 Losee Road

M/S NLV082

Las Vegas, NV 89030

U.S. Department of Energy

2 (CD ROM)

Office of Scientific and Technical Information

175 Oak Ridge Turnpike

P.O. Box 62

Oak Ridge, Tennessee 37831 


\section{$\underline{\text { Copies }}$}

U.S. Department of Energy

Technical Information Resource Center (TIRC)

DOE/Nevada Operations Office

P.O. Box 98518, M/S 505

Las Vegas, NV 89193

Ken Hoar

1 (CD ROM)

Environmental Protection Division

DOE/Nevada Operations Office

P.O. Box 98518, M/S 505

Las Vegas, NV 89193-8518

Russell Patterson

$1(\mathrm{CD}$ ROM)

U.S. Department of Energy

Yucca Mountain Site Characterization Project Office (YMSCO)

1551 Hillshire Drive,

Las Vegas, NV 89134

Eleonor Handman

$1(\mathrm{CD}$ ROM $)$

Library

U.S. Geological Survey

333 W. Nye Lane

Carson City, NV 89706

Doug Trudeau

1 (CD ROM)

U.S. Geological Survey

Water Resources Division

6770 South Paradise Road

Las Vegas, NV 89119

Martha Garcia

1 (CD ROM)

Library

U.S. Geological Survey

P.O. Box 25046

Denver, CO 80225-0046

District Ranger

U.S. Forest Service

Las Vegas District Office

2881 South Valley View Blvd., Suite 16

Las Vegas, NV 89102 


\section{$\underline{\text { Copies }}$}

Tim Mayer

$1(\mathrm{CD}$ ROM $)$

U.S. Fish and Wildlife Service

Division of Engineering

Eastside Federal Complex

911 NE 11th Ave.

Portland, OR 97232-4181

Bureau of Indian Affairs

1

1677 Hot Springs Road

Carson City, NV 89706

Jack Norman

$1(\mathrm{CD}$ ROM $)$

Bureau of Land Management

4765 Vegas Drive

Las Vegas, NV 89018

Lawrence Hancock

1

Bureau of Reclamation

P.O. Box 61470

Boulder City, NV 89006

Col. Mike Fukey

1 (CD ROM)

Nellis Air Force Base

Environmental Protection

$99 \mathrm{ABW} / \mathrm{EM}$

4349 Dusser Drive, Suite 1601

Nellis Air Force Base, NV 89101

Lt. Col. Chris Long

1 (CD ROM)

USAF/DOE Liaison

232 Energy Way

North Las Vegas, NV 89030

Honorable Richard Bryan

U.S. Senate

300 S. Las Vegas Blvd.

Las Vegas, NV 89101

Honorable James A. Gibbons

U.S. House of Representatives

1116 Longworth

HOB

Washington, DC 20515 


\section{$\underline{\text { Copies }}$}

Honorable John Ensign

U.S. House of Representatives

1000 East Sahara Ave., Suite D

Las Vegas, NV 89104

Honorable Harry Reid

U.S. Senate

500 E. Charleston Blvd.

Las Vegas, NV 89104

Donald Garrepy

1 (CD ROM)

State of Nevada

Division of Environmental Protection

Bureau of Federal Facilities

555 E. Washington, Suite 4300

Las Vegas, NV 89101

Paul Liebendorfer

1 (CD ROM)

State of Nevada

Division of Environmental Protection

Bureau of Federal Facilities

333 W. Nye Lane, Room 138

Carson City, NV 89706-0851

Dennis Bechtel

1

Clark County

Nuclear Waste Division of Comprehensive Planning

530 S. Grand Central, Suite 3012

Las Vegas, NV 89155

Governor Robert J. Miller

1

State of Nevada

555 E. Washington, Suite 1500

Las Vegas, NV 89101

Albert Douglas

City of Las Vegas

Office of Business and Development

400 Las Vegas Boulevard, South

Las Vegas, NV 89101-2986 


\section{$\underline{\text { Copies }}$}

Nick Stellavato

1 (CD ROM)

Nye County

Nuclear Waste Repository Project Office

P.O. Box 675

Mercury, NV 89023

Steve Bradhurst

1 (CD ROM)

Nye County Rural Consortium

c/o Janice Williams

P.O. Box 1767

Tonopah, NV 89049

Les Bradshaw

1 (CD ROM)

County Manager

Nye County

P.O. Box 153

Tonopah, NV 89049

Brad Mettam

1 (CD ROM)

Inyo County Water Department

163 May Street

Bishop, CA 93514

Bill Werrell

1 (CD ROM)

National Park Service

Death Valley Visitor Center

P.O. Box 579

Death Valley, CA 92328

Daniel McLouthlin

1 (CD ROM)

National Park Service

Water Rights Division

1201 Oak Ridge Drive, Suite 250

Fort Collins, CO 80525

Michael DeLee

1

Avery Realty

1401 Maryland Parkway

Las Vegas, NV 89114

Chuck Russell

1 (CD ROM)

Desert Research Institute

P.O. Box 19040, M/S 433

Las Vegas, NV 89132-0040 


\section{$\underline{\text { Copies }}$}

Don Baepler

1 (CD ROM)

Nevada Risk Assessment and Management

Program (NRAMP)

Harry Reid Center - UNLV

4505 Maryland Parkway

Las Vegas, NV 89154

James E. Kannard

1 (CD ROM)

Bechtel Nevada

P.O. Box 98521, M/S 022

Las Vegas, NV 89193-8521

Greenpeace

1

1436 U Street NW

Washington, DC 20009

Dale Schutte

2 (1 Paper \& 1 CD ROM)

c/o Earl Dixon

Community Advisory Board (CAB)

Harry Reid Center - UNLV

4505 Maryland Parkway

Las Vegas, NV 89154

George B. Maxey

1 (CD ROM)

Desert Research Institute

Science Center

7010 Dandini Boulevard

Reno, NV 89512

Richard A. Nielsen

1

Citizens Alert

P.O. Box 1681

Las Vegas, NV 89125

Paul K. Ortego

1 (CD ROM)

Bechtel Nevada

2621 Losee Road

M/S NLV082

Las Vegas, NV 89030 


\section{$\underline{\text { Copies }}$}

Ward Hawkins

1 (CD ROM)

Los Alamos National Laboratory

P.O. Box 1663 - M/S D443

SM-30 Bikini Atoll Road

Los Alamos, NM 87545

Dave Smith

1 (CD ROM)

Lawrence Livermore National Laboratory

P.O. Box 808, M/S L-231

Livermore, CA 94551

Gayle Pawloski

1 (CD ROM)

Lawrence Livermore National Laboratory

P.O. Box 808, M/SL-231

Livermore, CA 94551

Kay Brothers

1 (CD ROM)

Southern Nevada Water Authority Resources

1001 S. Valley View Blvd

Las Vegas, NV 89107

Buqo, Thomas

1 (CD ROM)

P.O. Box 127

Blue Diamond, NV 89004

James C. Weeks

1 (CD ROM)

Beatty Water and Sanitation District

P.O. Box 99

Beatty, NV 89003

Ken Anderson

1

Las Vegas Paiute Tribe

1 Paiute Drive

Las Vegas, NV 89124

Janet Wille

1 (CD ROM)

IT Corporation

2621 Losee Road, B-1

N. Las Vegas, NV 89030 